UNIVERSIDADE DE SÃO PAULO

FACULDADE DE FILOSOFIA, LETRAS E CIÊNCIAS HUMANAS

DEPARTAMENTO DE HISTÓRIA SOCIAL

PROGRAMA DE PÓS-GRADUAÇÃO EM HISTÓRIA SOCIAL

\title{
Entre a escrita e a prática: direito e escravidão no Brasil e em Cuba, c.1760-1871
}

(Versão Corrigida)

WALDOMIRO LOURENÇO DA SILVA JÚNIOR 
UNIVERSIDADE DE SÃO PAULO

FACULDADE DE FILOSOFIA, LETRAS E CIÊNCIAS HUMANAS

DEPARTAMENTO DE HISTÓRIA SOCIAL

PROGRAMA DE PÓS-GRADUAÇÃO EM HISTÓRIA SOCIAL

\section{Entre a escrita e a prática: direito e escravidão no Brasil e em Cuba, c.1760-1871}

(Versão Corrigida)

WALDOMIRO LOURENÇO DA SILVA JÚNIOR

Tese apresentada ao Programa de Pós-Graduação em História Social do Departamento de História da Faculdade de Filosofia, Letras e Ciências Humanas da Universidade de São Paulo para obtenção do título de Doutor em História

Orientador: Prof. Dr. Rafael de Bivar Marquese 
Para Daniel, um pedacinho do papai. 


\section{Agradecimentos}

As minhas primeiras palavras de agradecimento se dirigem à Fundação de Amparo à Pesquisa (FAPESP) pelo financiamento realizado por meio da bolsa no país (2010/51703-3) e da Bolsa Estágio de Pesquisa no Exterior (BEPE) (2012/22955-0). Sem tais recursos, a realização da presente pesquisa, que demandou a ida a diversos arquivos e instituições de pesquisa no Brasil e no exterior, não teria sido possível.

Em seguida, devo externar minha enorme gratidão para com meu orientador, o professor Rafael de Bivar Marquese. Por certo, a sua orientação se baseou em comentários, críticas e sugestões regularmente efetuados sobre a investigação. Mas as principais lições foram aprendidas a partir do contato com um pesquisador excepcional, sempre interessado, exclusivamente, na produção do conhecimento. Após mais de uma década de convívio, a relação professor/aluno se transformou em uma sólida amizade que durará para a vida toda.

Agradeço também aos funcionários das diversas instituições de pesquisa por onde passei, recolhendo as fontes necessárias. No Brasil, fui muitíssimo bem acolhido no Arquivo Edgard Leuenroth (AEL) da Universidade Estadual de Campinas, no Arquivo Nacional do Rio de Janeiro, no Museu do Judiciário, no Arquivo Central do Poder Judiciário do Estado do Rio de Janeiro e no Centro de Documentação Histórica da Fundação Educacional Severino Sombra (CDH/Fusve), em Vassouras. A todos o meu muito obrigado. No ano de 2013, passei uma temporada de pouco mais de dois meses na ilha de Cuba, percorrendo o Archivo Nacional de Cuba, o Archivo Histórico Provincial de Matanzas, a Biblioteca de la Universidad de la Habana, a Biblioteca del Instituto de Literatura y Lingüística e, finalmente, a Biblioteca Nacional José Martí. Devo destacar, especialmente, o auxílio dos funcionários do Archivo Nacional, onde realizei a maior parte das atividades. O suporte dado por Silvio Facenda, que chefiava a seção onde se encontram os fundos pertinentes a pesquisa, foi de grande valia. Obrigado! A minha permanência na ilha dependeu do vínculo acadêmico o Instituto Cultural Juan Marinello, onde contei com a supervisão do admirável historiador cubano, Carlos Venegas. O meu muito obrigado a todos do instituto e, particularmente, ao professor Venegas.

Uma nota à parte cabe ao auxílio concedido pelas destacadas historiadoras cubanas Aisnara Perera e María de los Ángeles Meriño, que me receberam excepcionalmente bem logo em meu primeiro dia. Com uma generosidade inigualável, mostraram-me como o Arquivo funcionava, transmitiram-me notas pessoais de pesquisa, nunca se furtando a partilhar comigo o seu vastíssimo conhecimento sobre o acesso dos escravos ao judiciário cubano. Desde então, selamos uma sólida e produtiva amizade. Muito obrigado! 
Ainda em Cuba, tive a oportunidade de estabelecer um intercâmbio bastante proveitoso com diversos pesquisadores locais e estrangeiros, como Beatriz Joda, Claudia Martínez, Marial Iglesias, Reinaldo Funes, Jorge Felipe, Imilcy Balboa e Claudia Varella. Tive também a oportunidade de estabelecer contato com a ilustre professora Gloria García, que, infelizmente, veio a falecer em fins de 2013. Registro aqui a minha homenagem.

Não posso deixar de fazer especial menção à família que me acolheu em Cuba. Os laços criados com dona Victoria e sua filha Gabriela na casa onde estive hospedado em Havana foram verdadeiramente familiares. Lá, tive a enorme satisfação de conviver com Adriana Chira, pesquisadora excepcional, que se tornou também uma pessoa da família. Devo muito a todas elas.

Ao longo da pesquisa, tive contato com professores que contribuiriam bastante para a realização da pesquisa, como Edward Baptist, Beatriz Mamigonian, João Paulo Pimenta, José Antonio Piqueras, Maria Helena Machado, Robin Blackburn, Rebecca Scott, Ricardo Salles, Jaime Rodrigues e Andrea Slemian. Os dois últimos gentilmente compuseram a banca do exame de qualificação desta pesquisa. As suas primorosas observações foram fundamentais para o encaminhamento do trabalho. Obrigado a todos.

No ano de 2013, tive o privilégio de realizar um estágio de pesquisa na Universidade de Pittsburgh, nos Estados Unidos, onde pude conviver com os integrantes do Center for Latin American Studies (CLAS) da Universidade, em especial Luis Bravo, Marta e Adriana, usufruir do vasto acervo da Hillman Library, e aprender muito com o contato com historiador Alejandro de la Fuente, supervisor do estágio. Os encontros com o professor De la Fuente foram, sem dúvida, cruciais para o desenvolvendo das ideias presentes na tese. O meu muito obrigado!

Vários colegas de academia também deram sua contribuição, tanto pelo debate quanto por dividirem suas angústias. Vale especial menção aos companheiros André Nicacio, Breno Moreno, Bruno Stefanis, Fernanda Bretones, Felipe Landim, Marco Holtz, Mariana Ferraz, Marcelo Ferraro, Leonardo Marques, Gabriel Aladren, Priscila Lima, Orlando Rivero, Thiago Araújo, Ynaê dos Santos e a todos do Laboratório de Estudos sobre o Brasil e o Sistema Mundial (Lab-Mundi) da Universidade de São Paulo (USP).

Aos colegas de orientação que se tornaram meus grandes amigos, Alain El Youssef e Tâmis Parron, agradeço muitíssimo por tudo!

Um agradecimento especial cabe à excepcional pesquisadora Mariana Armond Dias Paes, com quem tenho tido o privilégio de conversar, trocar ideias e, sobretudo, aprender muito sobre as relações entre direito e escravidão. Os seus comentários sobre o texto foram cruciais. 
Igualmente, não posso deixar de citar amigos e pessoas próximas que contribuíram de diversas maneiras para a realização do trabalho (e para a minha sobrevivência ao longo do estudo): Alvaro Magalhães, Fabiana Matavelli, Felipe Marin, Fernanda Luciani, Gonzalo Casas, Isabela Carrizo, Kayna Turchiai, Larissa dos Santos, Roberto Gomes, Rodrigo Salvador, Ronne Peterson.

Agradeço muito a meus pais, Marilene e Waldomiro, e à Ana Paula, pelo companheirismo e por cuidar tão bem do nosso precioso filho Daniel. 
Vanidad de creer que comprendemos las obras del tiempo: él entierra sus muertos y guarda las llaves. Sólo en sueños, en la poesía, en el juego - encender una vela, andar con ella por el corredor - nos asomamos a veces a lo que fuimos antes de ser esto que vaya a saber si somos.

Rayuela, Capítulo 105 Julio Cortázar 


\title{
Resumo
}

Esta tese examina o papel do Direito na dinâmica que envolveu a reprodução do sistema de escravidão no Brasil e em Cuba no longo século XIX, a partir do nexo fundamental entre o tráfico transatlântico de escravos e a prática da alforria. Se, por um lado, a ordem jurídica abriu espaço para a ações criativas dos sujeitos históricos vitimados pela escravização, permitindo a reclamação de direitos adquiridos em juízo, especialmente em busca da liberdade, por outro, ela foi um dos elementos estruturantes dos respectivos sistemas de escravidão. Apesar das muitas semelhanças e pontos de contato, a configuração assumida pelos respectivos quadros jurídicos divergiu quanto a tópicos essenciais, especialmente no tocante ao reconhecimento legal do direito dos escravos à alforria onerosa, que se verificou precocemente em Cuba, enquanto que, no Brasil, ocorreu apenas em 1871, com a promulgação da Lei do Ventre Livre. O contraponto verificado não conduz a uma nova dicotomia entre uma escravidão mais branda ou severa do que a outra, mas à compreensão dos traços específicos que envolviam a ordenação do cativeiro e o alcance do protagonismo dos escravos naqueles dois espaços.

\section{Palavras-chave: escravidão, direito, alforria, tráfico de escravos}

\begin{abstract}
This thesis analyzes the role of the law in the slave system's dynamics in Brazil and Cuba during the long nineteenth century, from the fundamental connection between the transatlantic slave trade and the manumission. The main argument is that, if on the one hand the law created possibilities for the historical subjects victimized by slavery act creatively, seeking freedom in the courts, particularly, on the other, it was part of the structuring elements of those slave systems. Despite the similarities, the configuration assumed by the respective legal frameworks diverged as the essential topics, especially with regard to legal recognition of the right of slaves to the onerous manumission, which occurred early in Cuba, while, in Brazil, only in 1871, with the enactment of the Free Womb Law. The observed counterpoint does not lead to a new dichotomy between a milder and a severe slave system, but the understanding of the specific characters involving the regulation of slavery and the slave agency in those two spaces.
\end{abstract}

Keywords: slavery, law, manumission, slave trade 


\section{SUMÁRIO}

Introdução

\section{Capítulo - I}

Brasil, Cuba e a reestruturação sistêmica da escravidão.

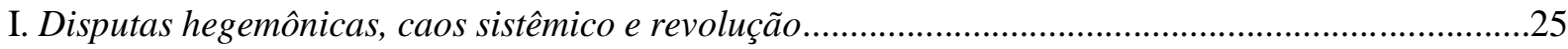

II. Guerra dos Sete Anos, Ilustração e o tráfico negreiro.............................................................................

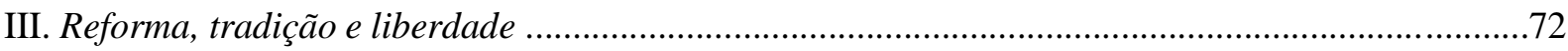

\section{Capítulo - II}

O direito escravista do Império do Brasil, 1823-1871 .............................................................103

I. Fundação da ordem constitucional e a preservação das bases jurídicas da escravidão ......................107

II. $O$ direito escravista refundado: alforria, litígio e a dinâmica do cativeiro oitocentista.....................138

III. Fim do tráfico negreiro e a Consolidação das leis escravistas ........................................................170

\section{Capítulo - III}

O direito dos escravos e o escravismo hispano-cubano, 1820-1870....................................197

I. Tráfico, Faculdades Onímodas e a preservação da ordem colonial escravista.....................................211

II. Turnbull, Resistência Escrava e o Reglamento de 1842 .................................................................239

III. Coartação e os direitos dos escravos no debate jurídico cubano.........................................................267

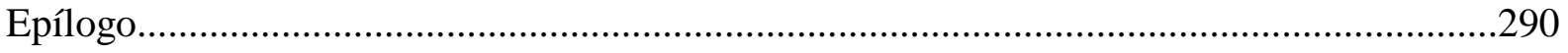

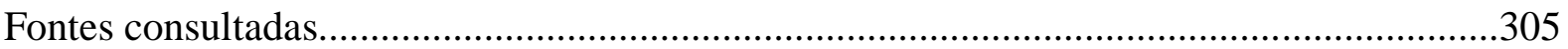

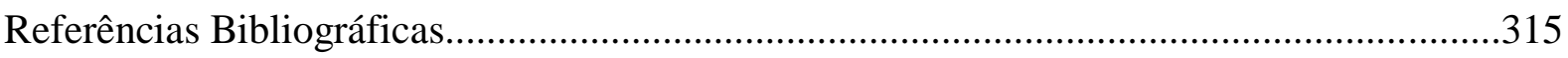




\section{Introdução}

O historiador Luiz Felipe de Alencastro, em seu artigo de 1979, La traite négrière et l'unité nationale brésilienne, pôs em destaque a importância do sistema escravista herdado da colonização para a unificação nacional brasileira após a independência. O poder imperial, ao criar condições políticas e diplomáticas para a continuação do tráfico de escravos e a manutenção da economia de plantação, teria reunido as forças necessárias para manter a unidade do país. Uma das consequências do fluxo contínuo de africanos escravizados provenientes do comércio atlântico seria o seu suporte à prática da alforria em níveis constantes, o que, no interior do sistema, corrigiria superinvestimentos - aliviando a situação de senhores que não estavam em condições de empregar seus cativos de forma rentável -, ajudando, ao mesmo tempo, a manter o controle sobre os escravos, funcionando como estímulo ideológico pela promessa de liberdade como prêmio por bom comportamento ${ }^{1}$. De maneira semelhante, articulando tráfico negreiro, taxas de alforria e ordem social, Rafael de Bivar Marquese, em seu artigo A dinâmica da escravidão no Brasil, buscou construir uma interpretação a respeito da singularidade da dimensão assumida por Palmares na história nacional. Partindo das proposições teóricas de Orlando Patterson e Igor Kopytoff, que compreendem escravização, cativeiro e alforria, como partes integradas de um mesmo processo institucional ${ }^{2}$, o autor tratou de explicar os fundamentos da estabilidade da ordem social escravista brasileira na longa duração. O nexo explicativo para a redução do potencial revolucionário dos diversos atos de rebeldia que eclodiram ao longo do tempo girou em torno da relação estreita entre o volume do tráfico transatlântico de escravos e os elevados índices de alforria existentes no Brasil. A incorporação geracional da população negra mediada pela manumissão e a disseminação da propriedade escrava pelos diferentes estratos da população livre, incluindo egressos do cativeiro e os seus descendentes, teria concorrido para diminuir as possibilidades de massificação dos conflitos, garantindo a reprodução sistêmica do regime brasileiro. Excetuando-se à regra, os mocambos da Serra da Barriga teriam emergido, quando na capitania de Pernambuco se verificavam padrões societários potencialmente convulsivos, próximos aos do chamado escravismo de plantation típico das colônias francesas e inglesas, marcado por uma desproporção acentuada entre livres e escravos, pela presença preponderante de africanos nas

\footnotetext{
${ }^{1}$ Luiz Felipe de Alencastro. "La traite négrière et l'unité nationale brésilienne. Revue française d'histoire d'outremer". Histoire et politologie en Amérique Latine, tome 66, n.244-245 (3e et 4e trimestres 1979). pp. 395-419.

2 Igor Kopytoff. "Slavery". Annual Review of Anthropology, vol.11, 1982, pp. 221-22; Orlando Patterson.Escravidão e morte social - Um estudo comparativo (trad.port.). São Paulo: Edusp, 2008.
} 
escravarias e pela redução das oportunidades de alforria, o que teria se somando ao cenário internacional de disputas entre portugueses e holandeses ${ }^{3}$. Mais recentemente, Marcel van der Linden, desenvolveu uma equação baseada em uma lógica análoga para explicar as condições que tornavam estáveis os regimes de trabalho baseados na escravidão em longo prazo, assim visualiza-se: o crescimento do número de cativos depende da soma entre o resultado líquido da mobilidade social (diferença entre escravizados e libertos), do crescimento natural e da migração involuntária ${ }^{4}$.

Como a maioria dos grandes esquemas interpretativos, os acima citados deixam escapar aspectos particulares, específicos do cotidiano das relações e dos conflitos sociais. Não obstante, eles oferecem um bom ponto de referência para o entendimento da dinâmica que envolvia a reprodução sistêmica da escravidão. Embora Marquese se refira a um sistema tipicamente brasileiro, é possível observar um nexo bastante parecido na reprodução do regime escravista hispano-cubano do século XIX. Até então, realmente inexistiu no Império espanhol uma sociedade genuinamente escravista ${ }^{5}$. Mas as transformações ocorridas na economiamundo capitalista na segunda metade do século XVIII deram margem ao surgimento de novas zonas de exploração escravistas no espaço atlântico, sob um arranjo sistêmico original, que se integraria ao cerne da produção industrial por meio do fornecimento de um volume cada vez maior de matérias-primas e de gêneros alimentícios vendidos a preços compatíveis com o padrão de consumo da classe trabalhadora europeia. Essas mudanças engendraram a nova estrutura histórica que Dale Tomich denominou "segunda escravidão", distinta pelo incremento inaudito da produtividade do braço cativo e pela criação de novas modalidades de reposição da mão de obra escrava frente ao avanço da pressão inglesa pelo fim do tráfico negreiro transatlântico. A Revolução de Saint-Domingue marcou o declínio dos antigos centros escravistas e precipitou o desenvolvimento de localidades até então secundárias, como o Sul dos Estados Unidos (algodão), o sudeste do Brasil (café) e a parte ocidental da ilha de Cuba (açúcar). Decerto, também este esquema não contempla toda a realidade. A produção escravista mais intensa daquelas três regiões coexistiria com atividades produtivas de ritmos diferenciados. Esta questão será retomada mais adiante. Por agora, importa destacar que a reprodução dos regimes de escravidão brasileiros e hispano-cubano, que inegavelmente

\footnotetext{
${ }^{3}$ Rafael de Bivar Marquese. "A dinâmica da escravidão no Brasil: resistência, tráfico negreiro e alforrias, séculos XVII a XIX”. Novos estudos. - CEBRAP, n.74 (2006), pp.107-123.

${ }^{4}$ Marcel van der Linden. Trabalhadores do mundo: ensaios para uma história global do trabalho. (trad.port.) Campinas: Editora Unicamp, pp.84-85.

${ }^{5}$ Para esta definição, ver: Moses Finley. The slave systems of Greek and Roman Antiquity. Philadelphia: American Philosophical Society, 1955, pp.84-85.
} 
ganharam novo fôlego depois do colapso do Haiti, pautou-se efetivamente por uma dinâmica que associou o tráfico transatlântico, a experiência da escravidão e a prática da manumissão. Partindo desta premissa, o presente trabalho se debruça sobre os fundamentos jurídicos que informaram a reprodução sistêmica do cativeiro no Brasil e em Cuba no longo século XIX, considerando o seu período formativo, que se deu no momento que sucedeu a Guerra dos Sete Anos (1756-1763), até o início de sua desarticulação definitiva, com a promulgação das leis de liberação do ventre, a Lei Moret, de 4 de julho de 1870, e a Lei Rio Branco, de 28 de setembro de 1871. O objetivo é evidenciar - considerando a legislação relacionada ao comércio negreiro e as possibilidades que o ordenamento jurídico apresentava para a alforria em suas distintas modalidades - como o direito civil se integrou ao sistema de escravidão no período. $\mathrm{O}$ argumento principal, em termos sintéticos, é o de que, se por um lado a ordem jurídica abriu espaço para a ações criativas dos sujeitos históricos vitimados pela escravização, permitindo a reclamação de direitos adquiridos em juízo, por outro, ela fez parte dos elementos estruturantes dos respectivos sistemas escravistas. Apesar das muitas semelhanças e pontos de contato, a configuração assumida pelos respectivos quadros jurídicos divergiu quanto a tópicos essenciais, especialmente no tocante ao reconhecimento legal do direito dos escravos à alforria onerosa, que se verificou precocemente em Cuba, enquanto no Brasil ocorreu apenas em 1871. A contribuição que se pretende oferecer aqui é a de uma história social da escravidão com base em textos normativos, o que difere de um trabalho mais propriamente produzido na seara da história do Direito. Mesmo assim, inevitavelmente empreende-se um diálogo entre os dois campos. Por isso, cabem algumas considerações sobre a inserção da pesquisa no movimento mais amplo da historiografia e dos estudos jurídicos.

O posicionamento crítico das duas primeiras gerações dos Annales perante a historiografia do poder e das instituições e a influência do chamado marxismo clássico fizeram com que a análise de fenômenos jurídicos fosse relegada a segundo plano. Entretanto, há algumas décadas vêm ocorrendo significativas mudanças no enquadramento do Direito enquanto objeto da História. A partir dos anos 1970, fez-se sentir de modo cada vez mais nítido um processo de superação, tanto do formalismo tradicional da história do Direito, quanto da rigidez de concepções marxistas inclinadas à compreensão unilateral dos sistemas jurídicos como instrumentos de dominação de classe. Essas mudanças estiveram associadas, entre outros fatores, às reformulações ocorridas no seio da historiografia marxista, com destaque para os trabalhos de Edward Palmer Thompson, que ressaltou a insuficiência da antiga conceituação do Direito ou das leis, stricto sensu, como componentes de uma superestrutura subordinada e apartada das relações de produção, passando a compreendê-las como espaço de conflito, 
mediação e atuação também por parte das camadas populares ${ }^{6}$; e, sob outro prisma, ao desenvolvimento de novas correntes no âmbito das teorias sociológicas que, encabeçadas por estudiosos como Pierre Bourdieu, Michel Foucault, Jürgen Habermas e Niklas Luhmann, sugeriram novos modelos para a articulação entre a realidade social e as formas políticoinstitucionais, especialmente nos níveis discursivos, ideológicos e simbólicos ${ }^{7}$.

A viragem na relação entre História e Direito coadunou-se, pelo último viés em especial, ao renascimento coetâneo da história política. Finalmente a estratégia interdisciplinar da nouvelle histoire passou a ser transposta também para as fontes, ideias e instituições políticas, as quais, por sua vez, são perpassadas pelos diversos mecanismos jurídicos de disciplina social ${ }^{8}$. As antigas críticas relativas ao caráter puramente descritivo, factual e superficial desse ramo da historiografia perderam a sustentação a partir da desconstrução de suas antigas categorias ${ }^{9}$. Ao mesmo tempo em que foi reconhecido o caráter 'específico e duradouro destas esferas da realidade, buscou-se a reconstituição das relações multifacetadas das instituições políticas e jurídicas com as diferentes instâncias sociais. Em outras palavras, vem sendo observado um processo de renovação da história política, das instituições e do direito que converge para uma via de aproximação com a história social ${ }^{10}$.

No que diz respeito à literatura atinente à escravidão nas Américas, antes das transformações assinaladas, é possível distinguir uma proeminência de interpretações pautadas em aspectos jurídicos. Uma primeira onda de estudos comparativos, iniciada na década de 1940,

\footnotetext{
${ }^{6}$ Cf. Douglas Hay, Peter Linebaugh, Edward P. Thompson (eds.). Albion's Fatal Tree: Crime and Society in Eighteenth-Century England. London: Allen Lane, 1975; Edward P. Thompson. Senhores e caçadores: a origem da lei negra. (trad.port.). Rio de Janeiro: Paz e Terra, 1987 [1975]; Idem. Costumes em comum: estudos sobre a cultura popular tradicional. (trad.port.). São Paulo: Cia das Letras, 1998 [1991]. No tocante à renovação da história do direito pela via marxista, Hespanha salienta, previamente, a importância da retomada, no ambiente pós68, de interpretações gramscianas a partir dos trabalhos de autores como G. Della Volpe e L. Althusser. Cf. Antônio M. Hespanha. A História do Direito na História Social.Lisboa: Livros Horizontes, 1978, pp.14-15.

${ }^{7}$ Entre outros trabalhos dos autores citados, conferir especialmente: Pierre Bourdieu. "A força do direito. Elementos para uma sociologia do campo jurídico", in: O poder simbólico. (trad.port.). Lisboa: Difel, 1989 [1986], pp.209-54; Michel Foucault. Em defesa da sociedade. (trad.port.). São Paulo: Martins Fontes, 1999 [1976]; Jürgen Habermas.Teoria de la acción comunicativa. Tomo II: Crítica de la Razón Funcionalista (trad.esp.). Madrid: Taurus, 1987 [1981]; Niklas Luhmann. Sociologia do Direito (I/II). (trad.port.). Rio de Janeiro: Tempo Brasileiro, 1983 [1972].

${ }^{8}$ Para uma discussão a respeito dos fatores históricos que levaram ao declínio da história política no início do século XX, ver: René Remond. (Org.). Por uma história política. Rio de Janeiro: FGV, 2003.

${ }^{9}$ Como destaca o historiador J. Schaub, "a oposição demasiado simples entre Estado e Sociedade perdeu a sua validade, os fenômenos de poderes são agora analisados nas suas configurações sociais e a escalas diversas, os procedimentos de negociação com suas regras próprias são tão fortemente interrogados como as manifestações de autoridade. Assim, as categorias da história política (Estado, ministério, administração, centro...) são criticadas e reformuladas. A renovação da reflexão histórica sobre a política passa por uma crítica do 'paradigma estadualista', para a qual contribuem poderosamente as ciências sociais e a ciência jurídica". Jean-Frédéric Schaub. "A História Política nos Annales ESC: mutações e reformulações”. Penélope. Fazer e Desfazer a História, n 14, 1994, pp.153154.

${ }^{10}$ Cf. Antônio Carlos Wolkmer. "Paradigmas, historiografia crítica e direito moderno". Revista da Faculdade de Direito, Curitiba, n.28, 1994/95, p.55-67.
} 
atribuiu grande peso à ordem legal dos estados colonialistas modernos para a configuração de seus regimes de escravidão no Novo Mundo. O seu marco inicial foi sem dúvida o livro Slave and Citizen, de Frank Tannenbaum, publicado em 1946 ${ }^{11}$. Para este autor, portugueses e espanhóis, por terem seguido com a prática da escravidão no período medieval, contariam com um arcabouço empírico e normativo alheio à experiência anglo-saxônica. Mais importante até do que a prática longeva teria sido a sobrevivência de uma longa tradição jurídica que reconheceria a personalidade moral dos cativos, favorecendo a manumissão e a assimilação dos ex-escravos como cidadãos. Essa tradição, condensada nas Siete Partidas - compilação do século XIII herdeira do Código de Justiniano e constituída sob os preceitos do cristianismo -, teria sido transmitida in totum pelos castelhanos para o Novo Mundo, beneficiando com seu viés franqueador os cativos trazidos d'África. Inversamente, a América britânica, desprovida de um sistema legal escravista previamente constituído, forjaria um regime violento, avesso à alforria e no qual os cativos seriam tratados meramente como gado ou bens móveis ${ }^{12}$.

O contraste assim desenhado sobre a importância da transmissão de princípios normativos informou nas duas décadas seguintes a realização de uma série de estudos comparativos acerca da escravidão e das relações raciais no continente americano ${ }^{13}$. No entanto, essa linha de estudos receberia críticas duríssimas já a partir dos anos 1960. Questionou-se a existência de uma discrepância tão acentuada entre o regime de escravidão britânico e o ibérico. Diversos historiadores e cientistas sociais, partindo de pesquisas empíricas fortemente influenciadas pelo materialismo histórico e pelo consequente descrédito do mito da democracia racial, apontaram o exagero de diferenças nacionais e a existência de uma unidade básica no fenômeno da escravidão no Novo Mundo. Em toda parte, os escravos estariam à mercê da vontade de seus senhores e sob o jugo perene da violência. Os eventuais distanciamentos seriam pontuais e decorrentes de condicionantes eminentemente materiais ${ }^{14}$.

\footnotetext{
${ }^{11}$ Frank Tannenbaum. Slave and Citizen: The Negro in the Americas. New York: Alfred A. Knopf, 1946.

12 Buscando romper com a escola racista norte-americana capitaneada por Ulrich Phillips e influenciado pelos trabalhos de Gilberto Freyre, Tannenbaumadvoga a tese de que as diferenças de cunho moral e legal existentes entre os regimes escravistas teriam dado o tom das relações interétnicas estabelecidas após a emancipação. Uma pretensa situação mais favorável encontrada pelos cativos nas possessões luso-hispânicas resultaria em um menor preconceito racial nos países latino-americanos. A sociedade racista e estratificada dos Estados Unidos seria decorrência de um regime bem mais severo e restritivo quanto aos "direitos" dos escravos.

${ }^{13}$ Cf. Stanley M. Elkins and Eric McKitrick. "Institutions and the Law of Slavery: The Dynamics of Unopposed Capitalism". American Quarterly, vol. 9, no. 1 (Spring, 1957), pp. 3-21; Idem. "Institutions and the Law of Slavery: Slavery in Capitalist and Non-Capitalist Cultures”. American Quarterly, vol. 9, n. 2, Part 1 (Summer, 1957), pp. 159-179; Stanley M. Elkins. Slavery. A Problem in American Institutional and Intellectual Life. Chicago: The University of Chicago Press, 1959; Herbert S. Klein. Slavery in the Americas. A Comparative Study of Cuba and Virginia. Chicago: The University of Chicago Press, 1967.

${ }^{14}$ Sidney Mintz. "Reviewed work: Slavery by Stanley M. Elkins".American Anthropologist, New Series, Vol. 63, No. 3 (Jun., 1961), pp. 579-587; Arnold A. Sio. "Interpretations of Slavery: The Slave Status in the Americas". Comparative Studies in Society and History, VII (1965), pp.289-308; Marvin Harris. Patterns of Race in the
} 
Do ponto de vista jurídico, multíplices aspectos foram observados criticamente: o papel exagerado atribuído aos textos legais como agentes de transformação social; a fundamentação rasa no tocante ao grau efetivo em que teria se verificado a transmissão da cultura legal; o predomínio dos interesses senhoriais e do fisco na elaboração das normativas; a evidente desconsideração de variáveis espaciais, temporais, econômicas e institucionais para o efetivo cumprimento das leis; o fato de, embora originárias de tradições distintas, tanto a legislação norte-americana quanto a de origem ibérica conceber os escravos simultaneamente como simples instrumentos e como seres humanos, a depender das circunstâncias; a existência de semelhanças marcantes na fundamentação de ações judiciais envolvendo escravos nas diferentes regiões; e assim por diante ${ }^{15}$. Conferindo maior relevo a fatores objetivos, demográficos sobretudo, o antropólogo Marvin Harris sustentou que tanto nos Estados Unidos quanto na América Latina, leis e realidade guardariam ínfima semelhança entre si; e que, não importando a profusão legislativa dos poderes centrais, in the lowlands, sugar was king ${ }^{16}$. Seguindo argumentação similar, Jacob Gorender sublinhou a inocuidade dos estatutos concernentes aos cativos: "no caso específico do Brasil, é suficiente tomar conhecimento da imensa legislação específica dedicada aos escravos (em parte, aos libertos) para evitar a tagarelice sobre igualdade, equidade e imparcialidade" ${ }^{17}$. Desse modo, para além do questionamento interpretativo, procedeu-se a depreciação mesma das fontes legais para o estudo do regime escravista.

Não obstante, a mencionada revisão da relação entre História e Direito incidiria também sobre os estudos da escravidão, especialmente a partir da década de 1980. O amparo dos mecanismos legais aos interesses dos senhores e do Estado deixou de ser a única forma de encarar o direito escravista. Para além do direito positivo formalmente em vigor (law in books), a ênfase dos inquéritos veio gradativamente residir no direito socialmente praticado (law in action), concretamente imiscuído na vivência dos atores sociais do mundo da escravidão. Não

\footnotetext{
Americas. Nova York: Greenwood Publishing Group, 1964; David B. Davis. "A contradição contínua da escravidão: uma comparação entre América Inglesa e a América Latina.”. In: O Problema da escravidão na cultura ocidental. (trad.port.). Rio de Janeiro: Civilização brasileira, 2001 [1966], pp.258-259; Eric Williams. British Historians and the West Indies. Port of Spain: PNM Publishing, 1966; Carl N. Degler, Neither White Nor Black: Slavery and Race Relations in Brazil and the United States.Madison: The University of Wisconsin Press, 1971.

${ }^{15}$ Para balanços recentes dessa discussão, ver: Keila Grinberg. "Alforria, direito e direitos no Brasil e nos Estados Unidos". Revista Estudos Históricos. Rio de Janeiro, n.28 (2001), pp.; Waldomiro Lourenço da Silva Júnior. A escravidão e a lei: a legislação escravista no Antigo Regime ibero-americano. São Paulo: Annablume/Fapesp, 2013, pp.10-18; Alejandro de la Fuente \& Ariela Gross. "Comparative Studies of Law, Slavery and Race in the Americas". University of Southern California Legal Studies Working Paper Series (February, 2010). Disponível em: 〈http://law.bepress.com/usclwps/lss/art56>. Acesso em: 04/06/2010.

${ }^{16}$ Harris. Patterns of Race in the Americas, p.76.

17 Jacob Gorender. A escravidão reabilitada. São Paulo: Ática, 1990, p.30.
} 
apenas a legislação foi tomada por um prisma dilatado e mais atento às instâncias locais, como também houve a ampliação do leque de elementos jurídicos assimilados como fontes. Além do que, novos sujeitos como advogados, magistrados, parlamentares, jurisconsultos e outros intermediários e agentes burocráticos foram trazidos à baila ${ }^{18}$. Tanto nos Estados Unidos quanto na América Latina, ocorreu uma proliferação maior de histórias da escravidão tomada de "baixo para cima”. Um número considerável de pesquisadores, refinando a compreensão acerca dos preceitos normativos formais, buscou devassar as estratégias utilizadas pelos escravos, o grau e a repercussão social da aplicação das leis, a incidência da interferência dos poderes institucionais e as oportunidades para a abertura de ações judiciais pró-cativos em localidades díspares, inclusive naquelas de utilização massiva da mão-de-obra. Com recortes espaciais e temporais variados, uma torrente de estudos agregou de modo mais ordenado textos legais, judiciais e cartoriais, reavaliando antigos problemas como a manumissão, as uniões matrimoniais e as barreiras raciais, e percorrendo campos pouco explorados como os aparelhos de controle, a constituição de redes de sociabilidade, negociação e clientela, a re-escravização de libertos e a garantia efetiva dos direitos de cidadania. Cada vez mais, o exame das formas pelas quais os escravos aproveitaram as brechas existentes nos sistemas jurídicos para criar e ampliar "direitos" ou fazer valer práticas costumeiras passou a ser alvo da dedicação dos historiadores ${ }^{19}$. Tal movimento foi seguido por uma parcela significativa da produção historiográfica brasileira, assumidamente influenciada pelos escritos de E. P. Thompson. No contexto do centenário da abolição, em contraposição ao referido posicionamento de $\mathrm{J}$. Gorender, pesquisadores como Silvia H. Lara e Sidney Chalhoub advogaram a vinculação entre o estudo da escravidão e do exercício das normas jurídicas com vistas ao exame da chamada

\footnotetext{
${ }^{18}$ De la Fuente \& Gross. Alejandro de la Fuente \& Ariela Gross. "Comparative Studies of Law, Slavery and Race in the Americas", pp.2-11. Norman Meiklejohn. "The Implementation of Slave Legislation in Eighteenth-Century New Granada". In: Robert Toplin (ed.). Slavery and Race Relations in Latin America. Westport: Greenwood Press, 1974.

${ }^{19}$ Arthur Howington. What Sayeth the Law: The Treatment of Slaves and Free Blacks in State and Local Courts of Tennessee.New York, Garland, 1986; Carlos Aguirre. Agentes de su propia libertad: los esclavos de Lima y la desintegración de la esclavitud, 1821-1854.Lima: Pontificia Universidad Católica del Perú, 1993; Manuel Lucena Salmoral. Sangre sobre piel negra: la esclavitud quiteña en el contexto del reformismo borbónico.Quito: Ediciones Abya-Yala, 1994;Judy Bieber Freitas, "Slavery and social life: in the attempts to reduce free people to slavery in the Sertão Mineiro, Brazil, 1850-1871”. Journal of Latin American Studies, v. 26, n. 3, 1994, pp.597-619; Christine Hünefeldt, Paying the Price of Freedom: Family and Labor among Lima's Slaves, 1800-1854.Berkeley: University of California Press, 1994; Thomas D. Morris. Southern slavery and lhe law, 1619-1860. Chapel Hill, University of North Carolina Press, 1996; Jane Landers. Black Society in Spanish Florida. Champaign: University of Illinois Press, 1999; María E. Díaz. The Virgin, the King, and the Royal Slaves of El Cobre: Negotiating Freedom in Colonial Cuba, 1670-1780.Stanford: Stanford University Press, 2000; Gloria García. Op.cit; Alejandro de la Fuente. "Slaves and the Creation of Legal Rights in Cuba: Coartación and Papel". Hispanic American Historical Review, vol.87, n.4 (Nov. 2007), pp.659-92.
} 
agência escrava ${ }^{20}$. Desde então, a historiografia da escravidão no Brasil vem produzindo, com o aporte de fontes jurídicas, um expressivo conjunto de pesquisas acerca do cotidiano das relações escravistas, especialmente sobre o período do século XIX. O protagonismo social das vítimas do cativeiro se cristalizou como objeto essencial de muitos pesquisadores, que encontram em processos-crime, inventários, testamentos, cartas de alforria e toda sorte de litígios e demandas judiciais um rico manancial para descortiná-lo. Por conta disso, nos dias atuais, é possível acessar uma volumosa produção acadêmica que vem se valendo de elementos vários do campo do Direito para compreender o fenômeno da escravidão nas diversas partes do continente americano, inclusive no Brasil ${ }^{21}$.

Por outro, é possível notar a existência de certas lacunas ou deficiências, as quais, no plano mais geral, residem na redução excessiva do escopo das investigações e na ausência de estudos comparativos. Assim como em diversos outros ramos da produção historiográfica, verifica-se nos estudos da escravidão com aporte a fontes do Direito uma hipertrofia temática, cronológica e espacial. As críticas contra a vertente encabeçada por Tannenbaum acarretaram um nítido prejuízo à elaboração de análises que estrapolassem os limites das histórias nacionais $^{22}$. A retomada de textos jurídicos pelas gerações mais recentes da historiografia da escravidão tem se mantido demasiadamente presa a recortes regionais, em especial no que tange a produção acadêmica brasileira ${ }^{23}$. Mais do que o esclarecimento acerca de convergências e discrepâncias havidas entre os territórios escravistas, perde-se a chance de esmiuçar

\footnotetext{
${ }^{20} \mathrm{O}$ conflito de gerações foi evidenciado em debate bastante intenso divulgado nas páginas do jornal Folha de São Paulo entre novembro de 1990 e janeiro de 1991, a partir da resenha escrita por Chalhoub a respeito da obra $A$ escravidão reabilitada, de Jacob Gorender:A escravidão reabilitada. São Paulo: Ática, 1990; Sidney Chalhoub. "Gorender põe etiquetas nos historiadores". Folha de São Paulo, Caderno Letras 24/11/1990, p.H-7; Jacob Gorender. "Como era bom ser escravo no Brasil". Folha de São Paulo, Caderno Letras 15/12/1990; Silvia Hunold Lara. "Gorender escraviza a história". Folha de São Paulo, Caderno Letras 12/01/1991. Cf. Silvia Hunold Lara. "Escravidão no Brasil: um balanço historiográfico". LPH - Revista de História, v.3, n.1 (1992), pp.215-244.

${ }^{21}$ Sílvia H. Lara. Campos da Violência: escravos e senhores na Capitania do Rio de Janeiro, 1750-1808. Rio de Janeiro: Paz e Terra, 1988; Sidney Chalhoub. Visões da Liberdade. Uma história das últimas décadas da escravidão na Corte.São Paulo: Companhia das Letras, 1990; Keila Grinberg. Liberata, a lei da ambigüidade. As açães de liberdade da corte de Apelação do Rio de Janeiro no século XIX. Rio de Janeiro: Relume-Dumará, 1994; Maria Helena P. T. Machado. O plano e o pânico: os movimentos sociais na década da abolição. São Paulo: EDUSP, 1994; Flávio dos Santos Gomes. Histórias de quilombolas: mocambos e comunidades de senzalas no Rio de janeiro, século XIX. Rio de Janeiro: Arquivo Nacional, 1995; Maria C. Cortez Wissembach. Sonhos africanos, vivências ladinas: escravos e forros em São Paulo, 1850-1880. São Paulo: Hucitec, 1998; Hebe Maria Mattos. Das cores do silêncio: os significados da liberdade no sudeste escravista. Rio de Janeiro: Nova Fronteira, 1998; Robert Slenes. Na senzala, uma flor: esperanças e recordações na formação da família escrava - Brasil Sudeste, séc. XIX. Rio de Janeiro Nova Fronteira, 1999; Joseli Mendonça. Entre a mão e os anéis: a lei dos sexagenários e os caminhos da abolição no Brasil. Campinas: Editora Unicamp, 1999; Elciene Azevedo. Orfeu de carapinha: a trajetória de Luiz da Gama na imperial cidade de São Paulo. Campinas: Editora Unicamp, 1999; Enidelce Bertin. Alforrias na São Paulo do Século XIX: liberdade e dominação. São Paulo: Humanitas, 2004.

${ }^{22}$ Silva Júnior. A escravidão e a lei..., pp.19-35.

${ }^{23}$ Keila Grinberg. "Alforria, direito e direitos no Brasil e nos Estados Unidos". Estudos Históricos, n. ${ }^{\circ} 28$ (2001), p.64.
} 
intersecções e sincronismos entre fenômenos constituídos de elementos associados a múltiplos nexos e temporalidades ${ }^{24}$.

Mais recentemente, é importante reconhecer, vêm sendo desenvolvidas análises abarcadoras de diferentes territórios nacionais imbricando o estudo da escravidão a elementos do universo jurídico, com destaque para problemáticas concernentes ao acesso à liberdade. Entretanto, o foco dos trabalhos nesse sentido tem estado circunscrito ao campo da microanálise ${ }^{25}$. Como observam De la Fuente e Gross, "progressivamente, historiadores do Direito estão escrevendo a partir de perspectivas comparativas e transnacionais, mas, eles têm se eximido de grandes comparações, em parte porque muitos têm optado pela forma da microhistória" 26 . Com efeito, existe uma carência de estudos com abordagens mais amplas, que promovam a amarração entre as experiências locais e particulares do mundo da escravidão aos macrofenômenos políticos e econômicos. Não se trata de negligenciar as contribuições trazidas pelas pesquisas locais ou realizadas em escala reduzida, mas, antes, de articular seus resultados mais proeminentes para a obtenção de respostas sobre a velha questão da relação entre estrutura e agência, e que, ao mesmo tempo, escapem de perspectivas deterministas, seja do global sobre particular, seja do particular sobre o global $^{27}$.

O que está colocado é o velho impasse sobre como integrar os diversos níveis que compõe o processo histórico, articulando as experiências individuais ao contexto mais amplo, ao quadro sistêmico, à estrutura. Não se trata de substituir o processo pela estrutura, tampouco de reduzir a análise a rés do chão, mas de compreender os extremos como integrantes de um processo estruturado (o escravismo oitocentista), inserido por sua vez em um processo maior (o sistema capitalista). Em seu comentário sobre o pensamento de Louis Althusser, em $A$ miséria da teoria, Thompson, ao considerar questões mais gerais, acena exatamente nessa direção, destacando que a crítica ao estruturalismo e ao determinismo histórico não pode ser confundida com a execração das noções de estrutura ${ }^{28}$ e de determinação. Esta última, por sinal,

\footnotetext{
${ }^{24}$ Márcia Berbel, Rafael Marquese e Tâmis Parron. Escravidão e Política: Brasil e Cuba, c. 1790-1850. São Paulo: Hucitec, 2010.

${ }^{25}$ Camillia Cowling. Matrices of Opportunity: Women of Colour, Gender and the Ending of Slavery in Rio de Janeiro and Havana, 1870-1888. Tese de Doutorado - University of Nottingham/Doctor of Philosophy, (Novembro 2006); Edlie L. Wong. Neither Fugitive nor Free: Atlantic Slavery, Freedom Suits, and the Legal Culture of Travel. New York: NYU Press, 2009; Rebecca Scott. "Émigrés, enslavement, and the 1808 Louisiana Digest of the Civil Laws". Tulane European and Civil Law Forum. n.24, 2009.

${ }^{26}$ Alejandro de la Fuente \& Ariela Gross. "Comparative Studies of Law, Slavery and Race in the Americas", p.18.

${ }^{27}$ Idem, p.26.

${ }^{28}$ Como destaca o autor, "logo que falamos sobre 'organização' (ou 'organismo'), sobre 'sistema', sobre as 'leis' da oferta e procura, ou sobre 'instituições' (e sobre 'funcionários'), estamos falando de estrutura, e provavelmente também estaremos falando sobre as maneiras pelas quais o comportamento humano é regulado, ordenado, limitado e determinado".E. P. Thompson. A miséria da teoria ou um planetário de erros: uma crítica ao pensamento de Althusser. (trad.port.). Rio de Janeiro: Zahar Editores, 1981, p.164.
} 
parece-lhe um conceito-chave, devendo ser compreendido nos "sentidos de 'estabelecer limites', 'exercer pressões', e de definir 'leis de movimentos' como 'lógica do processo'29. Desse modo, o problema efetivo não se encontra na incorporação da estrutura à análise, mas na anulação da "referência material" e de "qualquer espaço para a iniciativa ou criatividade da massa do povo", que se realiza apesar das pressões e dos limites impostos, e mesmo a partir deles $^{30}$. Em seu livro sobre a rebelião de Demerara, a historiadora Emilia Viotti da Costa demonstra ser factível trabalhar sob esta perspectiva ao redor do tema da escravidão, cravando que fora do "contexto mais amplo, seria impossível compreender a sublevação dos escravos, as ações dos missionários e as reações dos colonizadores", destacando ao mesmo tempo em que “os escravos se apropriaram de símbolos cujo propósito original era sujeitá-los, e converteramnos em instrumentos de sua emancipação. Nesse processo, não apenas transformaram a si mesmos como transformaram todos a sua volta e ajudaram a traçar o curso da história" 31 . Concordando com esta afirmação, é necessário levar em conta, igualmente, que o curso da história traçado com a participação dos subalternos nem sempre é tão transgressor quanto gostaríamos; que as ações criativas em prol, por exemplo, do rompimento dos laços privados de escravidão, muitas vezes tinham um alcance restrito. Em massa, tais ações realmente podiam gerar melhorias e concorrer para a validação de muitos direitos, mas, as suas repercussões não chegavam a ser efetivamente revolucionárias, convivendo com a lógica dominante do sistema de dominação e exploração.

Com efeito, a condução do discurso tem como norte a recomposição analítica dessa articulação entre o geral e o particular. A inspiração, do ponto de vista metodológico, é a proposta de variação de escalas feita no âmbito da micro-história, sem desempenhar um procedimento propriamente microanalítico em moldes usuais. Há pelo menos duas posições divergentes entre os micro-historiadores, as quais encontram-se expressas no livro Jogos de escalas: a experiência da microanálise, coletânea de textos sobre o tema organizada por Jacques Revel ${ }^{32}$. De um lado, identifica-se a posição "fundamentalista", cujos signatários, largamente influenciados pela obra do antropólogo norueguês Fredrik Barth, distinguem uma hierarquia causal do particular sobre o global, isto é, apregoam que "na produção das formas e das relações sociais, o ‘micro' engendra o ‘macro' e defende[m] portanto um privilégio absoluto

\footnotetext{
${ }^{29}$ Idem, p. 176.

${ }^{30}$ Idem, p. 205.

${ }^{31}$ Emilia Viotti da Costa. Coroas de glória, lágrimas de sangue: a rebelião dos escravos de demerara em 1823. (trad.port.). São Paulo: Cia das Letras, 1998, p.17.

32 Idem, ibidem.
} 
do primeiro"33. Do outro lado, identifica-se a posição "relativista", encampada pelos que enxergam "no princípio da variação de escala um recurso de excepcional fecundidade, porque possibilita que se construam objetos complexos e, portanto que se leve em consideração a estrutura folheada do social. Ela afirma ao mesmo tempo em que nenhuma escala tem privilégio sobre a outra, já que é o seu cotejo que traz o maior benefício analítico" ${ }^{34}$. Evidentemente, a opção feita aqui é pela segunda vertente, variando, principalmente, entre a escala que envolvia o processo político associado à produção legislativa e aquela que permeava os litígios judiciais envolvendo a liberdade dos escravos. A temporalidade dos fatores envolvidos também será levada em consideração.

Como sabemos, Fernand Braudel discerne sobre a existência de uma dialética entre três níveis temporais na compleição da totalidade histórica, a saber, a longa duração, a conjuntura e o acontecimento ${ }^{35}$. O ponto de vista crítico compartilhado pelos adeptos da micro-história se baseou muito no juízo de ter havido uma apreensão desproporcional e, por decorrência, limitadora das duas primeiras dimensões - as tendências longas (de ritmo estável e desacelerado, associado a configurações geo-históricas) e as de média duração (movimentos cíclicos vinculados a configurações socioeconômicas regulares e, portanto, passíveis de quantificação) - em relação à terceira. Ainda assim, o historiador Dale Tomich indica uma espécie de via conciliatória entre a perspectiva micro-histórica e a concepção de tempo plural que parece bastante pertinente aos presentes fins ${ }^{36}$. Ele defende que as escalas, instâncias ou objetos ímpares revelados pelos estudos microanalíticos não deixam de ser permeados por fatores históricos globais. Não se trata de tomar um background externo ao qual a atuação dos sujeitos históricos estaria hierárquica e integralmente subsumida, mas de articular elementos constituídos em ritmos de tempo variados, estruturando dialeticamente o raio de ação dos sujeitos. Em suas palavras, "tais instâncias são espaciais e temporalmente densas, complexas e pontos multifacetados de convergência, confluência e concentração de múltiplas temporalidades" ${ }^{37}$. Esta percepção se adéqua muito bem à prática do cativeiro e ao repertório normativo correspondente, que respondiam a temporalidades bastante variadas. Nesse mesmo sentido, Pior Sztompka escreveu que "a natureza processual da sociedade implica fases

\footnotetext{
${ }^{33}$ Jacques Revel (org.). Jogos de escalas: a experiência da microanálise. (trad.port.). Rio de Janeiro: FGV, 1998, p.14.

${ }^{34}$ Idem, ibidem.

${ }^{35}$ Fernand Braudel. "História e Ciências Sociais: a Longa Duração". In: Escritos sobre a história. (trad.port.). São Paulo: Perspectiva, 2005.

${ }^{36}$ Dale Tomich. "A Ordem do Tempo Histórico: a Longue Durée e a Micro-História". Almanack. Guarulhos, n.02, ( $2^{\circ}$ semestre de 2011), 38-51.

${ }^{37}$ Idem, p.56.
} 
anteriores ligadas por vínculos causais à fase presente, por sua vez portadora das condições causais determinantes da fase seguinte" e que "a sociedade não é uma entidade, é um conjunto

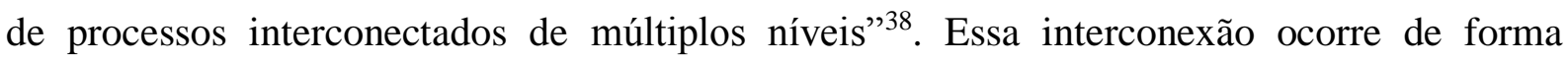
dinâmica, combinando aspectos materiais e simbólicos constituídos na longa duração e rearticulados por intercorrências conjunturais e episódicas. Por esta chave deve ser lida a escravidão no Império do Brasil e na colônia espanhola de Cuba no longo do século XIX, isto é, como um fenômeno marcado por processos interconectados com continuidades relevantes (hierarquias sociais, práticas econômicas variadas, tradições culturais e jurídicas) e modificações fundamentais (reordenamento do regime político e do sistema produtivo ante aos câmbios havidos na economia mundo capitalista e na política internacional).

A tese é composta por três capítulos. O primeiro deles, Brasil, Cuba e a reestruturação sistêmica da escravidão, tem por finalidade reconstituir o quadro mais amplo de reestruturação da economia-mundo capitalista e do escravismo atlântico, a partir da Guerra dos Sete Anos. Apesar da coerência reconhecida ao conceito delineado por Dale Tomich, ainda se fazia necessário refinar um pouco mais certos aspectos que envolveram o novo arranque da prática da escravidão para ter clareza sobre as suas repercussões sobre a regulação do tráfico e da alforria. Em Cuba as respostas foram exprimidas em alterações legislativas mais evidentes, enquanto no Brasil verificou-se uma reinvenção da antiga tradição. Na sequência, seguem-se dois capítulos espelhados, um sobre o Brasil, O direito escravista do Império do Brasil, 18231871, e outro sobre Cuba, $O$ direito dos escravos e o escravismo hispano-cubano, 1820-1870, que buscam propiciar uma visão de conjunto a respeito da evolução das relações entre direito, comércio negreiro, escravidão e alforria ao longo do período. Apesar da vinculação a uma mesma estrutura econômica mundial e da base comum de origem romana dos respectivos ordenamentos jurídicos, as diferenças essenciais em seus arranjos políticos internos, os traços específicos culturais que orientaram a regulação do cativeiro naqueles espaços e a variação ocorrida quanto ao prolongamento do tráfico transatlântico imprimiram traços específicos à articulação entre direito e escravidão no Brasil e em Cuba. No epílogo do trabalho é efetuado um exame breve sobre o momento de ruptura do quadro jurídico escravista representado pelas leis de liberação do ventre. As fontes primárias utilizadas variaram entre textos legislativos, debates parlamentares e jurídicos, doutrina e ações cíveis envolvendo a liberdade de escravos. A partir desta última documentação de natureza judicial se procede a redução da escala de observação para a apreensão da dinâmica social que envolvia o acesso aos ramos do judiciário

\footnotetext{
${ }^{38}$ Piotr Sztompka. A sociologia da mudança social. Rio de Janeiro: Civilização Brasileira, 2005, p.111.
} 
na luta pela liberdade. Para tanto, foi efetuado um encurtamento do perímetro especial, abarcando as jurisdições do Rio de Janeiro e de Havana. Em função da dilatação do recorte temporal não foi possível realizar uma análise exaustiva em termos quantitativos dos processos judiciais. O procedimento consistiu na análise qualitativa de demandas judiciais, considerando, para a composição do discurso, uma amostragem média de menos quatro ações por década. ${ }^{39}$

${ }^{39}$ Esta versão da tese passou por algumas correções por indicação da banca, que foi composta pelos professores Andrea Slemian, Beatriz Mamigonian, Keila Grinberg e Leonardo Marques. Agradeço muito pelas leituras atentas e pelas excelentes arguições. Os seus comentários serão de grande valia para a contunidade do trabalho. 


\section{Capítulo 1}

\section{Brasil, Cuba e a reestruturação sistêmica da escravidão}

A prática da escravidão no Novo Mundo foi fortemente impactada pelas transformações que permearam a consolidação da hegemonia britânica no sistema-mundo moderno no período que se seguiu à Guerra dos Sete Anos (1756-1763). Com a decorrente reestruturação da divisão internacional do trabalho, foram criadas as condições para o declínio do cativeiro nas regiões tradicionais e para a sua expansão revigorada por áreas até então periféricas, mais especificamente, o sudeste do Brasil, o ocidente de Cuba e o sul dos Estados Unidos. Essa nova onda de exploração do trabalho escravo assumiu um arranjo sistêmico original, distinto, basicamente, pelo aumento da produtividade do trabalho cativo e pela sua integração ao cerne da produção industrial, que se revolucionava. Para se referir a esse fenômeno, o historiador norte-americano Dale Tomich cunhou a categoria segunda escravidão $o^{40}$. No entanto, como o seu emprego se refere às zonas de plantation, sucedem algumas dúvidas a respeito de seu alcance quando se leva em consideração variadas relações de escravidão em convívio, pensando-se nos traços específicos do serviço doméstico, da escravidão urbana e do trabalho no campo em regiões menos dinâmicas em termos econômicos.

O primeiro aspecto a ser observado é o de que, ao se trabalhar com uma categoria como esta, parte-se do entendimento de que é possível ampliar a inteligibilidade sobre as experiências humanas a partir da recomposição de sua inserção em um campo sistêmico de possibilidades objetivamente constituído. Foi o que Fernand Braudel buscou desenvolver ao acenar para a especificidade do emprego da noção de estrutura em história, no conhecidíssimo artigo "História e ciências sociais: a longa duração", publicado originalmente em 1958. Ali, o historiador francês argumentou que as estruturas descrevem ao mesmo tempo, apoios e obstáculos; parâmetros envolventes estabelecidos por excelência na longa duração, providos de um caráter concreto, cronologicamente preciso, histórico propriamente. Àquela altura, o que estava em jogo era escapar da abstração pertinente ao estruturalismo, ou mais precisamente à antropologia estrutural encabeçada por Claude Lévi-Strauss, aproximando, de modo dinâmico, na multiplicidade dos tempos, a superfície dos acontecimentos, o indivíduo, o tempo breve ao profundo, ao estrutural, à totalidade. Ao final, expressando compartilhar do entendimento de Jean-Paul Sartre a respeito de que ainda havia o que ser dito sobre a biografia de personagens como Flaubert ou Tintoretto, indo de encontro a uma certa tradição marxista afeita

\footnotetext{
${ }^{40}$ Dale W. Tomich. Through the Prism of Slavery. Labor, Capital, and World Economy. Boulder, Co.: Rowman \& Littlefield Publ., 2004, pp.56-71.
} 
unilateralmente a grandes modelos, Braudel acrescentou que estaria ainda mais de acordo "se a ampulheta fosse invertida nos dois sentidos: primeiro do acontecimento para a estrutura e depois das estruturas e dos modelos para o acontecimento" ${ }^{41}$. Desse modo, delineia-se uma perspectiva holista e dialética, que abarca a conexão das duas extremidades, do instantâneo para a longa duração, e vice-versa ${ }^{42}$.

O grande ganho a ser extraído da categoria elaborada por Dale Tomich é justamente o emprego de uma tal perspectiva holística e dialética às relações de escravidão. A sua adoção, porém, não deve constituir uma amarra, no sentido de que todo o exercício discursivo e analítico estaria pré-condicionado a demonstrar a sua manifestação ou determinação indelével em todos os instantes, em todos os lugares, em todas ações. Isto seria um equívoco. Dois aspectos elementares e interligados devem ser levados em consideração. O primeiro é o de que as regiões alavancadas no processo de materialização da nova onda escravista, embora tenham sido impactadas por modificações sistêmicas, dispunham de um repertório de normas, costumes e valores herdados do convívio pregresso com a instituição do cativeiro, o qual se faria sentir de modo mais ou menos vívido e persistente a depender dos atores envolvidos e do contexto: se rural ou urbano, se periférico ou central ao que se poderia chamar de zona direta da segunda escravidão.

O segundo aspecto a ser observado é que no interior de uma ordem socioeconômica dada nem todas as práticas estão diretamente ligadas à atividade econômica principal, isto é, àquela que gera a reprodução do capital em ritmo mais intenso. Novamente, o trabalho de Braudel indica o caminho. Ao analisar a arquitetura do capitalismo na era pré-industrial, o historiador observa que as atividades que o distinguiam, isto é, aquelas que promoviam a geração de lucros extraordinários (grandes feiras, bolsas de valores), constituíam estágios superiores que não envolviam, em absoluto, o conjunto das práticas econômicas; estas coexistiam com mecanismos rudimentares de produção da vida material, ligados ao consumo imediato, de circulação restritíssima, e com atividades ordinárias da economia de mercado que não encerravam em si as mesmas práticas capitalistas ${ }^{43}$.

\footnotetext{
${ }^{41}$ Fernand Braudel. "História e ciências sociais: a longa duração". In: Escritos sobre aHistória. Lisboa: Editorial Presença, 1990, p.37.

42 Antonio Penalvez Rocha. "Braudel: Tempo Histórico e Civilização Material - Um Ensaio Bibliográfico". Anais do Museu Paulista. História e Cultura Material, São Paulo (1996), v. 3, p. 239-231; Dale Tomich. "A Ordem do Tempo Histórico: a Longue Durée e a Micro-História". Almanack, Local de publicação (editar no plugin de tradução o arquivo da citação ABNT), n.2, nov. 2011. Disponível em: $<$ http://www.almanack.unifesp.br/index.php/almanack/article/view/746>. Acesso em: 23 Aug. 2012.

${ }^{43}$ Para a síntese do argumento, ver a introdução do primeiro dos três volumes: Fernand Braudel. Civilização Material, Economia e Capitalismo, séculos XV-XVIII. V.1. As estruturas do cotidiano: o possível e o impossível. São Paulo: Martins Fontes, 1995, pp.11-14.
} 
Assim, também, nem todas as relações de escravidão constituídas no Brasil e em Cuba no decorrer do longo século XIX estavam na ponta de lança da produção agroexportadora. Era possível encontrar no campo condições de infraestrutura, modos de trabalho e de vida, padrões de propriedade e de posse bastante variáveis. A noção de que coexistiam modalidades distintas de exploração do trabalho escravo em convívio (o que está longe de ser novidade na historiografia) de modo algum pode acarretar a presunção de que havia uma espécie de impermeabilidade. Todas elas integravam uma mesma dinâmica, cujos componentes de forma mais ou menos direta, intensa e imediata sofriam o empuxo do sistema capitalista e das pressões que partiam de seu campo hegemônico. A incidência do processo econômico majoritário e da articulação política e legislativa correspondente podia ocorrer de diversas maneiras sobre as atividades escravagistas secundárias, sustentando o seu patamar periférico ou dilapidando-as em favor do centro.

\section{Disputas hegemônicas, caos sistêmico e revolução}

Nesta seção do capítulo será feita exposição sobre a unidade de análise da presente investigação, isto é, o campo maior no qual a unidade de observação (as articulações entre direito civil, escravidão e liberdade) esteve inserida ${ }^{44}$. Como mencionado acima, a construção da hegemonia britânica sobre a economia-mundo capitalista envolveu profundas transformações na dinâmica de reprodução do capital, na divisão internacional do trabalho, no padrão de demanda dos mercados e na configuração geopolítica do espaço atlântico. No bojo desse processo, foram criadas as condições para o desenvolvimento renovado da escravidão em áreas até então na periferia do escravismo atlântico, ao mesmo tempo que emergiu e ganhou força um movimento político sistemático contrário à instituição ${ }^{45}$. A compreensão da maneira como tais transformações afetaram Brasil e Cuba demanda um exame, ainda que sucinto, do conjunto mais amplo das relações internacionais no contexto no qual o controle do sistema ainda estava em disputa.

Como é de amplo conhecimento, a expansão econômica ocorrida ao longo dos Setecentos acirrou novamente as disputas pela supremacia comercial no globo. França e

\footnotetext{
44 Earl Babbie. The Practice of Social Research. Fifth Edition. Belmont: Wadsworth Publishing, 2010, p.102; Ahmet Nuri Yurdusev, "Level of Analysis and Unit of Analysis: A Case for Distinction". Millennium: Journal of International Studies, v.22, n.1 (Spring 1993), pp.77-88.

${ }^{45}$ Dale W. Tomich. Through the Prism of Slavery. Labor, Capital, and World Economy. Boulder, Co.: Rowman \& Littlefield Publ., 2004, pp.56-71.
} 
Inglaterra, cujas bases materiais haviam se engrandecido a partir de uma articulação bemsucedida entre o colonialismo escravista e o nacionalismo econômico, firmaram-se como as duas grandes potências antagônicas. Contudo, a força de suas atividades comerciais foi concentrada em terrenos distintos. Enquanto os franceses dominaram com certa folga os mercados internos da Europa, os ingleses assumiram o controle das trocas coloniais, penetrando extensivamente no espaço de seus competidores. Para tanto, a posição de fragilidade das antigas potências ultramarinas no desenrolar da Guerra de Sucessão Espanhola (1702-1714) foi crucial. Os termos do chamado Tratado de Methuen, assinado em 1703, no instante da adesão lusa à Grande Aliança, e a obtenção do asiento para a introdução de africanos escravizados nas Índias espanholas, em meio às tratativas de paz de Utrecht, são fatores que explicam o primado alcançado pelos britânicos durante a primeira metade do século, ao lado, é claro, da intensificação de práticas contrabandistas (comércio interlope) e da exploração de suas próprias colônias. A seu favor contava, ainda, a transferência vultosa de capitais provenientes das Províncias Unidas. Na bolsa de Amsterdã, os fundos ingleses, com os juros elevados garantidos pelo Parlamento londrino, constituíam os investimentos mais lucrativos e, logo, os mais apreciados, em relação, inclusive, aos fundos holandeses. A consequência era a injeção vantajosa de créditos no Estado, nos bancos e nas companhias comerciais da Inglaterra, conferindo-lhe considerável superioridade competitiva em relação à França ${ }^{46}$.

Após quase três décadas de acomodação, a rivalidade anglo-francesa voltou a se manifestar no plano bélico. No conflito envolvendo a Sucessão da Áustria (1740-1748), os franceses, junto aos espanhóis, apoiaram as pretensões de Frederico II, da Prússia, enquanto os britânicos, junto aos holandeses, se colocaram a favor de Maria Teresa, herdeira de Carlos VI, indicada ao trono na Pragmática Sanção assinada ainda em 1713; Portugal, embora já bastante dependente do suporte inglês, conseguiu preservar a sua neutralidade. Iniciados os enfrentamentos, o teatro de operações extravasou o solo europeu, atingindo o mundo colonial. A cidade de Louisbourg, no Cabo Breton, ponto estratégico situado na foz do Rio São Lourenço, foi tomada pelos britânicos em 1745. No ano seguinte, Madras, zona portuária indiana controlada pela East India Company, caiu diante das tropas de Luis XV. As batalhas persistiram até a assinatura do Tratado de Aix-la-Chapelle, em outubro de 1748, que foi pautado pelo

\footnotetext{
${ }^{46}$ Fernand Braudel. Civilização Material, Economia e Capitalismo, Séculos XV-XVIIII. Volume 3. O Tempo do Mundo. (Trad. port.). São Paulo: Martins Fontes, 1998, pp.238-240; Fernando A. Novais. Portugal e Brasil na crise do Antigo Sistema Colonial (1777-1808). (1 $1^{\mathrm{a}}$ ed., 1979). São Paulo: Hucitec, 2006, p.52; Immanuel Wallerstein. The modern world-system III - the second era of great expansion of the capitalist world-economy, 1730-1840s. Nova York: Academic Press, 1989, pp.53-71; Giovanni Arrighi. O longo século XX: dinheiro, poder e as origens de nosso tempo. (trad.port.) Rio de Janeiro: Contraponto/Ed.Unesp, 1996, pp.45-58; 163-179.
} 
princípio de restituição mútua das conquistas ${ }^{47}$. No entanto, a situação estava longe de ser resolvida. Afora o descontentamento gerado pela devolução das terras conquistadas, pesava contra a paz a conservação do choque de interesses austro-prussianos, notadamente em torno da região da Silésia, bem como a tensão competitiva associada à crescente importância econômica do comércio atlântico ${ }^{48}$.

O que se promoveu em Aix-la-Chapelle foi, portanto, uma trégua. A paz armada estabelecida na sequência se desfez menos de uma década depois. Atritos ocorridos na América do Norte entre britânicos, franceses e aliados autóctones, deram origem a uma nova guerra. A tomada de Louisbourg nas pugnas anteriores havia deixado evidente à França a fragilidade de suas possessões na região. Na década de 1750, colonizadores franceses, com apoio indígena, ergueram diversas fortificações contíguas ao rio Ohio até o Mississipi a fim de romper com o isolamento de seus assentamentos, ampliando o suporte militar. Em reação a esse avanço, em 1755, os britânicos capturaram cerca de trezentos navios de bandeira francesa, além de enviar uma força expedicionária liderada pelo general Edward Braddock ao Forte Duquesne, na atual cidade de Pittsburgh. No começo de 1756, após a recusa de reparação, tropas francesas ocuparam a ilha de Minorca, no Mediterrâneo, então controlada pelos rivais. Em maio daquele ano, a guerra, em pleno andamento, era formalmente declarada entre as duas grandes potências $^{49}$. Foi o início do que viria a ser chamado de Guerra dos Sete Anos (1756-1763), primeiro conflito de proporções efetivamente mundiais, cujos resultados alteraram significativamente o curso do sistema-mundo moderno.

Na Europa, a rede de alianças já vinha sendo costurada. O Tratado de Westminster consumou a aproximação da Inglaterra com o antigo inimigo Frederico II, enquanto a França selou em Versalhes um compromisso de apoio mútuo com a Áustria. Era a chamada inversão de alianças. Um segundo Tratado de Versalhes, firmado em 1757, agregou a Rússia e a Suécia à união franco-austríaca. Com o Terceiro Pacto de Família, de 1761, o primeiro ministro Choiseul conseguiu o apoio da Espanha, que também via o seu império ameaçado pelos progressos britânicos. No entanto, o poderio econômico e militar dos ingleses se mostraria mais efetivo do que a coalizão mais numerosa de seus inimigos. Na passagem para a década seguinte, a Inglaterra já havia tomado praticamente toda a parte francesa da América do Norte e avançava

\footnotetext{
${ }^{47}$ Jack M. Sosin. "Louisburg and the Peace of Aix-la-Chapelle, 1748". The William and Mary Quarterly, Third Series, Vol. 14, No. 4 (Oct., 1957), pp. 516-535.

${ }^{48}$ Fernando A. Novais. Portugal e Brasil na crise do Antigo Sistema Colonial..., pp.17-47; Immanuel Wallerstein. The modern world-system III..., p.68.

${ }^{49}$ George Moir Bussey \& Thomas Gaspey. A History of France and of the french people. Vol. II. Londres: W. S. O. and Co., Amen Corner, Peternoster Row, 1850, pp.563-461; Arthur R. Ropes. " The Causes of the Seven Years' War”. Transactions of the Royal Historical Society, New Series, Vol. 4 (1889), pp. 143-170.
} 
sobre as Índias Orientais e o mar do Caribe, ao mesmo tempo em que financiava a recuperação das tropas prussianas nos campos europeus ${ }^{50}$.

Tendo em vista os interesses específicos da presente investigação, é preciso observar que, em maio de 1760, Carlos III havia encaminhado uma missão especial ao seu embaixador em Londres para tratar das diferenças entre as duas monarquias. No mês de setembro, o conde de Fuentes, então ocupante do cargo, apresentou dois memoriais exibindo as demandas de seu país sobre os direitos de pesca em Terra Nova (Newfoundland) e os estabelecimentos ingleses no golfo de Honduras. O tom peremptório impresso nos documentos e nas atitudes do emissário, que anunciava aos quatro ventos que os franceses aguardavam pela resolução da questão, indicava claramente aos ingleses que a Espanha estava a ponto de fazer causa comum com a França, em prol da garantia de seus interesses coloniais. William Pitt, o poderoso ministro da guerra britânico, embora tenha dado um primeiro sinal de boa vontade, emitindo ofício avesso ao corso sobre embarcações espanholas, despachou réplica negativa ante às reivindicações pertinentes ao primeiro tema, delongando o parecer acerca do segundo. As tratativas, já ardilosamente postergadas, foram um pouco mais embaraçadas pelo processo de sucessão monárquica resultante da morte do rei Jorge II, ocorrida em outubro. Na entrada do ano seguinte, dilatada a segurança sobre a sua superioridade militar, os britânicos jogaram uma pá de cal sobre as reivindicações espanholas, negando-as por completo ${ }^{51}$.

Em janeiro de 1761, o governo espanhol, em alarme, enviou a Cuba um novo governador, Juan de Prado Portocarrero, levando consigo tropas adicionais e ordens para que as defesas fossem reforçadas de modo que se pudesse resistir a um possível ataque dos ingleses. Sabia-se que a importância comercial e geopolítica da ilha tornava-a um alvo em potencial ${ }^{52}$. Ao mesmo tempo, foram aceleradas as conversações com os franceses, que desde o início da guerra cortejavam Madri com a proposta de uma nova aliança de família, oferecendo Minorca, uma de suas raras conquistas, e auxílio para a retomada de Gibraltar. Em fevereiro, chegava em

\footnotetext{
${ }^{50}$ Karl W. Schweizer. England, Prussia, and the Seven Years War: Studies in Alliance Policies and Diplomacy. Nova York: Edwin Mellen Press, 1989, pp.83-120; John Shy. "The American Colonies in War and Revolution, 1748-1783". In: P.J.Marshall (ed.). The Oxford History of British Empire. Vol. II - The Eighteenth Century. Nova York: Oxford University Press, 1998, pp.305.

${ }^{51}$ Francis Thackeray. A history of the Right Honorable William Pitt. Vol. II. Londres: R. Gilbert, 1827, pp.486495; William Stanhope Taylor \& John Henry Pringle (eds.).Correspondence of William Pitt, Earl of Chatham. Vol. II. Londres, John Murray, 1838, pp.30-95; Julian S. Corbett. England in the Seven Years' War. A study in combined strategy. Vol. II. Londres: Longmans, Green, and Co., 1907, pp.97-153; Frank Edgar Melvin. Pitt's Spanish Policy in 1761. The University of Kansas Pre-1923 - Dissertations and Theses Collection, 1909, pp.3042; Diego Téllez Alarcia. "Guerra y regalismo a comienzos del reinado de Carlos III: el final del ministerio Wall". Hispania, LXI/3, núm. 209 (2001), pp.1051-1090.

${ }^{52}$ Ramiro Guerra y Sanchéz. Manual de Historia de Cuba ( ${ }^{\text {a }}$ ed.: 1938). Havana: Editorial de Ciencias Sociales, 1971, p.154-155; Manuel Moreno Fraginals. Cuba/Espanha, Espanha, Cuba. (Trad. port.). Bauru: Edusc, 2005, p.151-153.
} 
Paris o marquês de Grimaldi, representante encarregado de conduzir o diálogo com Choiseul. Mas o acerto não se deu imediatamente, pois, interpunham-se, de um lado, o intento castelhano de obter o convênio mais vantajoso possível e, de outro, a abertura de negociações de paz entre ingleses e franceses, cujo resultado poderia tornar sem efeito o enlace com os Bourbons espanhóis. Entretanto, após reiteradas recusas às suas pretensões, ficou claro ao premiê da França que não haveria sucesso na tentativa de conciliação com os britânicos. Ao menos, não, nas condições almejadas. A guerra prosseguiria. Em 15 de agosto, a liga entre França e Espanha foi finalmente sacramentada com a assinatura do mencionado Pacto de Família e da adoção da convenção adicional que previa o ataque à Inglaterra com a incorporação de Portugal às fileiras $\operatorname{agressoras}^{53}$.

Jacob O’Dunne, ministro plenipotenciário de Luís XV em Lisboa, foi logo incumbido de pressionar o governo português a tomar uma posição. Exigia-se a liberação para o posicionamento de efetivos aliados nos portos lusitanos para que fosse impedido um eventual desembarque dos ingleses. A neutralidade cultivada durante várias décadas por Portugal não podia mais ser sustentada ${ }^{54}$. Ocorria que o forte vínculo de seu país com a Inglaterra tornava impraticável a junção de d. José I à aliança bourbônica, não obstante os laços de sangue da rainha. A situação calamitosa das forças portuguesas teria levado o ministro Carvalho e Melo, então conde de Oeiras, a aventar a possibilidade de transferência da Corte para o Brasil diante do claro prenúncio de invasão (algo que já havia sido pensado por d. Luís da Cunha). O jogo diplomático e o movimento estratégico da Espanha, que oficialmente ainda não estava em guerra com os ingleses, deram o tempo necessário para a chegada de alguma ajuda financeira e militar. Além de seis regimentos de infantaria e um de cavalaria, o governo britânico enviou o conde de Lippe para organizar os débeis destacamentos lusos. Ainda assim, as chances de resistência frente às tropas franco-espanholas, melhor guarnecidas e em maior número, permaneciam escassas ${ }^{55}$. Enquanto isso, os ingleses intensificavam a preparação para a sua investida sobre as possessões ultramarinas de Carlos III. O conde de Fuentes, ainda em Londres, enviou seguidas mensagens notificando ao ministro Ricardo Wall o armamento de uma

\footnotetext{
53 Antonio Ferrer del Rio. Historia del reinado de Carlos III, en España. Tomo I. Madri: Matute y Compagni, 1856, p.298; João Lúcio de Azevedo. O Marquês de Pombal e a sua época. (1 $1^{\mathrm{a}}$ ed. 1909). São Paulo: Alameda, 2004, p.242; Didier Ozanam. "Les origines du troisième Pacte de famille (1761)". Revue d'Histoire diplomatique, 75e année (1961), n. 4, pp.307-340; Karl W. Schweizer. "William Pitt, Lord Bute, and the Peace Negotiations with France, May-September 1761". Albion: A Quarterly Journal Concerned with British Studies, vol. 13, n. 3 (Autumn,1981), pp. 262-275; Diego Téllez Alarcia. "Guerra y regalismo a comienzos del reinado de Carlos III: el final del ministerio Wall"..., p.1061.

${ }^{54}$ Fernando A. Novais. Portugal e Brasil na crise do Antigo Sistema Colonial..., op.cit.

55 João Lúcio de Azevedo. O Marquês de Pombal e a sua época..., pp.242-252.
} 
esquadra no porto de Spithead e o envio de naves para o reforço das frotas posicionadas no Atlântico norte. $\mathrm{O}$ alvo pretendido para o ataque não lhe era preciso ${ }^{56}$.

Em 4 de janeiro de 1762, a Inglaterra declarou guerra à Espanha, que retribuiu na mesma moeda doze dias depois. Em 5 de março, saía de Spithead uma expedição relativamente modesta, composta por quatro navios de linha, uma fragata e dezenas de embarcações menores transportando cerca de quatro mil homens, armamentos e provisões. O objetivo era audacioso. Promover a conquista de Havana, capital da ilha de Cuba, ponto geopolítico estratégico, centro da defesa e da comunicação do império espanhol no Atlântico. A tarefa não era nada simples. Tratava-se de uma das principais praças-fortes do Novo Mundo, a mais fortificada das possessões espanholas, circundada por quase dois quilômetros de muralhas e guardada pelas imponentes fortalezas de Fuerza, Morro e Punta ${ }^{57}$. Em 20 de abril, após superar algumas intempéries em alto-mar, a expedição se concentrou em Barbados, rumando dias depois para Martinica, que tinha acabado de capitular. Ali, engrossou enormemente seus efetivos, incorporando a frota que havia tomado a ilha francesa e, em seguida, outros reforços que chegaram da América do Norte e da Jamaica. A fortíssima esquadra que despontou na baía de Matanzas no dia 5 de junho era composta por quarenta e cinco vasos de guerra, entre navios de linha, fragatas e bombardeiros, e por centenas de embarcações auxiliares. Agora, o contingente chegava perto dos trinta mil homens, entre marinheiros, fuzileiros navais e soldados de infantaria. Dois dias depois, foi iniciado o ataque à capital. O extraordinário volume numérico (aumentado ao longo do assédio por novas brigadas), a eficiência dos armamentos empregados, a superioridade logística e os graves equívocos cometidos pelos espanhóis selaram o destino do combate em favor dos invasores, não obstante a heroica resistência perpetrada. Nas palavras de Moreno Fraginals, "Havana tinha sido pensada como uma Numância americana; contudo, os tempos numantinos tinham passado" ${ }^{, 58}$. O fortalecimento das defesas orientado no ano anterior não foi suficiente para evitar a derrota. Em 13 de agosto, o governador Portocarrero assinava a rendição. No dia seguinte, os britânicos, vitoriosos, adentravam a cidade. Concretizava-se, assim, um dos maiores feitos de guerra da era colonial. Tinha início o breve, mas emblemático período de ocupação inglesa na ilha de Cuba, reconhecida até então como inexpugnável ${ }^{59}$.

\footnotetext{
${ }^{56}$ Diego Téllez Alarcia. “Guerra y regalismo a comienzos del reinado de Carlos III: el final del ministerio Wall”..., p.1063.

57 Alejandro de la Fuente. Havana and the Atlantic in the sixteenth century. Chapel Hill: University of North Carolina Press, 2008, pp.67-80.

${ }^{58}$ Manuel Moreno Fraginals. Cuba/Espanha, Espanha, Cuba..., p.153.

${ }^{59}$ Pedro José Guiteras. Historia de la conquista de la Habana. (1762). Philadelphia: Perry and McMillan, 1856; Jacobo de Pezuela y Lobo. Sitio y rendición de la Habana en 1762: Fragmento de la historia inédita de la isla de Cuba. Madri: M. Rivadeneyra, 1859; Ramiro Guerra y Sanchéz. Manual de Historia de Cuba..., pp154-176; Allan
} 
Nesse meio tempo, os portugueses haviam sido arrastados para o conflito. Em 16 de março daquele mesmo ano de 1762, foi entregue ao governo lusitano um memorial convidando D. José I, na qualidade de cunhado de Carlos III, à adesão imediata ao Pacto de Família. A essa altura, tropas se deslocavam lentamente pelas regiões montanhosas a nordeste da fronteira. Em 23 de abril, diante da recusa cabal, os plenipotenciários bourbônicos abandonaram Lisboa. Uma semana depois, o marquês de Sarriá, comandante do exército inimigo, proclamava a invasão. Começavam as escaramuças conhecidas pela hiperbólica denominação de Guerra Fantástica, que se estendeu pelos seis meses seguintes. A declaração de guerra contra Portugal, oficializada em julho, abriu margem para ofensivas no além-mar. Lembremos que a demarcação dos limites entre as colônias luso-espanholas na América meridional encontrava-se novamente em estado de indefinição, especialmente no que dizia respeito à região platina. Em virtude das querelas em torno da desocupação dos territórios intercambiados, o Tratado de El Pardo, do início de 1761, anulara as resoluções acordadas em Madri. Notificado de que o conflito havia sido deflagrado na Península, D. Pedro de Cevallos, governador de Buenos Aires, há tempos empenhado em repelir os portugueses, iniciou o ataque que levou à tomada da Colônia de Sacramento, em 29 de outubro de 1762. No dia 3 do mês seguinte, foi assinado, em Fontainebleau, na França, o armistício que pôs fim às hostilidades em território peninsular. Não obstante, os castelhanos abriram 1763 avançando pelo sul da América portuguesa, ocupando as fortalezas de Santa Teresa e São Miguel e a vila de São Pedro, no Rio Grande, ao mesmo tempo em que os franceses se empenhavam na arquitetura de um plano para invadir o Rio de Janeiro e, em seguida, a capital, Salvador. Seria uma forma de contrabalancear as enormes perdas sofridas na América do Norte e no Caribe ${ }^{60}$.

O que salvou a colônia portuguesa foi a pacificação ocasionada pela vitória inconteste da Grã-Bretanha nas linhas gerais do conflito. Nos termos estipulados no Tratado de Paris, assinado em 10 de fevereiro de 1763, foi prevista a restituição integral das praças perdidas por Portugal. Como não poderia deixar de ser, os britânicos tiveram as maiores compensações, incorporando ao seu império numerosos territórios: o Canadá, com todas as suas dependências,

J. Kuethe. Cuba, 1753-1815. Crown, Military, and Society. Knoxville: The University of Tennessee Press, 1986, pp.3-23.

${ }^{60}$ João Lúcio de Azevedo. O Marquês de Pombal e a sua época..., pp.245-252; Alden Dauril. Royal Government in Colonial Brazil. Los Angeles:University of California Press, 1968, pp.67-115; Maria Fernanda Bicalho. A cidade e o império: o Rio de Janeiro no século XVIII. Rio de Janeiro: Civilização Brasileira, 2003, pp.60-80. Sobre um projeto de corso anglo-fluminense que deveria se realizar, naquele mesmo contexto, sobre Buenos Aires e Montevideo, ver:Maria Fernanda Bicalho. "A Fronteira dos Impérios: conexões políticas, conflitos e interesses portugueses na região platina". Actas do Congresso Internacional «Espaço Atlântico de Antigo Regime: poderes e sociedades». Lisboa 2 a 5 de Novembro de 2005, FCSH/UNL. Disponível em: <http://cvc.institutocamoes.pt/conhecer/biblioteca-digital-camoes/cat_view/75-coloquios-e-congressos/76-espaco-atlantico-deantigo-regime.html>. Acesso em: 21 de out. 2012. 
assim como as ínsulas do golfo do Rio São Lourenço, incluindo o Cabo Breton; Granada, Granadinas, São Vicente, Dominica e Tobago; as feitorias do rio Senegal; e a ilha de Minorca, restituída. O destino da Espanha poderia ter sido mais amargo, considerando a sua posição de país derrotado; obteve o território da Luisiana dos franceses e recebeu de volta Manila e a ilha de Cuba, que foi trocada pela Flórida. Inversamente, a depauperação do império colonial francês só não foi maior em virtude do reconhecimento de seus direitos de pesca em Terra Nova e da recuperação de Guadalupe e Martinica ${ }^{61}$. Afora o desempenho da diplomacia de Luís XV nas negociações, a concessão da Inglaterra neste particular parece ter sido movida pelo forte temor manifestado por negociantes e proprietários coloniais britânicos de que o aumento exponencial da oferta, decorrente da anexação daquelas ilhas, ocasionasse um achatamento nos preços dos artigos caribenhos no mercado metropolitano. Ainda assim, o saldo foi extremamente negativo para os franceses, pelas perdas territoriais e prejuízos financeiros, evidentemente, mas, sobretudo, pelo absoluto malogro em frear o poderio marítimo dos ingleses, ratio essendi do conflito ${ }^{62}$.

É necessário observar que o período que se seguiu a 1763 foi marcado por uma notável retração no jogo internacional das trocas, uma espécie de "fase b" de Kondratieff, que perdurou até os anos $1790^{63}$. A posição de ampla vantagem na qual o Reino Unido terminara a guerra assegurou-lhe as condições para o gradual reequilíbrio de suas finanças e para o seu protagonismo no deslanche da Revolução Industrial, na década de $1780^{64}$. Todavia, a consolidação de seu posto hegemônico ocorreu somente em 1815, ao ser virada a última página do embate secular contra a França. Nesse ínterim entre o fim da Guerra dos Sete Anos e a cristalização da supremacia inglesa houve graves e fecundas turbulências. Combinado aos problemas derivados dos gastos bélicos e do agravamento do processo inflacionário, se instaurou no mundo atlântico um quadro de crescente agitação política e de desordem social,

\footnotetext{
${ }^{61}$ Afora as perdas do circuito atlântico, a coroa francesa foi obrigada a abrir mão de suas pretensões políticas nas Índias Orientais, especialmente sobre a região de Bengala.

${ }^{62} \mathrm{O}$ Tratado de Hubertusburg, firmado cinco dias depois entre Áustria, Prússia e Saxônia, completou o encerramento da Guerra dos Sete Anos, ratificando o domínio prussiano sobre a Silésia. Cf. Coleccion de los tratados de paz, alianza, comercio \&c. ajustados por la corona de España con las potencias extrangeras desde el reynado del señor don Felipe V hasta el presente. Tomo I. Madri: Imprenta Real, 1796, pp.143-217; Immanuel Wallerstein. The modern world-system III..., pp.67-71; Rafael de Bivar Marquese. Feitores do corpo, missionários da mente - senhores, letrados e o controle dos escravos nas Américas, 1680-1860. São Paulo: Cia. das Letras, 2004, p.94; J. Holland Rose. "Frederick the Great and England, 1756-1763 (Continued)". The English Historical Review, v.29, n.114 (Abril, 1914), pp. 257-275.

${ }^{63}$ Immanuel Wallerstein. The modern world-system III..., p. 73; Sobre a relação entre as grandes ondas econômicas e os conflitos globais, cf. Joshua S. Goldstein. "Kondratieff Waves as War Cycles". International Studies Quarterly, Vol. 29, No. 4 (Dez., 1985), pp. 411-444.

${ }^{64}$ Eric J. Hobsbawm. A Era das Revoluções: Europa, 1789-1848. (Trad. port.). Rio de Janeiro: Paz e Terra, 2004, pp.49-82.
} 
que culminou em uma verdadeira situação de "caos sistêmico". O tempo do ocidente se acelerou rumo a modificações profundas, estruturais. Colonos, burgueses e escravos figuraram entre os principais agentes de "rebeliões sistêmicas" que impactaram fortemente a prática econômica e a dinâmica dos governos, inaugurando uma nova era. A primeira delas foi sem dúvida a luta pela emancipação das Treze Colônias, cujo desfecho abriu a perspectiva independentista no horizonte do continente americano ${ }^{65}$.

O inchaço do império e o decorrente déficit orçamentário acarretaram modificações na política colonial inglesa, tradicionalmente caracterizada por padrões moderados de tributação e por uma acentuada descentralização jurídica e administrativa. A partir de abril de 1763, o gabinete encabeçado por George Grenville buscou implementar um programa reformista, visando inibir a evasão de receitas via contrabando e transferir para o nível local o custeio do aparato de defesa. O estreitamento das amarras coloniais conjugada à elevação da carga tributária, mais a falta de representatividade parlamentar, foram encarados pelos colonos norteamericanos como intoleráveis violações de seus direitos enquanto próceres cidadãos britânicos. Sim, pois era dessa maneira que se autoidentificavam, sobretudo após seu empenho nas campanhas militares contra os franceses. A reação à nova diretriz metropolitana, que envolveu a aprovação de uma série de Atos normativos pelo Parlamento (Sugar, Currency, Stamp acts), gerou a tensão resultante na Guerra de Independência dos Estados Unidos (1776-1783). Naquele cenário de crise imperial, o problema da escravidão foi recolocado. A plataforma insurgente se contrapôs invariavelmente ao signo da escravização do povo americano enquanto que, na metrópole, propagava-se a aversão à natureza corrupta do poder exercido pelos colonos na América, antítese da noção de liberdade que compunha a identidade britânica. A exaltação patriótica tecida interessadamente pelos dois lados abriu caminho para a reverberação de discursos e ações propriamente antiescravistas ou que em alguma medida circunscreviam a expansão escravagista ${ }^{66}$.

Desencadeado o conflito, declarada a independência, iniciou-se em solo americano um processo legislativo e constitucional que deu margem para que os estados regulassem questões pertinentes à escravidão. No ano de 1778, em meio à conturbação trazida pela presença de tropas inglesas e pela promessa de liberdade aos escravos que abraçassem a causa colonialista,

\footnotetext{
${ }^{65}$ Giovanni Arrighi. O longo século XX: dinheiro, poder e as origens de nosso tempo..., pp.51-52.

66 John Shy. "The American Colonies in War and Revolution, 1748-1783”..., pp.300-310; Jack P. Greene. "The American Revolution". The American Historical Review, v.105, n.1 (Fev., 2000), pp. 93-102; Jack P. Greene and J. R. Pole (eds.). A companion to the American Revolution. Malden: Blackwell Publishers Inc., 2000, pp.112-151; Francis D. Cogliano. Revolutionary America, 1763-1815: a political history. Nova York, 2009; Robin Blackburn. The American Crucible. Slavery, Emancipation and Human Rights. Londres: Verso, 2011, pp.145-171.
} 
a Virginia emitiu estatuto proibindo o tráfico de escravos para a região. Dois anos depois, a Pensilvânia aprovou legislação prevendo a emancipação gradual de seus cativos, o que foi repetido em vários outros estados nortistas após o término da guerra. Na década de 1780, a militância contra a escravidão ganhou corpo com a participação de negros livres do norte e de religiosos protestantes; quacres, sobretudo, mas, também, batistas e metodistas. Surgiram sociedades de manumissão, antitráfico e pró-abolição. Em certas regiões, como Massachusetts e New Hampshire, foram tomadas decisões judiciais francamente desfavoráveis à propriedade escrava. Contudo, o peso econômico e o enraizamento social da instituição no sul obstruíram o avanço político do movimento no plano nacional ${ }^{67}$.

A deliberação efetuada na Convenção Constitucional, que se reuniu em 1787 na Filadélfia, buscou harmonizar interesses nortistas e sulistas. Ficou acordado que o Congresso só poderia regular aspectos pertinentes ao tráfico negreiro após 1808. Nesse meio tempo, cada estado teria liberdade para legislar de acordo com o interesse local. Os escravos que cruzassem as fronteiras interestaduais deveriam ser restituídos aos seus senhores, não obstante a existência de normas antiescravistas nas diferentes localidades. Para fins de representação política e de repartição tributária, foi estipulado que cada escravo equivaleria a três quintos de um cidadão livre. Existe a hipótese de que o acordo sobre este último ponto, claramente favorável aos interesses escravocratas, foi fruto de uma barganha para que fosse aprovado no Congresso Continental, no mês de julho, o regulamento que vedou a existência de escravos nos territórios a norte do rio Ohio e a leste do Mississipi, corroborando o princípio embutido na ordenança encaminhada três anos antes por Thomas Jefferson e fortemente rebatida por George Washington. De qualquer maneira, estava dada a segurança jurídica necessária para a continuidade da escravidão na parte meridional do país ao mesmo tempo em que se abria espaço para a consolidação do trabalho livre nos estados do norte, selando-se a polarização que marcou a história estadunidense até a década de 1860. Mais do que isso, fundava-se naquele momento o lastro político que amparou a manutenção do escravismo atlântico durante grande parte do século XIX ${ }^{68}$.

\footnotetext{
${ }^{67}$ David Brion Davis. The Problem of Salvery in the Age of Revolution, 1770-1823. (1a ed: 1975). Oxford: Oxford University Press, 1999, pp.24-27; 46-48; 347; Robin Blackburn. A queda do escravismo colonial. 1776-1848. Rio de Janeiro, Record, 2002, pp.45-147; Seymor Drescher. Abolition. A history of slavery and antislavery. Cambridge: Cambridge University Press, 2009, pp.115-146.

${ }^{68}$ David Brion Davis. The Problem of Salvery in the Age of Revolution,.., p.154-155; Robert F. Berkhofer, Jr. "Jefferson, the Ordinance of 1784, and the Origins of the American Territorial System". The William and Mary Quarterly, Third Series, v. 29, n. 2 (Abr., 1972), pp. 231-262. A Northwest Ordinance está disponível em: <http://www.ourdocuments.gov/doc.php?doc=8\&page=transcript $>$. Acesso em: 26 de abril 2015.
} 
$\mathrm{Na}$ Inglaterra, a contestação do trabalho escravo foi elevada a um novo patamar após o êxito da Revolução Americana. A estrutura administrativa do regime colonial britânico, que delegava às esferas locais a regulação das matérias pertinentes ao governo dos escravos, manteve por muito tempo a temática alheia ao debate parlamentar, limitando a repercussão das opiniões antiescravistas. No entanto, a derrota sofrida para os colonos pôs em xeque a autoridade metropolitana, conduzindo a um reexame político e moral sobre a natureza do império. Uma das consequências principais foi que a crítica à escravidão passou a estar no centro da discussão política. Logo em 1783, os quacres apresentaram petição requerendo o fim do tráfico transatlântico de escravos, tópico sobre o qual o Parlamento tinha plena competência para deliberar. O texto não obteve aprovação, mas a campanha foi adiante. Panfletos e livros com teor antiescravista foram impressos e distribuídos. Em 1787, os ativistas fundaram a Society for Effecting the Abolition of the Slave Trade, que no ano seguinte organizou a primeira campanha nacional contra o comércio de africanos, contando com ampla adesão popular. $\mathrm{O}$ movimento conquistara a opinião pública. Mas, a disputa não era simples. Vozes pró-escravidão se levantaram. Afinal, o império britânico contava com numerosas colônias escravistas no Caribe, afora as possessões na costa africana. Em 1792, a Câmara dos Comuns aprovou a extinção do negócio para 1796, mas os Lordes barraram a medida. Finalmente, no ano de 1807, a Inglaterra proibiu o tráfico negreiro para as suas colônias. Havia condições materiais para tanto. $\mathrm{O}$ arranque da industrialização reduzira o peso do açúcar antilhano no cômputo total da economia britânica. Ademais, o controle exercido pelo país sobre o comércio atlântico era de tal monta que o sortimento interno de gêneros tropicais e subtropicais podia ser garantido a baixo custo, independentemente do tipo de mão-de-obra empregado em suas terras. $\mathrm{O}$ foco da política antiescravista sobre a eliminação do fornecimento de escravos e, não, sobre o regime em si, pretendia dar fôlego para que a economia colonial se organizasse sobre novas bases ${ }^{69}$.

Papel decisivo nesse processo foi desempenhado pela Revolução de Saint-Domingue, outro fenômeno basilar inserido no quadro de "rebeliões sistêmicas" resultante da Guerra dos Sete Anos. A explosão do movimento rebelde na mais rica colônia escravista das Américas deveu-se à combinação entre o acirrado antagonismo social existente na localidade e a subversão trazida pela Revolução na França. Antes de abordar o evento, é preciso lembrar que o desnível entre as economias francesa e britânica, manifesta com nitidez em 1763, aprofundou-

\footnotetext{
${ }^{69}$ David Brion Davis. The Problem of Salvery in the Age of Revolution,.., pp.25-32; Linda Colley. Britons: Forging the Nation, 1707-1837. Londres: Pimlico, 1992, pp.350-61; Dale W. Tomich. Through the Prism of Slavery..., pp.62-63; Christopher Leslie Brown. Moral Capital. Foundations of British Abolitionism. Chapel Hill: The University of North Carolina Press, 2005, pp.1-101; Márcia Berbel, Rafael Marquese \& Tâmis Parron. Escravidão e Política: Brasil e Cuba, c. 1790-1850. São Paulo: Hucitec, 2010, pp.54-85.
} 
se na década de 1780. A perda sofrida pelo Reino Unido na América, embora financeira e politicamente impactante, não foi capaz de desestruturar a sua economia, em curva ascendente com o avanço da industrialização. Por outro lado, os problemas financeiros da monarquia francesa foram seriamente agravados pelo apoio revanchista que concedera aos rebeldes norteamericanos. A vitória veio às custas da total bancarrota do estado, que só fez piorar a drástica crise que assolava o país, especialmente no campo. Ciosa na defesa de seus privilégios, a aristocracia fez com que os Estados Gerais fossem convocados para abril de 1789. Foi a brecha decisiva para a derrocada do ancien régime. Os acontecimentos seguintes são conhecidíssimos. O importante aqui é observar que a realidade colonial pôs à prova os princípios revolucionários, notadamente com respeito à equidade entre os cidadãos e à permanência da escravidão ${ }^{70}$.

Não há dúvida de que a primeira etapa da Revolução Francesa não favoreceu diretamente a emancipação escrava. A inviolabilidade da propriedade e o respaldo da distinção social em prol da "utilidade comum" acobertaram a alienação da liberdade dos cativos. Não obstante, a inexistência de critérios étnico-raciais na Déclaration des Droits de l'Homme et du Citoyen encorajou negros e mestiços livres, com o apoio da sociedade abolicionista Amis des Noirs e da Societé des Citoyens de Couler, a demandarem igualdade de direitos. Em SaintDomingue, as "pessoas livres de cor" compunham uma parcela importante da demografia local $^{71}$. Parte delas havia concentrado um notável poder econômico, dedicando-se à produção escravagista de café, que carecia de menores inversões do que o açúcar e cuja demanda apresentou rápido crescimento de meados do século XVIII em diante. A presença massiva dessa comunidade, tida como potencialmente perigosa, e a sua ascensão social em detrimento de pessoas brancas pobres (petits blancs) que chegavam aos montes da França, serviu pretexto para a adoção de medidas restritivas. Após a Guerra dos Sete Anos, foram ampliados os limites à manumissão, outrora autorizada com liberalidade pelo Code Noir, e impostas barreiras de cor que apequenaram o estatuto civil dos afrodescendentes. A tensão inerente a uma sociedade escravista brutal, que contava com um contingente de quase meio milhão de almas cativas, foi aguçada também fora do cativeiro. Ao tomarem conhecimento dos acontecimentos de 1789, as gens de couleur libres trataram logo de enviar uma delegação para reivindicar seus direitos junto à Assembleia Nacional. Não houve sucesso. Em outubro de 1790, o mulato livre Vincent

\footnotetext{
${ }^{70}$ Eric J. Hobsbawm. A Era das Revoluções..., pp.83-113; Wallerstein. The modern world-system III..., p.86; David Geggus. "Racial Equality, Slavery, and Colonial Secession during the Constituent Assembly". The American Historical Review, (dez.1989), v.94, n.5, pp.1290-1308.

${ }^{71}$ Estima-se que, em 1789, havia em Saint-Domingue 465.000 escravos (africanos em imensa sua maioria), 31.000 brancos e 28.000 negros e mulatos livres. Cf. Laurent Dubois. Avengers of the New World: the story of the Haitian Revolution. Cambridge/Londres: Harvard University Press, 2004, p.30
} 
Ogé, homem de posses e instruído, membro dos Amigos dos Negros, liderou seus pares em uma rebelião armada em Le Cap. O braço da repressão caiu pesado sobre os rebeldes. Ogé foi torturado e morto junto com alguns de seus companheiros.

As informações do ocorrido chegaram à Constituinte, que ordenou a eleição de uma nova assembleia local, remetendo dois destacamentos para auxiliar o governador. A situação política na França, até então adequada aos interesses dos grandes proprietários brancos, começava a mudar de rumo. O destino dos rebeldes dera conta dos riscos do autogoverno, defendido de forma ardorosa pelos colonialistas representados pelo Club Massiac. O debate se intensificou e, em maio de 1791, foi aprovado decreto reconhecendo os direitos políticos das gens de couleur nascidas de pais livres que satisfizessem critérios censitários, o que não contemplaria muito mais do que quatrocentas pessoas em Saint-Domingue. Ainda assim, a notícia dessa resolução foi recebida como sinal de injúria pela oligarquia dominicana, que ensaiou uma articulação com fins independentistas. Mas não houve tempo para isso. Como escreveu Cyril James, o conflito entre brancos e mulatos "despertou os escravos adormecidos". No mês de agosto, começava na província do norte, onde se concentravam as maiores plantações da colônia, o movimento que, sob a extraordinária liderança de Toussaint L'Ouverture, converter-se-ia na "única revolta de escravos bem-sucedida da história”. Durante doze anos de luta, os insurgentes enfrentaram e derrotaram tropas francesas, espanholas e inglesas, conquistaram a liberdade e proclamaram a independência quando Napoleão revogou a abolição decretada pelos jacobinos. Em 1804, tinha início a história do Haiti, segunda nação da América a se tornar independente. Sem dúvida, um feito de enorme alcance, que lançou no ar o espectro da revolução escrava. O receio, mais ou menos factível, de que algo do gênero ocorresse informou desde então discursos e ações políticas relacionadas ao cativeiro, a começar pela determinação inglesa de abolir o tráfico. A interrupção do comércio negreiro seria a solução para evitar a eclosão de revolta semelhante à de Saint-Domingue nas Índias Ocidentais. Decididamente, o argumento influenciou a acolhida do pleito pelo centro de poder político da Grã-Bretanha ${ }^{72}$.

\footnotetext{
${ }^{72}$ Sobre a Revolução de Saint-Domingue, cf.: Cyril L. Robert James. Os jacobinos negros. Toussaint L'Ouverture e a revolução de São Domingos. (trad.port.). São Paulo: Boitempo, 2000, pp.15 e 80 (citações); David Geggus. "Racial Equality, Slavery, and Colonial Secession during the Constituent Assembly"..., op.cit; Marquese. Feitores do corpo, missionários da mente..., pp.124-125; Dubois. Avangers of the New World..., pp.60-90; Robin Blackburn. "Haiti, Slavery, and the Age of the Democratic Revolution". William and Mary Quarterly, (out.2006), 3d Series, v.63, n.4, pp. 643-74; Idem. The American Crucible..., pp.171-251;John D. Garrigus. Before Haiti: Race and Citizenship in French Saint-Domingue. New York: Palgrave-Macmillan, 2006, pp.1-59; Márcia Berbel, Rafael Marquese \& Tâmis Parron. Escravidão e Política..., pp.86-93; Malick W. Ghachem. The Old Regime and the Haitian Revolution. Nova York. Cambridge University Press, 2012, pp.77-166.
} 
Do ponto de vista material, o contrapeso do triunfo haitiano foi a falência da economia responsável por $30 \%$ da produção mundial de açúcar e por $50 \%$ da de café. A revolução destruiu por completo a atividade agroexportadora da ex-colônia francesa, que também era uma importante fornecedora de índigo e algodão. Consequentemente, abriu-se uma enorme lacuna a ser preenchida. As colônias inglesas foram as primeiras a se beneficiarem do decréscimo da oferta de Saint-Domingue, já na década de 1790. No entanto, fatores como o esgotamento dos solos, a obsolescência do regime de produção e do sistema de transporte, somados à falta de mão-de-obra derivada do fim do tráfico relegaram-lhes um papel secundário no decorrer do século XIX. Por outro lado, a reconfiguração do mercado suscitada pela industrialização, pela ampliação dos centros urbanos e pelo crescimento demográfico expandiu a necessidade de matérias-primas e de artigos para o proletariado, abrindo espaço para o surgimento de novas áreas produtoras. Foi então que ganhou impulso a onda de exploração do trabalho denominada segunda escravidão pelo historiador Dale Tomich, difundida pelo Sul dos Estados Unidos, pelo ocidente da ilha de Cuba e pelo sudeste do Brasil. Mais do que a realocação geográfica, a novidade do sistema fundeou-se em sua inserção no novo ciclo de acumulação da economiamundo, o qual, sob o predomínio inglês, substituiu o nexo monopolista do antigo sistema colonial pelo o controle interestatal sobre a circulação de bens de consumo. O algodão, o açúcar e o café dos novos produtores escravocratas se impuseram no mercado em razão de sua superioridade competitiva, conquistada a partir da aclimatação bem-sucedida das culturas, da racionalização da atividade produtiva, da disponibilidade de terras e créditos, e do emprego de avanços tecnológicos trazidos pela Revolução Industrial. Jamais o trabalho escravo atingiria tamanha produtividade ${ }^{73}$.

O historiador Tâmis Parron acrescenta que elites políticas e regionais, em sincronia com o empuxo do capitalismo industrial e em sintonia com o repertório do liberalismo, desempenharam papel decisivo para a manutenção da escravidão naquelas três grandes áreas, favorecendo a produção e o comércio, conferindo estabilidade à ordem social e atenuando os efeitos da pressão antiescravista internacional ${ }^{74}$. De fato, para a devida reconstituição da escravidão oitocentista, é impossível dissociar a reestruturação sistêmica do capitalismo dos arranjos políticos delineados intestinamente. Mas havia outros elementos envolvidos. A nova onda escravista do Oitocentos, embora inserida em um cenário de mudanças estruturais, não desapareceu com a identidade institucional que o cativeiro já possuía nas regiões por onde se

\footnotetext{
${ }^{73}$ Dale W. Tomich. Through the Prism of Slavery..., op.cit.

${ }^{74}$ Tâmis Peixoto Parron. A política da escravidão no Império do Brasil, 1826-1865. Rio de Janeiro: Civilização Brasileira, 2011, pp.24-39.
} 
propagou. Existia um conjunto de práticas, normas e valores acumulados em torno da instituição, culturalmente arraigados, que cumpriam um papel importante na fluência das relações sociais e que ganharam nova carga de significado ao longo do século XIX. No Brasil e em Cuba a manumissão constituía elemento central daquela identidade, era reconhecida e validada pelo direito e pôde ser preservada como prática social constante enquanto foi mantido um fluxo satisfatório de reposição da mão-de-obra ${ }^{75}$.

\section{Guerra dos Sete Anos, Ilustração e o tráfico negreiro}

Ao longo das páginas anteriores, buscou-se mostrar o nexo causal entre as lutas pelo controle de espaços e fluxos de capitais, o caos sistêmico que se instaurou e a transformação do fenômeno da escravidão no espaço atlântico. Agora, cumpre examinar mais de perto as implicações de todo esse processo no contexto hispano-cubano e luso-brasileiro, convergindo para enfoque específico da presente investigação. O primeiro passo é recuperar a sua inscrição original no sistema atlântico ibérico, complexo de exploração mercantil constituído no início da modernidade com a expansão ultramarina de Portugal e Castela, em associação ao primeiro ciclo sistêmico de acumulação, controlado no nível das altas finanças pelos genoveses ${ }^{76}$. Concomitantemente à exploração compulsória dos ameríndios, os espanhóis e, de forma mais extensa, os portugueses deram efeito à primeira fórmula do escravismo atlântico, marcada por um vínculo estreito entre tráfico volumoso e taxas elevadas de alforria. O regime assumiu traços específicos no Novo Mundo, mas a experiência prévia com cativos na Península e a existência de um quadro legal correspondente influíram em sua conformação. De modo semelhante, os feitios do sistema atlântico ibérico informaram a configuração escravista do Império do Brasil e da colônia oitocentista de Cuba. Isto se deu por três vias essenciais, a saber, pela tradição jurídica, pelas sobrevivências práticas e pelo conjunto de reformas despregados em seu contexto de crise. Sobre a primeira, basta dizer por ora que havia entre os ibéricos um repertório normativo sobre a escravidão, baseado no direito romano, que influenciou a regulação de matérias pertinentes ao cativeiro até os estertores do sistema, na década de 1880, em ambos os

\footnotetext{
${ }^{75}$ Nos Estados Unidos, onde o tráfico transatlântico foi bloqueado em 1815, as oportunidades de alforria foram reduzidas ao extremo, alimentando-se um modelo de crescimento vegetativo da população escrava. Sobre as mudanças ocorridas na escravidão nos Estado Unidos nas décadas iniciais do século XIX, cf. Edward E. Baptist.The half has never been told: slavery and the making of American capitalism. Nova York: Basic Books, 2014, pp.104-244. Sobre o tráfico de escravos, ver: Leonardo Marques. The United States and the Transatlantic Slave Trade to the Americas, 1776-1867. Tese de Doutorado, Emory University, 2013, pp.85-155.

${ }^{76}$ Márcia Berbel, Rafael Marquese \& Tâmis Parron. Escravidão e Política..., pp.21-54.
} 
espaços recortados. Sobre a segunda, deve-se perceber que, embora a segunda escravidão tenha constituído o núcleo do poder econômico e político, continuaram existindo práticas variadas de escravidão, com ritmos menos céleres de trabalho e produção, que conservaram muito do modus operandi pregresso da instituição; no cultivo periférico da cana e do tabaco, na criação do gado, na lavoura de subsistência, no serviço doméstico, nos fazeres urbanos. Sobre a terceira, e a ela serão dedicadas as páginas seguintes, cabe assinalar que as medidas da época da ilustração, ao não evitarem (tanto pela sua eficácia quanto pelo seu insucesso) a desestruturação do antigo sistema, configuraram etapa importante do processo que conduziu à subsequente arrancada escravista, deixando seus rastros pelo novo século. Se é possível encontrar certo cabimento tanto em quem enfatiza o arcaísmo da permanência da escravidão no século XIX, quanto em quem realça a sua plena adequação aos novos tempos é porque o regime encerrou dialeticamente e de forma singular ambos os aspectos, o moderno e o tradicional ${ }^{77}$. O problema todo reside em elucidar a arquitetura dialética de tal singularidade.

A partir da segunda metade do século XVII, com o êxito do mercantilismo francês e inglês, os impérios marítimos de Espanha e Portugal foram reduzidos a uma condição subalterna na economia global, como observado na seção anterior. $O$ endurecimento da concorrência, a inépcia administrativa, a ausência de uma produção manufatureira consistente e o rebaixamento de sua posição no quadro das relações internacionais, notadamente entre os tratados de Vestfália (1648-59) e de Utrecht (1713-15), sacramentaram a periferização das antigas potências peninsulares ${ }^{78}$. Apesar de tentativas anteriores, foi no século XVIII, sobretudo em sua segunda metade, que as políticas coordenadas para a superação de seu retardo econômico ganharam materialidade entre os ibéricos. As práticas mercantis anglo-saxônicas e colbertianas foram tomadas como norte, à diferença de que ao invés da atração de metais preciosos, como na concepção original, o que se impunha era a sua retenção. Em outras palavras, o desafio não era apenas dinamizar a produção e a extração de riquezas naturais, mas evitar o seu esvaimento, para além das medidas habituais de inibição do descaminho.

O fomento ordenador e fiscalista da economia escravista colonial - de modo integrado ao estímulo dos setores manufatureiros metropolitanos - constituía ponto-chave a ser trabalhado para a promoção dos superávits ambicionados. Havia dois expedientes básicos

\footnotetext{
${ }^{77}$ Para a perspectiva do arcaísmo da escravidão, ver, em especial, Ilmar Rohloff de Mattos. O Tempo Saquarema - a formação do Estado Imperial [1 $1^{\mathrm{a}}$ ed. 1986]. São Paulo: Hucitec, 2004.

78 Berbel, Marquese e Parron chamam a atenção para a unidade sistêmica do expansionismo seiscentista, gerado em uma etapa distinta da formação do mundo moderno, ao pé da consolidação de Amsterdã no topo das finanças internacionais. Trata-se do sistema atlântico do noroeste europeu, que coexistiu, em patamar de ascendência, com o sistema atlântico ibérico. Cf.Escravidão e Política..., pp.21-94.
} 
relativos a este fim, a instituição de companhias privilegiadas de comércio e navegação e a liberação setorial das transações. Procedimentos conflitantes, em essência, mas que integravam o leque de experiências exitosas dos rivais, perfazendo meios a serem empregados pragmaticamente para o alcance do objetivo estabelecido. Embora seja equivocado falar em ruptura, é possível discernir dois momentos do mercantilismo ibérico ilustrado. No primeiro, que atravessou a década de 1750 e parte da seguinte, ainda que tenha havido alguma abertura comercial em zonas determinadas, existia uma tendência maior às feições mais ortodoxas do mercantilismo, com a preservação de monopólios e do controle sobre a circulação ${ }^{79}$. De meados da década de 1760 em diante, em meio à assimilação de ideias fisiocráticas e do pensamento econômicos ingleses e à pressão exercida por colonos, comerciantes autônomos e indivíduos com influência política, ocorreu uma convergência paulatina ao livre comércio ${ }^{80}$.

Aqui, cabe uma breve digressão. Para a viabilização do sistema de frotas para a América portuguesa, havia sido fundada uma companhia de comércio em 1649. Em troca de apoio na escolta dos carregamentos a Lisboa, a Companhia Geral de Comércio do Brasil, financiada com capitais extraídos de cristãos-novos, obteve o estanco da introdução de vinho, azeite, farinha e bacalhau e da saída de pau-brasil. Para o trato de escravos, foi instituída, em 1675, a Companhia de Cachéu, cuja abrangência foi mais tarde estendida a Cabo Verde. No ano de 1678, foi designada uma companhia independente para o Maranhão. No geral, o desempenho dessas e de outras sociedades criadas na época foi pífio, tanto pela falta de inversões privadas como pela espécie dos artigos mercadejados, de escasso valor agregado na metrópole. A atuação da empresa do Maranhão esteve entre as causas principais da conhecida revolta liderada pelos irmãos Beckman, em 1684. A sua extinção se deu no ano seguinte. Após o término do assento que lhe permitiu o sortimento da América espanhola (1696-1703), a companhia de Cachéu e Cabo Verde declinaram e foram extinta em 1706. A Companhia Geral, sem investimentos suficientes, foi integralmente assumida pelo governo e acabou sendo abolida em 1720, durante o reinado de d. João V. O aumento exponencial da extração aurífera, ao mesmo tempo em que compensou monetariamente o desequilíbrio comercial com a Inglaterra, provocou o abandono das iniciativas de ampliação da agricultura colonial e de melhoria das indústrias reinóis. O

\footnotetext{
79 Para uma definição conceitual precisa a respeito das formas embutidas no exclusivismo metropolitano, cf. Fernando A. Novais. Portugal e Brasil na crise do Antigo Sistema Colonial..., pp.88-90.

80 Fernando A. Novais. "O Reformismo Ilustrado Luso-brasileiro: Alguns aspectos". Revista Brasileira de História, v. 4, n. 7 (1984), pp.105-118; Pedro Rodriguez Campomanes. Reflexiones sobre el Comercio Español a Indias. [1762]. Vicente Llombart Rosa (edição e estudo preliminar). Madri: Instituto de Estudios Fiscales, 1988; Kenneth Maxwell. "Hegemonias antigas e novas: o Atlântico ibérico ao longo do século XVIII". In: Chocolates, Piratas e Outros Malandros. Ensaios Tropicais (trad.port). São Paulo: Paz \& Terra, 1999, pp.225-227; Francisco Calazans Falcon. "Pombal e o Brasil". In: José Tengarrinha (org.). História de Portugal. Bauru: Edusc, 2001, pp.227-243.
} 
escoamento legal das riquezas da colônia continuou sendo efetuado pelo enrijecido esquema de frotas e, o provimento de mão-de-obra escrava, assegurado para as regiões mais dinâmicas por circuitos autônomos nas mãos de traficantes brasílicos, que se valiam de produtos do Brasil (tabaco e jeribita) como moeda de troca na costa africana ${ }^{81}$.

No plano geral, o estado da economia imperial espanhola era muito semelhante na passagem para o século XVIII. A elite ministerial bourbônica buscou responder à situação de crise logo nas décadas iniciais da centúria, concedendo isenções e privilégios a sociedades destinadas à produção peninsular e ao comércio transatlântico. Em 1728, sob os auspícios do secretário de estado José Patiño, foi criada a Real Compañía Guipuzcoana, com direitos de exclusividade para exploração do comércio na região de Caracas. Os progressos da empreitada levaram o governo a patrocinar uma série de outras companhias, dentre as quais, a Real Compañía de la Habana, estabelecida em 1740. A esta foi concedido o monopólio para a exportação de tabaco e, em seguida, privilégios e isenções para o comércio de açúcar e artigos de menor valor como couro e madeira, e para a importação da metrópole de farinhas, tecidos, louças, e de gêneros diversos. As contrapartidas seriam militares, por meio do traslado de tropas, da construção de barcos de guerra, da manutenção de embarcações armadas para a repressão do contrabando, entre outras. É bom lembrar que a escravidão na ilha de Cuba, embora antiga, estava longe de configurar um fato econômico comparável aos patamares atingidos pelas rivais caribenhas. Um dos principais embaraços era a ausência de um provimento satisfatório de mão-de-obra. Os espanhóis, diferentemente dos lusitanos, não tinham se envolvido de forma substantiva no tráfico. Mas as coisas começavam a mudar. Desde 1739, caminhava a Guerra do Asiento, conhecida entre os ingleses pela insólita alcunha de Guerra da Orelha de Jenkins, sobrenome do capitão contrabandista que compareceu ao Parlamento para avalizar as alegações belicistas do primeiro-ministro Walpole, após supostamente ter a orelha decepada pelos espanhóis. Ocorria que, conforme acordado em Utrecht, a South Sea Company, beneficiária do asiento, poderia enviar apenas um navio mercante por ano à América espanhola. Apesar disso, eram diversos os traficantes ingleses atuando nos domínios hispânicos. Das tentativas de impedir o comércio ilegal, nasceu esta peleja, que opôs as armadas de Espanha e Inglaterra nas proximidades de Nova Granada. O

\footnotetext{
${ }^{81}$ José Ribeiro Júnior. Colonização e monopólio no nordeste brasileiro. A Companhia Geral de Pernambuco e Paraíba (1759-1780). São Paulo: Hucitec, 2004, pp.18-23; Frédéric Mauro. "Portugal e o Brasil: a estrutura política e econômica do império, 1580-1750”. In: L. Bethell (org.), História da América Latina. Vol. I. América Latina Colonial. (Trad.port.) São Paulo/ Brasília: EDUSP/FUNAG, 1997, pp.467-494; Gustavo Acioli \& Maximiliano Menzs. "Resgate e mercadorias: uma análise comparada do tráfico luso-brasileiro de escravos em Angola e na Costa da Mina (século XVIII)". Afro-Ásia, 37 (2008), pp.43-73.
} 
evento acabou agregado ao conflito de proporções mais amplas envolvendo a Sucessão na Áustria, mencionado páginas atrás. Mas os seus efeitos foram além da mera restituição das conquistas. Em 1750, um tratado à parte acertou o fim do contrato de asiento em troca de uma indenização de 100 mil libras esterlinas. A coroa espanhola, com uma pitada a mais em seu rombo orçamentário, recobrou o exclusivo colonial, podendo então modificar a política sobre o tráfico negreiro. No ano seguinte, o monarca concedeu autorização à companhia de Havana para a introdução de africanos na ilha, ampliando permissão prévia, concedida em 1744 . No entanto, faltavam-lhe subsídios essenciais, como experiência, capacidade técnica e a disponibilidade de feitorias na costa africana. A saída encontrada foi buscar a intermediação de negreiros atuantes na Jamaica ${ }^{82}$.

Este era o panorama em meados do Setecentos. A ambos os impérios estavam postas demandas comuns, como o equilíbrio das finanças públicas; a modernização das esferas político-administrativas; a amplificação e a diversificação da produção; a intensificação das exportações e da circulação interna de bens de consumo e insumos; o aprimoramento do sistema fiscal; a redução do contrabando; e o direcionamento do fluxo de capitais para a Península. Os portugueses tinham a vantagem de possuir canais abertos para o provimento de mão-de-obra, mas os espanhóis estavam um passo à frente quanto à instituição de sociedades comerciais. No controle do governo após a ascensão de D. José I ao trono, Sebastião José de Carvalho e Melo, futuro marquês de Pombal - que na década de 1740 encaminhara um projeto de uma Companhia da Índia Oriental - tratou de retomar os projetos de monopolização mercantil ensaiados no século anterior em seu país, porém, de forma mais ambiciosa e ordenada ${ }^{83}$. Em 1755, ano do terremoto que arrasou Lisboa, foram adotadas medidas importantes nesse sentido. Duas delas merecem destaque. No mês de junho, foi instituída uma companhia para o norte da América portuguesa, região com potencial para expansão, mas que tinha uma produção pouco relevante e enfrentava dificuldades relacionadas à tutela exercida pelos jesuítas sobre os ameríndios; o papel da Companhia Geral do Comércio do Grão-Pará e Maranhão seria promover o povoamento, o intercâmbio mercantil e o desenvolvimento de plantações com a introdução

\footnotetext{
${ }^{82}$ Cf. Antonio Muro Orejón. Cedulario americano del siglo XVIII: colección de disposiciones legales indianas desde 1680 a 1800, contenidas en los Cedularios del Archivo General de Indias. Sevilla, 1956, t. III, pp.253-276; Pablo Tornero Tinajero, Crescimento económico y transformaciones sociales. Esclavos, hacendados y comerciantes en la Cuba colonial (1760-1840). Madri: Ministério del Trabajo y Seguridad Social, 1996, p.34-35; David A. Brading ."A Espanha dos Bourbons e seu império americano". In: Leslie Bethell (org.). História da América Latina. Vol. I. América Latina Colonial. (Trad.port.) São Paulo/ Brasília: EDUSP/FUNAG, 1997, pp.412418; Enrique López Mesa. "La trata negrera en el puerto de La Habana a mediados del siglo XVIII". Sotavento (verano 1999), v. 3, n. 6, pp.19-31.

${ }^{83}$ Fernando A. Novais. "A extinção da escravatura africana em Portugal no quadro da política pombalina". In: Aproximações. Estudos de História e Historiografia. São Paulo: Cosac Naify, 2005, p.92.
} 
exclusiva de cativos africanos. Em dezembro, foi vedada a atuação dos comissários volantes, comerciantes autônomos imiscuídos parasitariamente no trato colonial, sonegando impostos e injetando mercadorias inglesas diretamente na rede contrabandista do Rio da Prata. Como assinala Kenneth Maxwell, "a companhia e a extinção dos comissários volantes constituíam poderosa alavanca modificadora do nexo comerciantes estrangeiros/contrabando/livrecomércio" $" 84$.

O projeto pombalino era multiplicar a experimentação de Grão-Pará e Maranhão para as capitanias mais desenvolvidas, majorando a arrecadação e abocanhando a parte do leão concentrada nas mãos dos colonos, sobretudo em face ao comércio da costa africana. Em 1759, foi criada a Companhia Geral do Comércio de Pernambuco e Paraíba a fim de revitalizar a economia açucareira do local e ampliar a produção de gêneros diversos, como o tabaco, o couro e o cacau. A companhia obteve o monopólio do trato de escravos para a circunscrição, engajando-se no Golfo da Guiné e em Angola, ocupando parte do espaço dominado por mercadores baianos. Segundo consta, havia, ainda, planos para a criação de uma terceira companhia para a Bahia e o Rio de Janeiro, responsáveis pelas principais entradas para os cofres régios. João Lúcio de Azevedo conjeturou que a razão provável para a dissuasão do governo em relação a tal propósito foi à dificuldade em reunir o cabedal necessário no Reino ${ }^{85}$. Mas, é provável que outros fatores tenham pesado. A virtual companhia, além dos vassalos das referidas praças coloniais, contrariaria diretamente os negociantes ingleses estabelecidos em Lisboa, que já vinham reclamando desde a criação da primeira empresa, não obstante ela fosse aberta a investimentos estrangeiros. O fato é que o empreendimento em questão restringiria o acesso aos principais polos comerciais da América portuguesa e a suas conexões no Atlântico sul, portas de entrada ao proveito ilegal da prata espanhola e do ouro das Gerais. Maxwell é certeiro ao indicar que Pombal sempre esteve atento aos termos dos tratados que vinculavam Portugal à Inglaterra, respeitando-os, e que o objetivo de seu nacionalismo econômico era atingir a reciprocidade no intercâmbio luso-britânico, não, eliminá-lo. Nada impediria que os gêneros industrializados do parceiro continuassem sendo introduzidos regularmente pelas frotas. Contudo, a experiência demonstrava que a legalidade não era suficiente para evitar o estremecimento das relações diplomáticas com a Inglaterra. Uma orelha bastava para respaldar

\footnotetext{
${ }^{84}$ Kenneth Maxwell. A Devassa da Devassa. A Inconfidência Mineira: Brasil e Portugal, 1750-1808 (trad.port). Rio de Janeiro: Paz \& Terra, 1978, p.35

85 João Lúcio de Azevedo. Épocas de Portugal Económico. [1ª ed. 1929]. Lisboa: Clássica editora, 1988, p. 438.
} 
suas aspirações imperialistas. Os tempos eram de beligerância e não se podia abrir mão do apoio londrino. Para Rio e Salvador, outras ações tiveram de serem traçadas ${ }^{86}$.

Provisão de 30 de março de 1756, cujo texto manifestava as "desordens e quase monopólio com que certos negociantes fazem comércio do resgate dos escravos nas Costas da Mina, Guiné e mais portos de África, pervertendo os meios próprios do seu aumento", determinou que o trato fosse realizado "por todas as pessoas que a quiserem cultivar, permitindo a liberdade da dita negociação e comércio, não só nos portos em que de antes se fazia, mas em todos os da África, assim nos que ficam dentro como nos de fora do cabo da Boa Esperança" ${ }^{\text {" }}$. Isto era necessário decretar, pois o sistema de sorteio que escalonava a saída de embarcações rumo à costa africana, em vigor desde a década de 1740, havia sido corrompido, caindo nas mãos de um grupo fechado de pessoas. Sentindo-se lesados, traficantes da Bahia (os tais que monopolizaram o resgate) encaminharam à Coroa um projeto de uma companhia para o comércio de escravos. Ela se chamaria Companhia Geral da Guiné. Porém, o fato de o futuro empreendimento ser controlado por agentes econômicos locais ia de encontro ao projeto pombalino. A proposta foi recusada. Pela ótica do governo, se não era possível instituir o monopólio desde a metrópole, tratava-se de inibi-lo nos círculos coloniais, fomentando-se de forma disciplinada a livre concorrência para que houvesse o aumento da oferta, com preços equilibrados. Este princípio esteve na base da legislação emitida pela coroa portuguesa para fora do raio de cobertura das companhias, de modo conjugado ao aprimoramento do regime tributário. Em 25 de janeiro de 1758, um alvará com força de lei reformou o sistema de arrecadação sobre os escravos resgatados em Angola, simplificando-se a aferição e a cobrança ${ }^{88}$. Evidente que continuou havendo contrabando e concentração de poder local em torno do tráfico. Mas as brechas foram estreitadas, inaugurando-se um período de operação simultânea de portugueses e brasílicos, em um setor até então plenamente dominado pelos últimos ${ }^{89}$.

\footnotetext{
${ }^{86}$ Kenneth Maxwell. A Devassa da Devassa..., pp.58-59.

${ }^{87}$ Silvia Hunold Lara. "Legislação sobre escravos africanos na América portuguesa". In:, José Andrés-Gallego (coord), Nuevas Aportaciones a la Historia Jurídica de Iberoamérica. Madrid: Fundación Histórica Tavera/Digibis/Fundación Hernando de Larramendi, 2000 (Cd-Rom), p.327.

${ }^{88}$ Foi estabelecida uma variação de tarifas sobre os escravos por critério de altura, isentando-se as "crias de peito" de tributação "Por cada escravo, ou seja, macho ou fêmea que se embarcar no Reino de Angola e portos da sua dependência, excedendo a altura de quatro palmos craveiros da vara, de que se usa na cidade de Lisboa, se pagará $8 \$ 700$ réis em uma só e única adição e por um só e único despacho, sem que para isso se pratique outra alguma avaliação ou diligência que não seja a referida medida que para esse efeito estará sempre na Provedoria da minha Real Fazenda e na Câmara da cidade de Luanda, aferida com toda a exatidão". Lara. "Legislação sobre escravos africanos na América portuguesa", p.333.

${ }^{89}$ Maurício Goulart. Escravidão africana no Brasil. [1 ${ }^{a}$ ed. 1965]. São Paulo: Alfa-Ômega, 1975, pp.177-202; Pierre Verger. Fluxo e refluxo do tráfico de escravos entre o golfo de Benin e a Bahia de Todos os Santos: dos séculos XVII a XIX, São Paulo, Corrupio, 1987, pp.20-22; Andrée Mansuy-Diniz Silva, "Portugal e Brasil: a
} 
Do lado espanhol, não se verificou de antemão o mesmo zelo quanto ao controle acionário e diretivo das sociedades mercantis ${ }^{90}$. A companhia comercial de Havana, à diferença da atuante em Caracas, que funcionava com fundos bascos, tinha parte apreciável de seus capitais partilhada entre acionistas de Cuba (400 mil pesos de um total de 900 mil ${ }^{91}$. Na prática, a empresa acabou sendo controlada pela oligarquia local por meio da Junta de Diretores estabelecida na capital ilhéu. A historiografia indica que houve diminuições deliberadas de importações e exportações para que os preços fossem elevados, gerando maiores lucros; e que seus administradores, não apenas fecharam os olhos, como tiraram proveito da continuidade do comércio ilegal $^{92}$. Ao longo da década de 1750, a Coroa deu sinais sucessivos de que almejava impor uma gestão mais controlada. Os diretores habaneros foram afastados e, no ano de 1758, criou-se uma junta de diputados indicados por Madri. Em 1762, uma nova regulamentação foi elaborada, prevendo, entre outros pontos, o traslado da direção da companhia para a corte e prestações de contas melhor detalhadas. Porém, os efeitos da determinação foram suspensos em razão de um acontecimento de força maior, a tomada de Havana pelos ingleses ${ }^{93}$.

A ocupação foi terrível para a companhia havanesa. Além da paralisação de suas atividades, ela padeceu com o confisco de seus armazéns. Com relação ao abastecimento de mão-de-obra, o conde de Albemarle, chefe da expedição e governador inglês estabelecido em Cuba, repassou o direito do comércio de escravos a um único negociante, chamado John Kennion, já bem atuante no Caribe. Para evitar o prejuízo das demais colônias britânicas, foi estipulado um limite anual de dois mil cativos. Ainda assim, nos onze meses que se seguiram houve um comércio negreiro bastante intenso, superando em mais de um milhar o montante fixado. Muitos escravos foram introduzidos clandestinamente por outros traficantes, além dos

\footnotetext{
reorganização do Império, 1750-1808.” In: L. Bethell (org.), História da América Latina. Vol. I. América Latina Colonial. (Trad.port.) São Paulo/ Brasília: EDUSP/FUNAG, 1997, pp.488-498; Joseph C. Miller.Way of Death: Merchant Capitalism and the Angolan Slave Trade, 1730-1830. University of Wisconsin Press, 1988, pp.360 e ss; Lara. "Legislação sobre escravos africanos na América portuguesa", pp.330-42; José Ribeiro Júnior. Colonização e monopólio no nordeste brasileiro. A Companhia Geral de Pernambuco e Paraíba (1759-1780). São Paulo: Hucitec, 2004, p.76; Maria Beatriz Nizza da Silva. Ser nobre na colônia. São Paulo: Editora Unesp, 2005, pp.178180; Clóvis Moura. Dicionário da escravidão negra no Brasil. São Paulo: Edusp, 2004, p394-395; Luiz Felipe de Alencastro. "Le versant brésilien de l'Atlantique-Sud: 1550-1850". Annales. Histoire, Sciences Sociales 2/2006 (61e année), p.359-361.

90 A Companhia Geral de Pernambuco e Paraíba, por exemplo, tinha sedes administrativas em Lisboa, na cidade do Porto e no Recife. Mas, havia uma nítida preeminência da junta lisboeta. Cf. José Ribeiro Júnior. Colonização e monopólio no nordeste brasileiro..., p.83-88.

${ }^{91}$ Ramiro Guerra y Sanchéz. Manual de Historia de Cuba..., p.148.

92 Luis Navarro García (coord.). Historia General de España y América. Vol. XI. Los primeros Borbones. Madri: Rialph, 1983, p.585; Olga Portuondo Zúñiga. "La consolidación de la sociedad criolla (1700-1765)". In: Instituto de História de Cuba. Historia de Cuba. La Colonia. Evolución socioeconómico y formación nacional. Havana: Editora Política, 1994, pp.198-200.

${ }^{93}$ Raquel Rico Linage. Lai reales compañías de comento con América: los órganos de gobierno. Sevilha: Excma. Diputación Provincial/ Escuela de Estudios Hispano-Americanos, 1983, pp.27-98.
} 
que funcionários e membros da campanha militar se desfizeram. Após a reintegração, o governo espanhol legalizou as aquisições efetuadas mediante uma tributação em $4 \%$ de seu preço. $\mathrm{O}$ interessante é que os negreiros ingleses permaneceram em Havana, colocando-se a serviço da companhia. Entre 1763 e 1765, durante o mandato do conde de Ricla como capitán general, eles facilitaram a entrada de algo em torno de nove mil escravos na ilha. Esse quadro criava um impasse para a coroa espanhola. De um lado, estava o programa de nacionalização monopolística do comércio imperial e, de outro, a clara superioridade estrangeira, entre outros aspectos, no provimento dos braços necessários ao avanço da agricultura cubana. Em junho de 1765, após rechaçar um novo acordo feito entre Ricla e negociantes ingleses, a coroa delegou o sortimento de escravos para diferentes partes da América espanhola, inclusive, Cuba, a uma nova empresa nacional, a Compañía Gaditana de Negros, controlada por Cádiz e tendo Porto Rico como centro de distribuição. Obstáculos como a resistência de parte da oligarquia cubana em aceitar a sua ingerência, a falta de know-how e a persistente necessidade de intermediação nos entrepostos do tráfico atravancariam o seu êxito, levando à concessão de licenças paralelas $^{94}$.

Não obstante essa insistência no comércio privilegiado, mudanças importantes estavam em curso. A perda de Manila e, sobretudo, de Havana havia desvelado a grave fragilidade militar das possessões espanholas. Além do mais, o incremento das transações comerciais verificado durante a permanência estrangeira realçara o subdesenvolvimento que o modelo econômico espanhol vinha alimentando. Urgia o fortalecimento das redes de defesa (e do aparato militar de uma maneira geral), tendo-se em perspectiva a provável retomada das hostilidades. Para tanto, era fundamental uma reformulação mais incisiva das bases estruturantes da economia do império. Os primeiros passos nesse sentido haviam sido dados logo após a Guerra dos Sete Anos, com a reformulação ministerial que sucedeu a renúncia de Ricardo Wall, a quem recaiu a principal responsabilidade pelas derrotas sofridas. Carlos III procurou se acercar ainda mais de homens de sua confiança dos tempos em que governara Nápoles e Sicília, antes de ser coroado rei da Espanha. O marquês de Esquilache, no comando das finanças desde 1759, assumiu também a pasta da Guerra, tornando-se cada vez mais influente na corte castelhano. Grimaldi, que havia sido embaixador em Versalhes e articulador do Pacto de Família, assumiu a secretaria de Estado. Ambos, junto ao frei espanhol Julián de Arriaga, secretário de Indias y de Marina, compuseram a junta ministerial incumbida pelo rei de estudar as ações necessárias para o estreitamento do controle político e fiscal sobre o

\footnotetext{
${ }^{94}$ Enrique López Mesa. "La trata negrera en el puerto de La Habana a mediados del siglo XVIII"..., p.30; Tornero Tinajero, Crescimento económico y transformaciones sociales ..., pp.34-38.
} 
território americano. Deu-se, então, a nomeação de D. Ambrosio Funes, o referido conde de Ricla, para o posto de capitán general de Cuba, com faculdades de visitador general, a cujo cargo também estaria, portanto, a inspeção do estado em que se encontrava o quadro administrativo local. Para lhe assessorar em sua missão, foi destacado o mariscal de campo Alejandro O'Reilly, o qual ficara encarregado mais especificamente das reformas no plano bélico. Eles deveriam buscar meios para que a ilha gerasse maiores entradas para os cofres da coroa e custeasse seus próprios gastos militares (problema comum, como se nota), reduzindose ao máximo a necessidade de realocação de verbas provenientes do México. Conforme instruções secretas, a elite patrícia havanesa deveria ser instada sobre a necessidade de elevação da carga tributária, mediante contrapartidas de fomento econômico.

Uma reorganização do sistema tributário foi iniciada; novos impostos foram criados; outros, já existentes, foram reajustados. Em abril de 1764, a alcabala, imposto tradicional castelhano sobre as transações comerciais, foi elevada de $2 \%$ para $4 \%$. Em outubro, foi criada a Real Intendencia de la Habana, órgão responsabilizado pelo controle fazendário local e pelos aspectos financeiros relativos à guarnição militar. Todavia, o pretendido aumento da arrecadação só seria obtido caso houvesse uma política de estímulo da produção aliada à redução das barreiras para a entrada e a saída de mercadorias. Foi este o cálculo que embasou a edição do Real Decreto e Instrucción sobre la libertad de comercio a los vasallos, para que puedan hacerlo a las islas de Cuba, Santo Domingo, Puerto Rico, Margarita y Trinidad, de 16 de outubro de 1765. Em suas Reflexiones, Pedro Rodriguez Campomanes, político eminente, destacado pensador do iluminismo espanhol, entusiasta que era do mercantilismo liberal dos britânicos, defendia a liberação integral do trato entre as Índias e os diversos portos espanhóis ${ }^{95}$. O parecer emitido pela comissão espanhola encarregada de estudar as mudanças cabíveis e pelos emissários em Cuba seguia pelo mesmo caminho, destacando as vantagens da abertura do comércio atlântico. Porém, os setores reacionários - representados por indivíduos como Arriaga, homem conservador afinado aos interesses estacionados no antiquado sistema de porto único, e por ministros do Consejo de Indias - impediram que a normativa tivesse maior amplitude. Como está explícito no título, o seu teor ateve-se ao Caribe, onde os interesses gadatinos eram de menor estima e estavam de certa forma contemplados pela companhia recém criada. Ainda assim, o dispositivo marcou o passo inicial para a quebra da exclusividade andaluz. Mais oito portos foram habilitados para o intercâmbio com as praças pontuadas, a saber, Sevilha, Alicante, Cartagena, Málaga, Barcelona, Coruña e Girón. As ilhas também

\footnotetext{
${ }^{95}$ Cf. Pedro Rodriguez Campomanes. Reflexiones sobre el Comercio Español a Indias...3, pp.XXII-XLV.
} 
poderiam comerciar entre si, desde que não envolvessem produtos negociados pela Espanha. $\mathrm{O}$ decreto chegou a Havana junto à outra disposição com a mesma datação que elevava uma vez mais o valor da alcabala, a qual chegou ao patamar de 6\%. A tarifa de $3 \%$ sobre as rendas líquidas, imposta inocuamente na década de 1720, foi eliminada. Em um cenário econômico marcado pela reprodução do capital mercantil, o acréscimo das tarifas sobre a circulação se apresentava como a solução mais proveitosa. O balanceio entre liberalização e incremento fiscal marcou a política adotada para Cuba no Pós-guerra dos Sete Anos ${ }^{96}$. Mas faltava encaixar o trabalho escravo nesse quadro. A liberdade para o tráfico negreiro figuraria as principais bandeiras defendidas desde então pela oligarquia local. Como destacam Eltis e Richardson, até fins da década de 1780, poucos escravos eram vendidos em Cuba levados diretamente da África. Os que entravam eram fundamentalmente crioulos, reexportados de ilhas próximas e a preços muito mais elevados, “em níveis que colaboravam para a lentidão do desenvolvimento da indústria de açúcar cubana"97.

Do lado lusitano, o encaminhamento da Guerra dos Sete Anos também teve as suas implicações. A queda de Havana não deixou de causar alarme. Afinal, o mesmo podia ocorrer, e porventura com mais facilidade, nas praças portuguesas. A experiência mostrava que o ultramar luso estava na alça de mira dos rivais e a aliança mantida com os ingleses não parecia ser fator suficiente para inibir pretensões de sua parte sobre o Estado do Brasil. A transferência da capital para o Rio de Janeiro, em maio de 1763, inseriu-se exatamente nesse contexto. Faziase necessário melhor guarnecer a cidade-porto que havia se tornado o centro articulador da economia colonial e a base do posicionamento estratégico de Portugal no Atlântico Sul ${ }^{98}$. Em verdade, tal ato foi o corolário de uma série medidas que já vinham sendo tomadas para a sofisticação do aparato administrativo da colônia. Em 1751, havia sido instalado o Tribunal da

\footnotetext{
${ }^{96}$ G. Douglas Inglis \& Allan J. Kuethe. "El Consulado de Cádiz y el reglamento de Comercio Libre de 1765". Actas de las IV Jornadas de Andalucía y América: Universidad de Santa María de La Rábida, marzo, 1984. Sevilla: Escuela de Estudios Hispanoamericanos, 1985, pp.79-95; Allan J. Kuethe. "La fidelidad cubana durante la edad de las revoluciones". Anuario de estudios americanos, Tomo LV, 1, 1998, p.212; Allan J. Kuethe. e G. Douglas Inglis. "Absolutism and Enlightened Reform: Charles III, the Establishment of the Alcabala, and Commercial Reorganization in Cuba". Past \& Present, No. 109 (Nov., 1985), p.120; Juan B. Amores Carredano \& José M. Serrano Álvarez. "El Conde de Ricla y las reformas fiscales em Cuba (1763-65): ¿Negociación o imposición?”. Orbis incognitvs: avisos y legajos del Nuevo Mundo: homenaje al profesor Luis Navarro García / coord. por Fernando Navarro Antolín, v.1, 2007, pp.385-403; Márcia Berbel, Rafael Marquese \& Tâmis Parron. Escravidão e Política..., pp.76-79. O decreto está disponível em: http://www.mcu.es/archivos/lhe/action.find.jsp\#. Acesso em: 26 de abril 2015.

${ }^{97}$ David Eltis \&David Richardson. "Os mercados de escravos africanos recém-chegados às Américas: padrões de preços, 1673-1865”. Topoi, Rio de Janeiro (março 2003), p.35.

${ }_{98}$ Maria Fernanda Baptista Bicalho. "A Cidade do Rio de Janeiro e a Articulação da Região em Torno do Atlântico Sul: Séculos XVII e XVIII”. Revista de História Regional, Ponta Grossa (1998), v. 4, n.3, p. p.21; Idem, A cidade e o império. O Rio de Janeiro no século XVIII. Rio de Janeiro: Civilização Brasileira, 2003, pp.60-77; Idem, "O Rio de Janeiro no Século XVIII: A transferência da capital e a construção do território centro-sul da América portuguesa". Urbana - Revista Eletrônica do Centro Interdisciplinar de Estudos da Cidade, (2006) v. 1, pp.1-20.
} 
Relação no Rio, a fim de desafogar o tribunal superior soteropolitano, ampliando o acesso à justiça nas capitanias do Sul. Medidas de fomento econômico e de ajuste fiscal também foram adotadas. A capitação do ouro foi substituída pelo quinto extraído compulsoriamente nas Intendências do Ouro e na Casa de Casa de Fundição; severas penalidades contra o contrabando de diamantes foram impostas, incluindo a possibilidade de denúncias dos escravos contra seus senhores; as tarifas sobre as exportações de açúcar e do tabaco foram reduzidas, sendo instituídas inspetorias para o controle da qualidade e dos preços nas principais cidades litorâneas da América portuguesa; os custos de transporte foram reduzidos. Em dezembro de 1761, deu-se a criação do Erário Régio, órgão responsável pelas transações financeiras aquém e além-mar, dividido em contadorias concernentes às diferentes partes do império, e que trouxe consigo as Juntas da Fazenda, que assumiram a administração dos contratos de direitos régios ${ }^{99}$.

O ano de 1765 também foi de liberalização para o império português. Os esforços da Junta de Comércio, criada dez anos antes, entre outras coisas, para organizar as transações do atlântico foram insuficientes. O tempo de espera era grande, produtos estragavam nos armazéns e o contrabando corria solto. O sistema de frotas e esquadras, que então funcionava nos portos da Bahia e do Rio de Janeiro, foi por essa razão extinto. Por alvará expedido em 10 de setembro, o rei ordenou que o comércio passasse a ocorrer livremente entre as ditas praças e os demais domínios portugueses, excetuando-se as áreas cobertas por "privilégios exclusivos" - o território a nordeste do Rio São Francisco seguia controlado pelas duas grandes companhias. Em junho do ano seguinte, nova disposição autorizou a navegação de cabotagem com fins mercantis, que estava vedada desde o século XVI. Até então, o trato legal entre os enclaves da América portuguesa era feito apenas por terra e toscamente controlado pela passagem em portos secos e por meio de registros variados ${ }^{100}$. Por essa época, buscou-se também encorajar a diversificação da agricultura no centro-sul. O próprio vice-rei, o segundo marquês do Lavradio, emprenhou-se na distribuição de sementes e mudas de diferentes culturas, tais como algodão, anil, arroz, café, cânhamo, cochonilha e trigo ${ }^{101}$. Quanto ao comércio de escravos, atuou-se para evitar o desvio de braços das indústrias coloniais, ademais da interdição da exportação de cativos (1751). Após ser vedada a introdução de escravos na Península, em 1761, o cativeiro

\footnotetext{
99 Kenneth Maxwell. A Devassa da Devassa..., pp.58-59; Andrée Mansuy-Diniz Silva, "Portugal e Brasil: a reorganização do Império, 1750-1808.” ..., pp.488-498.

100 Kenneth Maxwell. Marquês de Pombal. Paradoxo do Iluminismo (trad.port.) Rio de Janeiro: Paz \& Terra, 1996, pp. 132-3; Luiz Felipe de Alencastro. O trato dos Viventes. Formação do Brasil no Atlântico Sul. São Paulo: Cia das Letras, 2000, p.126; Berbel, Marquese \& Parron. Escravidão e Política..., p.80.

${ }^{101}$ Rafael de Bivar Marquese. Feitores do corpo, missionários da mente..., p.175.
} 
foi formalmente abolido em território reinol no ano de $1773^{102}$. Como observa Tâmis Parron, estas últimas disposições não procederam da assimilação política de uma agenda antiescravista, como se verificaria no império inglês, arrebatado por uma forte crise institucional, mas, antes, de um pragmatismo governativo que não punha em risco a existência da escravidão no interior do império, pelo contrário, buscava salvaguardá-la ${ }^{103}$.

A política pombalina reordenou o circuito econômico colonial. Porém, as despesas bélicas, o cenário adverso às exportações e o declínio progressivo da extração de metais preciosos obstruíram o crescimento. No campo da agroindústria, houve fracassos e sucessos, mas, estes, em sua maioria, se tornaram palpáveis somente depois da queda do poderoso ministro (1777), em consonância ao quadro de transformações instalado no mundo atlântico. Com a ascensão de D. Maria I, embora não tenham se verificaram alterações profundas na condução do estado, certos atos destoaram do que vinha sendo feito, em especial quanto à política monopolista. Não obstante as suas realizações, as empresas privilegiadas vinham sendo alvo crescente de reclamações por parte dos súditos, principalmente quanto à sua política de preços relativa aos escravos. Deu-se, então, a abolição das companhias do Grão-Pará e Maranhão (1778) e de Pernambuco e Paraíba (1779), e foi estabelecido o livre comércio também para a região norte da América portuguesa. Uma das consequências principais foi que o trato negreiro escapou novamente das malhas capitalistas metropolitanas, sendo reabsorvido pelos negociantes do Brasil ${ }^{104}$.

No campo diplomático, também ocorreu um desvio de curso na época da Viradeira. Imediatamente após a morte de D. José I e a saída de Pombal, foram retomadas as tratativas com a Espanha para a definição das fronteiras sul-americanas. A bem da verdade, os castelhanos se aproveitaram do momento de sucessão e da perene fragilidade das defesas portuguesas para forçar a circunstância em seu favor. O mandatário de Buenos Aires, agora vice-rei do Rio da

\footnotetext{
102 Os alvarás de 19 de setembro de 1761 e de 16 de janeiro de 1773, com vigência estrita ao território reinol, respectivamente, suprimiram o tráfico e decretaram liberdade aos nascituros e aos escravos de quarta geração. A historiadora Priscila de Lima evidencia que estes diplomas legais repercutiram consideravelmente na América portuguesa, sendo apropriados em demandas encaminhadas por escravos aspirantes à liberdade e a libertos desejosos de romper com seu estigma. No caso dos primeiros, não apenas sucedeu o translado à Península a fim de fazer cumprir o ponto da norma que concedia a liberdade aos doravante introduzidos em Portugal, como também proveio uma apropriação do discurso retórico antiescravista impresso na normativa que aboliu o cativeiro na metrópole em requisições de alforria remetidas desde a colônia. No caso dos segundos, avolumaram-se petições, em especial de pardos forros, reivindicando a equiparação de sua condição à de "habilitados", conforme ocorrera com os egressos reinóis, não mais classificados como libertos. Cf. Priscila de Lima. De libertos a habilitados: Interpretações populares dos alvarás anti-escravistas na América portuguesa (1761-1810). Dissertação de Mestrado - Programa de Pós-graduação em História da Universidade Federal do Paraná, 2011.

103 Tâmis Peixoto Parron. "Nova e Curiosa Relação (1764): escravidão e ilustração em Portugal durante as Reformas Pombalinas". Almanack Brasiliense, n.8 (nov.2008), pp.92-107.

${ }^{104}$ Luiz Felipe de Alencastro. “Le versant brésilien de l'Atlantique-Sud: 1550-1850”. Annales HSS, 2, pp.339-381.
} 
Prata, Pedro de Cevallos, voltou à cena, promovendo uma instantânea ocupação da ilha de Santa Catarina e, uma vez mais, da Colônia de Sacramento, avançando pelos pampas luso-brasileiros. Isto serviu de trunfo para o conde de Floridablanca, recém-empossado secretário de estado, para negociar o Tratado de San Idelfonso, firmado em primeiro de outubro de 1777, cujo texto dispôs a cessão de Sacramento e das Missões à coroa espanhola em troca da devolução da ínsula que havia sido usurpada. Em 24 de março do ano seguinte, foi assinado um segundo tratado, de El Pardo, que ratificou por uti possidetis os domínios portugueses no Rio Grande. Em contrapartida, a Espanha recebeu de Portugal as ilhas de Ano Bom e Fernando Pó na costa da Guiné, com abertura para acesso aos portos do rio Gabão, Camarões, São Domingos, Cabo Formoso e outros distritos adjacentes. Para não causar alarde, o governo espanhol procurou manter tal aspecto em segredo ${ }^{105}$.

Ao que parece, havia algum tempo que os castelhanos nutriam um interesse naqueles terrenos. Um documento anônimo constante do acervo da Britich Library, datado de 1776, expressava os proveitos a serem dali extraídos. Dizia ele,

\begin{abstract}
"De todos los establecimientos de la Costa de Africa [...] ninguno puede ser mas útil que el que el Rey va a formar en las islas de Annobón y Fernando Pó. [...] Será dicho establecimiento un depósito y una escala segura que facilitará tres beneficios. $1^{\circ}$ Tener con regularidad a los negros ya comprados, conservando y restaurando la salud de ellos hasta que se hallen en estado de embarcarse. $2^{\circ}$ Comprarlos de primera mano de los traficantes a menos precio, porque estos pueden darlos más baratos, vendiéndolos sin tantos riesgos y gastos de conducción y mantenimiento. $3^{\circ}$ Dirigirlos a América en navíos españoles, sin peligro de que se hagan los contrabandos; y conseguirse con el tiempo sea preferida la misma nación española para la venta a las otras naciones que comercian solo en factorías ${ }^{106 ”}$.
\end{abstract}

Foi exatamente dessa maneira que as novas aquisições passaram para a agenda política do governo espanhol. Despontavam no horizonte como a chance de se organizar uma plataforma nacional para o fornecimento de escravos, com um local de descanso, armazenagem e registro, feito os portugueses praticavam em São Tomé e Príncipe. A oligarquia havanesa logo se entusiasmou, enviando, por intermédio do cabildo local, uma representação indicando os indivíduos interessados em se engajar no comércio de escravos em Fenando Pó ${ }^{107}$.

105 José Ferreira Borges de Castro (org.). Collecção dos tratados, convenções, contratos e actos públicos celebrados entre a Coroa de Portugal e as mais Potências (desde 1640 até o presente). Lisboa: Imprensa Nacional, t.3, 1856, p.264. Para um estudo recente, ver: Dolores García Cantús. Fernado Poo: una aventura colonial española en África Occidental (1778-1900). Tese de doutorado, Universitat de Valencia, 2004, p.28. As informações apresentadas na sequência sobre Fernando Pó e Ano Bom foram extraídas, sobretudo, desse trabalho. ${ }^{106}$ British Library, Additional Ms. 13985. Papers relating to Spanish possession in American, v. II, f. 175r-178v, apud Manuel Lucena Salmoral, "Leyes para esclavos: el ordenamiento jurídico sobre la condición, tratamiento, defensa y represión de los esclavos en las colonias de la América española”, in José Andrés-Gallego (coord), Nuevas Aportaciones a la Historia Jurídica de Iberoamérica. Madrid: Fundación Histórica Tavera/Digibis/Fundación Hernando de Larramendi, 2000 (Cd-Rom), p.270.

107 Tornero Tinajero. Crescimento económico y transformaciones sociales..., p. 39; Fernando Armario Sanchez. "Esclavitud y aboliciosmo durante la regencia de Espartero", in: Francisco de Paula Solano Pérez-Lila 
Mas a empreitada se mostraria penosa. Tudo estava por ser feito. Não havia infraestrutura ou trânsito regular. As ilhas estavam praticamente desabitadas. Ano Bom é uma ilhazinha de não mais do que 17 km²; distante 670 km de Fernando Pó e 400 km da costa (Cabo López, atual Gabão); longe demais dos enclaves do tráfico e fora das melhores rotas paras as Índias espanholas. Fernando Pó tinha um feitio mais favorável, com uma extensão de 2,017 $\mathrm{km}^{2}$, boas condições naturais e bastante próxima das costas de Calabar e Bimbia, pólos tradicionais de distribuição de nativos escravizados. O problema era que se tratava de um setor pululado de traficantes ingleses e com um potencial de expansão pouco promissor. As atividades na região vinham declinando desde meados do século, concentrando-se nas áreas ao sul da linha equatorial (no Congo e em Angola, no caso dos vassalos portugueses). É possível que alguma conveniência pudesse ser alavancada, mas demandaria tempo e investimentos. Não foi por acaso que os portugueses abriram mão daqueles territórios tão resignadamente.

Tudo indica que a noção na Espanha a respeito da situação era bastante vaga. Lisboa se esquivou o quanto pôde de fornecer informações precisas e não foi feito um reconhecimento prévio. De todo modo, não houve perda tempo. Antes de completado um mês da assinatura do novo Tratado de El Pardo, saiu de Montevideo uma frota destinada a tomar posse das ilhas. Em 29 de junho de 1778, os barcos aportaram em Príncipe, de onde deveriam ser escoltados para a transmissão oficial. Porém, isto só foi providenciado quatro meses depois. Foi então que o segredo se perdeu e a presença espanhola na região se tornou de conhecimento geral.

É possível que o acesso ao continente africano tenha sido a peça que faltava para que o governo espanhol completasse a sua política comercial. Para Dolores García, não foi por acaso que, apenas seis meses depois do acerto com Portugal, Carlos III tenha baixado o Reglamento y Aranceles Reales para el Comercio Libre de España a Indias (12 de outubro de 1778), que completou o processo iniciado em 1765, pondo fim ao sistema de frotas e de exclusividade portuária, liberalizando a circulação no interior do império ${ }^{108}$. Caso Ano Bom e Fernando Pó cumprissem o papel ambicionado, o problema do provimento de cativos se resolveria intestinamente. Mas o projeto minguou. As razões principais encontram-se nas dificuldades assinaladas e na participação da Espanha, a partir de 1779, na Guerra de Independência dos Estados Unidos ao lado da França, em atenção mais uma vez ao Pacto de Família contra a GrãBretanha. O novo round do enfrentamento atrapalhou as transações oceânicas e bloqueou o já

(coord.).Esclavitud y derechos humanos: la lucha por la libertad del negro en el siglo XIX. Madri: CSIC, 1990, p.400.

${ }^{108}$ García Cantús. Fernado Poo..., p.36. 
difícil engajamento dos mercadores hispânicos no trato da Guiné ${ }^{109}$. Ao mesmo tempo, a situação de guerra declarada fechou as portas para o ingresso legal de negreiros britânicos em Cuba. A saída natural foi uma aproximação a mercadores norte-americanos, muito embora os ingleses seguissem injetando cativos na ilha de modo clandestino ou por meio de testas-de-ferro locais, licenciados momentaneamente para o transporte de escravos. Tal foi o caso de Miguel Antonio de Herrera e da viúva de Cárdenas de Monte Hermoso, admoestados por transferirem seu benefício às comerciantes da Inglaterra ${ }^{110}$.

Após a cessação do conflito, a coroa espanhola cedeu ao pragmatismo e acertou um contrato para o fornecimento de escravos com a casa Baker e Dawson, de Liverpool. O primeiro acordo, fechado em 1784, previu a introdução de 4000 escravos em Trinidad e o mesmo em Caracas, com isenção de direitos. Dois anos depois, a companhia inglesa assumiu o mercado cubano, tendo Felipe Allwood como representante estabelecido em Havana. Entre 1786 e 1789, ela introduziu algo em torno de 5.786 escravos na ilha. Aos membros da elite criolla estava claro que os comerciantes hispanos não estavam aptos a atender as necessidades de mão-deobra da economia local. No entanto, tampouco estavam satisfeitos com a persistência do privilégio exclusivo no setor, tendo em vista os ingressos ainda insuficientes e os preços elevados que o regime vinha propiciando. Para que houvesse entradas abundantes, a preços razoáveis, havia de ser decretada a livre concorrência com a participação de nacionais e estrangeiros, sem mais contratos, licenças ou asientos ${ }^{111}$.

Francisco de Arango y Parreño (1765-1837) foi o principal articulador dessa linha junto a coroa. Jovem e brilhante advogado havanês seguiu para a Espanha no ano de 1787 para completar os seus estudos, muito recomendado pelos oidores da Audiencia de Santo Domingo. Lá estando, rapidamente atraiu a atenção dos altos funcionários cortesãos, incluindo o próprio conde de Floridablanca. Em 1788, antes mesmo de atingir a maioridade civil, foi nomeado Apoderado General do Ayuntamiento de Havana, uma espécie de porta-voz oficial dos interesses locais. Não demoraria em que se tornasse o intelectual mais destacado de sua classe, a nascente plantocracia cubana. Quiçá tenha sido, nos dizeres de Moreno Fraginals, "o homem de mais sólida formação burguesa do império espanhol na época, incluindo a própria Espanha, no nível dos grandes pensadores europeus de então" ${ }^{\text {112 }}$. A função assumida seria desempenhada

\footnotetext{
${ }^{109}$ Idem, pp.29-90.

110 Tornero Tinajero.Crescimento económico y transformaciones sociales..., pp.40-41; García Cantús. Fernado Poo..., p.80.

111 James A. Rawley \& Stephen D. Behrendt. The Transatlantic Slave Trade: A History (Revised Edition). Nebraska: University of Nebraska Press: 2005, p.186.

112 Manuel Moreno Fraginals. "Os oligarcas se tornam sacarocratas". Cuba/España, España/Cuba: Historia Común. Barcelona: Crítica, 1995, pp.194.
} 
com afinco. Logo após sua nomeação, encaminhou a seus superiores o documento intitulado "Primer papel sobre el comercio de negros", no qual advogou francamente a abertura do tráfíco de escravos por mãos estrangeiras diante da alienação histórica da Espanha na participação direta daquele miserable comercio. Contudo, caberia alguma cautela a fim de que se estreitassem as brechas para o contrabando e a evasão fiscal. A melhor saída seria aderir a uma mescla entre a habilitação de portos com liberdade absoluta, em que traficantes de todas as nacionalidades pudessem atuar, e a de portos com liberdade limitada, para que os vassalos espanhóis pudessem sair a obter escravos onde melhor lhes aprouvesse. O sentido era, por um lado, garantir a oferta nas regiões de maior demanda e melhor estruturação administrativa e, por outro, fomentar um engajamento progressivo de nacionais em regiões menos guarnecidas, mas com demanda ascendente. A reflexão sobre a liberação integral ou controlada assume um tom generalista no discurso, remissível à toda a América hispânica, mas converge para a situação cubana; havanesa, em particular. Para Havana caberia única e exclusivamente a liberdade integral. Em suas palavras, "por si só e sem a liberdade absoluta de nada serviria esse partido porque, ademais de que podia ser ilusório pelos poucos conhecimentos e capitais que há para estas expedições". Centrando-se nos problemas de sua jurisdição, prescreve: "ainda que todo estrangeiro ou nacional possa prover de negros à Ilha de Cuba, não possa levá-los a outro porto que o da cidade de Havana" ${ }^{113}$.

A proposta parece ter soado bem aos ouvidos das altas esferas madrilenas, dada a enorme simetria entre o seu teor e a política adotada na sequência. Real cédula de 28 de fevereiro de 1789 finalmente concedeu liberdade para o comércio de escravos para Caracas e as Antilhas Maiores por um período experimental de dois anos. Portos específicos foram habilitados. No caso de Cuba, Havana e Santiago. Mas, conforme Arango recomendara, apenas o porto da capital poderia receber embarcações estrangeiras. A Santiago de Cuba estava liberado somente o trânsito de negreiros espanhóis e criollos. Como atrativo a mais, em ambas as situações, concedia-se isenção tarifária total. $\mathrm{O}$ artigo quarto da cédula versava que:

\footnotetext{
"los españoles y los extranjeros que por tiempo de dos años llevaren negros a las expresadas Islas y Provincia de Caracas para traficar con ellos, los podrán vender libremente a los precios que concierten con los compradores, sin que por parte del Ministerio Real, ni Municipal, se les ponga tasa alguna, que la de estar a la mira para evitar el contrabando y celar que los negros sean de buenas castas y calidades"114.
}

\footnotetext{
113 Gloria García Rodríguez. Biblioteca de Clásicos Cubanos. Francisco de Arango y Parreño. Obras (volumen I). Ensayo introductorio, compilación y notas de Gloria García Rodríguez. Havana: Imagen Contemporánea, Ciencia Sociales, 2005, pp.117-121.

${ }^{114}$ Lucena Salmoral. "Leyes para esclavos: el ordenamiento jurídico sobre la condición,...”, p.1146.
} 
A destinação dos escravos aportados deveria ser preponderantemente o setor agrícola, na lida das plantações, engenhos e afins. A utilização de cativos para serviços domésticos era desestimulada com a capitação anual de dois pesos ${ }^{115}$. Entre 1791 e 1804, a liberação foi sucessivamente prorrogada, outros portos locais foram autorizados (Batabanó, Manzanillo, Matanzas, Trinidad, Nuevitas) e o comércio negreiro para a ilha se intensificou, tendo sido desembarcados oficialmente cerca de 91.505 africanos ${ }^{116}$. Como destaca David Eltis, houve, então, uma integração inédita de Cuba ao circuito caribenho do tráfico, possibilitando um nivelamento dos preços em relação aos cativos que adentravam as demais praças antilhanas ${ }^{117}$. Dessa maneira, foi eliminado o mais grave entrave para o desenvolvimento da economia local, que era a falta de força de trabalho, ratificando-se o alinhamento entre a oligarquia havanesa e o gabinete de Madri.

Um ponto importante a realçar é a ausência de isonomia na abertura realizada. Nas cédulas que prorrogaram a liberdade de tráfico, manteve-se o privilégio do porto de Havana para o recebimento de embarcações estrangeiras. Isso persistiu até 1818, quando se deu a liberação integral do comércio colonial. Não é descabido pensar que, de todo modo, a capital seria o destino principal. Afinal de contas, era na hinterlândia habanera onde se concentrava o maior de número de engenhos e havia maior disponibilidade recursos para investimentos. Contudo, a restrição legal conferiu maior amplitude à rede de negócios tecida na sede da colônia, ao mesmo tempo em que limitou a margem de ação de negociantes das regiões mais distantes e circunscreveu o potencial de sua expansão produtiva. A oferta privilegiada facultada naqueles anos iniciais foi crucial para o acúmulo de ativos necessário ao movimento expansivo do capital produtivo no ocidente, concorrendo, ao mesmo tempo, para a solidificação do retraso da porção oriental. Segundo Moreno Fraginals, qualquer manufatura açucareira cubana típica, de leste a oeste, teria em escravos ao menos a metade dos capitais invertidos. Todavia, como o crescimento ocidental fora realizado sobre uma oferta mais ampla de mão-de-obra, a concentração em escravos seria mais acentuada, chegando aos $80 \%{ }^{118}$.

Como é possível observar, o contexto de redefinição da política espanhola sobre o tráfico de escravos coincidiu milimetricamente com a onda revolucionária que assolou o império francês, fazendo ruir o absolutismo na França e a economia de plantação de próspera

\footnotetext{
115 Idem, ibidem.

${ }^{116}$ Disponível em: <http://www.slavevoyages.org/tast/assessment/estimates.faces〉. Acesso em: 26 de abril 2015.

${ }^{117}$ David Eltis. Economic Growth and the Ending of the Transatlantic Slave Trade. New York: Oxford University Press, 1987, p.36.

118 Manuel Moreno Fraginals. "Desgarramiento azucarero e integración nacional” (publicado originalmente em 1970). In: Alfredo Prieto (ed.). Órbita de Manuel Moreno Fraginals. Havana: Ediciones UNIÒN, 2009 , pp.99.
} 
colônia de Saint-Domingue, o que sem dúvida potencializou os efeitos das medidas de fomento. Em seu célebre Discurso sobre la Agricultura de la Habana y Medios de Fomentarla (179192), escrevia Arango, no calor dos acontecimentos:

\footnotetext{
"Cuando empezaban a incomodar fue cuando la Providencia 11 descargó sobre Francia el azote que hoy la aflige. La confusión y desorden que reinaba en sus colonias disminuyó sus producciones, y dando valor a las nuestras hizo que no nos fuese nociva la abundancia de negros que nos trajo la citada Real Cédula de 1789. Hoy, en más feliz situación, por el funesto incremento que han tenido las desgracias del vecino, vendemos nuestros azúcares a un precio ventajosísimo"119.
}

De fato, Cuba, que já havia se tornado a terceira produtora mundial de açúcar com a penetração no mercado norte-americano, vive naquele momento uma "absurda orgia milionária". O porto de Havana cresceu ainda mais em suas atividades. A circulação monetária se elevou de modo estrondoso. As práticas econômicas, no campo e na cidade, convergiram para o ramo açucareiro. Desfigurando o meio ambiente, substituindo pastos e vegas tabaqueiras, a cultura da cana se alastrou rapidamente pelo departamento ocidental, até região de Matanzas, que em poucos anos se tornaria o principal centro produtor da ilha, o berço da grande manufatura cubana ${ }^{120}$.

No mencionado Discurso, a preocupação de Arango era propor meios para que a prosperidade do momento fosse sustentada no longo prazo. A situação do abastecimento de escravos, pela provisoriedade da liberação e pela dependência de mãos estrangeiras, causavalhe particular incômodo, sendo posta em destaque como primeiro inconveniente a ser sanado. O modos operandi luso-brasileiro servia-lhe de referência:

\footnotetext{
"Los portugueses como más vecinos a la Costa de Oro, y como el mismo Brasil les da frutos los más a propósito para este comercio, introducen anualmente en Pernambuco, Río Janeiro y Bahía cerca de veinte mil de todas clases. El agricultor toma porte si quiere en estas expediciones; y si no, encuentra los negros que necesita al precio cómodo de ciento treinta a ciento cuarenta pesos cuando más"121.

O remédio proposto era a concessão de prêmios e incentivos fiscais para traficantes nacionais e a fundação de estabelecimentos espanhóis no continente africano para a facilitação do acesso mercantil. No entanto, o fato é que a autonomia ambicionada pelo estadista cubano seria alcançada somente na década seguinte. Com os mercadores de escravos ingleses e norte-
}

\footnotetext{
119 García Rodríguez. Biblioteca de Clásicos Cubanos..., p.150.

${ }^{120}$ Manuel Moreno Fraginals. El ingenio: complejo econômico social cubano del azúcar. Havana: Editorial de Ciencias Sociales, v. 1, 1978, p.139.

${ }^{121}$ García Rodríguez. Biblioteca de Clásicos Cubanos..., p.152.
} 
americanos fora do circuito, a partir de 1807, os espanhóis finalmente encontraram a brecha que necessitavam para imiscuírem-se no trato de direto de africanos escravizados ${ }^{122}$.

Sobre o caso brasileiro, pode-se dizer que a imagem traçada por Arango, embora otimista em demasia, não escapava muito à realidade. Ainda que houvesse disputas regionais e manobras ilícitas para o proveito do negócio, as vias do tráfico estavam abertas. A oferta de mão-de-obra não era o obstáculo. A concorrência internacional nas exportações, sim. Tempos de guerra e de paz geravam oscilações nas atividades produtivas por causa das decorrentes elevações e quedas nos preços. Durante as guerras dos Sete Anos e da Independência do Estados Unidos, o ramo açucareiro da América portuguesa, o mais valioso de sua economia, apresentou crescimento. Mas o término das hostilidades reativava o comércio antilhano, causando novos declínios. A recuperação não se sustentava.

Os acontecimentos encabeçados pela Revolução em Saint-Domingue atingiram outro nível de implicações. O fenômeno, ao alterar profunda e decisivamente o jogo das trocas no espaço atlântico, revitalizou a agricultura da colônia portuguesa. Foi, então, que as sementes plantadas por Pombal puderam frutificar em seu pleno vigor. As exportações tradicionais ganharam novo fôlego em Pernambuco e na Bahia; também se ampliaram na região sudeste, com destaque para o distrito de Campos dos Goitacazes, cuja produção consolidaria o Rio de Janeiro como importante região açucareira ainda em fins do século XVIII. O algodão produzido no norte-nordeste tornou-se cada vez mais competitivo, chegando a compor $30 \%$ das exportações inglesas na década de 1790. Com commodities como o arroz, o anil e o cacau ocorreram algo semelhante, verificando-se notáveis elevações em suas saídas ${ }^{123}$.

Por outro lado, entre os grupos sociais tolhidos em seus interesses ou menos favorecidos pela recuperação econômica, brotaram sensíveis focos de tensão. A falta de liberdade e o arrocho fiscal, usual causa de descontentamento nas esferas coloniais, desencadearam reações carregadas de uma nova carga de princípios e reivindicações, dando ocasião à contestação direta do regime colonial. É bom realçar que a independência dos Estados Unidos tornara a sedição uma realidade tangível. Nas palavras de Fernando Novais, “em dois momentos pelo menos, em Minas em 1789 e na Bahia em 1798, transcendeu-se a tomada de consciência da situação colonial, e se projetou a mudança, intentando-se a tomada do poder" ${ }^{\prime 24}$. Os movimentos foram

\footnotetext{
122 Tornero Tinajero. Crescimento económico y transformaciones sociales ..., p.69.

${ }^{123}$ Stuart B. Schwartz. Segredos Internos. Engenhos e escravos na sociedade colonial, 1550-1835 (trad.port.). São Paulo: Companhia das Letras, 1988, pp.342-348; Andrée Mansuy-Diniz Silva, "Portugal e Brasil: a reorganização do Império, 1750-1808.” ..., pp.504-505; Dauril Alden. “O período final do Brasil colônia, 1750-1808”. In: Leslie. Bethell. (org.). História da América Latina. Vol.II. América Latina Colonial. (trad.port.) São Paulo: EDUSPBrasília: Fundação Alexandre de Gusmão,1999, pp.527-592.

${ }^{124}$ Fernando A. Novais. Portugal e Brasil na crise do Antigo Sistema Colonial..., p.169.
} 
contidos e a ordem foi preservada sem grande abalo, não há dúvida. Mas a sua ocorrência, mesmo que não refletisse um sentimento generalizado dos colonos de oposição ao sistema, premiu o centro de poder metropolitano a projetar modificações na estrutura da administração do império, à luz da situação de crise internacional. Os acontecimentos na América do norte e o processo revolucionário francês, com o seu desdobramento em Saint-Domingue, em curso, alertavam para a necessidade de reformas. Estava recolocado o problema da preservação da unidade imperial.

O principal empreendedor de ajustes na política portuguesa nessa época foi D. Rodrigo de Sousa Coutinho, secretário da Marinha e do Ultramar entre 1796 e 1801, igualmente destacado como teórico da ilustração portuguesa. O futuro conde de Linhares, era afilhado de batismo do marquês de Pombal e havia sido preparado desde cedo para servir ao estado, efetuando seus estudos no Real Colégio dos Nobres, fundado por seu padrinho, e na Universidade de Coimbra. Começou na carreira diplomática. Esteve em Paris, na década de 1770, onde teve contato direto com teóricos do quilate de D'Alembert e Raynal. De ideias arejadas, profundo conhecedor de Adam Smith, buscou compor, dentro dos marcos colonialistas, um amplo programa de reformas voltado, em especial, à eliminação dos estancos régios, ao desenvolvimento técnico da agricultura e da mineração, e ao alívio da pressão fiscal. Foi o responsável pelas punições severas impostas aos participantes da conjuração baiana. Mas, entendia que apenas a repressão não bastava, era necessário buscar uma aliança com a oligarquia local. Um passo dado nesse sentido foi o recrutamento de brasileiros para cargos de elevada importância, como foram os casos de Manuel Ferreira da Câmara, nomeado intendentegeral das Minas e do Serro Frio, e de José Bonifácio de Andrada e Silva, que ocupou, em Portugal, o cargo recém-criado de intendente das Minas e Metais.

Com relação à escravidão, Sousa Coutinho buscou, acima de tudo, apurar o fluxo do tráfico. Sob sua influência, o governo metropolitano buscou garantir o bom provimento da América portuguesa, inibindo o desvio de cativos para os domínios espanhóis e estimulando a exportação de cachaça para o trato africano (cartas régias de 24 de setembro de 1798 e de 19 de outubro de 1799). Para fomento da região norte, foi decretada isenção de direitos para os escravos introduzidos no Pará (decreto de 19 de outubro de 1798). Anotando a redução da atividade de holandeses e franceses na Costa da Mina, o secretário instou o governador da Bahia a elevar o volume das atividades de traficantes baianos na região. Os senhores de escravos tripulantes de navios mercantes foram tranquilizados com medida que esclareceu não ser 
motivo de alforria o fato de aportarem no Reino, não obstante a disposição de 1761 que proibiu o ingresso de cativos em Portugal (alvará de 10 de março de 1800) ${ }^{125}$.

$\mathrm{Na}$ presidência do Erário entre 1801 e 1803, além de promover a abolição dos monopólios do sal e da pesca da baleia, D. Rodrigo revitalizou o projeto de transferência da corte para a América, tendo em vista a centralidade do Brasil no concerto imperial e o novo quadro das relações internacionais, com Napoleão Bonaparte à frente de um império em recuperação. Para o estadista, partidário que era do esquema federativo, Portugal deveria ser relegado a um nível secundário, equivalente, aliás, ao que já ocupava no plano econômico. Seria a única forma de resguardar a porção essencial do império luso em caso de invasão, ampliandose, ademais, as possibilidades de expansão no Novo Mundo em direção ao Rio da Prata. O governo inglês prontamente abraçou a ideia, oferendo por intermédio de seu embaixador garantias de apoio e escolta no traslado. A proposta, porém, acarretou forte oposição em Lisboa, especialmente por parte do setor mercantil, que também se manifestou contrariamente a uma aliança com a Inglaterra. A neutralidade parecia mais propícia aos seus negócios. Sousa Coutinho foi taxado de anglófilo, perdeu espaço no governo e terminou pedindo demissão ${ }^{126}$.

Mas, o desenrolar dos acontecimentos deixaram exíguas alternativas ao regente lusitano. No dia 21 de novembro de 1806, Napoleão decretou em Berlim o Bloqueio Continental. A posição neutral pôde ser mantida por alguns meses, mas, após a assinatura do tratado de Tilsit, com a Rússia e a Prússia, em 7 de Julho de 1807, o imperador francês voltou suas atenções para Portugal a fim de fechar todas as brechas possíveis ao comércio britânico, ao mesmo tempo em que intensificava a aproximação com a Espanha, iniciada três anos antes. Em 12 de agosto foi encaminhado um ultimato ao ministro António de Araújo e Azevedo, para que o príncipe cerrasse imediatamente os portos portugueses, prendendo e confiscando os bens dos súditos da Grã-Bretanha. Em contrapartida, o Foreign Office ameaçou com a tomada da esquadra portuguesa no Tejo e com a invasão das colônias, se Portugal cedesse. Mas, caso D. João se mantivesse firme, receberia proteção da Royal Navy para uma possível retirada rumo ao Brasil. A opção foi aceita mediante assinatura de um acordo em 22 de outubro. Ainda assim, o governo

125 Dom Rodrigo de Sousa Coutinho. "Memória sobre o melhoramento dos domínios de Sua Majestade na América”. In: Textos Políticos, Económicos e Financeiros (1783-1811). Andrée Mansuy Diniz Silva (ed.). Lisboa: Banco de Portugal, 1993, 2v., v.II, pp.47-66; Boletim do Conselho Ultramarino. Legislação Antiga. Volume II. 1755-1834. Lisboa: Imprensa Nacional, 1867, p.3; Fernando A. Novais. Portugal e Brasil na crise do Antigo Sistema Colonial..., pp.260-261; Pierre Verger, Fluxo e refluxo do tráfico de escravos entre o Golfo de Benin e a Bahia de Todos os Santos, dos séculos XVII a XIX. (trad.port.) São Paulo: Corrupio, 1987, pp.113-5; Lara. "Legislação sobre escravos africanos na América portuguesa", pp.368-370; http://objdigital.bn.br/acervo_digital/div_obrasraras/or89_5_6n43.jpg

${ }^{126}$ Kenneth Maxwell. A Devassa da Devassa..., pp.254-257; Idem. Kenneth Maxwell. "A geração de 1790 e a ideia do império luso-brasileiro". In: Chocolates, Piratas e Outros Malandros. Ensaios Tropicais (trad.port). São Paulo: Paz \& Terra, 1999, pp.157-208. 
luso procrastinou o quanto pôde, negociando com ambos os lados. No dia 27 do mesmo mês outubro, Napoleão e o ministro espanhol, Manuel de Gody, assinaram em Fontainebleau um tratado prevendo a divisão do território português. A nova aliança, entretanto, não mais se baseava em laços consanguíneos, era mais frágil do que as de outros tempos. No dia 24 de novembro, com as tropas francesas a quatro dias de Lisboa, D. João por fim tomou a decisão de partir com a corte para o Brasil. Os eventos imediatos são de amplo conhecimento ${ }^{127}$. O importante a destacar são os elementos novos que a concretização da transferência da Casa de Bragança para o Rio de Janeiro e a subsecutiva crise da monarquia espanhola trouxeram para a arquitetura do escravismo atlântico ${ }^{128}$.

O processo de "interiorização da metrópole no Centro-Sul da colônia" desencadeou intensas alterações que afetaram sobejamente o curso da economia escravista do Brasil, e do Rio de Janeiro, em particular. O elo secular com Portugal foi imediatamente rompido. A interdição dos entrepostos reinóis ocasionada pela ocupação napoleônica levou o regente a promover, por meio de carta régia de 28 de janeiro de 1808 , a abertura dos portos brasileiros às nações amigas para a recomposição das atividades comerciais do Brasil. A liberação comercial, aliada ao vultoso fluxo imigratório que se seguiu, repercutiu prontamente sobre as atividades produtivas urbanas e rurais e, logo, sobre as importações de cativos para o porto do Rio de Janeiro. As entradas praticamente duplicaram na década de 1810, chegando ao patamar médio de 19.000 escravos anuais, contra os 10.000 do decênio anterior ${ }^{129}$. A corte absorveria uma parcela substancial daqueles escravos, no trabalho do porto, no comércio, nas pequenas roças e criações, em indústrias e serviços diversos e na lida doméstica. O complexo açucareiro, já plenamente estabelecido, em especial, na região de Campos, era um importante sorvedouro dos cativos importados, sem contar aqueles redistribuídos para as demais regiões do eixo sulsudeste. Parte deles, porém, passou a ser empregada no cultivo do café, que começava a superar a esfera da pequena produção e do consumo local, quando era plantado no Maciço da Tijuca. O cenário internacional favorável incentivou a realização de investimentos no setor, que desde o final do século vinha aumentando sua importância comercial nos índices de exportação ${ }^{130}$. Esse foi o destino de parte dos capitais mobilizados na época, dando início a um ciclo de

\footnotetext{
${ }^{127}$ Leslie Bethell. “A independência do Brasil". In: L. Bethell (org.), História da América Latina. Vol. III. Da independência até 1870. (Trad.port.) São Paulo/ Brasília: EDUSP/FUNAG, 2001, pp.197-210; Jorge Miguel Pedreira. "Economia e política na explicação da independência do Brasil". In: Jurandir Malerba (org.). A independência brasileira: novas dimensões. São Paulo: FGV, 2006, pp.55-98.

${ }^{128}$ Berbel, Marquese \& Parron. Escravidão e Política..., pp.95-181.

${ }^{129}$ Manolo Garcia Florentino, Em Costas Negras. Uma História do Tráfico Atlântico de Escravos entre a África e o Rio de Janeiro (séculos XVIII e XIX). Rio de Janeiro: Arquivo Nacional, 1995, p.74.

${ }^{130}$ Dauril Alden. “O período final do Brasil colônia, 1750-1808”, pp. 576-577.
} 
inversões que gradualmente se sustentaria com a lucratividade gerada pela própria atividade. Dos arredores da cidade, o plantio do café foi se expandido pelas margens litorâneas e em direção ao Vale do Paraíba fluminense, em regiões que haviam permanecido virgens em razão do embargo legal para a ocupação do terreno estabelecido na década de 1730. Havia uma infraestrutura herdada dos tempos da mineração, aproveitada inicialmente para o aproveito da cana-de-açúcar, que passou a ser gradativamente mobilizada para o cultivo e o escoamento da produção cafeeira, com destaque para a rede de caminhos (o Caminho Novo e o Caminho Novo da Piedade) e para o complexo de transporte muar, alimentado pela região sul da colônia ${ }^{131}$.

O lado reverso da expansão econômica dinamizada com a transferência da sede do império foi o início do assédio britânico para o fim do tráfico de escravos. Dependente do apoio econômico e militar da Inglaterra, o governo português foi compelido a ampliar o leque de concessões, aceitando, entre outros pontos, a se comprometer pela extinção gradual do comércio negreiro. É o que consta do artigo décimo do tratado de Tratado de Aliança e Amizade, firmado em 19 de fevereiro de 1810:

\begin{abstract}
"Sua alteza real o príncipe regente de Portugal, estando plenamente convencido da injustiça e má política do comércio de escravos e da grande desvantagem que nasce da necessidade de introduzir e continuamente renovar uma estranha e factícia população para entreter o trabalho e indústria nos seus domínios do sul da América, tem resolvido de cooperar com sua majestade britânica na causa da humanidade e justiça, adotando os mais eficazes meios para conseguir em toda a extensão dos seus domínios uma gradual abolição do comércio de escravos. E movido por este princípio, sua alteza real o príncipe regente de Portugal se obriga a que aos seus vassalos não será permitido continuar o comércio de escravos em outra alguma parte da Costa da África que não pertença atualmente aos domínios de sua alteza real" 132 .
\end{abstract}

Como é possível depreender, a medida imediatamente tomada foi restringir as atividades dos tumbeiros nacionais aos domínios lusitanos na África, algo que, a princípio, não traria grandes abalos ${ }^{133}$. Porém, o tratado dispunha de artigos secretos. O segundo deles estipulava que os ingleses se empenhariam, quando chegassem as tratativas de paz, para que Portugal recobrasse os territórios de Olivença e Jurumenha - perdidos para os espanhóis durante o episódio bélico conhecido como Guerra das Laranjas, em 1801, no prelúdio da pressão contra a aliança anglo-portuguesa -, e preservasse o seu domínio sobre Caiena, ocupada em 1809 como retaliação aos franceses. Em retribuição, o mandatário português reforçava o pacto de

\footnotetext{
${ }^{131}$ Alice Piffer Canabrava. História Econômica: estudos e perspectivas. São Paulo: ABPHE-Hucitec-Ed.Unesp, 2005, pp.104-143; Rafael Marquese \& Dale Tomich. "O Vale do Paraíba escravista e a formação do mercado mundial do café no século XIX". In: Keila Grinberg \& Ricardo Salles (orgs.). O Brasil Império (1808-1889). Rio de Janeiro: Civilização Brasileira, pp.339-383.

${ }^{132}$ Lara. "Legislação sobre escravos africanos na América portuguesa", pp.393-396.

133 A disposição era potencialmente vantajosa aos traficantes hispânicos, pois ao obstruir o acesso de lusobrasileiros a regiões outrora dominadas por negociantes ingleses, reservava-lhes mercado.
} 
cooperação para a supressão do tráfico, comprometendo-se a aboli-lo nos estabelecimentos de Bissau e Cachéu, os quais, ademais, seriam cedidos "em plena soberania a sua majestade britânica" pelo período de cinquenta anos, em troca de uma indenização a ser combinada ${ }^{134}$.

Com base no convênio, a marinha britânica não tardou em efetuar apreensões de navios portugueses. D. Rodrigo de Sousa Coutinho, que tinha sido reintegrado ao governo como ministro da Guerra, e havia sido signatário do tratado, considerava tal procedimento um agravo à relação de amizade entre os dois países; motivo de reação vingativa por parte dos súditos portugueses e uma clara ameaça à economia local. Não lhe parecia razoável uma nação que havia levado duas décadas para chegar a um consenso sobre o problema exigisse "que Sua Alteza Real de Portugal possa abolir subitamente um comércio que é o único a poder fornecer os braços indispensáveis às minas e às culturas do Brasil". No entender do conde de Linhares, nem mesmo no prazo de meio século poderia Sua Alteza Real acabar com "este comércio triste mas necessário, como desejaria muito, se a coisa fosse compatível com o bem público e a existência de seus povos. Um tal resultado pode ser obtido somente lenta e progressivamente, e nunca pela força" ${ }^{135}$. Este seria o princípio orientador da reação pró-escravista então delineada contra a interferência britânica ${ }^{136}$.

Em 24 de novembro de 1813, o príncipe emitiu Alvará com força de lei em atenção ao transporte de os cativos da África ao Brasil. A justificativa apresentada era a seguinte:

\begin{abstract}
“[...] tendo-me sido presente o tratamento duro e inumano que no trânsito dos portos africanos para os do Brasil sofrem os negros que deles se extraem, chegando a tal extremo a barbaridade e sórdida avareza de muitos dos mestres das embarcações que os conduzem que, seduzidos pela fatal ambição de adquirir frete e de fazer maiores ganhos, sobrecarregam os navios, admitindo neles muito maior número de negros do que podem convenientemente conter, faltando-lhes com alimentos necessários para a subsistência deles, não só quantidade, mas até na qualidade, por lhes fornecerem gêneros avariados e corruptos que podem haver mais em conta, resultando de um tão abominável tráfico, que se não pode encarar sem horror e indignação, manifestarem-se enfermidades que, por falta de curativo e conveniente tratamento, não tardam a fazerem-se epidêmicas e mortais, como a experiência infelizmente tem mostrado"137.
\end{abstract}

A sequência do dispositivo recupera a tradição legal portuguesa na forma das normativas de 18 de março de 1684 e de $1^{\circ}$ de julho de 1730, de igual intenção, bem como do título 36 do livro V das Ordenações Filipinas, mantendo, em especial, as penalidades previstas, e atualizando o receituário na medida da conformidade "ao presente estado de coisas e ao adiantamento e perfeição a que têm chegado os conhecimentos físicos e novas descobertas

\footnotetext{
${ }^{134}$ Lara. "Legislação sobre escravos africanos na América portuguesa”, pp.395-396.

135 Apud Pierre Verger, Fluxo e refluxo do tráfico de escravos..., pp.301-2.

136 Berbel, Marquese \& Parron. Escravidão e Política..., pp.128-131.

${ }^{137}$ Lara. "Legislação sobre escravos africanos na América portuguesa” ..., p.403.
} 
químicas". É um texto típico da Ilustração, composto por onze pontos. 1) Que fosse respeitada a proporção de cinco negros por cada duas toneladas em navios de até 201 toneladas; e existisse um livro de carga, fabricado pelo juiz da alfandega do porto de saída, com registro do "número dos africanos que embarcaram, com a distinção do sexo, declarando-se se são adultos ou crianças, a quem vêm consignados e indicando-se a marca distintiva que o denote", bem como dos eventuais falecimentos a bordo - a ser apresentado para inspeção no porto de entrada. 2) Que em todas as embarcações houvesse um cirurgião perito. Na falta dele, que não fosse permitida a partida. 3) No castelo da proa ou outra parte conveniente do navio, deveria haver uma enfermaria para o tratamento das moléstias. 4) Não seria permitido o embarque de pessoa com doença contagiosa. 5) Os mantimentos embarcados deveriam ser examinados e aprovados em terra. 6) Ainda que o feijão fosse o principal alimento abordo, "tendo-se reconhecido pela experiência que estes o repugnam e rejeitam passados os primeiros dias da viagem", que houvesse um revezamento, "dando-lhes uma porção de arroz, ao menos uma vez por semana e misturando o feijão com o milho, alimento que os negros preferem a qualquer outro", fornecendo-se, também, "a competente porção de peixe e carne seca que igualmente deverá ser de boa qualidade", e para preparo da comida "se empregarão caldeirões de ferro, ficando reprovados os de cobre". 7) Sendo a falta d'água a carência mais difícil de suportar, que a aguada fosse gerida na razão de "duas canadas por cabeça em cada um dia", uma para beber e uma para cozinha, "regulando-se as viagens dos portos de Angola, Benguela e Cabinda para este do Rio de Janeiro a 50 dias, daqueles mesmos portos para a Bahia e Pernambuco de 35 a 40 dias e de três meses, quando o navio venha de Moçambique"138. 8) Que os recipientes de conserva e as vasilhas fossem devidamente limpos e vedados, excluindo-se aqueles que tivessem servido para vinho, vinagra, aguardente ou qualquer outro fim. 9) Que o asseio e a limpeza das embarcações, fator importante para manutenção da saúde de todos a bordo, fossem severamente inspecionados. 10) Que os negros fossem conduzidos pela manhã e pela tarde ao tombadilho a fim de respiraram ar livre, oferecendo-lhes uma porção de aguardente e obrigando-os a se banharem ao meio-dia com água salgada. 11) Que na última visita efetuada a antes da partida fosse examinado o estado dos negros, "e que sucedendo achar-se algum ou

\footnotetext{
138 "E querendo que mais se não pratique a barbaridade com que se procedia na distribuição da água, chegando a inumanidade ao ponto de espancar aqueles que, mais aflitos pela sede, vinham muito apressadamente saciar-se, determino que conservando-se a prática estabelecida para a comida dos negros, dividindo-se estes em ranchos de dez cada um, se forneça semelhantemente a cada rancho a porção da água que lhe toca, à razão de meia canada por cabeça, assim ao jantar como à ceia, fornecendo-se a cada rancho um vaso de madeira ou cassengos que contenha cinco canadas de água". Lara. "Legislação sobre escravos africanos na América portuguesa"..., p.407.
} 
alguns enfermos de moléstia que possa comunicar-se ou exigir mais cuidadoso curativo, devem desembarcar para serem curados em terra" ${ }^{\prime 39}$.

É cristalino o diálogo da norma com a necessidade premente de conferir legitimidade ao prosseguimento do infame comércio. A retórica impressa foi preparada com o cuidado de transparecer ao máximo a contínua preocupação da Coroa portuguesa através dos séculos de conferir condições de salubridade ao transporte, bem como o impulso de aprimorá-lo à luz da experiência acumulada e dos parâmetros hodiernos de ciência e humanitarismo. Mas havia outro nível de interesses contemplados pelo dispositivo. Como observa Joseph Miller, as especificações sobre a proporção de escravos por tonelagem eram quase proibitivas aos antiquados vasos utilizados por mercadores do Brasil, mas se ajustavam muito bem aos tumbeiros de fabricação inglesa. Ocorria que os traficantes britânicos vinham tratando de se associar a comerciantes de Portugal, repassando seus navios para o proveito dos negócios entre África e Brasil. Entre os principais prejudicados estiveram os negociantes cariocas, que já haviam perdido espaço na região do Prata por causa da presença britânica em Buenos Aires. Para escaparem da inspeção e das patrulhas inglesas, eles se viram obrigados a atuar em outros mercados, movendo-se à margem da malha administrativa em busca de portos alternativos, especialmente ao norte de Luanda. Dessa forma, conseguiam lucrar com o contrabando e a burla do fisco, mas tinham que enfrentar a crescente concorrência de traficantes empenhados no sortimento de Havana e outros portos hispânicos ${ }^{140}$.

Sobre o último ponto, vale a pena repassar que, a partir da liberalização comercial iniciada na passagem para a década de 1790, os negociantes hispano-crioulos começaram a robustecer o seu engajamento no tráfico, passando, porém, por um processo de aprendizagem e incertezas. Em 1792, por obra do governador Luis de Las Casas, foi formada a Compañía de Consignaciones de Negros. Ela foi encarregada de gerir o trânsito portuário dos negreiros, mas não detinha o controle das expedições. Em 1796, Arango defendia uma aproximação com Portugal para que fosse alinhada uma parceria em prol do abastecimento de cativos à ilha. Em seu entender, valia a pena tentar demover o vizinho ibérico das leis que vedavam as exportações

\footnotetext{
${ }^{139}$ Idem, pp.403-408

140 Joseph C. Miller.Way of Death...,pp.505-509. Ver também: Rodrigues, Jaime. De Costa a Costa. Escravos, marinheiros e intermediários do tráfico negreiro de Angola ao Rio de Janeiro (1780-1860). São Paulo: Companhia das Letras, 2005, pp.131-184; Guilherme de Paula Costa Santos. A Convenção de 1817: debate político e diplomático sobre o tráfico de escravos durante o governo de D. João no Rio de Janeiro. São Paulo: Faculdade de Filosofia, Letras e Ciências Humanas da Universidade de São Paulo (Produção acadêmica premiada), 2009, pp.19-21.
} 
de escravos a estrangeiros, por se tratar da nação praticava o trato com maior segurança. Tal intenção não foi adiante ${ }^{141}$.

De acordo com Moreno Fraginals, a primeira expedição exitosa de um negreiro cubano foi concretizada no dia 18 de setembro de setembro de 1798, quando foram desembarcados em Havana 123 africanos trazidos diretamente do Senegal por Luis Beltrán Gonet ${ }^{142}$. Porém, apenas no início do século, com as mudanças ocorridas na política internacional, que os nacionais tiveram a oportunidade de participar de modo mais ativo e direto no comércio de escravos. Escrevia o mesmo Arango em 1809:

\footnotetext{
"En estos últimos años se ha trastornado del todo el sistema de comercio de semejante ramo. Los ingleses y franceses que eran los que em grande lo hacían, lo han abolido enteramente. Los norteamericanos han ejecutado lo mismo. Los daneses se hallan casi em el próprio caso y de consiguiente no quedan otras banderas extranjeras capaces de poderse emplear em semejante tráfico que la portuguesa y la sueca, de suerte que ya no hay que contar com outro auxilio extranjero para esse ramo de comercio con el de que secretamente presten a nuestros negociantes sus conocimentos y fondos. Toda nuestra esperanza consiste en nosostros mismos y toda nuestra atención debe dirigirse a esses fin"143.
}

Segundo os dados apurados por Pablo Tornero, foi precisamente a partir de 1809 que os navios negreiros de bandeira espanhola se tornaram maioria absoluta entre as embarcações ancoradas em Havana. O problema é que naquele mesmo ano teve início a investida inglesa contra o tráfico hispânico. Conforme o historiador, a marinha britânica apresou diversos barcos que saíram de Havana, Matanzas, Trinidad e Santiago de Cuba. Dos 24 vasos que zarparam da capital ilhéu, 9 foram interceptados e não regressaram. Muitos mercadores optaram por se aliarem a negociantes estadunidenses, organizando saídas de portos norte-americanos. Contudo, com a nova guerra anglo-americana (1812-14), o comércio entre Cuba e os Estados Unidos seria reduzido praticamente à zero ${ }^{144}$.

Nesse meio tempo, surgia outro elemento complicador. As Cortes espanholas reunidas na cidade de Cádiz em 1810 abriram deliberação sobre o problema da escravidão. Ocorria que o peso material e simbólico do regime nas diferentes partes do império espanhol era bastante desigual, o que dava vazão a pontos de vista profundamente dissonantes. Em 25 de março de 1811, o deputado representante da Nova Espanha, José Miguel Guridi y Alcócer apresentou moção para a abolição do cativeiro, a começar pela proibição integral do comércio de escravos, interior e marítimo. O projeto, aparentemente inspirado na legislação adotada em estados do norte estadunidense, apontava o caminho da transição: mantinha-se o estatuto dos atuais

\footnotetext{
${ }^{141}$ Apud Tornero Tinajero, Crescimento económico y transformaciones sociales ..., p.80.

${ }^{142}$ Moreno Fraginals. El ingenio..., p.50.

143 Apud Pablo Tornero Tinajero, Crescimento económico y transformaciones sociales ..., p.72.

144 Tornero Tinajero, Crescimento económico y transformaciones sociales ..., pp.69-81.
} 
cativos, mas em condição melhorada, com o direito ao recebimento de salário e à alforria onerosa; os filhos porvindouros de escravos nasceriam livres; o principal atributo do escravo seria o de estar restrito a um único e invariável senhor até a obtenção da liberdade. Sobre a questão da manumissão mediante pagamento, é interessante notar que tal expediente já havia sido normatizado, como será explicado mais adiante. $\mathrm{O}$ diferencial da medida proposta seria assegurar os meios necessários para a compra da liberdade, isto é, o recebimento de soldo pelos trabalhos prestados ${ }^{145}$.

As proposições causaram sério embaraço, e foram encaminhadas para escrutínio da Comissão de Constituição sem serem publicadas no Diario de las Cortes. Entretanto, a matéria voltaria à baila poucos dias depois. Entre as proposições apresentadas no dia 2 de abril pelo deputado espanhol Agustín Argüelles constava a abolição do tráfico transatlântico de escravos para os domínios espanhóis. O seu tom, no entanto, era bem mais moderado e pragmático do que o assumido por seu par mexicano. Não tocava na instituição da escravidão em si, colocando na mira uma aproximação com os ingleses. Pregava que, após o Congresso haver abolido "para siempre tan infame tráfico", o Conselho de Regência deveria sem perda de tempo informar o governo britânico "a fin de que, procediendo de acuerdo en medida tan filantrópica, pueda conseguirse en toda su extensión el gran objeto que se ha propuesto la nación inglesa en el célebre bill de la abolición del comercio de esclavos". Com o monarca aprisionado e o território espanhol ocupado, a adoção de medidas antiescravistas poderia facilitar o apoio londrino ao recobro da soberania nacional. Dessa forma, tratava-se de ofertar um acerto semelhante ao efetuado com os portugueses em fevereiro ${ }^{146}$.

Os debates se acirraram, com opiniões bastante divididas. O deputado de Quito, José Mejía Lequerica, alegou que as proposições de Alcocér haviam sido acertadamente passadas para a Comissão de Constituição, pois versavam sobre um assunto distinto, “cual es el de abolir la esclavitud, negocio que requiere mucha meditación, pulso y tino [...], pero el impedir la nueva introducción de ellos es una cosa urgentísima”. A Grã-Bretanha havia proibido o comércio em seus domínios e estava tratando de ampliar tal encargo às demais potências. E argumentava o deputado: "acaba V.M. de ver que se ha puesto un artículo expreso aboliendo este comercio en la alianza firmada con Portugal. ¿Aguardaremos a que nuestros aliados nos

\footnotetext{
145 Gloria García Rodríguez. Biblioteca de Clásicos Cubanos. Francisco de Arango y Parreño. Obras (volumen II). Ensayo introductorio, compilación y notas de Gloria García Rodríguez. Havana: Imagen Contemporánea, Ciencia Sociales, 2005, pp.85-86; Cf. Berbel, Marquese \& Parron. Escravidão e Política..., pp.116-117.

146 Diario de sesiones de las Cortes Generales y Extraordinarias : dieron principio el 24 de setiembre de 1810 y terminaron el 20 de setiembre de 1813. Madrid: Imprenta de J.A. Garcia, 1870-1874, t.2, pp.811-812.
} 
lo vengan a enseñar y exigir?" 147 . O contraponto veio do representante cubano, Andrés de Jáuregui, cuja intercessão já havia conseguido abafar a primeira moção. A sua fala alertava, de forma insidiosa, para os perigos que a publicitação do tratamento do tema poderia trazer à tranquilidade da ilha e, em especial, da cidade de Havana, a qual representava mais diretamente, e fazia um apelo para que "este negocio se trate por quien V.M. determine; pero, precisamente, en sesión secreta, para evitar las consecuencias que de otro modo son de temer" $"$.

Não obstante, as proposições do dia 2 de abril foram publicadas no Diario de las Cortes, o que parece ter provocado alguma inquietação em Cuba, animando temores reacionários. $\mathrm{O}$ espectro da Revolução do Haiti estava no ar. Foi o que relatou o governador e capitão-general da ilha naqueles anos, o marquês de Someruelos. Em sua carta, fazia coro com Jáuregui, pedindo que a discussão sobre a questão não mais fosse divulgada. Ademais, sublinhava a importância dos impostos recolhidos em Cuba para a sustentação das tropas espanholas, cujo peso seria mesmo superior a de um eventual apoio inglês ${ }^{149}$.

No entanto, a resposta mais completa contra as propostas antiescravistas levantadas nas Cortes de Cádiz proveio de Francisco de Arango y Parreño. Em representação conjunta do Ayuntamiento, do Real Consulado e da Sociedade Econômica dos Amigos do País de Havana, de 20 de julho de 1811, o grande intelectual da plantocracia havanesa desde logo desabilitou o exemplo do compromisso assumido pelos portugueses, pois eles não haviam estabelecido as bases para a abolição, mantendo o tráfico em pleno funcionamento. Não lhe parecia lícito ou conveniente deliberar sobre uma matéria delicada como essa de forma tão exasperada, antes mesmo da promulgação da constituição; salienta a afronta ao direito de propriedade e critica as proposições de Alcócer uma a uma, observando a desconsideração dos pontos já garantidos pela legislação, bem como o retrocesso representado pela invariabilidade de senhor, pois: “iba [o escravo] a perder el mayor de los consuelos que nuestras humanas leyes le han concedido; esto es, el de mudar de amo con la causa más ligera"; sobre as previsíveis consequências, recorre ao arquétipo haitiano:

“si el Sr. Alcócer hubiera visto, por sus ojos, la fermentación que al principio produjo el anuncio de la felicidad que nos iba a procurar, habría temido, como temieron los juiciosos, que aquí se empezaba a encender la hoguera en que ardió Santo Domingo, si no con igual violencia, de certo con mayor culpa"150.

\footnotetext{
147 Idem, p.811.

148 Idem, p.812.

${ }^{149}$ Berbel, Marquese \& Parron. Escravidão e Política..., p.119.

${ }^{150}$ Gloria García Rodríguez. Biblioteca de Clásicos Cubanos..., v.II, pp.25-52.
} 
É possível compreender que a reprodução da escravidão como fundamento da fidelidade colonial cubana já estava posta de certa forma. Todavia, Arango era sútil ao colocar a questão, dizendo que, sim, era possível a existência de colônias sem o trabalho escravo; sublinhava, porém, ser o cativeiro, em certos complexos coloniais, condição si ne qua non para o progresso econômico, perfazendo instituto solidamente enraizado, de dificílima dissolução:

\footnotetext{
"Tal es la de que, sin negros esclavos, no pudiera haber colonias. Nosotros, contra ese dictamen, decimos que sin esclavitud, y aun sin negros, pudo haber lo que por colonias se entiende, y que la diferencia habría estado en las mayores ganancias, o en los mayores progresos. Pero los que decimos esto decimos también, Señor, que lo que se principió y consolidó de ese modo, no puede arrancarse de sus quícios con mucha facilidad, y menos con precipitación" 151 .
}

A pressão surtiu efeito e os projetos de Alcócer e Argüeles foram retirados de pauta. Em um cenário de solvência dos laços coloniais, pesou mais na balança a possibilidade de garantir os dotes de uma economia em franca ascensão como a cubana. Mas outro ponto de alteração, de maior alcance inclusive, estava por vir, a saber, a definição dos direitos de cidadania. Tendo em vista a ampliação da representatividade política, a absoluta maioria dos deputados americanos defendia uma definição bastante inclusiva, baseada no princípio de vecindad, conforme o qual a residência estabelecida seria o critério principal, não o nascimento. Dessa maneira, tanto ameríndios quanto africanos poderiam ser incluídos. Porém, o desnível representativo possibilitou que a proposta vitoriosa fosse aquela que neutralizou o maior peso demográfico da América. De todos os deputados americanos, Jáuregui foi o único americano a votar pela proposição vencedora encaminhada pelos peninsulares. Isto se deveu a dois motivos. Primeiro, o alinhamento solidificado pelo controle da ameaça abolicionista. Segundo, as modificações demográficas ocorridas na ilha em virtude do incremento do tráfico e a presença potencialmente ameaçadora de batalhões de pardos e morenos ${ }^{152}$.

As notícias sobre as discussões a respeito da escravidão e da cidadania chegaram à ilha e acabaram realmente inflamando uma tentativa de conjuração. O mulato livre José Antonio Aponte, ex-capitão de uma milícia, inspirado na experiência haitiana, buscou articular uma rebelião para pôr fim à escravidão e expulsar as autoridades espanholas. As intenções foram delatadas. Aponte foi preso e enforcado no dia 7 de abril de $1812^{153}$. Ainda assim, o episódio

\footnotetext{
${ }^{151}$ Idem, p.50.

152 Berbel, Marquese \& Parron. Escravidão e Política..., pp.124-128.

${ }^{153}$ Matt D. Childs. The 1812 Aponte Rebellion in Cuba and the struggle against Atlantic Slavery. Chapel Hill: The University of North Carolina Press, 2006, pp.17-91.
} 
reforçou a posição sobre a necessidade de silenciar o debate e manter a população afrodescendente sob controle ${ }^{154}$.

Aprovada em Cádiz em 19 de março de 1812, no dia de São José, La Pepa foi promulgada em Havana a 21 de julho. Mas, como destaca José A. Piqueras, um regime parlamentarista, como o instituído pela constituição, sempre poderia trazer à tona a discussão sobre o problema da escravidão. Por isso, quando as tropas napoleônicas retrocederam e o absolutismo foi restabelecido, em 1814, os oligarcas cubanos prontamente se dispuseram a colaborar com Fernando VII, enquanto que as diversas províncias da América espanhola apressaram o seu independentismo. Nesse momento, era refundado o alicerce da fidelidade havanesa, preservada ao longo do século XIX em troca de proteção à continuidade da escravidão ${ }^{155}$.

Com o fim do conflito, a Espanha assinou com a Inglaterra, em 28 de agosto de 1814, um tratado de paz, amizade e aliança, que trazia um artigo adicional relativo ao comércio negreiro. O monarca espanhol se comprometia a vedar a participação de seus súditos na distribuição de escravos para outros países e a impedir que fosse concedida proteção a traficantes estrangeiros. Os efeitos não seriam de grande monta, já que os negreiros hispânicos estavam comprometidos com o abastecimento interno, onde eram maioria. Tratava-se de um assédio preliminar ${ }^{156}$.

Durante o Congresso de Viena, a Grã-Bretanha buscou apertar um pouco mais o cerco contra o tráfico. $\mathrm{O}$ estrangulamento seria gradual, a começar pela porção setentrional da costa africana. Após alguns meses de negociação foi acertada com Portugal, no dia 21 de janeiro de 1815, uma convenção prevendo uma indenização de 300.000 esterlinas a ser redistribuída aos súditos prejudicados com apreensões efetuadas pela Royal Navy antes de 1 de junho de 1814 . No dia seguinte, foi assinado o tratado prevendo a abolição do tráfico ao norte da linha equatorial:

\footnotetext{
“Artigo I - Que, desde a ratificação deste tratado e logo depois da sua publicação, ficará sendo proibido a todo e qualquer vassalo da Coroa de Portugal o comprar escravos ou traficar neles, em qualquer parte da Costa de África ao norte do Equador"157.
}

\footnotetext{
154 José Antonio Piqueras Arenas. "La vida política entre 1780 y 1878”. In: Consuelo Naranjo Orovio (coord.). Historia de Cuba. Madri: CSIC, 2007, p.281.

155 José Antonio Piqueras Arenas. Sociedad civil y poder em Cuba: colonia y poscolonia. Madri: Siglo XXI, 2005, p.77.

${ }^{156}$ Lucena Salmoral. "Leyes para esclavos: el ordenamiento jurídico sobre la condición,...”, p.1211.

157 Portugal. Tratados etc.; Reino Unido, 1815 jan. 22. Tratado de abolição do traffico de escravos em todos os lugares da Costa da África ao Norte do Equador, entre os muito altos, e muito poderosos senhores o Principe Regente de Portugal, e El-Rei do Reino Unido da Grande Bretanha e Irlanda: feito em Vienna pelos
} 
Bissau e Cachéu não foram cedidas, mas ficaram excluídas do trato por sua localização. Isto foi mais danoso para negociantes da metrópole, que ainda desempenhavam papel importante nas exportações de cativos da região ${ }^{158}$. O abastecimento do Brasil era resguardado, pois havia à sua disposição importantes portos de procedência ao sul da linha equatorial, destacadamente, em Angola ${ }^{159}$.

Em 8 de fevereiro de 1815, foi assinada por todos os plenipotenciários, incluindo, claro, o português e o espanhol, uma declaração internacional contrária ao tráfico de escravos ${ }^{160}$. Entretanto, em virtude da resistência apresentada, o texto se limitou a definir o comércio de negros da África como contrário aos princípios morais e de humanidade. A saída encontrada pela Grã-Bretanha foi partir para a negociações bilaterais. Os espanhóis entram imediatamente na alça de mira da diplomacia antitráfico britânica. O resultado foi o tratado firmado em 23 de setembro de 1817, que, a exemplo do já acordado com os portugueses, interditou imediatamente o tráfico espanhol ao norte do Equador: "en adelante no será lícito a ningún súbdito de la corona de España el comprar esclavos o continuar el tráfico de esclavos en parte alguna de la costa de Africa al norte del Ecuador, bajo de ningún pretexto, o de cualquiera manera que fuere" ${ }^{161}$; e previu o término total do comércio de escravos para 30 maio de 1820: "y que desde esta época en adelante no será lícito a ningún vasallo de la Corona de España el comprar esclavos o continuar el tráfico de esclavos en parte alguna de la costa de Africa, bajo ningún pretexto, ni de ninguna manera que sea" ${ }^{\text {"162 }}$. No entanto, os termos deste tratado, bem como os da Real cédula de 19 de dezembro de 1817 que regulamentou as suas disposições no interior do império espanholas, seriam sistematicamente desrespeitados, como será visto no terceiro capítulo.

Plenipotenciarios de huma e outra Corte em 22 de janeiro de 1815, e ratificado por ambas. Rio de Janeiro : Na Impressão Regia, p.2

${ }^{158}$ Valentim Alexandre. "Portugal e a abolição do tráfico de escravos (1834-51)". Análise Social, v. XXVI (111), $1991\left(2 .^{\circ}\right)$, p.300.

${ }^{159}$ Silvia H. Lara. "Legislação sobre escravos africanos na América portuguesa", pp.410-415. O trânsito regular para a região subequatorial daria margem para que traficantes, do nordeste, em especial, continuassem a explorar o seu antigo nicho de mercado estabelecido na Costa da Mina, declarando portos ao do Equador nos registros oficiais. Cf. Manolo Florentino, Alexandre Vieira Ribeiro \& Daniel Domingues da Silva. "Aspectos comparativos do tráfico de africanos para o Brasil". Afro-Ásia, 31 (2004), pp.83-126.

${ }^{160}$ Manuel Lucena Salmoral. "Leyes para esclavos: el ordenamiento jurídico sobre la condición,...”, pp.1211-1213.

${ }^{161}$ Lucena Salmoral. "Leyes para esclavos: el ordenamiento jurídico sobre la condición,...”, p.1214.

162 Idem, ibidem. Sobre o tema, ver: Eduardo Torres-Cuevas. "La sociedade esclavista y sus condicciones". In: María del Carmen Barcia, Gloria García \& Eduardo Torres-Cuevas. História de Cuba. La colônia: evolución socioeconómica y formación nacional. De los origenes hasta 1867. Havana: Editora Politica, 1994, p.272; Márcia Berbel, Rafael Marquese \& Tâmis Parron. Escravidão e Política..., p.132. 


\section{Reforma, tradição e liberdade}

Para além de qualquer ímpeto humanitário ou religioso, havia por trás da proteção legal propiciada pelo Estado aos cativos o propósito claro de conservação da ordem social. O texto romano já o indicava, anotando interessar "à República que ninguém use mal de suas coisas" $(\text { I.1.8.2 })^{163}$. O exercício do poder senhorial deveria conservar um equilíbrio, escapando tanto da indolência quanto da severidade demasiada. Rigor em excesso era um perigo ao status quo. Esta percepção foi manifesta sob diferentes matizes ao longo dos séculos e para diferentes contextos. Jean Bodin, o destacado teórico absolutista, se ocupou em seus Les six livres de la republique (1576) “do poder senhorial e de se devem ser admitidos escravos na República bem ordenada" (título do capítulo quinto do primeiro livro). Dada a circunstância que impunha a presença de escravos, uma república bem ordenada não poderia se dar ao luxo de ignorar quanto poder senhorial poderia tolerar em suas fronteiras. Uma vez introduzida, a escravidão tentava os senhores a estabelecerem sua autoridade de maneira despótica, o que tinha efeitos nocivos para toda a estabilidade social e política, não apenas pela competição resultante em relação ao poder central, mas em razão das conspirações e revoltas que poderiam emergir. O cativeiro era, por conseguinte, uma ameaça que deveria ser, senão eliminada, ajustada e regulada, o que significava interferir, em alguma medida, no livre exercício do poder doméstico, cuja salvaguarda, no entanto, estava na base do pacto social que fundamentava a constituição do estado monárquico. A saída para o impasse residia no fato de que a doutrina da soberania absoluta era também a da soberania limitada. Assim como o príncipe tinha o seu poder circunscrito pelas leis divinas e naturais, a soberania dos detentores da propriedade escrava poderia ser limitada em nome da manutenção da justiça e do bem-estar geral da república ${ }^{164}$.

Bodin escreveu antes da imergência da França no escravismo atlântico, mas, como observa o historiador Malick Ghachem, as suas reflexões oferecem um bom norte para a demarcação de um dos desígnios por trás da elaboração do Code Noir (1685): afastar os riscos de uma escravidão desregulada, encurtando-se o espaço tanto para a brutalidade senhorial quanto para os vícios de comportamento de negros e mulatos (alardeados nos relatos que informaram a elaboração do edito), causadores de desordens que acabavam afugentando migrantes brancos. Com efeito, um aspecto importante se colocou aos redatores do Código

\footnotetext{
${ }^{163}$ Marly de Bari Matos (adapt.) Instituições de Justiniano - Origem do Direito brasileiro. São Paulo, Ícone Editora, 1999, p.23.

164 Jean Bodin. The Six Books of a Commonweale. (reimpressão da tradução inglesa de 1606). Londres: University of London, 1903, pp.32-388; Malick W. Ghachem. The Old Regime and the Haitian Revolution. Nova York. Cambridge University Press, 2012, pp.29-77.
} 
Negro, a saber, o de como considerar objetivamente os escravos: inimigos domésticos ou súditos? Como ressalta Ghachem, buscou-se um balanceamento entre uma coisa e outra. Primeiro com a estipulação de sanções punitivas a escravizados e negros livres, o que era também uma forma de evidenciar o impulso da autoridade metropolitana no sentido de garantir proteção e segurança aos colonos e, por extensão, o domínio francês sobre o território. Segundo, com a demarcação das responsabilidades dos senhores, discriminando-se itens mínimos de vestuário, alimentação e de cuidado para com os enfermos, interditando-se torturas e mutilações ${ }^{165}$.

No entanto, era preservada, pelo artigo 55, a subsunção integral do ato da alforria à soberania doméstica senhorial, em consonância com a linha seguida nas colônias ibéricas. Isso mudou no século seguinte, e logo nas décadas iniciais. O poder para a liberação de escravos nas colônias francesas foi sucessivamente abreviado, marcando uma crescente identificação da presença de affranchis com a degeneração da ordem social ${ }^{166}$. Além de interdições que externam o processo de racialização no universo francófono ${ }^{167}$, medidas diversas, como a que compõe o artigo 50 da versão de 1724 do Code Noir, invalidaram as alforrias concedidas sem autorização prévia do Conselho Superior. A justificativa era a de que a existência de amos "mercenários" o bastante para colocar preço na liberdade incitavam os escravos ao cometimento de atos ilícitos para acumularem o montante necessário. Tal argumento existiu em terras ibéricas, mas não chegou a se converter em semelhante censura legal. Especificamente sobre o caso luso-brasileiro, a historiadora Silvia Lara observa que, não obstante a constante preocupação de autoridades e letrados com a crescente "multidão de libertos", o problema da manumissão permaneceu em aberto. E acrescenta: "Embora tenha legislado sobre alguns aspectos que limitavam o exercício do poder dos senhores [quanto ao tratamento e ao trabalho em dias santos, p.e.], a Coroa portuguesa nunca ousou interferir na prerrogativa senhorial da alforria" ${ }^{\prime 168}$.

Em 5 de julho de 1787, Felipe, um escravo residente na cidade do Rio de Janeiro, escreveu diretamente à rainha, D. Maria I, solicitando que seu senhor, Custódio Martins Pinheiro, fosse compelido em juízo a lhe dar a liberdade pelo valor previamente acordado entre eles. Conforme narrado na carta, Felipe serviu fielmente por cerca de vinte e nove anos, catorze

\footnotetext{
${ }^{165}$ Ghachem, The Old Regime and the Haitian Revolution, pp.53-55. Sobre o contexto de elaboração do Code Noir e suas fontes, ver: Vernon Valentine Palmer. "The Origins and Authors of the Code Noir". Louisiana Law Review, v. 56, n.2 (1996), pp.363-407.

166 Idem, pp.82-86.

${ }^{167}$ Jennifer Michel Spear. Race, Sex, and Social Order in Early New Orleans. Baltimore: Johns Hopkins University Press, 2009, pp.67-68.

${ }^{168}$ Silvia Hunold Lara. Africana Studia, 14 (2010), pp.73-92.
} 
dos quais propiciando "seguidos e avultados" jornais (algo em torno de três a quatro mil réis mensais), além de se vestir às suas próprias custas. Por isso, acreditava ser justo que fosse recompensado com a alforria, afinal, se ia um quarto de século de serviços bem prestados e lucrativos. Consultado sobre esta possibilidade, o senhor o teria estimado na elevada quantia de 256 réis com o intuito de dificultar a sua libertação. Mesmo assim, Felipe concordara, esforçando-se ao máximo para poupar a soma necessária. "E logo que os aprontou, recusou o suplicado recebê-los, desenganando o suplicante de que não o libertava ao mesmo passo que este já se sujeitava a dar-lhe duzentos e cinquenta e seis mil réis, e porque nem ainda assim o quer libertar sendo a liberdade a coisa mais favorecida por todo o direito"169. Não encontrei informações sobre o desfecho do caso de Felipe, mas em ofício de 7 de abril de 1799 o vice-rei do Estado do Brasil, o conde de Resende, deu conta ao secretário de estado da Marinha e Ultramar, D. Rodrigo de Sousa Coutinho, sobre ter executado a ordem de Sua Majestade, de 13 de abril do ano anterior, determinado a libertação do homem pardo Antônio Francisco Granjeiro, escravo de Joaquim Vicente dos Reis, havendo ele depositado o montante correspondente à sua avaliação ${ }^{170}$. Um pouco mais tarde, em 1807, Silvestre, homem pardo, solteiro, escravo de Antonio de Sá Brandão, morador do Rio de Janeiro, com o auxílio de seu procurador, escreveu ao príncipe regente, D. João, manifestando que "a aspereza do gênio de seu senhor lhe torna insuportável o cativeiro, e o faz ter bem fundado receio da sua morte desumana a impulsos de castigos bárbaros". Por isso, rogava pela emissão de um Aviso especial para que fosse avaliado "por louvados peritos o cativeiro do suplicante, e depositado o respectivo valor notifique ao suplicado para o levantar e conferir carta de alforria ao mesmo suplicante no peremptório termo de vinte e quatro horas" $" 171$.

Dessas três situações, é possível apreender uma noção de legitimidade em torno da consecução da alforria onerosa, que encontrava um espaço institucional para a sua reclamação, chegando a atingir, inclusive, os níveis mais elevados da hierarquia governativa. Nota-se, também, a noção socialmente construída a libertação prometida, em especial, pela oferta de indenização, aparecia claramente aos sujeitos históricos como um direito legítimo pelo qual lutar. No entanto, os artífices do direito positivo português foram menos inclinados à regulamentação das nuances envolvendo a transição para a liberdade. A principal referência

\footnotetext{
${ }^{169}$ Arquivo Histórico Ultramarino - Rio de Janeiro, cx. 140, doc. 9. Sobre correspondências diretas entre escravos e o monarca, cf. A. J. R. Russell-Wood. "Vassalo e soberano: apelos extrajudiciais de africanos e de indivíduos de origem africana na América portuguesa” (trad.port.). In: Maria Beatriz Nizza da Silva (coord.). Cultura portuguesa na Terra de Santa Cruz. Lisboa: Estampa, 1995, pp. 215-33

170 "Ofício do [vice-rei do Estado do Brasil], conde de Resende [...]”. AHU-RJ, cx. 173, doc. 38. (1799).

171 "Requerimento do escravo Silvestre [...]”. AHU-RJ, cx. 300, doc. 48 (1807). O documento não permite alcançar o desfecho.
} 
legal para a alforria na ordem legal portuguesa era, e continuaria sendo por um largo período, o livro 4 tít. $63 \S 7$ das Ordenações Filipinas (ano), que a enquadrava como uma doação (revogável em caso de ingratidão):

\footnotetext{
"Se alguém forrar seu escravo, livrando-o de toda a servidão e, depois que for forro, cometer contra quem o forrou alguma ingratidão pessoal, em sua presença ou em ausência, quer seja verbal, quer de feito e real, poderá esse patrono revogar a liberdade que deu a esse liberto, e reduzi-lo à servidão em que antes estava"172.
}

Esta disposição, de uma só vez, referendava a autoridade senhorial sobre a manumissão e o vínculo patriarcal posterior ao cativeiro. Ainda que vinculada na prática as condições de natureza pecuniária, ou as prestações futuras de serviços e obséquios variados, a norma impingia formalmente a gratidão do ex-escravo para com seu antigo senhor, estabelecendo um laço compulsório de clientela. Isto de forma bastante utilitária, sem a anotar especial favor em relação à libertação.

Decerto, o sistema jurídico lusitano sobre a escravidão ía além disso. Integrado ao quadro mais estrito do direito positivo figurava um leque plural de fontes jurídicas que extravasava o conteúdo dos diplomas legais sancionados pelos reis de Portugal. O colonialismo lusitano carregava uma sólida tradição em torno da prática do cativeiro e, correspondentemente, um conjunto variado de normas escritas e não escritas, que, embora tenha sofrido alterações pontuais com o passar do tempo, conservou os seus feitos essenciais até os estertores do regime no Império do Brasil. Tais feitios se ajustavam essencialmente às formulações do direito romano consolidadas na época do imperador Justiniano, que delineavam o caráter artificial e revogável da condição de escravidão. A tradição romanista, base do direito comum partilhado por Portugal, caracterizava a servitus como um produto dos direitos civil e das gentes: decorrente das "exigências dos costumes e das necessidades [...]. Vieram assim as guerras, seguiram-se as capturas e a escravidão, todas contrárias ao direito natural. Porque pelo direito natural, todos os homens nasciam livres desde o começo (I.1.3.2)"173. Com efeito, a manumissão equivaleria a um antídoto criado para possibilitar a restituição ao estado natural de liberdade, mas que encerrava, em termos formais, um ato unilateral de abdicação, por meio do qual o senhor abria mão do poder exercido sobre seu servi, que passava, então, a portar o estatuto de liberto ${ }^{174}$. De modo longevo, a alforria permaneceu definida como um ato de

\footnotetext{
${ }^{172}$ Lara. "Legislação sobre escravos africanos na América portuguesa”, pp.103-104.

173 Matos. Instituições de Justiniano..., p.11.

${ }^{174}$ Silva Júnior. História, direito e escravidão..., pp.60-61.
} 
“decisão livre e espontânea" do senhor ${ }^{175}$. Não obstante, é consensual o entendido de que na prática social a redenção condicionada ao comprimento de certas condições atingiu status equiparável ao de direito a ser reconhecido. Ainda que formalmente a pessoa do escravo e tudo que porventura estivesse em sua posse pertencessem a seu senhor, era razoavelmente comum a utilização de recursos próprios para a remissão do cativeiro, quando não se contava com o auxílio de parentes e benfeitores.

No século XVIII e, de forma mais aguda, no período da Ilustração, ocorreu um amplo movimento de crítica à cultura do ius commune. De maneira concomitante à revitalização da economia, o despotismo ilustrado buscou aperfeiçoar o aparelho de Estado, estreitando o controle sobre as atividades de poder, no que se incluíam a produção do direito e a atividade judiciária. O ideal era afiançar a primazia das leis pátrias sobre o ordenamento jurídico, desconstruindo a premência do Código de Justiniano e da doutrina criada ao seu redor, amortizando, consequentemente, o poderio político que os juristas haviam galgado no interior da antiga trama jurisdicional. A pedra-angular desse projeto em Portugal foi a lei de 18 de agosto de 1769, que procurou redimensionar as fontes do direito, condicionando-as todas ao arbítrio real e à Boa razão,

\footnotetext{
“que consiste nos primitivos princípios, que contém verdades essenciais, intrínsecas, e inalteráveis, que a Ética dos mesmos Romanos havia estabelecido, e que os Direitos Divino, e Natural, formalizarão para servirem de Regras Morais, e Civis entre o Cristianismo: ou aquela boa razão que se funda nas outras Regras, que de universal consentimento estabeleceu o Direito das Gentes para a direção, e governo de todas as Nações civilizadas: ou aquela boa razão, que se estabelece nas Leis Políticas, Econômicas, Mercantis e Marítimas, que as mesmas nações cristãs tem promulgado com manifestas utilidades, do sossego público, do estabelecimento da reputação, e do aumento dos cabedais dos povos, que disciplinas destas sábias, e proveitosas Leis vivem felizes à sombra dos tronos, e debaixo dos auspícios dos seus respectivos Monarcas, e Príncipes Soberanos"176.
}

O fato é que o Direito português até então tinha pouco de português. Na prática, as leis régias lusitanas suplementavam as suas próprias fontes. Mais do que isso, a lei enquanto meio normativo era minoritária e subordinada em relação ao sistema doutrinal e aos precedentes judiciais (estilo) ${ }^{177}$. O objetivo desta, que provavelmente é a disposição jurídica mais emblemática do período pombalino, foi conceber um Direito nacional suficientemente

\footnotetext{
175 A citação entre aspas foi extraída deOrlando Patterson.Escravidão e morte social - Um estudo comparativo (trad.port.). São Paulo: Edusp, 2008, p.304. Sobre a alforria como dádiva, ver: Márcio de Sousa Soares. A remissão do cativeiro. A dádiva da alforria e o governo dos escravos nos Campos dos Goitacases, c.1750-c.1830. Rio de Janeiro: Apicuri, 2009, pp.135-200.

176 Disponível em: <http://www.iuslusitaniae.fcsh.unl.pt/verlivro.php?id_parte=86\&id_obra=65\&pagina=264>. Acesso em 30 de set. 2012.

177 António M. Hespanha (org.). Justiça e litigiosidade: história e prospectiva. Lisboa: Fundação Calouste Gulbenkian, 1993, p.14.
} 
compreensivo e racional a ponto de limitar e disciplinar o recurso às fontes subsidiárias ${ }^{178}$. Mas, como a legislação escravista permaneceu lacunar, sem um tratamento normativo sistemático sobre as questões gerais envolvendo o governo dos escravos e os modos da alforria, a Lei deixou caminho aberto para que um leque plural de fontes - com destaque para os textos romanos, ajustados criticamente conforme a boa razão, à luz dos avanços na ciência do Direito e, supostamente, do processo civilizacional - continuasse embasando o arbítrio e a dissolução de litígios envolvendo o cativeiro, de forma combinada com as normas esparsas extraídas do repertório legislativo régio, recuperadas, na maioria das vezes, de forma enviesada ${ }^{179}$.

Vide, por exemplo, a noção de ser a liberdade a coisa mais favorecida por todo o direito presente na demanda do escravo Felipe. Isto era mais ou menos o que versava o Ord., livro 4 tít. $11 \S 4$ : "e porque em favor da liberdade são muitas coisas outorgadas contra as regras gerais", comumente citado em ações e apelos pró-emancipação ${ }^{180}$. O problema é que este era o enunciado de uma determinação associada a uma circunstância historicamente superada já no tempo em que o xará ilustre do escravo, o rei Felipe I, foi rei de Portugal (1580-1598), a saber, o resgate de cativos cristãos em domínio mouro, escapando, por conseguinte, da prática ordinária da manumissão no contexto da colonização. Dizia o prosseguimento do parágrafo:

\footnotetext{
"se alguma pessoa tiver algum mouro cativo, o qual seja pedido para na verdade se haver de dar e resgatar algum cristão cativo em terra de mouros, que por tal mouro se haja de cobrar e remir, mandamos que a pessoa que tal mouro tiver, seja obrigado de o vender e seja para isso pela Justiça constrangido" ${ }^{181}$.
}

Se por um lado tal formulação acrescenta inteligibilidade à configuração histórica da remissão do cativeiro em Portugal, por outro, remete a um claro desenraizamento material. Melhor dizendo, a citação desta disposição em causas envolvendo alforria nos séculos XVIII e XIX implicava necessariamente a desvinculação da norma de sua materialidade para uma adaptação voltada à ampliação do sentido originalmente proposto, algo que, não obstante encerrasse um exercício hermenêutico até certo ponto admitido (interpretação extensiva), era substancialmente distinto da referência a uma lei que tratasse diretamente dos modos pelos

\footnotetext{
${ }^{178}$ Além de restringir o direito canônico ao uso eclesiástico e reforçar o caráter estritamente subsidiário das leis romanas, dispôs-se que o estilo só valeria se aprovado em assento da Casa da Suplicação e, o costume, se não conferisse contra legem, tivesse mais de cem anos, além, claro, de ser conforme à boa razão. Cf. Nuno Espinosa Gomes da Silva. História do direito português: fontes do direito. Lisboa: Assoc. Acadêmica Fac. Direito Lisboa, 1980, pp.339-376.

${ }^{179}$ L. II, tít. V dos Estatutos na Universidade de Coimbra. Disponível em: <https://bdigital.sib.uc.pt/bg1/UCBGR-44-3_3/UCBG-R-44-3_3_master/UCBG-R-44-4/UCBG-R-44-4_item1/P276.html>. Acesso em: 03 de out. 2013

${ }^{180}$ Keila Grinberg. O fiador dos brasileiros. Cidadania, escravidão e direito civil no tempo de Antonio Pereira Rebouças. Rio de Janeiro: Civilização Brasileira, 2002, pp.119-124.

${ }^{181}$ Lara. "Legislação sobre escravos africanos na América portuguesa", p.98
} 
quais os escravos poderiam atingir a liberdade. Procedimento semelhante seria feito ao longo do tempo com relação a várias outras normativas, tais como a lei de primeiro de abril de 1680 , “sobre a liberdade do gentio do Maranhão", utilizada para reforçar o preceito extraído do tít. 11, por acusar serem "mais fortes as razões que há em favor da liberdade do que as que podem fazer justo o cativeiro"182, o alvará de 10 de março de 1682, expedido especificamente para o caso dos quilombolas de Palmares, cujo $\S 4$ fora pinçado para respaldar a liberdade por prescrição após cinco anos ${ }^{183}$. Outros exemplos poderiam ser evocados. Por agora, basta pontuar que se tratava de um exercício forçoso diante de um ordenamento em processo de transformação, tensionado entre o intento ilustrado de impor a predominância dos instrumentos legais e as limitações de um repertório normativo casuísta e pretérito, desprovido do caráter geral e abstrato exigido pelo novo paradigma, e particularmente omisso com relação ao tema da escravidão. A consequência direta era um certo alargamento da margem para a interpretação doutrinária (aquela realizada nos tribunais, em oposição à interpretação autêntica, efetuada apenas pelo legislador $)^{184}$. Cabe algum esclarecimento sobre isto.

Sabe-se que a lei de 18 de agosto de 1769 vedou taxativamente a citação e o acolhimento em juízo das glosas de Acúrsio e das opiniões de Bártolo, excluindo-se a sua doutrina como fonte do direito luso. Correia Telles, em seu Comentário crítico (1824), salientou que não se devia crer com isso "que na praxe de julgar deva ser reprovada qualquer opinião ou doutrina" e, na sequência, avança sua reprimenda sobre os moldes como se deu desautorização dos antigos doutores:

\footnotetext{
"A meu ver a revogação da Ord., que neste §. se fez, deixou a Jurisprudência nacional em um arbitrário mais amplo, do que antes era. Havendo como há em Direito tantas controvérsias, e um Código de Leis tão insuficiente para as decidir, que foi necessário buscar refúgio nas dos Romanos, e outras reconhecidas outrossim por defeituosas, e obscuras; quanto melhor não era mandar seguir as opiniões de tais ou tais DD. reconhecidos por melhores; do que deixar as decisões no arbítrio da boa razão! [...] Conviria, pois que a nossa Lei desautorizando Acúrsio, e Bártolo, lhes substituísse outros DD. de melhor nota, afim de ficar menos campo ao perigoso arbítrio dos Julgadores" $" 185$.
}

Esta observação, expondo a natureza deficitária do quadro jurídico português, denota a instabilidade imediatamente gerada pelo novo modelo. Claro que a manipulação dos textos

\footnotetext{
182 Keila Grinberg. Grinberg, Keila. Liberata: a lei da ambigüidade - As ações de liberdade da Corte de Apelação do Rio de Janeiro no século XIX. Rio de Janeiro: Relume Dumara, 1994, p.49.

${ }^{183}$ Lara. "Legislação sobre escravos africanos na América portuguesa"..., pp.41-45.

${ }^{184}$ Pascoal José de Mello Freire. Instituições de Direito Civil português: tanto público como particular. Livro I, Título I. (1 $1^{\text {a }}$ edição, 1789 - tradução de Miguel Pinto de Meneses). Lisboa: Procuradoria Geral da República, 1967, p.101.

185 José Homem Correia Telles. Commentario crítico á Lei da Boa Razão, em data de 18 de agosto de 1769. (1ª edição 1824). Lisboa: Typografia de Maria da Madre de Deus, 1865, p.49.
} 
jurídicos e a sustentação das sentenças precisava seguir certos parâmetros. A interpretação não mais devia beber da fonte dos antigos praxistas do Direito romano, mas das formulações do jusnaturalismo moderno impressas nas obras de Grócio e Pufendorf ${ }^{186}$. Os novos intérpretes deviam buscar o verdadeiro espírito das leis, o que implicava conhecer a sua razão, a intenção por trás de sua elaboração, esquadrinhada a partir do exame dos fatos e acontecimentos históricos que a cercaram, nem sempre concordando com as prescrições dos jurisconsultos, "por

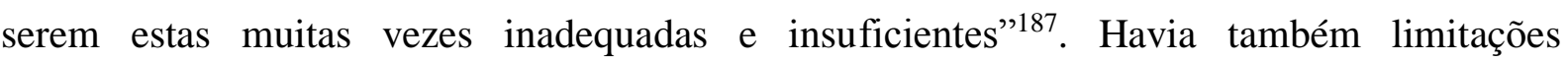
institucionais. A Lei delimitara o caráter vinculante (normativo) da jurisprudência, atribuindo tal autoridade apenas aos assentos proferidos pela Casa de Suplicação de Lisboa. No entanto, havia um modo sedimentado de se praticar o direito, de adaptar as normas aos casos concretos, que não mudaria da noite para o dia. Como assinalam Arno \& Maria Wehling, o Direito comum permanecia forte "na medida em que o ensino jurídico continuava impregnado por suas teses e que fracassavam, no plano legislativo, os esforços para dotar Portugal de novas leis" ${ }^{188}$. Muito embora as leis romanas e a respectiva carga doutrinária não fossem evocadas expressamente em libelos e sentenças, certamente os seus preceitos norteavam argumentações de advogados e tomadas de decisão de juízes, quanto maior fosse a sua formação letrada. Some-se a isto o fato de que as referências para a dosagem da tal boa razão falhavam em uniformidade. Os regulamentos das nações européias e as formulações sobre o usus modernus pandectarum não eram plenamente convergentes, o que deixava espaço para numerosas incertezas: um campo fértil à especulação dos administradores do Direito, ainda mais sobre um tópico como o do acesso à liberdade aos negros escravizados ${ }^{189}$.

É sabido que ainda na era colonial houve recomendações para um melhor tratamento legal da alforria, acompanhadas de certo reconhecimento doutrinário do direito à reversão do cativeiro $^{190}$. Manoel Ribeiro Rocha (1758), acenando para a transitoriedade da condição como componente de sua legitimação, defendera que escravos e escravas fossem havidos como

\footnotetext{
186 Sobre o tema do jusnaturalismo, ver: Norberto Bobbio \& Michelangelo Bovero. Sociedade e Estado na Filosofia política Moderna. São Paulo: pp.12-100.

${ }^{187}$ L. II, tít. VI, cap. VI dosEstatutos da Universidade de Coimbra. In: https://bdigital.sib.uc.pt/bg1/UCBG-R-443_3/UCBG-R-44-3_3_master/UCBG-R-44-4/UCBG-R-44-4_item1/P277.html, visto em 03/10/2013.

${ }^{188}$ Arno Wehling\& Maria José Wehling. "Despotismo Ilustrado e Uniformização Legislativa: O Direito Comum Pombalino e Pós-Pombalino". Revista da Faculdade de Letras (Porto, 1997), n. 14, p.421.

189 Guilherme Braga da Cruz. Obras Esparsas. Volume II. Estudos de História do Direito. Direito Moderno. $2^{a}$ Parte. Coimbra: Coimbra Editora, 1981, p.425. Para uma síntese sobre a interpretação na história do Direito, ver: José Reinaldo de Lima Lopes. O Oráculo de Delfos: O Conselho de Estado no Brasil-Império. São Paulo: Editora Saraiva/FGV, 2010, pp.1-90. Sobre a aplicação das mudanças impostas pela lei da Boa Razão, tendo em vista os litígios envolvendo a liberdade de escravos, ver: Keila Grinberg. O fiador dos brasileiros. Cidadania, escravidão e direito civil no tempo de Antonio Pereira Rebouças. Rio de Janeiro: Civilização Brasileira, 2002, pp.233-278.

${ }^{190}$ Silvia Hunold Lara. "O espírito das leis: tradições legais sobre a escravidão e a liberdade no Brasil escravista". Africana Studia, n. 14, (1 ${ }^{\circ}$ semestre 2010), pp.73-92.
} 
remidos em potencial, devendo permanecer cativos somente até que compensassem o seu valor (considerando gastos de criação e ofícios aprendidos) trabalhando até o período máximo de vinte e cinco anos ou antecipando o pagamento correspondente em dinheiro ${ }^{191}$. O jurisconsulto Pascoal de Melo Freire, se valendo de precedentes clássicos (gregos, em especial), sustentou em suas Instituições de Direito Civil (1789) que o direito de conservar cativos permaneceu vigente "em todas as nações", até que fosse paga uma indenização em dinheiro ou em trabalho prestado $^{192}$. Em fins do século, Luiz Antônio de Oliveira Mendes (1793), em sua Memória a respeito dos escravos e tráfico apresentada a Real Academia das Ciências de Lisboa, propôs a edição de lei municipal estabelecendo "como regra geral, e invariável, que o escravo, que contasse dez anos de escravidão, vida civil do homem, ficasse manumitido"193. Tais proposições não foram encampadas pelo governo na forma de lei, embora o seu teor estivesse longe de ser incidental. Tempo de trabalho e compensação pecuniária respaldavam a reivindicação da manumissão. $\mathrm{O}$ caso do escravo Felipe descrito anteriormente exibe uma expectativa comum, estabelecida no campo do possível, alimentada por uma noção de merecimento, razoabilidade e justiça, que extrapolava os limites impostos pelo direito escrito em vigor na América portuguesa. O problema é que o tal favorecimento da liberdade tinha os seus limites, que eram definidos pelo controle senhorial sobre a libertação. Inexistia preceito que obrigasse objetivamente o senhor a libertar o escravo mediante a satisfação de condições pecuniárias ou laborais. O contrário existia. Vale lembrar que aquele mesmo Ord. L. 4, tít.11, dispunha expressamente que ninguém deveria ser "constrangido a vender seu herdamento e coisas, que tiver, contra a sua vontade" ${ }^{194}$, ponto que respaldava intenções diametralmente opostas às dos libertandos, de senhores como Custódio Martins Pinheiro, que se recusara a libertar Felipe.

No entender da historiadora Silvia Lara, modificar o enquadramento legal da alforria, discriminando-se casos para a sua concessão em benefício dos cativos significaria "colocar em risco todo o sistema político da dominação escravista na colônia”, cuja base era o exercício paternal do poder senhorial ${ }^{195}$. Esta é a explicação usual para a omissão legislativa relativa à

\footnotetext{
${ }^{191}$ Manoel Ribeiro Rocha. Ethiope resgatado, empenhado, sustentado, corrigido, instruído e libertado. Lisboa: Oficina Patriarcal de Franscisco Luiz Ameno, 1758, pp.88-134.

${ }^{192}$ Pascoal José de Mello Freire. Instituiçães de Direito Civil português: tanto público como particular. Livro I, Título XI. (1 $1^{\mathrm{a}}$ edição, 1789 - tradução de Miguel Pinto de Meneses). Lisboa: Procuradoria Geral da República, 1967, p.130.

${ }^{193}$ Luis Antonio de Oliveira Mendes. "Memória a respeito dos escravos e tráfico da escravatura entre a costa d'África e o Brasil (1812)". Revista Latinoamericana de Psicopatologia Fundamental, v. 10, n. 2, (junio, 2007), pp.375; Eduardo Spiller Pena. Pajens da Casa Imperial: jurisconsultos, escravidão e a Lei de 1871. Campinas: Editora da Unicamp, 2001, pp.179-180.

${ }^{194}$ Lara. "Legislação sobre escravos africanos na América portuguesa", pp.98-99.

195 Lara. “O espírito das leis...”, pp.73-92.
} 
alforria onerosa durante a era colonial e a maior parte da história do Império do Brasil. Quer dizer, reconhecê-la na letra da lei como uma espécie de direito dos escravos representaria uma ameaça contundente à ordem escravocrata ${ }^{196}$. Todavia, o escopo comparativo traz elementos para a ampliação da reflexão sobre o assunto. Como irei expor nos parágrafos seguintes, houve para Cuba legislação estabelecendo a obrigatoriedade da concessão da carta de liberdade aos escravos que apresentassem o seu valor e nem por isso o regime foi abalado (muito pelo contrário, já que essa normatização se deu logo no momento da arrancada da economia escravista na ilha). Considerando a semelhança das condições, é pouco provável que a escravidão brasileira entrasse em colapso por conta de medida análoga. O regime apenas seria posto seriamente em risco caso os senhores não dispusessem de meios privados para o exercício do seu domínio e não houvesse meios de reposição de mão de obra constituídos. De qualquer maneira, o importante a salientar, por agora, é que a saída portuguesa foi a preservação de uma tradição jurídica longeva e solidamente arraigada, que sustentou o dom da alforria como componente irretocável do poder senhorial, sem a obstrução, em contrapartida, de ajustes privados em torno da liberação. Anote-se que o risco real sobre o sistema de dominação é menos tangível do que o receio de modificar um sistema solidamente arraigado. Isto sim, parece ter colaborado para que as coisas continuassem como sempre estiveram no ordenamento português.

Do lado espanhol, foram as Siete Partidas - compilação de preceitos legislativos e doutrinários editada no século XIII (1263-65) - a referência básica da ordem legal relativa à escravidão. Os seus títulos, embebidos na tradição romanista recém reabilitada, manifestavam a contrariedade da servidumbre em relação ao Direito natural, legitimando a manumissão (como prerrogativa senhorial), o casamento de escravos e o acesso à justiça em casos de maus tratos. No plano geral, esse quadro coincide com o que foi mencionado em relação ao universo português, salvo pelo fato de que as Partidas não admitiram simplesmente os textos da cultura do direito comum, mas os incorporaram seletivamente, nacionalizando os seus preceitos, tornando-os parte integrante do direito pátrio castelhano. A validação efetiva do dispositivo se deu com o Ordenamiento de Alcalá (1348), que organizou uma ordem de aplicação entre as distintas fontes normativas que foram sendo constituídas em Castela, determinando que nos vazios do direito real seguidamente promulgado e dos fueros municipais, que fossem aplicadas as Partidas, diferentemente do que ocorreu em Portugal e na Catalunha, por exemplo, onde se

\footnotetext{
${ }^{196}$ Manuela Carneiro da Cunha. "Sobre os silêncios da Lei: lei costumeira e positiva nas alforrias de escravos no Brasil do século XIX", in: Antropologia do Brasil: mito, história, etnicidade. São Paulo: Editora Brasiliense, 1987, pp.123-144.
} 
aceitou a vigência suplementar do ius commune de uma forma global. Após alguns avanços e recuos, esse sistema foi ratificado pelas leis de Toro (1505) e, em seguida, pela Nueva Recopilación (1567), cuja vigência foi transmitida ao Novo Mundo espanhol. A Lei II, tít. I, Liv. II da Repilación de leyes de los Reinos de las Indias (1680) dispôs

\begin{abstract}
"que en todos los casos, negocios y pleitos en que no estuviere decidido, ni declarado lo que se debe proveer por las leyes de esta Recopilación, o por cédulas, provisiones u ordenanzas dadas y no revocadas para las Indias, y las que por nuestra orden se despacharen, se guarden las leyes de nuestro Reino de Castilla conforme a la de Toro" ${ }^{197}$.
\end{abstract}

Portanto, as Siete Partidas foram consignadas como fonte de direito subsidiário para as Índias castelhanas, ocupando papel fundamental na regulação do direito privado, com destaque para as matérias em torno da escravidão. Não obstante a reação do pensamento ilustrado espanhol ao sistema de criação do direito típico do Antigo Regime, esta ordem foi sustentada até o século XIX, tendo sido incorporada à Novísima Recopilación, promulgada em $1805^{198}$.

Mas o quadro formado a partir deste ponto foi sensivelmente distinto do português. Embora também inserida em um sistema jurídico plural, no qual o costume tinha um peso enorme $^{199}$, a legislação escravista da Espanha deixou menos espaços para silêncios. Isto remete a uma característica mais ampla e essencial da ordem jurídica castelhana que era a sua tendência à profusão (chegando mesmo ao que Tomás y Valiente chamou de hipertrofia legislativa) ${ }^{200}$, no que claramente diferia do ordenamento luso, sempre cirúrgico, pontual, econômico. Desde os tempos iniciais da colonização, muito antes da promulgação do código negro francês, foram editados extensos diplomas legais (ordenanzas, em especial) sobre variados aspectos da escravidão, muitas vezes avançando em relação ao conteúdo das Partidas, impondo punições severas a atos de rebeldia, ditando parâmetros do tratamento a ser dispensado e assim por diante. Mas, até o século XVIII, o arbítrio senhorial sobre o ahorramiento foi mantido intocado.

Abelardo Levaggi, em um artigo bastante citado sobre "La condición jurídica del esclavo en la época hispânica", sustenta que as Siete Partidas previam, entre as causas da manumissão, a compra "por justo precio y probado" da liberdade, mesmo à revelia da vontade

\footnotetext{
197 Apud José María Ots Capdequí. "El estado español en las Indias". Ciudad de México: Fondo de Cultura Económica, 1946, p.9.

${ }^{198}$ Idem, pp.9-72; Francisco Tomás y Valiente. Manual de historia del derecho español. Madri: Editoril Tecnos, 1988, p.243-248. Sobre a influência do direito comum no Novo Mundo, ver: Alfonso Garcia-Gallo. "El Derecho común ante el Nuevo Mundo". Estudios de historia del derecho indiano. Madri: Instituto Nacional de Estudios Juridicos, 1972, pp.123-146.

${ }^{199}$ Víctor Tau Anzoátegui. "El poder de la costumbre: Estudios sobre el Derecho Consuetudinario en América hispana hasta la Emancipación". In: José Andrés-Gallego (coord), Nuevas Aportaciones a la Historia Jurídica de Iberoamérica. Madrid: Fundación Histórica Tavera/Digibis/Fundación Hernando de Larramendi, 2000 (Cd-Rom). 200 Tomás y Valiente. Manual de historia del derecho español, p.383.
} 
dos $\operatorname{amos}^{201}$. No entanto, cabe observar que a Partida IV, tít. XXII, Lei II, referida pelo autor para esta causa, versa sobre coisa distinta, a saber, "cómo puede seer libre el siervo de dos señores quando el uno lo quisiere aforrar et el otro no "202 . A norma diz que se apenas um dos donos quisesse alforriar um escravo em condomínio, poderia fazê-lo contrariando a vontade dos coproprietários. Para tanto, deveria indenizá-los pelo preço justo a ser definido pelo juiz do lugar, efetuando o pagamento em juízo em caso de recusa. Depois da quitação, a liberdade seria outorgada normalmente. Isto, aliás, já estava previsto pelo Direito romano do tempo de Justiniano e fazia parte também das referências portuguesas ${ }^{203}$. O que se pode extrair daqui, efetivamente, é a existência de dois precedentes importantes - a intervenção judicial para a estipulação do preço a ser pago para a libertação e a revelia da vontade senhorial para a realização da alforria - que só mais tarde assumiriam o sentido indicado por Levaggi.

Em 1526, o rei Carlos I chegou a escrever ao governador da Nova Espanha dizendo ter sido informado de que "para que los negros que se pasan a esas partes se asegurasen, y no se alzasen y se ausentasen, y se animasen a trabajar y servir a sus dueños con más voluntad, demás de casarlos" seria conveniente estipular que após certo tempo de serviço pudessem se libertar pagando o valor mínimo de 20 marcos de ouro. Em 1541, cartas com conteúdo semelhante foram enviadas às diversas Audiencias do Novo Mundo. No entanto, nenhuma determinação legal surgiu naquele momento a esse respeito ${ }^{204}$. A matéria à baila apenas no contexto do reformismo ilustrado, a reboque de questões associadas à reestruturação tributária após a Guerra dos Sete Anos. Como assinalado na seção anterior, à retomada de Havana foi acompanhada de uma série de medidas destinadas ao desenvolvimento da economia local e à revitalização das finanças régias. Para tal efeito, foram efetuadas modificações no regime tarifário, que na década de 1750 atingia a insuficiente média anual de 162 mil pesos ${ }^{205}$. Parte desse déficit era causado pela quase inexistência de receitas procedentes da alcabala, imposto tradicional transplantado para as diferentes partes da América espanhola, que recaía sobre as transações comerciais. Junto à elevação formal do imposto de $2 \%$ para $6 \%$ sobre as vendas

\footnotetext{
201 Abelardo Levaggi, “Condición jurídica del esclavo en la época Hispana”. Revista de Historia del Derecho, Instituto de Investigaciones de Historia del Derecho, n. 1 (1973), pp.83-175.

${ }^{202}$ Las siete partidas: del rey Don Alfonso el sabio, cotejadas con varios códices antiguos por la Real Academia de la Historia, t.3. Madrid: Imprenta Real, 1807, p.122.

203 Agostinho Marques Perdigão Malheiro. A escravidão no Brasil: ensaio histórico, jurídico, social. (1866), v.2. Fonte Digital: eBooksBrasil, pp.75-76.

${ }^{204}$ Manuel Lucena Salmoral, "Leyes para esclavos: el ordenamiento jurídico sobre la condición, tratamiento, defensa y represión de los esclavos en las colonias de la América española", in José Andrés-Gallego (coord), Nuevas Aportaciones a la Historia Jurídica de Iberoamérica. Madrid: Fundación Histórica Tavera/Digibis/Fundación Hernando de Larramendi, 2000 (Cd-Rom), pp.571-72; 653-655.

${ }^{205}$ Allan J. Kuethe. e G. Douglas Inglis. “Absolutism and Enlightened Reform: Charles III, the Establishment of the Alcabala, and Commercial Reorganization in Cuba”. Past \& Present, No. 109 (Nov., 1985), p.120.
} 
efetuadas, houve um efetivo esforço do corpo administrativo para a sua coleta, o que vinha ocorrendo até então ${ }^{206}$. Tendo em mente esse cenário, note-se o teor da cédula de 21 de junho de 1768, enviada ao governador de Cuba, D. Bucareli y Ursúa, sobre a extração do imposto sobre transações envolvendo escravos:

\begin{abstract}
"Con motivo de haberme hecho presente, en carta de 29 de julio de 1766, que en vista de las disputas que se habían suscitado en orden a la satisfacción de derecho de alcabala nuevamente establecido en esa Isla, que causa la venta voluntaria o involuntaria de parte de los amos de los negros, mulatos, esclavos coartados, habíais dispuesto, con acuerdo de abogados, que cuando los referidos esclavos se vendiesen por voluntad de sus dueños o por precisión inducida de algún apremio de paga o de causa justificada contra el poseedor, satisficiese éste indistintamente el expresado derecho, del mismo modo que se practicaba en la enajenación de los no coartados, pero que siempre que el que lo era obligase a su dueño a que lo vendiese, por sólo su gusto o conveniencia, le indemnizase, reportando por si o por el comprador el citado derecho, tuve a bien de preveniros por mi R.C. de 19 de noviembre del mismo año, remitieseis a mi Consejo de las Indias el expediente íntegro de los autos obrados en el asunto, $[\ldots]^{207}$."
\end{abstract}

Como está claro, perante o consenso a que chegara o governador, em suposto acordo com advogados locais, nos casos em que a venda ocorresse por espontânea vontade ou imposição legal, o ônus do tributo deveria recair sobre os amos. Já quando ela se desse por "conveniência ou gosto" dos cativos, eles próprios ou os seus compradores deveriam arcar com o tributo. Ao lado da situação ordinária envolvendo a venda de escravos e a sua tarifação, salta aos olhos o possível traço de contrariedade à vontade senhorial na transferência de domínio. Acompanhemos a tramitação.

Em conformidade com o recomendado, a demanda foi encaminhada ao escrutínio do Conselho das Índias, cujo parecer fora integralmente ratificado pelo rei. Tomando como referência a "práctica general y uniforme que se observaba indistintamente en los Reinos de la Nueva España y el Perú", o órgão estabeleceu, primeiramente, que todas as vendas e contratos envolvendo escravos deviam ser lavrados em escritura ou instrumento público perante o escribano (na falta dele, o juiz local), o qual ficava incumbido de enviar uma relação mensal ao arrecadador da alcabala para que a importância fosse cobrada dos vendedores (nos casos em que as vendas ocorressem a seu gosto). Quando a venda fosse feita em razão de ordem judicial expedida em atenção a "alguna vejación o malos tratamientos de los dueños", a estes caberia o estipêndio - "en pena de haber faltado a la humanidad y racionales modos que están obligados a usar con ellos" -, sem poder embutir o tributo no preço do escravo, o qual deveria permanecer o mesmo pago na aquisição. Agora, se o escravo agisse mal, cometendo delitos, forçando a sua

\footnotetext{
${ }^{206} \mathrm{O}$ contrapeso para a elite cubana seria a subsequente liberalização comercial. Cf. Allan J. Kuethe. "La fidelidad cubana durante la edad de las revoluciones". Anuario de estudios americanos, Tomo LV, 1, 1998, p.212.

${ }^{207}$ Lucena Salmoral. "Leyes para esclavos: el ordenamiento jurídico sobre la condición,...", p.1006.
} 
alienação, o senhor teria igualmente que pagar a importância da alcabala, mas poderia acrescentá-la ao preço final de venda do cativo,

\begin{abstract}
"siendo éste un medio racional, que a un mismo tiempo pena el delito del siervo y sirve de freno para contenerle en su deber, temeroso de que a proporción de sus graves faltas ha de subir su valor, y por consecuencia la imposibilidad de adquirir la libertad a que anhelan todos naturalmente" ${ }^{208}$.
\end{abstract}

Desse modo, o mal proceder dificultaria tanto a transferência para alguém eventualmente mais suscetível à liberação quanto a aquisição direta da liberdade pelo próprio escravo. Mas o cenário reverso é tratado:

\begin{abstract}
“[...] cuando los esclavos entregan a sus señores el importe de su valor adquirido lícitamente por medios honestos, bien sean industriales o por suplemento de parientes o amigos suyos, con el fin de redimirse del cautiverio o servidumbre, son obligados los expresados dueños a otorgarles llana y jurídicamente la carta de libertad, y los títulos en cuya virtud los poseían, quedando cancelados y anotados en sus respectivos lugares, sin que les sea facultativo en este caso pedir más precio, ni recibir otra cosas, que la cantidad que exhibieron al tempo de su adquisición, aunque aleguen que les han enseñado algunos oficios o habilidades extraordinarias, porque todo se sacrifica a beneficio de la libertad, en que siempre, o las más veces interesa el público, cuya utilidad preponderá a la privada del particular, y en éste caso no se contribuye cosa alguna por razón de la alcabala" ${ }^{209}$.
\end{abstract}

O que é nebuloso no quadro luso-brasileiro, fica cristalino na normativa espanhola. Aquele que apresentasse o seu valor original de compra, amealhado por meios lícitos, obrigava o dono a outorgar-lhe a carta de liberdade, de modo que aptidões desenvolvidas e o movimento inflacionário não poderiam ser acrescidos ao preço cobrado pela manumissão (ponto bastante polêmico). Assim, a prática costumeira da alforria onerosa com o correspondente acúmulo de pecúlio não apenas foi expressamente reconhecida e validada, como foi arbitrada em favor do escravo probo. Pequena parecia a perda da alcabala diante do benefício público por trás de tal medida, recompensadora de serviços bem prestados e da lisura na poupança do dinheiro. Era uma medida em favor da escravidão, da estabilidade do regime, tenha-se muito claro.

O texto da cédula não parou por ali. Leia- se o seu trecho final:

\footnotetext{
"Y finalmente cuando el esclavo entrega a su amo parte del precio que le costó, con el fin de que, rebajado de su valor principal, quede éste más moderado, y él en mayor aptitud de conseguir su libertad, se anota al instrumento que sirve de título, para que conste en todo evento; y acaeciendo muchas veces que antes de completar el total importe de su rescate muda de dueño el esclavo por su voluntad, o la de su dueño, se otorgó el instrumento con deducción de aquella partida que dio en cuenta de su libertad, y la alcabala se regula y cobra únicamente de la cantidad a que queda reducido su valor, también en obsequio de la libertad" 210 .
}

\footnotetext{
${ }^{208}$ Idem, p. 1007.

${ }^{209}$ Idem, ibidem.

${ }^{210}$ Idem, pp.1007-8.
} 
De modo semelhante ao efetuado em relação às alforrias liquidadas no ato, este ponto do texto referendava a prática da coartación, que consistia, à semelhança do que se praticava em alguns pontos da América portuguesa, na amortização gradativa da quantia correspondente à libertação ${ }^{211}$. A disposição oficializava a necessidade de que o acerto em relação à entrada $\mathrm{e}$ às parcelas fosse registrado por escrito em instrumento que serviria de título até a conclusão do pagamento. Trate-se de um tipo de respaldo legal que a congênere luso-brasileira, a chamada “carta de corte", não chegou a obter ${ }^{212}$.

Retomando o teor da cédula espanhola, note-se que o texto se limita a estabelecer que o tributo fosse cobrado sobre o valor restante do coartado. Assim, por exemplo, um escravo do valor de 500 pesos, após haver pago 100, ficava coartado em 400 pesos. Este último passava a ser o seu valor de mercado e sobre ele seriam extraídos os $6 \%$ correspondentes à alcabala em caso de venda. Todavia, não foi confirmado o discernimento sugerido pelo governador sobre a incidência do encargo. A redação ainda deixava dúvidas sobre a circunstância em torno da interferência da vontade do senhor e do coartado na consumação da mudança de dono. Haveria diferença entre o enteros e o coartados neste particular?

Esta questão e a anterior, associada à manutenção do preço de aquisição para a libertação, foram apresentadas ao monarca. Além de solicitar esclarecimentos sobre a isonomia das regras colocadas, o governador dera vasão aos interesses locais, argumentando não parecer razoável que o desenvolvimento de habilidades e competências diversas, que não só elevavam

\footnotetext{
${ }^{211}$ Manuel Lucena Salmoral. "El derecho de coartación del esclavo en la América española". Revista de Indias, v. LIX, n. 216 (1999), pp.357-374. Díaz sugere a ocorrência de uma primeira menção normativa à coartación em 1673, quando foi oferecido aos escravos régios da comunidade de El Cobre a possibilidade de que comprassem a sua liberdade a prazos após o pagamento inicial de um quarto de seu valor, daí, quiçá, a origem da nomenclatura. Cf. María Elena Díaz. The Virgin, the King, and the Royal Slaves of El Cobre. Negotiating Freedom in Colonial Cuba, 1670-1780.Standford: Standford University Press, 2000, p. 75. Também, Varella, Patrícia.Esclavos a sueldo: la coartación cubana en el XIX. Tese de Doutorado. Castellión: Universitat Jaime I, 2010, pp.29-30. Mas, segundo o historiador Alejandro de la Fuente, o expediente era praticado na ilha desde o século XVI, aparentemente sem uma identificação rígida com o pagamento de uma entrada correspondente a $25 \%$. Cf. Alejandro de la Fuente. "Esclavitud, 1510-1886". In: Consuelo Naranjo Orovio (coord.). Historia de las Antillas. Vol.1: Historia de Cuba. Madrid: Doce Calles-CSIC, 2009, pp.148-9. É possível que o termo se refira, não à fração de um quarto, mas simplesmente ao sentido semântico de seu radical "coartar", que significa "limitar, restringir, no conceder enteramente algo". Cf: <http://lema.rae.es/drae/?val=coartar>.

${ }^{212} \mathrm{Nem}$ por isso este documento foi desconsiderado como documento comprobatório e para a fundamentação de ações judiciais. Cf.: Laura de Mello e Souza. "Coartação: problemática e episódios referentes a Minas Gerais no século XVIII". In: Maria Beatriz Nizza da Silva (org.). Brasil: colonização e escravidão. Rio de Janeiro: Nova Fronteira, pp.275-295; Eduardo França Paiva. "Coartações e alforrias nas Minas Gerais do século XVIII: as possibilidades de libertação escrava no principal centro colonial." Revista de História. São Paulo - USP, n. 133, 1995, pp. 49-57; Marcos Magalhães de Aguiar. "A coartação: uma singularidade mineira no sistema de alforria colonial?"Revista da SBPH, Curitiba, n. 18, 2000, pp.77-91; Carlo G. Monti. O Processo de Alforria: Mariana (1750-1779). Dissertação de Mestrado. São Paulo: Universidade de São Paulo, 2001, pp.126-128; Renata Romualdo Diorio. As marcas da liberdade: trajetórias sociais dos libertos em Mariana na segunda metade do século XVIII. Dissertação de Mestrado. São Paulo: Universidade de São Paulo, 2007, pp.126-158.
} 
o preço de mercado como facilitavam a obtenção de ganhos próprios, fossem desconsiderados para a estima do preço:

\begin{abstract}
“[...] tenéis de ser muchos y frecuentes los casos en que los negros que se compran bozales del asiento por precio equitativo, aplicados a ejercicios de consideración, según sus robusted y aptitud, por ejemplo en los ingenios a la construcción del azúcar, o al manejo y temple de los tachos, en las estancias a la quema del cazabe, en los pueblos a la fábrica de casas, o a otras ocupaciones en que adquieren maestría y ganancias propias, en pocos años llegan a tener por estimación común la de 500 o 600 pesos, o si a los tales hubiese de ser preciso dar la libertad por sólo lo que costaron en el armazón, os parecía resultaría en detrimento grave de los dueños y de las haciendas, porque a poco tiempo de trabajo en estos ejercicios, que son lucrativos a los mismos esclavos, habrían ganado lo bastante para hacerse libres, y los dueños quedarían sin utilidad alguna de haberlos enseñado, padeciendo su falta [...]"’213.
\end{abstract}

A nova cédula despachada no dia 27 de setembro de 1769 esclareceu que as mesmas regras valiam para enteros e coartados. A não ser pela virtual proximidade em relação à concretização da alforria, não havia diferenciação entre uns e outros quanto à sua condição. Ambos permaneciam, igualmente, escravos. De maneira alguma poderia haver transferência contrária à vontade senhorial, a não ser nos casos já previstos pelo direito envolvendo abusos e maus tratos. Porém, era mantido o preço original de compra para a manumissão em ambas as modalidades, cabendo ao comprador o pagamento do tributo no caso de venda do coartado ${ }^{214}$.

O que ocorreu nesse momento foi a incorporação formal da manumissão por vias onerosas à política de gerenciamento da prática escravista em Cuba, tolhendo-se parte do arbítrio senhorial sobre a concessão da liberdade. Estudos recentes indicam que muitos escravos em Cuba, a partir desse quadro normativo, conseguiram fazer valer e até mesmo ampliar os direitos conquistados ${ }^{215}$. Todavia, há de se ter certa cautela. Note-se que nem todas as situações foram contempladas. $\mathrm{O}$ valor inicial a ser pago para que fosse dado início à coartación, por

\footnotetext{
${ }^{213}$ Lucena Salmoral. "Leyes para esclavos: el ordenamiento jurídico sobre la condición,...”, p.1012.

${ }^{214}$ Idem, p.1013;1021-23. Em 26 de fevereiro de 1773, o marquês de la Torre, sucessor de Bucareli no governo da ilha, remeteu nova consulta sobre a temática, mas o governo em nada alterou o anteriormente disposto. Manuel Lucena Salmoral. "El derecho de coartación del esclavo en la América española"..., p.366. Nova especificação viria no decênio seguinte, em 5 de dezembro de 1788, quando o Conselho das Índias baixou resolução a respeito do eventual impacto da coartação da mãe escrava sobre os seus filhos. Alguns letrados hispano-cubanos, interpretando o princípio tradicional do partus sectur ventrem, teriam se colocado a favor de que a coartação da progenitora repercutisse proporcionalmente sobre os filhos, orientando a edição de normativa nesse sentido. Porém, afirmando novamente a invariabilidade da condição até que o valor fosse compensado integralmente, $o$ Conselho apresentou parecer no sentido de que "la coartación en las madres es sólo para ellas tan personal que no puede ser transmisible a los hijos a fin de que estos logren del mismo beneficio, para que sean vendidos en menos valor de el que en realidad tienen. Que el que nace esclavo, aunque sea de madre coartada, no por esta calidad debe carecer de cuantos efectos causa la esclavitud en cuanto al absoluto dominio que deben tener los dueños y señores sobre ellos", o que foi ratificado por Real cédula de 10 de fevereiro de 1789. Lucena Salmoral. "Leyes para esclavos: el ordenamiento jurídico sobre la condición,...", p.1144.

215 Alejandro de La Fuente. "Slaves and the Creation of Legal Rights in Cuba: Coartación and Papel". Hispanic American Historical Review, vol.87, n.4 (Nov. 2007), pp.659-92; María de los Angeles Meriño Fuentes \& Aisnara Perera Díaz. Para librarse de lazos, antes buena familia que buenos brazos: apuntes sobre la manumisión en Cuba (1800-1881). Santiago de Cuba: Editorial Oriente, pp.44-59.
} 
exemplo, não fora estipulado, tampouco o procedimento a ser tomado para a fixação do preço da liberdade daqueles já nascidos em cativeiro. Além do mais, é preciso entender que não houve um esvaziamento objetivo do poder senhorial. Muito embora a Coroa tenha tocado em aspectos importantes, ampliando o campo para a interferência do estado nas relações de escravidão, o instrumental coercitivo que viabilizava o disciplinamento cotidiano ao trabalho cativo mantevese estruturado.

Mas o caso não morreu aí. Em 26 de fevereiro de 1773, o Marquês de la Torre, agora no comando da ilha, enviou novos questionamentos ao monarca, movido por uma representação feita pelo Cabildo de Havana. Não era o direito à alforria por pagamento que estava em debate, mas a demarcação do preço da primeira aquisição. Segundo a retórica dos juristas havaneses, tal medida representaria um impedimento indistinto para todos os casos de venda. Mais uma vez, fizera-se presente o processo de valorização dos escravos, que ocorreria em dois graus:

\footnotetext{
"[...] uno ordinario y natural, y otro industrial y extraordinario siendo el primero el de los Negros de Guinea, que se provee esa Isla para las labores, mejorándose naturalmente de su bozalidad, y nativa rudeza, aprendiendo el idioma y primeros rudimentos de la Religión, recibiendo el Bautismo, y exercitándose después en el trabajo a que eran destinados, en cuyo grado ordinario tenían la comun estimación de trescientos pesos y los del $2^{\circ}$ que eran aquellos que salían más habiles, y aplicados á algun oficio, ó ocupación particular adquiriendo Maestria, ascendian a superior estimación, correspondiente a la utilidad de su servicio, versandose la misma diferencia en los Criollos Negros, y Mulatos a beneficio de la disciplina y de la edad $[\ldots]^{\prime 216}$.
}

Após um lapso de tempo considerável (o que pode sugerir uma certa relutância por parte do poder central), a matéria passou outra vez pelo crivo do Consejo de Indias, que apresentou sua consulta ao monarca no dia 17 de fevereiro de 1777 , derivando na cédula de 8 de abril de 1778 , que deu uma nova solução para o assunto ${ }^{217}$. É possível resumir as suas resoluções outra vez em seis pontos. Primeiro, os donos de escravos não coartados poderiam vendê-los pelo preço que acertassem com os compradores; segundo, quando fossem obrigados a vendê-los (os escravos inteiros) por autoridade da justiça, que o preço fosse avaliado judicialmente, "en concepto al valor que tenían en aquella actualidad", a não ser que encontrassem compradores dispostos a comprá-los sem avaliação. Neste caso, poderiam combinar o preço, desde que o valor da alcabala não fosse minorado; terceiro, em todos estes casos, pagaria o vendedor o direito de alcabala, com base no preço efetivo de venda; quarto, se o escravo coartado, por seu mau procedimento, desse motivo para ser alienado, poderia o amo acrescentar o custo da alcabala ao importe da coartação; quinto, ficariam isentos do pagamento

\footnotetext{
${ }^{216}$ Reales Cédulas y Ordenes, Archivo Nacional de Cuba (doravante, ANC), leg. 14. exp. 120.

${ }^{217}$ Agradeço às historiadoras Aisnara Perera e María Meriño, que de forma muitíssimo generosa, cederam-me uma transcrição integral da cédula.
} 
da alcabala escravos inteiros e coartados que se resgatassem a si próprios com dinheiro adquirido por meios lícitos; sexto, conforme o costume, os senhores ficavam obrigados a conceder a liberdade, sem demora, sempre que lhes fosse apresentado o preço correspondente, "regulándose este en los no coartados por el valor que en la actualidad tubieren á justa tasación, si Dueño y siervo no se conviniesen”. Os coartados não deveriam satisfazer por sua liberdade quantidade maior do que aquela restante para a complementação do preço fixado à época da coartação ${ }^{218}$. Para que não pairassem mais dúvidas, declarou-se expressamente a revogação das cédulas de 21 de junho de 1768 e de 27 de setembro de 1769, "en quanto sean contrarias a ló dispuesto en esta". Isto é importante. Não houve uma anulação integral do teor das normativas anteriores, mas única e tão somente dos tópicos que contrariavam as resoluções desta nova. Por exemplo, a obrigatoriedade da outorga da carta de liberdade para os cativos que apresentassem o seu valor, já presente no texto de 1768, e o impedimento, definido em 1769, de que inteiros e coartados se transferissem contra a vontade dos donos, foram mantidos. O que ocorreu efetivamente foi a submissão, não apenas das vendas ordinárias, mas da própria manumissão à lógica comum do mercado, caindo a cláusula sobre a manutenção do valor original de compra, ordenando-se a avaliação judicial conforme a cotação atual. Mais do que atender à reivindicação insistente dos proprietários, deu-se um remanejamento do "obséquio à liberdade" em função dos imperativos do momento, em consonância com a disposição assumida pelo quadro político bourbônico frente à inserção do país na economia-mundo ${ }^{219}$.

Como se sabe, aquele mesmo ano de 1778 foi marcado por atos estratégicos para o desenvolvimento das práticas comerciais no interior do império espanhol, com destaque para a obtenção das ilhas de Ano Bom e Fernando Pó na costa da Guiné, pelo Tratado de El Pardo, e para a aprovação do Reglamento y Aranceles Reales para el Comercio Libre de España a Indias. Esquecendo-se do fracasso futuro do empreendimento no litoral africano, parece plausível o argumento de Dolores García de que não foi por acaso que apenas seis meses após o acerto com Portugal, Carlos III tenha baixado a normativa que completou o processo iniciado em 1765, pondo fim ao sistema de frotas e de exclusividade portuária. Caso Ano Bom e Fernando Pó cumprissem o papel ambicionado, o problema crônico do provimento de cativos para as colônias hispânicas se resolveria intestinamente com a liberalização comercial

\footnotetext{
218 Reales Cédulas y Ordenes, ANC, leg. 14., exp.120.

219 Tornero Tinajero.Crescimento económico y transformaciones sociales..., pp.34-35; Brading. "A Espanha dos Bourbons e seu império americano", pp.412-418; Llombart Rosa (edição e estudo preliminar). Madri: Instituto de Estudios Fiscales, 1988, pp.19-31; Marquese. Feitores do corpo, missionários da mente..., pp.194-198.
} 
realizada $^{220}$. Foi no olho desse furacão que veio a lume a cédula de 8 de abril. Uma medida em favor da propriedade e afinada às mudanças do mercado se encaixava perfeitamente ao contexto. Por outro lado, vale a pena insistir que houve uma linha de continuidade entre 1768 e 1778: o direito dos escravos à alforria onerosa foi sustentado, dando-se, inclusive, um passo a diante no que dizia respeito aos coartados, com o congelamento legal do valor uma vez pactuado. Finalmente, chegou-se ao quadro sugerido por Levaggi.

É possível observar de forma bastante clara a conexão entre este quadro legislativo e a prática judicial hispano-cubana. Em maio de 1784, Joseph Asención, residente em Havana, moveu uma ação judicial com o objetivo de fazer cumprir o trato realizado entre ele e o seu senhor, o capitán de mar Cayetano de Arcia. Estando coartado em 250 pesos, havia sido transferido a este amo após ser convencido de que seria libertado após trabalhar pelo período de dois anos como carpinteiro (ofício do qual alegava ser professor) recebendo, ainda, o jornal de dois reales. Mas o tempo passou e a carta de ahorro não veio. Em sua defesa, o amo buscou desacreditar as informações prestadas por Joseph, alegando que ele o pertencia desde o seu nascimento, sendo filho de uma negra de sua propriedade chamada Antonia del Castillo.

Durante o processo, surgiu um complicador, Joseph foi vendido a outras pessoas. Isto fez com que o litígio fosse transferido para os novos amos, Francisco Javier Matienzo e Rafael Duarte, que em nada facilitaram as coisas. Diante da impossibilidade de comprovar a promessa que lhe teria sido feita, Joseph desistiu do intento original, depositando em juízo os 250 pesos, conforme diligência de 21 de novembro de 1785, corroborando, no entanto, a sua condição de coartado. O caso ainda se arrastou por algumas semanas até que, no final de janeiro do ano seguinte, transcorridos quase dois anos desde a abertura do processo, o capitán general sentenciou que fosse formada escritura de liberdade ${ }^{221}$. Pelo menos três aspectos aqui presentes devem ser sublinhados. O primeiro é o da interferência da vontade do escravo para a troca de senhor, sem nenhuma justificativa de maus-tratos, situação bastante presente na realidade cubana, como será visto no terceiro capítulo. A argumentação tecida pelo procurador de Joseph deixa nítido que ele atuara para a concretização da mudança de domínio pensando em seu benefício, iludido pela proposta recebida. Como é possível observar, a questão colocada aos legisladores entre 1768 e 1769 sobre a mudança voluntária e involuntária de amo dialogava com situações concretas, que inclusive seguiram ocorrendo ao arrepio da lei. O segundo é o

\footnotetext{
${ }^{220}$ Dolores García Cantús. Fernado Poo: una aventura colonial española en África Occidental (1778-1900). Tese de doutorado, Universitat de Valencia, 2004, p.28.

221 "Autos que sigue Joseph Asención contra el Capitán Cayetano de Arcia sobre su libertad", 1784, ANC, Escribanías (Ortega), leg. 157, exp.4.
} 
sem-número de dificuldades que se colocavam os escravos que acessavam o judiciário cubano. Neste caso em particular, como se não bastasse a liberdade ter sido paga duas vezes, a primeira com meses de trabalho a fio, a segunda com a quitação da importância em dinheiro, o expediente termina com uma reclamação grave, segundo a qual Joseph estaria sendo mantido preso pelos pés a um tronco por aqueles que deveriam libertá-lo.

Em dezembro de 1799, José Ramón, escravo da região de Guanajay, cuja fronteira havia sido aberta para o desenvolvimento da plantação de cana e café, iniciou um litígio contra seu senhor, D. José Ignacio de Orta, o qual estava pedindo uma quantia exorbitante para concederlhe a liberdade em função das habilidades que ele havia desenvolvido na fabricação de trapiches e outros aparatos necessários ao engenho. Por isso, requeria em juízo que o tal senhor fosse compelido a receber a importância a ser definida por um perito avaliador (tasador). Orta, por seu turno, reclamou que o escravo se encontrava fora de seu serviço, causando graves prejuízos e representando mau exemplo aos demais escravos do engenho. Além disso, José teria atropelado os trâmites processuais, apresentando por conta própria a quantia de 650 pesos, sem que ele, amo tivesse concorrido para a estipulação da justa causa (o procedimento usual era a nomeação de um perito para cada uma das partes, e um de terceiro em caso de discórdia). Por tudo isso, Orta pediu o recolhimento de José ao cárcere, no que foi atendido. Ao final, o cativo desistiu de sua libertação, pedindo a restituição dos valores apresentados para que pudesse empregar na manumissão de sua mulher e filhos. Ademais, aceitou retornar para o poder de seu amo, contanto que não fosse seviciado. O senhor, então, comprometeu-se a não "ponerle la mano", mas requereu que fossem descontadas dele, escravo, as custas judiciais: foi acolhido ${ }^{222}$. A reclamação indica que o recurso aos tribunais, embora potencialmente mais acessível no espaço urbano, não estava de todo vedado ao meio rural, em especial os cativos com significativo grau de especialização como José Ramón. Outro ponto a ser realçado é que muito embora o cativo tivesse dinheiro equivalente a pelo menos dois terços de seu valor, ele não seguiu o caminho da coartação. Ainda que a remissão do cativeiro de seus familiares mais próximos tenha pesado, seria de se esperar que ele buscasse amortizar uma parcela de seu preço diante da impossibilidade de quitar todo o montante. Dessa forma, poderia adquirir maior autonomia e economizar para franquear sua família e a si mesmo. Uma explicação possível para a não confluência nesse sentido reside no fato de que a coartação, diferentemente das alforrias liquidadas no ato, ainda não configurava ainda um direito legal dos escravos. Conforme explicado, embora houvesse sido conferida validez e formalidade aos ajustes firmados, não foi

222 "D. José Ignacio de Orta sobre la libertad de su esclavo José Ramón". Archivo Nacional de Cuba (ANC), Escribanías (Valerio), leg. 640, exp. 9480. 
estabelecido que os senhores ficassem obrigados a coartarem os cativos que apresentassem uma determinada quantia inicial ${ }^{223}$.

Em julho de 1802, Carlos Atellón, moreno de nação francesa que pertencia a Gabriel Ascarrate, também buscou promover a sua liberdade. Alegava ter nascido livre na ilha de Granada sob dominação francesa. Feito prisioneiro na Martinica, teria sido conduzido a Havana com mais cinco negros por um capitão inglês chamado Guillermo, onde fora vendido a D. Sebastián de Laza, que, por fim, o revendeu a Ascarrete, quem o colocou para trabalhar em seu engenho nos serviços de madeiras. Tratar-se-ia de uma escravização ilegal, gerada no turbilhão de acontecimentos precipitados pela Guerra dos Sete Anos. Mas, não era a liberdade defraudada que estava sendo pleiteada. O que Carlos requeria era a intimação de seu primeiro dono havanês para a apresentação do seu recibo de venda a fim de que fosse alforriado pelo mesmo valor. $\mathrm{O}$ amo, por seu turno, afirmou consentir na manumissão, mas requeria a nomeação de um tasador para que seu escravo fosse avaliado conforme as suas qualidades de carpinteiro. A defesa de Carlos buscou impugnar a tasación, declarando que ele aprendeu o ofício antes de ser comprado por aquele senhor. Além do que, qualquer acréscimo em relação ao seu valor original havia de ser compensado por mais de seis anos de trabalho desempenhados. Por mais coerentes que fossem tais argumentos não foram suficientes. Cada lado indicou o seu perito, mas houve desacordo. Um terceiro foi indicado pelo tribunal, procedendo-se a fixação do elevado preço final de 600 pesos. Conforme sentença de 11 de março de 1803, o juiz decretou a outorga da carta de liberdade pela justa avaliação. Porém, o documento termina em dissenso, com Carlos, de um lado, alegando que já havia entregado a importância ao escrivão e o senhor, de outro, negando. Por este processo não é possível saber o final da história ${ }^{224}$. Neste evento, para além da incrível trajetória do cativo, vê-se, alegoricamente, um choque direto entre as cédulas de 1768 e 1778 quanto à definição do preço pela liberdade.

Entretanto, ainda restavam situações não contempladas pela legislação. No ano de 1782 , em analogia ao antigo princípio do partus sequitur ventrem segundo o qual o estatuto civil da genitora era transmitido ao filho, o homem "pardo" e cativo, Fernando Brito, com o auxilio de um defensor público, recorreu à justiça havanesa solicitando que a sua ama, Estefania Brito, libertasse-o mediante a apresentação de 225 pesos, quantia pela qual a sua mãe fora coartada. A defesa da senhora rebateu tal intenção, afirmando que "la condición de la madre que sigue el hijo es en cuanto a servidumbre o libertad", não configurando a coartação uma condição a

\footnotetext{
${ }^{223}$ Isto ocorreria apenas com o Reglamento de Esclavos de 1842, como veremos no terceiro capítulo.

224 “Carlos Atellón esclavo de D Gabriel Ascarrate promoviendo su libertad”, 1802, ANC, Escribanía (Cabello Oseguera), leg. 23, exp. 10.
} 
ser transmitida, e que o preço a ser pago, dadas as condições e habilidades do escravo, giraria em torno dos 700 pesos. O estado de deterioração do documento não me permitiu averiguar o desfecho do caso, contudo, há elementos para afirmar que a demanda de Fernando não foi excepcional e que houve algum espaço para êxito, ainda que temporário ${ }^{225}$. Em 25 de junho de 1786, o governador de Cuba recém empossado, Joseph de Ezpeleta, escreveu à metrópole dando conta de que os pontos judiciais e extrajudiciais mais controversos naquela cidade entre os escravos e os seus donos, desde que havia começado a escutar os contenciosos em seu tribunal, provinham da ambiguidade com que os advogados enxergavam a coartação. Alguns entendiam que os filhos de mãe coartada deveriam gozar do mesmo benefício que ela, "si bien a proporción del valor del hijo". Outros (sendo estes a maioria) opinavam que o rebaixamento do preço do filho deveria ser na mesma proporção em que o da mãe havia sido. Parecendo-lhe esta última a mais conforme ao princípio da equidade, expediu um auto provisório declarando que fosse observada a resolução do direito

\begin{abstract}
"que establece seguir el parto la condición de la madre, estimándose al hijo sujeto a sola la respectiva esclavitud a que lo estaba aquella; para lo cual tomando conocimiento del valor de ésta al tiempo de su coartación, y de la parte del que se redimió o se le hizo gracia por legado u otro beneficio, se tasase el hijo por peritos inteligentes, y de lo que importase la tasación, se rebajase aquella parte de precio que correspondía al de la libertad que gozaba la madre, y por consiguiente el hijo, y el resto fuese sólo lo que se hubiese de abonar al dueño en los casos que ocurriesen de libertad o venta, conforme a lo resuelto en las Reales cédulas de 21 de junio de 1768, 27 de septiembre de 1769 y 8 de abril de $1778^{\text {"226. }}$.
\end{abstract}

O expediente passou pela Contaduría General, cujo colegiado apresentou informe, em 16 de março de 1787, concordando com a resolução de Ezpelueta. No dia 30, o Fiscal do Consejo de Indias, Antonio Porlier, magistrado experimentado nas Audiencias americanas, apresentou parecer, convergindo, em princípio, com o posicionamento do governador e da Contaduría. Disse que se fossem atendidas apenas razões de direito e equidade, haveria de se considerar legítimo o rebaixamento do valor do filho pela mesma quantidade na qual a mãe estava coartada. O problema, segundo ele, era que havia outras razões, "no menos atendibles, respectivas a la pública utilidad y a lo que ésta recomendaba con reflexión a las circunstancia que concurrían en la Habana". Como é possível depreender, tais circunstâncias se referem à especial necessidade de trabalhadores cativos para o cultivo da terra na ilha de Cuba. O funcionário enfatizou a importância da escravidão para a economia local e chamou a atenção para os inconvenientes políticos e morais decorrentes da facilitação demasiada dos meios para

\footnotetext{
225 “Autos por Fernando Brito contra su ama Estefania Brito sobre su libertad". ANC, Archivo de Daumy, leg. 382, exp. 1.

${ }^{226}$ Lucena Salmoral. “Leyes para esclavos: el ordenamiento jurídico sobre la condición,...”, p.1142.
} 
a obtenção da liberdade. Este foi o ponto de vista que prevaleceu: o parecer final do Consejo, de 5 de dezembro de 1788, recomendou a revogação da providência tomada pelo governador, ditando que

\begin{abstract}
“[...] la coartación en las madres es sólo para ellas tan personal que no puede ser transmisible a los hijos a fin de que estos logren del mismo beneficio, para que sean vendidos en menos valor de el que en realidad tienen. Que el que nace esclavo, aunque sea de madre coartada, no por esta calidad debe carecer de cuantos efectos causa la esclavitud en cuanto al absoluto dominio que deben tener los dueños y señores sobre ellos; que si ésta puerta se abriera en la Habana, cuando en las demás Américas no se ha oído semejante sutileza, no sólo se perjudicaría el Real derecho de Alcabala, que bajaría considerablemente, sino que por las razones políticas que se dejan considerar causaría la tal providencia notables perjuicios, y con el tiempo vendrían a hacerse muchos libres, tal vez valiéndose para ello de medios ilícitos, por la consideración de las cortas cantidades en que avaluaban sus hijos, y serían éstos unos públicos haraganes en la sociedad, como lo experimenta con los más que consiguen la libertad, y se aminorarían los trabajadores, tan necesarios en aquellas preciosas poblaciones"227.
\end{abstract}

Esta resolução recebeu integralmente a chancela monárquica, assumindo forma legal por meio de real cédula expedida em 10 de fevereiro de $1789^{228}$. Desse modo, ficou resolvido que a coartação da mãe de maneira alguma afetava a sua prole. Assim, o favorecimento da liberdade por parte do centro de poder espanhol chegava ao seu limite, isso poucas semanas antes da aprovação da liberdade de importação de escravos para o império ( 28 de fevereiro) e da promulgação da Real cédula e instrucción circular a Indias, sobre educación, trato y ocupación de los esclavos en todos sus dominios de Indias e islas Filipinas (31 de maio), elaborada sob a responsabilidade do mesmo Antonio Porlier para propiciar uma destinação socialmente ordenada e economicamente eficiente às levas de africanos escravizados que estavam por ser incorporadas. Não há coincidência aqui ${ }^{229}$. O que se observa na tramitação dessas cédulas sobre coartação, alcabala e liberdade, é o processo de refinamento de um ordenamento que articulava a um só tempo a tradição (jurídica e empírica), os interesses fiscais e econômicos do estado no assunto da escravidão, a lógica da dominação senhorial e as compressões sociojurídicas exercidas pelos próprios escravos.

Nesta época, o desempenho dos defensores ainda não estava bem definido. Sabe-se que em meados do século XVI a Coroa espanhola decretou a nomeação de procuradores para defender ameríndios em causas de liberdade ${ }^{230}$, mas não fez o mesmo para possíveis pleitos envolvendo africanos, não obstante a recomendação para a acolhida de reclamações desse tipo

\footnotetext{
${ }^{227}$ Lucena Salmoral. "Leyes para esclavos: el ordenamiento jurídico sobre la condición,...”, p.114.

${ }^{228}$ Zamora y Coronado. Biblioteca de Legislación Ultramarina. Madri: Imprenta de Alegría y Charlaín, 1844, T. I, p.164.

${ }^{229}$ Manuel Lucena Salmoral. "Leyes para esclavos: el ordenamiento jurídico sobre la condición,...”,pp.367-370.

${ }^{230}$ Real Cédula de 28 de outro de 1548, generalizando o que havia sido feito para o México naquele ano, determinou a nomeação de procuradores para a defesa de ameríndios em causas de liberdade. Cf. Manuel Lucena Salmoral. "Leyes para esclavos: el ordenamiento jurídico sobre la condición,...”, p.79.
} 
impressa no mandamento de 15 de abril de $1540^{231}$. O Código Negro Carolino, elaborado entre 1783 e 1784 , definiu em seu $21^{\circ}$ capítulo que o procurador síndico general ficaria encarregado da defesa dos escravos interessados em atestar a sua liberdade em juízo. Mas essa codificação, feita para Santo Domingo, não chegou a vigorar ${ }^{232}$. É certo que desde a implantação dos primeiros cabildos, figurava entre o seu corpo de funcionários o procurador general, responsável, entre outras coisas, pela assistência à municipalidade em queixas e agravos. Mas, conforme apuraram Meriño \& Perera a partir de processos abertos em Havana e em Santiago de Cuba, não existem sinais de que esses agentes concelhios, que tiveram acrescido o título síndico em 1749, tenham intercedido em favor dos negros em cativeiro até fins do século XVIII. Naquele período, a representação dos escravos esteve a cargo de procuradores públicos também referidos como procuradores de número, por causa da definição de número fixo de vagas para o cargo. Real cédula de 25 de junho de 1758 estipulou a criação de 10 daqueles procuradores para Havana a serem conferidos em pregão. Tratava-se de um ofício venal e renunciável. De forma rotativa, tais funcionários faziam as vezes de procuradores de pobres, assistindo gratuitamente, também, escravos litigantes. A depender do local de residência e da rede relações na qual estava inserido, o cativo procurava diretamente um desses agentes, ou se dirigia por conta própria aos tribunais portando um papel simples com a descrição de seus clamores, ou expressando-os verbalmente, daí, então, conforme o caso, o juiz nomeava o procurador $^{233}$.

A qualidade de "Protectores de los Escravos" foi atribuída aos procuradores síndicos pelo texto da Real cédula de 31 de maio de 1789, mencionada dois parágrafos atrás. Na esteira da liberação do tráfico de escravos, esta extensa normativa, composta por 14 capítulos, integrava claramente o projeto imperial espanhol para a assimilação de contingentes substanciais de escravos. Impunha-se, aos olhos metropolitanos, a criação de uma base legislativa unificada para garantir uma destinação socialmente ordenada e economicamente

\footnotetext{
${ }^{231}$ Manuel Lucena Salmoral. "Leyes para esclavos: el ordenamiento jurídico sobre la condición,...”, p.648.

${ }^{232}$ Manuel Lucena Salmoral. Los Códigos Negros de la América Española. Madri: Universidad de Alcalá/ Ediciones UNESCO, 2000, pp.61-94.

${ }^{233}$ Aisnara Perera Díaz \& María de los Ángeles Meriño Fuentes. "El Síndico Procurador General de esclavos en Cuba: breves consideraciones desde la obra de José Serapio Mojarrieta". In: Elda E. Cento Gómez (comp.). Cuadernos de Historia Principeña 11. Patrimonio Legado al siglo XXI. Camagüey: Oficina del Historiador de Camagüey/Editorial Ácana, 2012, pp. 22-38 (agradeço às valiosas explicações das autoras sobre este ponto em particular); José María Zamora y Coronado. Biblioteca de Legislación Ultramarina. Madri: Imprenta de Alegría y Charlaín, 1846, T. V, p.178. Sobre outras localidades, ver: Carolina González. "El abogado y el procurador de pobres: la representación de esclavos y esclavas a fines de la Colonia y principios de la República".Sud Historia (dossiê: Relaciones Lego-Letrado en la Historia de la Justicia: Argentina y Chile, siglos XVIII y XIX), n.5 (JulioDiciembre 2012), pp.81-98.
} 
eficiente a todo das levas de africanos escravizados que estavam por ser incorporadas ${ }^{234}$. Como sabido, o caráter altamente invasivo da Instrucción causara grande rebuliço nas classes proprietárias hispano-americanas, que conseguiram interditar a sua execução. Em 14 de junho de 1790, Polier expôs à Junta de Estado o teor das representações encaminhadas pelos ayuntamientos ou diretamente pelos hacendados. A matéria, então, foi encaminhada para a análise do Conselho das Índias, postergando-se a publicação da cédula até a expedição de um parecer final ${ }^{235}$. Diante dos apelos, a monarquia espanhola recuou, desistindo do projeto de padronização normativa do cativeiro em suas colônias. No dia 31 de março de 1794, foi resolvido que "por todas estas razones es de dictámen el Consejo se suspendan los efectos de la Real Cédula"236. Ao que tudo indica a atribuição da incumbência aos síndicos dos Ayuntamientos se deu a partir da própria prática judicial, sem a injunção de uma determinação legal originária. Até porque, entre as responsabilidades específicas discriminadas pela cédula barrada, não constava a representação judicial dos escravos. Nas duas décadas iniciais do século XIX seria possível observar claramente a consolidação dos procuradores síndicos (ou síndicos procuradores) na defensoria dos escravos. A sua eleição era feita de modo bianual pelos ayuntamientos por voto dos regidores e com o referendo do capitán general, constituindo um cargo obrigatório, honorífico e sem vencimentos (a não ser o correspondente à custa processual). A formação advocatícia, embora desejável, não era forçosa ${ }^{237}$. Resolução de

\footnotetext{
${ }^{234}$ Assim, estava impresso em seu prólogo que "[...] teniendo en consideración, que con la libertad, que para el comercio de negros he concedido a mis vasallos por el artículo primero de la Real Cédula de veinte y ocho de febrero próximo pasado se aumentará considerablemente el número de esclavos en ambas Américas, mereciéndome la debida atención esta clase de individuos del género humano, [...]". Lucena. "Leyes para esclavos: el ordenamiento jurídico sobre la condición,...”, p.1150.

${ }^{235}$ Constava do Memorial que levara o governador Cabello a adiar a publicação da Instrucción em 1789 que "el temor de algún movimiento nace de ser ordinarias las sublevaciones entre los negros esclavos, y de haber en el día los de un ingenio incendiándole por tres partes, a que conspiró la voz común de estar los negros franceses de una de estas colonias armados contra sus dueños, y aún dicen que proveídos de venenos, para darlo a todos los blancos, quienes no dejan de defenderse día y noche, cuyo anuncio, aunque no tenga efecto, basta para tener en expectación a los de esta Isla".Lucena Salmoral. "Leyes para esclavos: el ordenamiento jurídico sobre la condición,...”, p.365. Repercutia, primeiramente, a atuação de maroons em Guadalupe e Martinica, onde plantações foram acometidas por levantes severos no segundo semestre de 1789 e, em seguida, os estrondosos acontecimentos de Saint-Domingue. Sobre o contexto, ver: C. L. R. James. Os jacobinos negros. Toussaint L'Ouverture e a revolução de São Domingos. (Trad. port.). São Paulo: Boitempo, 2000 (1ª edição: 1938), p.87; Robin Blackburn. A queda do escravismo colonial, 1776-1848. (Trad. port.). Rio de Janeiro: Record, 2002, pp.187188; Ada Ferrer. "A sociedade escravista cubana e a Revolução Haitiana”. Almanack, n.3 (maio. 2012), pp.37-53. Disponível em: <http://www.almanack.unifesp.br/index.php/almanack/article/view/742>. Acesso em: 18 Sep. 2013.

${ }^{236}$ Lucena Salmoral. "Leyes para esclavos: el ordenamiento jurídico sobre la condición,...”, p.378.

${ }^{237}$ Conforme as ordenanzas de 1573, redigidas para os ayuntamientos de Cuba por Alonso de Cáceres, oidor da Audiencia de Santo Domingo, a eleição dos procuradores generales ocorria anualmente por votação aberta entre os vecinos. De 1623 em diante, a escolha dos ocupantes do cargo deixou de feita por cabildo abierto, passando a ser definida por deliberação dos regidores. Após 1770, a incumbência passou de um para dois anos. Meriño \& Perera. "El Síndico Procurador General de esclavos en Cuba...", op.cit. À luz dos reparos efetuados por estas últimas historiadoras, cf. José Serapio Mojarrieta. Exposición sobre el origen, utilidad, prerrogativas, derechos y
} 
primeiro de julho de 1837, manifestava como dado consolidado que um dos deveres dos síndicos procuradores era a defesa dos escravos ${ }^{238}$.

No caso da América portuguesa, vale notar que, em 1596, no contexto de união das coroas ibéricas, foi instituído o cargo de Procurador dos Índios, incumbido do encaminhamento de pleitos em favor dos gentios, inclusive em causas de liberdade, a exemplo do que havia sido feito em terras castelhanas ${ }^{239}$. Tal como lá, o expediente não foi replicado em um possível Procurador dos Negros, mas, conforme indicado na introdução, em 5 de novembro de 1710, o rei D. João V, motivado pela representação feita pelo bispo Francisco de São Jerônimo sobre o rigor excessivo dos castigos dispensados aos escravos, despachou carta ao governador da capitania do Rio de Janeiro, encarregando o procurador da Coroa e Fazenda ${ }^{240}$ das causas dos escravos, com o apoio de um solicitador destacado da Fazenda Real. A razão de ser dessa medida era a constatação de que os cativos não tinham canais abertos para que procurassem a justiça. Ao ser maltratados, a única alternativa seria escapar mata adentro. Note-se que o remédio indicado na disposição era o da eventual "mudança de cativeiro", o que não significava o acesso à liberdade, mas, a tradicional medida que propiciava a transferência de domínio ao escravo seviciado, recolhida na tradição do direito comum e prevista anos antes em medidas que igualmente visavam coibir maus-tratos (cartas régias de 20 e 23 de fevereiro de 1688), ainda assim, seria uma via aberta para que voos maiores fossem alçados ${ }^{241}$. O problema é que não há conhecimento sobre a extensão do engajamento de tais funcionários régios na representação de escravos. Outro canal possível se encontraria nas câmaras municipais, onde também havia um posto fixo de procurador ${ }^{242}$, ao qual, à semelhança de seu congênere castelhano, recaíam incumbências de representação judicial e extrajudicial, mas também não há registros disponíveis sobre o envolvimento deste oficial na defesa de escravos. A historiadora Fernanda Domingos Pinheiro, estudando ações de primeira instância da cidade de Mariana, em Minas Gerais, observou como prática, em meados do século XVIII (1750-1769), a nomeação pontual de procuradores tanto por proprietários quanto por cativos em busca da liberdade. Funcionava assim: os interessados davam entrada com uma petição em seu próprio nome

deberes de los síndicos procuradores generales de los pueblos.Santiago de Cuba, Imprenta de la Real Sociedad económica, 1833.

${ }^{238}$ El libro de los síndicos de Ayuntamiento y de las Juntas Prectoras de Libertos. Havana: Imprenta del Gobierno, 1875, pp.14-16.

${ }^{239}$ Marcia Eliane A. Souza e Mello. “O Regimento do Pocurador dos Índios do Estado do Maranhão". Outros Tempos, v. 09, n.14, 2012. pp.222- 231.

240 As atribuições do ofício foram previstas no livro 1, tít. XII das Ordenações Filipinas. Para uam reprodução da carta régio de 5 de novembro de 1710, cf. Lara. "Legislação sobre escravos africanos na América portuguesa", p.232-233.

${ }^{241}$ Marquese. Feitores do corpo, missionários da mente..., p.66-68.

${ }^{242}$ Sobre o procurador do concelho, cf. livro 1, tít. LXIX das Ordenações Filipinas. 
apresentando a demanda, então, sem a intervenção do juiz, passavam uma procuração no tabelião indicando um procurador para o encaminhamento do processo. Não havia, portanto, um oficial do estado responsável especificamente pela defensoria dos escravos. Por outro lado, a indistinção quanto ao ato da vida citadina representado pela nomeação direta de um procurador sugere uma equiparação extraordinária entre livres e escravos quanto à sua capacidade civil. Mas isto parece ser algo localizado. No momento seguinte, consolidar-se-ia a atuação de curadores na representação de $\operatorname{escravos}^{243}$.

Como se sabe, a curatela (ou curadoria) era um instituto existente já no direito romano, que visava garantir cuidado aos bens daqueles que por si próprios não poderiam fazê-lo, como no caso de insanos (furiosos), gastadores inveterados (pródigos) e menores de vinte e cinco anos de idade. Em essência, tratava-se de um dispositivo relativo ao direito patrimonial e sucessório. Citando o trabalho de Francisco Bulhões de Carvalho (1957) ${ }^{244}$, a historiadora Keila Grinberg indica que o ordenamento luso-brasileiro teria tomado de empréstimo do direito romano o emprego do curador em outra circunstância, a saber, na mediação judicial em favor de pessoas miseráveis. A Constituição de Constantino teria conferido privilégio de foro a este grupo social, cujos membros poderiam requerer a nomeação de um curador. Segundo a autora, as Ordenações Filipinas incorporariam este precedente, estendendo-o a órfãos e viúvas, os quais, de acordo com a autora, teriam "os privilégios de escolher curadores, para suprir suas próprias incapacidades de administrar seus interesses". Muito embora não se referisse a eles, tal expediente, seria aplicado na prática aos escravos, auxiliados por curadores no encaminhamento de suas causas. Porém, o procedimento permaneceria na esfera do costume até que em 25 de janeiro de 1843 fosse lançado o Aviso de n. 7 , mandando que "fossem considerados miseráveis os pobres, os cativos, os presos em cumprimento de sentença, os loucos, (...)”245. A última parte está correta, quer dizer, este dispositivo chancelou a nomeação de curadores aos escravos, considerados dignos de amparo legal por sua condição reconhecidamente miserável. Mas creio haver problema na genealogia traçada por Grinberg. A regra atribuída a Constantino, recolhida no Digesto, diz que deveriam ser concedidos advocatos (note-se, não, curatorum) às pessoas que não tivessem meios materiais para constituí-los, o que incluía mulheres, pupilos (órfãos ainda menores) e deficientes mentais (D.1.16.9.5) - os

\footnotetext{
${ }^{243}$ Fernanda Aparecida Domingos Pinheiro. "Transformações de uma prática contenciosa: as 'Ações de Liberdade' produzidas em Mariana - 1750/69 e 1850/69”. Locus: revista de história, v.17, n.1 (Juiz de Fora, 2011), pp. 253271. Ver também: Diório. As marcas da liberdade..., op.cit.

${ }^{244}$ Francisco Pereira de Bulhões Carvalho. Incapacidade Civil e Restrições de Direito. Rio de Janeiro, Editor Borsoi, 1957, tomo I.

${ }^{245}$ Keila Grinberg. Liberata: a lei da ambigüidade as ações de liberdade da Corte de Apelação do Rio de Janeiro no século XIX. Rio de Janeiro: Centro Edelstein de Pesquisas Sociais, pp.35-36
} 
escravos não eram de qualquer modo contemplados, já que desprovidos de personalidade jurídica em Roma. No que diz respeito às Ordenações, é interessante notar que os parágrafos de 3 a 5 do tít. 5 do livro terceiro, citados expressamente pela historiadora, realmente conferem privilégio de foro a órfãos, viúvas e pessoas miseráveis, mas isto se referia à possibilidade de escolha dos juízes. Absolutamente nada versam sobre a escolha de curadores para a satisfação de suas necessidades. É possível que a participação de curadores na defensoria de escravos tenha se originado no juízo de órfãos, onde eram julgadas causas procedentes de inventários e suscitada a nomeação de tutores e curadores ${ }^{246}$. A função original destes últimos era zelar pela administração dos bens de menores e incapazes, mas, com a ocorrência frequentemente de litígios em torno da liberdade de escravos, talvez, por associação, tenha-se iniciado o enquadramento da curatela no auxílio à libertandos. O caso de Catharina Maria Preta (também nomeada Catharina Maria de Nação) é um desses. O processo envolvendo seu nome, iniciado em 1809, chegou dois anos depois à Casa da Suplicação, instalada no Rio de Janeiro junto com a Corte. O litígio principal, por assim dizer, era travado entre o capitão Salvador da Silva Campello e o menor Floriano José Filho, seu sobrinho. A disputa envolvia os bens que estavam em poder da falecida Maria Angélica, mãe de Floriano e irmã de Salvador. Entre os tais, constavam duas casas e dois cativos, Antônio e Catharina. No juízo de órfãos, Salvador alegou que sua irmã não tinha nada; que todas as coisas haviam sido compradas por ele e cedidas à irmã pelo tempo que ele desejasse. Em troca, ela havia se comprometido a ensinar o ofício de costureira à sua escrava, Catharina. Um documento supostamente escrito pela falecida Maria Angélica atestou as declarações do irmão perante o juiz de órfãos, que excluiu a casa e os escravos do inventário, transmitindo a sua posse a Salvador. O tutor do órfão, então, entrou com um pedido de embargo no tribunal superior, alegando a falsidade do documento exibido por Salvador e juntando aos autos certidão de propriedade dos cativos envolvidos. Isto interessava diretamente a Catharina, pois Maria Angélica a libertara em seu testamento. Por isso, ela tomou parte do processo, primeiro com a intervenção do tutor de Floriano e depois com o auxílio de um representante nomeado para intercedê-la a seu favor, primeiro mencionado como tutor, depois como curador ${ }^{247}$. O depósito foi requisitado e, Catharina, retirada do convívio de seu antagonista, que tratou de rechaçar suas alegações, afirmando que Maria Angélica não poderia

\footnotetext{
246 Vieira Ferreira. "Juízes e Tribunaes do Primeiro Império e da Regência”. Boletim do Instituto Historico e Geographico Brasileiro. Rio de Janeiro: Imprensa Nacional, 1937, pp.6-7.

${ }^{247}$ No direito português as diferenças fundamentais entre tutoria e curatela delineadas na tradição latina haviam se perdido. Uma diferença básica era que "o tutor era dado principalmente à pessoa, o curador aos bens". Cf. Pascoal José de Mello Freire. Instituições de Direito Civil português: tanto público como particular. Livro II, Título XII. (1 $1^{a}$ edição, 1789 - tradução de Miguel Pinto de Meneses). Lisboa: Procuradoria Geral da República, 1967, p.130.
} 
ter alforriado escrava que não lhe pertencia. Mas as provas apresentadas pelos suplicantes parecem ter sido mais convincentes. O tribunal acolheu o embargo do órfão. Porém, a situação daquela que ansiava por sua liberdade não se resolveu automaticamente ao final. A última manifestação do processo é uma declaração de Catharina, fazendo presente que estava impossibilitada de prosseguir nos serviços de sua causa por estar assoberbada de trabalho no local de seu depósito ${ }^{248}$.

É certo que percalços como este podiam acometer cativos tanto no Brasil quanto em Cuba. Havia também os que tentavam provar a condição de liberdade de direto contra a escravidão de fato. É o caso de Luís Albino. Em 29 de agosto de 1817, Felipe Pimienta, cabo retirado do Batalhão de Pardos da cidade de Havana, apresentou representação em juízo se defendendo da acusação de escravização ilegal do moreno Luis de Nación Mandinga, escravo de sua legítima propriedade, que teria saído de casa sem autorização, a pretexto de reunir testemunhas de sua condição de homem livre. A acusação seria improcedente, pois o teria comprado de forma legal no ano de 1812 do marinheiro Manuel Antonio, que por sua vez o adquiriu, em janeiro do ano anterior, das mãos de Antônio José Castão, piloto do navio Bom Sucesso, negreiro atuante na Costa da Guiné. Papéis de próprio punho, cuja veracidade não é possível atestar são apresentados confirmando todas essas transações. Por sua vez, Luís, com o auxílio de um curador, alega que o seu nome de batismo era Albino, que havia nascido livre na cidade da Bahia de Todos os Santos, no Brasil, e batizado na paróquia de Nossa Senhora do Pilar, sendo filho de Francisco Albino e Maria da Paixão, ambos pessoas livres. Com a idade de 18 anos, teria ingressado como marinheiro em um navio mercante que fazia o circuito entre África e Caribe. Vitimado pelo estigma em torno de sua cor, teria sido vendido ilegalmente como escravo ao aportar em Havana. As testemunhas do que estava afirmando foram efetivamente apresentadas: tripulantes baianos de um bergantim de bandeira portuguesa aportado em Havana. Manuel José Rodrigues, Manuel da Costa e Manuel Sanches confirmaram a história de Luís. Disseram que o conheciam e a seus pais da Bahia, sendo todos pessoas livres e bem estabelecidas na cidade. Nas palavras do primeiro, "el motivo de haber salido de su tierra fue el mismo que tienen todos los muchachos que es el salir huidos de sus padres", isto é, aventurar-se pelo mundo. Apenas um dos tripulantes, José Francisco de Sousa, afirmou desconhecer o litigante e a seus pais, bem como o seu estatuto civil, se livres ou escravos. À primeira vista, o processo parecia estar se encaminhando a favor de Luís, já que os documentos apresentados por Pimienta evidenciavam relações de compra e venda, mas não provavam ser

${ }^{248}$ Catarina Maria Preta. A apelante requer sua liberdade ao apelado que anteriormente foi concedida por sua dona já falecida (1809-1815). Código de referência: BR AN,RIO: EJ.0.ACI.0584 Série Apelação cível - ACI. 
Luís havia sido resgatado da forma usual nos enclaves do trato de escravos das Costa africana. A venda inicial poderia muito bem ter sido feita de forma ilegal. Ademais, havia testemunhas confirmando as suas declarações. Mas o procurador del número, representante de Pimienta, tratou logo de por em descrédito os testemunhos, em especial, com uma declaração de José Francisco Sousa, segundo a qual havia sofrido tentativa de suborno para que confirmasse toda a história. E diz: "pensó sin duda, que Sousa seria ganado con dos onzas de oro, cantidad tal vez mayor que la con que ganaría a los otros tres hombres de baja esfera y de moral corrompida". Dessa forma, tudo teria sido armado ali mesmo. Luís, não seria oriundo da Bahia, mas da Costa da Guiné, inexistindo qualquer conexão pregressa entre aquelas pessoas. Nenhum documento probatório efetivo, como o atestado de batismo ou mesmo uma carta dos seus pais, foi apresentado para fundamentar a liberdade proclamada, somando-se ao fato comprovado de que Pimienta o comprara de boa fé. Importante a sublinhar é o fato de que a defesa de Luís é abissalmente inferior à de seu escravizador. Afora o arrolamento das testemunhas, não há um esforço substantivo por parte do representante de rebater as alegações encaminhadas pelo procurador de Pimienta. Ademais, chama à atenção a presença, aparentemente excepcional para o caso cubano, não do síndico, mas de um curador, que, diferentemente do que normalmente ocorria no Brasil, não parece ter sido nomeado pelo juiz, mas constituído diretamente por Luís. É possível que isto se deva à condição na qual se colocava Luís. Não se tratava de um libertando, mas de um possível homem livre lutando para demonstrar o seu estatuto. Não era, ademais, de uma causa cível. Era uma ação contra o crime de cativeiro ilegal. Feito este aparte, cabe esclarecer como tudo acabou. Ao final, o julgador, em 19 de dezembro de 1818, declarou que o moreno Luís Albino não propiciou prova competente da demanda sobre sua liberdade. Felipe Piementa, ao contrário, havia administrado as necessárias comprovações de sua inocência, ficando, portanto, absolvido da denúncia, devendo continuar o referido Albino na escravidão, sendo entregue a seu antigo amo "para que disponga de él como le parezca entre los términos de moderación y humanidad que corresponden”. Para piorar, Luís foi incumbido das custas do processo, cujo montante, caso não tivesse como arcar imediatamente, deveria ser acrescido ao seu valor ${ }^{249}$.

${ }^{249}$ Luis Alvino contra Felipe Pimienta sobre libertad de un esclavo (en mal estado), 1817, ANC, Archivo de Valerio Ramírez, leg. 737, exp. 10799. 
Como é possível depreender do cenário descrito, as condições objetivas que envolviam a prática social da alforria e as bases jurídicas para a abertura de demandas judiciais podiam ser bastante parecidas nos dois espaços recortados. Havia semelhanças notáveis no teor das reivindicações e nas exigências do judiciário para a comprovação das intenções manifestadas. Problemas envolvendo inventários post-mortem, promessas de libertação quebradas e escravização ilegal podiam ocorrer tanto no Brasil quanto em Cuba, remetendo à base jurídica tradicional ainda em plena observância. No entanto, como foi visto, houve divergências bastante sensíveis. Enquanto no Brasil foram sustentados os feitos mais gerais do quadro normativo tradicional, Espanha/Cuba promoveram o reconhecimento legal do direito à alforria onerosa e consolidaram a atuação de funcionários encarregados especificamente à defensoria dos escravos. Isto não sugere, de modo algum, a existência de uma condição de vida melhor para os escravos cubanos, mas indica diferenças qualitativas importantes no tocante à mediação exercida pelo Estado nas relações domésticas entre senhores e escravos. Nos dois próximos capítulos, a configuração assumida pelos respectivos quadros jurídicos será examinada em sua evolução ao longo do século XIX, começando pelo caso brasileiro. 


\section{Capítulo 2}

\section{O direito escravista do Império do Brasil, 1823-1871}

O estudo de uma realidade na qual escravos, em determinadas circunstâncias, conseguiam romper as barreiras do cativeiro, estabelecer laços de reciprocidade, construir estratégias complexas, iniciar processos judiciais e, efetivamente, conquistar a sua liberdade, deve ser conduzido com cautela para evitar a atribuição de uma dimensão desmesurada às conquistas individuais dos cativos diante do sistema de escravidão. Para tanto, é preciso situar o protagonismo escravo por meio de sua imersão em movimento amplo, estabelecido na longa duração. Entenda-se bem, a busca pela alforria tinha implicações sociais irrefutáveis e deve ser valorizada enquanto conquista social dos trabalhadores escravos. Por sua natureza intrínseca, pelo incentivo que representava, pelos laços de clientela que engendrava, adequava-se plenamente ao regime de escravidão. Durante a maior parte da história do Império do Brasil, como, anteriormente, no período colonial, a manumissão foi incapaz de romper com a ordem social estabelecida ou de modificar as relações de produção. Não seria diferente enquanto os fundamentos que permitiam a reprodução sistêmica do cativeiro estivessem estruturados, isto é, enquanto houvesse um aparato coercitivo funcionando, opções viáveis para a reposição da mão de obra cativa e um quadro jurídico plenamente ajustado, que conservasse o arbítrio senhorial sobre a disciplina e a concessão da alforria. Neste capítulo, interessa examinar a evolução do direito escravista imperial, passando pelo início da desestruturação da dinâmica da escravidão brasileira com a abolição do tráfico de escravos, em 1850, até a passagem para a década de $1870 .^{250}$

É importante realçar que além da "riqueza das nações" e do esgotamento físico e mental dos trabalhadores, emerge das experiências produtivas um conjunto complexo de valores, ritos, tradições, comportamentos e representações, com relativa autonomia, que se reproduz e se

\footnotetext{
${ }^{250} \mathrm{O}$ conjunto de pesquisas produzidas desde os trabalhos pioneiros de Sidney Chalhoub e Keila Grinberg sobre ações cíveis envolvendo a liberdade de escravos vem iluminado aspectos fundamentais das relações de escravidão no Brasil, especialmente na segunda metade do século XIX, e servem de base para as análises aqui efetuadas. Cf. Sidney Chalhoub. Visões da liberdade: uma história das últimas décadas da escravidão na corte. São Paulo: Companhia das Letras, 1990; Keila Grinberg. Liberata: a lei da ambiguidade. Rio de Janeiro: Relume-Dumará, 1994. Elciene Azevedo. Orfeu de Carapinha. A trajetória de Luiz Gama na imperial cidade de São Paulo. 2. ed. Campinas: Editora da Unicamp, 1999; Elciene Azevedo. O direito dos escravos. Lutas jurídicas e abolicionismo em São Paulo. Campinas: Editora da Unicamp, 2010; Adauto Damásio. Alforrias e ações de liberdade em Campinas na primeira metade do século XIX. Dissertação de Mestrado. Campinas: Universidade Estadual de Campinas, 1995; Joseli Maria Nunes Mendonça. Entre a Mão e os Anéis - a Lei de 1885 e os caminhos da abolição no Brasil. 2 ed. Campinas: Editora da Unicamp, 2008; Regina Célia Lima Xavier. A Conquista da Liberdade: libertos em Campinas na segunda metade do século XIX. São Paulo: Centro de Memória/Editora da Unicamp, 1997.
} 
renova ao longo dos anos, integrando-se de forma variada e mutuamente determinada tanto às instituições políticas e jurídicas constituídas no interior das fronteiras nacionais, quanto ao movimento geral da economia. Portanto, além da economia e da política, é preciso observar uma dimensão cultural das relações e disputas entre senhores e escravos: um aparente lugarcomum que quase nunca é observado sob uma perspectiva mais ampla. O que se observa na longa duração, é um movimento conservador de reestruturação do escravismo em sua dimensão local, que desde o final do século XVII havia sedimentado uma dinâmica estreita entre a entrada volumosa de escravos e índices comparativamente elevados de manumissão ${ }^{251}$. No século XIX, os fatores dessa equação passaram a se configurar de forma diferente, com a realocação geográfica das principais regiões produtoras, aumento na escala produtiva, a nova configuração do Estado nacional, e assim por diante. Mas a cultura da escravidão construída no período colonial informaria a dinâmica do escravismo oitocentista, que guardaria traços essenciais do nexo organizacional constituído no passado, especialmente pela maneira de se regular as relações sociais. É importante considerar as transformações e as especificidades de cada época, sem perder de vista as interconexões entre um momento e outras mediadas pelo conflito social e pela transmissão geracional de costumes e elementos culturais.

Durante o período imperial, o tít. 63 do Livro 4 das Ordenações Filipinas, que enquadrava a alforria como uma doação revogável em caso de ingratidão, continuou válido, muito embora alguns jurisconsultos tenham relativizado tal enquadramento, observando a especificidade do ato ${ }^{252}$. A doutrina e a jurisprudência em diálogo com o costume e preceitos normativos esparsos (romanos e portugueses) ampliaram esse enquadramento. Ainda assim, a liberação seguiria como uma manifestação da livre vontade senhorial, podendo ser conferida a título oneroso ou gratuito; por ato entre vivos ou por testamento; por fideicomisso (a cargo de terceiro), a prazo ou sob condição. Nas últimas três hipóteses, criava-se um estado intermediário entre a escravidão e a liberdade, o estado-livre (statu-liber), os quais, na prática, eram tratados como escravos como quaisquer outros. Conforme o Direito romano, os filhos de um estadolivre nasciam escravos. Apesar de abalizadas opiniões em contrário, não há indícios de que tal princípio tenha sido significativamente subvertido nos foros imperiais. Casos de terminação

\footnotetext{
${ }^{251}$ Rafael de Bivar Marquese. "A dinâmica da escravidão no Brasil. Resistência, tráfico negreiro e alforrias, séculos XVII a XIX”. In: NovosEstudos Cebrap, 74 (março 2006), pp.107-123.

${ }^{252}$ Mariana Armond Dias Paes. Sujeitos da História, Sujeitos de Direitos: personalidade jurídica no Brasil escravista (1860-1888). Dissertação de mestrado, Faculdade de Direito/Universidade de São Paulo, 2014, pp.177178.
} 
forçada do cativeiro, nos quais não se demonstrassem por alguma via a expressão do arbítrio senhorial, seriam muito $\operatorname{raros}^{253}$.

Em estudo concluído recentemente, abrangendo as décadas de 1860 a 1880, Mariana Dias Paes rebateu a ideia de que o "direito da escravidão” no Brasil era "“lacunoso', 'cinzento', 'pouco sistemático', 'arbitrário', 'confuso', 'sujeito exclusivamente aos interesses políticos dos envolvidos', 'maleável', 'um verdadeiro dédalo', 'tortuoso'”, evidenciando o papel fundamental da doutrina jurídica e da jurisprudência em sua conformação ${ }^{254}$. O reparo é correto e ilumina o aspecto elementar, por vezes esquecido, de que o direito é muito mais amplo do que o teor dos textos das legais. Todavia, é preciso observar que o direito legislativo, stricto sensu, foi, sim, lacunar; faltou um tratamento legal sistemático, sobretudo a respeito das relações privadas entre senhores e escravos e as modalidades da alforria. Embora as referências normativas do escravismo colonial português tenham sido objeto alvo de interpretações diversas ao longo do século XIX, adequadas às novas concepções a respeito do direito, mais próximas do liberalismo jurídico e da concepção do indivíduo como fundamento do direito, a conservação de sua vigência deu sustentação à interconexão com o modo pregresso de viver a instituição ${ }^{255}$. A consolidação do direito de propriedade complementaria o quadro, reforçando os direitos senhoriais diante da equivalência nefasta de seres humanos à forma mercadoria.

Hebe Mattos, observando a prevalência de julgamentos em segunda instância favoráveis à liberdade no período até 1830 , e ponderando sobre as indicações de Manuela Carneiro da Cunha sobre a inexistência de legislação sobre a alforria onerosa, afirmou que as sentenças em favor da liberdade "se faziam em nome do costume e das 'mais fortes razões da liberdade', previstas em 'lei'" ${ }^{256}$. Contudo, o que ocorria era o reconhecimento da condição de livres ou alforriados de pessoas beneficiadas pela vontade senhorial já consumada, não a validação do direito à liberdade. É uma diferença qualitativa importante em relação a Cuba, como veremos no capítulo seguinte. No Brasil, a manumissão, enquanto ato jurídico estaria vinculado à comprovação da vontade senhorial. O direito escravista estava intimamente relacionado à “ideologia” mais ampla que sustentava a relação senhor-escravo ${ }^{257}$.

\footnotetext{
${ }^{253}$ Agostinho Marques Perdigão Malheiro. A escravidão no Brasil: ensaio histórico, jurídico, social. (1866), 2.v. Fonte Digital: eBooksBrasil, pp.19-90; Eduardo Spiller Pena. Pajens da Casa Imperial: jurisconsultos, escravidão e a Lei de 1871. Campinas: Editora da Unicamp, 2001, pp.79-96.

${ }^{254}$ Paes. Sujeitos da História, Sujeitos de Direitos..., p.217.

${ }^{255}$ Idem, pp.28-44.

${ }^{256}$ Hebe Mattos. Das cores do silêncio: os significados da liberdade no sudeste escravista (Brasil, século XIX). (ed.revista) Campinas: Editora Unicamp, 2013, p.190. O texto de Manuela Carneiro da Cunha citado é: "Sobre os silêncios da lei: lei costumeira e positiva nas alforrias de escravos no Brasil do século XIX", in: Antropologia do Brasil: mito, história, etnicidade. São Paulo: Brasiliense, 1987, pp.123-144.

${ }^{257}$ A indicação desta observação foi feita por Mariana Armond, a quem agradeço uma vez mais.
} 
As primeiras páginas deste capítulo se debruçam sobre o momento fundação da ordem constitucional no Brasil. A partir dos debates travados entre 1823 no âmbito da Assembleia Constituinte e a outorga do texto definitivo em 1824, é possível observar como o conjunto de costumes e práticas características do domínio sobre escravos informaram a definição dos poderes do estado e dos direitos fundamentais dos cidadãos. A omissão impressa no ato fundador da ordem constitucional ressoou na tessitura dos tempos, unindo de maneira singular a sociedade escravista do Império aos modos pregressos de viver, compreender e ordenar a instituição, estabelecendo as bases para o seu desenrolar futuro, marcado pelo que Hebe Mattos uma vez chamou de ética do silêncio, que circundaria as relações de escravidão e as disparidades étnico-raciais de forma duradoura ${ }^{258}$. A solução de continuidade assinalada não significa, porém, uma desvinculação em relação ao movimento geral do escravismo atlântico, da constituição da segunda escravidão. A manutenção de um sistema normativo plural, aberto e legalmente lacunar não implicou a emulação da sociedade escravista colonial na época do Império, mas o ajuste de um modo de regulação tradicional à nova realidade. Tratou-se, em síntese, de uma continuidade descontínua, que conferiu dinamismo e elasticidade ao que havia de tradicional ou típica na arquitetura do direito luso-brasileiro.

A validade do conceito de segunda escravidão na abordagem realizada neste capítulo não poderá ser observada pela demonstração das mudanças ocorridas na prática do cativeiro quanto à intensidade da produção, observadas no Vale do Paraíba e, mais tarde, no Oeste Paulista $^{259}$. O que se buscará efetuar nas páginas seguintes é um exame da formatação geral do sistema jurídico brasileiro na longa duração a partir de uma variação de escalas efetuada por intermédio de ações judiciais promovidas por escravos da cidade do Rio de Janeiro e freguesias próximas, que abrangem todo o período destacado. No Brasil, além de responsabilidade criminal, os escravos gozavam de certa personalidade jurídica, na medida em que tinham capacidade limitada de contrair direitos e obrigações, podendo figurar em juízo ${ }^{260}$. Apesar e também por causa disso, o Direito civil assumiu um caráter plenamente escravista, adequandose de maneira particular à dinâmica que envolvia a reprodução do cativeiro.

\footnotetext{
258 Martha Abreu, Hebe M. Mattos \&Carolina Vianna Dantas. "Em torno do passado escravista: as ações afirmativas e os historiadores".Antíteses, v. 3, n. 6 (jul.-dez. de 2010), p.34.

${ }^{259}$ Sobre isto, ver: Ricardo Salles. E o Vale era o Escravo. Vassouras, século XIX. Senhores e escravos no coração doImpério. Rio de Janeiro: Civilização Brasileira, 2008; Rafael Marquese \& Dale Tomich. "O Vale do Paraíba escravista e a formação do mercado mundial do café no século XIX”. In: Keila Grinberg \& Ricardo Salles (orgs.). O Brasil Império (1808-1889). Rio de Janeiro: Civilização Brasileira, 2009, pp.339-383.

${ }^{260}$ Paes. Sujeitos da História, Sujeitos de Direitos..., pp.28-48.
} 


\section{Fundação da ordem constitucional e a preservação das bases jurídicas da escravidão}

Abolir o infame comércio da escravatura e emancipar gradualmente os cativos existentes. Para José Bonifácio de Andrada e Silva, uma das principais personagens do processo de independência do Brasil, esta era a tarefa imperiosa a ser executada para que o Estado nacional em gestação tivesse condições de prosperar no futuro. Enxergando na "civilização" dos indígenas e na mobilização de brancos, "mesclados" e forros, a solução para o problema da mão de obra do jovem país e, na vitalidade inglesa, o indicativo de que era possível sobreviver à supressão do tráfico, não obstante as vozes alarmistas em contrário, o então deputado constituinte pela província de São Paulo, em sua conhecida Representação à Assembleia Geral Constituinte e Legislativa do Império do Brasil sobre a escravatura, arquitetou um projeto de lei composto por trinta e dois artigos a fim de dar vazão ao referido intento. Mãe de todos os vícios, causa de indolência entre os senhores, provedora de inimigos internos, incompatível com a ordem constitucional, a escravidão deveria ser erradicada. Mas não repentinamente. Distúrbios deveriam ser evitados. Ao passo que o negócio negreiro - por si só um cancro a corroer nossas entranhas - seria eliminado no prazo de quatro ou cinco anos, caberia "melhorar a sorte dos atuais cativos", cuidando-se para que fossem convertidos de forma paulatina, pela força da razão e pela lei, "de vis escravos em homens livres e ativos"261. Sintetiza-se aí a orientação antiescravista que Bonifácio vinha buscando articular desde a época em que o Brasil ainda se encontrava na condição de Reino Unido. Nas Instruções do Governo Provisório de São Paulo aos deputados da Província às Cortes Portuguesas, recomendou a abordagem do tema da escravidão, alegando o imperativo de se "melhorar a sorte dos escravos, favorecendo a sua emancipação gradual e conversão de homens imorais e brutos em cidadãos ativos e virtuosos, vigiando sobre os senhores dos mesmos escravos para que estes os tratem como homens e cristãos (...) mas tudo isso com tal circunspeção que os miseráveis escravos não reclamem estes direitos com tumultos e insurreições que podem trazer cenas de sangue e de horrores"262. Enquanto ministro, havia exercido forte controle sobre a imprensa, devassando

\footnotetext{
${ }^{261}$ José Bonifácio de Andrada e Silva. Representação à Assembléia Geral Constituinte e Legislativa do Império do Brasil sobre a escravatura. Paris: Tipographia de Firin Didot, 1825, pp.27-28.

262 José Bonifácio de Andrada e Silva. Escritos Políticos. São Paulo: Obelisco, 1964, p.18. Politicamente atrelados a interesses escravocratas, os representantes paulistas não levantaram a questão, nem sequer pela voz de Antônio Carlos de Andrada e Silva, irmão mais moço do redator das Instruções. Cf. Márcia Berbel, Rafael Marquese \& Tâmis Parron. Escravidão e Política: Brasil e Cuba, c. 1790-1850. São Paulo: Hucitec, 2010, pp.153-154.
} 
redatores dos periódicos mais destacados, veiculando discursos contrários ao cativeiro e silenciando opiniões pró-escravistas ${ }^{263}$.

Entre as principais medidas presentes na Representação de 1823, estava o reconhecimento legal do direito à alforria por pagamento: "todo escravo, ou alguém por ele, que oferecer ao senhor o valor por que foi vendido, ou por que for avaliado, será imediatamente forro" (art. V). No período restante para a importação e a comercialização interna de seres humanos, deveria ocorrer um registro, em livro público de notas, do preço de venda de cada escravo mercadejado: eis o preço da liberdade (art. II). Os escravos havidos anteriormente, desprovidos, portanto de tal registro, passariam por uma avaliação jurídica por jurados; um nomeado pelo senhor, outro pela autoridade pública competente (art. III). Nas avaliações, atentar-se-ia aos anos de cativeiro e de serviço do escravo, ao seu estado de saúde e à sua idade (art. IV). Algo análogo à coartação também foi previsto. Caso o escravo, ou alguém por ele, não pudesse pagar o preço total, poderia apresentar a sexta parte, e o senhor ficaria obrigado a recebê-la e a liberar-lhe em um dia da semana, "e assim à proporção mais dias, quando for recebendo as outras sextas partes até o valor total" (art. VI) ${ }^{264}$.

Na sequência, Bonifácio indicou diversas outras ações para facilitar a liberação e trazer "melhorias" para cativos e forros, estimulando a manumissão graciosa, ao mesmo tempo procurava minimizar os prejuízos patrimoniais. O senhor que alforriasse gratuitamente, como prêmio por sua "beneficência", poderia manter o forro ao seu serviço por 5 anos, apenas com o ônus ordinário de seu sustento, sem a obrigação de pagar-lhe qualquer jornal. Caberia, ainda, uma indenização pelos forros liberados por estranhos nos termos dos artigos V e VI, cujo contrato firmado seria aprovado por um "juiz curador dos escravos" (art. VII). Não seria permitida a venda em separado de integrantes de um mesmo núcleo familiar (art. IX). Os "homens de cor forros", que não tivessem ofício ou "modo certo de vida", receberiam do estado uma pequena sesmaria para que cultivassem, além de um pequeno financiamento, a ser pago suavemente com o tempo (art. X). A união conjugal ou a formação de prole com mulher escrava acarretaria a liberdade à mãe e aos filhos $(\operatorname{art.} \mathrm{XI})^{265}$.

Ponto fundamental para a consecução do direito à alforria por pagamento: o escravo seria "senhor legal do seu pecúlio", podendo inclusive legá-lo por herança ou doação a quem bem entendesse no caso de não ter herdeiros diretos (art. XII). Todo escravo que demonstrasse

\footnotetext{
${ }^{263}$ Alain El Youssef. Imprensa e escravidão: política e tráfico negreiro no Império de Brasil (Rio de Janeiro, 1822 1850). Dissertação de Mestrado - FFLCH/USP, 2010, pp.79-80.

${ }^{264}$ Andrada e Silva. Representação à Assembléia..., pp.27-28.

${ }^{265} \mathrm{O}$ historiador Eduardo Pena explora, entre outros, o tema específico das sugestões legais para "não 'deixar seu sangue na escravidão", incluindo a de Bonifácio. Cf. Pena. Pajens da Casa Imperial..., pp.179-190.
} 
perante as autoridades ter sido tratado com crueldade, teria o direito de buscar novo senhor, a não ser que estivesse "estropiado" ou mutilado, pois, então, seria imediatamente forro por lei (art. XIV). A escrava que conseguisse dar à luz a cinco filhos sãos ficaria forra (art. XIX). O senhor não poderia impedir o casamento de seus escravos com mulheres livres ou com suas escravas (art. XX). O governo ficaria autorizado a tomar as medidas necessárias para que os senhores de engenho e grandes plantações tivessem pelo menos dois terços de seus escravos casados (art. XXI) e a cuidar para que eles fossem instruídos "na religião e moral" (art. XXII). Nas manumissões feitas pela "Caixa de Piedade", virtuais precursoras do futuro Fundo de Emancipação seriam "preferidos os mulatos aos outros escravos, e os crioulos aos da Costa" (art. XXV), indicando a importância da integração sanguínea e cultural no processo civilizatório vislumbrado pelo patriarca da independência ${ }^{266}$. Todo senhor que dessa alforria a mais de oito famílias de escravos e lhes distribuísse terras e os utensílios necessários, seria contemplado pelo Governo como "benemérito da Pátria" e teria direito a requerer mercês e condecorações públicas (art. XXVII). Para estimular o "amor ao trabalho entre os escravos, e a sua maior felicidade doméstica", que fossem estabelecidas, em todas as províncias, caixas de economia, nas quais os cativos pudessem poupar e fazer render "os produtos pecuniários dos seus trabalhos e indústria"267.

Dessa forma, a alforria, importante válvula de escape para os subalternos e, ao mesmo tempo, historicamente ajustada aos interesses da classe senhorial, já que insuficientemente expansiva a ponto de por em risco a composição das populações escravas, era redefinida neste projeto como o meio fundamental de promoção da abolição gradual ${ }^{268}$. O que estava posto para a viabilização desta nova função era primeiro, a cessação em curto prazo do tráfico negreiro, via essencial para a estabilidade e o crescimento das escravarias - fator que vinha permitindo a realização da manumissão, em suas diferentes modalidades, a níveis seguros; segundo, a criação de mecanismos que conduziriam a um incremento progressivo dos meios para a obtenção da liberdade. Além do enquadramento de liberações obrigatórias e de estímulos à concessão de alforrias por graça e à poupança dos escravos, um instrumento que poderia impulsionar o

\footnotetext{
${ }^{266}$ Miriam Dolhnikoff. “O projeto nacional de José Bonifácio”. Novos Estudos, n.46 (nov.1996), pp.125-126.

${ }^{267}$ Andrada e Silva. Representação à Assembléia..., pp.27-34.

${ }^{268}$ A noção de classe empregada neste estudo parte do emprego heurístico proposto por Edward Palmer Thompson, que indissocia o conceito de classe da noção mais abrangente, perene e praticamente universal de "luta de classes". Isto porque as classes inexistem em separado, como entidades independentes. Antes, elas se estruturam em função do conflito multifacetado entre os que experimentam a exploração e os que buscam manter o poder sobre a massa de explorados. Não se trata de uma mera questão de nomenclatura, mas da sustentação de um modo de observar o processo histórico, considerando-se as transformações e as especificidades de cada época, sem perder de vista as interconexões entre um momento e outro. Cf. Edward Palmer Thompson. "La sociedade inglesa del siglo XVIII: ¿Lucha de clases sin clases?". Tradición, revuelta y consciencia de classe: estúdios sobre la crisis de la sociedade preindustrial. Barcelona: Editorial Crítica, 1989, pp.13-60.
} 
número de manumissões seria a referida Caixa de Piedade, destinada a financiar a liberação de cativos junto a seus senhores. Entre as fontes de recursos para este fundo, constavam penas pecuniárias a serem aplicadas sobre senhores que surrassem seus escravos longe do pelourinho e sem licença do "Juiz policial"269; tributos cobrados sobre sacramentos católicos realizados fora da igreja e sobre a renda de propriedades e instituições religiosas (conventos, mosteiros, irmandades e confrarias); parte dos "legados pios" anteriormente aplicados a hospital e orfanato portugueses; bens vacantes sem herdeiros e sem senhores certos, conforme lei de 4 de dezembro de 1775; pecúlios deixados por escravos sem herdeiros; joia a ser entregue por todos que obtivessem mercês de hábitos de Cristo ou honrarias da Mordomia-mor do Império; $1 \%$ a ser pago sobre o arremate de contratos e rendas nacionais ${ }^{270}$.

É inegável que a aprovação de um projeto como este representaria uma clara afronta ao poder senhorial, haja vista que a tradição jurídica portuguesa assegurou ciosamente, durante séculos, a soberania doméstica dos senhores de escravos, especialmente no que dizia respeito à faculdade de se conceder ou não a liberdade. Mais do que isso, uma vez abolido o tráfico, caso o movimento das liberações se sobrepusesse ao crescimento natural dos plantéis, a instituição escravista principiaria um processo efetivo de declínio. O prazo seria longuíssimo, decerto, tendo-se em vista que, às vésperas da independência, havia algo em torno de 1.107.389 escravos no Brasil $^{271}$, que a condição do ventre escravo permaneceria inalterada, e que artigos do projeto fomentavam a formação de núcleos familiares e o acréscimo reprodutivo nas escravarias. Para cada mãe alforriada pela sua função reprodutora, novos cinco escravos, de plena propriedade, teriam sido legados aos donos. Ademais, certas regulamentações seriam necessárias, principalmente no que tangia os critérios de aplicação dos recursos da Caixa de Piedade, pois a única especificação dada, como mencionado, foi à relativa à preferência a mulatos e crioulos. Não obstante, haveria uma redefinição significativa da arena sobre a qual o antagonismo social em torno do cativeiro passaria a se realizar no Brasil. O teor do projeto, ainda que de forma interessada e derivada das "razões de Estado" defendidas por seu autor, surgia como a possibilidade de reconhecimento, pela via legislativa, de vários dos direitos que gerações de escravos vinham buscando arrancar na dura dinâmica da luta de classes. Isto daria margem para que a ação social das vítimas do cativeiro pudesse acelerar o processo calculado por Bonifácio, extrapolando mais rapidamente os limites das melhorias rumo à abolição. O momento histórico

\footnotetext{
269 Isto, porque, caso contrário, estariam autorizados a fazê-lo (art. XIII). Andrada e Silva. Representação à Assembléia..., p.30.

${ }^{270}$ Idem, pp.34-35.

${ }^{271}$ Maria Luiza Marcílio. “A população do Brasil colonial”, in: Leslie Nethell. História da América Latina: América Latina Colonial, v. II. São Paulo, Edusp, 1999, p.338.
} 
no qual esta proposta surgia era crucial, visto que estava sendo criado o pacto político que daria sustentação ao Império do Brasil ${ }^{272}$. De maneira inédita por essas bandas, as malhas do tempo abriam espaço para que houvesse uma rearticulação entre a base material e o desenho institucional do governo. Bonifácio bem o sabia, por isso preparou o documento. Privilegiados pelo devir histórico, sabemos bem o que efetivamente ocorreu. Mas, antes de tratar do destino da Representação e do sistema de escravidão mais concretamente, cumpre voltarmos nosso olhar mais para o locus das discussões, a Assembleia Constituinte reunida no Rio de Janeiro, desde maio de $1823^{273}$.

Em um ensaio bastante instrutivo, o historiador Jaime Rodrigues relativizou o consenso em torno da suposta ausência de discussões sobre a escravidão na Constituinte. Embora periférico em relação aos pontos centrais envolvendo a organização político-administrativa do país, o tema não foi tão alheio aos debates quanto se costuma dizer. $\mathrm{O}$ autor encontrou requerimentos de escravos endereçados à Assembleia. Como objeto específico, realçou o episódio envolvendo um grupo envolvido em uma complicada batalha judicial por sua liberdade. Seguindo essa trilha, é possível acompanhar o caso, com referência direta aos Anais da Constituinte ${ }^{274}$. Os litigantes, vencidos por sua senhora (Agueda Caetana) na Casa da Suplicação - tribunal superior que havia sido transplantado para o Rio de Janeiro com a vinda da Família Real, em 1808 - entraram com pedido de revista ${ }^{275}$. Porém, estavam impossibilitados de acompanhar as tramitações. Além de faltar-lhes recursos financeiros, sucediam que sua senhora colocara alguns deles à venda para o campo para desarticular suas possibilidades de defesa. Diante disso, aproveitando a oportunidade posta pelos acontecimentos, porventura inspirados por uma analogia possível entre independência e liberdade ${ }^{276}$, solicitaram à Constituinte ordem para que pudessem "tratar livremente das suas vidas, até que se decida

\footnotetext{
${ }^{272}$ Sobre aspectos gerais do constitucionalismo e sua evolução histórica, ver, de Maurizio Fioravanti, Los derechos fundamentales: apuntes de la Historia de las constituciones. Madri: Trotta, 1998; Constitución: de la Antigüedad a nuestros días. Madri: Trotta, 2001.

${ }^{273}$ A abordagem dos debates ocorridos na Assembleia Constituinte sobre escravidão e cidadania acompanha de perto o exame realizado em: Berbel, Marquese \& Parron. Escravidão e Política..., pp.95-180.Ver, também: Andréa Slemian. Sob o império das Leis: constituição e unidade nacional na formação do Brasil (1822-1834). São Paulo: Hucitec/Fapesp, 2009, pp.45-143.

274 Jaime Rodrigues. "Liberdade, humanidade e propriedade: os escravos e a Assembleia Constituinte de 1823". Revista do Instituto de Estudos Brasileiros, n.39 (1995) pp.159-167.

275 O pedido de revista era um último recurso encaminhado para que houvesse reconsideração de sentença proferida. Caso a revista fosse concedida, havendo a constatação de alguma nulidade ou injustiça, o processo era remetido para outro Tribunal da Relação para novo julgamento. Entre 1808 e 1828, esta prerrogativa foi da Casa da Suplicação, instalada no Brasil com a transferência da Corte. De 1828 em diante, coube ao Supremo Tribunal de Justiça a análise de tais recursos. Cf. Keila Grinberg. Liberata, a lei da ambigüidade. As ações de liberdade da corte de Apelação do Rio de Janeiro no século XIX. Rio de Janeiro: Relume-Dumará (versão digital), 1994, p.11. 276 Rodrigues. "Liberdade, humanidade e propriedade...”, p.161.
} 
legalmente a questão da sua liberdade" ${ }^{277}$. A comissão de legislação analisou a solicitação e emitiu parecer em 17 de junho de 1823, afirmando que não pertencia à Assembleia o deferimento de tal demanda. Na sessão do dia 19 do mesmo mês, diversos deputados se posicionaram sobre o caso. Joaquim Manuel Carneiro da Cunha (Paraíba do Norte), disse que "sendo a liberdade do homem um objeto de tanta ponderação", era dever do estado prestar a proteção devida àqueles "infelizes”. Não the parecia razoável que a Assembleia não levasse em consideração "a sorte de tais miseráveis". O "negócio" devia, ao menos, ser remetido ao governo, com a recomendação de que o auxílio pretendido fosse concedido. Antônio Ferreira França (Bahia) acusou a existência de antiga normativa portuguesa, cuja referência exata no instante não recordava, mas que sabia atribuir ao procurador da Coroa e fazenda, e a um solicitador, a promoção de causas de liberdade de escravos. Como não interessava "senão a esses miseráveis", a lei havia caído em esquecimento. Cabia, portanto, reavivar a observância da norma, afinal, "para fazer leis novas, e zelar a observância das leis velhas é que nós aqui nos ajuntamos". França prosseguia com suas ponderações, dizendo não importar que o "suposto escravo" de um injusto senhor tivesse notório direito a ser declarado livre, se não tivesse como para dar continuidade ao processo; e que ele próprio era testemunha de muitos casos em que a opressão sobre o escravo, seu desamparo, era o único título de seu cativeiro:

\footnotetext{
"Ainda ontem me apareceu um destes miseráveis com um testamento em que lhe fora legada a liberdade; e não obstante o qual fora preso como escravo fugido pela barbaridade do testamenteiro que a força o detinha no cativeiro. Tal imoralidade dos nossos conterrâneos deve acabar pondo-se estes infelizes debaixo da proteção que lhe dá uma lei existente, cuja observância deve reviver"278.
}

Inácio Accioli de Vasconcelos (Alagoas) replicou afirmando não constar-lhe a existência da lei citada por seu colega, e que a defesa das pessoas "miseráveis", conforme a legislação em vigor, se dava pela nomeação de um curador, escolhido entre advogados de probidade. Se o juiz não optou por este procedimento, então deixou de cumprir com a sua obrigação. Bastava, a seu ver, que fosse posta em prática a regra corrente. Ainda mais porque lhe custava acreditar que estivesse sendo pedida uma quantia exorbitante para uma petição de revista, principalmente em se tratando de pessoas tão "desgraçadas". França voltou à carga, dizendo ser líquido e inquestionável o direito do escravo de apresentar requerimento à justiça. A questão era atribuir um caráter público e subvencionado à causa de liberdade, como havia feito o legislador ao indicar o procurador da Coroa para a representação dos cativos em tais

\footnotetext{
277 Annaes do Parlamento Brazileiro: Assembleia Constituinte, Tomo II. Rio de Janeiro: Tipografia do Imperial Instituto artístico, 1874, p.82

278 Idem, ibidem.
} 
demandas. Em seu entendimento, tal lei era justa; "e se digna de um governo despótico, muito mais de um sistema verdadeiramente constitucional”. Lúcio Soares Teixeira de Gouveia (Minas Gerais), por sua vez, sublinhou a seriedade de um objeto "qual a liberdade de um homem", o que impunha a sua consideração pela Assembleia. O parecer da comissão de legislação podia estar conforme as regras estritas de direito, "mas eu não sei se o rigor de direito neste caso se compadece com a justiça universal”. Todavia, segundo seu entendimento, seria possível buscar ali um remédio para a situação, sem infringir a lei, nem usurpar as atribuições de outros poderes. Na representação encaminhada, os libertandos acusaram três sentenças a seu favor, o que lhe fazia crer na existência de alguma "justiça" em sua demanda "e que talvez a sentença que revogou as três fosse por contemplações". A solução mais acertada, a seu ver, seria trazer os autos para exame da comissão. Caso fosse verificada injustiça manifesta, que se mandasse rever o processo na Casa da Suplicação, José Ricardo da Costa Aguiar (São Paulo), sobrinho de José Bonifácio, também interveio dizendo que o problema todo vinha mesmo da falta de gratuidade na administração da justiça aos mais precisados. Com efeito, o melhor seria "que com urgência se faça uma lei, que regule tais negócios, e que ponha ao abrigo da justiça os desvalidos e miseráveis". Mas, como tal providência levaria tempo, servindo apenas a futuras demandas, sugeria, a exemplo de Carneiro da Cunha, que o problema fosse encaminhado ao governo ${ }^{279}$.

Ao final, França retomou a palavra, recomendando que a discussão fosse adiada até que ele apresentasse a lei que havia mencionado e assim se decidiu. Poucos dias depois, na sessão do dia 23 de junho, o tema voltou à baila. O representante da Bahia havia encontrado a lei que mencionara. Tratava-se da Carta régia de 5 de novembro de 1710, "a qual estabelecendo ordenados ao procurador da Coroa e fazenda, e ao solicitador da mesma que mandava criar, lhes incumbe a obrigação de defenderem e solicitarem não só as causas da Coroa e fazenda, mas também as dos escravos sobre seus cativeiros" ${ }^{280}$. Este aspecto, segundo França, deixava claro que as causas e a condição daqueles "miseráveis" se achavam debaixo da proteção do governo. Assim sendo, suas demandas deveriam "ser tratadas como causa pública por oficiais públicos a isso destinados". E retomou o argumento de que se os tais "infelizes" mereceram atenção de um governo despótico como o do Império português, um sistema de governo liberal, como o nascente, de modo algum poderia deixar de fazê-lo. Votava, portanto, pela recuperação da dita Carta régia para que o procurador da Coroa se pusesse a cargo dos pleitos envolvendo a liberdade de escravos. Quanto ao caso específico de Inácio Rodrigues e seus companheiros de

\footnotetext{
${ }^{279}$ Annaes do Parlamento Brazileiro: Assembleia Constituinte, Tomo II, pp.82-83.

${ }^{280}$ Para uma cópia da "Carta Régia de 5 de novembro de 1710”, ver: Silvia Hunold Lara. "Legislação sobre escravos africanos na América Portuguesa”. Madrid: Tavera/Digibis, 2000, p.237 (CD-Rom).
} 
luta, que fosse enviado ofício ao governo solicitando o despacho de ordem para a manutenção de sua liberdade até que o pleito de revista pendente fosse concluído, "pois toda a dificuldade que no caso há, e pela qual os recorrem a esta Assembleia é a obrigação que lhes resulta de serem entregues e repostos no domínio de seu suposto senhor por virtude da sentença" ${ }^{281}$. Em contraposição, Teixeira de Gouveia assumiu a palavra afirmando que o meio recomendado pelo ilustre colega, além de não sanar o mal, era oposto à lei. Não sanava o mal porque não oferecia os recursos pecuniários necessários para a continuidade do recurso. Era oposto à lei, na medida em que prescrevia a manutenção dos litigantes em liberdade, isto porque a tramitação do pedido de revista em nada impedia a execução da sentença em revisão, devendo, por isso, "o senhor entrar na posse dos seus escravos". O contrário representaria uma "verdadeira violação de uma das garantias concedidas aos cidadãos, qual a inviolabilidade do direito de propriedade. E seremos nós, Senhor Presidente, os primeiros a dar terrível exemplo! De certo, que não”. Seguindo de perto o receituário liberal, o constituinte mineiro, futuro ministro da justiça, abandonou o estilo sucinto de sua primeira intervenção e atacou o casuísmo presente na solução indicada de seu interlocutor baiano, a qual, para contemplar uma causa particular, agredia um direito individual fundamental,

\footnotetext{
"e se nos fosse lícito violar estas garantias [as dos direitos individuais] sem a evidente necessidade de salvar a pátria, em breve desapareceria a segurança pública e individual; e o despotismo que nas monarquias absolutas é exercido por um passaria a ser exercido por muitos, e por consequência ficaria perdida a liberdade dos povos" 282 .
}

Por isso, votou contra a opinião do colega, dizendo que a compaixão não podia acarretar injustiça.

Ensaiando um argumento apaziguador, Costa Aguiar foi o último a tocar no assunto. Mantendo sua ponderação original sobre a urgência de "causa tão sagrada" e a pertinência de se remeter o negócio ao governo "a fim de dar as providências que julgasse adequadas para proteger e socorrer estes miseráveis", o constituinte paulista, sem negar a validade dos

\footnotetext{
${ }^{281}$ Idem, p. 110.

282 Lara. "Legislação sobre escravos africanos na América Portuguesa", p.111. Bosi efetuou uma análise semântico-histórica sobre os significados do termo liberal no período de formação do Estado-nacional brasileiro. Seriam quatro significados básicos. Primeiro, como conservador das liberdades de produzir, vender e comprar, conquistadas em 1808; segundo, como conservador da liberdade de representar-se politicamente, conquistada em 1822; terceiro, como conservador da liberdade de submeter o trabalhador escravo mediante coação física, "recebida como instituto colonial e relançada pela expansão agrícola"; quarta, como a capacidade de adquiri novas terras em regime de livre concorrência, no espírito da Lei de Terras de 1850. A argumentação desenvolvida por Teixeira de Gouveia se aproxima do primeiro significado, muito embora apresente uma sofisticação maior em relação ao insinuado pelo autor. Alfredo Bosi. "A escravidão entre dois liberalismos". Estudos Avançados, v.2, n.3 (set./dez., 1988), p.8.
} 
princípios gerais expostos por Teixeira de Gouveia, buscou subscrever o espírito das observações de França, assinalando que a existência de norma pregressa era mais uma razão para a consideração do problema.

Então, a matéria foi dada como discutida e encaminhada novamente para a comissão de legislação, por arbítrio do presidente, que era ninguém menos do que José Bonifácio de Andrada e Silva, o qual aproveitou para declarar que "sobre aquele importante objeto, apresentaria ao congresso uma memória em que trabalhava, e como a matéria pedia"283.

O novo parecer viria na sessão do dia 28 de junho. A comissão, que mantivera quatro dos cinco membros que elaboraram o ditame original, alterou bastante o seu posicionamento. Se antes se afirmara a isenção da assembleia perante assuntos como este, desta vez o direito dos escravos de darem continuidade ao processo de revista foi acudido. "Procurando conciliar o favor da liberdade, a causa da humanidade, com os direitos de propriedade", apresentaram-se três formas possíveis para que Ignacio Rodrigues e os outros aguardassem o desfecho do processo: "ou debaixo de fiança, se a tiverem, ou em depósito, ou em poder da pretendida Senhora, obrigando-se esta por termo a não os seviciar, a não dispor deles, e a conceder-lhes os dias de estilo para tratarem da sua causa"284. Das três, certamente a última possibilidade era a indesejável pela ótica dos escravos, ainda que no papel a sevícia e a venda fossem interditadas. Estranhamente, na sequência do parecer, recomendou-se que a defesa e a promoção dos termos da revista ficassem a cargo da Santa Casa de Misericórdia. Assim, nem se reforçava a prática judiciária usual da nomeação de curador, indicada por Accioli de Vasconcelos, nem se aderia à fórmula da carta régia setecentista desengavetada por França.

De todo modo, o parecer foi aprovado e, a matéria, dada como discutida. A resposta do imperador viria a lume na sessão do dia de 14 de julho. D. Pedro I determinou a transmissão de ordem ao chanceler da Casa da Suplicação para que os suplicantes fossem postos em poder da suplicada até o final da sentença, "assinando ela termo de não dispor deles, de os não seviciar e de conceder-lhes os dias do estilo para tratarem da sua causa, cujo prosseguimento fez também recomendar ao zelo e caridade da mesa da Santa Casa da Misericórdia”. Como observou apropriadamente Rodrigues, preponderaram as razões em torno da manutenção da propriedade $^{285}$. Vale dizer, todavia, que é difícil estabelecer um contraponto incisivo entre a decisão final do chefe do governo e os rumos tomados pela deliberação dos constituintes até aquele ponto do debate. Naquele momento, o que se procurou assentar ou, antes, redefinir, a

\footnotetext{
${ }^{283}$ Annaes do Parlamento Brazileiro: Assembleia Constituinte, Tomo II, p.111.

${ }^{284}$ Idem, p.148.

${ }^{285}$ Rodrigues. “Liberdade, humanidade e propriedade...”, pp.165-166.
} 
partir da representação encaminhada, foram as garantias para que os escravos pudessem ajuizar e acompanhar ações judiciais em prol de liberações particulares. Nada subversivo dentro da ordem legal-escravista vigente. $\mathrm{O}$ passo adiante seria uma reformulação efetiva da velha tradição legislativa: fronteira de dificílima transposição em virtude dos interesses envolvidos. A arena judicial apresentava maiores gradações, dando vida ao direito dos livros. Cumpre colocá-la em evidência.

O processo envolvendo Ignacio e Agueda, que foi objeto da discussão no plenário da Constituinte, não foi localizado no decorrer da pesquisa. Porém, há outra ação, da mesma época, que pode ser bastante elucidativa sobre como as coisas funcionavam. Em 7 de novembro de 1815, a menor ${ }^{286}$ Joaquina Maria Parda, residente no distrito de Santo Antonio de Sá, em Macacu, antiga região produtora de açúcar ${ }^{287}$, apresentando-se na Corte ao corregedor da Casa da Suplicação do Brasil, ajuizou um libelo cível para provar ter sido liberta no ato de seu batismo por sua antiga senhora, Francisca Thereza da Madre de Deus, viúva de Antônio Novais de Oliveira. A alforria teria sido compensada com dois anos e meio de serviços prestados por seu pai, Ignacio Francisco Coelho, passando, desde então, a ser tratada como forra por sua antiga senhora e por todos da casa. Contudo, após a morte de Francisca, sua filha, Teresa Maria de Jesus, sabedora de todos os fatos, ignorou-os, mantendo Joaquina indevidamente em cativeiro. Eis o motor do litígio ${ }^{288}$.

Nesta ação, não se verificou a nomeação de curador, muito embora o constituinte Accioli de Vasconcelos tenha acusado ser prática comum já naquela época. A defesa foi conduzida por procuradores, advogados constituídos por procuração, que se sucederam no decorrer do processo. Para não ser "consumido" antes de demonstrar sua condição, Joaquina Maria, por intermédio de seu primeiro procurador, Francisco Luis de Maris Sarmento, requereu e obteve ordem para ser depositada em poder do "depositário geral", que nada mais era do que um depositário particular chamado Manuel José Fernandez. Ao longo do processo, ela foi traslada para o poder de um novo depositário, chamado José Antônio de Azevedo.

Não dispondo da carta de alforria, a comprovação sobre o ato da manumissão e o tratamento recebido posteriormente à alegada alforria foi sustentado com base em prova testemunhal. Após a oitiva das testemunhas, em 17 de abril de 1817, o juiz Claudio José Pereira

\footnotetext{
${ }^{286}$ Naquele tempo, a maioridade civil só se atingia aos 25 anos de idade. Sobre as implicações jurídicas, ver Pascoal José de Mello Freire. Instituições de Direito Civil português: tanto público como particular. Livro I, Título I. (1 $1^{\mathrm{a}}$ edição, 1789 - tradução de Miguel Pinto de Meneses). Lisboa: Procuradoria Geral da República, 1967, p.144. ${ }^{287}$ Márcia Amantino \& Vinicius Maia Cardoso. "Múltiplas Alternativas: diversidade econômica da Vila de Santo Antonio de Sá de Macacu - Século XVIII". Revista de História Econômica \& Economia Regional Aplicada, v. 3, n. 5 (Jul-Dez 2008), pp.78-106.

288 Arquivo Nacional (RJ). Apelação Cível, Casa da Suplicação, EJ.0.ACI.3 (1815-1822).
} 
da Costa proferiu sentença desfavorável, afirmando que a autora não havia apresentado prova plena e que os fundamentos da ação não eram concludentes. Joaquina Maria foi, então, mantida escrava e condenada nas custas. Pesou bastante o fato de sua madrinha, Joaquina Lozarda dos Prazeres, branca, viúva, moradora da mesma localidade, em Macacu, não ter corroborado a versão da alforria na pia batismal. Ao contrário, disse ter notícia de que ela andava pedindo esmolas pela Corte a fim de juntar dinheiro para se libertar.

O procurador de Joaquina Maria recorreu da decisão. Nos embargos apresentados, realçou os testemunhos que corroboravam a versão da embargante, procurando, ao mesmo tempo, desqualificar o depoimento da madrinha, uma criança, à época do batismo. O litígio correria ainda por mais alguns anos, com várias interposições de parte a parte. Nesse meiotempo, aconteceu, inclusive, da autora ser "furtada" pelo pai de seus filhos, cuja liberdade também passou a ser questionada. Claro, a vida não foi paralisada enquanto o processo se arrastava indefinidamente no tribunal. Na folha 359, o advogado da senhora embargada afirmou o seguinte:

"Três são os princípios pelos quais unicamente se poderia mostrar a $\mathrm{A}$. liberta, $1^{\circ}$ que nascera de ventre livre, $2^{\circ}$ que comprara a sua liberdade, $3^{\circ}$ que a senhora lhe dera gratuita. Nada disto serve nestes autos mais do que um labirinto de confusões e enredos, misturados com astúcias que nele se somou um Francisco Pinto Meireles, que furtou a A. como se vê da certidão f.143, por ter da mesma três filhos e pretendia libertar a todos pelo modo que estes autos recontam [...]"289.

Ainda assim, em 8 de maio de 1820, o desembargador José Freire Gomes emitiu sentença favorável aos embargos apresentados. Com base no princípio embutido na lei indigenista de 6 de junho de 1755 e nas Leis Romanas (sem citar nenhuma especificamente), sustentou que "a prova incumbe aos que defendem contra a liberdade", sendo a priori mais críveis os juramentos a favor deste preceito. E considera não constar dos autos documento algum que ateste ser a embargante uma escrava. Entretanto, a continuidade da sentença apresentava um teor profundamente perverso. Como também não havia provas, segundo o entendimento do julgador, de que os serviços acordados haviam sido mesmo prestados pelo pai da libertanda, ela ficaria obrigada a prestar serviços à Teresa, até que esta morresse.

Miguel Borges de Castro Azevedo e Mello, advogado que representou Joaquina Maria na segunda instância, apresentou último recurso, argumentando contra o caráter compulsório dos serviços atribuído pelo magistrado; afirmou que o mesmo juiz considerou plenas as provas

\footnotetext{
${ }^{289}$ Arquivo Nacional (RJ). Apelação Cível, Casa da Suplicação, EJ.0.ACI.3 (1815-1822), f.452.
} 
consignadas e que isto deveria bastar para a efetivação da liberdade irrestrita; que novos testemunhos, incluindo da madrinha e de seu pai, o padrinho, atestavam a versão da apelante:

\begin{abstract}
"e é costume do Brasil, principalmente nas terras do interior, em que comumente os homens brancos, que tem alguma condecoração, não consentem que suas filhas sejam madrinhas de escravos, reputando grande injúria o serem os seus afilhados cativos; ora se o cabo de esquadra fez disso tanto caso, como se lê a f. 90, que não queria ser padrinho se a apelante fosse batizada por escrava" 290 .
\end{abstract}

Um dado interessante que aparece mais claramente na explanação é a correlação entre a dinâmica da alforria e o estabelecimento de laços de compadrio, típico do mundo da escravidão no Brasil desde os tempos coloniais. A "criação de aliados" entre pessoas que estavam do lado de fora do cativeiro integrava o leque de estratégias para o estreitamento do caminho rumo à liberdade. Nesse caso, o prestígio social do padrinho é inserido como evidência do fato declarado 291 .

$\mathrm{Na}$ sequência de suas razões, o defensor ressaltou que o componente condicional da alforria havia sido plenamente satisfeito, conforme atestavam as provas testemunhais, não cabendo qualquer tipo de compensação adicional. Explorando a lógica jurídica, observou que

\begin{abstract}
"ainda quando não aparecesse tão exuberante prova bastaria lembrarmos que os serviços devidos ao patrono não são os de continuar a servir todo o tempo da vida, pois que deste modo viria a ser a liberdade nominal, e que somente se limitam aos socorros em necessidades e ao respeito e reverência como é sabido em direito, bem supérfluo de se apontar a tão eminentes senadores. Se contudo a liberta absolutamente libertada deva em serviços perpétuos ao patrono gracioso, nem por isso os ficaria devendo aos seus herdeiros, pois que se os ficasse devendo aos herdeiros, seguir-se-ia que os devia a todos e a cada um. Porém, isto é um absurdo [...]"292.
\end{abstract}

Quanto mais porque, segundo anotava, os preceitos legais conhecidos de modo algum fundamentavam a decisão do desembargador. Retrocedendo ao Corpus Iuris Civilis, indicava que o livro 25 , tit. III, $\S 20^{\circ}$ do Digesto, embora tenha atribuído aos libertos o dever de prover alimentos aos filhos dos patronos, isto apenas ocorreria em caso de risco de morte por desnutrição e quando os franqueados fossem financeiramente remediados ${ }^{293}$. Do livro 3, tít.

\footnotetext{
${ }^{290}$ Arquivo Nacional (RJ). Apelação Cível, Casa da Suplicação, EJ.0.ACI.3 (1815-1822), f.384.

291 João Fragoso. "O capitão João Pereira Lemos e a parda Maria Sampaio: notas sobre hierarquias rurais costumeiras no Rio de Janeiro do século XVIII", in: Carla Maria Carvalho de Almeida \& Mônica Ribeiro de Oliveira (orgs.). Exercícios de micro-história. Rio de Janeiro: Editora FGV, 2009, pp.157-207.

${ }^{292}$ Arquivo Nacional (RJ). Apelação Cível, Casa da Suplicação, EJ.0.ACI.3 (1815-1822), f.385.

293 Contudo, o que texto romano (D.25.3.5.20) diz é o seguinte: "mas é possível discutir se devem alimentar somente os patronos ou também os filhos dos patronos. E eu opino que, com conhecimento de causa, hão de decretar os juízes que também sejam alimentados os filhos dos patronos, não certamente com tanta facilidade como os patronos, mas às vezes também como eles; porque também devem ter atenção não apenas com os patronos, como também com os seus filhos" (tradução livre). Havia margem para interpretação diversa, portanto. Cf. Idelfonso García. Cuerpo del Derecho Civil Romano. Barcelona: James Molinas, 1892, pp.217-218. Sobre o teor
} 
LXIII, $\S 9^{\circ}$ das Ordenações Filipinas, extraía que tampouco a ingratidão podia acarretar ação dos herdeiros contra o liberto, a não ser que o doador houvesse manifestado ter sido agravado em vida, o que não era o caso ${ }^{294}$. Em síntese, não havia, segundo busca atestar, transmissão automática aos descendentes de obrigações devidas pelo liberto ao doador. Cabe um aparte aqui. O defensor não diz, mas nós sabemos que foi muito comum em alforrias condicionais a estipulação da prestação de serviços a parentes ${ }^{295}$. Porém, normalmente, alguma das partes alegava o fato ou requeria-se prova de que a condição havia sido prescrita. Esta sentença, portanto, destoava do usual, já que o julgador chegou à sobredita solução prescindo da manifestação da vontade do patrono, apegando-se apenas à inconsistência presumida do relato sobre a contrapartida realizada.

Ao final, o advogado, como de costume, declarava restar demonstrado que a liberdade da apelante havia sido adquirida por meio dos serviços de seu pai, não tendo sido a alforria "pura e simplesmente" concedida. E, mesmo que não fosse assim, nem por isso ficaria a apelante obrigada a prestar serviços à apelada. Mas de nada adiantou. A sentença foi mantida. Joaquina Maria foi reconhecida como liberta, porém, continuaria, na prática, cativa de Teresa Maria de Jesus.

Para alívio de Joaquina e de sua família, no entanto, a filha da antiga senhora teria vida curta. Corvos já espreitavam sua morada. Não é possível saber a causa da morte, mas o fato é que, dois anos depois da sentença que havia atribuído precariamente a liberdade a Joaquina e seus filhos, Teresa morreu, com a idade de quarenta e nove anos de idade, conforme atesta certidão anexada ao processo. O procurador, então, entrou com requerimento para que sua representada recebesse o título que lhe permitiria "gozar livremente da mesma liberdade", assim

\footnotetext{
dessa normativa, ver: Albertina Guerra de la Espriella. "La obligación alimentaria fijación y reajuste de su cuota: problemática actual y deficiencias legislativas". Cuadernos de derecho público, n.2 (oct. 2010), p.33.

${ }^{294}$ Neste caso, há maior congruência. Leia-se o texto do parágrafo: "E se o doador, de que acima falamos, e o patrono, que por sua vontade livrou o escravo da servidão em que era posto, não revogou em sua vida a doação feita ao donatário ou a liberdade que deu ao liberto, por razão da ingratidão contra ele cometida, ou não moveu em sua vida demanda em Juízo para revogar a doação ou liberdade, não poderão, depois de sua morte, seus herdeiros fazer tal revogação. E bem assim não poderá o doador revogar a doação ao herdeiro do donatário por causa da ingratidão pelo donatário cometida, pois a não revogou em vida do donatário, que a cometeu. Porque esta faculdade de poder revogar os benefícios por causa da ingratidão, somente é outorgada àqueles que os benefícios deram, contra os que deles os receberam, sem passar aos herdeiros, nem contra os herdeiros de uma parte, nem da outra", in: Lara. "Legislação sobre escravos africanos na América Portuguesa", p.104.

${ }^{295}$ Kátia de Queirós Mattoso. Ser escravo no Brasil. São Paulo: Brasiliense, 1982, pp.207-2013; Marcio de Sousa Soares. A remissão do cativeiro. A dádiva da alforria e o governo dos escravos nos Campos dos Goitacases, c.1750-c.1830. Rio de Janeiro: Apicuri, p.143; Sheila de Castro e Faria. "A riqueza dos libertos: os alforriados no Brasil escravista", in: Marco Antonio Silveira \& Cláudia Maria das Graças Chaves. Território, conflito e identidade. Belo Horizonte: Argumentvm, 2007, p. 11-24; Peter Eisenberg. Homens esquecidos: escravos e trabalhadores livres no Brasil - séculos XVIII e XIX. Campinas: Editora da Unicamp, 1989, pp.256-267.
} 
como a seus filhos. Com efeito, em 20 de julho de 1822, a Casa da Suplicação ordenou a liberação definitiva e integral da suplicante.

Assim, após sete anos, Joaquina Maria saiu-se vencedora de uma difícil batalha transferida para o espaço público com sua admirável iniciativa de escapar da casa senhorial na vila de Santo Antonio de Sá e se deslocar até a Corte para fazer valer o seu direito. Com uma dose de sorte, tendo-se se em vista o relativamente célere infortúnio de seu algoz, a aposta acabou dando certo, o que não teria acontecido se ela tivesse se resignado ao processo social de coisificação. A sua subjetividade humana, por circunstanciais excepcionais, considerando-se o destino da grande massa da população cativa, pôde aflorar de maneira plena por meio de um trajeto que culminou na restituição de sua condição natural, a liberdade ${ }^{296}$.

Alguns traços do raio de possibilidades daqueles que conseguiam acessar a arena judicial podem ser sublinhados a partir do ocorrido com Joaquina. Diferentemente do ocorrido com Ignacio Rodrigues e seus consortes, atrelados em um processo judicial com diversos autores, menos comum naquela época, Joaquina não teve problemas aparentes com o encaminhamento processual em função das custas, nem com a defensa. Se os teve, conseguiu superá-los por conta própria e/ou com a ajuda de amigos ou parentes. As circunstâncias quanto a este aspecto eram variáveis, portanto. A representação de seus interesses se deu em moldes comuns ao século anterior, com a instituição de procuradores. É possível que outros processos, naquela mesma época, já se conduzissem com recurso à curadoria, tendo-se em mente a fala de Accioli na constituinte. O caso destacado encontra-se em momento de redefinição dos procedimentos de designação para a defensa dos escravos ${ }^{297}$. A natureza do processo também merece destaque. Como se sabe, uma ação perfaz um remédio jurídico segundo o qual, mediante o cumprimento dos ritos formais, o juiz ou órgão judicial é convencido a obrigar outra pessoa a dar ou fazer algo de que tenha obrigação perfeita. Nas ações ordinárias, como era a de Joaquina, as intenções eram propostas por meio de um libelo, um documento no qual eram expostos os fatos fundamentadores do que se pretendia. Daí, então, constituídos os procuradores, seguiam-se arrazoados de parte a parte, petições, requerimentos, despachos, certificações, arrolamento e oitivas de testemunhas, prolatação de sentença, interposição de apelações, até a decisão colegiada final. As causas pertinentes ao término dos laços de escravidão correspondiam às chamadas ações prejudiciais, que diziam respeito ao estado das

\footnotetext{
296 Arquivo Nacional (RJ). Apelação Cível, Casa da Suplicação, EJ.0.ACI.3 (1815-1822), ff.478-487.

${ }^{297}$ Fernanda Aparecida Domingos Pinheiro. "Transformações de uma prática contenciosa: as 'Ações de Liberdade' produzidas em Mariana - 1750/69 e 1850/69”. Locus: revista de história, v.17, n.1 (Juiz de Fora, 2011), pp. 253 271.
} 
pessoas, o qual se entendia tripartido entre cidadania, família e liberdade ${ }^{298}$. O seu fundamento não era um direito sobre ou em relação a uma coisa, mas a afirmação ou a negação do estado ou qualidade da pessoa. Com efeito, no tocante à liberdade, a causa seria promovida: ou por alguém tratado indevidamente como cativo (ação de liberdade) ou por um senhor interessado em recompor o domínio sobre seu escravo (ação de escravidão). Não se tratava de agenciar a manumissão ou a escravização de indivíduos, mas, antes, de reconhecer o estado legitimamente constituído e de algum modo denegado. Em suma, o direito à liberdade tinha que já ter sido conquistado no âmbito intestino das relações de escravidão para ser reconhecido pelo judiciário.

Com efeito, aos negros que buscavam o judiciário para cuidar da sua liberdade se lhes impunha demonstrar que eram livres por nascimento, que haviam sido alforriados ou que o pacto realizado em prol de sua liberação havia sido desrespeitado. A argumentação impressa na fundamentação das razões de dona Teresa Maria, reproduzidas acima, acena claramente nesse sentido. O advogado de dona Teresa sintetizou: "os princípios pelos quais unicamente se poderia mostrar a A. liberta, $1^{\circ}$ que nascera de ventre livre, $2^{\circ}$ que comprara a sua liberdade, $3^{\circ}$ que a senhora lhe dera gratuita" ${ }^{299}$. O que estava em jogo, vale a pena insistir, não era o direito de obter a liberdade, mas o de tê-la validada ${ }^{300}$.

O processo constitucional parecia caminhar para uma inflexão neste cenário. No Projeto de Constituição, apresentado à Assembleia no dia primeiro de setembro de 1823, havia tópicos sensivelmente antiescravistas. Na comissão responsável pela elaboração do texto do que se supunha ser a futura Carta Magna do Império estava José Bonifácio, seu irmão, Antonio Carlos Ribeiro de Andrada Machado e Silva, Antonio Luiz Pereira da Cunha, Francisco Moniz Tavares, Manoel Ferreira da Câmara de Betencourt e Sá, Pedro de Araújo Lima e José Ricardo da Costa Aguiar de Andrada, que havia tomado parte das discussões sobre o caso de Ignacio Rodrigues $^{301}$. Muito embora os tópicos concebidos por Bonifácio não tenham sido implantados in totum no Projeto, é possível identificar pelo menos dois artigos que convergiam para o desmanche gradual do regime de escravidão, previsto na Representação. O de número 254, inserido no título XIII, Da Instrução Pública, Estabelecimentos de Caridade, Casas de Correção, e Trabalho, definia a criação de "Estabelecimentos para a catequese, e civilização dos Índios, emancipação lenta dos negros, e sua educação religiosa, e industrial”. Assim, índios

\footnotetext{
298 José Homem Correia Telles. Doutrina das ações acomodada ao foro de Portugal. Lisboa: Impressão Régia, 1824, pp.11-13; Freire. Instituições de Direito Civil português..., p.111.

${ }^{299}$ Arquivo Nacional (RJ). Apelação Cível, Casa da Suplicação, EJ.0.ACI.3 (1815-1822), f.452.

${ }^{300}$ Malheiro. A Escravidão no Brasil, v.I., p.86.

${ }^{301}$ Eduardo Martins. A Assembleia Constituinte de 1823 e sua posição em relação à construção da cidadania no Brasil. Tese de Doutorado apresentada à Faculdade de Ciências e Letras de Assis, 2008, p.85.
} 
e negros seriam preparados para a sua integração cívica e ao que chamaríamos de população economicamente ativa, mediante um processo difuso e vagaroso, mas, de antemão, institucionalizado, de injunção cultural e de eliminação dos laços servis. Já o de número 265, disposto no título XIV, Disposições gerais, conforme o qual "a Constituição reconhece os contratos entre os Senhores e os Escravos; e o Governo vigiará sobre a sua manutenção", transgredia a tradição legal sobre as relações domésticas ${ }^{302}$. Ainda que no âmbito do costume fossem corriqueiros os ajustes com a pressuposição de obrigações mútuas entre livres e cativos, a capacidade contratual dos escravos, em termos formais, sempre foi derivativa da vontade senhorial $^{303}$. O alvará de 16 de janeiro de 1773, que estabeleceu a abolição gradual em Portugal, externava que a condição dos escravos os tornava "incapazes para os ofícios públicos, para o comércio, para a agricultura e para os tratos e contratos de todas as espécies" ${ }^{304}$. O Projeto, portanto, reconfigurava o enquadramento legal dos pactos celebrados entre escravos e senhores, o que incidia, especialmente, nos acertos em torno da consecução da liberdade.

Desencadeada a tal "emancipação lenta", seria fundamental ajustar a integração de negros livres e libertos ao corpo da sociedade imperial, o que havia sido tratado logo no artigo $5^{\circ}$ do Projeto. O parágrafo primeiro havia englobado os descendentes de africanos ao definir como brasileiros "todos os homens livres habitantes no Brasil, e nele nascidos". Já o parágrafo sexto incluiu os escravos que tivessem obtido carta de alforria. Os termos do artigo foram intensamente debatidos entre os dias 23 e 30 de setembro. Manuel José de Sousa França (Rio de Janeiro), observando a heterogeneidade da população brasileira, ponderou sobre a distinção a ser feita entre brasileiros e cidadãos brasileiros, titulares de direitos cívicos. Como exemplo, evocava os "crioulos, ou filhos dos escravos que nascem no nosso continente são sem dúvida brasileira, porque o Brasil é o seu país natal", mas que não gozavam do foro de cidadãos. Sendo assim, propôs emenda à denominação do artigo, que passaria de "São brasileiros" para "São cidadãos brasileiros", a qual foi aprovada na sessão do dia 25 de setembro ${ }^{305}$. Isto reforçava a divisão social da sociedade escravista a partir de uma dicotomia simples entre livres e escravos. Mas, deixava caminho aberto para os egressos do cativeiro e seus descendentes.

Imediatamente, o parágrafo primeiro entrou em discussão. Os critérios para a definição de quem seriam os cidadãos brasileiros causaram polêmica. José Arouche de Toledo Rendon

\footnotetext{
302 Idem, p. 192.

${ }^{303}$ W. W. Buckland. A Text-Book of Roman Law: From Augustus to Justinian, pp.405-414; Alan Watson. Legal Origins and Legal Change, pp.256-257.

${ }^{304}$ Lara. "Legislação sobre escravos africanos na América Portuguesa", p.359; Paes. Sujeitos da História, Sujeitos de Direitos..., p.129.

305 Annaes do Parlamento Brazileiro: Assembleia Constituinte, Tomo V. Rio de Janeiro: Tipografia do Imperial Instituto artístico, 1874, p.185.
} 
(São Paulo) observou que os redatores do projeto haviam concedido os parágrafos do artigo de acordo com uma compreensão geral sobre a abrangência da nacionalidade. A inserção do vocábulo "cidadão" modificava o quadro e impunha a realização de ajustes. Para ele, não era exato que "todos os homens livres habitantes no Brasil, e nele nascidos" fossem cidadãos, "porque o botocudo nasceu no Brasil, nele habita, é livre, e, contudo nunca direi que é brasileiro cidadão". O parágrafo $6^{\circ}$ incorreria, a seu ver, problema semelhante, na medida em que incluía os escravos que obtivessem carta de alforria. Todos aqueles não poderiam ser cidadãos, pois "se um africano logo que chega for liberto, o mais que pode ficar sendo é um estrangeiro, e não um brasileiro cidadão”. Ferreira França interveio concordando com a ressalva de seu par sobre a existência de sujeitos livres, habitantes do Brasil e naturais do lugar, aos quais não seria correto atribuir o título de cidadãos. Mas entendia ser possível manter os três requisitos embutidos no texto, isto é, liberdade, domicílio e naturalidade, desde que o texto fosse modificado para "todos os homens livres residentes no Império e nele nascidos de pais brasileiros ou de portugueses residentes no mesmo Império antes de 12 de outubro de 1822". A proposta não foi apoiada. Sobre o caso dos povos indígenas, José Teixeira da Fonseca Vasconcelos (Minas Gerais) argumentou que a epígrafe do capítulo, "Dos membros da sociedade do Império do Brasil", já dava conta da situação, visto que, alheios ao novo pacto social, estariam automaticamente excluídos da tal sociedade. Ao final, após mais algumas intervenções, votou-se mesmo pela conservação do texto original ${ }^{306}$.

O parágrafo $6^{\circ}$ entrou para ordem do dia em 27 de setembro. Pedro José Costa Barros (Ceará) foi o primeiro a se pronunciar. Disse que nunca se conformaria com a concessão indistinta do título de cidadão brasileiro a todo escravo que alcançasse a alforria: "negros boçais, sem ofício, nem benefício, não são, no meu entender, dignos desta honrosa prerrogativa". Seria necessário, em sua visão, corrigir a generalidade, modificando os termos da norma para algo como "os escravos, etc. que têm emprego ou ofício". Para o representante cearense, portanto, a constituição dos egressos do cativeiro como um setor produtivo da sociedade seria condição sine qua non para o seu acesso aos direitos cívicos. No que foi apoiado.

Sousa França assumiu a palavra e, ignorando completamente o argumento do colega, fundamentou seu ponto de vista baseando-se no princípio da naturalidade. Para ele, o parágrafo poderia passar se os escravos fossem todos nascidos no Brasil, "porque tendo o direito de origem territorial para serem considerados cidadãos uma vez que se removesse o impedimento

306 Idem, p. 186. 
civil da condição de seus pais, ficavam restituídos plenos jure ao gozo desse direito, que estivera suspenso pelo cativeiro" 307 . Porém, não podia ser assim, já que grande parte dos libertos era estrangeira de diferentes nações da África e "excluindo nós em regra os estrangeiros da participação dos direitos de cidadania, é clara a conclusão, sendo coerentes em nossos princípios, que o parágrafo só pode passar pelo que respeita aos libertos crioulos”. O parágrafo deveria ficar, conforme sua emenda, da seguinte forma: "Os libertos que forem oriundos do Brasil". Para o que também foi registrado apoio. Esgotado o tempo, o presidente declarou adiada a discussão.

No dia 30, a matéria retornou ao centro da discussão. Francisco Muniz Tavares (Pernambuco) tomou a palavra. Em seu entender, o tópico deveria passar sem discussão. Ocorria-lhe que

\footnotetext{
"alguns discursos de célebres oradores da assembleia constituinte de França produziram os desgraçados sucessos da Ilha de S. Domingos [...]; e talvez entre nós alguns Srs. Deputados arrastados de excessivo zelo a favor da humanidade, expusessem ideias (que antes convirá abafar), com o intuito de excitar a compaixão da assembleia sobre essa pobre raça de homens, que tão infelizes são só porque a natureza os criou tostados. Eu direi somente que no antigo sistema apenas um escravo alcançava a sua carta de alforria, podia subir aos postos militares nos seus corpos, e tinha ingresso no sagrado ministério sacerdotal, sem que se indagasse se era ou não nascido no Brasil. (Não se ouviu o resto)." ${ }^{308}$
}

Usando de certa chicana ao creditar ao "tostado" da pele o sórdido destino das vítimas do cativeiro, o deputado manifestava o receio de que o teor das discussões na Constituinte suscitasse eventos semelhantes aos ocorridos em São Domingos. Com este pretexto, esposava que o assunto fosse silenciado, mantendo-se as coisas exatamente como eram desde os tempos do Antigo Regime, com limites bem definidos para a mobilidade social dos libertos, pela ocupação de postos militares em regimentos próprios e pelo exercício do sacerdócio ${ }^{309}$. Sousa França se pronunciou na sequência, dizendo que o regimento vedava tais interrupções e que, portanto, a inclusão do parágrafo na ordem do dia exigia a sua discussão. Quando algum deputado considerasse, em qualquer caso, que o silêncio fosse vantajoso, teria o direito de oferecer emenda supressiva. Neste ponto, sobressai o choque entre o modo tradicional de se encarar as matérias associadas à escravidão no processo legislativo luso-brasileiro, isto é, tocando-se o mínimo possível nos pontos centrais das relações de escravidão, e a perspectiva

\footnotetext{
307 Idem, p.201.

${ }^{308}$ Idem, p. 204.

${ }^{309}$ Jaime Rodrigues. O infame comércio: propostas e experiências no final do tráfico de africanos para o Brasil (1800-1850). Campinas: Editora Unicamp, 2005, pp.52-53
} 
de redefinição que se colocava no cenário de formação constitucional pela sistematização legalista ${ }^{310}$.

Sobre a matéria ou doutrina do parágrafo, Sousa França ratificou seu posicionamento do dia 27, afirmando não haver sentido em se conceder a cidadania aos estrangeiros vindos da África, já que aos de outras partes do mundo tal direito seria negado, a não ser mediante a naturalização. Exclamou, também, que não era o caso de se estabelecer o mesmo que na Constituição portuguesa de 1822, na qual haviam sido reconhecidos direitos de cidadania para libertos africanos e brasileiros, conforme sugeriam alguns constituintes. Segundo ele, as Cortes de Portugal "faziam uma constituição adaptada às suas possessões da Costa d'África, onde indispensavelmente se devia generalizar o foro de cidadão aos libertos de nação [...] e nós fazemos uma constituição circunscrita somente ao nosso país natal" ${ }^{311}$. Portanto, sustentava a emenda oferecida anteriormente, "na intenção de restringir o foro de cidadão aos libertos crioulos somente" 312 .

José Martiniano de Alencar (Ceará) externou opinião oposta à de seu colega do Rio de Janeiro, sustentando que o artigo estava plenamente conforme os "princípios de justiça universal, e que as emendas" lhe pareciam “injustas, contraditórias e impolíticas". Em verdade, em seus dizeres, a justiça universal seria plenamente contemplada apenas se todos os habitantes do território fossem feitos cidadãos brasileiros. No entanto, este princípio não poderia ser seguido por causa da existência dos escravos, impossíveis de serem incluídos sem pôr em risco a salvação do estado, a ordem social, a economia da nação e o direito de propriedade. Por isso, o artigo estabeleceu que apenas os que tivessem obtido a carta de alforria seriam cidadãos. A questão sobre a sua origem não se colocaria, "visto que nunca tais indivíduos pertenceram à sociedade alguma". Assim, por um enorme desvio valorativo em relação às nacionalidades africanas, o deputado defendia a inclusão também dos libertos introduzidos via tráfico transatlântico. Arrematava considerando ser descabida a exigência de condições adicionais, como ter algum ofício ou emprego, pois bastava "que ele tenha trabalhado toda a sua vida, sem que seja necessário no fim vencer mais essa dificuldade"; e defendendo que, por princípios de "sã política", o comércio da escravatura deveria ser bloqueado o mais prontamente possível para que futuramente o foro de cidadão brasileiro pudesse ser concedido a todos. Carneiro da Cunha tomou a palavra, em seguida, perfilando-se ao lado de Alencar pela manutenção do

\footnotetext{
${ }^{310}$ Andréa Slemian. Sob o império das Leis: constituição e unidade nacional na formação do Brasil (1822-1834). São Paulo: Editora Hucitec, 2009, p.26-32.

311 Annaes do Parlamento Brazileiro: Assembleia Constituinte, Tomo V, p.204.

312 Idem, ibidem.
} 
artigo tal como estava. Acrescentou que o escravo que se libertava tinha a seu favor, "geralmente falando", a presunção "de bom comportamento e de atividade", porque cumprira com suas obrigações, havendo adquirido "pelo seu trabalho com que comprasse a liberdade". Por essa razão, não interessando a origem, "tais homens bem merecem o foro de cidadãos"313.

Manuel Caetano de Almeida e Albuquerque (Pernambuco) colocou-se totalmente contrário ao teor do artigo: "se não conhecesse as boas intenções dos ilustres autores do projeto diria que eles avançavam um absurdo". Para ele, o "simples fato de se obter carta d'alforria" não poderia acarretar a aquisição do direito de cidadão. A fim de sustentar o seu argumento, recorreu aos artigos 14 e 15, dispostos no $2^{\circ}$ capítulo do Projeto, que vedavam direitos políticos aos que não professassem a religião cristã. O fato de serem "pagãos" e "idólatras" impediria o reconhecimento da cidadania aos africanos. Na sequência, dizia:

\footnotetext{
"Prescindindo desta razão, que me parece mui justa, como é possível que um homem sem pátria, sem virtudes, por meio de um comércio odioso, do seu território, e trazido para o Brasil, possa por um simples fato, pela vontade de seu senhor, adquirir de repente na nossa sociedade direitos tão relevantes? Se os europeus, nascidos em países civilizados, tendo costumes, boa educação e virtudes, não podem sem obter carta de naturalização, entrar no gozo dos direitos de cidadão brasileiro" "314.
}

Enquanto o preopinante realçou as virtudes associáveis ao empenho dos escravos que conseguiam se libertar, o representante pernambucano manifestou a mais pura ideologia escravocrata a respeito da alforria, afirmando-a categoricamente como um ato procedente da vontade senhorial. As duas perspectivas, a da conquista e a da concessão, que se entrelaçam variadamente na vida diária das relações de escravidão, espelhavam-se no debate constitucional substanciando de forma parcial projetos políticos antagônicos. Naquela época, o preço pago pela libertação costumava ser o mesmo do da compra e havia certo equilíbrio quantitativo entre manumissões onerosas e não onerosas. Dados coligidos pelo historiador Manolo Florentino indicam que, em 1821, entre as alforrias sacramentadas nas freguesias urbanas do Rio de Janeiro, $51 \%$ haviam sido gratuitas e, $49 \%$, pagas ${ }^{315}$. Não obstante, para Almeida e Albuquerque, a iniciativa dos senhores em findar o cativeiro era insuficiente para apagar a origem desvirtuada, selvagem e apátrida dos antigos escravos, impeditivos invencíveis, a seu ver, para o exercício da cidadania, principalmente no que dizia respeito aos direitos políticos.

\footnotetext{
313 Idem, ibidem.

314 Idem, p. 205.

315 Manolo Florentino. “Alforrias e etnicidade no Rio de Janeiro oitocentista: notas de pesquisa”. Topoi, Rio de Janeiro (set. 2002), p.20.
} 
Costa Barros, o constituinte cearense que havia proposto a inclusão de critérios laborais para o reconhecimento da cidadania aos libertos, retornou ao centro das discussões apregoando não ser injusto exigir-se "daquele a quem se faz a graça de chamar para o grêmio da nossa sociedade, que ele tenha em que se empregue para adquirir meios de subsistência, e não entre para ser entre nós simplesmente um vadio”. Em seguida, acrescentou:

\footnotetext{
"O sr. Carneiro da Cunha disse que o escravo que adquiria carta d'alforria dava com isso uma prova de atividade e boa conduta, pois além de desempenhar as suas tarefas ganhava com que se forrar; eu não estou persuadido disso, as cartas d'alforria são quase sempre passadas por amor, e a maior parte a escravos mal criados, e talvez se possa dizer que um grande número delas se obtém só pela qualidade de Pages de Jaiás não preciso explicar-me mais" 316 .
}

Assumindo um tom faccioso, a fala reduzia a alforria a uma premiação afetuosa a "escravos mal criados" e a amantes cativas. A boa conduta e a laboriosidade indicadas por outros constituintes como elementos decisivos para a libertação eram descredenciados no discurso por traços de afetividade e pelo engajamento sexual. Decerto que, tendo-se em conta o desequilíbrio de forças, a violência e a exploração que indelevelmente presentes, ninguém pode duvidar de que a dinâmica das relações sociais abrangia uma miríade de situações que culminavam na manumissão, as quais podiam contemplar, inclusive, a instrumentalização da sexualidade $^{317}$. Entre alforriados e alforriados, estiveram àqueles mais argutos, os tais “mal criados", outros que tiraram proveito da rede de relações na qual se inseriam, como também os mais industriosos e ordeiros. O que vale reforçar é que, naquele momento de redefinição política, abriu-se um campo de possibilidades que poderia implicar a resignificação de um expediente solidamente arraigado e plural como a alforria - cuja restrição, saliente-se, não estava em tela - e um novo enquadramento político da presença de libertos da sociedade.

O debate continuou. O próximo a tomar a palavra foi José da Silva Lisboa (Bahia). Em uma fala bastante prolixa, o futuro Visconde de Cairu, homem culto, grande conhecedor dos princípios hodiernos da economia política, posicionou-se favoravelmente em relação ao parágrafo $6^{\circ}$, o qual entendia ser "justo e político", não admitindo as restrições sugeridas. Parecia-lhe conveniente, apenas, torná-lo mais "simples ou amplo", declarando-se ser cidadão brasileiro, não só o escravo que obtivesse de seu senhor a carta de alforria, mas também aquele que adquirisse a liberdade por qualquer título legítimo,

\footnotetext{
316 Annaes do Parlamento Brazileiro: Assembleia Constituinte, Tomo V, p.205.

${ }^{317}$ Douglas Cole Libby\&Júnia Ferreira Furtado.Trabalho livre, trabalho escravo: Brasil e Europa século XVIII e XIX.São Paulo: Annablume, 2006, p.166.
} 
"visto que também se dão liberdades por autoridade da justiça, ou por disposição de lei, e ora temos mais as que pela convenção com o governo britânico se concedem aos africanos, em consequência de confisco feito pelo tráfico ilícito de escravatura, ficando eles inteiramente livres depois de certos anos de tutela em poder de pessoas de confiança da comissão mista"318.

À primeira vista, talvez sobressaia um certo preciosismo desta ponderação. As liberdades efetivadas judicialmente, bem menos volumosas do que as alforrias passadas normalmente em âmbito privado, não criavam um estatuto jurídico específico, que pudesse acarretar restrições quanto aos direitos de cidadania para esses libertos nos termos originais do artigo. Muito embora compreendessem situações bastante estritas como a entrega de diamantes de mais de 20 quilates, a denúncia ao contrabando de itens como tapinhoã e pau-brasil, e a morte natural, os casos previstos em lei para o término compulsório do cativeiro criavam categorias especiais de forros $^{319}$. Os efeitos das liberdades concedidas pela repressão legal ao tráfico poderiam ser distintos, é verdade. A comissão mista citada por Silva Lisboa foi aquela instalada no Rio de Janeiro para apurar casos de africanos ilegalmente escravizados ao norte do equador. Isto decorria, como sabido, da política traçada originalmente no tratado angloportuguês de 22 de janeiro de 1815, depois retificada pela convenção adicional de 28 de julho de 1817 e internamente regulamentada pelo alvará de 26 de janeiro de 1818 . $\mathrm{O}$ artigo $7^{\circ}$ da convenção determinava que os escravos apreendidos em navios condenados por viagem ilícita deveriam receber carta de alforria da comissão, sendo consignados ao governo para que fossem empregados na qualidade de criados ou trabalhadores livres. Mas a sociedade escravista tinha uma maneira traiçoeira de libertar as pessoas. $\mathrm{O} \S 5^{\circ}$ do alvará português estipulou que os africanos, naquelas condições, consignados à Real Fazenda, seriam destinados "a servir como libertos" por 14 anos em algum serviço público ou alugados a particulares, "assinando este termo de os alimentar, vestir, doutrinar, e ensinar-lhe o ofício ou trabalho". Contudo, bem na linha "meritocrática" presente na fala de alguns constituintes de 1823, previu-se que o tempo poderia ser reduzido em dois anos ou mais, caso os libertos, por seu préstimo e bons costumes, se fizessem "dignos de gozar antes dele do pleno direito de sua liberdade" 320.

Embora não tenha sido cunhado um estatuto jurídico específico para os indivíduos libertos pela comissão mista, o fato é que eles se encontrariam em uma condição civil diferenciada em relação a escravos e libertos. Como observou Beatriz Mamigonian, "os 'africanos livres' no Brasil possuíam status jurídico semelhante ao de pessoas livres sob tutela

\footnotetext{
318 Annaes do Parlamento Brazileiro: Assembleia Constituinte, Tomo V, p.205.

319 Perdigão Malheiro. A Escravidão no Brasil., p.72

320 Disponível em: <http://www2.camara.leg.br/legin/fed/alvara/anterioresa1824/alvara-39266-26-janeiro-1818569131-publicacaooriginal-92391-pe.html>. Acesso em 27 de abril 2015.
} 
e submetidos a trabalho compulsório e partilhavam essa condição com os grupos emancipados nos domínios coloniais britânicos, espanhóis e holandeses”321. Ainda que a liberdade fosse plenamente reconhecida àquelas após o cumprimento dos anos de trabalhos forçados, poderiam pairar dúvidas sobre o seu enquadramento como cidadãos brasileiros por conta da peculiaridade de sua acolhida. Nesse sentido, a sugestão de Silva Lisboa viria a calhar, praticamente eliminando as chances de discórdia, tendo-se em vista a regularidade da emancipação.

No entanto, o alargamento do $\S 6$ do art. 5 ía além das possibilidades de consumação da alforria por imposição legal e/ou nos meios judiciais em conformidade com o ordenamento jurídico existente, e mesmo dos 352 africanos liberados por meio do julgamento do Emília, único navio condenado no período de funcionamento da comissão no Rio de Janeiro, entre 1819 e $1822^{322}$. O que importava realmente ali era a perspectiva de futuro que se abria; os novos arranjos legais que poderiam advir na ordem constitucional vindoura em torno da liberdade dos cativos; as novas possibilidades de emancipação na arena judicial; assim como as solturas decorrentes da repressão ao tráfico transatlântico de escravos, presumível da negociação em curso com a Inglaterra para o reconhecimento da independência ${ }^{323}$.

Dando continuidade às suas considerações, Silva Lisboa, apoiava-se no pensamento ilustrado de Montesquieu em $O$ espírito das Leis, para anunciar o desacerto em se multiplicar “particularidades e exceções". Em uma ordem constitucional, a simplicidade era o que dava força à regra. $\mathrm{O}$ teor das emendas propostas, fincadas nos critérios da naturalidade e do "préstimo e ofício", configuravam distinções arbitrárias e contraproducentes:

"Uma vez que adquiriram a qualidade de pessoa civil, merecem igual proteção da lei e não podem ter
obstáculo de arrendar e comprar terras, exercer qualquer indústria, adquirir prédio, entrar em estudos
públicos, alistar-se na milícia e marinha do império. Ter qualidade de cidadão brasileiro é, sim, ter uma
denominação honorífica, mas que só dá direitos cívicos e não direitos políticos, que não se tratam no
capítulo em discussão e que são objeto do capítulo seguinte, em que se trata do cidadão ativo e proprietário
considerável, tendo as habilitações necessárias à eleição e nomeação dos empregos políticos do
império" 324 . Aqui é possível perceber claramente o limite da perspectiva inclusiva abraçada. Aos negros caberiam os direitos civis da sociedade liberal, incluindo as proteções legais ligadas à livre iniciativa e ao acesso à propriedade. A posição subalterna nas relações de produção

\footnotetext{
${ }^{321}$ Beatriz Gallotti Mamigonian. "O direito de ser africano livre”, in: Silvia Hunold Lara \& Joseli Maria Nunes Mendonça. Direitos e justiças no Brasil: ensaios de história social. Campinas: Editora Unicamp, 2006, p.131.

${ }^{322}$ Beatriz Gallotti Mamigonian. To be a libereted african in Brazil: labor and citizenship in the nineteenth century. Tese de doutorado - Universidade de Waterloo, 2002, cap. 1.

${ }^{323}$ Cf. Guilherme de Paula Costa Santos. No calidoscópio da diplomacia: formação da monarquia constitucional e reconhecimento da independência e do império do Brasil, 1822-1827. Tese de Doutorado - Universidade de São Paulo, 2015.

${ }^{324}$ Annaes do Parlamento Brazileiro: Assembleia Constituinte, Tomo V, p.205.
} 
garantiria o alijamento da imensa maioria daquelas pessoas dos níveis próprios ao campo político, tendo-se em vista o praticamente inatingível rendimento anual equivalente aos cento e cinquenta alqueires de mandioca que credenciariam os cidadãos ativos, conforme o artigo 122 do projeto. As habilitações referidas incluíam, ainda, conforme o artigo 123, a necessidade de os libertos haverem nascido no Brasil, ou seja, os africanos estavam impreterivelmente excluídos do círculo de eleitores e de elegíveis para os postos do legislativo imperial - ao que se deve somar, evidentemente, a totalidade das mulheres negras.

Portanto, os receios manifestados seriam todos sem fundamento. Ao alarme sobre a inconveniência mesma de se botar tal artigo em discussão, em referência à "catástrofe" da melhor colônia francesa, Saint-Domingue, Silva Lisboa rebateu afirmando que a perda da Rainha das Antilhas deveu-se aos erros anteriores do "governo despótico" somados à "fúria de Robespierre, o qual bradou na assembleia: pereçam as nossas colônias, antes que pereçam os nossos princípios" ${ }^{\text {"25 }}$. O recado era claro: a emenda que estava propondo nada tinha de tirânica ou revolucionária, afinando-se, antes, às diretrizes de um estado liberal garantidoras da sociedade de classes. O "cancro do cativeiro" deveria ser extirpado, sim, mas "só mui paulatinamente se pode ir desarraigando". De modo algum poder-se-ia proclamar a abolição da escravatura de forma "súbita e geral", tal como tinham feito os "anarquistas" jacobinos. A salvaguarda da base material estava à frente do humanitarismo e da filantropia, princípios que, conforme o seu discurso deveria ser resolutamente aplicado, mas, por assim dizer, em doses homeopáticas ${ }^{326}$. Isto estaria garantido pela combinação do $\S 6$ do art. 5 com os dispositivos do projeto que circunscreviam os benefícios aos escravos à sua lenta emancipação e instrução moral. O perigo dos forros vadios, alegado no debate, era mero objeto de polícia, não devendo influir na composição de artigo constitucional.

Com uma retórica hábil, Silva Lisboa, demonstrando erudição no campo do direito sem, é claro, aprofundar-se nas condições objetivas da exploração do trabalho escravo e nas

\footnotetext{
${ }^{325}$ Sobre o temor de acontecimentos semelhantes à Revolução de Saint-Domingue, ver: Kenneth Maxwell. "A geração de 1790 e a idéia do império luso-brasileiro". In: Chocolates, Piratas e Outros Malandros. Ensaios Tropicais (trad.port). São Paulo: Paz \& Terra, 1999, pp.157-207; Maria Odila Leite da Silva Dias. A interiorização da metrópole e outros estudos. São Paulo: Alameda, 2005, p.23; Eduardo Silva, Negociação e conflito. A resistência negra no Brasil escravista. São Paulo: Companhia das Letras, 1989; Matthias Röhrig Assunção ("Miguel Bruce e os 'horrores da anarquia' no Maranhão, 1822-1827"), Ana Rosa Cloclet da Silva ("Identidades políticas e a emergência do novo Estado nacional: o caso mineiro") e Marcus J.M. de Carvalho ("Os negros armados pelos brancos e suas independências no Nordeste (1817-1848)"), todos inseridos em volume editado por István Jancsó. Independência: História e Historiografia. São Paulo: Hucitec-Fapesp, 2005; para uma visão ampla sobre a repercussão de notícias a respeito do Haiti na sociedade escravista brasileira, ver: Flávio Gomes. "Experiências transatlânticas e significados locais: ideias, temores e narrativas em torno do Haiti no Brasil Escravista." In: Tempo, 13: 209-246, 2002.

${ }^{326}$ Annaes do Parlamento Brazileiro: Assembleia Constituinte, Tomo V, p.206.
} 
pressões sociais que, concretamente, condicionam os arranjos e rearranjos normativos - tratou de retraçar a evolução dos preceitos jurídicos envolvendo o cativeiro. Pretendia com isso desnudar que o rigor do sistema de escravidão havia sido mitigado ao longo do tempo, e que seus egressos haviam sido historicamente acolhidos no âmago da sociedade civil. Lembrou que originalmente, em Roma, o servo era tido apenas como coisa, não como pessoa, não podendo poupar para si a quantia correspondente à sua liberdade para ofertar ao seu senhor. Porém, o princípio original fora abrandado e, a validade do pecúlio contraído pelos escravos, reconhecida pelos notáveis jurisconsultos. Justiniano, por fim, incluiria na órbita dos cidadãos romanos (cujo peso político nem de longe se equiparava ao de outros tempos) a totalidade dos homens livres, incluindo aqueles que tivessem recebido a liberdade de seus senhores, ato tomado como de "restituição da ingenuidade da natureza". Assim também o rei D. José I, pelo célebre alvará de 19 de setembro de 1761, concederia plenos direitos de pessoas livres aos escravos que fossem trasladados do Brasil a Portugal, "sem distinguir origens, cores e habilitações". O alvará de 16 de janeiro de 1773 seria ainda mais liberal, eliminando "a nota distintiva de libertos", que "a união cristã e a sociedade civil faz hoje intolerável"327.

Aos africanos não caberia temor maior ou posição diferenciada: a expectativa de um dia poderem dispor de seu trabalho de maneira integral, os tornariam, no geral, industriosos e subordinados. O “infernal tráfico de sangue humano", iniciado pelos portugueses, multiplicara guerras, impossibilitando a sua civilização. Portanto, o simples fato de serem da África, já os faria merecedores da liberdade. Acrescia, também, que a apreciação, a diferenciação pretendida entre crioulos e estrangeiros seria per se nociva, reforçando um problema social a ser superado: "bastem já, senhores, as odiosas distinções que existem das castas, pelas diferenças das cores. Já agora o variegado é atributo quase inexorável da população brasileira"328.

Em vista do referido, não podia aquela "augusta assembleia", forjada na era do liberalismo, ser menos equitativa do que a legislatura produzida em tempos despóticos. E arrematou enviando sua emenda à mesa com a fórmula já anunciada: que fossem considerados cidadãos brasileiros "os libertos que adquiriram sua liberdade por qualquer título legítimo”, a qual foi apoiada.

O próximo a falar foi João Severiano Maciel da Costa (Minas Gerais), também versado no pensamento ilustrado, havendo destilado uma defesa da escravidão em sua Memória sobre

\footnotetext{
327 Idem, p. 206.

328 Idem, p. 207.
} 
a Necessidade de Abolir a Introdução dos Escravos Africanos no Brasil ${ }^{329}$. A sua linha de pensamento era oposta à de Silva Lisboa; julgava que o destino a ser dado aos libertos era "matéria espinhosa, em que têm vacilado nações alumiadas e humanas, que como nós, os temos em seu seio". No entanto, o ponto central da argumentação do futuro marquês de Queluz girou em torno do problema da acolhida de estrangeiros ao grêmio da sociedade. Tomando o caso inglês como referência principal, alegou que a assimilação de pessoas de outras nacionalidades variava conforme necessidades pragmáticas, sendo acompanhada de condições que pudessem garantir "a afeição dos estrangeiros ao país, às suas instituições, à sua prosperidade, à sua liberdade". Entre tais condições estavam o casamento com "mulher nacional" e a aquisição de propriedade, "vínculos que por experiência sabemos que prendem o homem". Assim, para que os africanos fossem "admitidos à nossa família", que se lhes exigissem o casamento com mulher brasileira e uma atividade da qual tirassem o seu sustento. Interessante notar que, para reforçar o seu argumento, Maciel da Costa tomou contraexemplo o caso dos Estados Unidos, defendendo uma solução nacional para o problema:

\footnotetext{
"Senhores, não queiramos ser mais filantrópicos que os americanos do norte com os africanos; eles procuram como sabemos, acabar com a escravidão, mas não querem nada deles para os negócios da sociedade americana, antes desejam desembaraçar-se deles, e nisso trabalham" ${ }^{330}$.
}

Nesse ponto, o argumento de Maciel da Costa convergia com o de Silva Lisboa, acenando para a incorporação da população negra nos marcos dos direitos civis elementares. A diferença estava nos critérios para a inclusão dos africanos, os quais, segundo o primeiro, deviam atender requisitos de naturalização. A sua emenda ficou assim: “os libertos nascidos no Brasil, e os que não tendo nascido no Brasil casarem com brasileira e exercerem algum gênero de indústria”. A qual também recebeu apoio.

Após uma intervenção do padre Venâncio Henriques de Rezende (Pernambuco), que subscreveu a proposta de Silva Lisboa, Maciel da Costa, motivado por interposição crítica de Antônio Carlos de Andrada, cujo teor não se registra, voltou à carga para ratificar o seu ponto de vista. Disse que argumentos proferidos por outros constituintes contrariando a origem estrangeira dos africanos libertos, a saber, a inserção na família à qual serviram e a equiparação da alforria ao nascimento para o Brasil, não passavam de "metafísica”. Segundo ele,

\footnotetext{
329 João Severiano Maciel da Costa.Memória sobre a necessidade de abolir a introdução dos escravos africanos no Brasil; sobre o modo e condições com que esta abolição se deve fazer; e sobre os meios de remediar a falta de braços que ela pode ocasionar. Coimbra: Imprensa da Universidade, 1821.

${ }^{330}$ Annaes do Parlamento Brazileiro: Assembleia Constituinte, Tomo V, p.208.
} 
“O africano é africano, e quando tratamos de habilitá-lo brasileiro, havemos de conformar-nos com os princípios de direito político universalmente reconhecido pelas nações. [...] Diminuir gradualmente o tráfico de comprar homens e, entretanto tratar com humanidade os que são escravos, eis-aqui, senhores, tudo quanto lhes devemos" 331 .

O decréscimo do tráfico negreiro aparece no discurso como o dado indelével; um compromisso mesmo a ser firmado com os estrangeiros nascidos em solo africano. No entanto, a progressividade da tal diminuição era indeterminada, ao mesmo tempo em que, na outra ponta das ações, colocava-se um difuso tratamento humanitário que em nada ameaçava a continuidade do regime de escravidão. Na perspectiva de Maciel da Costa, estava o provimento de "segurança política" para uma sociedade que teria que lidar ainda por muito tempo com a presença ameaçadora de africanos (libertos e escravizados), sopesando tanto os que aqui estavam na época da independência quanto os que estavam por chegar. A filantropia, raiz da desgraça francesa, não seria o princípio adequado a nortear as ações do governo. Os Estados Unidos da América, nação não menos filantrópica e "alumiada", tinha dificuldade em lidar com o destino a ser dado aos libertos, tanto que ali organizaram-se sociedades para estimular o seu traslado à África e criaram-se entraves legais para a concessão de alforrias. Se por lá, tal grupo inspirava temores, aqui não havia de ser diferente. Cumpriria, a seu ver, controlar a admissão dos libertos africanos mediante um processo bem definido de naturalização.

O fechamento da discussão se deu com as considerações de Silva Lisboa, que retomou a palavra, respondendo diretamente a Maciel da Costa. Para ele, "o temor justo deve ser o de perpetuarmos a irritação dos africanos e de seus oriundos, manifestando o desprezo e ódio, com sistema fixo de nunca melhorar-se a sua condição" ${ }^{332}$. A liberalidade constitucional proposta, por outro lado, inspiraria "gratidão e emulação, para serem obedientes e industriosos, tendo futuros prospectos de adiantamentos próprios e de seus filhos”. Causava-lhe espécie a menção à "polícia de alguns estados da América do norte, em que existe o sistema do cativeiro e onde, aliás, não transborda a sabedoria, como na Virgnia, Carolina, etc.," e, não, à "sabedoria do Congresso, que já proibiu absolutamente o tráfico da escravatura africana e até já se marcou a época em que deve cessar o sistema de cativeiro" ${ }^{333}$. Insistia que os males sofridos pelos franceses provinham do choque entre a forma abrupta e geral como a liberdade fora decretada e a desumanidade dos senhores de escravos, "que não quiseram admitir nenhuma modificação do seu terrível Código Negro". Ademais, "mesmo o bom rei Luis XVI", teria concorrido para

\footnotetext{
331 Idem, p.209.

332 Idem, p. 210.

${ }^{333}$ Idem, ibidem.
} 
os transtornos ocorridos, animando e facilitando o tráfico negreiro, do que resultou o acréscimo vultoso da população africana escravizada e, com isso, "o incêndio de paixões, vinganças e resistências, que terminaram no estado que ora vemos a ilha de São Domingos". Ao final, conclamava seus colegas a deixarem de enxergar os africanos com maus olhos. Para sensibilizálos, citou episódios glorificantes do passado envolvendo a África, atribuiu ao comércio de escravos a causa dos desvios civilizacionais do presente e sustentou que a formação dos homens para terem a "dignidade da sua espécie" se dava por meio de "boas instituições, com reta educação", não de suas cores. O arrazoado foi convincente. A matéria foi dada como discutida e o $§ 6$ passou com a emenda de Silva Lisboa, isto é, seriam considerados cidadãos brasileiros os libertos que adquirissem sua liberdade por qualquer título legítimo. De modo conexo a esta delimitação, estavam os artigos que previam a criação de estabelecimentos para a emancipação lenta dos escravos e o inédito reconhecimento dos contratos entre senhores e escravos, ainda por serem discutidos, assim como a definição do destino a ser dado ao infame comércio ${ }^{334}$.

Em abril, José Bonifácio, ainda na condição de ministro dos negócios estrangeiros, havia afixado a posição oficial do novo governo - em consonância com peso econômico, político e social da classe senhorial e dos traficantes de escravos - no sentido de que a abolição precipitada do trato negreiro colocaria em risco a existência mesma do governo brasileiro ${ }^{335}$. Em 16 de outubro, o deputado Francisco Carneiro de Campos (Bahia), propôs que se permitisse ao governo imperial a nomeação de deputados para uma missão diplomática encarregada de negociar o reconhecimento da independência, proposto pelo governo da Grã-Bretanha, sob a condição de que o tráfico de escravos fosse suprimido no prazo de um ano. Porém, a matéria acabou sendo discutida em sessão secreta. Os constituintes admitiram, então, delegar ao Executivo o poder de negociação junto à Inglaterra, contanto que o prazo para a interdição do infame comércio fosse para dali a quatro anos apenas (como pontuara Bonifácio em sua Representação) e que se arrancassem dos ingleses o reconhecimento da independência e um compromisso de preservação do regime representativo no Brasil ${ }^{336}$.

Sublinhe-se bem. O que se desenhava não era o plano de uma sociedade radicalmente abolicionista ou democrática em termos de inclusão social e integração política. Tratava-se, antes, do estabelecimento das bases para a superação lenta e controlada da ordem escravocrata, a qual transitaria em longo prazo para uma economia fundeada no trabalho livre, mas, ao mesmo

\footnotetext{
${ }^{334}$ Idem, pp.210-211

${ }^{335}$ Luiz Felipe de Alencastro. "Traite négrière et unité nationale brésilienne". Revue française d'histoire d'outremer, tome 66, $\mathrm{n}^{\circ} 244-245$, (3e et 4e trimestres 1979). Histoire et politologie en Amérique Latine, p.401

336 Tâmis Peixoto Parron. A política da escravidão no Império do Brasil (1826-1865). Rio de Janeiro: Civilização Brasileira, 2011, p.59.
} 
tempo, profundamente desigual e elitista, em especial no que dizia respeito aos direitos políticos dos cidadãos. Com efeito, o cenário que parecia estar sendo costurado era o de uma ordem constitucional com um caráter antiescravista moderado, prevendo (sem regulamentar) mecanismos para a desagregação progressiva do sistema de exploração do trabalho escravo, com uma difusa integração cívica dos libertos, crioulos e africanos.

De todo modo, é possível considerar que ali estavam sendo plantadas as bases para a desestabilização da população escrava. Apesar dos temores manifestados, os dispositivos inseridos no projeto não ensejavam restrições à prática da alforria, tampouco atrapalhavam o acesso dos indivíduos indevidamente escravizados ao sistema judiciário ou inibiam futuras leis que melhorassem a condição ou instituísse um leque de direitos e benefícios mais bem definido às vítimas do cativeiro. Antes, dava-se margem para que uma proposta de lei geral como a contida na representação de Bonifácio fosse discutida e posteriormente entrasse em vigor. Com efeito, a manumissão (não apenas irrestrita, mas estimulada por lei e judicialmente respaldada) combinada ao corte da imigração de africanos escravizados no prazo previsto de quatro anos, desempenharia um papel disruptivo, antissistêmico, na medida em que se sobrepusesse quantitativamente ao crescimento "natural" da população escrava, tradicionalmente deficitária em terras luso-brasileiras. Marcel van der Linden, seguindo John Moes, observa que os sistemas de escravidão tendem a se desintegrarem no longo prazo, caso não haja ingressos de novos cativos provenientes do estrangeiro e existam possibilidades claras de mobilidade social. O motivo não seria meramente de ordem demográfica ou estritamente legal, mas corresponderia ao atrelamento entre o aumento da produtividade do trabalho dos escravos empenhados na compra de sua liberdade e o interesse material dos senhores em permitir que isto ocorresse, com a possibilidade de cobrança pela liberdade de um preço mais elevado que o de mercado por outro cativo de semelhantes condições ${ }^{337}$.

O projeto constitucional entrou em choque com um movimento histórico de renovação sistêmica do fenômeno da escravidão, que travou a sua concretização. Os atores políticos mais contrários à escravidão envolvida no processo de formação do Estado nacional brasileiro, como Bonifácio e Silva Lisboa, defendiam a sua incompatibilidade com a nova ordem, mas, ao mesmo tempo afirmavam os riscos de mudanças repentinas e desordenadas; entendiam que as escravarias compunham parte substancial do capital dos proprietários rurais e urbanos, e que os egressos precisavam ser assimilados de forma segura à população livre. Ainda assim, enxergavam na escravidão uma página a ser virada junto com o antigo sistema colonial,

\footnotetext{
${ }^{337}$ Marcel van der Linden. Trabalhadores do mundo: ensaios para uma história global do trabalho. Campinas: Editora Unicamp, pp.84-85.
} 
sepultado de vez em 1822, e se articularam politicamente para dar vazão a este intento, já no momento de definição dos marcos constitucionais do país. Como nunca antes, a conjuntura dava sinais de que o desmantelamento da escravidão podia ser vislumbrado. Afinal, presenciara-se o esfacelamento da ordem escravista de Saint-Domingue e tanto o Parlamento britânico quanto o Congresso dos Estados Unidos haviam decretado o fim do tráfico transatlântico de africanos cativos para os seus territórios. Pôr fim à escravidão era algo palpável, de impacto mensurável. Para alguns, inclusive, um dado inevitável e a questão toda a ser enfrentada era a de como manejar o processo.

O problema era que, em termos materiais, o cativeiro não havia definhado junto com o Antigo Regime português. Pelo contrário, a produção escravista local vinha em franca recuperação, em especial, desde a vinda da Família real e a abertura dos portos, em 1808, com elevação das exportações de açúcar, algodão e café. Só no ano da independência, foram desembarcados cerca de 57.145 escravos no Brasil, número recorde. Naquele mesmo 1823, enquanto os debates aconteciam na Assembleia, entravam outros 38.343. Portanto, a Constituição da mandioca, como ficou conhecida, ia de encontro a um movimento de reestruturação das atividades escravocratas na ex-colônia lusitana. Nem o caráter paulatino, a perder de vista mesmo, de um processo abolicionista interessava a uma classe senhorial que se renovava, adquiria novas terras e investia em um capital produtivo visceralmente atrelado ao universo da produção escravista. O antiescravismo embutido no discurso e nas propostas de diversos constituintes apresentava um profundo descompasso em relação às circunstâncias econômicas.

O que explica essa contradição é o fato de estar ocorrendo naquele momento uma confluência entre temporalidades históricas, que influiu diretamente nas mentalidades e nas práticas políticas. Os ares revolucionários abertos pela independência se conjugavam a uma atmosfera internacional de mudanças que imbuíam os sujeitos históricos de uma presunção extraordinária a respeito de sua força transformadora. A construção do Estado nacional aparecia como a oportunidade de se construir uma sociedade sobre novas bases, mais avançadas, inclusive, em relação ao que se fizera em outras partes do mundo. No entanto, um contrafluxo de forças delimitou a extensão efetiva das transformações a serem realizadas. O arranjo que estava sendo assumido pela divisão internacional do trabalho na economia mundo capitalista combinou-se à natureza processual da sociedade brasileira nos níveis nodais de sua complexidade interna, refundando seus elementos tradicionais e influenciando a arquitetura das instituições do Império do Brasil. 
O fechamento da Constituinte no dia 12 de novembro não pode ser creditado simplesmente às divergências envolvendo escravos e libertos. Mas é possível inseri-las no contexto de disputas que culminou naquele episódio, tanto mais quando se identifica que deputados como Antônio Ferreira França e José da Silva Lisboa, que nutriam ideias relativamente arejadas a respeito da escravidão e dos direitos dos libertos, foram também avessos à centralização do poder. Do mês de julho em diante, quando os irmãos Andrada passaram à oposição e os representantes da Bahia assumiram suas cadeiras, as tensões cresceriam seriamente em torno do arranjo político-institucional do Império. Conforme destacou Emilia Viotti da Costa, a gota d'água veio com a discussão do poder de veto do imperador, "um direito que a maioria dos liberais queria reduzir ao máximo e alguns chegavam até mesmo a negar-lhe" 338 . Diante da possibilidade de esvaziamento de suas competências por meio da afirmação de princípios federalistas, D. Pedro I agiu dissolvendo a Assembleia na famosa Noite da Agonia. José Bonifácio partiria então para o exílio sem haver tido ocasião de expor sua Representação aos colegas constituintes.

Os passos seguintes são conhecidíssimos. O imperador nomeou um conselho formado por dez homens de sua confiança ${ }^{339}$ com a atribuição de elaborar um novo projeto de constituição, o qual foi concluído rapidamente, a 11 de dezembro de 1823. Outorgada no dia 25 de março de 1824, após apreciação das câmaras municipais, a Carta Magna brasileira robusteceu o poder do monarca, em especial, pela instituição do poder Moderador, mas manteve um texto afinado aos princípios do liberalismo, como a separação de poderes e a promessa de inviolabilidade dos direitos civis e políticos dos cidadãos, que tinham por base "a liberdade, a segurança individual, e a propriedade”. Quanto aos dispositivos de teor antiescravista existentes no projeto anterior discutido na Constituinte, houve um retrocesso absoluto. Atuando em favor dos interesses gerais da classe senhorial, a Coroa suprimiu os estabelecimentos para a promoção da lenta emancipação dos negros, assim como o reconhecimento dos contratos entre senhores e escravos. Sobre a cidadania aos libertos, os africanos foram excluídos em sua totalidade. Segundo o $\S 1^{\circ}$ do artigo $6^{\circ}$, eram reconhecidos cidadãos brasileiros apenas os indivíduos alforriados que tivessem nascido no Brasil ${ }^{340}$. Isto excedia, evidentemente, a proposta feita antes por Maciel da Costa, integrante do seleto grupo de redatores da constituição definitiva.

\footnotetext{
${ }^{338}$ Emília Viotti da Costa. Da monarquia à república. São Paulo: editora Unesp, 1998, p.141.

339 João Severiano Maciel da Costa, Luiz José de Carvalho e Mello, Clemente Ferreira França, Marianno José Pereira da Fonseca, João Gomes da Silveira Mendonça, Francisco Villela Barboza, Barão de Santo Amaro, Antonio Luiz Pereira da Cunha.- Manoel Jacintho Nogueira da Gama e José Joaquim Carneiro de Campos.

${ }^{340}$ Disponível em: <http://www.planalto.gov.br/ccivil_03/constituicao/constituicao24.htm>. Acesso em 27 de abril 2015.
} 
Os critérios de naturalização que sugerira anteriormente para a inclusão dos alforriados nascidos n’África deixaram de ser incorporados. Provavelmente porque, na posição em que estavam, sem haver a necessidade de barganha em plenário, seus pares e ele próprio tenham concluído que mais seguro ainda do que dificultar o acesso fosse negá-lo totalmente. Assim foi feito. Não é possível precisar qual teria sido o destino da escravidão caso o projeto de 1823 tivesse sido aprovado. Um caminho diferente poderia ter sido traçado. Isto é certo.

\section{O direito escravista refundado: alforria, litígio e a dinâmica do cativeiro oitocentista}

A Carta outorgada de 1824 projetou a codificação das leis do país. O § 18 do seu artigo 179 previu que códigos civis e criminais fossem editados de forma célere: "Organizar-se-á quanto antes um Código Civil, e Criminal, fundado nas sólidas bases da Justiça, e Equidade". Enquanto isso seguiria valendo "Ordenações, Leis, Regimentos, Alvarás, Decretos, e Resoluções promulgadas pelos Reis de Portugal, e pelas quais o Brasil se governava até o dia 25 de Abril de 1821", conforme havia estipulado lei de 20 de outubro de $1823^{341}$. O problema é que o provisório se perpetuaria, atingindo em cheio a regulação do cativeiro ${ }^{342}$. Melhor dizendo, os traços específicos, nacionais, da sociedade escravista brasileira seriam determinantes para que a sistematização do direito nacional emperrasse, notadamente no campo civil. Não pela existência da escravidão em si, afinal, a Louisiana, território dos Estados Unidos também influenciados pela tradição do direito romano justinianeu em função das dominações francesas e espanholas, incluiu em seu Código Civil, promulgado em 1825, artigos estabelecendo, entre outros pontos, a irrevogabilidade da manumissão e a incapacidade jurídica dos escravos, salvo pelo que envolvesse a sua liberdade ${ }^{343}$.

É necessário insistir na ideia de que havia uma cultura da escravidão no Brasil, um modo próprio, solidamente arraigado, de viver e ordenar a instituição, que tinha como um de seus pontos centrais a redução do controle estatal sobre as relações domésticas entre senhores e

341 Disponível em: <http://www2.camara.leg.br/legin/fed/lei_sn/anterioresa1824/lei-40951-20-outubro-1823574564-publicacaooriginal-97677-pe.html>. Acesso em 27 de maio 2014.

${ }^{342}$ As referências normativas do escravismo colonial português continuariam válidas por um longo período, o que sem dúvida contribuiu para que o arranjo tomado pelo ordenamento jurídico do Império. Este dado deu especial sustentação para a interconexão com o modo pregresso de viver a instituição. Conforme apurou Keila Grinberg, ao estudar as 402 ações de segunda instância relativas à liberdade de escravos constantes do Arquivo Nacional, até meados do século XIX, as Ordenações Filipinas predominaram entre a legislação citada, decaindo apenas de $1850 \mathrm{em}$ diante. Cf. Keila Grinberg. O fiador dos brasileiros. Cidadania, escravidão e direito civil no tempo de Antonio Pereira Rebouças. Rio de Janeiro: Civilização Brasileira, 2002, pp.250-51.

${ }^{343}$ Keila Grinberg. Código Civil e cidadania. Rio de Janeiro: Jorge Zahar, 2008, pp.47-58; Keila Grinberg \& Sue Peadody. Escravidão e liberdade nas Américas. São Paulo: FGV, 2013. 
escravos, em especial no que dizia respeito à concessão da alforria. No momento da constituinte, como foi visto representações diversas construídas em meio aos séculos de experiência do cativeiro e novas perspectivas abertas pelo contexto coevo de transformações vieram à tona. Possíveis alterações em seu manejo foram vislumbradas, especialmente diante do cenário internacional de deterioração da legitimidade do tráfico e do próprio cativeiro. No entanto, o modo antigo foi regenerado no ato fundador da ordem constitucional, ganhando nova força e significado à luz das concepções políticas e da correlação de forças domésticas e internacionais constituídas nos novos tempos. O movimento não foi linear, é bom que se diga. A omissão do texto constitucional abria espaço para tanto para a reprodução quanto para a adoção de medidas para a dissolução. Nos anos que se seguiram, a escravidão e, em especial, a sua precondição básica, o tráfico transatlântico, voltariam a ser debatidos por sucessivas vezes, a começar pelo momento de assinatura do tratado que selou o reconhecimento da independência do país pela Inglaterra. Raimundo José da Cunha Matos, deputado por Goiás, membro dissonante da comissão diplomática que aprovou o Convênio firmado com a Inglaterra prevendo o fim do infame comércio em 1830, expôs seu voto no Parlamento no dia 2 de julho de 1827, defendendo que não havia chegado o momento de se por fim ao tráfico de escravos e que a decisão quanto a tal ação cabia unicamente à nação brasileira, conforme as necessidades internas de desenvolvimento, nunca por intervenção armada estrangeira. Entre outros pontos, alegava que o comércio de africanos era menos odioso do que comumente se supunha e que a sorte dos "pretos sentenciados à escravidão" era melhor do que a daqueles que lá permaneciam para serem assassinados em sacrifícios em memória dos antepassados; que a imoralidade e a corrupção dos costumes existente no país, amiúde atribuída à existência mesma do trabalho servil, não superava o que havia na França, na Inglaterra ou na Itália. Alfinetando o comportamento de D. Pedro I, proferiu que "se os soberanos são imorais, os povos querem tenham ou não escravos, também são imorais; e se os soberanos são exemplares de virtude, os povos também são virtuosos". Cabia, portanto, ao monarca manter uma conduta reta para dar o exemplo ao restante da população, evitando, assim, de forma geral a "libertinagem". Reconhecia que havia excessos por parte de mestres de navios e de senhores de escravos, "que olham com mais complacência um boi ou um cavalo do que para o escravo". Ao governo imperial, em termos institucionais, tocava garantir que os escravos fossem tratados com "caridade" por meio de leis e da fiscalização do seu cumprimento, para que os motivos que levavam à deploração da sua miserável condição fossem amainados. A intervenção governamental pela via legal apareceria, portanto, como uma saída para se manter as condições mínimas necessárias para a continuidade do cativeiro. Naquele instante, porém, nem a soberania 
brasileira se sobreporia aos termos do tratado, nem haveria mudanças significativas na lógica interna do quadro normativo. Muito menos D. Pedro I poria freio a seus ímpetos mundanos, evidentemente ${ }^{344}$.

Neste quadro, a revalidação do modo tradicional de regulação (o que não significa a petrificação das leis existentes, mas a reprodução da lógica embutida no modo de ordenar as relações) das relações escravistas desempenharia papel importante. Observe-se a decisão de D. Pedro I de 8 de março de 1830 sobre a liberdade requerida por dois escravos:

Desejando Sua Majestade o Imperador facilitar e promover a liberdade dos escravos, sem, todavia coartar o exercício dos direitos dos senhores permitidos por lei; Há por bem que V. S. procure, por meios dóceis e persuasivos, fazer realisar aos suplicantes João e Manoel, mencionados no requerimento incluso, a liberdade prometida por sua senhora, uma vez que eles entreguem a soma pela mesma designada ${ }^{345}$.

Não é preciso acessar o teor do processo para saber do que se tratava. João e Manoel entraram na justiça porque sua senhora estava se negando a cumprir a promessa de conceder a alforria mediante compensação em dinheiro. O teor da decisão do imperador manifesta coerência com a opção política tomada em 1824. O estímulo à procura de "meios dóceis e persuasivos", ao invés da fixação legislativa clara das regras para as diferentes modalidades da alforria e o correlato resguardo dos direitos senhoriais revigoravam a antiga receita portuguesa de conduzir a escravidão, que de antemão pendia contra o escravo, a favor do sistema, sob a máscara ideológica do benefício da liberdade pelo direito. É preciso deixar claro o que está sendo dito aqui. Não se trata de subestimar as chances reais que muitos escravos tinham de acessar a liberdade em suas relações domésticas ou por meio dos tribunais, sobretudo em espaço urbano, tampouco de revitalizar qualquer concepção mecanicista de subordinação automática das instituições aos interesses da classe dominante. Thompson disse e é verdade: "se a lei é manifestamente parcial e injusta, não vai mascarar nada, legitimar nada, contribuir em nada para a hegemonia de classe alguma" ${ }^{\text {346 }}$. No Brasil, vale reforçar, desenvolveu-se um modo específico de regular a prática da escravidão, marcado pelo diálogo criativo com a tradição pregressa, pela abrangência limitada (embora crescente) do quadro legislativo e pelo pluralismo de fontes. A experiência jurídica, isto é, todo o processo de (re)produção das fontes de direito (legais, costumeiras, doutrinárias e jurisprudenciais), as variáveis em torno do cumprimento e

\footnotetext{
${ }^{344}$ Anais da Câmara dos Deputados, 2 de julho de 1827, pp.10-11. Ver: Alencastro Luiz Felipe. "La traite négrière et l'unité nationale brésilienne. Revue française d'histoire d'outre-mer". Histoire et politologie en Amérique Latine, tome 66, n.244-245 (3e et 4e trimestres 1979). pp. 395-419.

${ }^{345}$ Collecção das decisões do governo do Império do Brazil. Rio de Janeiro, Typographia Nacional, 1876, p. 59.

${ }^{346}$ Edward Palmer Thompson. Senhores \& Caçadores: a origem da Lei Negra. São Paulo: Paz e Terra, 1987, p.354.
} 
de sua violação, as reflexões e interpretações suscitadas (em sintonia com evolução das concepções jurídicas coevas), a fundamentação das ações, a tramitação dos litígios nas diferentes instâncias, desde a petição inicial até a decisão final, tudo isso, enfim, imprimiria organicidade e fluidez ao direito escravista imperial.

O ponto-chave é compreender que as eventuais conquistas pessoais envolvendo a liberdade eram plenamente compatíveis com o sistema de escravidão e que o direito escravista brasileiro, precisamente por conservar alguma coerência e razoabilidade de acordo com os critérios da época, de fato mascarou a realidade em sua profundidade ${ }^{347}$, legitimou a estrutura de dominação que envolvia o cativeiro e contribuiu de forma efetiva para a hegemonia da classe senhorial. Tudo isso de uma maneira particular, nacional, baseada em sistema jurídico particularmente pluralista e tributário do direito romano, ainda que realinhado à ordem constitucional e aos princípios do liberalismo jurídico ${ }^{348}$.

Para trazer novamente concretude à análise, cumpre examinar um caso semelhante àquele que caiu nas mãos do imperador. Em 29 de maio de 1829, Maria Thereza, africana de nação conga, moveu um libelo cível de liberdade no juízo de órfãos da Corte contra Maria Josefa Matildes do Rocher, herdeira de sua senhora, Ana do Rocher, mulher estrangeira residente no país. A situação descrita é a seguinte: um homem chamado José Fernandes Cardoso Guimarães, teria procurado dona Ana para fazer uma proposta de compra por Maria Thereza. A senhora disse que não a venderia, mas concordava em libertá-la por 300 mil-réis (quantia abaixo da média de preços da época, que girava em torno de 500 mil-réis) ${ }^{349}$. Após decidir-se por realizar o pagamento pela liberdade, José Guimarães retornou à casa de dona Ana, que, no entanto, voltou atrás, desistindo de alforriar sua escrava: eis o motivo da ação. Amparando-se em textos normativos diversos que declaravam serem mais fortes e de maior consideração as razões em favor da liberdade do que aquelas que faziam justo o cativeiro, expressamente, o alvará de 16 de janeiro de 1759, o § 4, tít. XI do Livro IV das Ordenações Filipinas, o alvará de

\footnotetext{
${ }^{347}$ Mais para os observadores futuros do que para os coevos, diga-se; os sujeitos alforriados sentiam na pele o quão difícil era sobreviver como libertos na sociedade escravocrata. Cf. Maria Sylvia de Carvalho Franco. Homens livres na sociedade escravocrata. São Paulo: Unesp, 1997; Walter Fraga Filho. Mendigos, moleques e vadios na Bahia do século XIX. Salvador: Edufba; São Paulo: Hucitec, 1996; Denise A. Soares de Moura. Saindo das sombras: homens livres no declínio do escravismo. São Paulo: Centro de Memória da UNICAMP, 1998; Henrique Espada Lima. "Sob o domínio da precariedade: escravidão e os significados da liberdade de trabalho no século XIX”, Topoi, v. 6, n.11 (2005), pp. 289-325; Renata Romualdo Diório. As marcas da liberdade: trajetórias sociais dos libertos em Mariana na segunda metade do século XVIII. Dissertação de Mestrado - FFLCH/USP, 2007; Renata Romualdo Diório. Os libertos e a construção da cidadaniaem Mariana, 1780-1840. Tese de doutorado FFLCH/USP, 2013.

348 António Manuel Hespanha. A história do direito na história social. Lisboa: Livros Horizonte, 1978, pp. 71-95.

${ }^{349}$ Mircea Buesco. 300 anos de inflação. Rio de Janeiro: Apec, 1973, p.146.
} 
30 de julho de 1609 e a lei de 6 de junho de 1755, a autora requereu o seu depósito judicial ${ }^{350}$ e apresentou a quantia estimada por sua liberdade, cedida pelo referido benfeitor, para que o tribunal obrigasse a herdeira a cumprir a promessa de sua mãe. Houve um contratempo. Sendo Maria Thereza "pessoa ilegítima para figurar em juízo", o libelo teve que ser reapresentado, pois foi contestado por falta de representação. O documento somente foi validado com a nomeação de um curador, o senhor Diocleciano Augusto Cesar do Amaral ${ }^{351}$.

$\mathrm{Na}$ sequência, seguindo o rito processual, Maria Josefa, também devidamente representada, tratou de desacreditar as razões expostas pela autora, afirmando que tudo não passava de "um montão de calúnias" inventadas por José Guimarães, que era amasio da escrava. A história começou porque a mãe da ré encarregava Maria Thereza de fazer compras para o sortimento da lojinha da família. Durante as saídas, Guimarães, taberneiro de profissão, teria começado a assediar a cativa, conseguindo o que dela pretendia "com grandes promessas de liberdade". Após o início do envolvimento, Maria Thereza teria passado a demorar mais tempo do que o habitual na rua, muitas vezes chegando em casa arranhada, machucada; Guimarães era ciumento e, por isso, batia nela. Inteirada do que estava acontecendo, a mãe da ré tratou de impor maior recato a sua escrava, proibindo-lhe de sair de casa. Sentido falta de sua amante, o taberneiro passou a fazer "todos os esforços que lhe sugeria a sua criminosa afeição" para tê-la de volta. Nada mais surtindo efeito, bolou "a estratégia de que trata o libelo". Tudo, "uma refinada mentira de propósito inventada para ludibriar o direito de propriedade da ré e iludir a lei”. Pelo prisma legal, argumentava inexistir norma que protegesse a liberdade do escravo "para fins libidinosos". Além do mais, nunca teria sido feita nem a Guimarães nem a qualquer outra pessoa uma oferta sequer de venda ou de concessão da alforria mediante pagamento. A autora seria incapaz de provar o contrário, a não ser com testemunhas dependentes dos copos de cachaça que Guimarães lhes pudesse dar ou dos "afagos e carícias africanas" de Maria Thereza. Ademais, manifestando a sua baixa condição econômica, a ré alegava que jamais desejaria vender a autora, porque carecia dos seus serviços, principalmente na cozinha, muito menos alforriá-la, já que Maria Thereza não fazia por merecer com a prestação de bons serviços, indigna, portanto, "da menor contemplação benéfica" ${ }^{352}$.

\footnotetext{
${ }^{350}$ A origem legal do depósito judicial de escravos normalmente é a atribuída ao Aviso da Casa de Suplicação de Lisboa, de 3 de novembro de 1783, que "declarou as Pretas que se achavam em cadeia pública, em quanto se litigava sobre sua liberdade, fossem por esta ser mui favorável transferidas para depósitos particulares, onde seus contendores as sustentassem durante o litígio". Manuel Borges Carneiro. Direito Civil de Portugal. Lisboa : Typ. Maria da Madre de Deus, 1858. L. 1., p.96.

${ }^{351}$ Arquivo Nacional (RJ). Apelação Cível, Tribunal da Relação, 84.0.ACI.207 (1833-1836 RRJ mr 063/ Arquivo Edgard Leuenroth - AEL) (Antiga C3683N544).

352 Arquivo Nacional (RJ). Apelação Cível, Tribunal da Relação, 84.0.ACI.207 (1833-1836 RRJ mr 063/ Arquivo Edgard Leuenroth - AEL) (Antiga C3683N544), f.55.
} 
Em 23 de outubro de 1831 veio a primeira sentença. As alegações da autora foram consideradas infundadas pelo juiz, que determinou o seu retorno ao cativeiro. Mas a batalha não parou por aí, subindo ao Tribunal da Relação do Rio de Janeiro. Afora o registro de mais uma antiga norma portuguesa que dizia serem mais fortes as razões a favor da liberdade, o alvará de 10 de abril de 1680, e outra referência à lei de 6 de junho de 1755, pelo que declarava incidir a obrigação de prova sempre sobre os que requeriam contra a liberdade, na apelação de Maria Thereza mencionou-se um Aviso de 18 de março de 1701, pelo qual, em caso idêntico, ordenou-se que o governador da Bahia obrigasse uma senhora da localidade a passar carta de liberdade a uma escrava sua. Do ponto de vista argumentativo, a estratégia seguida pela defesa de Maria Thereza foi reforçar a tese de que uma vez "aberto preço à liberdade e do qual não podia ser espoliada porque os tratos se devem cumprir religiosamente, máxime a favor da liberdade, que de todas é a causa mais favorecida". Buscou-se, também, refutar a história de que tinha um relacionamento "ilícito" com o benfeitor, José Guimarães: "tais razões são a evasiva ordinária a que recorrem os opressores da liberdade". Também, novos fatos foram acrescentados. Tamanho seria o mau ânimo de Maria Josefa para com Maria Thereza e sua oposição à consecução da liberdade que, em 1829, ela teria mandado dar-lhe tantas pancadas que delas resultaram feridas e contusões nos pés e, principalmente, no peito, "de forma que esteve em perigo de vida". A intenção seria uma só: cometer assassinato ${ }^{353}$.

Na nova exposição de suas razões, a defesa de Maria Josefa sustentou que ninguém poderia estar seguro em suas propriedades sobre os escravos caso os argumentos colocados pelo defensor de Maria Thereza fossem aceitos. A mãe da apelada havia comprado a apelante de forma legítima, tendo-a tratado sempre com caridade e desvelo, educando-a de maneira muito superior, diferente do tratamento que muitas pessoas davam aos seus escravos. "E qual foi o pagamento? Deixar-se seduzir por um taberneiro, fugir de casa de sua senhora e levantar contra esta calúnia”, propiciando, enfim, a sua morte com todos os desgostos e incômodos de um pleito injusto. "Se por um só minuto fosse entendida a nossa legislação como manhosamente quer a apelante, [...] seríamos na prática a maior anarquia que se pode imaginar [...]. Não haveria escravo que se não jurasse forro e como a prova da liberdade lhe não incumbia, segundo capciosa doutrina do patrono da apelante, não precisava fazer mais nada do que fugir, [...] visto que a seus senhores, não a eles, pertencia provar o cativeiro" 354 . Quanto ao aviso de 1701, a analogia seria incabível, já que no episódio ocorrido no século XVIII era certo que a senhora havia prometido a liberdade e aberto preços, diferentemente do ocorrido neste caso. Por fim,

\footnotetext{
${ }^{353}$ Idem, f.91

${ }^{354}$ Idem, f. 133.
} 
no concernente à denúncia de agressão, seria esta mais uma tramoia de Guimarães, que já havia facilitado todos meios para a evasão de Maria Thereza, preparado depósitos para sua pessoa, comprado testemunhas, estaria, agora, tratando de corromper o cirurgião, um velhaco que acabou expulso de seu ofício, para que celebrasse um falso auto de corpo de delito. Teria havido, sim, um incidente alguns anos antes, mas os fatos seriam outros. Um dia, quando a apelada tinha a idade de catorze anos, saiu de casa por incumbência de sua mãe. Por acaso, encontrou a apelante pela rua e tentou persuadi-la com palavras a retornar à presença de sua senhora. Mas, Maria Thereza, "confiada em seu protetor, estava por isso atrevida, e longe de tratar com boas maneiras e com aquele respeito que devia à apelada, como escrava que era de sua mãe, não cumpriu assim, antes, com os mais atrozes impropérios, se lançou a ela e a levou por terra, o que conseguiu facilmente, em razão das poucas forças da apelada naquela idade”. Tal ato, praticado em plena luz do dia, em rua pública, teria escandalizado alguns indivíduos que transitavam por ali, que então foram acudir Maria Josefa. Então, ao salvá-la do insulto que sofria, foi que desferiram murros em Maria Thereza, conduzindo-a a força para a residência de sua senhora. Esta julgou-se no direito de reter a escrava no interior de sua casa, sem fazer-lhe, porém, o menor castigo. Por esta ocasião, Guimarães teria feito com que a apelante fosse conduzida para o depósito na casa de um fiador, por ordem do Intendente Geral de Polícia. "Eis aí, Ilustríssimos Togados, a verdade do fato" ${ }^{355}$.

No dia 26 de março de 1835 veio a lume o Acórdão do Tribunal: a sentença apelada foi mantida. Maria Thereza, mulher africana, de nação conga, deveria ser reconduzida ao cativeiro, além de ser condenada nas custas processuais. Um último recurso ainda seria interposto. No entanto, o derradeiro Acórdão emitido em 18 de fevereiro de 1836 manteve as decisões anteriores. Os elementos apresentados por Maria Thereza para a confirmação de seu direito à liberdade foram todos insuficientes ao final. Triste destino. Os fatos narrados demonstram a complexidade e as nuances da sociedade escravista brasileira. Não foi o poder econômico puro e simples que prevaleceu, visto que havia um agente externo, aparentemente, com maiores recursos. Imperou a lógica do direito escravista. Como visto, o descumprimento de uma promessa de alforria seguida da fixação de preço constituiu o ponto central da ação. Trata-se de um dado importante. Os termos da defesa de Maria Josefa não questionaram a validade abstrata da força coercitiva do ato senhorial de se prometer a liberdade. O seu ímpeto concentrou-se em desacreditar a existência fática da promessa e do ajuste de preço alegados, algo facilitado por se tratar de um pacto sem comprovação por registro formal, por escrito, em uma carta ou no

${ }^{355}$ Idem, ibidem. 
testamento, por exemplo. Está claro que prometer a alforria gerava uma obrigação social e jurídica para o senhor, que podia ser vindicada como geradora de um direito adquirido em juízo. Nisto talvez repousasse alguma importância das referências todas às normas antigas que haviam afirmado o favorecimento da liberdade pelo direito. Mesmo assim, salta aos olhos a fragilidade de um expediente como esse. Caso houvesse sido incorporada uma norma como a idealizada no artigo quinto da Representação de Bonifácio, que estipulava o direito à manumissão onerosa, o problema de Maria Thereza seria de solução muito mais simples, pelo menos em termos de fundamentação jurídica. A questão da promessa seria irrelevante diante da oferta do valor corresponde à alforria. Da forma como estava, o sistema jurídico afunilava as brechas, favorecendo muito mais a propriedade do que a liberdade. Manuela Carneiro da Cunha credita ao período do predomínio liberal (1827-1837) um período de maior suscetibilidade do judiciário à promoção das alforrias onerosas. Aliada à recomendação de D. Pedro I, em 1830, para a adoção de "meios dóceis e persuasivos", mencionada acima, a antropóloga menciona dois avisos daquele mesmo ano (17 de março e 29 de julho) e outro de 15 de dezembro de 1831 aconselhando meios conciliatórios para que senhores aceitassem libertar seus escravos mediante indenização. Porém, tais indicações em absoluto significam uma chancela, ainda que temporária do direito à alforria onerosa, à revelia da vontade senhorial ${ }^{356}$.

Voltando ao caso de Maria Josefa, cumpre realçar o princípio ventilado pela defesa de Maria Thereza de que o ônus da prova tocava ao que requeria contra a liberdade. Ele realmente podia ser derivado de normativas como a lei citada de 6 de junho de 1755, o famoso alvará de 10 de março de 1682 e outros extratos originários do direito romano ${ }^{357}$. Mas o contrário também existia como frequentemente ocorre na seara jurídica. José Homem Corrêa Telles, por exemplo, ao explicar do que se tratava uma ação de liberdade, afirmou categoricamente que cabia ao autor o ônus de provar sua liberdade. A verdade é que as razões contestatórias apresentadas pela defesa de Maria Josefa sobre o tópico se aproximam bastante da realidade da sociedade escravista. Os proprietários podiam dormir tranquilos com relação a isso. Livres ou libertandos, as pessoas negras em geral eram reiteradamente constrangidas a comprovar a sua condição ${ }^{358}$. $\mathrm{Na}$ prática, as ameaças ao domínio senhorial eram muito reduzidas, lembrando que afora os casos corriqueiros de escravização ilícita, o período entre 1818 e 1831 fez crescer em aproximadamente 50 mil vidas o número de homens e mulheres livres indevidamente em

\footnotetext{
${ }^{356}$ Cunha. "Sobre os silêncios da lei...", pp.128-129.

${ }^{357}$ Lara. "Legislação sobre escravos africanos na América Portuguesa”, p.41.

${ }^{358}$ Lima. "Sob o domínio da precariedade...", op.cit.;Sidney Chalhoub. "Precariedade estrutural: o problema da liberdade no Brasil escravista (século XIX)". História Social, n. 19 (segundo semestre de 2010), pp.34-62.
} 
cativeiro, ilegalmente trazidos de regiões africanas ao norte do Equador. Este quadro não melhorou com a primeira lei nacional de supressão do tráfico, promulgada em 7 de novembro de 1831, já no período regencial. Os trabalhos de Jaime Rodrigues, Beatriz Mamigonian e Tâmis Parron demonstram que, ao contrário do que ficou consagrado no dito popular, a norma não foi feita meramente para agradar os olhos britânicos ${ }^{359}$. Sob a égide da segurança social e da correição moral dos costumes, instalara-se no Parlamento uma atmosfera antitráfico que se traduziu em um arranjo político majoritariamente partidário ao banimento efetivo do infame comércio, no limite, da própria escravidão. Em de sessão do dia 15 de junho, o senador Antônio Luís Pereira da Cunha, agora marquês de Inhambupe, que havia participado da redação da carta constitucional, enunciou claramente: “estamos todos conformes, ninguém quer conservação da escravatura, do que se trata é de remediar o mal e tirar o inconveniente" 360 .

Fruto de deliberação autônoma do poder legislativo do país, dominado nos primeiros anos da regência pelo grupo político dos moderados, a lei de 1831 previu que ficariam livres (não, libertos) os africanos que entrassem no território ou nos portos do Brasil dali em diante. Sem passar por comissão mista, caberia como punição o estipulado no artigo 179, que tipificava o crime de se "reduzir à escravidão a pessoa livre, que se achar em posse da sua liberdade", a saber, pena de três a nove anos de prisão, mais multa. A punição se aplicaria a todos os qualificados como "importadores", o que abrangia traficantes, negociantes locais e até senhores que porventura adquirissem africanos livres a partir daquela data, o que extrapolava as exigências que o tratado de 1826 com a Inglaterra haviam previsto ${ }^{361}$. Homens fortes do executivo como Bento da Silva Lisboa, no ministério dos negócios estrangeiros, e Diogo Antônio Feijó, na pasta da justiça, apoiariam de modo vívido o cumprimento da lei. O último inclusive mandou que fossem distribuídos cartazes anunciando a punição aos infratores. Houve um resultado imediato. Os ingressos baixaram de mais de 50 mil em 1830 para algo em torno de 6 mil escravos em 1831. Decreto de 12 de abril de 1832 regulamentaria a execução da lei, estabelecendo, entre outros pontos, que todos os barcos deveriam passar por inspeção imediata ao aportarem e antes de zarparem (arts. 1-4); que os negros apreendidos deveriam ser postos imediatamente em depósito, ficando os importadores obrigados a financiar a sua "reexportação" (art.5); que a autoridade perante a qual fosse manifestada a compra de "preto boçal" procedesse à averiguação sobre o entendimento ou não da "língua brasileira" por meio de intérprete,

\footnotetext{
${ }^{359}$ Mamigonian. To be a libereted african in Brazil, op.cit.; Jaime Rodrigues. O infame comércio: propostas e experiências no final do tráfico de africanos para o Brasil (1800-1850). Campinas: Editora Unicamp, 2005;Parron. A política da escravidão no Império do Brasil, op.cit.

${ }^{360}$ Anais do Senado, 15 de julho de 1831, pp.361-374.

${ }^{361}$ Coleção de Leis do Império do Brasil - 1831, vol. 1, p.182.
} 
ouvindo, em todos os casos, de forma sumária, as partes envolvidas (art.9) ${ }^{362}$. O crescimento das apreensões levaria o Executivo a emitir instruções em 13 e 29 de outubro de 1834 sobre o destino a ser dado aos africanos sob custódia do estado na Casa de Correção, instituição penal recém criada. Não havendo passado no Corpo Legislativo "medida alguma para a pronta reexportação dos africanos ilicitamente introduzidos no Império, como havia solicitado o Governo, e como o determina a Lei de 7 de Novembro de 1831, vendo crescerem as despesas com os que foram depositados na Casa de Correção", que os seus serviços fossem empregados em obras públicas ou arrematados por "pessoas de muita probidade e inteireza", até que a reexportação fosse providenciada pelo estado. Aos africanos seria entregue uma latinha para que prendessem ao pescoço com inscrições declarando que era livre e com seus dados pessoais. Também seria nomeado um curador pelo juiz para que fiscalizasse a tratamento dispensado e a manutenção de sua liberdade, e arrecadasse anualmente o salário estipulado ${ }^{363}$.

No plano institucional mais amplo, haveria mudanças importantes. O Código do Processo Criminal de 29 de novembro de 1832, primeiro grande êxito dos liberais moderados durante o período Regencial, também dispôs acerca da administração da Justiça Civil. Pelo seu texto, as antigas colocações, isto é, ouvidores de comarcas, juízes de fora e ordinários foram formalmente extintas (art. $8^{\circ}$ ). Adotou-se uma divisão administrativa entre distritos de paz, termos e comarcas $\left(\operatorname{art.} 1^{\circ}\right)$. O juizado de paz - previsto na carta constitucional, regulamentado por Lei de 15 de outubro de 1827 e com sucessivos reforços em suas funções - teve o seu papel solidificado. Aos juízes de paz incumbia a conciliação prévia das partes, o julgamento de causas cíveis que não excedessem dezesseis mil réis, o conhecimento de atos criminosos, entre outras funções correlatas. O provimento do cargo se daria por eleição popular, para um período de um ano, cabendo um a cada distrito (arts. $12^{\circ}-13^{\circ}$ ). A demarcação dos distritos de paz deveria ser efetuada pelas câmaras municipais, contendo, cada um, pelo menos setenta e cinco casas habitadas (art. $\left.2^{\circ}\right)^{364}$. A jurisdição dos termos corresponderia aos juizes municipais, que grosso modo substituíam os antigos juízes ordinários. Criados por meio do Código do Processo, a sua nomeação seria efetuada, não pelo poder central, mas pelo presidente de província, que escolheria um para cada termo a partir de listas tríplices fornecidas pelas respectivas câmaras

\footnotetext{
${ }^{362}$ Isabele Mello. Legislação, escravidão, século XIX. Tribunal de Justiça do Estado do Rio de Janeiro. Serviço de Gestão de Acervos Arquivísticos Permanentes (DGCON/ SEGAP) (mimeo), 2010, p.40.

${ }^{363}$ Mamigonian. To be a libereted african in Brazil..., cap 2.

${ }^{364}$ O Ato Adicional (1834) transferiu essa atribuição para Assembleias Provinciais. Cf. Wilson Carlos Rodycz. "O juiz de paz imperial: uma experiência de magistratura leiga e eletiva no Brasil”. Revista Justiça \& História, v. 3, n. 5. Disponível em: <http://www.tjrs.jus.br/export/poder_judiciario/historia/memorial_do_poder_judiciario/memorial_judiciario_gau cho/revista_justica_e_historia/issn_1676-5834/v3n5/doc/02-Wilson_Rodycz.pdf >. Acesso: 30 de jun. 2012.
} 
municipais. A lei impunha a formação em direito, embora, na prática, isso dificilmente tenha sido observado. Entre as suas atribuições estava: substituir o juiz de direito em seus impedimentos; executar sentenças e mandatos expedidos pelas esferas superiores; e exercitar cumulativamente a jurisdição policial (arts. $33^{\circ}-35^{\circ}$ ). Aos juízes de direito pertenceria alçada das comarcas. Previstos no texto constitucional, foi apenas no Código do Processo que as suas funções foram regulamentadas. Haveria um por comarca, a não ser nas cidades populosas, onde poderiam existir até três, com jurisdição cumulativa (art. $6^{\circ}$ ). Ocupando o topo do judiciário em primeira instância, único posto vitalício, entre as suas funções estavam: percorrer os termos de sua jurisdição para presidir os Conselhos de Jurados; conceder e derrogar fianças; inspecionar os juízes de paz e municipais, instruindo-os e julgando os atos cíveis que ultrapassassem a sua competência (arts. $44^{\circ}-47^{\circ}$ ). O Ato Adicional aprovado em 12 de agosto de 1834, que instalou no país um sistema administrativo mais centrífugo, aumentou um pouco mais a descentralização judiciária estabelecida com o Código do Processo, facultando às então criadas Assembleias Provinciais, por meio de seu artigo $11 \S 7^{\circ}$, a competência de suspender ou demitir magistrados ${ }^{365}$.

Essas modificações tiveram algum impacto sobre as possibilidades de acesso dos cativos ao poder judiciário, que se expandiu ${ }^{366}$. Isto não foi suficiente para engendrar uma atmosfera disruptiva. Como as ações envolvendo a liberdade de escravos não configuravam ações especiais, nenhuma medida ditou fórmulas ou competências específicas aos julgadores que tomassem conhecimento de libelos ou petições de libertandos; muito menos foram previstos novos direitos aos cativos ou reconhecimento práticas costumeiras em torno da manumissão. A revogação do tráfico seria um duro golpe no escravismo, caso se completasse, mas seria preciso ir além. Aqueles que lutavam pela alforria nas arenas judiciais continuavam tendo que encarar um ordenamento que sustentava a primazia da vontade senhorial, consagrada pelo direito constitucional à propriedade. Nisto, ninguém iria mexer.

O cenário pode ser mais bem compreendido a partir do processo envolvendo o libertando Vicente Ferreira e o senhor Antônio José Francisco Guimarães. Homem africano de nação mina, Vicente, com o auxílio de seu curador, o Dr. Carlos Ferreira da Silva, ajuizou uma ação para a manutenção de sua liberdade no dia 22 de julho de 1833 na $2^{\mathrm{a}}$ vara cível da Corte, alegando ter sido alforriado. A prova de sua condição era uma certidão extraída da Intendência

\footnotetext{
${ }^{365}$ Coleção de Leis do Império do Brasil - 1834, Vol. 1, p.15. Cf, Thomas Flory. Judge and Jury in Imperial Brazil, 1808-1850. Social Control and Political Stability in the New State. Texas: University of Texas Press, 1981, pp. 45-128; Miriam Dohlnikoff. O pacto imperial. Origens do federalismo no Brasil. São Paulo: Globo, 2005, pp. 81124.

${ }^{366}$ Diório. Os libertos e a construção da cidadania em Mariana, pp.188-190.
} 
Geral de Polícia que registrava o seu despacho como forro para uma viagem com destino a Angola e Benguela em 14 de maio de 1829. Antônio Guimarães, porém, apresentara um libelo chamando-o à escravidão, negando que o havia libertado. A decisão de primeira instância foi favorável à liberdade. Mas o senhor recorreu da decisão e o processo chegou ao Tribunal da Relação do Rio de Janeiro.

A intenção de conduzir Vicente de volta ao cativeiro foi sustentada com base em três ideias ajustadas ao ordenamento jurídico vigente: primeira, que a liberdade conferida a um escravo não se presumia sem se provar, segunda, que esta prova podia ser por testemunhas, mas, mais essencialmente, por documentos dos quais resultasse um título legítimo de liberdade conferida gratuita ou onerosamente, terceira, que sem este requisito "é perigoso postergar o direito de liberdade tão sabidamente garantido pela constituição, quando se intente julgar temerariamente a favor da liberdade". No entanto, a certidão apresentada por Vicente de modo algum poderia configurar prova da alegada alforria. Tratar-se-ia, meramente, de um despacho feito pelo senhor por precaução antes de partir ao continente negro. Isto porque, caso a embarcação fosse tomada por "corsários" que então pululavam o oceano Atlântico, eles não levariam Vicente como "costumavam fazer a respeito dos escravos, deixando apenas os criados livres". O arrazoado do advogado se vale de certa sutileza, mas a situação é mais do que clara. Os "corsários" não eram outros senão os tripulantes dos cruzeiros britânicos que aumentavam suas perseguições às embarcações dedicadas ao comércio transoceânico de escravos ${ }^{367}$. Antônio José Francisco Guimarães atuava como capitão de navio negreiro. A base de dados The voyages database, disponível na rede, registra o seu nome no comando do bergantim Novo Triunfo, de propriedade João Gomes Neto, que desembarcou 408 escravos provenientes majoritariamente de Luanda no porto do Rio de Janeiro em 19 de abril de 1830. É possível que Vicente tenha tripulado esta mesma nave ${ }^{368}$.

A ação passou pelo escrutínio do Tribunal da Relação do Rio de Janeiro, que, por meio do Acórdão de 8 de agosto de 1835, reformou a sentença de primeira instância, devolvendo Vicente ao cativeiro. Ante o revés, foi encaminhado pedido de revista ao Supremo Tribunal de Justiça. No recurso, insistiu-se no fato de que o senhor havia comparecido à repartição pública da polícia e declarado livremente e sem constrangimento que o recorrente era forro e que o levaria em sua companhia como criado. Alegou-se, ademais, que o título de alforria existia. Porém, vivendo, não mais como escravo, mas como criado de seu benfeitor, "confiando muito

\footnotetext{
${ }^{367}$ Arquivo Nacional (RJ), Revista Cível, Supremo Tribunal de Justiça, BU.0.RCI.5 (C3683N544) (1833-1836 STJ mr 003 - AEL).

${ }^{368}$ Disponível em: <www.slavevoyages.com>. Acessado em 10 de jun. 2014.
} 
neste, e debaixo de boa-fé, deixou que o recorrido guardasse o referido título, o qual nunca mais lhe deu". De nada adiantou. Em 14 de abril de 1836, o Supremo manifestou recusa ao pedido de revista: a escravidão venceu. Em verdade, o regozijo do traficante estaria além da vitória contra Vicente ${ }^{369}$.

Em um contexto de expansão do mercado mundial, o tráfico voltava a ganhar impulso, fomentando o desenvolvimento do Vale do rio Paraíba do Sul e, em escala variada, noutras zonas como Campos dos Goytacazes, o Sul de Minas Gerais e o Recôncavo baiano, bem como nos principais centros urbanos do império, a começar pela Corte ${ }^{370}$. A interdição legal do ingresso de novos escravos africanos representava, portanto, um grave estorvo aos interesses do setor, que se articularia politicamente sob a batuta de homens como Bernardo Pereira de Vasconcelos, Honório Hermeto Carneiro Leão, Joaquim José Rodrigues Torres e Paulino José Soares de Souza, os fundadores do Regresso conservador. Por um breve (porém, intenso) período, o campo político ficou em disputa. Medidas contrárias ao tráfico e à escravidão seriam barradas pela oposição. O Regente Diogo Feijó, eleito em abril, logo tentou obter a aprovação parlamentar de Artigos Adicionais à convenção de 1826. Assinada pelo então ministro dos negócios estrangeiros, Manoel Alves Branco, diante da pressão da diplomacia britânica, seu teor endurecia os instrumentos de perseguição e captura aos operadores do comércio clandestino. Não teve sucesso. Do Parlamento, ainda surgiam propostas esparsas direcionadas à superação do trabalho escravo. $\mathrm{O}$ antigo constituinte baiano Antonio Ferreira França voltou novamente à cena, propondo na Câmara a decretação da liberdade para os pardos nascidos no Brasil e a contrapartida em serviços para as pessoas que os criassem, fazendo-os aprender as primeiras letras e um ofício. Já Antônio Luís Patrocínio da Silva Manso, representante do Mato Grosso, foi além, apresentando um extenso projeto de lei prevendo uma remodelação do regime de trabalho a partir de uma nova classificação dos trabalhadores em domésticos, serventes e escravos. Os últimos, dispondo do valor correspondente, teriam o direito à liberdade. Bastaria que "dessem parte" de seu propósito ao curador e, este, ao juiz de paz, que por sua vez mandaria

\footnotetext{
${ }^{369}$ Arquivo Nacional (RJ), Revista Cível, Supremo Tribunal de Justiça, BU.0.RCI.5 (C3683N544) (1833-1836 STJ mr 003 - AEL), f.107. Para um estudo de caso semelhante, ver: Mariana Armond Dias Paes. "Precarização do direito e da liberdade no Brasil Império: estudo do processo de reescravização de Brasília". II Seminário Internacional Mundos do $\quad$ Trabalho, $2012 . \quad$ Disponível <https://www.academia.edu/11655434/Precariza\%C3\%A7\%C3\%A3o_do_direito_e_da_liberdade_no_Brasil_Im p\%C3\%A9rio_estudo_do_processo_de_reescraviza\%C3\%A7\%C3\%A3o_de_Bras\%C3\%ADlia>. Acesso em 27 de abril 2015.

370 Rafael de Bivar Marquese, Feitores do corpo, missionários da mente. Senhores, letrados e o controle dos escravos nas Américas, 1660-1860. São Paulo: Companhia das Letras, 2004, pp.259-298; Francisco Vidal Luna \& Herbert S. Klein. Evolução da Sociedade e Economia Escravista de São Paulo, de 1750 a 1850. (trad.port.) São Paulo: Edusp, 2005, pp.81-106; Ricardo Salles, E o Vale era o escravo: Vassouras, século XIX. Senhores e escravos no coração do Império. Rio de Janeiro: Civilização Brasileira, 2008, pp.258-9.
} 
aviso ao senhor para que apresentasse o escravo em dia determinado para o recebimento do dinheiro e o lavramento da escritura de liberdade. O cativo que tivesse apenas metade do seu valor poderia igualmente apresentá-la, tendo 15 anos para quitar o restante do débito; passado este prazo, seria liberto automaticamente, mesmo não havendo saudado a dívida ${ }^{371}$. Nada disso chegou a ser objeto de deliberação. Pior para os escravos, não há dúvida. Algo daquele tipo ajudaria Vicente, por exemplo, que, após avaliação, chegou a oferecer a soma equivalente ao seu valor ao longo do processo (400 mil-réis), mas, teve sua proposta rechaçada pelo senhor, que alegou não ser obrigado a se desfazer de sua propriedade, nos termos do tít. 11 do Livro IV das Ordenações Filipinas ${ }^{372}$.

Em função dos temores atiçados após a Revolta dos Maleses, ocorrida em janeiro de 1835, foi desengavetado o projeto de lei formulado quase dois anos antes, após outra rebelião escrava, a de Carrancas, ocorrida em Minas Gerais. A lei promulgada em 10 de junho estipulou a pena capital para os escravos e escravas que "matarem por qualquer maneira que seja propinarem veneno, ferirem gravemente ou fizerem outra qualquer grave ofensa física a seu senhor, a sua mulher, as descendentes ou ascendentes, que em sua companhia morarem, a administrador, feitores e às suas mulheres, que com eles viverem" ${ }^{373}$. Mas as penalidades não pareciam suficientes diante do crescimento evidente dos "inimigos internos". Deputados provinciais da Bahia encaminharam à Assembleia Geral um conjunto de medidas para conter a ameaça. Entre elas constava o estabelecimento de uma colônia na costa da África para receber os africanos libertos (nenhuma novidade), a realização de uma convenção com o Uruguai e Províncias do Rio da Prata para a interdição da entrada de africanos na região e a proibição absoluta do comércio direto do Brasil com a costa africana de leste a oeste, com exceção à colônia do Cabo. Reclamava-se do desrespeito à lei de 1831, visto que a "sórdida e insaciável cobiça de alguns traficantes imorais, os quais a despeito das leis, e de gritos de terror de seus concidadãos, continuam a inundar nossas províncias de inimigos tão mortais, que com a morte nos legam os ódios de seus filhos". De todos os pontos, apenas o último foi acatado. Resolução

\footnotetext{
${ }^{371}$ Anais da Câmara dos Deputados, 29 de agosto de 1835, pp. 218-225; Parron. A política da escravidão..., pp.98100.

${ }^{372}$ Como veremos no próximo capítulo, em Cuba, havia desde o fim do século XVIII o direito legal dos escravos à alforria onerosa, mas o arranjo do regime tinha suas peculiaridades.

${ }^{373}$ Mello. Legislação de escravos, pp.49-50; João Luiz Ribeiro. No meio das galinhas, as baratas não têm razão: a lei de 10 de junho de 1835, os escravos e a pena de morte no Império do Brasil (1822-1889), Rio de Janeiro: Renovar, 2005; Marcos Ferreira de Andrade. Rebeldia e resistência: as revoltas escravas na província de Minas Gerais (1831-1840). Dissertação de mestrado - UFMG, 1996; Idem. "Rebelião escrava na Comarca do Rio das Mortes, Minas Gerais: o caso Carrancas" in: Revista Afro-Ásia, números 21-22, 1998-1999, pp.45-82; Idem. Elites regionais e a formação do Estado Imperial Brasileiro: Minas Gerais - Campanha da Princesa (1799-1850). Rio de Janeiro: Arquivo Nacional, 2008, pp. 298-322; Ricardo Figueiredo Pirola. A lei de 10 de junho de 1835: justiça, escravidão e pena de morte. Tese de Doutorado - UNICAMP, 2012.
} 
de 17 de agosto de 1835 estabeleceu a interrupção de quaisquer atividades comerciais com as costas da África. Neste momento exato, o contrabando, em escala ascensional, ainda acontecia ao arrepio dos poderes públicos do império ${ }^{374}$. O panorama mudaria, e rapidamente.

Perfilados em torno da reforma do Código do Processo Criminal e do Ato Adicional, os maiores êxitos institucionais dos liberais moderados, e da ineficácia da Lei de 1831, tomada como a condição fundamental para a prosperidade do setor agroexportador, os regressistas começavam a montagem de um campo majoritário que os levaria ao poder no "segundo ato". O representante mineiro, Bernardo Pereira de Vasconcelos, que no início de sua carreira política havia se colocado a favor da vedação do tráfico diante do isolamento internacional do Brasil, tornar-se-ia o principal articulador da política a favor do contrabando de escravos nos anos seguintes. Em verdade, a sua iniciativa original foi promover a revogação da norma. Sem delongas, no dia 24 de julho de 1835, ele mandou à mesa da Câmara a seguinte emenda: "fíca abolida a lei de 7 de novembro de 1831". O colega Bernardo José da Gama, visconde de Goiana, o mesmo que havia sido preso e deposto da presidência da província do Grão-Pará pelos rebeldes da Confederação do Equador, objetou com uma franqueza exemplar, classificando a emenda como "impolítica [sic] e ociosa; que a lei que a emenda pretende abolir fora fundada sobre um tratado; [...] que, finalmente, não parecia decente que o corpo legislativo abula essa lei existente de 1831, não obstante ela já estar em pouco uso"375. Com alguma adequação, é possível extrair dessa fala o signo da política a respeito do contrabando de escravos costurada no momento seguinte: não pareceria conveniente derrogar uma lei que cuja existência atendia ao compromisso internacional firmado, nem necessário, já que não se cumpria.

Como demonstraram os trabalhos de Alain El Youssef e Tâmis Parron, a política do contrabando negreiro, que conferiu respaldo institucional à continuidade do infame comércio e segurança jurídica à propriedade ilegal, só se estabeleceu por meio de uma forte articulação na imprensa, nas esferas legislativas e, finalmente, nas ações do Executivo. A proibição do tráfico foi intensamente criticada e, a escravidão, ideologicamente reabilitada. Em artigo publicado no jornal $O$ Sete d'Abril, em primeiro de agosto de 1835, Vasconcelos desencadeou a campanha pública pela reabertura da importação de cativos, destacando o ajuste da escravidão aos costumes do país, a sua conveniência econômica e o seu suposto proveito aos próprios africanos, "que melhoravam de condição". Em 25 de junho de 1836, o político voltou à carga no parlamento, propondo a revogação "apenas" dos seis primeiros artigos da lei de 1831, isto

\footnotetext{
${ }^{374}$ Parron. A política da escravidão..., pp.121-190. Naquele ano entraram cerca de 35 mil escravos ilegais no país. Ver índices em <www.slavevoyages.com>.

375 Anais da Câmara dos Deputados, 24 de julho, 1835.
} 
é, aqueles que propriamente barravam a importação de escravos, em razão dos "fatos que não podem continuar a praticar-se sem grave prejuízo da moral e do interesse público e particular"376. A possibilidade de anulação do teor coercitivo da norma em relação ao contrabando entusiasmou corações e mentes escravocratas. A sua repercussão entre os plantadores do Vale do Paraíba foi imediata, ganhando forma com a representação encaminhada pela Câmara do município cafeeiro de Valença, que reforçou a iniciativa parlamentar, cobrando a legalização do tráfico que correntemente praticavam "por necessidade". De fato, o contrabando já corria solto. Os negreiros despontavam aos montes pela orla brasileira. Naquele ano de 1836, entraram mais de 52 mil escravos no país, 42 mil apenas para a região sudeste, aquecida com a crescente produção cafeeira vale-paraibana.

Na sessão do dia 30 de junho de 1837, Felisberto Caldeira Brant Pontes de Oliveira Horta, o marquês de Barbacena, apresentou no Senado uma proposta para "refundir a lei de 7 de novembro de 1831, em outras que dê providências mais amplas e mais eficazes em seus feitos". No introito do projeto, fez um balanço a respeito da experiência de seis anos de proibição do tráfico, começando por observar que não obstante o empenho do Corpo Legislativo, "foi poderoso o estímulo para dar energia, desteridade e fortuna a essa classe de negociantes, que especialmente se ocupa de importar escravos”. Nos primeiros dois anos, prosseguiu Barbacena, foi pequena a importação, pois

\footnotetext{
"ainda não se haviam descoberto os meios de iludir os exames na entrada e saída dos portos; não se haviam estabelecido vários depósitos para recepção dos escravos, o ensino da língua portuguesa; não existiam corretores organizados em força para levar os escravos a cada fazenda, para tentar a inocência dos lavradores. Logo porém, que toda esta máquina foi montada, começou a crescer a importação a ponto, que bem se pode dizer sem receio de exageração, que ela tem sido nestes últimos três anos muito maior do que nunca fora nos tempos do comércio franco e legal”377.
}

Prosseguiu traçando uma ponderação parcimoniosa a respeito do engajamento dos lavradores na ilegalidade, os quais

\footnotetext{
"comprando a princípio os escravos, que supunham ladinos, porque falavam mais ou menos português, e tirando grandes proveitos deste recrutamento, pelo alto e constante preço de nossos gêneros, principalmente do Café, não duvidaram depois comprar quantos apareciam ladinos ou novos, seduzidos pelo irresistível desejo, natural em todos, de conservar e aumentar a própria fortuna. Entretanto qual não pode vir a ser o funesto resultado desta infração da Lei? A Assembleia Geral Legislativa que, com tanta previsão política, soube ocupar-se da cessação do tráfico da escravatura, saberá agora, com igual previsão benéfica, ocupar-se da sorte dos lavradores. Longe de mim fazer o elogio daqueles que infringem a lei com pleno conhecimento de causa; mas confesso ingenuamente, que nenhuma infração de lei jamais
}

\footnotetext{
${ }^{376}$ Anais da Câmara dos Deputados, 25 de junho, 1836, p. 224.

${ }^{377}$ Anais do Senado, 30 de junho de 1837, p.176.
} 
houve que apresentasse tão plausíveis razões para ser atenuada, se não esquecida como aquela que tem cometido os lavradores do Brasil" ${ }^{378}$.

Como se pode ler, a fala do senador atribui aos traficantes o pecado original da associação dos plantadores à importação de cativos africanos em sua forma ilegal: o impulso "natural" de propiciar a conservação e o crescimento da própria fortuna - especialmente alentado pelo panorama internacional favorável à exportação dos gêneros nacionais, com destaque para o café - teria conduzido à generalização da prática criminosa. Entretanto, as circunstâncias colocadas a faria dignam de absolvição. As medidas propostas na sequência visavam o desmonte da máquina estruturada em torno do contrabando, desimplicando, porém, os compradores. O seu artigo primeiro cravava: "é proibida a importação de escravos, e de pretos livres no território do Brasil”. Mas, diferentemente da Lei de 1831, a autoria do crime de importação de escravos, especificada no artigo quinto, recairia apenas sobre o capitão e a tripulação dos negreiros; os promotores do desembarque e os agentes de sua ocultação das autoridades por mar ou por terra. Em vez de prisão, a pena seria o degredo de 3 a 9 anos para a ilha de Fernando de Noronha, além do custeio das despesas de reexportação dos escravos para os portos de origem. O artigo 14 anistiava escancaradamente os receptores dos viventes sequestrados: "nenhuma ação poderá ser tentada contra os que tiverem comprado escravos, depois de desembarcados". Seria uma via de aproximação com a classe senhorial, que teria plenamente resguardada a sua propriedade, livrando-se, ao mesmo tempo, de qualquer espécie de responsabilização no campo criminal. Mas, isto estava aquém das pretensões dos escravocratas, que teriam novos obstáculos para a aquisição de cativos. Impunha-se a seus olhos dar prosseguimento aos ingressos de trabalhadores escravizados, não uma solução intermediária que atravancasse a satisfação de seu "irresistível desejo" ${ }^{379}$. O projeto chegou a ser aprovado no Senado, mas empacou na Câmara dos Deputados, onde foi engavetado.

Em 19 de setembro, após a renúncia do padre Feijó, o grupo do Regresso chegou ao Executivo pela ascensão de Pedro de Araújo Lima. Com Vasconcelos na pasta da justiça, maioria parlamentar e a intensificação dos clamores escravagistas, podia-se apostar na revogação da lei antitráfico. No entanto, o Império brasileiro não tinha a mínima condição de fazer frente à oposição que a reabertura legal do tráfico provocaria no governo britânico, que, aliás, foi atiçado com os possíveis rumos da movimentação no parlamento brasileiro em torno da matéria. Por duas vezes, em 1838, os ingleses requereram formalmente que o novo governo

\footnotetext{
${ }^{378}$ Idem, ibidem.

${ }^{379}$ Idem, p. 181.
} 
classificasse como pirataria o comércio de escravos e tratassem como praticantes de tal delito os envolvidos, tal como rezava o compromisso de 1826. Ademais, os representantes da diplomacia britânica no Brasil reportavam contínua insatisfação com a escancarada nulidade da interdição do tráfico. Com efeito, se a Lei Feijó não havia sido feita "para inglês ver", a sua manutenção o seria. A solução política encontrada foi o que Tâmis Parron denominou "legalização sem lei”, isto é, a criação de um contexto de respaldo estatal ao contrabando equiparável à positivação normativa ${ }^{380}$. Tratava-se, aliás, de uma operação plenamente ajustável à cultura jurídica luso-brasileira. O direito português mantivera em sua essência uma linha de complementaridade utilitária entre direito positivo e costumeiro, não raro sobrepondo o equilíbrio à coerência, reconhecendo-se a validade do costume mesmo contra legem em diversas situações, não obstante a afirmação formal da primazia da lei. Muito embora os tempos do Antigo Regime se afastassem no horizonte e o modelo liberal se impusesse progressivamente com os princípios gerais firmados no movimento de fundação da ordem constitucional do Brasil, a convivência secular no seio da sociedade com um padrão normativo fortemente baseado nas relações costumeiras combinado à naturalização do patriarcalismo como forma de organização e disciplina mediaram a adequação do suporte à ilegalidade da propriedade escrava ao quadro social, garantindo a manutenção da ordem estabelecida ${ }^{381}$.

Neste ponto, a natureza escravista do direito imperial pode ser mais uma vez identificada. Alguma "legalização sem lei” também havia quanto à prática da alforria, que mui frequentemente implicava o reconhecimento de capacidade contratual, da aquisição de obrigações, da posse de propriedade na forma de pecúlio, da aquisição de direitos sucessórios, por parte do escravo, e entre outros tópicos que não tinham nenhum respaldo legal. A força conjunta da ação de escravos e escravas ao longo do tempo, certamente os fez sujeitos de direitos importantes, com potencial transformador em suas vidas. Contudo, quando se apresentavam perante a Justiça, a sustentação de suas razões tinha que convencer os magistrados de que haviam sido beneficiários da vontade senhorial e que a benesse, uma vez concedida, lhes estava sendo negada. Isto é, em termos objetivos, não obstante as brechas encontradas e as exceções aceitas, no geral, imperavam o desejo do doador, inclusive quando a liberdade era reconhecida ao final. Ora, o mesmo zelo pela legalidade não valeu para os escravos vendidos clandestinamente a partir de 1831. O governo se furtou a emitir instruções

\footnotetext{
${ }^{380}$ Parron. A política da escravidão..., p.344.

381 Waldomiro Lourenço da Silva Júnior. A escravidão e a lei: a legislação escravista no Antigo Regime iberoamericano. São Paulo: Annablume/Fapesp, 2013, pp.13-112; Paolo Grossi. El orden jurídico medieval. Madrid: Marcial Pons, 1996, pp. 103-105; Franz Wieacker. História do direito privado moderno.Lisboa: Fundação Calouste Gulbenkian, 2004.
} 
semelhantes àquelas de outro de 1834 a respeito sobre a arrematação - que previa a fiscalização e o amparo de curadores específicos - para as vítimas do contrabando. O motivo é claro: absolver os crimes de sequestro e escravização ilegais cometidos diante dos olhos de todos, inclusive daqueles que deviam zelar pela administração da justiça e pelo cumprimento das leis. Neste caso, a prática social, realizada em benefício da classe senhorial, se imporia ao legalmente estipulado, consagrando-se a ética do silêncio em prol dos interesses de uma classe senhorial, desde sempre bárbara, daí em diante, escancaradamente criminosa e ilegítima. A associação entre a cor da pele e o cativeiro se tornaria ainda mais estreita nas décadas seguintes, no Tempo Saquarema, quando as instituições todas funcionariam como se a Lei Feijó de fato não existisse $^{382}$. O componente ideológico da ordem jurídica objetivamente floresceria, ajudando a mascarar toda aquela situação com parâmetros de equidade especialmente frágeis, na medida em que não se enfrentava a questão da ilicitude epidêmica da propriedade escrava, com o ingresso de mais de 750 mil cativos ilegais.

Nesse contexto, a alforria, concessão e conquista a um só tempo, seguiria praticada normalmente no âmbito das relações privadas sem impedimentos legais, sendo associada a laços afetivos e de parentesco, relações de clientela, bem como às oscilações de mercado, à necessidade de evitar custos de manutenção e remediar um investimento, desdobrando-se eventualmente ao judiciário, em caso de desacerto. Mas o acúmulo de pecúlio para compra da liberdade, sempre tolerado pelo costume, se tornaria cada vez mais complicado. De $49 \%$ do total das alforrias concedidas em 1821 nas freguesias urbanas do Rio de Janeiro, as libertações onerosas cairiam para $30 \%$ em 1838 e para $25 \%$ em 1849, refletindo o movimento inflacionário ${ }^{383}$.

Aqueles que porventura já tivesse na posse de sua liberdade não poderiam descuidar de sua condição. Pode-se observar o ocorrido com Catarina Maria, de nação congo. Em 11 de junho de 1836, ela procurou o juízo cível da $3^{\text {a }}$ vara e entrou como uma justificação de sua liberdade. Nela, declarava ser forra, "tendo dado a José Domingues a importância do valor em que era estimada para obter a liberdade, a qual obteve e tem estado em gozo há mais de 11 anos". O problema era que a casa onde vivia com o preto Antônio, também forro, havia sido roubada 4 anos antes e, com ela, por desgraça, o conteúdo da caixa, onde guardava a sua carta de alforria. Marcelino Guedes Pereira de Amorim, irmão e testamentário de seu falecido

\footnotetext{
382 Ilmar Rohloff de Mattos. O tempo Saquarema. São Paulo: Hucitec, 2004.

${ }^{383}$ Manolo Florentino. "De escravos, forros e fujões no Rio de Janeiro Imperial”. Revista USP, São Paulo, n.58, p. 104-115, junho/agosto 2003, p.113; Luiz Carlos Soares. O “povo de Cam” na capital do Brasil: a escravidão urbana no Rio de Janeiro do século XIX. Rio de Janeiro: 7 Letras/Faperj, 2007, p.449.
} 
patrono, sabendo do sucedido, apresentou um requerimento ao juiz de paz do $3^{\circ}$ distrito de Sacramento negando que a manumissão tivesse sido algum dia concedido, e solicitando que ela fosse capturada como escrava fugida. O juiz de paz atendeu ao pedido, ordenou a sua prisão e ela foi levada ao depósito público da Corte. A batalha judicial prosseguiu. De um lado, foram reforçadas as razões iniciais com testemunhas que atestavam as alegações de Catarina, que recorreu ao direito de prescrição. Já era indiferente o fato de que a apelante não dispunha da carta de alforria, visto que estava na posse de sua liberdade havia mais de 10 anos; o direito à liberdade havia sido adquirido por prescrição aquisitiva ${ }^{384}$. De outro, buscou-se seguir com a negação da concessão da alforria, afirmando que inexistia registro cartorial da carta de liberdade. A isto, o curador de Catarina respondeu que se tratava de "um absurdo em jurisprudência cível”, pois "muitos contratos se fazem e por eles são ajuizados e condenados, sem que sejam reduzidos a notas, ou a termos em Autos, pela regra que os instrumentos particulares provam contra quem os fez" ${ }^{385}$. De fato, embora fosse muito comum o registro das cartas de alforria em Tabelião de Notas, não se tratava de um procedimento obrigatório para a validação da alforria.

Com esses elementos colocados sobre a mesa, parecia que tudo se encaminhava para a vitória de Catarina. Porém, um quesito relacionado à fórmula do processo levaria tudo a perder. O advogado do testamentário, baseando-se no artigo 161, que dizia "sem se fazer constar, que se tem intentado o meio da reconciliação, não se começará Processo algum”, requereu a nulidade do processo da justificação. De imediato, deveria ter havido uma tentativa de conciliação com a outra parte. Por haver escapado tal procedimento, o processo foi declarado nulo em primeira instância, não obstante o argumento válido da liberdade por prescrição. Com o auxílio de seu curador, Catarina apelou ao Tribunal da Relação, alegando que uma ação prejudicial como a de liberdade nunca poderia ser julgada nula por falta de conciliação, o que só teria lugar nas causas principais. Ademais, a apelante esperava ser favorecida como pessoa miserável, digna da proteção das Leis, sobretudo por se tratar da reclamação de sua alforria:

"É uma verdade inegável que as causas de liberdade gozam de grande favor das Leis, as quais muito as
protegem; e certo que o legislador que se presume coonestar sempre suas disposições com os ditames da
Boa Razão, não podia favorecer a liberdade. Todavia este favor, esta proteção se deve entender concedida
em termos hábeis, na acepção dada pelos alvarás de 30 de julho de 1609 e 16 de janeiro de 1773 , e vem

${ }^{384}$ Paes. Sujeitos da História, Sujeitos de Direitos..., p.5; Keila Grinberg. "Reescravização, direitos e justiças no Brasil", in: Silvia Hunold Lara \& Joseli Mendonça (org). Direitos e Justiças no Brasil. Campinas: UNICAMP, 2006, pp. 101-128. A liberdade por prescrição também era prevista nas Siete Partidas e foi reclamada em outras sociedades escravistas. Cf. Rebecca Scott. "Paper Thin: Freedom and Re-enslavement in the Diaspora of the Haitian Revolution". Law and History Review, v.29, n.4 (November 2011), p.1082.

385 Arquivo Nacional (RJ). Apelação Cível. Relação do Rio de Janeiro. 84.0.ACI.13 (C3682N648) (1836-1838 RRJ mr 004 - AEL). 
a ser que são mais fortes as razões que há a favor da liberdade do que as que podem fazer justo o cativeiro" 386 .

Desafortunadamente, foram mais fortes as razões em favor da fórmula do processo. Acórdão de 10 de março de 1838 confirmou a sentença de primeira instância "por seus fundamentos em vistas dos autos dos quais não consta que a apelante, sendo autora, intentasse conciliação; e a condenação nas custas" ${ }^{387}$. Quer dizer, Catarina, uma mulher que estava livre havia mais de uma década, havendo presumidamente pago pela sua alforria, foi condenada a retornar ao cativeiro por uma questão meramente formal; uma falha na condução de seu processo; algo que escapava totalmente de seu controle. Difícil imaginar o tamanho do sofrimento dessa mulher e de seu marido, Antonio. O destino não estava selado, claro. Ela pode ter retornado à liberdade no momento seguinte. Quem sabe até, pagando uma segunda vez por sua alforria. Mas é preciso perceber que, não obstante as garantias do direito de ação às pessoas escravizadas no Brasil, os caminhos a serem percorridos eram extremamente penosas, sobretudo dentro do contexto de revitalização do regime de trabalho no país, no período de configuração do campo hegemônico do projeto saquarema. Isto pode ser percebido, inclusive, no resultado das sentenças. Conforme os dados levantados pela historiadora Hebe Mattos, no período entre 1832 e 1850, predominaram nos processos julgados pelo Tribunal da Relação do Rio de Janeiro sentenças favoráveis aos senhores ${ }^{388}$. Na segunda metade do século, a tendência se inverteria, passando a predominar, ao menos pelos registros de segunda instância, vereditos favoráveis à liberdade. As condições objetivas para a manutenção do cativeiro tinham se alterado e o horizonte de expectativa se abrira para transformações no regime de trabalho. A pesquisa de Mariana Dias Paes, sobre o pós-1860, demonstra que existiram situações bastante semelhantes de alegações de prescrição, nas quais, diante de petição de nulidade em função da ausência de um procedimento como o pedido de vênia, o tribunal seguiu caminho oposto, apontando a "futilidade de sua matéria" 389 . Advirta-se, porém, que o desequilíbrio entre sentenças pró e contra a liberdade não seria grande o suficiente para se considerar que o judiciário tenha se convertido em um instrumento para o desafio sistemático ao poder senhorial.

Antes de avançar, cabe realçar outra situação recorrente na época, a que envolvia alforrias condicionais. Como demonstram os dados coligidos pelo historiador Luiz Carlos Soares, das 589 alforrias registradas (225 masculinas, 364 femininas) nos $1^{\circ}$ e $2^{\circ}$ Ofícios de

\footnotetext{
${ }^{386}$ Idem, f.97.

${ }^{387}$ Idem, f. 100.

${ }^{388}$ Mattos, Das cores do silêncio..., pp.183-195.

${ }^{389}$ Dias Paes. Sujeitos da História, Sujeitos de Direitos..., p.144.
} 
Notas do Rio de Janeiro, entre 1808 e 1850, 158 exigiam a satisfação de alguma condição (64 masculinas, 94 femininas), ou seja, cerca de $27 \%$ do total ${ }^{390}$. Algumas circunstâncias presentes neste tipo de manumissão podem ser capturadas, por meio da análise de uma ação judicial movida por uma mulher parda chamada Felisminda. Em 18 de maio de 1836, ela iniciou um libelo cível tendo em vista a manutenção de sua liberdade contra Francisco Machado, marido de dona Antonia de Jesus, sua antiga senhora, que a teria libertado no longínquo ano de 1809,

\begin{abstract}
"Assim como outras crias, pelo amor que lhes tinha, com o ônus de acompanhá-la enquanto viva fosse, sendo semelhante instrumento de doação da liberdade lançado nas notas do tabelião Peres. [...] Porque casando-se depois daquela época a dita D. Antonia Maria de Jesus com o R., este se separou depois dela, e porque nada obteve da A. que resistiu a seus torpes desejos, começou a maltratá-la. Porque fazendo-a levar para a fazenda de Iguaçu, denominada Do Provedor, aí a reteve como se fosse escrava, até que a A. chegou a evadir-se ao mau tratamento que se lhe dava. Porque chegava a esta cidade, achando-se residindo em casa de sua antiga senhora na Rua do Valongo, foi pelo R. dali tirada, e conduzida à prisão do Castello, dizendo o mesmo que a A. era sua escrava e ali esteve como se na verdade o fosse [...]. Porque a A. desde 1809 foi sempre tida por todos como livre em virtude da doação de liberdade que obteve da dita D. Antonia Maria de Jesus" ${ }^{\circledR 391 .}$
\end{abstract}

Em contraposição, o defensor do réu expôs as seguintes razões:

\begin{abstract}
"Porque Antonia Maria de Jesus que faz menção o papel, por desgraça do R. é sua mulher, da qual se separou por escritura, qual que se junta; e cuida do divórcio legal por se considerar de estar unido a uma mulher tão devassa e de costumes tão corrompidos. Porque querendo ela prejudicar o R. sucede que houvera dois ou três anos morando com ela na Rua do Príncipe tratou de passar a carta de liberdade à A., que então se houvera em companhia do R. na sua fazenda do Provedor, Freguesia do Iguaçu, e teve artifício de enganar a testemunha $\mathrm{D}$. Tereza Maria de Jesus, que assinou na mesma carta ignorando a data que nela se pôs, e pensando ser assim com data verdadeira. [...] Porque a A. nunca passou por forra; antes sempre foi tida e tratada como escrava; e tanto ela disto sempre esteve convencida que não quis acompanhar a dita Antonia Maria, chegando a fugir para casa do Major Francisco Antonio, onde esteve enquanto se fez o ajuste da escritura justa; e era ela mesma que publicava os desaforos e escandalosos procedimentos da mulher do R., ${ }^{392}$
\end{abstract}

Menos importante do que especular sobre quem estava dizendo a verdade é perceber como estes fragmentos sinalizam traços muito marcantes daquela realidade. A escravidão era muito mais do que um regime de trabalho em sentido estrito; algo mecânico com os senhores de um lado mandando e os escravos, de outro, cumprindo suas funções, sendo premiados com a alforria quando iam bem, sendo açoitados quando tentavam fugir ou algo que o valha. A exploração e o conflito social se faziam presentes em meio a tramas sociológicas que muito frequentemente envolviam fortíssimos vínculos passionais e sensuais tachados de

\footnotetext{
${ }^{390}$ Luiz Carlos Soares. O "povo de Cam" na capital do Brasil: a escravidão no Rio de Janeiro do século XIX. Rio de Janeiro Faperj/7 Letras, 2007, p.449.

${ }^{391}$ Arquivo Nacional (RJ). Apelação Cível, Relação do Rio de Janeiro, 84.0.ACI.14 (C3685N866) (1836-1839 AEL mr 004), f.12

392 Idem, f.39.
} 
"libertinagem" pelos coevos, muito embora praticamente todos vivessem atolados até os pescoços nelas. A alegação da autora da ação, falsa ou não, pautava-se em situação absolutamente crível dentro daquele contexto social, por isso, claro, a sua inserção no mérito do processo: ter sido alforriada com a condição de serviços perpétuos à senhora.

É importante anotar alguns aspectos evidentes da história. Francisco Machado claramente explorava sexualmente Felisminda em sua fazenda localizada na freguesia de Iguaçu (zona portuária de escoamento da produção cafeeira do Vale do Paraíba). A autora, por sua vez, tinha como aliada dona Antonia de Jesus, ex-esposa do réu, dado interessante, que destoa das narrativas correntes de senhoras que despejavam sua ira sobre as cativas que provocavam desatinos em seus senhores. Daí em diante, há duas hipóteses, ou Antonia era mesmo a proprietária e havia alforriado condicionalmente Felisminda, ou ela estava querendo se vingar por alguma razão de Francisco, que não era flor que se cheirasse. Além disso, outros elementos foram adensando o enredo. De acordo com o réu, seria seu antigo feitor, Antonio Maria Sobral, o grande responsável pela tramoia com a finalidade de livrar Felisminda do cativeiro. Isto porque ele teria passado a viver com ela como seu amásio. Da parte da autora, seria manifesta a preocupação com o destino de sua "inocente filha", que também podia padecer com o retorno da mãe ao cativeiro dada a transmissão de sua condição pelo ventre.

Um traço importante a ser observado: o elemento de prova. Diferente de outros casos examinados até aqui, a autora apresentava um documento escrito para sustentar suas intenções. Francisco Machado, como sugere o excerto reproduzido acima, empenhou-se em desacreditálo. O papel apresentado, com data de 1809, teria sido adulterado, "o que mais ainda se apura pelo disfarce que se busca na cor da tinta, porém que bem se deixa ver ser nova e descorada". O juiz de direito aceitaria a alegação de falsidade, pois a defesa de Felisminda não apresentou atestado do registro em cartório e os testemunhos colhidos foram considerados contraproducentes, contradizendo sua versão em vários pontos, nada dizendo, também, sobre os maus-tratos e sevícias alegados. Assim, em 15 de dezembro de 1837, foi proferida a seguinte sentença:

\footnotetext{
"Vistos estes Autos do Libelo f.11, documento f.13, contrariedade f.38, documento f.41, inquirições f.61 e 67, razões f.37 pelo R. de tudo é claríssimo ser à A. aplicável aquele princípio de direito actore non probante, reus absolvitur, porque dos autos se evidencia que a A. não provou por isso que o papel f.33 fora feita na época em que ele de ter sido feito; que nada dizem suas testemunhas sobre ela ter sofrido maus-tratos e sevicias que diz lhe causara o R.; que suas testemunhas não só se contradizem em seus depoimentos, como também chegam a ser contraproducentes; a vista do que é manifesto o dolo com que foi feito aquele papel f.33 e sua nulidade e ser a A. escrava do R. não liberta como tal semelhante alegava. Portanto, julgo improcedente e improvada a Ação e a A. escrava do R. não liberta e pague as custas" ${ }^{393}$.
}

\footnotetext{
${ }^{393}$ Idem, f.92.
} 
É significativo o princípio latino utilizado pelo juiz para basear sua sentença: actore non probante, reus absolvitur, isto é, se o autor não prova, o réu é absolvido. Felisminda fracassou em demonstrar a sua condição de forra condicional. Acórdão de 15 de setembro de 1838 considerou bem julgado a ação. A autora voltou para o domínio de seu algoz para sofrer sabemse lá quais tipos de atrocidades. Tudo, claro, com base em um processo transitado em julgado, dentro dos parâmetros normativos plenamente aceites à época, dado que uma vez mais demonstra muito bem o encaixe do ordenamento jurídico no sistema de escravidão. Não pelo resultado per se, mas pela regularidade intrínseca, manifesta na condução e na conclusão do processo e em seu sentido na dinâmica que envolvia a regulação do cativeiro e o acesso à liberdade.

Decerto, houve quem tivesse melhor sorte que Felisminda. Veja-se o caso de Joaquina, de nação Moçambique. Por intermédio de seu curador, o bacharel José Batista Silva, ela moveu uma ação contra Florêncio Paz, na posse de quem se encontrava após o falecimento de seu senhor, Domingos dos Santos Carvalhal. Este seu senhor a teria alforriado em 3 de julho de 1838, como atesta carta adjunta ao processo. Florêncio foi citado para "declarar em juízo os títulos por que dizia ser senhor da preta de Joaquina de nação Moçambique”. Na defesa de seus interesses, afirmou ter comprado a escrava de Domingos em 1843 pela quantia de 500 mil-réis, o qual havia declarado-a livre de qualquer embaraço. O pagamento não foi à vista. Entregou 350 mil-réis no ato, adquirindo a escrava por empréstimo, até que quitasse a diferença no ano de 1845. Desta vez, foi reconhecida a autenticidade da carta de liberdade. Na sentença proferida em 3 de dezembro de 1846, o juiz entendeu que o réu não apresentou "motivos fortes e legais" pelos quais demonstrasse possuir Joaquina. A escritura apresentada é de 5 de outubro de 1845 , data muito posterior à manumissão da autora. Assim,

\footnotetext{
"não produzindo o R. razões algumas plausíveis perante a Lei, pelas quais mostre, que aquela carta não deva produzir os seus devidos efeitos, antes o contrário, vê-se que a A. desde 3 de julho de 1838 já gozava de sua liberdade, e se não gozou, deveria ter estado nesse gozo, e por isso não podia em outubro de 1845 ser vendida, porque sobre ela já ninguém tinha domínio algum ou direito para da mesma dispor e, por conseguinte, nulla est jura é a escritura f.9 nesta parte. Portanto, [...] julgo a esta liberta e o R. obrigado a reconhecê-la como tal, e pague as custas" 394 .
}

Joaquina poderia, então, desvencilhar-se do cativeiro ilegal no qual se encontrava e passar a usufruir de sua liberdade na sociedade escravocrata brasileira.

\footnotetext{
${ }^{394}$ Arquivo Nacional (RJ). Apelação Cível, Relação do Rio de Janeiro, 84.0.ACI.24.2 (C3689N104) (1840-1846 AEL RRJ mr 007), f.38.
} 
No plano mais amplo da dinâmica da escravidão, cabe observar que resultados como o de Joaquina em nada abalavam o sistema. Embora a pressão antitráfico da Inglaterra ganhasse corpo, o contrabando arraigava-se de maneira visceral na sociedade e na economia nacional. Uma fatia significativa dos lucros obtidos com o comércio de gêneros agrícolas era invertida na importação ilícita de trabalhadores africanos. Tratava-se do correspondente a 34,4\% do total das exportações do país, como apurou o historiador Luiz Felipe de Alencastro ${ }^{395}$.

No Parlamento, a linha de frente do Regresso seguiria escorando o tráfico clandestino e defendendo inescrupulosamente a exploração das populações trazidas da África. Em 1840, teria dito Vasconcelos:

\footnotetext{
"daquele continente veio o trabalhador robusto, o único que sob este céu africano e num clima mais inclemente então que hoje, poderia ter produzido, como produziu, as riquezas que proporcionaram a nossos país recursos para mandar seus filhos estudar nas academias e universidades da Europa, ali adquirirem os conhecimentos de todos os ramos do saber, os princípios da Filosofia do Direito, em geral, e do Direito Público Constitucional, que impulsionaram e apressaram a Independência e presidiram à organização consagrada na Constituição e noutras leis orgânicas, ao mesmo tempo fortalecendo a liberdade" 396 .
}

Não há registro dela nos anais parlamentares daquele ano. Mas é provável que Vasconcelos tenha proferido algo assim em algum momento, tendo-se em conta a natureza de suas alocuções e a linha seguida em sua participação política. O conteúdo do texto é tão estarrecedor - à luz da reprovação intransigente com relação à prática da escravidão que deve imperar em nossos dias - quanto revelador da essência da classe senhorial brasileira, de seus representantes políticos e da sociedade brasileira em geral. O ideal de uma "civilização" construída mediante "a superexploração de populações africanas", como disse Alencastro, ao invés de marca da vergonha nacional, era propagado como fundamento de um projeto de perpetuação do cativeiro ${ }^{397}$. Tudo para manter as riquezas de um país exclusivista, a instrução das elites e a liberdade positiva própria a homens livres e proprietários. Algo muito distante, sem dúvida, da liberdade que Joaquina de nação Moçambique teria oportunidade de vivenciar.

Executado o Golpe da Maioridade, em 23 de julho de ano de 1840, o jovem D. Pedro II assumiria o trono formando um Gabinete Maiorista (liberal). Mas a alteração foi efêmera. Menos de um ano depois, por conta do desgaste ocasionado pelo pleito eleitoral realizado nos meses finais daquele ano, as famosas "eleições do cacete", os regressistas foram reconduzidos

\footnotetext{
395 Alencastro. "Traite négrière et unité nationale brésilienne", p.408.

396 Apud Rafael de Bivar Marquese \& Tâmis Peixoto Parron. "Azeredo Coutinho, Visconde de Araruama, e a Memória sobre o Comércio dos escravos de 1838". Revista de História 152 (1 - 2005), 100-101.

${ }^{397}$ Luiz Felipe de Alencastro. Le commerce des vivants: traite d'esclaves et "pax lusitana" dans l'Atlantique sud. Tese de doutorado. Paris: Universidadede Paris X, 1985-6, v.2, p.515.
} 
ao Poder Executivo, dando continuidade à sua plataforma política, inclusive quanto à centralização do judiciário imperial. O principal motivo era pôr fim à influência local sobre as autoridades judiciais, tida como fator importante para a eclosão das revoltas provinciais. $\mathrm{Na}$ véspera do Golpe da Maioridade e no momento seguinte à montagem do gabinete Palaciano (conservador), foram aprovadas a interpretação do Ato Adicional, em 12 de maio de 1840, e a reforma do Código do Processo Criminal, em 3 de dezembro do 1841, que retiraram das Assembleias provinciais a competência de suspender ou demitir membros dos Tribunais Superiores, subtraíram as competências criminais e policiais dos juizes de paz e restringiram a nomeação de juízes municipais e de direito ao desígnio direto do imperador, sem a indicação de uma lista tríplice pelas câmaras como antes se fazia ${ }^{398}$. Essas mudanças não desfiguraram a compleição do sistema judiciário como um espaço de desdobramento do conflito social e de sustentação das alforrias conquistadas pelas vítimas do cativeiro em suas relações cotidianas. Todavia, o quadro jurídico, pela sua natureza, acomodou-se perfeitamente ao sistema de escravidão, que atingia, agora, plena vigor. As arenas judiciais, apesar de sua inegável relevância sociais, eram, por excelência, veículos de afirmação da vontade senhorial como princípio essencial, não obstante as derrotas pontuais de alguns senhores. Apenas como expressão daquela vontade, os libertandos logravam desvencilharem-se de seus grilhões.

Claro que continuavam havendo ameaças à estabilidade do sistema. Naquela época, o Parlamento britânico entrincheirava-se ainda mais em torno da "supressão total do tráfico da escravatura" com a aprovação do Bill Palmerston, em 1839, que autorizou o apresamento de navios negreiros portugueses. Para o Brasil, a situação se complicava com o vislumbre do término dos acordos firmados em 1826 com os ingleses, que buscariam costurar um novo trato ao mesmo tempo em que intensificariam suas investidas no próprio litoral brasileiro. Enquanto isso dava cumprimento forçoso aos Artigos Adicionais de 1835, permitindo a captura de embarcações aprovisionadas para o tráfico e o subsequente encaminhamento dos envolvidos nas comissões mistas no Rio de Janeiro e em Serra Leoa. Entre fins de 1839 e 1842, mais de 160 embarcações seriam detidas, reduzindo-se pela metade os ingressos de africanos no Brasil $^{399}$.

Em território nacional, acontecia de cativos ilegais chegarem às mãos das autoridades policiais e judiciais. Havia casos de fugitivos, doentes abandonados ou denúncias que acabavam

\footnotetext{
${ }^{398}$ Flory. Judge and Jury in Imperial Brazil, 1808-1850, pp.157-180; Berbel, Marquese \& Parron. Escravidão e Política..., pp.230-234; José Murilo de Carvalho. A construção da ordem. Teatro de sombras Teatro de sombras. Rio de Janeiro: Civilização Brasileira, 2003, pp. 145-168; Mattos. O tempo Saquarema, pp.142-204.

399 Leslie Bethell. A abolição do comércio brasileiro de escravos. A Grã-Bretanha, o Brasil e a questão do comércio de escravos, 1807-1869. (1ªd: 1969; trad.port.) Brasília: Senado Federal, 2002, pp.131-210.
} 
levando à apreensão de africanos ${ }^{400}$. Aqui, é possível destacar uma dessas ocorrências, que chegaria até o Supremo Tribunal de Justiça. Em 8 de janeiro de 1844, na Intendência de polícia, diante do desembargador chefe de polícia, o famosíssimo Eusébio de Queirós Coutinho Matoso da Câmara, foi realizado um exame no africano Caetano congo, apreendido por pedestres da polícia. Após prestarem juramento sobre os sagrados evangelhos, os peritos, Manoel Resende Gouvêa e Silva e Manoel Candido do Nascimento, declararam que "em suas consciências estavam persuadidos ser o mesmo africano boçal, por não saber nada do português". No dia 12, foi realizado um auto de perguntas. Algo bastante sumário: "como se chama o seu senhor? Respondeu que era branco". "Perguntado, então, qual era o nome do seu senhor. Respondeu que não entendia". "Perguntado seu nome (o primeiro e o de nação). Respondeu Caetano de nação Congo". "A que tempo veio de sua terra? Respondeu que há pouco tempo”. Feitas várias perguntas mais, não foram respondidas por falta de entendimento. Os elementos levantados pareceram satisfatórios ao juiz municipal da $2^{\mathrm{a}}$ vara, Agostinho Machado Nunes, porventura um representante do "sem-número de curadores de juízes de vara simpáticos à causa da liberdade" de que falou Chalhoub, em Visões da Liberdade ${ }^{401}$. No dia 16, proferiu a sentença: “à vista do interrogatório e auto de exame, julgo o africano Caetano ser importado depois da proibição do tráfico da escravatura e, portanto, o declaro no gozo de sua liberdade de hoje e para sempre; e não sem constar atendida a natureza da causa". Decisão em seguida corroborada pelo juiz de direito da $2^{\mathrm{a}}$ vara criminal da Corte ${ }^{402}$.

O problema é que um suposto senhor apareceu. Pedro d'Alcântara Ferreira e Costa, dispondo do recibo da compra de Caetano, do ano de 1841, contestou a ilegalidade da procedência de Caetano. Além disso, uma vez mais pesariam aspectos procedimentais. O seu advogado interpôs recurso de revista no Supremo, anotando irregularidades na sentença, que deveria ser considerada nula: "o decreto de 12 de abril de 1832, no art. 9, determina expressamente duas causas especiais sem o que o juiz não podia validamente sentenciar, a saber, $1^{\circ}$ que se proceda ao exame por meio de interprete e $2^{\circ}$ que em todo caso se ouça sumariamente as partes". Nada disso havia sido procedido. No dia 12 de maio de 1846, o pedido de revista foi concedido:

\footnotetext{
${ }^{400}$ Sidney Chalhoub. A força da escravidão: ilegalidade e costume no Brasil oitocentista. São Paulo: Companhia das letras, 2012, p.85.

${ }^{401}$ Sidney Chaloub. Visões da liberdade: Uma história das últimas décadas da escravidão na corte. São Paulo: Companhia das Letras, 1990, p.72.

${ }^{402}$ Arquivo Nacional (RJ). Apelação Cível, Supremo Tribunal de Justiça, BU.0.RCI.14 (C3694N20) (1844-1847 AEL STJ mr 007).
} 
"vistos, expostos e relatados estes autos de revista cíveis entre partes Recorrente Manoel Pedro d'Alcântara Ferreira e Costa, e Recorrido, Caetano, africano, concedem a revista pedida por nulidade manifesta, visto que seus exames e interrogatórios que se fizeram ao recorrido [...] não interveio intérprete contra o determinado no art. 9 do decreto de 12 de abril de 1832, onde expressamente se exige essa solenidade, tornando-se por isso nula a sentença, assim do juiz municipal, assim como a do juiz de direito, que a sustenta. Portanto, remetam-se os autos à Relação desta Corte"403.

Assim foi feito. O processo foi repassado ao Tribunal da Relação do Rio de Janeiro, que em 13 de fevereiro de 1847 proferiu Acórdão julgando improcedente a apreensão "do escravo Caetano" e concludentemente provada a propriedade de Ferreira e Costa sobre ele. Sobressai o extremo zelo das instâncias superiores quanto à execução da normativa de 1832, sobretudo à luz do descumprimento sistemático da Lei de 1831.

Sidney Chalhoub, que analisou a correspondência da chefia de polícia da corte, os Livros da Casa de Detenção e processos judiciais de natureza variada, observou que apreensões como as de Caetano "pingaram o tempo inteiro" na década de 1840. Havia um interesse prático nisso: a utilização dos africanos livres em serviços públicos e a sua concessão a particulares para trocas de favores. Portanto, caso a referida sentença pela liberdade tivesse sido mantida, o africano em questão estaria dentro de uma margem aceitável e até desejável dessa mão de obra baratíssima que se formava. Por outro lado, o fato é que o domínio sobre a grande massa de cativos ilegais permanecia incólume. $\mathrm{O}$ historiador identificou três fatores que permitiam às autoridades fazerem "vistas grossas" em relação à maioria. Primeiro, a ampliação da noção de "ladino", que passaria a incluir "qualquer africano capaz de balbuciar algumas palavras em português". Interessante que isto não se cumpriu com Caetano. O registro do auto de exame, realizado na presença do chefe, sugere que ele proferiu e compreendeu, sim, "algumas palavras”. Não obstante, foi considerado “africano boçal”. Segundo, “a frouxidão na questão da prova da propriedade escrava, [...] a vigência de mecanismos que isentavam o senhor de apresentar certificado de importação legal do africano escravizado e a prática de produção de papéis que dava aparência de legalidade ao que fora adquirido em contrabando". Só que a produção de títulos falsos de propriedade por quem mantinha pessoas sob cativeiro ilegal não era nenhuma novidade. A “frouxidão" maior, naquele contexto, esteve na falta de realização de buscas e apreensões em escala compatível com as entradas de africanos ilegais, bem como na eventual verificação dos documentos. O terceiro fator, sem dúvida o mais importante na tese do livro A força da escravidão, seria a "radicação, nas práticas da administração pública, do costume de considerar todo preto - o africano em particular, mas não só ele - um escravo até prova em contrário". Este pressuposto, delineado por Eusébio de Queiróz no exercício de sua chefia na polícia da Corte (1833-1844), permaneceria em voga até a virada da década de 1860

${ }^{403}$ Idem, f.61. 
para 1870. A doutrina queiroziana, como denominou Chalhoub, seria verbalizado no final de 1835, em resposta a indagações do ministro da justiça Antônio Paulino Limpo de Abreu, futuro visconde de Abaeté, sobre a prática de captura de escravos fugitivos ${ }^{404}$. Perante orientação para que, na ausência de provas, fosse presumida a liberdade, Queiróz, sem se recusar a acatar a ordem, contra-argumentou parecer-lhe "mais razoável a respeito dos pretos presumirem a escravidão, enquanto por assento de batismo, ou carta de liberdade não mostrarem o contrário" 405 . A partir de uma análise bastante acurada da documentação, o historiador busca evidenciar que o procedimento adotado pelo aparato policial se coadunou com a manutenção do domínio senhorial, tanto pela captura de escravos fugidos quanto por responsabilizar a população negra em geral pela comprovação de seu estatuto.

O sentido geral desta conclusão é aceitável. Ninguém duvida que a cumplicidade das forças de repressão fosse decisiva para a normalização da escravização ilegal dos africanos livres que entraram em território brasileiro após 1831, gerando, ao mesmo tempo, “zonas amplas de incerteza social sobre as fronteiras entre escravidão e liberdade na sociedade brasileira oitocentista"406. No entanto, o autor superdimensiona a "doutrina de Eusébio de Queiróz". Primeiro, passando por cima do fato de que ela não abrangia toda a zona escravista do império. Segundo, não demonstrando a suposta virada na presunção da liberdade para a de escravidão da população negra. A liberdade dos negros livres e libertos sempre foi precária. As forças de repressão sempre estiveram a serviço da classe senhorial. Para isso elas existiam. Tratava-se de um aspecto inerente ao sistema de escravidão. Na época de institucionalização da escravização ilegal dos africanos houve um agravamento, não uma inflexão. A tal doutrina queiroziana não era de Eusébio de Queiróz e tampouco se realizava de forma irrestrita. Por vezes, simplesmente cumpria-se o procedimento, sem o dolo raivoso da presunção da escravidão a todo e qualquer negro indocumentado que chegasse à chefatura de polícia da Corte. $\mathrm{O}$ caso de Caetano bem o demonstra. Isto não facilitava a vida daquelas pessoas, necessariamente. No judiciário, nada leva a crer que em algum momento tenha bastado aos autores de ações de liberdade recorrer ao princípio de que a prova incumbia aos que requeriam contra ela, e esperar que o réu viesse apresentar provas de sua propriedade. Era preciso comprovar as alegações, preferencialmente, com documentos escritos e com algum tipo de registro formal como assentos de batismo ou cartas de liberdade, com o reforço de

\footnotetext{
${ }^{404}$ Sidney Chalhoub. A força da escravidão..., pp.104-108.

405 Apud Sidney Chalhoub. A força da escravidão..., p.228.

${ }^{406}$ Idem, pp.232-233.
} 
testemunhas, conforme evidenciado nas páginas anteriores deste trabalho e demonstrado pela historiografia $^{407}$.

A fórmula processual manteve certa uniformidade ao longo do tempo. O interessante é acompanhar como as situações concretas se amarravam ao quadro jurídico estabelecido, conforme os determinantes do contexto. Com efeito, vale a pena acompanhar a ação iniciada pela preta Carlota, em cinco de novembro de 1848 no juízo de direito da $3^{\text {a }}$ vara. Natural de Angola, ela teria sido levada para o Reino de Portugal por José Roiz da Conceição, sendo lá batizada como inocente no ano de 1828, como constava de sua certidão de batismo. Eram anos de intensificação do tráfico negreiro sob bandeira portuguesa. O tratado entre a Grã-Bretanha e o Brasil (1826) colocou o término daquele negócio no horizonte dos traficantes lusitanos, que trataram de intensificar as suas atividades. É possível que Carlota estivesse entre os mais de 130 mil escravos exportados para o Brasil entre 1827 e 1829 em barcos de bandeira portuguesa. De Lisboa, ela foi conduzida à "cidade da Bahia deste império por Gervásio de tal, este aí a vendeu como escrava e ultimamente transportada a esta Corte foi vendida por Caetano José Ribeiro Lousada a dona Rosa Maria, hoje casada com o réu Jerônimo da Costa Jácomo”. Mas a sua passagem pela antiga metrópole selaria o seu destino. Conquanto Carlota tenha sido batizada como escrava, ela seria por direito livre, não apenas por nascimento, mas em virtude dos alvarás portugueses de 19 de setembro de 1761 e 16 de janeiro de 1773. Portanto, autorizada por seu curador, Joaquim Manoel Gaspar de Almeida, Carlota solicitava que fosse declarada livre e apta a requerer os jornais pelo tempo que prestou serviços ao réu e a seus antecessores. Notificado, Jácomo compareceu em juízo, explicando que Carlota pertencia ao espólio do finado Luiz Francisco da Silva, pai de sua esposa, Maria Rosa da Silva, e de Maria Joana de Jesus, por sua vez, casada com José Tomé da Silva, cabendo-lhe, também, “por cabeça de sua mulher", tomar parte na defesa da causa ${ }^{408}$.

Com feito, Joaquim José de Azevedo, advogado de Tomé da Silva, apresentou um arrazoado bastante prolixo e erudito, contrariando o libelo de Carlota. Requerendo que a ação fosse julgada improcedente, afirmou que a autora havia sido legalmente arrematada em praça pública no juízo do inventário, "por isso não podem os efeitos desta venda deixar de subsistir, sem existir sentença que previamente a anule; que o alvará de 1761, que libertou os negros “carregados" para Portugal, não teve em vista casos isolados de escravos que ali aportavam em

\footnotetext{
${ }^{407}$ Paes. Sujeitos da História, Sujeitos de Direitos..., op.cit; Fernanda Aparecida Domingos Pinheiro. Em defesa da liberdade: Libertos e livres de cor nos tribunais do Antigo Regime português (Mariana e Lisboa, 1720-1819). Tese de Doutorado - UNICAMP, 2013;

${ }^{408}$ Arquivo Nacional (RJ). Apelação Cível, Relação do Rio de Janeiro, 84.0.ACI.43 (C3687N4728) (1848-1853 AEL RRJ mr 014).
} 
companhia de seus senhores, como consignado em outro alvará, o de 10 de março de 1800; que a condição da autora de modo algum era abrangida pelo alvará de 16 de janeiro de 1773, visto que a sua letra tocava apenas nos escravos nascidos no Reino português; que, mesmo na hipótese de Carlota ser de algum modo beneficiada pelos alvarás citados, "só lhe diriam vantagem se ela reclamasse em Portugal, país a que são peculiares, e independentes deste império, aonde na espécie vertente, não é possível julgar por lei estrangeira"; que o documento apresentado pela autora, isto é, seu atestado de batismo, era contraproducente, "porque dele só se depreende que a autora nascera em terras dos domínios portugueses, aonde a liberdade de condição se não presume (Coelho da Rocha. Insti. De Dir. Civ. Port. § 54) como também mostra que as autoridades de Portugal reconheceram que a A. vive sujeita à escravidão". De fato, Coelho da Rocha, neste ponto de sua obra, em que trata das "noções gerais sobre pessoas", salienta a tolerância da escravidão nas possessões lusitanas na África ${ }^{409}$.

Nada disso convenceu o juiz Carlos Antônio de Bulhões, que emitiu a seguinte sentença:

\begin{abstract}
"Vistos estes autos que pretende a A. pelo seu libelo f.4 competentemente autorizada pelo seu curador ser declarada livre; porque alega a mesma A. que ela não fora diretamente importada da Costa da África neste Império; que sendo natural de Angola fora conduzida a Lisboa onde foi batizada e que daí então que veio para Bahia onde foi ilegalmente vendida como escrava que não era nem podia ser a face da disposição do alvará de 19 de abril de 1761: defende-se o R. chamando a autoria com a matéria de sua contrariedade a f. 30 em que alega que adquirira a A. por título de arrematação e os efeitos deste título subsistem enquanto não houver sentença que nulifique; que o citado alvará tem em vistas somente evitar a importação de grande quantidade de escravos, porém não de um ou outro; que a A. não apresenta certidão de alforria como exige o citado alvará; que ela não reclamara em Portugal a sua liberdade. Por tudo visto e o mais dos autos não se apresentando por parte do R. dúvida alguma acerca da identidade da pessoa da A. e mostrando-se pela certidão f.4 do apenso que a A. fora de Angola conduzida a Lisboa onde se batizara, torna-se manifesto o direito que lhe assiste a ser declarada livre segundo a disposição do alvará de 19 de abril de 1761, que conferiu a liberdade a todos os escravos que desembarcassem em Portugal, sem de maneira alguma referir-se somente à importação de grande quantidade sendo pelo conteúdo bem expresso em configurar a hipótese de todo e qualquer preto que desembarcasse em Portugal: nem era mister que a A. o tivesse reclamado; pois que segundo as disposições da citada lei, a liberdade nesses casos se adquiria ispso facto do desembarque em Portugal sem dependência de carta alguma de manumissão; e conquanto a A. não apresente a certidão da alforria, esta se acha sobejamente suprida pela de f.4 do apenso por onde se mostra, que a A. não só desembarcou em Lisboa, como que aí fora batizada; o título de arrematação nada obsta: porquanto se a arrematação extingue o ônus da coisa arrematada, não extinguiu porém o vício ou nulidade da aquisição daquele de quem foi o objeto arrematado; portanto pelo mais dos autos julgando como julgo procedente a ação, provado o libelo, julgo a A. livre da escravidão na forma pedida no libelo e condeno o Réu nas custas. Rio, 12 de junho de $1850 " 410$
\end{abstract}

A complexidade dos elementos que compõem este escrito é espantosa, e ilumina muito bem a compleição do quadro jurídico imperial, que a esta altura ainda mantinha o essencial da

${ }^{409}$ Cf. Keila Grinberg \& Cristina Nogueira da Silva. "Soil Free from Slaves: Slave Law in Late Eighteenth- and Early Nineteenth-Century Portugal”. Slavery \& Abolition, v. 32 (2011), pp.431-446.

${ }^{410}$ Arquivo Nacional (RJ). Apelação Cível, Relação do Rio de Janeiro, 84.0.ACI.43 (C3687N4728) (1848-1853 AEL RRJ mr 014), f.46. 
tradição normativa lusitana sobre o cativeiro em plena vigor. Isto abriu espaço para que a experiência escravista luso-brasileira, compreendida como o passado atualizado, formasse explicitamente a substância da decisão judicial. Sem vacilar, o juiz aplicou os termos dos alvarás portugueses emitidos pelo marquês de Pombal, estreitando laços históricos entre complexos temporais objetivamente distintos. Foram apresentados embargos à sentença da Relação do Rio de Janeiro, mas a sentença do juiz de direito foi mantida.

Para completar o quadro, é importante lembrar que força da escravidão estava fincada, também, na busca incessante por parte de muitos egressos da escravidão pela apropriação do mundo material e da cultura dominante. Em outubro de 1847, a preta forra Maria Benedita ajuizou uma ação contra o casal Antônio Victorino de Barros e Silva e Maria Joaquina de Melo Menezes Palhares, viúva de seu antigo patrono, o tenente coronel Pedro José Taveira da Veiga. A autora relatou, com o auxilio de um curador, que seu antigo senhor, ainda quando solteiro, a havia alforriado juntamente com sua mãe, Maria Angélica, por carta de liberdade de 20 de abril de 1828 , cuja cópia foi anexada ao processo. Mas o objeto da causa não era este ${ }^{411}$.

O que estava em jogo era o direito de propriedade sobre uma escrava chamada Joana, doada a ela pelo ex-senhor no ato da alforria. Fato também documentado. Ocorreu que mesmo depois da manumissão, Maria Benedita continuou vivendo em companhia de Taveira da Veiga, que se casou com Maria Joaquina em 1829. Muitos anos depois, em 1841, o segundo marido de Maria Joaquina, Vitorino de Barros expulsou-a de casa, dizendo que "fosse embora para onde lhe conviesse, visto ser liberta, mas não the entregou a dita escrava de nome Joana". Os réus, então, retiveram a escrava em sua posse, declarando-a indevidamente entre os bens arrolados no inventário do falecido. A autora, portanto, havia sido prejudicada "em seu direito sobre a propriedade que tinha na referida escrava". Contrariando o libelo, os réus afirmaram que Joana não era escrava de Maria Benedita; que ela não tinha sido alforriada em 1828, mas em 1836; e que o certificado de propriedade apresentado era falso. Não adiantou. Em 22 de setembro de 1849, o juiz municipal da primeira vara, José Siqueira Barbosa de Madureira e Queirós, sustentou que

\footnotetext{
"Tudo bem visto e examinado não padece dúvida à justiça do pedido no libelo, como demonstrado nas razões finais da mesma A. que adoto como parte fundamental desta sentença [...]. Portanto, por estas razões e pelo mais que dos autos consta e disposições das Leis, e de direito condeno na forma pedida no libelo aos réus a fazerem entrega da referida escrava à A. sua legítima senhora, e bem assim a pagarem a esta os salários da escrava a contar do dia do óbito do finado tenente coronel doador, os quais serão competentemente liquidados" 412 .
}

\footnotetext{
${ }^{411}$ Arquivo Nacional (RJ). Apelação Cível, Relação do Rio de Janeiro, 84.0.ACI.42 (C3686N3370) (1847-1849 RRJ mr 014).

412 Idem, f.109.
} 
A ação ainda subiu às instâncias superiores. Mas a sentença favorável a Maria Benedita foi sucessivamente mantida no Tribunal da Relação e no Supremo Tribunal de Justiça; o direito de propriedade sobre Joana foi ao final ratificado em 19 de novembro de 1851. Deparamo-nos, aqui, uma vez mais, com a enorme complexidade daquela sociedade; com uma perfeita manifestação da forma como manumissão e cativeiro se uniam em um mesmo processo institucional, em meio ao qual o direito escravista desempenhava um papel essencial de mediação. Nascida de ventre cativo, Maria Benedita tornava-se insider em sociedade de proprietários de escravos por obra de seu antigo senhor: fechava-se um circuito ideal; inatingível, sem dúvida para a maioria dos egressos. Em nenhum momento a autora, que havia passado pelo jugo do cativeiro durante vários anos, juntamente com sua mãe e sabem-se lá quantos parentes e amigos, manifestaram a intenção de libertar Joana. Não se trata de algo desprezível, quanto mais se considera a enorme recorrência de menções ao favorecimento da liberdade pelo direito para a fundamentação das razões pelas partes. Se não citou, foi porque o intuito era usufruir da escrava. A constatação é importante. O domínio sobre escravos por negros livres forros não era nenhuma novidade na sociedade escravista brasileira ${ }^{413}$. Mas o contexto de grande valorização da mão de obra escrava decorrente da erradicação do contrabando muito provavelmente aguçou o interesse sobre Joana. O preço médio dos escravos subiria mais de $150 \%$ naqueles anos ${ }^{414}$.

\section{Fim do tráfico negreiro e a Consolidação das leis escravistas}

As três últimas ações judiciais examinadas decorreram por um período bastante turbulento, de intensa movimentação política, com atos decisivos para o futuro da escravidão. No primeiro quinquênio da década, houve uma tensa renegociação do tratado comercial de 1826, que acabou prorrogado até 1844. Então, sob o Gabinete Liberal, foi realizada uma reforma na política alfandegária que aumentou em até $60 \%$ a tributação sobre importados. Programou-se a famosa Tarifa Alves Branco, contrariando sobremaneira as pretensões britânicas. Simultaneamente, com anteparo do tratado anglo-americano de Ashburton-Webster, que havia interditado a abordagem de embarcações estadunidenses, o governo imperial se

\footnotetext{
413 A. J. R. Russell-Wood. Escravos e Libertos no Brasil colonial. Rio de Janeiro, Civilização Brasileira, 2005, pp.83-127.

${ }^{414}$ Florentino. "De escravos, forros e fujões no Rio de Janeiro Imperial", p.115.
} 
esquivou da renovação do acordo antitráfico, expirado em 1845. Em revide, o Parlamento londrino aprovou o Bill Aberdeen, que autorizou a Royal Navy e ao alto tribunal do Almirantado britânico e suas subseções a tratar o tráfico de escravos praticados pelos súditos brasileiros como ato de pirataria. Nos cinco anos seguintes, mais de 400 navios seriam apreendidos e suas tripulações enviadas para julgamento nos tribunais do vice-almirantado em Santa Helena, Serra Leoa e no Cabo da Boa Esperança. Mas o fluxo do contrabando nem por isso arrefeceu. Muito pelo contrário. Com a demanda em alta, a quantidade de africanos introduzidos no Brasil saltou de 25.718, em 1845, para 64.262, em 1846, batendo a marca dos 70 mil nos três anos seguintes $^{415}$. Consequentemente, a capital do império concentraria, no final da década, uma população cativa com mais de 110 mil almas para um total de 266 mil habitantes. Como lembrou Alencastro, a maior concentração urbana de escravos desde o fim do Império Romano $^{416}$. Nas fazendas cafeeiras, a escravidão estava mais forte do que nunca, plenamente consolidada, produzindo a todo vapor.

Não obstante, em $1^{\circ}$ de setembro de 1848 , foi reapresentada à Câmara uma versão revisada do projeto de lei antitráfico do marquês de Barbacena de 1837. Ato que chegou a surpreender gente como o deputado liberal Joaquim Nunes Machado (Pernambuco). Conhecido por ser um dos futuros líderes dos praieiros, o congressista se posicionou favoravelmente à sua aprovação, declarando toda a sua ojeriza ao tráfico e à escravidão:

\footnotetext{
"Um grande erro tem, na sua opinião vogado na população, e é entender-se que sem a continuação do tráfico a sua agricultura estaria hoje morta [....]; os agricultores, considerando-se isoladamente, cada um por si, fascinados pelo receio de não poderem progredir em sua indústria sem os braços africanos, caíram no precipício, e o país será para ele arrastado se a sabedoria dos poderes de estado, se o bom senso, da nação não tratarem de o evitar. [...] É um engano terrível, observa o orador, supor-se que a agricultura só pode alimentar-se com trabalho dos escravos; todos os escritos, todas as opiniões dos homens sensatos que têm pensado sobre a matéria protestam contra semelhante crença, todos concordam que o trabalho escravo é o mais miserável de todos, que a razão de não estar a agricultura do país em maior altura é terse ele habituado a servir-se com escravos" ${ }^{\prime 417}$.
}

No entanto, algo mais do que o senso de moralidade e o juízo sobre a ineficiência relativa do trabalho escravo informou a nova tramitação do projeto de 1837 . A historiografia apresenta caminhos interpretativos diferentes a respeito. A explicação mais difundida sublinha a iniciativa do Gabinete Liberal, chefiado por Francisco de Paula Souza desde 31 de maio, no

\footnotetext{
415 Disponível em: <www.slavevoyages.com>.

${ }^{416}$ Alencastro. "Traite négrière et unité nationale brésilienne", p.412; Mary Karasch.A vida dos escravos noRio de Janeiro(1808-1850). São Paulo: Companhia das Letras, 2000.

Ynaê Lopes dos Santos. Irmãs do Atlântico. Escravidão e espaço urbano no Rio de Janeiro e Havana (17631844). Tese de Doutorado - FFLCH/USP, 2013.

${ }^{417}$ Anais da Câmara dos Deputados, $1^{\circ}$ de setembro de 1848, pp.326-327.
} 
sentido de tomar as rédeas da situação e controlar a supressão do tráfico de forma soberana antes que o país fosse obrigado a fazê-lo pela imposição estrangeira, preservando-se a dignidade nacional. O cerne da questão estaria, portanto, nos efeitos progressivos da execução do Bill Aberdeen. No entanto, mais recentemente, a resistência escrava tem recebido cada vez mais destaque como chave explicativa. Naquele mesmo ano de 1848, as autoridades policiais de Vassouras descobriram um conluio de grandes proporções contra a classe senhorial, o qual visava deflagração de atos insurrecionais por vários pontos do Vale do Paraíba no dia de São João (24 de junho). O plano, que tinha como base o culto religioso de origem kongo e mbundu, teria início com o envenenamento dos senhores pelas escravas que trabalhavam no interior das casas, chamadas mocambas do anjo. Para Robert Slenes, o historiador que reconstituiu essa Conspiração, o temor causado pelo episódio teria se somado à pressão inglesa, concorrendo para a formação de uma opinião consensual em torno da supressão do tráfico entre 1848 e 1850, quando a Lei Eusébio de Queirós foi aprovada. Sem refutar o possível aporte deste ato de rebeldia para a iniciativa antitráfico do governo, Tâmis Parron ponderou acertadamente o peso distinto da política internacional naquele processo e a ausência de homogenia no "comportamento administrativo" do estado brasileiro ${ }^{418}$.

A posição de Nunes Machado não fez fortuna entre seus pares. A opinião favorável à continuidade do tráfico não estava em voga apenas entre a população, claro. Parlamentares partidários do infame comércio buscaram frear o debate. O deputado Casimiro José de Moraes Sarmento (Rio Grande do Norte) requereu que a discussão do projeto fosse tratada em sessão secreta. Apelava-se à prudência a fim de que fossem evitados os distúrbios que a publicização do debate poderia causar entre os escravos. Por outro lado, o ministro da Justiça, Antônio Manoel de Campos Mello, presente na sessão, manifestou a posição do Executivo, salientando a necessidade de se anular a normativa de 1831 e suas imputações: era senhor esquecer o passado. O que estava em mira era a ab-rogação da Lei Feijó com a criação de mecanismos de repressão mais efetivos e, ao mesmo tempo, a preservação da propriedade ilegal das centenas de milhares de escravos trazidos para o país via contrabando, que enchiam as senzalas das fazendas. O décimo terceiro e último artigo do projeto previa que "nenhuma ação poderá ser intentada em virtude da lei de 7 de novembro de 1831, que fica revogada". Por isso, era o mais polêmico. A sua discussão poderia proceder noutra direção, despertando "paixões perigosas".

\footnotetext{
418 Parron. A política da escravidão..., pp.234; Rafael de Bivar Marquese. O poder da escravidão: Política e economia-mundo na construção da ordem escravistabrasileira. Tese de Livre-Docência - FFLCH/USP, 2012; Sérgio Buarque de Holanda. História geral da civilização brasileira. O Brasil monárquico: reações e transações, t. II, v. 3. Rio de Janeiro: Bertrand Brasil, 2004, p.43.
} 
Chegou-se a um consenso no sentido de que a apreciação do projeto seguiria em plenário até o penúltimo artigo. Daí seria decidido o modo de apreciação do último deles, se público ou secreto. Procedeu-se dessa forma. As deliberações se prolongaram até o dia 21 daquele mês, com a aprovação de todos os doze artigos. No dia 22 foi decretada sessão secreta a fim de que o artigo que revogava a Lei de 7 de novembro de 1831 fosse examinado. O resultado foi a indefinição: adiou-se por tempo a deliberação sobre o projeto. O malogro sepultou o período conhecido como quinquênio liberal no dia 29 de setembro. Formou-se, então, um novo Gabinete Saquarema, que não se mostrou resoluto em dar continuidade à plataforma de seus antecessores quanto ao tráfico. Muito pelo contrário. Vasconcelos, como era de seu feitio, veio à cena criticar toda aquela movimentação em torno de "uma lei que já nasceu há onze anos, que não devia entrar em debate" 419 . A matéria ficou em suspenso durante o resto de 1848 e por todo o ano de 1849, quando se procedeu a dissolução da Câmara (fevereiro) e a realização de novas eleições (dezembro), que culminou na formação de uma maioria conservadora na Câmara. $\mathrm{O}$ que se fez foi dar alguma satisfação de medidas antitráfico aos ingleses para acalmar os ânimos, efetuando-se algumas apreensões por embarcações do império, ao mesmo tempo em que se informavam os traficantes sobre a incerteza sobre o futuro do contrabando ${ }^{420}$.

O ano de 1850 começou fervilhando. A pressão dos britânicos atingia um novo estágio de intensidade. Havia o entendimento de que o governo brasileiro tinha plenas condições de pôr fim ao contrabando e que eram necessárias medidas mais agudas para forçá-lo a caminhar nesta direção. Concretamente, a ideia era realizar um bloqueio do Rio de Janeiro e da Bahia, para vedar a introdução de novos cativos. Um primeiro passo nesse sentido foi o deslocamento da esquadra que estava estacionada no Rio da Prata para o apresamento de tumbeiros que cabotavam o litoral do país, chegando até Santos. Simultaneamente, alastrava-se uma grave epidemia de febre amarela, que castigaria de maneira grave a população. Supostamente, a doença provinha dos africanos recém-chegados ao país, o que teria reforçado a desconfiança da população em relação àquelas pessoas e as convicções políticas em torno da suspensão do contrabando. Abolir o tráfico passava a ser uma questão de saúde pública ${ }^{421}$.

O tópico não é ponto pacífico na historiografia, como sabido. Jeffrey Needell descarta a eclosão da doença como um fator influente para a opção governamental pelo término do

\footnotetext{
${ }^{419}$ AS, 27 de setembro de 1848, p.384.

${ }^{420}$ Bethell. A abolição do comércio brasileiro de escravos..., pp.337-370.

${ }^{421}$ Alencastro. Le commerce des vivants..., p.517; Sidney Chalhoub. Cidade febril. Cortiços e epidemias na Corte imperial. São Paulo: Companhia das Letras, 1996, pp.60-96; e Dale T. Graden. “An Act 'Even of Public Security': Slave Resistance, Social Tensions, and the End of the International Slave Trade to Brazil, 1835-1856". Hispanic American Historical Review. 76 (2), pp.249-82; Rodrigues. O infame comércio..., pp.31-62 e 97-119.
} 
infame comércio. Em sua perspectiva, seria preciso demonstrar a figuração da febre amarela nas deliberações, ou nos debates dos estadistas imperiais envolvidos no processo. Em um texto publicado pela revista Afro-Ásia, em resposta a uma resenha de Sidney Chalhoub, que se ressentiu, entre outros pontos, da refutação deste elemento no livro The Party of Order $(2006)^{422}$, Needell foi taxativo: "o que precisa ser demonstrado, com evidência, é que a febre foi um fator crucial na decisão e provas disto simplesmente não existem. Este é o ponto principal: a coincidência entre a data da febre e a data da decisão não constitui evidência de que uma coisa causou a outra" 423 . De fato, é impossível desmentir o historiador. As evidências às quais ele faz menção não existem. O problema é que nosso passado é cheio de silêncios, omissões e evasivas. Ignorar o que permanece velado é quase sempre deficitário para a reconstituição da história do Brasil. As febres amarelam, assim como as recentes mobilizações escravas, também descartadas por Needell, compunha o cenário no qual os políticos incumbidos de conduzir a política sobre o tráfico negreiro estavam atuando. Difícil supor, por exemplo, que a morte de Bernardo Pereira de Vasconcelos, defensor ferrenho do tráfico e da escravidão, em razão da doença, não tenha causado espécie em seus pares e que a Conspiração descoberta em Vassouras em nada tenha contribuído anteriormente para a reapresentação do projeto de Barbacena. O que os registros oficiais indicam é que o fator decisivo foi o recrudescimento da intervenção militar da Grã-Bretanha, mas os outros elementos envolvidos não podem ser descartados para a recomposição do contexto.

No dia 14 de janeiro, dias após o reconhecimento oficial dos primeiros casos de febre amarela na Corte e a retomada das incursões de vapores de guerra britânicos, como o Rifleman e o Cormorant, contra negreiros brasileiros, o agora ministro da Justiça, Eusébio de Queirós, pronunciou-se dando conta da posição do Executivo saquarema no sentido de fazer passar uma nova lei contra o tráfico negreiro. Em 12 de fevereiro, o ministro dos negócios Estrangeiros, Paulino José Soares de Sousa, instruiu o representante brasileiro em Londres para que utilizasse o argumento de que uma segunda lei antitráfico estava por ser aprovada no Parlamento. $\mathrm{O}$ objetivo era obter do Foreign Office, um compromisso de suspensão dos ataques. Em 19 março, William Hutt, pertencente a um setor favorável ao abandono da campanha inglesa contra o tráfico, bem que tentou emplacar uma moção para a retirada da esquadra britânica em atividade na costa africana, abafando o bill Aberdeen. Mas a maioria do Parlamento londrino votou pela

\footnotetext{
422 Jeffrey Needell. The Party of Order: The Conservatives, the State and Slavery in the Brazilian Monarchy, 1831 1871. Stanford, California: Stanford University Press, 2006, p.

423 Jeffrey Needell. "Resposta a Sidney Chalhoub e à sua resenha "Os conservadores no Brasil Império". AfroÁsia, 37 (2008), pp.293-294.
} 
continuidade dos esforços pelo fim do tráfico. Em meados de junho, outro vapor, o Sharpshooter, enviado para fortalecer a esquadra britânica na região, apontou na costa do Rio de Janeiro fazendo logo duas presas. A reação armada por parte de brasileiros servia de pretexto para novas investidas. No início de julho, houve confronto aberto entre as guarnições de Paranaguá e o Cormorant, que sofreu algumas avarias, menores, claro, do que as causadas na fortaleza brasileira. Os ânimos ingleses se acirraram ainda mais ${ }^{424}$. Não havia mais margem de manobra para o governo brasileiro. O conflito estava praticamente deflagrado. No dia 11 de julho, foi convocada reunião no Conselho de Estado para avaliar como era possível sair daquela situação. A conclusão foi a de que não havia outro caminho que não a da proibição efetiva do tráfico. No dia 16, o projeto de lei para a repressão do infame comércio entrou para a ordem do dia da Câmara. Mas, por sugestão do ministro da justiça, a discussão correu em sessões secretas. Subindo ao Senado, a nova lei foi discutida duramente a primeira quinzena de agosto, divulgando-se, no dia 13, a aprovação do projeto de 1837, com as emendas da Câmara, sem os dois primeiros e o último artigo do original ${ }^{425}$.

Sancionada pelo imperador em 4 de setembro de 1850, a Lei Eusébio de Queirós, como passou para a história, manteve, portanto, a validade da Lei de 1831. Contudo, algumas diferenças podem ser realçadas, a começar pela classificação dos importadores. Conforme o artigo $4^{\circ}$ eram autores do crime de importação - que passava a ser considerada pirataria - “o dono, o capitão ou mestre, o piloto e o contramestre da embarcação, e o sobrecarga". A pena continuaria sendo a declarada no artigo $2^{\circ}$ da Lei de 1831 , a saber, a pena corporal do artigo 179 do Código Criminal. A cumplicidade-imputável à tripulação e todos os que concorressem para o desembarque, sua ocultação ou obstrução da apreensão dos tumbeiros - seria punida conforme as regras dos artigos trinta e quatro e trinta e cinco do Código Criminal. O mesmo valendo para a tentativa de importação. Ademais, transferia-se a alçada correspondente ao julgamento dos infratores, anteriormente pertencente ao juízo criminal ordinário, para a Auditoria de Marinha, em primeira instância, e para o Conselho de Estado, em segunda. Os compradores "conscientes" dos escravos ilegais, responsabilizados pelo artigo $3^{\circ}$ da Lei de 1831, continuariam sendo julgados e processados no foro comum. Nas palavras de Chalhoub, “conseguiu-se, enfim, uma saída astuciosa, que, ao evitar o custo político de revogar a lei de 1831, aprofundou-se o que havia nela para a repressão no mar e no desembarque, e deixou tudo como estava no que concerne aos atos de escravização ilegal em terra" ${ }^{426}$. Em verdade, o

\footnotetext{
${ }^{424}$ Bethell. A abolição do comércio brasileiro de escravos..., pp.356-393.

${ }^{425}$ Parron. A política da escravidão..., pp.230-266; Chalhoub. A força da escravidão..., pp.121-122.

426 Chalhoub. A força da escravidão..., p.126.
} 
aprofundamento dos instrumentos de repressão marítima e costeira se deu pelos decretos 708 e 731, de 14 de outubro e 14 de novembro, assinados pelo célebre ministro da justiça. Regulando a execução da lei, os dispositivos detalharam os meios de apresamento, os sinais que constituíam presunção legal sobre o envolvimento no tráfico, os procedimentos das inspeções e as formas dos processos contra os infratores. Os anos todos à frente da polícia da Corte foram cruciais para a elaboração de tais mecanismos, cuja execução se mostrou efetiva para a repressão do contrabando. Em dois anos, o contrabando estaria extinto. Este importante acréscimo ao quadro jurídico pertinente à escravidão modificou o dinamismo sistêmico do regime brasileiro. Mas, não decretou o seu fim necessário.

O modelo de Marcel van der Linden, já mencionado, acusa a tendência histórica dos sistemas de escravidão se desintegrar no longo prazo. A dilatação temporal aqui é importante. Como ressaltou Ricardo Salles, “entre 1850 e 1871, decorrem duas décadas. Duas décadas de grandeza do Império e da classe senhorial, assentada sobre uma escravidão madura, consolidada, tendente a se auto-reproduzir pelo crescimento vegetativo da população escrava" ${ }^{27}$. O fim das importações de braços cativos constituía um fator de crise, mas, nem os senhores, nem os estadistas do império, previam o fim próximo da escravidão. A implicação imediata seria o rearranjo. O direito escravista, como estava sedimentado, era um componente importante. O controle senhorial sobre a manumissão, juridicamente validado em sua multiplicidade, propiciaria um ajuste flutuante sobre as taxas de liberação de acordo com os imperativos das diferentes zonas de escravidão. Nas grandes plantações do sudeste cafeeiro, os índices de alforria seriam gradativamente achatados, contribuindo para a tendência de crescimento constante dos planteis, pela reprodução natural e pelo tráfico interno ${ }^{428}$. O município da Corte, núcleo geoeconômico fundamental da segunda escravidão, alteraria sua função no circuito de abastecimento de mão de obra, intermediando o tráfico interprovincial e constituindo uma grande reserva de braços para as fazendas de café. Em sua dinâmica interna a prática da alforria sofreria também uma retração volumétrica e alguma alteração em suas tendências gerais. As liberdades concedidas entre 1808 e 1850, conforme apurações do historiador Luiz Carlos Soares, somaram 589, enquanto que as do período pós-1850, até 1888, não passaram de 388. As liberações gratuitas continuaram preponderando, mas em proporção ainda maior. Da primeira para a segunda metade do século XIX, as alforrias concedidas

\footnotetext{
${ }^{427}$ Ricardo Salles. “Abolição no Brasil: resistência escrava, intelectuais, e política (1870-1888)". Revista de Indias, 2011, vol. LXXI, núm. 251 p.268.

${ }^{428}$ Robert Conrad. Os últimos anos da escravidão no Brasil, 1850-1888. (trad.port.) Rio de Janeiro: Civilização Brasileira, 1975, pp.30-88; Robert Slenes, The Demography and Economics of Brazilian Slavery: 1850-1888. Tese de Doutorado em História. Stanford: Stanford University, 1976, pp.120-178;
} 
mediante compensação monetária baixaram de $37,01 \%$ para $22,68 \%$ do total. A formação de pecúlio suficiente para a compra da liberdade ficava cada vez mais complicada diante da restrição da oferta de africanos escravizados e da demanda crescente no cenário externo por mercadorias produzidas pelo trabalho cativo ${ }^{429}$.

Se o volume de alforrias concedidas diminuiu, o das ações judiciais aumentou. Muito embora tenha havido permanências quanto ao perfil, com a prevalência de autores crioulos (80\%) e a menção frequente a relações familiares no polo ativo do processo, o número de recursos encaminhados ao Tribunal da Relação do Rio de Janeiro saltou de 77 (161 cativos), entre 1831 e 1850, para 194 (736 cativos), entre 1850 a 1871, sugerindo uma maior apropriação das esferas judiciais pelos envolvidos nas relações de escravidão ${ }^{430}$. A autora credita a elevação do número de recursos à instância superior ao alargamento do espaço geográfico da abertura dos processos, que passou a abranger cada vez mais a zona rural. Causas originadas do interior das províncias do Rio de Janeiro, Minas Gerais e São Paulo, cuja alçada pertenceria à Relação da Corte até a década de 1870, somariam 68,97\% do total. Quanto ao resultado, Hebe Mattos indica que $55,8 \%$ das sentenças seriam favoráveis à liberdade $(55,8 \%)^{431}$.

A historiografia nacional vem destacando o papel das ações judiciais para a deslegitimação da escravidão ${ }^{432}$. Mas é preciso compreender que este papel não é remissível a todo o século XIX. Para refletir um pouco mais sobre este tópico, pode ser tomado como ilustrativo o caso de Isabel crioula, que em 29 de agosto de 1850, moveu uma ação contra o seu senhor Antônio Dias de Sousa no juízo de direito da terceira vara:

\footnotetext{
"Diz Isabel crioula, representada por seu curador nomeado: que sendo escrava de Antonio Dias de Sousa Castro tem a suplicante sofrido maus tratamentos, e atos de crueldade de sua senhora, mulher de Castro, obrigando-a a trabalhar continuamente em atender ao lastimoso estado em que a suplicante se acha, de extrema magreza com contusão pelo corpo, tosse, calafrios cotidianos, respiração difícil, dores de peito, e muitos sofrimentos constantes do corpo de delito a que se procederam [...] tem todos os despachos como declaram os peritos, acrescendo a tudo isto que o suplicado falta à suplicante com o mínimo alimento para sua subsistência; e que tais atos são inteiramente contrários ao direito e à e religião, e tornam insuportável o já tão desgraçado estado de escravidão, que em todos os tempos mereceu a proteção das Leis e governos ainda mesmo dos absolutos como se vê da carta régia de 10 de janeiro de 1790 ; carta de lei de $1^{\circ}$ de outubro de 1828 art.59, e de 20 de outubro de 1823 art.24 10 , além de outros, pretende a suplicante, visto que encontrou seu benfeitor, que está pronto a fornecer-lhe a necessária quantia para obter a sua libertação, fazer citar o suplicado para na $1^{\mathrm{a}}$ audiência deste juízo nomear e aprovar louvados que avaliem a suplicante para que à sua revelia se faça a avaliação, de perito do valor, e servir a sentença final de título
}

\footnotetext{
${ }^{429}$ Soares. O "povo de Cam” na capital do Brasil..., pp.277-278.

${ }^{430}$ Mattos. Das cores do silêncio..., pp.190-191; Keila Grinberg. "Senhores sem escravos: a propósito das ações de escravidão no Brasil Imperial". Keila Grinberg. "Senhores sem escravos: a propósito das ações de escravidão no Brasil Imperial”. Almanack braziliense, n. 6 (nov.2007), pp.4-13.

${ }^{431}$ Idem, ibidem.

${ }^{432}$ Sidney Chaloub. Visões da liberdade, op.cit.; Azevedo. Orfeu de carapinha, op.cit.; Pena, Pajens da Casa Imperial, op.cit.; Mendonça. Entre a mão e os anéis. Campinas, Unicamp, 1999; Hebe Mattos, Das cores do silêncio, op.cit.; Grinberg. Liberata, a lei da ambiguidade, op.cit.; Grinberg. O fiador dos brasileiros, op.cit.
} 
de liberdade à suplicante em vista do que determina a citada carta régia e demais Leis, e atendendo-se ao estado lastimoso da suplicante" 433 .

Como se pode notar, a sevícia sofrida (atestada por exame de corpo de delito) serviu de base para a solicitação da avaliação à revelia e da consecutiva venda ao benfeitor disposto a quitar o preço correspondente à liberdade. As normas citadas somente de forma tangencial podiam sustentar este propósito. Não localizei a tal Carta régia de 1790. O artigo 59 da lei de $1^{\circ}$ de outubro de 1828 diz o seguinte: "Participarão ao Conselho Geral os maus tratamentos e atos de crueldade, que se costumam praticar com escravos, indicando os meios de preveni$\operatorname{los}{ }^{434}$. O $§ 10$, do $24^{\circ}$ artigo da lei de 20 de outubro de 1823 - que não é mesma que referendou a legislação pregressa, mas outra, que deu nova forma aos governos das províncias, criando a figura do presidente - “cuidar em promover o bom tratamento dos escravos, e propor arbítrios para facilitar a sua lenta emancipação" ${ }^{435}$. Nada disso implicava a avaliação e a venda a terceira como forma de punição. Melhor embasamento teria feito se citasse Carta régia de 23 de março de 1688, que previa a punição a maus-tratos com a venda a terceiros. Isto indica a tendência já identificada por Keila Grinberg quanto à gradativa substituição da legislação "antiga" pela “moderna" na fundamentação das ações ${ }^{436}$.

Não obstante a inconsistência no embasamento legal, a avaliação foi realizada, de forma muito semelhante ao que acontecia em Cuba, como será visto no próximo capítulo. Vale a pena reproduzir seus termos:

\footnotetext{
"Nós abaixo assinados fomos à Praça do Saco do Alferes, n. 39, e aí, em presença do senhor juiz José de Souza, avaliamos a preta Izabel, e crioula, que representa ter 28 anos de idade; sabendo coser, engomar e pouco; achando-se ela atualmente impossibilitada de qualquer serviço pelo seu estado de grave moléstia, por $400 \$ 000$

Rio de Janeiro, 14 de setembro de 1850

Manoel Jesus da Silva

Guilherme Midosi Pereira do Nascimento"437
}

Antônio Dias de Sousa, por seu turno, representado por Miguel Borges de Castro Azevedo e Mello, apresentou embargos de nulidade à notificação decorrente do libelo de sua escrava e à avaliação realizada. O exemplo do observado no caso de Maria Thereza e José

\footnotetext{
433 Arquivo Nacional (RJ). Apelação Cível, Relação do Rio de Janeiro, 84.0.ACI.45 (C3683N4975) (1850-1852 AEL RRJ mr 015), f.2.

434 Disponível em: <http://www2.camara.leg.br/legin/fed/lei_sn/1824-1899/lei-35062-1-outubro-1828-532606publicacaooriginal-14876-pl.html $>$. Acesso em: 22 de fev. 2015.

435 Disponível em: <http://www2.camara.leg.br/legin/fed/lei_sn/anterioresa1824/lei-40978-20-outubro-1823574639-publicacaooriginal-97736-pe.html>. Acesso em: 22 de fev. 2015.

436 Grinberg. O fiador dos brasileiros..., pp.250-259.

${ }^{437}$ Arquivo Nacional (RJ). Apelação Cível, Relação do Rio de Janeiro, 84.0.ACI.45 (C3683N4975) (1850-1852 AEL RRJ mr 015), f.17.
} 
Guimarães, ao anunciado benfeitor foi atribuído a responsabilidade sobre o ato: "a presente notificação, nada mais era quer ser o embargante espoliado da sua propriedade sem prova da parte da escrava, ou antes, do seu curador, e melhor direi de seu mentor oculto dos falsos e injuriosos convícios aí alegados contra a respeitável mulher do embargante”. Alegou-se, também, a nulidade do exame de corpo de delito, que teria sido feito sem a necessária solenidade legal, mostrando-se, impreciso quanto às lesões e ao estado físico geral. Os castigos "bárbaros e cruéis" descritos seriam “fantásticos". Em tempo algum teria excedido a moderação correcional exigida pelo art. $14 \S 6$ do Código Criminal; "e nem se diga que à liberdade são outorgadas coisas contra as regras gerais de direito, porque essas coisas não podem ser mais dignas de atenção que o absoluto Direito de propriedade tão respeitado em todas as Nações cultas e tão garantido pelas Leis supracitadas, e arraigado no Pacto Social deste Império" ${ }^{438}$.

Este arrazoado é uma peça exemplar do liberalismo escravista brasileiro; afirmava a submissão ao trabalho escravo mediante coação física "moderada", com base no direito constitucional à propriedade. Neste caso, o princípio constitucional era corroborado pela lei de 9 de setembro de 1826, que definiu as raras ocasiões nas quais era facultada ao estado o ato de desapropriação "por necessidade, e utilidade pública", e pelo decreto de 21 de Maio de 1821 , cujo texto determinou que "a ninguém possa tomar-se contra sua vontade cousa alguma de que for possuidor, ou proprietário; sejam quaisquer que forem as necessidades do Estado, sem que primeiro de comum acordo se ajuste o preço”. Haveria, portanto, impeditivos legais diretos ao procedimento requerido pelo curador de Isabel. Conforme a lei, para que uma desapropriação ocorresse, deveria haver uma motivação associada à defesa do estado, à salubridade e à segurança públicas ou ao socorro em tempo de fome. O eventual ajuste de preço dependeria de comum acordo. Dias de Sousa se opunha ao preço fixado, considerando-o subestimado em função da idade e os predicados da escrava. O arremate com o descarte peremptório do antigo brocardo jurídico que à liberdade são outorgadas coisas contra as regras gerais de direito afirmava o senso de prevalência da propriedade privada.

No dia 15 de setembro de 1851, o juiz Carlos Antonio de Bulhões Ribeiro aprovou os embargos, julgando improcedente a notificação. Em seu entendimento, não havia provas efetivas sobre a gravidade desmedida das lesões sofridas, nem sobre a falta de alimento ou o excesso da carga de trabalho. Além da inconsistência das evidências documentais, as oitivas de testemunhas realizadas teriam sido contraproducentes. No Tribunal da Relação, no entanto, a sentença foi reformada. Acórdão dia 18 de dezembro de 1852, reconheceu as provas

\footnotetext{
${ }^{438}$ Grifo meu. Idem, f.23.
} 
apresentadas no sentido de considerar Isabel liberta, uma vez que se certificasse o depósito da quantia pela qual a apelante foi avaliada. A sentença era reforçada com a afirmação de que o direito de propriedade não podia se sobrepuser aos princípios de direito natural e de direito civil, que proscreviam "a aplicação de castigos violentos contra os que nos são subordinados". Seria possível interpretar esta sentença como um sinal de que o processo de "deslegitimação" do poder senhorial estava em sua fase inicial? Afinal de contas, o controle senhorial sobre a alforria fora quebrado. Desta vez, a saída não foi a procura de meios dóceis e persuasivos. O tribunal superior ordenou a concessão da carta de liberdade à revelia da vontade do proprietário, quem, aliás, tinha amparo legal para pleitear a manutenção de seu domínio.

Enquanto o processo de Isabel tramitava na Relação carioca, a Seção de Justiça do Conselho de Estado, composta por figuras de peso como o ex-ministro da justiça, Limpo de Abreu, Honório Hermeto Carneiro Leão, o Visconde do Paraná, que a partir do ano seguinte encabeçaria o Célebre Ministério da Conciliação, como também Candido José de Araújo Viana e Caetano Maria Lopes da Gama, discutia justamente o procedimento a ser tomado em casos de sevícia. O mote do debate era o caso do negociante rio-grandense Antônio Gonçalves Carneiro e do espanhol Fernando Ortiz, presos e processados no Rio Grande do Sul pela aplicação de castigos excessivamente rigorosos, resultantes na morte de seus cativos. Cinco escravas do primeiro e uma do segundo encontravam-se em depósito judicial. O procurador da Coroa sugeriu - com base em fórmula que adotou no tempo em que havia servido como provedor do termo e da comarca do Rio de Janeiro, inspiradas em provisões da Mesa de Consciência e Ordens de Portugal - que as escravas em questão fossem mantidas depositadas, sendo-lhes permitida a escolha de novo senhor entre particulares que oferecessem lance em pregão ${ }^{439}$.

A proposta foi rechaçada com veemência no parecer emitido pela Seção, pois "este ato seria um verdadeiro esbulho de propriedade cometido pela autoridade sem forma alguma de processo" ${ }^{440}$. Ademais, não se observava com as escravas depositadas o caso de sevícias graves "para poderem invocar em seu favor o Direito Romano como subsidiário". Ampliando o exame da matéria, recordou-se a inexistência de legislação no Brasil que obrigasse o senhor a vender o seu escravo. "Temos muito pelo contrário a ordenação do Livro $4^{\circ}$ - Título 11 , a qual muito expressamente determina que ninguém seja constrangido a vender o seu herdamento, e coisas, que tiver contra sua vontade". Portanto, executando-se a lei com rigor, não haveria caso algum em que o escravo poderia intentar contra o senhor ação para vendê-lo. "Entretanto a prática de

\footnotetext{
${ }^{439}$ Atas do Conselho de Estado Pleno. Terceiro Conselho de Estado, 1850-1857, p.44.

${ }^{440}$ Idem, p.47.
} 
julgar tem admitido, em algumas hipóteses, a sobredita ação, e em virtude de sentenças de Tribunais têm alguns senhores sido obrigados a vender os seus escravos". O caso de Isabel, portanto, não era uma ocorrência isolada. A doutrina que autorizava aquela prática advinha de preceitos originários do Direito Romano - referendado como direito subsidiário pela vigência plena da Lei da Boa Razão (1769) -, que previam a aceitação de denúncias em caso de injúria ou lesão grave e a perda do domínio (§2, Lei 1ª , Dig.).

\begin{abstract}
"Não podendo negar-se que estas disposições do Direito Romano, tendentes a proteger os escravos contra a barbaridade dos senhores fundam-se nas máximas do Direito Divino, e Natural, evidente é que em virtude da Lei de 18 de agosto de 1760 devem elas ser adotadas no foro como regra de julgar sendo por consequência legais os arestos que tem reconhecido nos escravos o direito de obrigarem os senhores a vendê-los nos casos, em que o Direito Romano admita ação para este fim. Esta doutrina torna-se tanto mais incontestável quanto é certo que na nossa legislação, assim antiga como moderna encontram-se diversas providências, que têm por abjeto amparar, e proteger tanto as causas de liberdade como as pessoas dos escravos. Com referência à legislação antiga temos a Ordenação Livro 4, Título 11, parágrafo 4 onde se consigna o princípio de que em favor da liberdade muitas coisas são outorgadas contra as regras gerais de Direito, e a do Livro 5, Título 36, parágrafo 1, onde se determina que o senhor, em castigando ferir o escravo com arma, não será relevado das penas impostas na mesma Ordenação. Pelo que respeita à legislação moderna temos, além de outras disposições a Lei do $1^{\circ}$ de outubro de 1828 , a qual no artigo 59 prescreve às Câmaras Municipais a obrigação de participarem ao Conselho Geral da respectiva Província os maus tratamentos, e atos de crueldade, que se costumam praticar com os escravos, indicando os meios de preveni-los, e bem assim a Código Criminal, que no artigo $6^{\circ}$, § 11 veda aos senhores a aplicação aos escravos de castigos, que não sejam moderados, incorrendo em caso contrário nas penas correspondentes aos delitos, que cometerem" ${ }^{\text {"41 }}$.
\end{abstract}

Como é possível depreender, o curador de Isabel estava atuando em um terreno bem mapeado. O tratamento cruel, com aporte à doutrina extraída do Direito romano, constituía fundamento plenamente aceito para a requisição em juízo da venda para um novo senhor e de seu equivalente na forma da alforria onerosa.

Interessante observar que, ao final, a Seção de Justiça apresentou uma proposta de lei com três meios básicos para melhor "amparar os escravos contra a barbaridade de alguns senhores" a ser encaminhada ao Poder Legislativo. Primeiro, que a autoridade judicial (o juiz municipal do termo ou o juiz de direito da comarca) - ao tomar conhecimento de que algum senhor cometia ato de sevícia contra escravos seus, procedendo aos exames e averiguações necessárias - informasse o Presidente da Província e ao Governo municipal. Segundo, que estes últimos pudessem, à vista das informações recebidas, instruir que a ação competente para a obrigação de venda fosse intentada ex officio. Terceiro, que, neste caso, as despesas do pleito ficariam a cargo da Câmara municipal, que deveria havê-las do senhor do escravo em caso de condenação. Segundo o texto, tais medidas não teriam por efeito "prejudicar o direito, que tem

${ }^{441}$ Atas do Conselho de Estado Pleno. Terceiro Conselho de Estado, 1850-1857. 
o escravo, em caso de sevicias, de intentar por si a ação, que lhe compete contra o senhor, sendo apenas mais um meio, que se estabelece para proteger e tornar efetivo esse direito" 442 .

Procedeu-se a votação, começando por Araújo Lima, o Visconde de Olinda, que declarou estar de acordo com o recurso à doutrina que respaldava ações por maus-tratos, mas não lhe parecia conveniente a parte "em que se propõe novas medidas a exigir do Corpo Legislativo pelo perigo que pode ter legislar-se sobre a matéria, pondo em risco a segurança ou, ao menos, a tranquilidade das famílias, pelo que é seu voto se conservem as coisas como estão". Os demais conselheiros acompanharam, um a um, o voto do ex-regente, incluindo o Visconde de Abrantes, Clemente Pereira, Holanda Cavalcante, e mesmo membros da Seção, como Paraná e Araújo Viana, que se declararam persuadidos. Apenas Limpo de Abreu, relator do parecer, corroborou-o, sustentando ambas as conclusões,

\footnotetext{
"a primeira de conformidade com as disposições das leis em vigor; e a segunda em que nada se propõe de novo a respeito dos escravos contra a crueldade de seus senhores, apenas se indica a alteração de serem auxiliados com a intervenção da autoridade Judiciária ex-officio pela impossibilidade de se apresentarem eles por si só, e sem auxílio e pelo receio que deve ter-se de que outros façam o que a essa autoridade se incumbe, sendo notória a existência de sociedades filantrópicas de amigos mais dos negros, que dos brancos, cuja proteção aos escravos pode ser perigosa" $" 43$.
}

Toda essa discussão, que terminou com uma resolução apoiando apenas o primeiro ponto do parecer, sem o encaminhamento de proposta de lei, significa que embora houvesse espaço para o reconhecimento de certos “direitos" para os escravos, este espaço era bastante limitado. O marcos escravista do direito ainda estava bem delimitado. Mantendo-se inscrito em uma na tradição pluralista e tributária do direito romano justinianeu, que havia expurgado o direito de vida e morte sobre os cativos, a jurisprudência imperial, preenchendo a lacuna da legislação, sancionou a solução aplicada no caso de Joana crioula. A intervenção judiciária e executiva, sem dúvidas estimuladas pela pressão exercida pelas vítimas do cativeiro, tinha em perspectiva, ainda em 1852, a velha questão da preservação do regime pela contenção dos excessos. Conferia-se estabilidade aos instrumentos sociais de subordinação, mantendo-se a legitimidade do uso privado da violência dentro de um patamar tido como aceitável e necessário chancelado pelo Código Criminal do Império. O arbítrio senhorial continuaria essencialmente preservado desde que fosse respeitado o limiar da moderação. Ao mesmo tempo, inibia-se ao máximo o passo adiante no sentido de ampliar os marcos legais das relações de escravidão e dos instrumentos de defesa e representação em juízo. O contexto aguçava a tradição do silêncio. O embaraço do debate sobre a preservação ou não da Lei de 1831 ainda estava quente, e

\footnotetext{
${ }^{442}$ Idem, ibidem.

${ }^{443}$ Atas do Conselho de Estado Pleno. Terceiro Conselho de Estado, 1850-1857.
} 
reforçava a cautela dos estadistas quanto a evitar abrir o plenário do Parlamento para enfrentar temas associados ao cativeiro. Novamente, tomava-se o caminho da continuidade, da preservação, ainda que os fundamentos objetivos do sistema estivessem descontinuados pelo término do tráfico. Naquela década, a escravidão ainda seria tomada como signo de inscrição do país na modernidade, tomando-se o Sul dos Estados Unidos como o modelo a ser seguido, na medida em que havia logrado êxito na ampliação da população cativa após o fechamento do tráfico transatlântico ${ }^{444}$.

Decerto, havia uma contracorrente. A partir daqueles anos, discursos favoráveis à melhoria da condição, ao reconhecimento de certos direitos, e mesmo à emancipação dos escravos ganhariam novo fôlego. O historiador Eduardo Spiller Pena reconstituiu com maestria os debates realizados no âmbito do Instituto de Advogados do Brasil em torno de questões relacionadas à escravidão entre as décadas de 1840 e 1860. Criado em 7 de setembro de 1843 , o IAB seria composto por advogados e jurisconsultos de peso na cena política nacional, tanto no Legislativo quanto em postos do alto escalão do Executivo. Com uma orientação majoritariamente legicentrista, as falas do instituto enalteceriam de forma recorrente a importância da positivação normativa na sociedade, "tanto para sua ordenação jurídica básica (relacionada à preservação dos direitos civis da família e da propriedade) como para seu constante aperfeiçoamento e desenvolvimento no mundo moral, político e econômico" Vários de seus membros e alguns presidentes defenderiam amplamente a codificação das leis civis, prevista na constituição e permanentemente adiada pelo Poder Legislativo nacional. Entre as várias matérias discutidas, estariam matérias polêmicas associadas ao cativeiro, passíveis de interpretações distintas nos tribunais. Embora houvesse limites à hermenêutica jurídica, o caráter pluralista do ordenamento jurídico dava margem a uma variação considerável quanto à fundamentação processual e à interpretação de certos tópicos. ${ }^{446}$

Uma das polêmicas mais famosas foi a que envolveu Caetano Alberto Soares, autor de uma memória sobre o melhoramento da sorte dos escravos (1845) e signatário de uma proposta para a emancipação gradual da escravatura (1852), e Augusto Teixeira de Freitas, “o maior dos jurisconsultos brasileiros". Em 8 de outubro de 1857, Soares colocou em discussão uma polêmica envolvendo a condição dos filhos de escrava alforriada em testamento com a condição de prestar serviços a terceiros. Competia saber se seriam ou não escravos; se lhes caberia a

\footnotetext{
${ }^{444}$ Rafael de Bivar Marquese \& Tâmis Peixoto Parron. "Internacional escravista: a política da segunda escravidão". Topoi, v. 12, n. 23, jul.-dez. 2011 p. 97-117.

${ }^{445}$ Pena. Pajens da Casa Imperial, p.45.

${ }^{446}$ Idem, p.17-69.
} 
mesma obrigação, caso fosse tomados como livres; e a quem pertenceriam, caso fossem considerados escravos. O tópico estava longe de ser ponto pacífico. Spiller Pena identificou dois arestos do Supremo Tribunal de Justiça com decisões antagônicas a respeito. Um primeiro, de 1847, confirmou o cativeiro de uma mulher parda chamada Joaquina e, um segundo, do mesmo ano de 1857, que teria decidido pela liberdade da menor Jacintha. Ambas nascidas no tempo em que as mães, alforriadas, cumpriam a sua condição. Este tipo de oscilação dependia bastante dos termos impressos no testamento, sendo alimentada pela configuração fluida do quadro jurídico. As variações de contexto também importavam ${ }^{447}$.

Para Caetano Soares, os filhos de escravas alforriadas com cláusula de prestação de serviços seriam livres. Para basear sua posição, recorria, em conformidade à Boa razão, as regras extraídas do Digesto (L.5 ${ }^{\mathrm{a}}, \S 2$ e L.24), relacionadas às regras do usufruto. Perante o seu entendimento, não sendo "frutos" os filhos das escravas alforriadas por condição, não pertenceriam aos usufrutuários dos serviços. Tampouco, cabia-lhes a prestação de serviços. Salles Rosa concordou parcialmente, defendendo que a liberdade não eximia os filhos da obrigação de prestarem serviços, fazendo menção ao artigo 196 do Código da Luisiana (1724), que estipulava a liberdade às pessoas naquela situação, atrelando-as, porém, às obrigações da progenitora $^{448}$. Já Agostinho Marques Perdigão Malheiro acompanhou totalmente Caetano Soares, defendendo a liberdade e a isenção de serviços. Teixeira Freitas, que ocupava a presidência do instituto, interveio refutando totalmente as teses levantadas, apregoando que o dispositivo do usufruto não cabia àquela situação, já que inexistia desmembramento de domínio entre proprietário, de um lado, e usufrutuário de outro; que o Direito romano sempre considerou a manumissão uma doação (Inst. L.1, tit. 5 princ. de libertin), tal como aceito pela "nossa" legislação na Ord. L. $4^{\circ}$, tit. 63 , e que nos termos do seu $\S 5$ podia ser pura e simples ou condicional $^{449}$; que, igualmente pelo Direito romano, o escravo libertado em testamento sob condição era chamado statu-liber, ao qual pesariam todas as atribuições de escravo enquanto durasse a obrigação estabelecida, podendo ser, inclusive vendido (a não ser que o testador proibisse); que, portanto, os filhos gerados seguiam a condição da mãe, inclusive quanto à

\footnotetext{
${ }^{447}$ Idem, pp.85-86.

448 Vernon Valentine Palmer. "The Origins and Authors of the Code Noir". Louisiana Law Review, v.56, n.2 (1996). Disponível em: <http://digitalcommons.law.lsu.edu/lalrev/vol56/iss2/5>. Acesso em: 24 de ago. 2013.

${ }^{449}$ Aqui, o jurisconsulto faz uma interpretação de uma das causas que previam a revogação da doação em caso de ingratidão: "A quinta causa é quando o donatário prometeu ao doador, por lhe fazer a doação, dar-lhe ou cumprirlhe alguma coisa, e o não fez nem cumpriu, como prometeu". Lara. "Legislação sobre escravos africanos na América Portuguesa", p.59. Cf. Carta de renúncia de Augusto Teixeira de Freitas, p.51. Disponível em: <http://www.iabnacional.org.br/article.php3?id_article=2047>. Acesso em: 22 de nov. 2014.
} 
prestação de serviços, assumindo a liberdade somente após o término dos termos afixados pela expressão da vontade senhorial.

A exposição das ideias divergentes não transcorreu de forma cordata. Os ânimos se exaltaram de tal maneira que Teixeira de Freitas renunciou à presidência da casa em 22 de outubro de 1857. Em seu discurso, explicaram em pormenor os fundamentos de seu posicionamento; lamentou a postura de seus pares; rebateu os que o acusavam de "romanista", manifestando orgulho por sua erudição nas leis e doutrinas do Direito romano, "onde está depositada toda a filosofia do direito"; observou que o problema estava na admissão legal da escravidão no país e em suas implicações quanto à perda da personalidade e à equiparação dos escravos a coisas; e arrematou com ironia, oferecendo mil-réis para a aquisição de um exemplar do Corpus Iuris para a biblioteca do IAB. Em dezembro, os membros voltaram a se reunir, decidindo em votação pela liberdade dos filhos de uma statu-liber ${ }^{450}$.

Nos anos seguintes, outras matérias associadas à escravidão seriam debatidas, como, por exemplo, a possibilidade do filho do senhor com sua escrava ter sua própria mãe como escrava, ou de se manter a prole ou descentes em cativeiro, deliberando-se favoravelmente à liberdade de filhos e parentes. No entanto, como constata Spiller Pena, o IAB fracassou em normatizar a jurisprudência. Os ímpetos emancipacionistas de suas principais figuras, Caetano Soares e Perdigão Malheiro, se mostraram resilientes diante da manutenção da ordem e do direito à propriedade. Não há dúvida de que todas as hipóteses colocadas eram baseadas em situações concretas que passavam pelos tribunais. Entretanto, eram todas periféricas e não colocavam em risco a dinâmica do sistema. O "emancipacionismo jurídico" do IAB não foi além dos marcos estabelecido desde a constituição. A não ser por arroubos isolados e infrutíferos, como o de Caetano Soares, em 1845, e o do membro-fundador, Francisco Gê Acayaba de Montezuma, em 1865, o núcleo duro do instituto nunca se engajou de forma orgânica em um projeto efetivo de desarticulação do cativeiro, que previsse a garantia legal ao pecúlio e à alforria, melhorasse os mecanismos de proteção e as condições de acesso às esferas judiciais. Toda aquela enorme influência de seus membros não se converteu em uma mudança efetiva na regulação das relações de escravidão. Teixeira de Freitas, reputado como derrotado, foi o único que realmente validou o seu ponto de vista, estando a cargo, desde 1855, da sistematização das leis do país que resultaria na Consolidação das leis civis, "um índice

${ }^{450}$ Pena. Pajens da Casa Imperial, pp.115-119. 
autorizado" das normas existentes; teoricamente, um trabalho preparatório para o Código Civil propriamente dito ${ }^{451}$.

Decerto, não apenas a sua enorme erudição e reputação de grande jurista (o maior de todos), mas o fato dele estar "à direita" em relação a seus colegas explica a incumbência atribuída pelo ministro Nabuco de Araújo. Sabia-se exatamente o que esperar de Teixeira de Freitas. Um "romanista" tão devotado não haveria de causar estribilho desnecessário ou se pôr a desviar demasiadamente da tradição jurídica luso-brasileira. Como se sabe, o jurisconsulto não incluiu em sua obra um tratamento da legislação pertinente à escravidão. Como se tratava de "uma exceção, um capítulo avulso, condenado a extinguir-se em época mais ou menos remota", cumpria não macular a reforma das Leis Civis com disposições "vergonhosas", que não serviriam à posteridade. "As Leis concernentes à escravidão (que não são muitas) serão

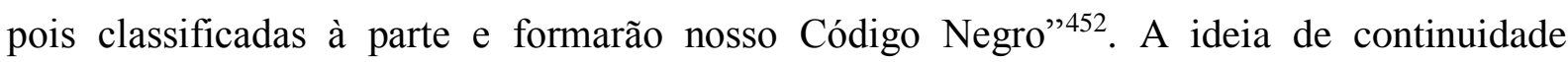
descontínua se encaixa bem em mais este ponto. O silêncio, uma característica muito forte do modo lusitano de regulação do cativeiro, ligava-se, agora, ao vislumbre de término do regime. Mas o seu efeito prático continuava sendo a inalterabilidade dos fundamentos essenciais do poder senhorial, que estavam longe de serem desfigurados.

Em 1858, uma comissão do Ministério da Justiça, composta pelo próprio Nabuco de Araújo, o desafeto Caetano Soares e Paulino de Souza, revisou a primeira versão da obra, emitindo um parecer bastante elogioso, mas que pontuou a omissão sobre a escravidão ${ }^{453}$. Ainda que fosse pertinente a formulação de uma lei especial, um código específico, "motivos políticos e de ordem pública" impunham, segundo os pareceristas, o esclarecimento do "estado defectivo da legislação a este respeito". O ponto não é tão crítico como já se deu a entender. O que estava sendo cobrado do autor era que ele esclarecesse o estado atual das normas vigentes a respeito do cativeiro para orientar a administração do direito. Ainda que metodologicamente renovado e atento às tendências jurídicas modernas, o trabalho de Teixeira de Freitas tinha uma função eminentemente compilatória. Na segunda edição da obra (1865), ele encontrou um meio-termo, coligindo as normas que tratavam dos aspectos gerais envolvendo a prática do cativeiro, sem inseri-las, porém, ao corpo do texto. Redigiu, portanto, o que Spiller Pena chamou de código negro de rodapé, que nada tinha de código, ao modo do racionalismo jurídico do século XIX,

\footnotetext{
${ }^{451}$ Joaquim Nabuco. Um estadista do império: Nabuco de Araújo, sua vida, suas opiniões, sua época. Rio de Janeiro: H. Garnier, pp.340-341.

${ }^{452}$ Augusto Teixeira de Freitas. Consolidação das Leis Civis. Rio de Janeiro: Typographia Universal Laemmert, 1865 , p.XI.

${ }^{453}$ Augusto Teixeira de Freitas. Consolidação das Leis Civis. (terceira edição) Rio de Janeiro: Garnier, 1876, p.XIX..
} 
vale realçar. A nota principal a tratar dos escravos é a primeira do título II, Das Cousas, bem representativo da concepção do jurisconsulto a respeito da natureza da condição de escravidão. Mas esclarecia,

\footnotetext{
"Na classe dos bens móveis entram os semoventes, e na classe dos semoventes entram os escravos. Posto que os escravos, como artigos de propriedade, devam ser considerados cousas; não se equiparam em tudo aos outros semoventes, e muito menos aos objetos inanimados, e por isso tem legislação peculiar" ${ }^{\text {"54 }}$.
}

Na sequência, enfileirava as normas pertinentes, a começar pelo alvará de 6 de junho de 1755, do qual extraía presunção de liberdade, "incumbindo sempre o encargo da prova aos que requerem contra a liberdade" ${ }^{\prime 45}$.

Pela sua natureza, conforme o alvará de 16 de janeiro de 1759, as causas sobre liberdade não admitiam estimação (L. 106 Dig.), e por isso excediam sempre a alçada quando se julgava contra a liberdade; o que não se verificava quando se julgava a favor da liberdade, visto que, para o apelante, seu contendor era um objeto de propriedade. Isto é, deveria sempre haver recurso para sentenças contrárias à liberdade. Os escravos eram inábeis para adquirir e suceder, conforme Ord. L. 4, tit. 92 e Aviso n. 16 de 13 de fevereiro de 1850. Todavia, havia uma tolerância "em nossos costumes" para que os escravos possuíssem dinheiro e bens móveis. Os escravos deixavam sua condição pela alforria ou manumissão, e esta podiam ser dadas a título oneroso ou gratuito. O título gratuito, por ato entre vivos ou por disposição de última vontade, não sendo reconhecidos os outros modos de manumissão do Direito Romano.

Como a alforria podia ser dada por fideicomisso, a prazo, ou debaixo de condição, havia um estado médio entra e escravidão e a liberdade, a dos estado-livres, os quais estariam destinados a serem livres depois de certo tempo ou do cumprimento de uma condição (L. $1^{\circ}$ Dig. de statulib). A condição do estado-livre seria tal, que, ao ser vendido, nada perderia do direito que tinha à liberdade (L. $2^{\circ}$ Dig de statulib). $\mathrm{O}$ herdeiro de um testador não poderia tirar a liberdade de um estado-livre (L. 33 Dig de statulib). Originalmente, o estado-livre estava sujeito às mesmas penalidades dos demais escravos (L. 29 Dig de statulib), mas a L. $9^{\circ} \S 16$ Dig. de panis determinou que a punição se desse como se fora livre. Os filhos de uma estadolivre nasciam escravos do herdeiro (L. 16 Dig de statulib). Mas, reforçando sua opinião exposta no debate do IAB, opinava que as proles de mulher portadora do direito absoluto à liberdade futura deveriam seguir a sorte da mãe após a satisfação da condição, segundo a interpretação que fazia do artigo 196 do código da Luisiana.

\footnotetext{
${ }^{454}$ Freitas. Consolidação das Leis Civis, p.35.

455 Idem, ibidem.
} 
A alforria só aconteceria (L.17 $\S 1^{\circ}$ Dig.), se o senhor tivesse a intenção de libertar seu escravo. A não ser em caso de abandono de escravo doente (Provisão $1^{\mathrm{a}}$ de 15 de dezembro de 1823 ) e de declaração falsa a respeito da liberdade em juízo para obter isenção de castigo ${ }^{456}$.

Em 1865, sairia uma versão da Consolidação com observações do célebre político e advogado de ações cíveis envolvendo a liberdade de escravos (tendo defendido, como usual, tanto escravos quanto senhores), Antonio Pereira Rebouças, que anotou alguns pontos de divergência. Era o desfecho de uma polêmica moderada iniciada anos antes quando da publicação da primeira edição do trabalho, em 1857. Registram-se alguns pontos de discordância. O caso da revogação da alforria em caso de ingratidão, por exemplo. Neste ponto, Teixeira de Freitas se mostrou menos apegado ao tradicionalismo do que seria de se esperar, apregoando que aos libertos nascidos no Brasil de modo algum caberia o retorno ao cativeiro por haver sido ingrato, na medida em que gozando das garantias constitucionais que interditavam qualquer possibilidade de escravização dos cidadãos brasileiros. Rebouças, por seu turno, advertiu que tal benefício não se aplicava aos que porventura houvessem obtido a liberdade por meios enganosos ${ }^{457}$. Mais interessante, porém, para os presentes fins pode ser notar o que Rebouças não mencionou em suas observações a respeito das omissões ou desvios existentes na Consolidação e que deve saltar aos nossos olhos.

Teixeira de Freitas furtou-se a aludir às leis antitráfico entre as normas consolidas sobre a escravidão no Brasil. Encobrindo sua existência, o jurisconsulto teceu seu compêndio como se todo o cativeiro no Brasil fosse regido ainda sobre títulos legítimos e não existisse a situação mais do que evidente de dezenas de milhares de africanos livres ilegalmente escravizados no Brasil. Não foi o que fez o jurista Antonio Joaquim Ribas, por exemplo, que as incluiu em sua seção sobre a “origem da escravidão entre nós", em sua obra, Direito administrativo brasileiro, de 1861 , usada nos cursos de direito ${ }^{458}$. A diferença era que a Consolidação não era uma publicação destinada aos estudos jurídicos, ela tinha um caráter normativo, sancionado pelo poder Executivo. Talvez não haja casualidade aqui. Tal omissão, mantida nas sucessivas edições revistas, inclusive na de 1876, contribuia para amainar os efeitos da Lei de 31. Mesmo fazendo strictu sensu parte da esfera do direito criminal, os efeitos da norma antitráfico incidiam diretamente sobre o estatuto civil de centenas de milhares de indivíduos, fragilizando a legitimidade de propriedade escrava. Caberia, portanto, a menção.

\footnotetext{
${ }^{456}$ Idem, pp.35-37.

457 Augusto Teixeira de Freitas. Consolidação das Leis Civis - Observações do advogado conselheiro Antonio Pereira Rebouças, confirmando a ampliando as da primeiraed. Rio de Janeiro: E. \& H. Laemmert, 1867.

${ }^{458}$ Antonio Joaquim Ribas. Direito administrativo brasileiro. Noções Preliminares. Rio de Janeiro: F. L. Pinto, pp.188-189.
} 
Isto ficaria claro na manifestação do Conselho de Estado, na sessão de 24 de outubro 1874, quando foi sustentado, diante de interpretações judiciais mais favoráveis à liberdade, que a Lei de 1831 deveria ser seguida unicamente quanto à criminalização do tráfico, nunca no que respeitava a liberdade dos escravos. Merece destaque o voto do Visconde Jaguary. Com base em lei de 1854, que facultava a prescrição de fatos passados, o conselheiro efetuaria uma interpretação restritiva da medida antitráfico, sustentando o seguinte:

\begin{abstract}
"Essa prescrição se funda em evidentes reclamações de ordem pública, porquanto um grande número de escravos provenientes de importações anteriores à época da efetiva repressão, importações constantes da fama pública, mas não constatadas legalmente, tinham sido adquiridos e transmitidos, bona fide por título inter vivos ou causa mortis, e seria uma medida revolucionária arrancá-los sem indenização de seus senhores" $"$ "
\end{abstract}

O trabalho de Elciene Azevedo sobre extraordinária atuação do abolicionista Luis Gama demonstra que a lei de 1831 passou a ser usada em juízo com fins de libertação de escravos ilegais a partir de 1868. Nota, ainda, a crescente politização das ações de liberdade a partir dessa época e a maneira como os usos do direito assumiam "um papel central no recrudescimento do abolicionismo". Indo além, a historiadora destaca que a atuação de advogados "em ações de liberdade impetradas pelos escravos contra seus senhores, contribuíram para desestruturar a política de domínio senhorial, minando as bases da ideologia que sustentava a escravidão" 460 . O trabalho de Azevedo é certeiro para o contexto que analisa. Mas seria erroneo se projetássemos seus resultados para o período anterior.

Cabe sempre observar que as formas jurídicas, embora preservem uma história e uma lógica próprias, não constituem uma realidade à parte, descolada das práticas econômicas e das articulações políticas. O Direito não está sendo chamado aqui de escravista somente por versar sobre aspectos envolvendo senhores e escravos, mas porque se manteve na própria dinâmica que envolvia a reprodução do cativeiro. Keila Grinberg pontuou muito bem: "havia limites demarcados por regras jurídicas, com os quais mesmo os mais politizados advogados, defensores da liberdade ou da manutenção da escravidão tinham de conformar-se". ${ }^{461} \mathrm{O}$ que se pode ressaltar é que esses limites ajudaram a sustentar a escravidão. Havia um potencial transformador no desempenho de Luiz Gama e de outros advogados, assim como na iniciativa dos próprios escravos e nas articulações políticas internas, mas a sua efetivação se deu

\footnotetext{
${ }^{459}$ Apud José Reinaldo de Lima Lopes. O Oráculo de Delfos: o Conselho de Estado no Brasil-Império. São Paulo: Editora Saraiva/FGV, 2010, p.286-287.

${ }^{460}$ Elciene Azevedo. O direito dos escravos: lutas jurídicas e abolicionismo na província de São Paulo. Campinas: Editora Unicamp, 2010, p.93.

${ }^{461}$ Grinberg. O fiador dos brasileiros..., pp.251-252.
} 
conjugada ao movimento geral que desencadeou a crise geral do escravismo atlântico, evidente em escala sistêmica após a vitória da União na Guerra da Secessão ${ }^{462}$.

Para reforçar o argumento, cumpre tomar mais alguns casos ocorridos entre os anos 1850 e 1860. Nessa época, ficou cada vez mais comum a abertura de processos judiciais envolvendo vários autores. Em 26 de abril de 1852, os pretos Manuel, João e Francisco, e as pretas Maria, Emerenciana, iniciaram uma ação, reportando-se ao municipal da $2^{\mathrm{a}}$ vara da Corte, apresentando certidão atestando que seu falecido senhor os havia deixando forros em testamento, a partir de 19 de fevereiro de 1851 . Ocorrera, porém, "que tendo decorrido 11 meses e tantos dias" desde a citação da testamentaria, permaneciam sujeitos ao testamenteiro, Joaquim de Souza Monteiro,

\begin{abstract}
"[...] guardando-lhe grande obediência, e prestando-lhe seus serviços em tudo e por tudo, sem que de seus suores tenham tido o menor recebimento ainda mesmo conhecido o direito sagrado que lhes assiste, [...] nunca quiseram tomar a si a liberdade de que gozam sem judicialmente usarem dos meios competentes a bem de serem mantidos na posse de suas liberdades. Mas, porém, vendo-se os suplicantes tolhidos de poderem sobre si cuidarem no que lhes for mister a bem de suas pessoas: recorrem competentemente habilitados nesta autoridade para serem manutenidos na posse de suas liberdades" ${ }^{\prime 463}$.
\end{abstract}

Luis Alves de Azevedo Macedo, o curador nomeado, encaminhou um mandado de manutenção de liberdade para que os autores passassem "a manutenir na posse de suas liberdades". O réu, por sua vez, se defendeu “alegando grandes dívidas do casal, hipotecas dos escravos [...], que os bens do respectivo casal não são suficientes para solver todas as dívidas passadas". Em 22 de abril de 1853, o juiz Carlos Honório de Figueiredo, julgou que, pelas escrituras apresentadas, via-se que os bens hipotecados eram superiores ao valor das dívidas,

\begin{abstract}
"[...] preterir portanto os embargados do pleno gozo de suas liberdades seria a mais consumada desumanidade, e contra o credor, por outro lado, os bens chegam para o pagamento das dívidas para assim serem satisfeitas as hipotecas constantes das escrituras. A liberdade está garantida da condição humana, tão protegida e proclamada pelas leis, que tanto garantem não pode estar sujeita a oscilações, ações deste quilate gozam de infinitos privilégios [...] portanto, considerados não provados os embargos opostos à manutenção, seja esta declarada firme e valiosa, e os autores garantidos no pleno gozo de suas liberdades e ao embargante condeno nas custas" $" 464$.
\end{abstract}

A sentença foi mais tarde confirmada no Tribunal da Relação do Rio de Janeiro, em Acórdão proferido em 17 de junho de 1854, que considerou seus fundamentos conformes às provas apresentadas e às disposições de direito, "mormente porque a liberdade dada aos

\footnotetext{
${ }^{462}$ Rafael de Bivar Marquese \& Tâmis Peixoto Parron. "Internacional escravista: a política da segunda escravidão", op.cit.

${ }^{463}$ Arquivo Nacional (RJ). Apelação Cível, Relação do Rio de Janeiro, 84.0.ACI.54 (C3682N183) (1852-1854 AEL RRJ mr 019), f.3.

${ }^{464}$ Idem, f. 189 .
} 
apelados está provada com o documento f.7”. É possível observar uma retórica favorável à liberdade, mas ela só se sustenta por causa da constatação de que os interesses dos credores não seriam lesados, e de que havia provas efetivas de que a vontade do testador era a conceder a alforria.

Em 16 de dezembro de 1858, Casemiro crioulo, por seu curador, José Maria da Silva Velho, reportou-se ao juiz municipal suplente da $3^{\text {a }}$ vara, dando conta de que havia sido libertado por sua antiga senhora, Joana Nepomuceno da Silva Bithencourt com a condição de servi-la pelo período de cinco anos, na época em que se procedia o inventário de bens pelo falecimento de seu primeiro marido. Caso ela morresse antes do prazo, o tempo restante de serviço deveria ser prestado a sua filha. Contudo, o réu, Higino de Assunção Gomes, segundo marido de Joana, teria executado toda sorte de "tropeços e chicanas" para impedir o autor de entrar na posse de sua liberdade, tendo, inclusive, sem ciência de sua mulher, "a concessionária da dita liberdade", e com "a mais requintada má fé, matriculado Casemiro na Recebedoria como seu escravo. Higino, porém, apresentou provas de que, originalmente, a condição afixada foi para toda a vida de Joana. Mais tarde, já após haver contraído segundas núpcias, é que ela teria modificado os termos da prestação de serviços, algo sem validade, dada incapacidade civil das mulheres casadas. $\mathrm{O}$ argumento convenceu o juiz municipal, que julgou sem efeito jurídico a renúncia aos serviços, por não ter, à época da opção efetuada, poder para administrar os bens do casal, determinando que Casemiro deveria voltar a servir e acompanhar a outorgante, mulher do réu, enquanto ela fosse viva. Haveria, porém, uma reviravolta no caso. Acórdão do Tribunal da Relação, pronunciado em 7 de agosto de 1860, interpretou que a liberdade havia sido conferida pela outorgante quando ela era viúva, configurando uma servidão "personalíssima, intransferível e incomunicável", por isso, não podia deixar de surtir o devido efeito a decisão de abreviar o tempo da condição estabelecida. Com efeito, o apelante era considerado livre de qualquer sujeição e "no pleno gozo de sua liberdade". Higino ainda tentou embargar a decisão, porém, Acórdão de 12 de março de 1861, corroborou-o. É possível especular sobre a possível predisposição do Tribunal Superior em tecer uma interpretação favorável à liberdade. Mas, se tal predisposição houve, ela se estabeleceu em pleno acordo com as linhas mestras da política de dominação senhorial. O arbítrio de Joana sobre a concessão da liberdade foi totalmente referendado ${ }^{465}$.

O ponto é que se o postulante à liberdade não apresentasse evidências ou uma alegação sustentável a respeito de sua condição, nada fariam os julgadores para aliviar a sua situação.

465 Arquivo Nacional (RJ). Apelação Cível, Relação do Rio de Janeiro, 84.0.ACI.78 (C3690N8367) (1858-1861 AEL RRJ mr 026). 
Vejamos, por exemplo, o caso do menor Odorico pardo, que moveu uma ação sumária de liberdade em 19 de novembro de 1862, no juízo municipal da primeira vara. O seu curador, o advogado Carlos Antonio Cordeiro, expôs que o menor era filho de uma mulher parda chamada Felismina, de condição livre, que havia sido vendida de forma criminosa sob o nome de Thereza a Manoel Marques Perdigão, "que reconhecendo não ser ela escrava, sempre como livre a tratou, até para garantir-lhe a liberdade por sua morte, a deixou encostada a uma sua filha", Ana Rangel de Macedo. Havendo o menor nascido de Thereza, era evidente que também ele era livre, "pelo princípio de direito, o pardo segue o ventre, não podendo de sorte alguma comprometer a sua condição e reduzi-lo à qualidade de escravo o fato de haver sido batizado por escravo, sendo isso um abuso, ou antes, um crime perpetrado por D. Mariana Rangel de Caldas", uma sobrinha de Marques Perdigão. O caso é complicado. A história de que a mãe de Odorico seria uma mulher negra livre vendida ilegalmente como escrava se apoiava apenas em provas testemunhais. Além do que, ele havia sido vendido a terceiro, o que dificultava o rastreamento do crime original (é possível aventar a hipótese de se tratar de um recurso corriqueiro para a "lavagem" da propriedade escrava). Um recibo de venda anexado ao processo dá conta da compra realizada por José Antonio Teixeira, de Leopoldino dos Santos Pereira, marido de Mariana, em 31 de dezembro de 1859, pela inflacionada quantia de 1.200\$000. Vistos os autos, em 25 de julho de 1863, o juiz municipal considerou não provado a história sobre a venda da parda Felismina “em seu estado de livre”, julgando a ação improcedente. Deuse a apelação, mas os desembargadores da Relação confirmaram a sentença original, em 12 de abril de $1864^{466}$.

Outra ação iniciada naquele mesmo ano de 1864 chama bastante atenção. Com um teor recorrente no sul do império ${ }^{467}$, mas que foge um pouco da curva em relação aos processos ajuizados no Rio de Janeiro, é o da parda Brenda, o qual merece ser aqui mencionado. Sendo ela escrava de João Ignácio Teixeira de Magalhães, foi alugada a um tal Francisco Silveira de Magalhães. Este a conduziu a Montevideo em sua companhia e a serviço de sua esposa, demorando-se ali por cerca de duas semanas, o que lhe daria direito à liberdade, tendo-se em vista a convenção firmada em 12 de outubro de 1851 entre o Império do Brasil e o Estado Oriental, onde a escravidão havia sido abolida em 1842. Um dado interessante e obscuro no

\footnotetext{
466 Arquivo Nacional (RJ). Apelação Cível, Relação do Rio de Janeiro, 84.0.ACI.99 (C3680N10002) (1862-1864 AEL RRJ mr 033).

${ }^{467}$ Keila Grinberg. “A Fronteira da Escravidão: a noção de 'solo livre' na margem sul do Império brasileiro”. III Encontro Escravidão e Liberdade no Brasil Meridional; Thiago Leitão de Araújo. "A escravidão entre a Guerra e a Abolição: o impacto das fugas e os pedidos de extradição de escravos nas fronteiras platinas (década de 1840)". VI Encontro Escravidão e Liberdade no Brasil Meridional.
} 
documento é a forma como a informação sobre a aquisição do direito à liberdade por conta de sua estadia em Montevideo chegou ao conhecimento de Brenda. Pela letra do processo, ela não soube imediatamente, visto que retornou ao domínio de seu senhor, submetendo-se sem reclamar. Somente depois ela procuraria fazer valer seu direito junto ao poder judiciário. Claro que isto pode não estar correto. É bem possível que alguém a tenha informado durante sua permanência em terras orientais ou no trajeto, enfim.

Em sua contrariedade, o advogado de Magalhães argumentou que, pelos termos do tratado, só seria livre o escravo pertencente a cidadão brasileiro que passasse para terras orientais por vontade de seu senhor, o que não era o caso, já que Brenda foi levada até a capital do país vizinho sem a sua ciência e consentimento. Portanto, não poderia o réu responder e perder sua propriedade por isso. Pronunciando-se no dia 10 de março de 1863, o juiz considerou provado que a autora tinha ido para Montevideo sem haver fugido, lá demorando por quinze dias mais ou menos. Restava, portanto, averiguar o que efetivamente se achava convencionado entre os dois países a este respeito. Considerando não apenas o tratado de 1851, como também o de 20 de julho de 1858, o magistrado observou que Brenda não se enquadrava nos casos estipulados para a extradição de escravos, os quais envolviam fuga e situações peculiares da lida de cativos na região fronteiriça. Assim sendo, contrariando a alegação do defensor do réu, acatou o reconhecimento efetuado pelo governo imperial de que todo escravo que saísse do Brasil para a República vizinha deveria ser considerado livre. A autora foi, então, restituída ao seu estado de liberdade, condenando-se o réu às custas. Acórdão de 15 de setembro de 1865 confirmou esta sentença. Um Pedido de Revista ainda foi apresentado, mas, em 4 de julho de 1866, o Supremo recusou-o "por não haver injustiça notória nem nulidade manifesta" 468 .

Paulo, de nação Cassange, não teria a mesma sorte que Brenda, sendo colocado na posição de réu em uma ação de escravidão ajuizada por seu senhor, Manoel José da Silva Cruz, em 13 de setembro de 1864. As alegações constantes no libelo eram as seguintes:

\footnotetext{
"Havendo-se evadido de seu poder, há cerca de dois meses, o seu escravo, Paulo, de nação Cassange, acontece que, apreendido pela Polícia declarou que era livre, apresentando uma Carta de liberdade, que diz lhe ter passado José Alves de Castilho, seu antigo senhor, de que o suplicante o houve; sendo a mesma carta datada muito posteriormente à compra do suplicado. Em consequência do que, vê-se o suplicante obrigado a propor contra seu dito escravo a competente ação de escravidão"469.
}

\footnotetext{
468 Arquivo Nacional (RJ). Apelação Cível, Supremo Tribunal de Justiça, (C3689N6907) (1864-1866 AEL STJ mr 014).

${ }^{469}$ Arquivo Nacional (RJ). Apelação Cível, Relação do Rio de Janeiro, (C3694N11037) (1866-1867 AEL RRJ mr 037), f.2.
} 
Por este relato, Paulo teria planejado uma estratégia para escapar do cativeiro, obtendo uma carta de alforria de seu antigo dono, para o caso de ser pego pela polícia no ato da fuga. É possível, também, que Paulo realmente achasse que seu antigo senhor poderia alforriá-lo, tendo escapado de boa fé. Não é possível saber. O fato é que a apreensão ocorreu ao que tudo indica, por denúncia de Manoel José.

Como atesta recibo apenso ao processo, Manoel José adquiriu Paulo de José Castilho em 24 de fevereiro de 1845 pela quantia de $400 \$ 000$ e o levara para a fazenda de sua propriedade na freguesia do Irajá. Como Castilho se encontrava em má situação, Manoel o teria acolhido em sua fazenda, dando-lhe um sítio, e permitindo que Paulo lhe fosse fazendo alguns serviços. Assim ficou até que Castilho se mudasse para a freguesia da Glória, para onde o réu o acompanhou, voltando dali algum tempo depois para o poder de seu senhor. Nesse ínterim deve ter se fortalecido o vínculo que possibilitou a Paulo obter a carta de alforria tardia de seu ex-senhor.

A região do Irajá, encravada na baía da Guanabara, uma antiga zona de circulação de pessoas e mercadorias, inclusive escravos, assim como outras freguesias rurais do Rio de Janeiro, sofreu o impacto do fim do tráfico e da promulgação da Lei de Terras em $1850^{470}$. Em 1857, no fluxo dessas mudanças, Manoel acabou vendendo sua fazenda e se mudando para São Cristóvão, levando consigo o réu e outros escravos de sua propriedade. Todos devidamente matriculados na estação competente. Anos mais tarde, em 1863, daria licença para que Paulo vivesse ao ganho, mas manteve seu domínio, sem nunca ofertar a alforria. Então, no princípio de julho de 1864, Paulo fugiria de casa, sendo preso pouco depois, portando a carta de liberdade passada muito depois de sua venda pelo primeiro senhor. Vistos os autos, em 12 de junho de 1865, o juiz municipal considerou convincentes todos os documentos apresentados pelo autor e nula a carta de liberdade apresentada, na medida em que o seu artífice não tinha mais o direito de manumitir o réu. Paulo teria, portanto, que retornar ao cativeiro. A sentença foi confirmada em 7 de junho de 1867.

O caso de Paulo e Manoel escapam um pouco da tendência geral observada pela historiadora Keila Grinberg sobre ações de re-escravização perpetradas naquela mesma época para o Vale do Paraíba. Ela demonstra que as maiores partes daquelas ações eram ajuizadas por senhores de poucas posses, muitas vezes, egressos ou descendentes de escravos, que, sem poder para submeter os fugitivos por outras vias, buscavam o poder judiciário para não se tornarem “senhores sem escravos", em meio ao "processo de perda de legitimidade da instituição

\footnotetext{
${ }^{470}$ Rita de Cássia Ribeiro da Silva. "Entre Posseiros e Arrendatários uma História Social Agrária da Freguesia de Irajá (1850-1890)". Caminhos da História, Vassouras, v. 7, Edição Especial (2011), pp.179-188.
} 
escravista na segunda metade do século XIX" ${ }^{471}$. Mas é preciso considerar que um dos fatores que diferem o escravismo oitocentista (segunda escravidão) do regime barroco (primeira escravidão, ou seja, qual for a denominação adotada), é o fato de existir durante todo o período um questionamento da legitimidade ou da conveniência moral e econômica da continuidade do regime do tráfico e da escravidão, correlacionado a um movimento antiescravista internacional capitaneado pela Grã-Bretanha, imbuída de seu capital moral ${ }^{472}$. No auge da direção saquarema, as vozes dissonantes foram sistematicamente abafadas no meio político e na imprensa, criando um contexto desfavorável também no interior dos tribunais, como sugere a primazia de sentenças contrárias à liberdade ${ }^{473}$. Na segunda metade do século, haveria um novo espaço para o embate entre posições escravistas e antiescravistas. Mas, sempre com gradações e limites. O controle social da população dos egressos e a defesa da propriedade estariam sempre na perspectiva de grande parte dos "intelectuais" devotados ao debate. O sistema jurídico, da forma como estava constituído, simplesmente impossibilitava a desarticulação do domínio senhorial, por maior que fosse o empenho dos autores, o auxílio propiciado por seus curadores e a boa vontade de juristas e magistrados quanto à interpretação das normas existentes. Só com a mudança no quadro normativo, ocorrido em 1871, que a manumissão e a sua defesa nos tribunais assumiriam um lugar desestruturante, inserindo-se em um processo mais amplo de desagregação e, isto, porque o tráfico já havia sido abolido. Quando se diz, por exemplo, que "sistemas de direito simultaneamente contribuíram para perpetuar o poder de proprietários sobre seus escravos e serviram como base a partir da qual escravos e libertos conseguiram desafiar o poder de seus senhores" ${ }^{\$ 74}$, é preciso ter em conta, antes de qualquer coisa, que tal simultaneidade era brutalmente assimétrica, pois o desafio ao poder dos senhores só se concretizava, no caso do sistema brasileiro, quando ele objetivamente não mais se fundamentasse. A não ser, claro, em casos excepcionais como o de Brenda.

\footnotetext{
${ }^{471}$ Keila Grinberg. "Senhores sem escravos: a propósito das ações de escravidão no Brasil Imperial". Almanack Braziliense, [S.1.], n. 6 (nov. 2007), p.13.

${ }^{472}$ Christopher Leslie Brown. Moral Capital. Foundations of British Abolitionism. Chapel Hill: The University of North Carolina Press, 2005.

${ }^{473}$ Mattos, Das cores do silêncio..., pp.177-206.

${ }^{474}$ Grinberg. "Senhores sem escravos...", p.5.
} 


\section{Capítulo 3}

\section{O direito dos escravos e o escravismo hispano-cubano, 1820-1870}

Conforme firmado na Real cédula de 8 de abril de 1778, o governo espanhol, avançando em relação às Siete Partidas, determinou que nenhum senhor poderia se furtar a outorgar a carta de liberdade ao escravo de sua propriedade que apresentasse a soma correspondente ao seu preço integral, podendo ser compelido em juízo a fazê-lo mediante avaliação pericial, acompanhando-se sempre o valor de mercado. Consequentemente ocorreu um acréscimo importante em relação aos precedentes legais originados do Direito romano, abreviando-se o controle senhorial em relação à liberdade dos cativos. É digno de nota que esta ocorrência foi plenamente compatibilizada com o discurso pró-escravista cubano. É o que se nota na Representación hecha a su majestade con motivo de la sublevación de esclavos en los domínios franceses de la isla de Santo Domingo, assinada em 20 de novembro de 1791 por Francisco de Arango y Parreño, elaborada no bojo do debate sobre a validação da Instrucción de 31 de maio de $1789^{475}$. Nesse texto, o Apoderado da cidade de Havana buscou a "sossegar" o monarca, explicando as diferenças fundamentais entre Cuba e a colônia francesa sublevada. Seriam três basicamente: o forte espírito de subordinação e obediência ao Soberano generalizado entre a população livre da ilha, a melhor guarnição da cidade de Havana em comparação ao Cabo Francês e, principalmente, o tratamento dado aos escravos. Disse ele,

\footnotetext{
"Los franceses los han mirado como bestias y los españoles como hombres. El principio de aquellos amos y aun de su legislación negrera ha sido siempre el excesivo rigor, infundir a sus esclavos todo el temor que se pueda, creídos de que de este solo modo era capaz un blanco de gobernar cien negros en el centro de los bosques y en medio de unas tareas tan fuerte y tan continuas" ${ }^{\prime 476}$.
}

A tal consideração dos escravos como homens, não como bestas, seria resultado da progressiva acomodação jurídica, iniciada ainda na Antiguidade, de princípios que protegiam os escravos, propiciando-lhes todos os "consolos possíveis e compatíveis com a segurança dos amos", com destaque para a vigilância das autoridades sobre o bom tratamento, a faculdade de queixas contra crueldades, a mudança de senhor em situações de sevícia e, claro, o estabelecimento dos meios necessários para que chegassem à liberdade. As leis civis

\footnotetext{
${ }^{475}$ Manuel Lucena Salmoral, "Leyes para esclavos: el ordenamiento jurídico sobre la condición, tratamiento, defensa y represión de los esclavos en las colonias de la América española", in José Andrés-Gallego (coord), Nuevas Aportaciones a la Historia Jurídica de Iberoamérica. Madrid: Fundación Histórica Tavera/Digibis/Fundación Hernando de Larramendi, 2000 (Cd-Rom), p.1150.

${ }^{476}$ Gloria García Rodríguez. Biblioteca de Clásicos Cubanos. Francisco de Arango y Parreño. Obras (volumen I). Ensayo introductorio, compilación y notas de Gloria García Rodríguez. Havana: Imagen Contemporánea, Ciencia Sociales, 2005, p.141.
} 
espanholas, culminância exemplar de todo esse processo, teriam balanceado com perfeição a contenção dos extremos representados pelos abusos dos proprietários e a "insubordinação e insolvência" dos escravos, de modo que nada havia a temer. O ideal a se fazer era permitir uma vigilância secreta da conduta dos senhores, "pero que de ningún modo sea conocida a los negros para que no dé bríos a su natual insolência"477. Postura que, ao ser encampado pelo centro de poder espanhol, embaraçava qualquer passo adiante na regulação do governo dos $\operatorname{escravos}^{478}$. O saldo daquela discussão foi uma nova demarcação dos limites para a ingerência do estado sobre o governo dos escravos, com a reafirmação do caráter apaziguador da liberação individual. Isto seguramente fez parte do cálculo a que se referiu a historiadora Ada Ferrer para a assimilação massiva de escravos com vistas à equiparação dos níveis produtivos da colônia francesa em crise ${ }^{479}$.

À luz do capítulo anterior, salta aos olhos a diferença fundamental em relação ao Brasil, onde a alforria onerosa, muito embora constituísse prática corrente, foi formalmente mantida como um ato de graça, dependendo sempre de sua vinculação ao voluntarismo senhorial para que fosse vindicada em juízo. Em Cuba isto não era necessário, na medida em que foi facultado ao escravo, legalmente, o direito de requerer a sua liberdade pela compensação financeira, ao arrepio da vontade do amo. Não parece descabido associar tal fato à preponderância de manumissões pagas em relação às graciosas em território cubano ao longo do mesmo período (final do século XVIII e século XIX). Uma pesquisa ampla sobre as taxas a incidência das modalidades de alforria na ilha de Cuba ainda está por ser feita, mas os dados existentes apontam para a preponderância da auto-compra sobre as manumissões gratuitas, enquanto que, em terras brasileiras, as alforrias pagas não superaram a média de $35 \%$ do total ${ }^{480}$.

Decerto, não foi apenas o direito legal à alforria onerosa que rebaixou os atos de graça na ilha de Cuba, que se mantiveram, cabe realçar, dependentes do arbítrio senhorial, cumprindo as mesmas funções sociais que no Brasil, estabelecendo laços de reciprocidade, estimulando o

\footnotetext{
477 Idem, p.142.

${ }^{478}$ Rafael de Bivar Marquese. Feitores do corpo, missionários da mente - senhores, letrados e o controle dos escravos nas Américas, 1680-1860. São Paulo: Cia. das Letras, 2004, pp.207-211.

${ }^{479}$ Ada Ferrer. "A sociedade escravista cubana e a Revolução Haitiana"..., p.42 A sociedade escravista cubana e a Revolução Haitiana. Almanack, n.3, mai. 2012, p.42. Disponível em: <http://www.almanack.unifesp.br/index.php/almanack/article/view/742>. Acesso em: 27 Abr. 2014; Ada Ferrer. Freedom's Mirror: Cuba and Haiti in the Age of Revolution. Cambridge: Cambridge University Press, 2014, pp.173-205.

${ }^{480}$ Laird W. Bergad, Fe Iglesias García \& María del Carmen Barcia. The Cuban Slave Market, 1790-1880. Cambridge: Cambridge University Press, 1995; Aisnara Perera Díaz \& María de los Angeles Meriño Fuentes. Para librarse de lazos, antes buena familia que buenos brazos: apuntes sobre la manumisión en Cuba (18001881). Santiago de Cuba: Editorial Oriente, 2009, p.142. Para um inventário dos dados existentes para o Brasil, ver: Francisco Vidal Luna \& Herbert S. Klein. Slavery in Brazil. Cambridge: Cambridge University Press, 2010, pp.261-262.
} 
trabalho, respondendo ao parentesco e desonerando proprietários em tempos de retração. A prática da coartação é um elemento essencial, na medida em que surgia como uma solução intermédia ente a graça total e a venda da liberdade. Na perspectiva do senhor, era uma forma de estabelecer algum laço de clientela, sem perder o domínio sobre o escravo, para quem abriase, se não um caminho certo para a liberdade, uma margem maior de autonomia e de luta pela melhoria de sua condição. No levantamento realizado no estudo de Laird Bergard, Fe Iglesias e María del Carmen Barcia, foram identificadas 23045 vendas de escravos realizadas entre 1790 e 1880. Destas, 3438 envolveram escravos coartados, o que equivale a dizer que $13 \%$ dos cativos comercializados na ilha encontraram-se nesta condição no decorrer do período. Do que se pode inferir, primeiro, que havia um mercado bastante aberto para os escravos que iniciavam o seu processo de coartação, o que se explica pelo decréscimo que havia em seu valor de mercado e, presumidamente, pela maior engenhosidade de um trabalhador disposto a levantar a quantia necessária para amortizar o mais brevemente possível o preço de sua alforria; segundo, que o patamar geral de coartados entre os escravos era superior aos 3438, considerando-se que nem todos os coartados eram vendidos, permanecendo sob o domínio do amo que o coartou ou acessando diretamente a liberdade ${ }^{481}$.

Como também observado na parte inicial do presente estudo, até a década de 1840, a coartação não era formalmente um direito do escravo, na medida em que não havia uma determinação que obrigasse o proprietário a aceitar uma quantia determinada para o rebaixamento do preço total do escravo. Porém, havia um reconhecimento formal dos ajustes firmados em âmbito privado, o que conferia segurança jurídica ao estatuto, inclusive para possíveis pleitos judiciais. Decerto, é preciso escapar de qualquer visão idílica a este respeito. Das 6027 cartas de liberdade levantadas pelos mesmos autores citados no parágrafo anterior, apenas 550 traziam a inscrição carta de libertad coartado, isto é, nem $10 \%$ do total de liberdades outorgadas e cerca de $16 \%$ em relação aos coartados encontrados nos registros de venda; todas as outras cartas traziam a inscrição carta de libertad venta, que representavam as alforrias adquiridas por escravos inteiros. Mesmo se descontarmos os registros que ocultaram a condição real dos beneficiários, pode-se concluir que parte substancial dos cativos que iniciavam sua coartação nunca chegava realmente a se livrarem do cativeiro ${ }^{482}$. Disso devemos depreender um arranjo específico na ordenação das relações de escravidão, com pontos nítidos de distinção em relação ao modo brasileiro.

\footnotetext{
${ }^{481}$ Bergad, Iglesias \& Del Carmen. The Cuban Slave Market, 1790-1880, pp.122-142.

${ }^{482}$ Idem, p.128. Claudia Varella. Esclavos a sueldo: la coartación cubana en el XIX. Tese de Doutorado. Castellión: Universitat Jaime I, 2010.
} 
Como ponto de partida para a exposição da perspectiva adotada na presente investigação, é possível destacar o trabalho recente dos historiadores Alejandro de la Fuente e Ariela Gross. Por meio de uma análise from the bottom up sobre as relações entre direito e escravidão em Cuba, Louisiana e Virginia, os pesquisadores se debruçaram sobre os esforços legislativos locais, os arranjos costumeiros e os apelos judiciais feitos pelos escravos ${ }^{483}$. Mesmo dentro dos limites de um artigo, trata-se de um estudo abrangente, que busca examinar a evolução dos regimes legais desde o seu período formativo (estendido até a década de 1760), passando pela Era das Revoluções (1770-1820) até o século XIX. Os autores desenvolvem o argumento de que o quadro legal, correlacionado à dinâmica política local, à ideologia racial e à configuração demográfica, criou oportunidades diferenciadas para escravos e negros livres. A questão da tradição jurídica parece-lhes especialmente importante no período formativo, mas de uma forma distinta do que geralmente se prega, tendo em vista que o arcabouço que informou a organização das sociedades coloniais ibéricas teria propiciado uma tipificação para uma demarcação imediata da inferioridade dos negros na hierarquia social, estreitando a distância entre escravos, liberta e seus descendentes. Na Virgínia, ao contrário, haveria um tempo de indefinição, ambiguidade e relativa fluidez da condição do cativeiro, sem diferenciação substantiva na legislação entre os africanos e os sujeitos atrelados a outras modalidades de trabalho (servos por contrato europeus e ameríndios). Por outro lado, a capacidade normativa da elite colonial cubana, e ibérica de um modo geral, teria sido em alto grau limitada pela reiteração dos precedentes que, entre outros aspectos, sancionavam com liberalidade a prática da manumissão, dando margem à formação gradual de uma significativa comunidade de negros e mulatos livres, que não encontrou paralelo na colônia britânica, onde foram impostas pesadas restrições a partir da década de 1690.

Avançando no tempo, os autores reconhecem na chamada Era das Revoluções um momento de aproximação das experiências escravistas, com um afluxo de ideias favoráveis à liberdade e um crescimento generalizado de chances efetivas para a manumissão, inclusive na Virginia, onde haveria um relaxamento das normas contrárias às liberações ${ }^{484}$. Lei de 1778 , que baniu a importação de escravos para o estado, alimentaria a abertura de pleitos judiciais, já que

\footnotetext{
${ }^{483}$ Alejandro de la Fuente \& Ariela Gross. "Slaves, Free Blacks, and Race in the Legal Regimes of Cuba, Louisiana and Virginia: a Comparison”. North Carolina Law Review, n.91 (2013), pp.1699-1756. O posicionamento crítico de Gross \& De la Fuente diz respeito ao procedimento adotado por Herbert Klein em trabalho de 1967, que contrapôs de maneira estrita os estatutos locais da Virginia às leis metropolitanas para Cuba. Cf. Herbert S. Klein. Slavery in the Americas: A Comparative Study of Virginia and Cuba. Chicago: The University of Chicago Press, 1967.

${ }^{484}$ A referência direta neste ponto é ao artigo da historiadora Keila Grinberg: Freedom Suits and Civil Law in Brazil and the United States. Slavery \& Abolition (2001), 22, pp.66-82.
} 
entre as penalidades constava a libertação de escravos introduzidos ilegalmente. No entanto, o crescimento da presença de negros entre a população livre não seria suficientemente abundante a ponto de sedimentar a conjuntura favorável (passou de $1 \%$ na década de 1770 para 1,7\% na década de 1790). Na Luisiana, que foi para as mãos espanholas em 1763, o cenário seria notavelmente mais aberto, denotando o relevo da cultura jurídica proveniente de Castela, que logo sobrepujaria as normas restritivas inseridas no Código Negro francês promulgado em $1724^{485}$. Naqueles anos, as chances dos cativos obterem a sua liberdade em Nova Orleans seriam três vezes maiores do que na Virginia, chegando a uma centena de liberações anuais no início da centúria seguinte. No caso de Cuba, ocorreria o fortalecimento do padrão já solidamente arraigado a partir do nexo entre os precedentes e a presença ascensional de negros e mulatos na população livre. As medidas expedidas no âmbito do reformismo bourbônico referendariam antigas práticas costumeiras potencialmente favoráveis aos escravos, como a coartación, mantendo as portas abertas para demandas por liberdade ${ }^{486}$.

No século XIX, haveria um novo distanciamento. A pequena importância numérica e a consequente rarefação de sua potencial pressão sócio-política fariam com que os breves ganhos da população negra livre da Virginia fossem achatados, em meio ao avanço da ideologia racial e aos conflitos internos em torno da escravidão nos Estados Unidos (a partir de 1806, seriam novamente impostas barreiras legais à manumissão). Na Luisiana, incorporada aos Estados Unidos em 1803, após um novo e breve domínio francês, restrições também seriam impostas, mas persistiria um sistema legal híbrido, com contínuas remições a preceitos espanhóis e franceses para o respaldo de reclamações de liberdade, com alguma margem de sucesso. Em Cuba, o bem estabelecido conjunto de princípios legais e costumeiros associados à manumissão continuaria em franca operação. A sua sedimentação ao pé da volumosa presença de egressos impediria que a elite proprietária cubana pudesse embarreirar legalmente o acesso à alforria, "a despeito do desenvolvimento de uma economia de plantação na ilha"487.

Esse modelo explicativo articula elementos importantes para o esclarecimento das diferenças legais e de suas implicações nas regiões abordadas ao longo de todo o processo. No entanto, há outros aspectos que poderiam contribuir para o enriquecimento do quadro. É preciso ter em conta os traços constitutivos dos ordenamentos jurídicos destacados, que extravasam a questão da presença prévia de diplomas concernentes à escravidão e a opção analítica de

\footnotetext{
485 Vernon Valentine Palmer. "The Origins and Authors of the Code Noir". Louisiana Law Review, v.56, n.2 (1996). Disponível em: <http://digitalcommons.law.lsu.edu/lalrev/vol56/iss2/5>. Acesso em: 24 de ago. 2013; Alan Watson. "The Origins of the Code Noir Revisited". TUL. L. REV., n.71 (1997), pp.1041-1055.

${ }^{486}$ De la Fuente \& Gross. "Slaves, Free Blacks, and Race in the Legal Regimes...", pp.1708-1716.

${ }^{487}$ De la Fuente \& Gross. "Slaves, Free Blacks, and Race in the Legal Regimes...”, p. 1707.
} 
abordar ou não as normas locais. Em termos comparativos, havia no interior do império britânico, ordenado sob a tradição da common law, um grau diferenciado de autonomia jurídica e um peso da jurisprudência para a fixação das normas. Isto inclusive ajuda a explicar porque foi possível a permanência de um sistema híbrido na Luisiana. Desse modo, mesmo que houvesse um arcabouço prévio sobre a escravidão na Inglaterra, que sancionasse o ato privado da alforria, a sua assimilação não necessariamente teria os mesmos efeitos sociais, demográficos observados para o cenário ibero-americano ${ }^{488}$.

Como sabido, a configuração do regime jurídico da América espanhola teve como base o direito tradicional vigente no reino de Castela, que por intermédio notadamente das Siete Partidas conservava um repertório substantivo sobre a escravidão, enquadrando-a como instituto próprio aos direitos civil e das gentes, mas avesso ao direito natural, remissível pelo instituto da manumissão. No processo de consolidação do que se chama "direito indiano" ou “direito da época colonial” hispânica, o repertório original castelhano foi cedendo espaço para normas específicas editadas tanto na metrópole quanto pelas esferas delegadas nas “conquistas”. É inegável que a pressão exercida pelos escravos em busca de sua liberdade e pela presença massiva de negros e mulatos entre a população livre ajuda a explicar por que os precedentes concernentes à transição da escravidão para a liberdade, não apenas foram mantidos, como foram ampliados em um dado momento ${ }^{489}$. Ocorre, porém, que, da maneira como o argumento é desenvolvido por Gross \& De La Fuente, os senhores de escravos cubanos e ibero-americanos, por extensão, são enquadrados como impotentes diante da injunção dos precedentes e do movimento desencadeado pelos próprios cativos. O problema é que o ímpeto generalizado que observam tendente à contenção da alforria, abafado pelas circunstâncias, não é empiricamente demonstrado. Além do que, o texto pressupõe uma contradição entre a grande plantação, a prática da manumissão e os interesses da classe senhorial. Em pelo menos duas passagens é assinalada a inexistência de impeditivos legais ao alforriamento e ao acesso à auto-

\footnotetext{
${ }^{488}$ Alan Watson. Slave Law in the Americas. Athens: University of Georgia Press, 1989, pp.63-82; Idem. The Evolution of Law. Baltimore: The Johns Hopkins University Press, 2001, pp.234-247; Paul Finkelman (ed.). Slavery \& the Law. Madison: Madison House, 1997, pp.379-418.

489 Alejandro de la Fuente. "Slavery and claims-making in Cuba: The Tannenbaum debate revisited". Law and History Review, vol. 22, 2004, pp. 339-69; Idem. "La esclavitud la ley, y la reclamación de derechos en Cuba: repensando el debate de Tannenbaum". Debate y Perspectivas. Cuadernos de Historia y Ciencias Sociales - Su único derecho: los esclavos y la ley. Madri: Fundación Mapfre Tavera, n. ${ }^{\circ}$ 4, 2004, pp.37-68; Idem.."Slaves and the Creation of Legal Rights in Cuba: Coartación and Papel". Hispanic American Historical Review, vol.87, n.4 (Nov. 2007), pp.659-92; Alejandro de la Fuente \& Ariela Gross. "Comparative Studies of Law, Slavery and Race in the Americas". University of Southern California Legal Studies Working Paper Series (February, 2010), pp.340. Disponível em: <http://law.bepress.com/usclwps/lss/art56>. Acesso em: 04/06/2010; Waldomiro Lourenço da Silva Júnior. A escravidão e a lei: a legislação escravista no Antigo Regime ibero-americano. São Paulo: Annablume/Fapesp, pp.35-66.
} 
compra durante o século XIX, não obstante o incremento da grande lavoura, como se houvesse uma incongruência de princípio ${ }^{490}$.

A manumissão entre os ibéricos era mais do que um preceito legal herdado do direito romano. Tratava-se de um fator social indissociável das relações de escravidão. A experiência com o cativeiro mouro dos tempos da Reconquista e com os africanos trazidos primeiro por terra, através do Saara, depois por mar, com a abertura do Atlântico no século XV, foi o que deu o tom para a incorporação do repertório escravista contido na cultura do Direito comum. Daí nasceu uma tradição comum entre portugueses e castelhanos, que integrava um conjunto convergente, mas não plenamente coincidente, de normas escritas e não-escritas em constante acomodação, que enredava senhores e escravos em um sistema brutal de sujeição e alienação, mas, também, de negociação e clientela, cuja culminância podia ser a cessão da alforria. Dessa forma, foi forjado um modo de viver a instituição que desde logo compreendia brechas para a sua reversão em âmbito doméstico. Durante todo o Antigo Regime, subsistiu um forte respeito do estado ao arbítrio dos amos a esse respeito. O domínio senhorial tinha como um de seus estruturantes originais a faculdade de conceder ou não a liberdade ${ }^{491}$.

A Era das Revoluções foi, de fato, um momento de aproximação, mas, também, de reordenamento, no qual caminhos distintos foram traçados em resposta aos novos tempos. Como visto no capítulo anterior, a solução encontrada no Brasil consistiu na refundação do modo tradicional de ordenação do cativeiro sob a ordem constitucional do Império, que se moldou à reestruturação local do regime de escravidão. As permanências brasileiras podem dar a falsa impressão de que o sistema jurídico saiu ileso ao empuxo da segunda escravidão. Não saiu. A ordem jurídica assumiu forma dinâmica, espelhando as mudanças, aproximando, sem planificar, as experiências no interior de um sistema produtivo com ritmos produtivos assimétricos. Simplificando: os escravos do Sul de Minas Gerais, do Vale do Paraíba Fluminense, do Recôncavo baiano, e assim por diante, estavam sujeitos às mesmas regras e essas regras se estruturaram da forma como se estruturaram, porque os agentes históricos atuantes na conformação política do Império do Brasil reinventaram a tradição existente, dando vazão a uma fórmula nacional de regulação do regime, que convergia para a sua estabilização. O delineamento do caso cubano depende de menos abstrações. Como foi demonstrada anteriormente, a edição das cédulas que estabeleceram o direito legal à alforria onerosa e

\footnotetext{
${ }^{490}$ De la Fuente \& Gross. "Slaves, Free Blacks, and Race in the Legal Regimes...", p. 1707; 1724.

${ }^{491}$ Silva Júnior. A escravidão e a lei...,pp.44-112; Waldomiro Lourenço da Silva Júnior. "Alforria, liberdade e cidadania: o problema da fundamentação legal da manumissão no Antigo Regime ibérico". Revista de Indias, v. LXXIII, n. 258 (2013), pp.431-453; Blackurn, Robin. A construção do escravismo no Novo Mundo. Do Barroco ao Moderno, 1492-1800. (trad. port.) Rio de Janeiro: Record, 2003. p.68.
} 
validaram os ajustes de coartação, representam uma resposta direta aos efeitos da Guerra dos Sete Anos, imbricando-se de forma manifesta à montagem da segunda escravidão na ilha de Cuba. Aspectos culturais foram igualmente importantes. A alteração no campo legislativo representou efetivamente uma inflexão, mas ela dialogava com uma tendência histórica da experiência jurídica castelhana, tradicionalmente mais inclusiva e abrangente em relação às práticas sociais.

Na década de 1820, Cuba já havia deixado de ser uma colônia militar e um entreposto do circuito comercial hispano-americano, tornando-se um território de "primeiríssima importância produtiva", para utilizar as palavras de Moreno Fraginals ${ }^{492}$. Por todo o seu peso econômico e administrativo, Havana encerrava um centro polarizador fundamental e, a sua jurisdição, o ponto nodal da produção açucareira, que se expandia em direção às zonas centrais da ilha. Mas, assim como no Brasil, a experiência da escravidão variaria bastante no interior da ilha, com relações de trabalho e condições de vida distinta, tanto no campo - com o emprego da mão de obra em ingenios (que por sua vez também apresentavam moldes bem variáveis), cafetales, ganaderias, Vegas de tabaco - quanto nas cidades, com o engajamento dos escravos em atividades diversas, no interior das casas, no comércio e nas atividades portuárias. A historiadora Rebecca Scott acertadamente chama a atenção para a necessidade de cautela para a atribuição de um caráter geral à escravidão cubana ${ }^{493}$. Sob esta perspectiva cautelar é que a adoção da categoria de segunda escravidão torna-se útil, pois ela dá a dimensão da temporalidade estrutural que move o eixo nuclear da formação da base material da ilha, com suas consequências políticas e sociais, servidos como ponto de contato entre os diversos ritmos e gêneros de atividades. Ler a noção de segunda escravidão pela ótica da planificação das formas do cativeiro é um erro.

Uma perspectiva semelhante à adotada para a análise do quadro jurídico brasileiro se faz necessária. Cumpre saber de que forma o quadro jurídico concernente à escravidão e à alforria no universo cubano se ajustaram ao escravismo consolidado no século XIX. Não é demais lembrar que a estabilidade da população escrava dependia de uma migração líquida e de um crescimento natural superiores à mobilidade social decorrente da manumissão em suas variadas formas e, evidentemente, à mortalidade dos cativos. O autor da melhor síntese sobre as estatísticas cubanas envolvendo a população negra, Kenneth F. Kiple ratifica o senso geral

\footnotetext{
${ }^{492}$ Manuel Moreno Fraginals. El ingenio: complejo económico social cubano del azúcar, t.1. Havana: Editorial de ciencias sociales, 1978, p.128.

493 Rebecca J. Scott. Emancipação escrava em Cuba: a transição para o trabalho livre, 1860-1899. São Paulo: Paz e Terra/Campinas: Editora da Unicamp, 1991, pp.29-31.
} 
de que a mortalidade normalmente excedeu os nascimentos ${ }^{494}$. Aparentemente, não se deu um movimento semelhante ao observado por Ricardo Salles para o Vale do Paraíba, onde foram estreitadas as chances de alforria para o incremento do crescimento vegetativo ${ }^{495}$. Isto se explica pelo fato de que o tráfico permaneceu aberto por um período mais dilatado. A não ser por uma retração na década de 1840, o tráfico de escravos não cessou em Cuba até os estertores da Guerra Civil Norte-americana. Entre 1820, quando o tráfico entrou para a ilegalidade, e 1866, ano de ingresso do último navio negreiro, entraram mais de 635 mil cativos contrabandeados na ilha de Cuba, cifra incomparavelmente superior às alforrias obtidas em âmbito privado ou sob a intervenção da Justiça. Os hispano-cubanos também desenvolveram uma forma própria de lidar com o sistema de escravidão, estribado em um leque ampliado de modalidades de alforrias articulado ao comércio negreiro ininterrupto. Os subalternos, por seu turno, buscaram explorar as brechas existentes nas esferas privadas e nas vias judiciais constituídas.

Para uma melhor orientação da leitura, alguns aspectos, também aqui, devem ser explicitados. Para a pesquisa de arquivo necessária ao levantamento dos processos judiciais aqui analisados, foi estabelecido um raio geral delimitado pelas jurisdições governativas imediatas de Havana, isto é, o seu perímetro urbano, bairros e distritos, bem como os partidos pedáneos $^{496}$, em correspondência com as suas alçadas judiciais. A divisão administrativa da ilha passou por diversas mudanças ao longo do tempo. Parece útil sumariá-las, com brevidade. Até o início de século XVII, Cuba foi gerida localmente por um governo único, que abrangia indistintamente todo o território, sendo capitaneado por Santiago de Cuba até 1589 e, desde então, pela villa de San Cristóbal de la Habana, que recebeu o título de cidade em 1592. Para que fosse dada maior atenção à parte oriental da colônia, palco frequente de pirataria e de práticas comerciais ilícitas, a Coroa espanhola, em 8 de outubro de 1607, dividiu a ilha em duas gobernaciones, uma radicada em Havana, cujo distrito alcançava até cinquenta léguas além da baía de Matanzas, e a outra em Santiago, que abrangia, afora a sua própria municipalidade, Bayamo, Baracoa e Puerto Príncipe. Os dois governos eram independentes entre si, a não ser em questões militares, cuja orientação deveria partir de Havana. Durante esse século e o seguinte, em função do crescimento demográfico e das transformações econômicas que se seguiram, houve alguns rearranjos jurisdicionais e administrativos. Nesse tempo, houve a fundação da vila de Santa Clara (1689) e da cidade de Matanzas (1693), duas regiões que

\footnotetext{
${ }^{494}$ Kenneth F. Kiple. Blacks in Colonial Cuba (1774-1899). Flórida: University of Florida Press, 1976, pp.78-82. ${ }^{495}$ Ricardo Salles. E o Vale era o Escravo. Vassouras, século XIX. Senhores e escravos no coração do Império. Rio de Janeiro: Civilização Brasileira, 2008, pp.237-267.

496 Puentes Grandes, Quemados, Arroyo Naranjo, Calvario.
} 
despontariam na produção açucareira do século XIX. Todavia, a ilha continuou dividida entre as duas grandes jurisdições por um longo tempo ${ }^{497}$.

Modificações mais pronunciadas vieram no decorrer do século XIX. Em 1825, na esteira do estabelecimento do regime das faculdades onímodas aos capitães generais, o território foi dividido na sequência em três departamentos, o occidental, o central e o oriental por meio de ordem régia de 17 de junho de $1827^{498}$. A tripartição perdurou até 21 de outubro de 1853 , quando, após alegações de inconvenientes econômicos e estratégicos, o monarca assinou decreto que pôs fim ao departamento do centro, dividindo a ilha mais uma vez entre ocidente e oriente $^{499}$. O posto de comando mais elevado permanecera sempre em Havana, nas mãos do gobernador superior e capitán general, cabendo a administração das diversas jurisdições ou tenencias de gobierno a delegados nomeados denominados tenientes gobernadores, a não ser no que no que dizia respeito a Havana, Fernandina de Jagua, Matanzas ${ }^{500}$ e Santiago, que carregavam o estatuto de gobiernos, sendo, portanto, geridas por gobernadores ${ }^{501}$. Cada tenencia era subdividida em distritos e Barrios para as cidades, e em partidos, para os pueblos $^{502}$.

A nova ampliação das jurisdições de Havana e Santiago de Cuba voltou a gerar problemas à ordem administrativa cubana, fosse pela real dificuldade em atender as regiões mais afastadas, fosse pela resistência local em abrir mão dos postos de comando uma vez

\footnotetext{
${ }^{497}$ Félix Erénchun. Anales de la isla de Cuba: Diccionario administrativo, economico, estadistico y legislativo. Habana: Imprenta La Habanera, 1856, verbete "gobierno", pp.1626-1628.

${ }^{498} \mathrm{O}$ departamento ocidental foi subdividido em onze jurisdições, a saber, Habana (capital), Matanzas, Jaruco, Lagunillas, Macuriges, Güines, Quivacan (Bejucal), Palacios, Filipinas (futura Pinar del Río), Guanajay e Quemados. O central, em cinco: Trinidad (capital), Jàgua, Villa-Clara, Sancti-Spíritus e Puerto Príncipe. O oriental, em quatro: Santiago (capital), Bayamo, Holguin e Baracoa. Ramon de la Sagra. Historia económicopolíticay estadistica de la isla de Cuba o sea de sus progresos en la población, la agricultura, el comercio y las rentas. Habana: Imprenta de las Viudas de Arazoza y Soler, Impresoras del Gobierno y Capitania General, de la Real Hacienda y de la Real Sociedad Patriótica por S. M., 1831, pp.319-321.

${ }^{499}$ A linha fronteiriça entre os departamentos ocidental e o oriental seria dada pelos limites a leste da jurisdição de Sancti Spíritus. O departamento occidental, também referido como Provincia de Havana, era composto, em 1860, por 21 jurisdições: Bahía-Honda, Bejucal, Cárdenas, Cienfuegos, Colón, Guanabacos, Guanajay, Güines, Habana, Jaruco, Matanzas, Pinar del Río, Sagua la Grande, San Antonio de los Baños, San Cristóbal, San Juan de los Remedios, Santa María del Rosario, Santiago de las Vegas, Sancti-Spiritus, Trinidad, Villa-Clara e a ilha de Pinos. O Departamento Oriental, também referido como Provincia de Cuba, simplesmente, era integrado por: Baracoa, Bayamo, Guantánamo, Holguín, Jiguani, Las Tunas, Manzanillo, Nuevitas, Puerto Príncipe, Santa Cruz e Santiago de Cuba.

${ }^{500}$ Matanzas recebera tal estatuto em 1815, quando foi criado o governo político y civil da cidade. Cf. Mireya Cabrera Galán (dir.)Historia del municipio de Matanzas. Mimeo. Versão mimeo cedida pelo Dr. Ercilio Vento, um dos autores.

${ }^{501}$ Até 1845 , os gobernadores contaram com a assessoria de três tenientes de gobernador. Aisnara Perera \&María de los Ángeles Meriño Fuentes. Capitulo II: "Las demandas de libertad y la estructura de la administración de justicia en Cuba", in: Estrategias de libertad: un acercamiento a las acciones legales de los esclavos en Cuba (1762-1872). No prelo, versão cedida pelas autoras.

502 Jacobo de la Pezuela. Diccionario Geografico, Estadistico, Historico de la Isla de Cuba. Tomo IV. Madri: Imprenta del Banco Industrial y Mercantil, 1867, pp.240-244.
} 
adquiridos. Em consequência, foi decretado, em 14 de julho de 1866, o restabelecimento do departamento central, sob a mesma configuração territorial de antes, mas com a capital estabelecida em Puerto Príncipe, não mais em Trinidad ${ }^{503}$. Uma distribuição mais fragmentada seria efetuada somente na década seguinte, quando já havia estourado a primeira guerra de independência. Poucos meses depois de firmado o pacto em Zanjón, marco final da Guerra de los Diez Años, foi definido em 21 de junho de 1878 uma divisão de Cuba em seis províncias, que tomariam o nome das respectivas capitais: Pinar del Río, Havana, Matanzas, Santa Clara, Puerto Príncipe e Santiago de $\mathrm{Cuba}^{504}$. A direção de cada uma delas estaria a cargo de um gobernador nomeado pelo Ministro de Ultramar e subordinado ao gobernador general, o qual centralizaria o comando político e militar da ilha, cabendo-lhe inclusive a suspensão de medidas remetidas pela metrópole, muito embora não mais lhe fossem reconhecidas as faculdades onímodas. Desse momento diante, Cuba passava a ser uma "província de províncias"505.

Sobre a estrutura judiciária, cabe observar que, até a década de 1840, o acesso à justiça em primeira instância se deu pelo recurso aos tribunais compostos pelos alcaldes ordinarios, juízes leigos eleitos anualmente pelos cabildos. Também era possível o encaminhamento de queixas ao arbítrio do capitán general, dos gobernadores ou dos tenientes gobernadores. $\mathrm{O}$ governo metropolitano buscou alterar esse quadro por meio de Real decreto baixado em 24 de julho de 1845. O objetivo foi introduzir uma organização um pouco mais profissional e autônoma ao judiciário cubano, de modo, aliás, semelhante ao que havia sido executado anos antes para Puerto Rico. Foi instituída a magistratura dos alcaldes mayores, oficiais letrados necessariamente instruídos na legislação indiana e com experiência advocatícia. As atribuições de alcaldes ordinarios foram reduzidas à celebração de juízos de paz verbais até a quantidade de 50 pesos fuertes e à instrução de diligencias aos capitanes de partido (gestores dos partidos pedáneos). Para o exercício da jurisdição ordinária dos gobernadores político-militares, dos tenientes-gobernadores e dos alcaldes nos pueblos, onde ainda não tivessem sido nomeados

\footnotetext{
${ }^{503}$ Caridad Jiménez Morales. "La división político-administrativa en Cuba. Mirada retrospectiva”. Equipo Federal del Trabajo - Sección: Notas de Cátedra Universitaria, n.52 (set. 2009). Disponível em: <http://www.newsmatic.epol.com.ar/index.php?pub_id=99\&sid=1174\&aid=40462\&eid=52\&NombreSeccion=Notas\%20de\%20c\%C3\%A 1tedra\%20universitaria\&Accion=VerArticulo\#>. Acesso em: 01 de ago. 2012.

${ }^{504}$ Para sínteses da organização política de Cuba no período, ver os capítulos 10, 11 e 12 da obra coordenada por Consuelo Naranjo Orovio. Historia de las Antillas. Volumen I. Historia de Cuba. Madri: CSIC, 2009, pp. 253339.

${ }^{505}$ Real decreto de 9 de junho de 1878, que regulou as atribuições da autoridade superior da ilha. Cf. Sebastián Martín-Retortillo, Luis Cosculluela Montaner \& Enrique Orduña Rebollo. Autonomías Regionales en Espana: Traspaso de Funciones y Servicios. Madri: Instituto de Estudios de Administración Local, 1978, pp.185-194; Inés Roldán de Montaud.“La política española en Cuba: una década de cambios (1876-1886)”. Ayer, 2003, pp.175203; Luis Miguel García Mora. "Un nuevo orden colonial: del Zanjón al Baire, 1878-1898”. In: Consuelo Naranjo Orovio. Historia de las Antillas. Volumen I. Historia de Cuba. Madri: CSIC, 2009, pp.305-308.
} 
alcaldes mayores, deveriam ser indicados asesores com formação jurídica para o devido encaminhamento dos processos ${ }^{506}$.

Real decreto de 10 de janeiro de 1851 ab-rogou formalmente a jurisdição ordinária de gobernadores, tenientes e alcaldes ordinarios nos povoados, onde houvesse alcaldes mayores ou asesores titulares (os previstos do decreto de 1845), que passaram a fazer às vezes de juízes ${ }^{507}$. Real cédula de 30 de janeiro de 1855 , texto extenso sobre a organização e competência dos “juzgados e tribunales de La isla de Cuba", em seus diversos níveis, chancelou a judicatura já exercida na prática pelos asesores titulares, designando-os como alcaldes mayores, jueces de partido, com o acréscimo da denominação do pueblo onde residissem. A atividade judicial de primeiro grau (incluindo a dos alcaldes mayores dos centros urbanos) se daria em zonas chamadas partidos judiciales, os quais, apesar de certo esforço nesse sentido, não reproduziam exatamente a divisão política e militar de toda a ilha, chegando nessa época ao número de vinte e cinco $^{508}$.

Nos anos seguintes, em meio ao clima de exaltação patriótica de lado a lado, o discurso adotado nas exposições que antecediam as normas lançadas pelo governo espanhol via de regra acenavam para o intento de equiparação institucional entre a organização judiciária peninsular e ultramarina. Em 9 de dezembro de 1865, a Lei de Enjuiciamiento civil espanhola se tornou extensiva a Cuba e Puerto Rico. Entre outros aspectos, esse dispositivo estabeleceu a existência de juezes de paz, cargo honorífico e leigo, com exercício de dois anos. A sua competência dizia

\footnotetext{
506 Amores Carredano, Juan B. "Reformas de la administración local en Cuba (1765-1845)". In: Manuel Torres Aguilar (coord..), Actas del XV Congreso del Instituto Internacional de Historia del Derecho Indiano, Córdoba, Universidad de Córdoba, tomo I, 2005, pp. 63-79.

507 As alcadías mayores foram dividas em três classes: de entrada (Fernandina de Jagua e Trinidad), ascenso (Matanzas, Santiago e Puerto Príncipe) e término (Havana). As asesorías titulares foram divididas em duas classes: entrada (pueblos e distritos em que não houvesse Ayuntamientos) e término (pueblos em que houvesse alcaldes ordinarios eleitos por Ayuntamientos). O que isto estabelecia era uma ordem de importância que justificava a diferença dos soldos recebidos (decrescentes, a partir de Havana) e pautava o caminho ascensional nos postos da magistratura cubana e do império espanhol. O exercício da função era de três anos. As competências eram as mesmas. Ninguém poderia servir como alcalde mayor nas Antilhas por mais de dez anos.

${ }^{508}$ Havana, compreendendo cinco alcadías mayores, fora dividida numericamente entre (1) Arroyo Naranjo, (2) Calvario, (3) a cidade de Havana com os seus subúrbios, (4) Puentes Grandes e (5) Quemados. Matanzas, com duas alcadías mayores, entre (1) Cabezas, (2) Canímar, (3) Corral Nuevo, (4) Guamacaro, (5) Matanzas, a cidade, (6) Sabanilla, (7) Santa Ana e (8) Seiba Mocha. Pinar del Río, entre (1) Baja, (2) Consolación del Norte, (3) Consolación del Sur, (4) Guanes o Filipinas, (5) Mántua, (6) Pinar del Río, a cidade, (7) San Juan y Martínez. Para as outras localidades, conferir decreto de 15 de dezembro de 1855. Alguns anos mais tarde essa divisão numérica foi substituída pelos nomes dos distritos onde se estabeleceram as alcaldias mayores na cidade de Havana. Assim, por Real ordem de 18 de novembro de 1859, atribuiu-se às alcadías mayores as seguintes denominações: San Cristóbal, Belen, Colon (não confundir com a tenencia de gobierno), Jesus María e Cerro. Haveria, então, uma linha de correspondência com os partidos pedáneos. Calvario corresponderia a San Cristóbal, Arroyo Naranjo a Belen, Puentes Grandes e Quemados ao Cerro.

Auto Acordado da Audiência local, de 27 de junho de 1861, realizaria algo semelhante para Santiago, Puerto Príncipe e Matanzas, que ficaria dividida entre as alcaldías dos distritos Norte (parte norte da cidade e os partidos Santa Ana, Seiba Mocha e Cabezas) e Sul (parte sul, Corralfalso, Sabanilla e Guamacaro).
} 
respeito ao conhecimento de atos de conciliação, juízos verbais, embargos preventivos diligenciam civis encomendadas pelos alcaldes mayores e à substituição destes últimos nos casos de ausência ${ }^{509}$. Em 15 de setembro de 1870, veio a lume na Espanha uma nova lei sobre a organização do poder judiciário em seus diversos níveis. Para efeitos judiciais, o território deveria ser dividido em distritos, estes, em partidos, estes, em cirscunspciones e, estes, em términos municipales. Em cada término, que houvesse um ou mais jueces municipales (que substituíam desde logo os juizados de paz); em cada circunscripcion, um juez de instruccion; em cada partido, um tribunal de partido. Mas essa divisão foi expressamente destinada à Península e às ilhas Baleares e Canárias, nada sendo versado sobre o que deveria ser praticado quanto às divisões judiciais do Ultramar. Apenas com a criação das províncias civis, em 1878, que teve efeito uma reestruturação equivalente em solo cubano, com a repartição de juzgados municipales e de primera instancia (com essa denominação) pelos partidos judiciales distribuídos nos distritos relativos a cada província, o que completa esta etapa da descrição ${ }^{510}$.

A grande maioria das ações judiciais disponíveis para consulta nos diversos arquivos cubanos é de primeira instância ${ }^{511}$. Mas era possível apelar para instâncias superiores e, de fato, senhores e escravos envolvidos em querelas judiciais em torno da liberdade chegaram a fazê$10^{512}$. Até a década de 1790, a corte superior para a ilha foi a Real Audiencia de Santo Domingo. Como consequência do Tratado de Balisélia, o tribunal foi transferido no ano de 1800 para a vila de Santa María Del Puerto Príncipe, cuja jurisdição se estendeu a todo o território cubano até a criação da Audiencia Pretorial de La Habana, em 1838, que abarcaria a parcela ocidental

\footnotetext{
${ }^{509}$ Ley de Enjuiciamiento Civil y disposiciones acordadas para su cumplimiento en las islas de Cuba y Puerto Rico. Edición Oficial. Madri: Imprenta Nacional, 1866; Eduardo Alonso y Colmenares. Práctica de los Juzgados de Paz de las islas de Cuba y Puerto-Rico. Havana: Imprenta del Gobierno y Capitania General y Real Audiencia por S. M., 1866.

${ }^{510}$ A província de Pinar del Río ficou dividida em três partidos judiciales: Pinar del Río, San Cristobal e Guanajay; a província de Havana, em doze partidos: Guanabacoa, Jaruco, San Antonio de los Baños, Bejucal, Güines, e mais sete distribuidos pela capital; a provícia de Matanzas, em cinco partidos: Cárdenas, Alfonso XII, Colón, e mais dois que repartiam a cidade de Matanzas. Cf. Juan José Sanchez y Guerrero. Leyes Provinionales. Municipal y Provincial de la isla de Cuba, concordadas y anotadas con las de 2 de octubre de 1877 vigentes en la Península. Havana: Librería e Imprenta "La Nueva Principal", 1881, p.437. Sobre a incompletude de tal reestruturação, cf. Real decreto Reorganizando los juzgados municipales de las islas de Cuba y Puerto Rico. Y Aranceles para los mismos. Havana: Imprenta del Gobierno y Capitanía General por S. M., 1886.

511 Os fundos concernentes à Audiencia de Santo Domingo, estão no Archivo General de Indias, em Sevilha, na Espanha, mas as buscas realizadas foram inócuas para o recorte efetuado. No Archivo Nacional de Cuba há dois fundos onde se podem encontrar apelações judiciais, a saber, o Audiencia de la Habana e o Audiencia de Santiago de Cuba, que fora catalogado erroneamente, já que era Puerto Príncipe, atual Camagüey, o sítio do tribunal em questão. No primeiro, há pouquíssimos documentos correspondentes ao período escravista. A maioria das fontes ali presentes datam já do século XX. No segundo, é possível localizar algumas apelações relacionadas a escravos libertandos, mas para o oriente da ilha, pelo que se pôde averiguar, com o auxílio das historiadoras Aisnara Perera e María de los Angeles Meriño.

${ }^{512}$ Claudia Varella.Esclavos a sueldo: la coartación cubana en el XIX. Tese de Doutorado. Castellión: Universitat Jaime I, 2010, p.160.
} 
do território insular ${ }^{513}$. As últimas esferas recusam era o Consejo Real y Supremo de las Indias e, após 1836, o Tribunal Supremo de Justicia ${ }^{514}$. A estrutura judicial que escravos litigantes por sua liberdade e senhores ciosos na defesa de sua propriedade tiveram que lidar na ilha de Cuba foi basicamente esta.

O esquema geral das ações cíveis ajuizadas na ilha não variou muito ao longo do tempo. As reclamaciones de libertad, como eram denominados os processos correspondem às ações de liberdade comuns no Brasil, eram iniciadas com um escrito de demanda, que nada mais era do que o libelo no qual o mérito da questão era manifestado preliminarmente, que devia ser assinada por um advogado ou pelo síndico procurador, quando estes assumiram a incumbência da representação dos cativos. Aceita a demanda, a autoridade judicial conferia traslado da notificação à parte contrária, à qual era dado o prazo de nove dias para responder. Uma vez apresentada a resposta, era dado traslado de seu conteúdo para a parte acusadora, para que fizesse a réplica, à qual cabia tréplica do senhor demandado (chamava-se dúplica, na verdade). É possível encontrar referências à jurisprudência e à legislação vigente. Não obstante as cédulas editadas em fins do século XVIII, as campeãs de citações foram sempre as Siete Partidas. Em muitas demandas, porém, nem havia referência à base legal. ${ }^{515}$ Discutia-se o mérito da questão. Quando se tratava de alforrias onerosas, em especial, não se questionava o direito do escravo a ela. Isto estava pressuposto. No mais das vezes, a querela girava em torno do preço justo a ser pago. Daí então, procedia-se a avaliação do escravo. Após a exposição dos escritos mencionados, o juiz realizava a citação das partes, marcando um prazo para a apresentação de provas, que podiam ser documentais, testemunhais ou periciais. Até 1855, o juiz tinha o prazo de vinte dias para emitir sua sentença. Depois da reforma realizada naquele ano, o prazo foi reduzido para doze dias ${ }^{516}$. Nas páginas seguintes, será examinado o quadro jurídico de maneira

\footnotetext{
513 Em 1853, a Audiencia de Puerto Príncipefoi suprimida juntamente com o departamento central. Com o restabelecimento do departamento na década seguinte, o tribunal superior foi também reinstituído na mesma cidade. Em 1871, foi criada mais uma Audiencia, em Santiago de Cuba, para o departamento oriental. Cf. Félix Erénchun, Anales de la isla de Cuba: Diccionario administrativo, economico, estadistico y legislativo. Habana: Imprenta La Habanera, 1857, verbete "apelación”, pp.394-477; Carreras, Julio A. Historia del Estado y el Derecho en Cuba. Habana: Ministerio de Educación Superior, 1981, pp.89-97. 514

Jesús Martínez Girón. Los pleitos de Derecho privado sobre esclavitud ultramarina en la jurisprudencia del Tribunal Supremo (1857-1891). Madri: Civitas, 2002. Essa documentação foi extraída do Repertorio de Sentencias del Tribunal Supremo espanhol localizado na Biblioteca del Tribunal Superior de Justicia de Galicia. 515 Isto deve estar associado ao fato de que o Direito espanhol, à época, não havia estabelecido a motivação de sentença como princípio. Agradeço à historiadora Andréa Slemian por haver chamado atenção a este aspecto. 516 Aisnara Perera Díaz \& María de los Angeles Meriño Fuentes. Capítulo III. "Entre el procedimiento judicial y la demografía: perspectivas desde las reclamaciones de libertad", in: Estrategias de libertad: un acercamiento a las acciones legales de los esclavos en Cuba (1762-1872). No prelo, versão cedida pelas autoras.
} 
integrada à evolução da política concernente ao contrabando de africanos, variando-se a escala de observação por meio de processos judiciais, tal como realizado em relação ao caso brasileiro.

\section{Tráfico, Faculdades Onímodas e a preservação da ordem colonial escravista cubana}

Em março de 1820, concretizava-se na Espanha o movimento político-militar que abriria o período do chamado Triênio Liberal (1820-1823), trazendo de volta a Constituição de 1812, jurada a contragosto, é claro, pelo rei Fernando VII. Sem caráter constituinte, as novas Cortes iniciaram as suas seções no dia 26 de junho, buscando dar continuidade ao processo reformista iniciado anos antes em Cádiz, levando a efeito reformas diversas, inclusive no campo jurídico. Abandonada no período absolutista, a tarefa codificadora foi retomada. Em 20 de agosto, foi nomeada uma comissão destinada à elaboração de um Código criminal, que seria promulgado em 9 de julho de $1822^{517}$. Em meio a deliberações administrativas e legais diversas, o problema da escravidão e do tráfico não passou incólume. Em 30 de maio terminaria o prazo estabelecido no tratado firmado com os ingleses em 23 de setembro de 1817 para que fosse suprimido o comércio negreiro no interior do império espanhol, mas houve uma prorrogação de 5 meses, e a data limite chegou ao fim em 30 de outubro de 1820. Diante da evidente inoperância da proibição, o ministro das Relações Exteriores, José María Queipo de Llano, o conde de Toreno, propôs, na seção de 23 de março de 1821, sob forte pressão da diplomacia britânica em Madri, a nomeação de uma comissão especial para a proposição, com a maior brevidade possível, das medidas necessárias para a repressão efetiva do tráfico de escravos, "que, en contravención a dicho tratado y en prejuicio de la humanidade, continúan haciendo bajo bamdera española varios comerciantes naturais e estrangeiros, adaptándose las leyes penales que juzguen convenientes para destruir trafico tan vergonzoso e inhumano" ${ }^{518}$. A proposição foi aprovada e a comissão se formou, contando com o próprio ministro entre os membros e nenhum cubano. O resultado foi um projeto de lei de penal, apresentado em 2 de abril, que destinava sanções pesadas de prisão e perda de capitais a traficantes e cúmplices, penalizando com a perda de cargos e vencimentos as autoridades omissas ou colaborativas em relação à atividade. Os escravos contrabandeados porventura apreendidos, provenientes não

\footnotetext{
${ }^{517}$ Francisco Tomás y Valiente. Manual de historia del derecho español. Madri: Tecnos, 1988, pp.493-507. 518 Apud Julia Moreno García. "La cuestión de la trata en el Trienio Liberal (1820-1823)". Cuadernos de Historia Contemporánea, 2003, núm. extraordinario, p.160. Cf. David Murray. Odious Commerce. Britain, Spain and the Abolition of the Cuban Slave Trade. Cambridge: Cambridge University Press, 1980, pp.82-83.
} 
apenas da África, mas de qualquer outro território estrangeiro, ficariam livres e sob a proteção dos governos locais. Interessante que não foi previsto o destino dos escravos apreendidos, o que abria brecha para a sua assimilação como mão de obra livre ${ }^{519}$.

Juan Bernardo O’Gavan - intelectual de destaque da sacarocracia cubana, que já havia representado os interesses ilhéus em Cádiz, novamente eleito como deputado em Havana, mas impossibilitado de participar das deliberações das Cortes após pedido de anulação das eleições havanesas - publicou em Madri um panfleto endereçado às Cortes, criticando frontalmente o tratado anglo-espanhol de 1817. Seguindo a trilha pro-escravista aberta por Arango y Parreño, argumentou que o tráfico transatlântico beneficiava tanto escravos, que eram retirados do estado de barbárie e alçados a uma condição de existência superior à dos operários ingleses, quanto plantadores, que tocavam a diante os cultivos necessários para a prosperidade da ilha e do império. Atacando a ingerência britânica, condicionou claramente a fidelidade colonial ilhéu à defesa do infame comércio pelo governo espanhol. Caso uma medida como a proposta por Toreno fosse implementada, o destino de Cuba seria a independência ou a anexação aos Estados Unidos, onde existia “um governo sábio, liberal em princípios e praticamente, poderoso e ativo, que procurava estender sobre ela [Cuba] uma mão benéfica, e atraí-la por todos os meios a seu sistema de liberdade e engrandecimento, prodigando-a com recursos abundantes para sua agricultura e seu comércio, que a Espanha não pode jamais prestá-la" ${ }^{\text {"520 }}$. Após polêmica sobre se o debate do projeto deveria ser público ou secreto, se poderia ser votado in totum ou nominalmente, artigo a artigo, "las cortes acordaron no haber lugar a votar sobre el proyecto de ley penal del trafico de negros, presentado por la comisión especial"521. Mas, a política não se cristalizaria em torno do contrabando com a serenidade que se poderia imaginar. Em terras cubanas se formariam vários grupos políticos, com intenções díspares a respeito da escravidão e do contrabando. A nova legislatura eleita para 1822-23, conduziu a Madri o influente catedrático do Seminário de San Carlos, o presbítero Félix Varela, que tinha uma visão oposta à de $\mathrm{O}^{\prime} \operatorname{Gavan}^{522}$.

\footnotetext{
${ }^{519}$ Moreno García. "La cuestión de la trata en el Trienio Liberal (1820-1823)", pp.160-161.

${ }^{520}$ Juan Bernardo O'Gavan. Observaciones sobre la suerte de los negros del Africa, considerados en su propia patria, y transplantados a las Antillas españolas: y Reclamacion contra el Tratado celebrado con los ingleses el año de 1817. Madri: Imprenta del Universal, 1821, pp.11-12. Cf. Márcia Berbel, Rafael Marquese \& Tâmis Parron. Escravidão e Política: Brasil e Cuba, c. 1790-1850. São Paulo: Hucitec, 2010, pp.143-144.

${ }^{521}$ Diario de las sesiones de Cortes: legislatura extraordinaria (Esta legislatura dio principio en 22 de setiembre de 1821 y terminó el 14 de febrero de 1822). Madri: Imprenta de J. A. García, 1871, vol.2, p.840; Moreno García. "La cuestión de la trata en el Trienio Liberal (1820-1823)", pp.161-162.

${ }^{522}$ Cf. José Antonio Piqueras. FélixVarela y la prosperidad de la patria criolla. Madri: Fundación Mapfre coedición con Ediciones Doce calles, 2007.
} 
Varela tratou de rebater o opúsculo de seu conterrâneo, escrevendo uma memória crítica à escravidão e ao rebaixamento da condição civil de negros e mulatos livres. Aludindo o exemplo de Saint-Domingue, acenava para a necessidade de reverter os cenários explosivos instalado em Cuba, com a ampliação dos direitos de cidadania a negros e muitos livres e a eliminação gradual do cativeiro na ilha. Para tal efeito, elaborou um Proyecto de decreto sobre la abolición de la esclavitud en la isla de Cuba y sobre los medios de evitar los daños que pueden ocasionarse a la población blanca y a la agricultura. A libertação se daria: a) após quinze anos de serviços prestados, mas, desejando se libertar antes poderia deduzir de seu preço o período trabalhado e quitar a diferença; o cálculo do preço consistiria na divisão preço de compra por quinze, somando-se as frações correspondes aos anos restantes (cada ano 1/15); b) pelo nascimento; seriam livres os crioulos nascidos após a publicação do decreto; os amos das mães ficariam obrigados seriam responsáveis por sustentá-los até a idade de 10 anos; em recompensa, poderiam continuar se servindo deles até que completassem os 20 anos de idade, sem o pagamento de salários; se um crioulo quisesse indultar-se daquela obrigação, deveria abonar a quantia de 250 pesos fortes à guisa de indenização; c) às custas de fundos públicos e contribuições voluntárias; seriam estabelecidas juntas filantrópicas para promover a arrecadação e a aplicação dos recursos para a promoção das liberações, cuidando para que os novos libertos se dedicassem à agricultura, às artes, ao serviço doméstico ou alguma ocupação útil, deixando-os, porém, plenamente livres para que elegessem a sua atividade ${ }^{523}$.

Como se sabe, a exemplo daquele preparado pouco tempo mais tarde por Bonifácio, o projeto de Varela não sairia do papel. No entanto, é errôneo pensar que o governo constitucional espanhol sucumbiu à pressão da oligarquia cubana. As ameaças de O'Gavan não demoveram a vontade política liberal quanto à repressão do trato de escravos. Sem oportunidade para emplacar uma lei geral específica, a brecha encontrada foi incluir no próprio Código penal de 1822 um artigo antitráfico, diluído entre os demais tópicos. Da comissão responsável por elaborar a codificação estavam José María Calatrava, Martinez de la Rosa, Florez Estrada, Agustín Argüelles, o mesmo que havia apresentado uma proposta de abolição do tráfico no período constitucional de Cádiz, e o conde de Toreno, articulador do projeto de lei malogrado em Madri. A criminalização do comércio negreiro, no âmbito do Código penal, foi discutida na sessão do 15 de janeiro de 1822. O sr. Dolarea tomou a palavra, afirmando compartilhar dos mesmos dos membros da comissão, reputando o comércio de escravos como contrário à natureza, mas indagava se aquela prática estava já proibida por alguma lei. Se havia, não lhe

\footnotetext{
${ }^{523}$ Moreno García. "La cuestión de la trata en el Trienio Liberal (1820-1823)”, pp.161-165.
} 
causaria espécie aprovar o artigo. Caso contrário, parecia-lhe necessário, "como dijeron algunos señores cuando el sr. Conde de Toreno hizo la proposición, que siendo este asunto de mayor gravidad, se trate con toda detención", isto é, julgava necessária a aprovação de uma normativa em separado. Calatrava respondeu afirmando que o tráfico estava proibido por uma real cédula de $1816^{524}$ e pelo tratado ajustado com os ingleses. Seguindo esta linha, tentou amenizar o fracasso de Toreno, garantindo que em nenhum momento as Cortes haviam considerado sua proposição injusta ou inconveniente quanto ao seu escopo principal, "sino que fundándose em que existia esa cédula, y por ella se habían estabelecido las penas y demás disposiciones oportunas, creyeron que no habia necesidad de dictar otras de nuevo"525. Após alguns ajustes a respeito das penalizações, o artigo de número 273 da versão final do código, inserido no Capítulo II do Título II, que versava sobre os delitos contra el derecho de gentes, dispôs o seguinte:

\begin{abstract}
"Los capitanes, maestres y pilotos de buques españoles que compraren negros en costas de África, y los introdujeren en alguno puerto de las Españolas, o fueren aprehendidos con ellos a bordo de su embarcación, perderán esta, y se aplicará su importe como multa, y sufrirán además la pena de diez años de obras públicas. Iguales penas sufrirán los capitanes, maestres y pilotos de buques extranjeros que hicieren igual introducción en alguno puerto de la monarquía. En cualquiera de los casos de este artículo los negros de dicha clase que se hallaren o introdujeren serán declarados libres, y a cada uno se aplicarán cien duros, si alcanzare para ello la mitad del valor del buque; y si no, se les distribuirá dicha mitad a prorrata. Los que compren negros bozales de los así introducidos contra la disposición de este articulo, sabiendo su ilegal introducción, los perderán también, quedando libres los negros, y pagarán una multa igual al precio que hubieren dado por ellos, de la cual se aplicará a la persona comprada" ${ }^{526}$.
\end{abstract}

Endurecendo em relação à proposta recusada do conde de Torene, a codificação estabelecia punições reclusivas e pecuniárias bastante duras para traficantes nacionais e estrangeiros, incidindo, ao mesmo tempo, sobre os compradores de escravos contrabandeados, que perderiam duplamente seu "patrimônio", ficando sem o cativo ilegal e pagando multa de igual valor. Isto facilita o entendimento do por que dos cubanos terem aceitado tão facilmente o encerramento de mais uma experiência parlamentar na Espanha. No limite, é possível

\footnotetext{
${ }^{524}$ Não existe real cédula de 1816 proibindo do comércio negreiro. O provável é que a cédula em questão seja a de 19 de dezembro de 1817 que, decorrendo do tratado anglo-espanhol daquele mesmo ano, estabeleceu em pormenor a proibição do tráfico para o império espanhol. O seu artigo primeiro definia: "Desde hoy en adelante prohíbo para siempre a todos mis vasallos, así a los de la Península, como a los de América, que vayan a comprar negros en las costas de Africa que están al norte del Ecuador. Los negros que fueren comprados en dichas costas serán declarados libres en el primer puerto de mis dominios a que llegare la embarcación en que sean transportados; ésta, con lo restante de su cargo, será confiscada para mi Real Hacienda, y el comprador, el capitán, el Maestre y Piloto irremisiblemente condenados a diez años de presidio en las islas Filipinas". Lucena Salmoral. "Leyes para esclavos: el ordenamiento jurídico sobre la condición,...”, pp.1217-1220.

${ }^{525}$ Diario de las sesiones de Cortes: legislatura extraordinaria (Esta legislatura dio principio en 22 de setiembre de 1821 y terminó el 14 de febrero de 1822). Madri: Imprenta de J. A. García, 1871, vol.3, pp.1822-1824.

${ }^{526}$ Grifo meu. Código Pena espanñol, decretado por las Cortes em 8 de junio de 1822. Madri: Imprenta Nacional, 1822, p. 55 .
} 
considerar que a ação militar estrangeira coordenada pelo Congresso de Verona, em 1822, que derrubou o governo liberal no ano seguinte teve o efeito de refrear a política antitráfico espanhola. A historiografia jurídica até hoje debate se o código teria ou não entrado efetivamente em vigor antes do refluxo absolutista ${ }^{527}$. Mesmo inexistindo registros na coleção de decretos ou nos diários das Cortes de algum acordo sobre a suspensão da vigência do Código penal, o fato é que ele não chegou a fundamentar o Direito penal espanhol nem na Europa e muito menos nas possessões americanas remanescentes. Ainda que não se possa ter certeza a respeito do efetivo impulso que o governo constitucional teria nos anos seguintes para fazer cumprir as medidas estipuladas, a restauração do absolutismo ocasionada da marcha dos Cien Mil Hijos de San Luis certamente garantiu a inoperância governamental a respeito da contenção do contrabando e, por conseguinte, das bases que sustentavam as amarras coloniais ${ }^{528}$.

No mesmo ano que o tenente coronel Rafael Riego havia se colocado à frente do contingente militar arregimentado em Sevilha para lutar contra os rebeldes americanos e proclamou uma vez mais a constituição de 1812, Bernardo Lucumí, escravo de D. Leandro García Sanabria, também travava a sua batalha. O seu campo era outro. Apresentando-se perante o juiz, em 9 de junho de 1820, disse que, havia quinze dias mais ou menos, demandara sua coartação a seu amo. Entrando em desacordo, recorreu ao tribunal para que fosse avaliado (tajado) por perito designado. Mas o senhor não se manifestou e, por isso, nada havia foi resolvido. O desejo de Bernardo era entregar a quantia de que dispunha a fim de se tornar coartado para, em seguida, buscar um novo amo que lhe permitisse ganhar os jornais necessários para a quitação do montante integral clausulado para a sua alforria. Como observou Alejandro de la Fuente, a obtenção de papel de venda para buscar um novo senhor, proveniente da punição tradicionalmente prevista contra maus-tratos, seria cruzada na prática social com a coartação por ação dos escravos em busca de ampliação de sua autonomia para a conquista da liberdade $^{529}$.

A sequência do arrazoado apresentado por Bernardo é interessantíssima:

“El sr. D. Leandro García su señor dice que nadie puede obligarle a que me enajene, está muy equivocado con semejante capricho, pues estando como sucede aquí, disgustando con su dueño el siervo, debe

\footnotetext{
527 José Anton Oneca. "Historia del Código Penal de 1822". Anuario del Derecho Penal y Ciencias Penales, (1965), pp.263-278.

528 Cf. Rafael Sánchez Mantero. Los Cien Mil Hijos de San Luis y las relaciones franco españolas. Sevilla: Universidad de Sevilla, 1981.

${ }^{529}$ Entre outros, o historiador cubano analisou este mesmo caso de Bernardo Lucumí. Cf. Alejandro de la Fuente. "Slaves and the Creation of Legal Rights in Cuba: Coartación and Papel". Hispanic American Historical Review, vol.87, n.4 (Nov. 2007), pp.659-92.
} 
precisamente deshacerse de su servicio vendiendo a otro, tanto por qué no puede servirle gustoso cuanto por qué así mismo a nadie le gusta ni conviene cosa forzada" ${ }^{530}$.

A lógica do argumento é irrepreensível e atemporal. A ninguém convém coisa forçada. Resta saber se ele prevaleceu.

Bernardo anexou ao processo um papel de venda que atestava que seu senhor tinha vontade de vendê-lo. Ademais, explicou que o seu desgosto em servir D. Leandro devia-se ao fato de que, sendo ele, Bernardo, casado e com filhos (sua mulher era livre), cabia-lhe buscar o seu sustento, o que estava sendo impossibilitado pela circunstância de estar destinado ao ingenho de seu senhor, localizado um pouco distante de Havana. O motivo da demanda, portanto, era algo o nosso olho bastante razoável e que denota o caráter absurdamente indigno do sistema de escravidão.

Ao final, suplicava que o juiz mandasse que o Corrector Mor de Lonja, D. Arturo de La Roza, perito recomendado de sua parte, procedesse a definição do preço justo, sendo-lhe passado novo papel de venda, isto porque o papel anterior, de 18 de maio, era extremamente desabonador: "Doy licencia a mi esclavo Bernardo Lucumí para que busque amo por tres días, por haberme pedido papel para buscarlo, en la cantidad de un mil pesos en venta real, y con las tachas de ladrón y cimarrón". Além da pecha de ladrão e cimarrón, que de qualquer modo dificultaria a venda, o senhor estipulava o exorbitante preço de mil pesos para a sua venda, o dobro da média de sua etnia para a época ${ }^{531}$. Notemos as palavras de sua representação:

\begin{abstract}
"[...] el siervo no aspira a otra cosa más que a que le quede clausulada una costa fija como es sabido para por este medio incitar que el dueño no pueda arbitrariamente pedir cuanto se le antoje, como sucede en mi que es conocido que por no querer mi venta pide mil pesos cantidad tan multiplicada con las tachas tan considerables que me pone; mas hoy dice que no vende por que no le he traído los mil pesos que pide por mí. ¡Qué despotismo de d. Leandro García Sanabria! Pero no me desconsuelo por qué estoy ante un señor juez que en observancia de las leyes que me protegen hará hacer en rigorosa justicia cuanto tengo demandado. En atención asimismo al segundo extremo de la expuesta demanda es asimismo de advertía que aun que dice que no se le puede obligar a que me enajene podría tal vez lograrlo, pero no habiendo un allanamiento pues no se he llevado los mil pesos que pidió, digo yo ahora ¿Habrá quien sea tan bobo que quiera sacrificar mil pesos por un esclavo que padece las tachas de ladrón y cimarrón, y haber estado relajado al peor de las habilidades que me supone abstengo? No lo creo señor juez"532.
\end{abstract}

D. Leandro contra-argumentaria, dizendo que nunca havia feito mal a Bernardo, tratando-o sempre com "demasiada bondad", "lo que há sido causa del abuso que ha querido y quiere tener dicho esclavo, quien no quiere hacer servicio en la casa de sus amos ni parar en

${ }^{530}$ Grifo meu. Bernardo Lucumí esclavo de don Leandro García Sanabria sobre su coartación y venta, 1820, ANC, Escribanías (Daumy), leg. 778, exp.3

${ }^{531}$ Bergad, Fe Iglesias \& Del Carmen Barcia. The Cuban Slave Market, 1790-1880, p.75.

${ }^{532}$ Grifo meu. Bernardo Lucumí esclavo de don Leandro García Sanabria sobre su coartación y venta, op.cit. 
ella, sino andarse todo el día en la calle de su cuenta, viniendo solamente a las horas de comer que le acomodar, y de noche a dormir, causando este mal manejo escándalo a sus compañeros". No dia 20 de junho, surgiu um problema a mais para Bernardo. A sua defesa estava sendo feita por um letrado chamado Antonio Barranco, mas o juiz determinou que o caso passasse para as mãos de um síndico procurador. A determinação foi contestada por Bernardo, que alegou ter forte desconfiança em relação aos síndicos, nomeadamente, D. Gustavo Montero e d. Mariano Hernández, pois, ao apresentar-se em suas casas, havia dado de cara com seu amo. Por isso, indicou outro advogado para dar prosseguimento à sua defesa, D. José Matías Maestri. O pedido foi negado. O juiz afirmou que a defesa e o patrocínio dos negros escravos eram encargos do síndico procurador general, não estando ao alcance do tribunal a nomeação do defensor pretendido. Aqui há dois pontos a serem realçados. Primeiro, a afirmação da competência dos síndicos quanto à representação dos cativos em juízo. Segundo, a ausência de garantias de que tais oficiais defenderiam da melhor maneira os interesses dos escravos. Em outras palavras, a defensoria em Cuba não era necessariamente superior à do Brasil pelo fato de existirem funcionários especificamente designados para a função.

A causa, de fato, foi entregue ao Caballero síndico primer procurador, o licenciado D. Mariano Hernández, que a conduziu até o final. Ao longo do processo, Bernardo realizou vários pedidos de depósito, para que fosse retirado do convívio de seu senhor, que lhe estaria tratando com crueldade e impedindo-o de acompanhar as tramitações da ação judicial. Em Cuba, o depósito judicial dos escravos homens, quando concedido, via de regra ficava a cargo de pessoas consideradas idôneas indicadas pelos magistrados. Podia acontecer também do cárcere público servir de depósito. As mulheres geralmente eram enviadas para instituições religiosas, como o Hospital de Paula ou a Casa de Beneficência ${ }^{533}$.

No entanto, o magistrado responsável, Juan Ignacio Rendón, entendeu que não havia necessidade. Em 17 de outubro, ainda do ano de 1820, foram definidos os trâmites para a avaliação, sendo nomeado um perito de cada parte, mais um terceiro, em caso de desacordo. $\mathrm{O}$ preço definido, observadas as habilidades, os vícios e os defeitos do escravo, foi a ainda elevada quantia de 750 pesos. Em 17 de dezembro, adveio a sentença final, determinando que fossem admitidas as quantidades oferecidas por Bernardo para a sua coartação. Entretanto, dele deveria continuar a serviço D. Leandro, já que não teria sido apresentada nenhuma prova efetiva de sevícias, dado que poderia acarretar a obrigatoriedade da troca de amo. Deste modo, é possível perceber que o êxito do autor foi bastante limitado. A coartação veio, mas a elevada quantia

\footnotetext{
${ }^{533}$ Bienvenido Cano \& Federico de Zalba. El libro de los síndicos y de las juntas protectoras de libertos. Havana: Impr. del gobierno y capitanía general por S .M., 1875, p.43.
} 
fixada praticamente inviabilizou a alforria, ainda mais se considerando as condições de vida de Bernardo, dedicado a atividades agrícolas. Ao final, o protagonista dessa história continuaria sendo forçado a fazer lo que no le gustava, distante de sua família.

Vale observar que nem sempre o resultado era este. Houve casos em que o ajuizamento do valor era compatível com a poupança do escravo postulante à liberdade e mais condizente com o preço de mercado. Em 23 de dezembro de 1822, D. Luis Serrano, vecino da cidade de Havana, compareceu em juízo manifestando que desde o dia 28 do mês anterior, seu escravo, o negro criollo Vicente, havia fugido de sua casa temendo ser punido por haver insultado sua filha "con palabras descatadoras y falsas de respecto hasta el extremo de desafiarla en altas voces". Para iludir sua correção, procurou o alcalde constitucional D. Florentino Armenteros, apadrinhado pelo síndico procurador, D. José Guerreiro, do que resultou o seu depósito na casa de D. Juaquín Valdéz. Aproveitando a oportunidade, Vicente reclamou a sua avaliação e a venda para um novo senhor. Também, solicitou que de seu valor fosse rebaixado 100 pesos em virtude de uma graça feita pela falecida esposa de D. Luis como recompensa pelo mérito de têla salva de uma tentativa de assassinato. Porém, Serrano alegou não haver "motivo para que se estreche al suplicante a su venta con la rebaja de cien pesos pues esto tendría lugar cuando mediase alguna tiranía de su parte, ni tampoco hay razón para que se le despoje de su servicio mientras se tasa, y encuentre otro amo" ${ }^{\text {} 34}$. Note-se bem: apenas o tratamento cruel podia acarretar naquela época a obrigação da venda, não obstante os escravos conseguirem na prática social arrancar papéis de venda de seus senhores, conforme registrado nas cédulas setecentistas.

Em resposta, D. José Guerrero, síndico do Ayuntamiento, agora, constitucional, da cidade de Havana, dirigiu-se ao juiz narrando que Vicente o havia procurado, alegando que havia contraído uma porção de feridas por tentar defender a esposa de D. Luis. Por isso, ela concedeu-lhe a liberdade "aunque bajo condiciones casi imposibles de cumplirse". Com uma hérnia e a perna em decomposição, desejava, pelo menos, mudar de dono. Pareceu ao síndico que aquela notável circunstância de haver oposto o escravo sua vida pela de sua senhora merecia consideração, ainda mais pelo seu mau estado de saúde.

Chegou a haver uma audiência de conciliação na qual D. Luis reconheceu a validade das intenções de Vicente, mas reclamou de sua permanência no depósito. Conforme o defensor desse senhor, o escravo deveria ser retornado ao serviço de seu amo para que, então, o síndico tratasse de sua venda ou da consecução da liberdade. Para isso, Vicente deveria renunciar à

\footnotetext{
${ }^{534}$ El Síndico $2^{\circ}$ Del Excmo. Ayuntamiento constitucional de esta ciudad Licdo. Don José Guerrero contra Don Luis Serrano sobre la libertad del negro Vicente Serrano esclavo de este, 1826 (não obstante a datação, o processo transcorre entre 1822 e 1823), ANC, Escribanías (Blanco), leg. 332, exp. 4.
} 
graça feita por sua ama defunta, abonando a quantia de 600 pesos para se alforriar. Para a venda, que fosse pago o valor de 700 pesos para ser vendido. Diante disso, o síndico manteve o pedido de avaliação, rechaçando a exorbitante quantia proposta pelo amo, que não seria razoável nem mesmo se Vicente estivesse em bom estado de saúde.

Na sequência, D. Luis apresentou nova reclamação sobre a permanência de Vicente no depósito, alegando que o depositário, D. Joaquín Valdez, estava se valendo dos serviços de seu escravo, "y yo carecendo de su servicio com grave prejuicio mío, pues me he visto em la necesidad de alquilar outro que me gana viente pesos mensuales". Em 11 de janeiro de 1823, o mesmo juiz do caso de Bernardo, Juan Ignacio Rendón, pronunciou-se determinando que Vicente fosse restituído ao serviço de seu senhor, prevenindo D. Luis que mantivesse o escravo na cidade e permitisse que ele fosse à casa do síndico para acompanhar o andamento do processo, "no afligiéndolo ni castigándolo por su presentación quedando advertido si lo hiciere se le privará de su servicio por la inobediência y falta de respecto".

Tudo parecia se encaminhar para um fim semelhante ao de Bernardo, até que a irmã de Vicente, a morena livre Coleta Serrano, tomou a dianteira do caso. Sua primeira intervenção foi registrada em 14 de janeiro, quando apresentou uma súplica para que o juiz reconsiderasse a decisão de tirar seu irmão do depósito por temer por sua integridade física, e refez o pedido em prol do cálculo de seu justo preço "para entregar dicha cantidad en el día otorgándole la correspondiente carta de libertad". Aqui houve um salto em relação à demanda original, que previa apenas a coartação e a troca de amo. Agora, a alforria direta entrava em perspectiva. Em 5 de março, Coleta depositou em juízo 300 pesos para a liberdade de seu irmão, por conta de exibir o restante quando fosse realizada a tasación. Ademais, a sua súplica sobre o depósito surtiu efeito, pois Vicente não retornou para a casa do amo.

$\mathrm{O}$ amo se pronunciou dizendo que os temores manifestos para que Vicente fosse vão, pois nunca lhe havia posto a mão, ainda que tenha dado vários motivos para ser castigado. $\mathrm{A}$ reintegração de posse requerida seria conforme o direito, "pues no debo estar despojado de su servicio como lo he estado más de tres meses sin haber motivo para ello: lo contrario sería un ejemplar que traería graves perjuicios a los propietarios". Sobre o dinheiro apresentado, apontava que a morena Coleta não tinha um real; que vivia reduzia à miséria e que a quantidade exibida era própria de seu irmão Vicente, “adquirida, sabe Diós como". A estratégia dos irmãos seria postergar as diligências o máximo possível, mantendo Vicente no local de depósito, pois não teriam meios completar o pagamento pela alforria. Em três de abril, Rendón determinou novamente o retorno de Vicente a seu amo. Ao que Coleta reagiu uma vez mais, sustentando que 


\begin{abstract}
"por decreto del tribunal se mandó que mi hermano Vicente volviera a poder de su amo, a quien tengo representado que ni tentar atropellarlo. En este concepto y el de que tengo exhibidos en el tribunal trescientos pesos a cuenta, y con reserva de exhibir lo demás en que sea tasado, estoy en el caso de suplicar al tribunal suspenda aquella determinación hasta tanto se verifique la tasación que se hará dentro de ocho días, y para la que se ha nombrado por su parte al Licdo. Don Francisco S. Bernal. En consideración de estas razones y que hare cuantos sacrificios sean posibles por mi hermano, A V.S. Suplico se sirva suspender los efectos de aquella providencia y mandar que se espere hasta que se verifique la tasación seguro de que como he dicho daré todo el demás dinero en que se tasare, pues no es justo que quien ha dado más de más mitad de su libertad, vaya a poder de su amo malicioso"s35.
\end{abstract}

O pedido foi acatado, sendo o preço da liberdade fixado em 400 pesos, desconsiderandose os 100 pesos debitados pela falecida senhora. Em 23 de maio de 1823, o juiz determinou que fosse outorgada a carta de liberdade a Vicente, assim que exibido o valor restante, o que ocorreu três dias depois. O êxito de Vicente dependeu da apresentação do dinheiro, obtido, "sabe Deus de que maneira”. Eis um exemplo lapidar de êxito pela via da agência escrava. Toda a iniciativa daquele libertado e o apoio de sua irmã, Coleta, evidenciam o campo de possibilidades aberto aos e pelos escravos no interior do ordenamento jurídico cubano de forma integrada às condições objetivas. Os indícios existentes levam a crer que todos os envolvidos viviam em Havana. A vida urbana havanesa propiciava melhores condições para o acúmulo de pecúlio do que para Bernardo, que tinha que se dedicar ao trabalho no ingenio. É uma lástima que o processo não forneça dados mais precisos sobre a forma como Coleta obteve o dinheiro para livrar seu irmão do cativeiro. Se os recursos eram mesmo de Vicente, como disse D. Luis, seria interessante saber como ele reuniu aquela quantia. Mas, para, além disso, é necessário sempre ponderar sobre os efeitos sistêmicos desse tipo de conquista, isto é, o impacto seu sobre o regime escravista cubano. Com o dinheiro recebido, o proprietário pôde comprar outro escravo entre os já existentes na ilha ou entre as levas de africanos que continuavam chegando a rodo via contrabando. Já Vicente, seguiria com a sua vida, agora na condição de liberto, o que o habilitava, entre outras coisas, para tornar-se também um senhor de escravos. Portanto, episódios como este não representam qualquer movimento de erosão da estrutura social de dominação dos trabalhadores cativos, antes, ilustram parte importante da dinâmica interna do regime.

Voltando ao plano político, cumpre reforçar que o Triênio Liberal instalado naqueles anos não seria satisfatório para os interesses da oligarquia açucareira da ilha. Em 1821, havia sido aprovada nas Cortes a elevação dos impostos sobre as importações e Cuba perdeu a liberdade de comércio outorgada por Fernando VII. A busca pela contenção do tráfico de

\footnotetext{
${ }^{535}$ Grifo meu. El Síndico $2^{o}$ Del Excmo. Ayuntamiento constitucional de esta ciudad Licdo. Don José Guerrero contra Don Luis Serrano sobre la libertad del negro Vicente Serrano esclavo de este, op.cit.
} 
escravos para a ilha não seria, portanto, o único sinal de desatenção dos liberais espanhóis às demandas dos hacendados escravistas. A restauração do absolutismo, em 1823, fez reacender a aliança com a metrópole, assinalada pela presença da elite criolla nos mais elevados postos da administração insular. Anos mais tarde, Juan de Montalvo, sintetizaria a diferença de contexto, dizendo que "la Habana comparativamente fue libre en tiempos del despotismo y esclava em tiempos de la libertad"536. Claro que a liberdade em questão era a de produzir sobre as costas de trabalhadores cativos como Bernardo. O Tribunal Misto instalado em Havana procederia resumidamente da seguinte forma: toda vez que um cruzeiro inglês apresava um negreiro, dava-se uma averiguação para se saber se os negros eram cativos antigos, em traslado de uma praça a outra no interior do império espanhol, como normalmente se alegava, ou se eram proveniente contrabando, como normalmente ocorria. Declarados livres, os emancipados, como eram chamados, passavam a uma tutela temporária, supostamente, para que aprendessem noções básicas da religião e técnicas elementares para o manejo da terra. Ao final, deveriam ser reconduzidos à liberdade plena. Em compensação pela exploração do trabalho de seus tutelados, os tutores deveriam vesti-los, alimentá-los, assisti-los em caso de enfermidade. A distribuição dos emancipados entre os tutores correria a cargo do capitão general. Os primeiros emancipados surgiram em dezembro de 1824, quando foi apreendido o bergantim Relâmpago, com 150 escravos, os quais foram depositados em um casario nas imediações de Havana para que não se misturassem com outros negros. Até 1834, entrariam em Cuba cerca de 5800 emancipados ${ }^{537}$. No princípio, os emancipados foram enviados para instituições religiosas, viúvas ou pobres incapazes, mas logo passariam a servir de moeda de troca nas redes de clientela estabelecidas na localidade, a exemplo do que foi descrito para o caso brasileiro. Segundo Ramiro Guerra, a obrigação de devolvê-los à liberdade não se cumpriu e a sua distribuição se converteu em fonte lucro ilegítimo para funcionários do governo ${ }^{538}$.

Nos anos seguintes, restrições ao comércio colonial, questões envolvendo a igualdade jurídica e política dos habitantes locais em relação aos metropolitanos e, claro, as manutenções do tráfico negreiro e da escravidão marcariam as relações entre Cuba e Espanha. Em 1824, o império continental espanhol estava praticamente liquidado e a perda da Perla de las Antillas

\footnotetext{
${ }^{536}$ Apud José A. Piqueras. Sociedad civil y poder en Cuba: colonia y poscolonia. Madri: Siglo XXI, 2005, p.78.

${ }^{537}$ Lucena Salmoral. "Leyes para esclavos: el ordenamiento jurídico sobre la condición,...”, p.404.

${ }^{538}$ Ramiro Guerra y Sánchez. Manual de Historia de Cuba (económica, social y política). Havana: Editorial Nacional de Cuba, 1964, pp.314-315; Inés Roldán de Montaud, “Origen, evolución y supresión del grupo de negros ‘emancipados' en Cuba, 1817-1870” Revista de Indias, n.42 (1982), pp.559-641; Aisnara Perera Díaz \& María de los Ángeles Meriño Fuentes. "Libertad sin abolición: la dimensión política de los conflictos entre africanos y traficantes en los tribunales cubanos. La Habana 1795-1844". (artigo inédito cedido pelas autoras); Babatunde Sofela. Emancipados: slave societies in Brazil and Cuba. Trenton, NJ : Africa World Press, 2011.
} 
era uma possibilidade real diante de manobras diversas com vistas à sua invasão, sem contar ações insurrecionais que brotariam internamente. Para fortalecer seu domínio, além de criar uma Comissão Militar Permanente para o julgamento de crimes diversos, inclusive o de traição à coroa, o rei Fernando VII, agora sem amarras constitucionais, reformulou o regime colonial, tradicionalmente assentado nas Leyes de Indias, atribuindo competências extraordinárias aos capitães generais, os quais, pela letra da Real Ordem de 25 de maio de 1825, passara a ter.

"todo el lleno de las facultades que por las reales ordenanzas se concedían a los gobernadores de las plazas
sitiadas; la más amplia e ilimitada autorización para separar de la isla a las personas, empleadas o no
empleadas, cualquiera que fuese su destino, rango, clase o condición, cuya permanencia en el territorio
se creyera prejudicial o infundiese recelo su conducta pública o privada reemplazándolas interinamente
con servidores fieles al rey y de la confianza del gobernador general [y] poder ilimitado para suspender
la ejecución de órdenes o providencias expedidas sobre los ramos administrativos que fueran
inconvenientes al real servicio" 539 .

Com isso, instituiu-se o chamado regime de faculdades onímodas, que persistiria até o fim da Guerra dos Dez Anos, em 1878, estando intimamente ligado à preservação da ordem colonial escravista. Munido de tais faculdades, o capitão general poderia ampliar tanto sua ingerência sobre a gestão do controle social da população negra, livre e cativa, quanto o suporte à importação de novos africanos, sobretudo pela sua reponsabilidade formal, estabelecida no tratado de 1817, sobre a implementação das medidas de combate ao contrabando. Nas gestões de Francisco Dionisio Vives (1823-1832), Mariano Ricafort (1832-1834) e Miguel Tacón (1834-1838), haveria ações claras para proteger o trato ilegal. Em 1826, ao ser pressionado por comissários ingleses para capturar a tripulação e localizar africanos desaparecidos, Vives respondeu que tal ação cabia às autoridades navais, escapando às suas atribuições. A recusa foi reportada pelos ingleses ao governo madrileno, que cobrou explicações. Após consultar seu auditor de guerra, o capitão general defendeu sua conduta, dizendo que nada no tratado e na cédula de 1817 impunha a perseguição ao contrabando em terra, limitando-se a proibição ao perímetro naval. Nos anos seguintes, a diplomacia britânica enviaria novas notificações a Madri sobre o descumprimento do compromisso de combate ao tráfico negreiro, com a conivência do capitão general, mas nada mudaria. Em 8 de outubro de 1829, este capitão general editou um bando proibindo a introdução de negros provenientes de colônias estrangeiras e de Costa Firme, a parte setentrional da América do Sul espanhola. Mas a efetividade de tal providência para a contenção do tráfico foi praticamente nula ${ }^{540}$. No posto, Ricafort responderia às inquirições inglesas alegando que a extensão do litoral da ilha impossibilitava que fosse evitado o

\footnotetext{
${ }^{539}$ Apud idem, p.305.

${ }^{540}$ Lucena Salmoral. "Leyes para esclavos: el ordenamiento jurídico sobre la condición,...”, p.1232.
} 
desembarque de escravos ilegais em todos os pontos, o que se somava ao desejo dos proprietários de obterem mais e mais escravos para o serviço de suas plantações. Reputado como liberal radical na Espanha, a indicação de Tacón para o comando da ilha parecia indicar o início de uma guinada na política delineada até então. Mas, como destacou David Murray, em Cuba, ele se tornaria tão reacionário quanto havia sido liberal na metrópole, chegando inclusive a vetar a publicação da convenção antitráfico efetuada em $1835^{541}$.

Quanto ao ordenamento jurídico, este regime fortaleceu o peso das esferas locais quanto à normatização das relações de escravidão, que se mantiveram de um modo geral alheias às descontinuidades do processo de sistematização do direito espanhol. Em junho daquele mesmo ano de 1825, uma grande revolta sacudiria o partido de Guamacaro, com saldo de 24 propriedades saqueadas e incendiadas e 15 brancos mortos. Para por freio às agitações dos escravos, o governador de Matanzas, Cecilio Ayllon, elaborou projeto de Reglamento de esclavos bem ao gosto da classe senhorial. O principal objetivo do "código de Ayllon" era homogeneizar os mecanismos de controle dos escravos no interior das haciendas, a fim de garantir a estabilidade social das regiões de plantação. Dividido em quatro partes, o regulamento previa medidas de segurança como o impedimento da comunicação entre os escravos de diferentes propriedades, a exclusão de "pessoas de cor" para a administração das fazendas, o trancamento de portas e portões após as orações, a restrição a visitas e a proibição a reuniões após as dez da noite. Sem tocar na jornada de trabalho, foram feitas especificações quanto ao tratamento. Toda a finca com dotação superior a 25 negros teria que possuir uma enfermaria. As punições deveriam ser aplicadas de acordo com a gravidade das infrações, sem excessos. O tempo necessário para o sono e o descanso dos escravos deveria ser respeitado. $\mathrm{O}$ casamento deveria ser favorecido como forma de estimular o bom comportamento e o apego à família. Deveria ser garantida alguma autonomia para a criação de animais e alguns pequenos roçados, assim como para a venda do excedente ${ }^{542}$.

Aprovado em 22 de outubro de 1825 para a jurisdição de Matanzas, o Reglamento de Ayllon em nada melhorou as chances dos cativos obterem a sua liberdade. Por outro lado, ele não invalidou os dispositivos então em vigor. Nenhum empecilho foi criado à concessão da liberdade em suas diferentes modalidades costumeiramente praticadas e corroboradas pelo

\footnotetext{
${ }^{541}$ Murray, Odious commerce,pp. 88-108; Berbel, Marquese \& Parron. Escravidão e Política..., pp.204-205.

542 Jean-Pierre Tardieu. "Morir o dominar": en torno al reglamento de esclavos de Cuba (1841-1866). Frankfurt: Vervurt; Madrid: Iberoamericana, 2003, pp.126-130; Rafael de Bivar Marquese. Feitores do corpo, missionários da mente. Senhores, letrados e o controle dos escravos nas Américas, 1660-1860. São Paulo: Companhia das Letras, 2004, pp.309-315. Manuel Barcia Paz. The great African slave revolt of 1825: Cuba and the fight for freedom in Matanzas. Luisiana: Louisiana State University Press, 2012, pp.133, 137-39, 144-45; 162-170 (cópia do Reglamento no Apendice 5).
} 
direito positivo. Em verdade, um de seus tópicos tocou de maneira tangencial a matéria, recomendando que os escravos bem comportados fossem recompensados de alguma forma para que servissem de exemplo perante os demais. Na tradição ibero-americana, entre tais recompensas constava, como sabemos a manumissão. Aqui há um dado de importante: a produção legislativa cubana não faria tábula rasa dos preceitos tradicionais ou dos costumes arraigados.

Naquele mesmo ano, o pardo Pedro José Celestino, escravo do pequeno proprietário, D. Juan Hernández, vecino do partido de San José de las Lajas - região associada à expansão da agricultura comercial havanesa, que concentrou 26 ingenios e 24 cafetales na primeira metade do século ${ }^{543}$ - procurou a Justiça para apurar sua condição pelos autos da testamentaria de seu senhor, que havia morrido. Conforme a cópia do testamento e outros documentos anexados ao processo, constava entre os bens do falecido cinco escravos. Entre eles, o autor da ação, citado em 400 pesos, havendo entregado 148 pesos por conta de sua liberdade. Tratava-se portanto, de um escravo coartado. Faltava entregar 252 pesos para que lhe fosse entregue a sua carta de ahorro, como de direito. A súplica era para que o juiz notificasse os herdeiros para que aceitassem a referida quantia. $\mathrm{O}$ processo se arrastou um pouco mais do que o necessário, porque o albacea (testamentário) também morreu e um novo teve que ser nomeado. Os interessados aprovaram a demanda, concordando em alforriar Pedro mediante a entrega dos 252 pesos. No dia primeiro de fevereiro de 1826 , veio a seguinte sentença:

"Se declara que el mulato Pedro José Celestino debe rebajarse los cuatrocientos pesos a que asciende la
tasación que de él se hizo y conste en testimonio a fojas veinte y dos la cantidad de ciento cuarenta y ocho
que reclama a su nombre el síndico procurador general del a común quedando desde luego cuartado en la
suma restante, y que facilitada que sea por el siervo debe otorgarse la correspondiente carta de ahorro" 544 .

Como é evidente, o juiz chancelou a coartação e a estima do valor restante para a aquisição da liberdade. Em verdade, a questão passou com tamanha conformidade que poderia muito bem ter sido resolvida sem a necessidade de um pleito judicial, como inclusive afirmou o curador de menores, D. Joaquín de la Vega, representante dos herdeiros. Disse ele:

"Debo notar que la pretensión de José Celestino jamás ha tenido contradicción, y que sin el costoso aparato de un pleito pudo haber conseguido su fin, siendo la prueba más voraz del allanamiento de los

\footnotetext{
${ }^{543}$ Lisette Roura Álvarez. "El bohío: vivienda esclava en las plantaciones cubanas del siglo XIX". La Jiribilla. Revista de cultura cubana. Año VI, (set./2007). Disponível em: <http://www.lajiribilla.cu/2007/n333_09/333_01.html\#_ftnref7>. Acesso em: 12 de março 2015; Arturo Echezarreta. Monografía histórica-geográfica de San José de las Lajas, s/p.

${ }^{544}$ Incidente a la testamentaria de D. Juan Hernández segundo que el caballero síndico procurador general del común sobre la libertad del pardo (Pedro) José Celestino, 1825, ANC, Escribanías (Pontón), leg. 50, exp. 10.
} 
interesados, el que apenas se les ha dado conocimiento cuando de plano han deferido a la solicitud; y paren de justicia que la masa hereditaria no se grave con erogación de costas que no han motivado los herederos ni el Albacea con inútiles contradicciones, imputándoselas a el promovente que las ha causado con representaciones inútiles en una materia propia de la jurisdicción domestica cuando no hay contracción ni reparo: en esta virtud y reiterando mis anteriores conceptos con la más útil y eficaz instancia" 545 .

De todo modo, tudo se encaminhava para um final favorável. No entanto, o processo se arrastaria por bastante tempo ainda. No dia 16 de fevereiro de 1826, o síndico apresentou um requerimento solicitando que o funcionário judicial fosse até o local onde se encontrava o pardo Pedro José Celestino, averiguando se ele dispunha do dinheiro de que necessitava para a sua liberdade, instando-o a exibi-lo imediatamente. Após protelar algum tempo, talvez para reunir a quantia restante, Pedro efetuou o pagamento, conforme registro do dia 4 de março. Porém, a sua carta de ahorro não lhe foi outorgada imediatamente. O albacea e os herdeiros queriam de qualquer maneira esquivar-se do pagamento das custas. $\mathrm{O}$ processo chegou ao fim apenas em 19 de janeiro de 1828, quando o juiz ordenou a consumação de sua liberdade.

A esta altura deve estar claro que, diferentemente do quadro mais restrito observado para o Brasil, em Cuba havia uma gradação entre as alforrias graciosas - que se mantinha integralmente dependente da vontade senhorial -, passando pela coartação - que assumiu uma posição de "semidireito" até a sua validação em 1842 - até a alforria onerosa, consolidada, efetivamente, como um direito dos escravos cubanos no século XIX. Evidentemente, vários senhores faziam tudo que podiam para impedir a alforria de seus escravos, movidos, às vezes, por outras motivações que não propriamente a defesa de um patrimônio rentável. Demonstração de poder, vingança, afeição, barbárie, enfim, uma miríade de sentimentos, traços psíquicos e manifestações simbólicas podiam estar envolvidos. Vejamos o caso do negro Antonio, de nação mandinga, que entrou na justiça contra sua senhora, D. Rita Chirino, em 1826. Com idade bastante avançada, sendo reconhecido como octogenário, ele atestou haver entregado por conta de sua liberdade a quantia de 291 pesos diretamente a sua ama e outros 100 pesos para o capitán Del partido. Mas, apesar de satisfazer com folga o preço de sua alforria, sobretudo em razão de seu estado de senilidade que o tornava incapaz para o trabalho. De fato, a média de preço de um escravo em idade produtiva, daquela mesma etnia girava em torno dos 380 pesos. Um idoso teria um rebaixamento de pelo menos $35 \%{ }^{546}$. E aqui nos deparamos com mais uma recorrência, a imposição e a satisfação de valores maiores do que o preço de mercado para a manumissão. Neste caso específico, D. Rita só tinha a ganhar. Além de livrar-se do sustento de um cativo

\footnotetext{
545 Idem.

${ }^{546}$ Bergad, Fe Iglesias \& Del Carmen Barcia. The Cuban Slave Market, 1790-1880, p.73.
} 
idoso, ela poderia usar o dinheiro para comprar outro escravo com a idade entre 15 e 40 anos. Claro, havia as possibilidades de que ela desejasse ficar com o dinheiro que lhe havia sido entregue e com Antonio ao mesmo tempo, não obstante o seu estado debilitado, ou, até, ficar com o dinheiro e se eximir-se das responsabilidades de cuidado para com seu cativo ${ }^{547}$.

Em nome de Antonio, o síndico suplicou que, havendo apresentado os dois papéis que comprovavam os pagamentos, o juiz ordenasse que fossem tomadas informações do capitão do partido e procedesse a tasación do escravo, fazendo constar seu verdadeiro valor, para que na sequência lhe fosse outorgada a carta de ahorro. Foi feito o pedido de depósito e o autor da ação foi para a casa de D. Manuel Gomez, nomeado depositário. Mas, Antonio ficou doente e teve que ser levado para o hospital. Enquanto isso, o síndico reiterava súplicas para que a senhora Chirino fosse compelida a consumar a manumissão. A senhora manifestou-se, afirmando concordar com a libertação a fim de manter a sua tranquilidade. Porém, surgiu todo um imbróglio sobre o pagamento das custas processuais e do tratamento médico de Antonio, que estava hospitalizado. Os responsáveis pelo hospital enviaram sucessivos requerimentos, questionando a cargo de quem ficaria o custeio das dietas e demais gastos hospitalares. A senhora se valeu de toda sorte de evasivas, afirmou já haver mandado conferir a carta de liberdade. O síndico contestou. Diligências diversas se seguiriam, mas o processo terminou sem definição. O último despacho, datado de 20 de outubro de 1828, não traz nenhuma indicação sobre a efetiva outorga da carta de alforria, da realização de algum ajuste extrajudicial, ou até da possível morte de Antonio ${ }^{548}$.

Outro processo inconclusivo (em termos judiciais), mas que diz bastante sobre as nuanças da realidade escravista cubana, é o que envolveu o criollo Francisco Xavier. Segundo relato elaborado pelo síndico, D. Domingo Rodriguez, soldado miliciano natural de la Palma, nas ilhas Canárias, havia comprado Francisco em 1820, coartado em 200 pesos, para destiná-lo aos lavores de um sítio que possuía no partido de Calvario Viejo. A compra teria sido feita com a condição de que Francisco fosse agraciado com uma pequena criação de animais da qual pudesse extrair algum ganho como compensação pelo seu trabalho, em virtude do preço módico pelo qual D. Domingo o havia adquirido. Porém, nada foi entregue a Francisco, que ficou, por causa disso, impossibilitado de economizar para a compra de sua liberdade. Ao manifestar-se, o amo limitou-se a alegar que seu negro escravo, Francisco Xavier criollo estava fugido havia mais ou menos um mês e que não sabia de seu paradeiro. O processo não seguiu a diante, mas

\footnotetext{
${ }^{547}$ El síndico procurador a nombre del negro Antonio de nación mandinga contra d. Rita Chirino, vecina del partido de San José de las Lajas, sobre su libertad, 1826, ANC, (Archivo de Salinas), leg. 722, exp. 8360. 548 Idem.
} 
por uma questão de foro. D. Domingo era militar, o alcalde determinou, em 24 de novembro de 1828, que o caso fosse remetido ao capital general. Não foi possível descobrir se Francisco Dionisio Vives deu ou não prosseguimento à ação. Mesmo assim, alguns aspectos presentes no caso devem ser realçados, a começar pela obrigação jurídica criada pelo trato realizado ${ }^{549}$.

Assim como frequentemente observado para os processos brasileiros, o síndico sustentou que se D. Domingo havia prometido a seu escravo como condição de sua compra, que lhe daria animais para que estabelecesse uma criação própria no sítio, deveria satisfazer o seu compromisso: a vontade senhorial criava o direito. Até 1842, a coartação representava um contrato voluntário pactuado entre senhores e escravos. Não obstante, interessa realçar que o acerto efetuado no caso de Francisco denota, uma vez mais, o peso fático da vontade do coartado para a transferência de domínio. Isto não significa que o antigo senhor tenha sido desconsiderado na negociação, mas sugere a existência de um campo de autonomia para os indivíduos naquela condição. Neste ponto, havia em Cuba uma coincidência em relação ao que Eduardo França Paiva, Laura de Mello e Souza e outros historiadores descreveram em torno da coartação mineira setecentista, pela qual o escravo, tendo obtido sua carta de corte, poderia se distanciar do domínio senhorial a fim de procurar meios para saldar as prestações referentes à sua alforria, aproximando-se dos escravos ao ganho, bastante comuns na cidade do Rio de Janeiro e em outras regiões do Brasil. No entanto, a rotatividade de domínio parece ter sido um traço bastante peculiar a Cuba. Os estudos dedicados à prática da coartação mineira e mesmo alguns casos registrados para outras regiões não indicam que os coartados brasileiros mudassem de senhor como faziam os cubanos ${ }^{550}$. Mas havia alguma vantagem nisso?

Mudar de dono podia significar uma melhoria nas condições de vida ou trabalho e a ampliação das possibilidades de poupança para a compra da alforria. Por outro lado, existia também um aproveitamento por parte dos senhores, que podiam adquirir escravos a preços menores - já que o valor restante para a liberdade perfazia o preço de mercado dos coartados propensos ao trabalho duro para a poupança do dinheiro necessário para a quitação da liberdade. A dúvida maior que emerge desta constatação não é sobre o porquê da existência dessa prática

\footnotetext{
549 1826, ANC, Escribanías (Galleti), leg. 780, exp. n.4.

${ }^{550}$ Laura de Mello e Souza. "Coartação: problemática e episódios referentes a Minas Gerais no século XVIII". In: Maria Beatriz Nizza da Silva (org.). Brasil: colonização e escravidão. Rio de Janeiro: Nova Fronteira, pp.275295; Eduardo França Paiva. "Coartações e alforrias nas Minas Gerais do século XVIII: as possibilidades de libertação escrava no principal centro colonial.” Revista de História. São Paulo - USP, n. 133, 1995, pp. 49-57; Marcos Magalhães de Aguiar. "A coartação: uma singularidade mineira no sistema de alforria colonial?"Revista da SBPH, Curitiba, n. 18, 2000, pp.77-91; Carlo G. Monti. O Processo de Alforria: Mariana (1750-1779). Dissertação de Mestrado. São Paulo: Universidade de São Paulo, 2001, pp.126-128; Renata Romualdo Diorio. As marcas da liberdade: trajetórias sociais dos libertos em Mariana na segunda metade do século XVIII. Dissertação de Mestrado. São Paulo: Universidade de São Paulo, 2007, pp.126-158;
} 
(coartação/troca de amo) em Cuba, mas de sua ausência na realidade escravista brasileira, em particular, no Rio de Janeiro, que guardava características socioeconômicas muito correlatas à Havana, com um enorme afluxo de pessoas, mercadorias e escravos, e uma intensa atividade comercial e portuária, toda ela pululada de trabalhadores escravos, que poderiam ter se beneficiado da amortização gradual do valor correspondente à sua liberdade ${ }^{551}$. O termo coartación vem de coartar, que significa limitar, restringir ou não conceder inteiramente algo. O certo é que tal procedimento não resultou de uma intervenção legislativa. Daí pode extrair uma lição fundamental da análise historiográfica, a saber, a inoperância de mecanicismos. Condições semelhantes não acarretam necessariamente as mesmas respostas sociais, econômicas e jurídicas, etc. Há uma gama complexa de fatores envolvidos nos processos de constituição das práticas sociais, que encerram a configuração cultural da sociedade em articulação com sua base material. O primeiro registro oficial do governo sobre a coartação parece ter sido mesmo a real cédula de 21 de junho de 1768, que nada mais fez do que acusar a sua recorrência. Como apurou Alejandro de la Fuente, a coartação já era praticada no sul da Espanha ao menos desde o século XVI. Trata-se, portanto, de uma prática peninsular transplantada para o Novo Mundo hispânico, que ganhou fôlego em função das condições objetivas encontradas em Cuba, sendo cruzado com o recurso de se pedir papel de venda. Mas não é possível saber ao certo. A prática pode ter surgido em Cuba, do mero acaso, tendo sido associada a posteriori às referências espanholas: um belo dia, um amo aceitou parte do valor de seu escravo como o início do pagamento pela manumissão, outros o copiaram e assim foi. Nem sempre existe uma razão profunda, ancestral, para tudo. O importante é notar que coartação, de uma variação da alforria onerosa criou um estado à parte entre o escravo e o livre. Estar coartado significava atingir um patamar intermediário, um meio de caminho entre o cativeiro e a liberdade que podia nunca se completar, mas que abria ao trabalhador escravo um campo de possibilidades diferenciado em relação aos cativos inteiros ${ }^{552}$.

A década de 1830 despontaria no horizonte com Cuba na dianteira absoluta das exportações mundiais de açúcar, com registros importantes nas exportações de outros derivados de cana, como rum e melaço, além de café, tabaco, cobre, madeiras, entre outros. A Espanha reforçaria seus nexos econômicos com a ilha, mantendo-se como importante compradora dos

\footnotetext{
551 Ynaê Lopes dos Santos. Irmãs do Atlântico. Escravidão e espaço urbano no Rio de Janeiro e Havana (17631844). Tese de Doutorado em História Social defendida na Universidade de São Paulo, 2012.

${ }^{552}$ Alan Watson. Slave Law in the Americas. Georgia: The University of Georgia Press, Athens and London, 1989, p. 51; De la Fuente. "Slaves and the Creation of Legal Rights in Cuba: Coartación and Papel", op.cit; Manuel Lucena Salmoral. "El derecho de coartación del esclavo en la América Española". Revista de Indias, v. LIX, n. 216 (1999), pp.357-374; Claudia Varella.Esclavos a sueldo: la coartación cubana en el XIX..., op.cit.
} 
seus produtos em valores brutos, ainda que o primeiro lugar pertencesse aos Estados Unidos. Sem mercado preferencial, os preços do açúcar cubano tiveram sempre que ser mantidos em patamares competitivos, para superar os entraves protecionistas da época. As condições naturais aliadas à crescente mecanização e aos investimentos em infraestrutura permitiriam tal façanha $^{553}$. Na esfera política, a cumplicidade entre as elites locais e as autoridades metropolitanas manteria o seu desenho. Mas o período não deixaria de contar com algumas turbulências. Após a morte de Fernando VII, em setembro 1833, María Cristina, sua esposa, assumiu como regente em nome de sua filha Isabel, que tinha apenas três anos de idade. A tentativa de Carlos de Bourbon, o irmão do rei morto, de chegar ao poder levaria o país à Primeira Guerra Carlista, uma guerra civil que se arrastou de 1833 a 1840. Isto não impediria que a Regência, com clara influência do campo liberal estabelecido em Madri, abrisse caminho, uma vez mais, para o constitucionalismo. Todavia, entre os liberais, havia tanto partidários de um novo retorno ao texto de 1812 e quanto aqueles mais "exaltados", defensores de uma Carta mais "progressista". No entanto, a saída se deu por uma via "moderada", com a formulação do Estatuto Real outorgado em 10 de abril de 1834, um novo texto constitucional bastante enxuto, composto apenas por artigos, que fixou um modelo bicameral no legislativo espanhol e um sistema censitário altamente excludente ${ }^{554}$. A participação eleitoral dos cidadãos ultramarinos foi definida em decreto de 20 de maio, que garantiu o controle das oligarquias locais sobre a eleição dos procuradores a serem escolhidos para as próximas legislaturas ${ }^{555}$.

Os ingleses ofereceram apoio militar para o combate às tropas carlistas. Em contrapartida, arrancaram do novo governo a assinatura de cláusulas de equipamento que tinham por finalidade impor penas mais pesadas, restringindo as chances de retorno dos traficantes ao negócio após a condenação. Estas cláusulas prepararam o terreno para o novo convênio antitráfico ajustado entre o plenipotenciário espanhol Francisco Martínez de la Rosa e o embaixador britânico George Villiers, que foi validado em 28 de junho de $1835^{556}$. Composto por quinze artigos, o novo tratado começava reiterando o compromisso por parte da Espanha de abolir o tráfico de escravos definitivamente. Segundo os termos do tratado, passados dois meses, deveriam ser promulgados a lei penal que impusesse castigos severos a

\footnotetext{
${ }^{553}$ Moreno. Manuel Moreno Fraginals. El ingenio: complejo econômico social cubano del azúcar. Havana: Editorial de Ciencias Sociales, v. 1, 1978, pp.172-173.

554 Tomás y Valiente. Manual de historia del derecho español, pp.442-445.

${ }_{555}$ Berbel, Marquese \& Parron. Escravidão e Política..., p.235; Josep Maria Fradera. Colonias para despues de un império. Barcelona: Edicions Bellaterra, 2005, p.143.

${ }^{556}$ Tratado entre su Magestad la Reina de España y su Magestad el Rey del Reino Unido, de la Gran Bretaña é Irlanda, para la abolición del tráfico de esclavos, concluido y firmado en Madrid en 28 de Junio de 1835. Havana: Imprenta del Gobierno y Capitanía General de S. M., 1853.
} 
todos os súditos que, sob quaisquer circunstâncias, tomassem parte do infame comércio. Berbel, Marquese e Parron aventam a hipótese de que tal previsão tenha sido inspirada na lei brasileira de 7 de novembro de 1831, ensejando punições duras para proprietários, capitães, mestres, pilotos e tripulação dos barcos apresados em virtude das estipulações do tratado ${ }^{557}$. No entanto, a tal lei penal demoraria uma década para ser promulgada.

Voltando ao teor do tratado, importa notar que ele reconheceu, ainda, o direito mútuo de registro e detenção das embarcações suspeitas de participação no tráfico. O anexo A do tratado trazia instruções para as embarcações destinadas a combater o tráfico, discriminado os procedimentos de apreensão e registro, bem como a forma de se conduzirem os cativos presentes nas embarcações apreendidas. As Comissões Mistas em funcionamento continuariam com suas atividades até que fossem instalados Tribunais Mistos de Justiça, formados por um número igual de indivíduos de ambas as nações, nomeados pelos respectivos soberanos. Seguindo a linha já prevista em 1817, um daqueles tribunais seria fixado na África e o outro nas possessões coloniais de Sua Majestade Católica. Os julgamentos deveriam ser sumários e as sentenças não poderiam ser apeladas. $\mathrm{O}$ anexo $\mathrm{B}$ do tratado traria um regulamento, discernindo melhor as atribuições daqueles tribunais, especificando sua composição, a fórmula dos processos, seu financiamento e assim por diante. Eles teriam jurisdição para decidir sobre a legalidade das detenções efetuadas pelos cruzeiros de ambas as nações. Os procedimentos judiciais deveriam ser efetuados o mais sumariamente possível, chegando-se a uma decisão em no máximo 20 dias. Os processos deveriam ser conduzidos da seguinte forma: os juízes e os árbitros nomeados examinariam os papéis da embarcação apreendida. Em seguida, tomariam declarações do capitão ou comandante e de dois ou três indivíduos entre os principais membros da tripulação. Acreditando-se necessário, também seria tomada a declaração do apreensor. Quando houvesse desacordo entre os julgadores, um dos árbitros nomeados seria sorteado para que tomasse a decisão ${ }^{558}$.

Entre 1835 e 1864, seriam incorporados à sociedade cubana cerca de 20 mil emancipados, os quais, somados aos que haviam sido capturados nos anos anteriores, representariam cerca de 4,09\% do número total de escravos introduzidos em Cuba via contrabando $^{559}$. Ainda que relativamente baixo em relação ao cômputo total do tráfico cubano, importa destacar que o número total de emancipados de Cuba (26.026) equivale a mais do que

\footnotetext{
${ }^{557}$ Berbel, Marquese \& Parron. Escravidão e Política..., p. 218.

${ }^{558}$ Lucena Salmoral. "Leyes para esclavos: el ordenamiento jurídico sobre la condición,...”, pp.1216-1244.

${ }^{559}$ Inés Roldán de Montaud. "En los borrosos confines de la libertad: el caso de los negros emancipados en Cuba, 1817-1870”. Revista de Indias, v. LXXI, n. 251 (2011), pp.159-192.
} 
o dobro dos africanos livres postos sob custódia do governo brasileiro. De acordo com Beatriz Mamigonian, entre 1821 e 1856, algo em torno de 11 mil cativos ilegais foi declarados africanos livres no Brasil, que absorveu um número de escravos muito maior ${ }^{560}$. Por esta época, entrou em território brasileiro, entre cativos legais e ilegais, algo em torno de 1.493 .528 pessoas, ou seja, os africanos livres não representam nem sequer $1 \%$ do total. Além disso, o tempo de consignação dos emancipados era bem inferior à dos africanos livres. Enquanto que no Brasil o período de tutela era de 14 anos, o que abrangia o período de maior vigor para o trabalho, em Cuba, variava entre 5 anos (para os adultos) e 7 anos (para menores e mulheres com filhos que não pudessem trabalhar).

Além disso, cabe destacar que o anexo $\mathrm{C}$ do tratado anglo-espanhol continha um Reglamento pra el buen trato de los negros emancipados, editado com o objetivo expresso de assegurar àquelas pessoas "un buen trato permanente, y una entera y completa emancipación, en conformidade com las intenciones benéficas de las Altas partes contratantes". Por ele, o governo espanhol se comprometia assegurar que os negros, uma vez entregues às autoridades em Havana, fossem iniciados nos preceitos da religião cristã, da moral, da civilização, e instruídos de forma suficiente para a realização de ofícios mecânicos a fim de que pudessem se manter por si mesmos. Instruções semelhantes constaram das Instruções de 29 de Outubro de 1834 relativas à arrematação dos serviços dos Africanos livres, despachadas pela secretaria da Justiça, por exemplo, mas com a diferença de que não se tratava de um dispositivo específico para a regulação do tratamento a ser propiciado àquela fração da população. Decerto, é impossível extrair desse quadro um padrão de vida qualitativamente superior dos emancipados em relação aos africanos livres. Como já observado páginas atrás, quando era descrito o primeiro momento das apreensões, a condição material de ambos os grupos era correlata. Como observou Inés Roldan, o sistema de consignação deu margem a incontáveis abusos e a um "autêntico tráfico de emancipados". Os períodos seriam sucessivamente renovados e, a prometida incorporação à sociedade, indefinidamente protelada. A manumissão, reconhecida em diferentes formas pelo direito hispano-cubano, não constituía uma válvula de escape possível aos emancipados, já que legalmente eles não eram escravos. Pela mesma razão, não contavam com a assistência dos síndicos procuradores e tampouco com uma curadoria equivalente à formalizada para os africanos livres no Brasil. Na gestão de Tacón, que coincidiu com o início da vigência do novo tratado, a condição deles sofreria evidente piora. Até então

\footnotetext{
${ }^{560}$ Beatriz Gallotti Mamigonian. "Revisitando a 'transição para o trabalho livre': a experiência dos africanos livres”, in: Manolo Florentino (org.) Tráfico, cativeiro e liberdade: Rio de Janeiro, séculos XVII-XIX. Rio de Janeiro: Civilização Brasileira, 2011, p.
} 
mantidos nas cidades, eles passaram a ser enviados para as zonas de plantação. A situação seria denunciada algum tempo depois por David Turnbull, notável articulador antiescravista, a grande pedra no sapato da classe senhorial cubana, nomeado Superintendente Geral dos Emancipados ${ }^{561}$. De tudo isso, é possível concluir que: a) sem colocar em risco o contrabando, a repressão ao tráfico foi um pouco mais funcional em Cuba do que no Brasil, o que pode ter contribuído para a amortização relativa da pressão britânica (aliado a fatores mais decisivos como o anteparo propiciado pelo Sul escravista norte-americano); b) que, ao menos em termos formais, o estado espanhol interveio um pouco mais em relação à situação dos cativos ilegalmente traficados. Desse modo, a política adotada em relação aos emancipados foi impecavelmente adequada ao modo hispano-cubano de gestão das relações sociais do mundo da escravidão, que tinha um caráter tradicionalmente intervencionista, ainda que com alguns limites importantes ${ }^{562}$.

Na década de 1830, o quadro jurídico relativo às possibilidades de transição para a liberdade permaneceu inalterado. Em termos legais, o direito à alforria continuou garantido aos escravos o seu valor integral, assim como a coartação, e a troca de amo permaneceram no campo de discricionariedade dos senhores. Esgotando-se as chances de acordo em âmbito doméstico, procurar o síndico e abrir um processo judicial surgia como uma chance de convencer os amos a "largarem o osso". Nem sempre funcionava. Em dezembro de 1834, o Caballero síndico general, Francisco del Clavo, manifestou-se em juízo em nome do escravo José Emilio de la Peña contra sua senhora, D. Felipa Alcázar. Segundo o libelo, José Emilio estava coartado em 500 pesos e era casado com uma morena livre, com quem tinha quatro filhos, os quais sustentavam com os pesos que ganhava com seu trabalho, à parte dos jornais que entregava à sua senhora. Entretanto, havia alguns meses que sua ama estava se apoderando de todo o dinheiro que ele ganhava. Ainda conforme o relato, José Emilio era escravo de D. Felipa havia seis anos. Neste tempo todo, sua senhora não teve nenhum motivo para queixar-se dele. Além de satisfazer pontualmente os jornais estabelecidos, vestia-se e alimentava-se por conta própria, além de cuidar do sustento de sua família e da educação dos seus quatro filhos ${ }^{563}$.

O cerne da demanda repousava na alegação de que o influente Rafael O'Farrill havia feito a José Emilio uma oferta de compra pela soma de 500 pesos pelos quais estava coartado,

\footnotetext{
${ }^{561}$ Inés Roldán de Montaud. "En los borrosos confines de la libertad...", pp.170-171; Robert L. Paquette. Sugar is made with blood. The conspiracy of La Escalera and the conflicto between Empires over slavery in Cuba. Middletown: Wesleyan University Press, 1988, p.135.

${ }^{562}$ Silva Júnior. História, direito e escravidão..., pp.35-66.

${ }^{563}$ Diligencias promovidas por el caballero síndico general a nombre de José Emilio de la Peña contra su ama d. Felipa Alcázar, 1836, ANC, Escribanías (Vergel), leg. 13, exp. 15.
} 
prometendo alimentá-lo, cuidar de seus filhos e outorgar-lhe a liberdade dentro de pouco tempo, caso o seu comportamento continuasse irrepreensível. Contudo, D. Felipa estaria se negando a consentir na alienação de seu escravo, furtando-se mesmo a comparecer ao escritório do síndico para uma tentativa de acerto extrajudicial para que fossem evitados os gastos e os aborrecimentos que acarretavam os procedimentos escritos. O síndico arrematou afirmando considerar justíssima “la reclamación hecha por José Emilio y no lo ha vacilado un instante en protegerla y patrocinarla toda a la vez que media un promesa acerca de la preciosa libertad. Aun cuando no se trate de libertad, siempre es justa la solicitud del siervo puesto que mejora visiblemente su condición" ${ }^{564}$. Por tudo mencionado, o defensor requereu que D. Felipa fosse intimada a comparecer em juízo no prazo de 48 horas para realizar a venda de seu escravo ao senhor proponente.

D. Felipa conseguiu protelar as diligências e obteve de D. Rafael O'Farrill um documento que desmentia as alegações de José Emilio. Em 20 de janeiro, ela escreveu ao influente hacendado perguntando se era certa a versão de que ele havia feito a tal oferta de compra por 500 pesos conjugada à promessa de liberdade dentro de pouco tempo. No dia seguinte, O'Farrill respondeu afirmando que conhecia José Emilio, que já havia utilizado seus serviços algumas vezes, que cogitou, sim, comprá-lo, mas negou categoricamente haver-lhe feito qualquer promessa de liberdade. Isto foi suficiente para convencer o alcalde ordinario, quem em 20 de outubro de 1835 deu ganho de causa à senhora, condenando José Emílio nas custas processuais. Uma vez mais, é possível extrair elementos diversos da realidade escravista a partir de uma narrativa como esta, em especial sobre a inserção dos coartados no interior da economia havanesa e a constituição de laços familiares. Numa situação semelhante à vivenciada por Bernardo, referida páginas atrás, José Emilio não apenas constituiu uma família fora do cativeiro, como também encontrou meios para sustentá-la em parceria com sua esposa livre, que tinha uma margem de ação obviamente maior do que a dele. Outro ponto digno de nota é a intermediação prévia dos conflitos realizada pelos síndicos. A proposta de acerto extrajudicial com D. Felipa fracassou, mas não é difícil presumir a existência de casos nos quais senhores e escravos entravam em acordo na presença daquele funcionário, tornando desnecessária a ação judicial. Por fim, cabe realçar o teor da afirmação final do defensor. Está claro ali que, apesar da alforria ser o fim último, muitas vezes tratava-se de obter alguma melhoria na condição de vida. José Emilio, desafortunadamente, fracassou. Talvez, se D. Rafael O'Farrill, considerando sua posição social, tivesse mantido sua proposta e pressionado D. Felipa para vender-lhe o

564 Idem. 
escravo, o resultado seria outro. Ainda assim, a expressão da vontade da proprietária teria que ser de algum modo circunstanciado.

As chances continuavam maiores para os escravos que dispunham da quantia integral para o resgate de sua liberdade. Em janeiro de 1836, o pardo Rafael Paterson iniciou uma ação judicial requerendo a outorga de sua carta de ahorro. Quem procurou o síndico foi seu irmão, Agustin Ullman, queixando-se de que D. Lorenzo Covarrubias, marido de D. Leocadia Paterson, a verdadeira senhora dele, recusava-se a receber 450 pesos em troca da liberdade, "que se parecía excesiva en consideración a que Rafael no tiene optimo oficio que servir a la mano". Também aqui, o síndico tentou um acordo amigável antes de iniciar o processo, mas não possível. Sendo assim, solicitou o depósito de Rafael junto à "persona de abono" e que o corrector mayor de lonja, perito normalmente designado para a tasación dos escravos, procedesse a sua avaliação, levando em considerando que se tratava de uma demanda pela liberdade e não de uma negociação de venda. O juiz atendeu a ambas as reivindicações. Rafael foi depositado na casa de D. Alejandro de Frías e, no dia 02 de maio, o corrector, D. Ramón de Mano y Vega, procedeu a seguinte avaliação: “Que por ser sano y sin tachas, criollo de Charleston, como de 24 años, cabrero y repostero, y teniendo presente que se hace por su libertad y la carestía actual de esclavos, lo taza en cuatrocientos cincuenta y nueve pesos "565. Como é possível notar, quatro aspectos fundamentais concorrem para o resultado da avaliação: a ausência de marcas desabonadoras, a procedência, as habilidades profissionais e o destaque para os tempos de carestia. Não se tratava de um criollo cubano, mas de alguém vindo dos Estados Unidos, com uma carga cultural diferenciada, que não tinha marcas na pele que o identificasse como cimarrón ou prófugo, dotado de habilidades específicas, valorizadas tanto para a lida do campo, por se tratar de um pastor de ovelhas, quanto para o serviço doméstico e o setor de serviços do espaço urbano, já que sabia preparar doces e massas. Tudo isto, aliado à sua idade, concorria para a fixação do preço. Sobre a questão da carestia, ao que parece, travase mais de um argumento retórico para justificar a taxação. Não há indícios sobre um movimento inflacionário à época. Segundo Bergard, Iglesias \& Barcia, entre 1835 e 1850, o preço médio de mercado de um escravo em idade ativa girava em tono dos 400 pesos $^{566}$.

\footnotetext{
${ }^{565}$ El Síndico Procurador General en representación del pardo Rafael Paterson para que se otorgue carta de ahorro por d. Lorenzo Covarrubias, 1837, ANC, Escribanías (Daumy), leg. 661, exp. 9. Sobre as articulações entre os portos de Charleston e Havana, cf.: Leonardo Marques.The United States and the Transatlantic Slave Trade to the Americas, 1776-1867. Tese de Doutorado, Emory University, 2013, pp.35-69; Idem. "Slave Trading in a New World: The Strategies of North American Slave Traders in the Age of Abolition". Journal of the Early Republic, 32 (Summer 2012), pp.233-260.

${ }^{566}$ Bergard, Iglesias \& Barcia. The Cuban Slave Market, 1790-1880. Cambridge: Cambridge University Press, 1995, p.69.
} 
No entanto, Covarrubias não se satisfez com aquele preço. O perito por ele nomeado chegou ao valor de 550 pesos. Em função do desacordo, o tribunal, como de praxe, indicou um terceiro avaliador, que chegou à quantia intermediária de 500 pesos. O amo, então, consentiu:

\begin{abstract}
"Los quinientos pesos en que ha avaluado al pardo Rafael son en las actuales circunstancias de la plaza muy inferiores al mérito que prestan las cualidades de ese siervo, pero como mi animo no es otro que el de concluir este negocio por si demasiado largo, convengo en que se aprueba dicha tasación, esperando que el tribunal así lo haga sin admitir rebaja alguna en consideración al prejuicio que se me infiere con obligarme a deshacerme de en esclavo, que para reemplazar lo necesitaré en el día desembolsar setecientos o mil pesos. A V.S. suplico se sirva, habiendo por satisfecho el traslado, y a mi por conforme con la tasación corriente a f.17 vuelva, aprobarla en todas sus partes, mandando en consecuencia que se extienda a Rafael Paterson la carta de libertad que lo solicita, previo el deposito en la venia de los quinientos pesos, pues así es de justicia que pido" ${ }^{\circ 67}$.
\end{abstract}

Como se pode observar, à semelhança do que ocorria no Brasil, D. Leocádia, a senhora de Rafael não pôde tomar voz ativa na resolução em decorrência as limitações impostas sobre sua capacidade jurídica pelo caráter patriarcal do direito vigente. Covarrubias, o marido, exagerando sua boa vontade (visto que a alforria onerosa em tais circunstâncias era um direito do escravo) e o prejuízo do ato (já que os 500 pesos eram, sim, suficientes para a compra de um novo escravo), aceitou promover a libertação pelo valor acordado. Em 29 de abril de 1836, o juiz determinou a outorga da carta de liberdade mediante a exibição dos quinhentos pesos e assim se cumpriu 568 .

Assim como no Brasil, não havia lei impondo o registro da carta de liberdade em instrumento cartorial, mas isto se tornou procedimento ordinário, especialmente quando havia decisão judicial ${ }^{569}$. Havia casos em que o senhor afirmava concordar em ceder a liberdade, mas o processo se arrastava porque ele não se preocupava em realizar o registro perante o escrivão. Em 16 de agosto de 1837, um amo chamado D. Blas Lucas de Ozequeza manifestou-se em juízo afirmando o seguinte:

\footnotetext{
"tengo por mi esclavo un negro nombrado Patricio de nación Carabalí como de cuarenta años de edad, el mismo que hubo de d. Mariano José Ozegueza por escritura ante d. José Ignacio Salina y por cuanto me ha pedido le otorgue carta de libertad, ofreciéndome por ella 300 pesos en que se halla cuartado, y conociendo la fidelidad amor y buen servicio, con que siempre me ha servido: vengo en formársela por solo ciento cincuenta pesos, que de mano del siervo he recibido en reales de contado moneda corriente, lo que por tenerlos en mi poder de ellos me doy por entregados a mi satisfacción ... de que otorgo formal recibo y mediante lo cual me aparto del derecho de propiedad, posesión útil y señorio que a dicho negro había y tenia" 570 .
}

\footnotetext{
${ }^{567}$ El Síndico Procurador General en representación del pardo Rafael Paterson..., op.cit.

${ }^{569}$ Cf. Michael Zeuske\& Orlando García Martínez. "Estado, notarios y esclavos en Cuba". Nuevo Mundo Mundos Nuevos [online], Débats, mis en ligne le 22 avril 2008, consulté le 22 mars 2015. URL : http://nuevomundo.revues.org/15842 ; DOI : 10.4000/nuevomundo.15842

570 1839, ANC, Escribanías (Barreto), leg. 145, exp. 15.
} 
Nesse discurso é possível observar com clareza a economia do dom universalmente impingida na concessão da alforria, com a marcação da situação hierárquica e da benevolência do ato (tendo aceitado metade do valor coartado), assim como a associação, não menos universal e hipócrita, da libertação com o bom comportamento e o serviço dedicado ${ }^{571}$. No entanto, isto não serviu como garantia da liberdade. Após muita insistência do síndico, a carta de ahorro seria lavrada em janeiro de 1840, com a subscrição do tribunal.

Mantendo a argumentação sobre este mesmo tópico, vale à pena pontuar que até este momento da história, isto é, as viradas da década de 1830 observaram uma articulação entre direito e escravidão sendo delineada de forma tributária, mas já sensivelmente distinta em relação ao período anterior à ocupação de Havana pelos ingleses, quando imperava integralmente a lógica do direito comum nacionalizada por intermédio das Siete Partidas. Os preceitos antigos continuaram em vigor, mas houve uma modificação importante em relação à troca simbólica que envolvia a consumação da manumissão. Como observou Orlando Patterson, a alforria pode ser enquadrada na teoria da troca de bens ou dons, segundo a qual os rituais de redenção nas mais diferentes sociedades escravistas, ainda que condicionada a compensações diversas, impunha uma dívida de gratidão permanente entre liberto e patrono. Esta relação Patterson alcunhou wala, termo árabe para designar um laço de clientela com uma qualidade diferenciada de obrigatoriedade, esperando-se "que o liberto seja grato pela generosidade do senhor em libertá-lo", não importando "o quanto ele tenha pagado por isto, o que era uma decorrência natural da concepção universal da manumissão como um presente do senhor" 572 . Esta conceituação tem, de fato, um alcance generalizante, encaixando-se com perfeição em diferentes sociedades com escravos ou escravistas, inclusive a brasileira. Porém, ela deixa escapar a tonalidade específica do quadro jurídico constituído no âmbito do escravismo oitocentista cubano. O senhor que assinava a carta de liberdade para o escravo que apresentasse o seu valor, mesmo que exprimisse no documento toda a cantilena da ritualística que envolvia a doação usual da alforria, não estava dando efeito a uma prerrogativa sua. Tratava-se já de algo fora de sua discricionariedade. Era um direito do escravo. Uma conquista legalmente reconhecida, que não acarretava per se imposição de reciprocidade. Inclusive, é possível tencionar o próprio conceito de manumissão para aquela situação, já que representa,

\footnotetext{
${ }^{571}$ Marcel Mauss. Ensaio sobre a dádiva. São Paulo: Cosac \& Naify, 2003; Orlando Patterson.Escravidão e morte social - Um estudo comparativo (trad.port.). São Paulo: Edusp, 2008, pp.301-339; Márcio de Sousa Soares. A Remissão do Cativeiro. A dádiva da alforria e o governo dos escravos nos Campos dos Goitacases, c.1750-c.1830. Rio de Janeiro: Apicuri, 2009, pp.152-155; Silva Júnior. História, direito e escravidão..., pp.77-112.

572 Patterson.Escravidão e morte social..., p.342.
} 
etimologicamente, a ideia de dispensar, largar, soltar por força da própria vontade, pelo comando da própria mão. Ora, a alforria onerosa cubana tinha deixado de ser algo assim quando foi convertida em um direito legal do escravo. É impossível sustentar que liberações como as obtidas por Rafael Paterson, por exemplo, engendrassem um tipo de vínculo de molde wala (ironicamente, temos aqui um Paterson desmentindo o outro). Decerto, não é possível tirar conclusões demasiadamente otimistas desta constatação. Primeiro, porque continuaram existindo os laços tradicionais de clientela em decorrência das alforrias graciosas em geral, as consumadas no ato do batismo, por testamentos e mesmo pelas coartações, como evidenciado pela ação reproduzida no parágrafo anterior. Segundo porque, como já sugerido anteriormente, a redução do alcance do poder senhorial a respeito da liberdade de seus escravos não foi capaz de pôr em risco o sistema, nem do ponto da sujeição das massas escravizadas à disciplina laboral, nem do ponto de vista da reprodução sistêmica do regime. Se os laços pós-cativeiro eram restringidos juntamente com o controle da alforria onerosa, continuavam existindo cativos empenhados ao trabalho fossem pela coerção moral e física, fosse pela ambição de um dia atingirem a liberdade.

Decerto, a manutenção desse quadro não dependia apenas da dinâmica local envolvendo a pressão exercida pelos escravos em uma busca incessante pela melhoria de suas condições e pela presença de uma população negra livre a níveis tão importantes que inviabilizaria qualquer recuo no sistema legislativo, para lembrar do esquema explicativo de De la Fuente \& Gross ${ }^{573}$. Essa mobilização social da população negra era muito importante, mas ela se inseria em conjuntura mais ampla que envolvia necessariamente o estatuto político da ilha e sua inserção no império espanhol (no que restava dele). Em agosto de 1836, ocorreu na Espanha uma nova sublevação militar conhecida como Motín de los Sargentos de La Granja, levada a efeito pelo regimento da Guarda Real do Palácio de La Granja, em Segóvia. O resultado foi a revogação do Estatuto Real e o restabelecimento a ordem constitucional de 1812, resgatando a perspectiva de igualdade estatutária entre os espanhóis de ambos os hemisférios. Nova convocatória para a eleição de deputados foi realizada, mas Miguel Tacón, contrário à ascensão política dos criollos, fez de tudo para obstar a vigência da Constituição na ilha. O seu aviso foi enérgico: mil forcas seriam erguidas para pender os pescoços dos que ousassem jurar a Carta de Cádiz ${ }^{574}$.

Porém, Manuel Lorenzo, governador de Santiago de Cuba, afrontou destemidamente a autoridade do capitão general, procedendo ao juramento do texto constitucional e afirmando

\footnotetext{
573 De la Fuente \& Gross. "Slaves, Free Blacks, and Race in the Legal Regimes...", op.cit.

${ }^{574}$ Olga Portuondo Zúñiga. Cuba: Constitución y liberalismo (1808-1841). Santiago de Cuba: Editorial Oriente, 2008, pp.47-48.
} 
não respeitar outra autoridade que não a da Rainha Governadora. Em pronunciamento, acrescentou: "el porvenir dirá de parte de quien, en tan penoso como excusable conflito, se hallan la razón y la justicia, la conveniencia y la legalidad, la lealtad y el patriotismo"575. $\mathrm{O}$ capitão general reagiu, mobilizando as forças militares disponíveis por terra e decretando o bloqueio naval de Santiago por dois navios de guerra. Estes acontecimentos, evidentemente, chegaram ao conhecimento das Cortes. Porém, nada foi feito para socorrer aquele que defendia as ações do novo governo. Era Tacón, não Lorenzo, quem melhor representava os interesses madrilenos: urgia manter o controle sobre a sua galinha dos ovos de ouro. A nova onda constitucionalista e a instabilidade gerada pelos acontecimentos no departamento oriental, de onde partiam rumores de uma possível abolição da escravidão, poderiam demover a sacarocracia ocidental de sua fidelidade à Coroa espanhola. Os principais partidos da metrópole foram convencidos de que a melhor saída era separar as colônias do regime político espanhol ${ }^{576}$. "La isla de Cuba, digo que si no es española, es negra, necesariamente negra, y eso nadie ignora" ${ }^{\circ 77}$, assim falou o deputado progressista Vicente Sancho, que persuadiu seus pares de que às províncias ultramarinas não cabia representação parlamentar, e que o seu governo deveria se dar mediante um regime de Leis Especiais adequadas às suas especificidades populacionais, à existência da escravidão e conservadoras de suas amarras em relação à metrópole ${ }^{578}$. Assim, ao invés do ordenamento jurídico formatado nos limites da ordem constitucional espanhola, as províncias do Ultramar hispânico seriam regidas por uma legislação especial. As Cortes aprovaram quase por unanimidade essa proposta, tratando também de excluir, com uma margem menor, é verdade, os deputados eleitos por Cuba e Porto Rico $^{579}$. A implicação concreta dessa decisão para Cuba não foi à promulgação de uma nova séria legislativa, mas a blindagem do modo particular, localmente sedimentado, de regulação das relações sociais e escravistas, submetida à poderosa autoridade militar local constituída em nome do Executivo espanhol e ainda dotada de faculdades onímodas, cuja limitação formal seria dada basicamente pelas imposições pertinentes aos tratados internacionais. Como se sabe, uma parcela da elite criolla, capitaneada por José Antonio Saco, que estava entre os deputados cubanos impedidos de assumirem seus postos, ficou contra este arranjo, defendendo a equiparação da cidadania e a integração das diversas partes da nação espanhola, numa espécie

\footnotetext{
575 Idem, ibídem.

${ }^{576}$ Leví Marrero. Cuba: sociedad y economia. Azucar, Ilustración y Conciencia. (1763-1868). Madri: Editorial Playor, 1984, p.135.

577 Apud Manuel Chust (ed.). Las independencias iberoamericanas en su laberinto. Controversias, cuestiones, interpretaciones. Valencia: Universitat de Valéncia, p.144.

${ }^{578}$ Berbel, Marquese \& Parron. Escravidão e Política..., p.239.

${ }^{579}$ Piqueras. Sociedad civil y poder en Cuba, p.84.
} 
de refundação da tradição castelhana integracionista. Mas a política prevalente foi a aquela que articulou a anulação dos direitos políticos da população negra, o resguardo de um estatuto colonial autonomista com relação ao sistema de escravidão e a manutenção de um quadro jurídico relativamente intervencionista e abrangente. Tudo isso regado a muita violência física e psicológica, é evidente ${ }^{580}$.

\section{Turnbull, Resistência Escrava e o Reglamento de 1842}

Não obstante o cenário favorável construído nos anos anteriores, a década de 1840 despontaria ruidosa para o escravismo cubano, com a intensificação das articulações diplomáticas e das investidas navais da Grã-Bretanha contra o tráfico, a presença barulhenta do abolicionista David Turnbull em Havana, designado cônsul e superintendente-geral dos emancipados, e a nomeação feita pelo novo presidente do Consejo de Ministros, Baldomero Espartero, de Jerónimo Valdés para o posto de capitão general, indivíduo mais propenso a combater o contrabando como nenhum outro de seus congêneres. O antecessor de Turnbull, Richard Madden, tinha preparado o terreno para a sua atuação, aproximando-se dos hacendados avessos ao arranjo de 1837 e propensos a municiar os britânicos de informações sobre o contrabando. Domingo Del Monte era um daqueles indivíduos e foi persuadido por Madden a responder um extenso questionário sobre aspectos diversos envolvendo o comércio ilegal de escravos, como as taxas de lucro, a logística empregada e a atuação das autoridades locais. Em suas respostas, Del Monte não se furtou a implicar diretamente o governo espanhol e os capitães generais, nomeadamente Tacón, na conservação do odioso comércio, o que incluía uma vantajosa rede de corrupção. Este relato integrou o material enviado a World Antislavery Convention, em junho de 1840, e a subsequente publicação destinada a informar o público britânico sobre os horrores da escravidão em diferentes partes do Mundo. O novo alento ao abolicionismo britânico, do qual Turnbull participava de maneira ativa, afetaria diretamente as atividades cubanas ${ }^{581}$

Desembarcando em novembro de 1840, o novo cônsul e superintendente daria prosseguimento à sua cruzada pessoal contra o tráfico e a escravidão no Caribe. Não era a sua

\footnotetext{
${ }^{580}$ Idem, pp.251-252.

${ }^{581}$ Murray. Odious Commerce..., pp.131-132; Berbel, Marquese \& Parron. Escravidão e Política..., pp.263-264; Interrogatorio de Mr. R. R. Madden, absuelto por mim en 17 de septiembre de 1839, por Domingo del Monte. In: José Antonio Saco. Historia de la esclavitud de la raza africana en el nuevo mundo y en especial en los paises americo-hispanos. Habana: Editorial Alfa, 1944, vol. V, pp. 367-374.
} 
primeira estada em Cuba. Entre 1838 e 1839 ele havia percorrido toda a ilha colhendo informações para a escritura do seu livro Travels in the West, no qual propôs expandir o poder dos Tribunais Mistos, incluindo investigações sobre escravos ilegais residentes na ilha, implicando criminalmente compradores e possuidores. Depois de apresentar pessoalmente este seu programa de combate ao tráfico lord Palmerston, foi que obteve suas nomeações. Agora investido de autoridade, Turnbull, agindo de forma concomitante às novas investidas diplomáticas inglesas sobre Madri, buscaria, primeiro, refrear as introduções fraudulentas de africanos, segundo, remediar a situação dos emancipados, perscrutando a situação de africanos ilegais com direito à liberdade. Além disso, extrapolando suas funções, fomentaria aos máximos comitês favoráveis à independência e à abolição. A ingerência estrangeira achacou as elites locais, que formalizaram protestos por meio de órgãos como a Junta de Fomento e o Tribunal de Comércio. A saída pela anexação aos Estados Unidos ganhava eco e a supressão do contrabando surgia como um mal menor a ser abraçado diante da ameaça real sobre a ordem escravocrata $^{582}$.

Nos primeiros dias de janeiro de 1842, Valdés recebeu orientações da metrópole para que começasse a preparar a emancipação dos escravos importados depois de 1820. Apesar de sua predisposição em por em prática os termos do tratado de 1835 , o governador sabia que os efeitos daquela ordem podiam ser desastrosos para a integridade do pacto colonial, por isso se esquivou de sua execução, escrevendo à Madri, solicitando a saída imediata de Turnbull de Cuba por conta do alvoroço provocado por suas ações. A determinação madrilena era fruto das pressões coordenadas por Palmerston, que as reforçou enviando a Cuba uma esquadrilha de guerra composta por um grande navio de linha e três embarcações menores. O comandante da expedição, o vice-almirante Parker, comandante das forças navais britânicas no Caribe, levava consigo instruções claras do governo londrino para que entrasse em acordo com o capitão general de Cuba sobre os meios de realizar uma pesquisa geral sobre os cativos provenientes do tráfico ilegal. Valdés se pôs, então, a persuadir o emissário sobre o impacto desastroso que tal procedimento causaria. O que salvou a escravidão cubana foi primeiro, a existência de fortes interesses comerciais britânicos na ilha. A instabilidade gerada por uma política tão ostensiva não estava causando prejuízos somente aos cubanos. Segundo, em agosto de 1841, tinha havido uma recomposição no Parlamento londrino. Lord Peel assumiu a chefia do governo no lugar de Melbourne. Com isso, o agressivo Palmerston foi sacado da pasta das relações exteriores,

${ }^{582}$ Berbel, Marquese \& Parron. Escravidão e Política..., p.260-303; Paquette. Sugar is Made with Blood, p.136. 
cedendo lugar a nosso velho conhecido, lord Aberdeen, que adotou uma postura um pouco mais $\operatorname{moderada}^{583}$.

Turnbull se enfraqueceu politicamente, perdeu o cargo de cônsul, foi expulso da Sociedade Econômica e teve a vida ameaçada, sendo obrigado a se refugiar em um barco inglês. O abolicionista faria uma última abordagem, elaborando um projeto para a extinção da dominação espanhola e da escravidão, com uma perspectiva unionista entre brancos e negros. Segundo seus termos, todos os criollos dispostos a cooperar se uniriam aos negros que já se encontravam prontos e com energia para proclamar a independência da ilha; seria publicado um proclama no qual seriam expostas as causas pelas quais a ilha se separava da Espanha, declarando-se traidor contra a independência do seu país todo homem livre, branco ou negro, que não se alistasse; todo escravo criollo que se apresentasse voluntariamente para tomar as armas pela independência poderia fazê-lo; todo escravo que levantasse armas contra os seus senhores seria considerado culpado de alta traição e castigado; imediatamente seria procedida a completa emancipação de todos os escravos, assegurando-se-lhes a liberdade, sem comprometer a segurança dos seus amos. Turnbull foi à Jamaica para tentar obter apoio da população negra mais influente e o auxílio das autoridades inglesas. Em seguida, foi a Santiago de Cuba, Manzanillo, Trinidad e Cienfuegos com o objetivo de encontrar adeptos para o seu plano. Estas ações chegaram aos ouvidos de Valdés, que tratou de informar o governo na Espanha, ditando medidas preventivas. Os planos de conspiração alarmaram as elites coloniais, inclusive aqueles que se colocavam contra o tráfico. No final, Turnbull não obteve o suporte necessário nem entre cubanos, nem entre britânicos. Em novembro, foi desligado de suas funções e foi obrigado a se retirar da ilha ${ }^{584}$.

Como sabemos isto não significou um abandono da política antitráfico. O que houve foi uma mudança no tom. $\mathrm{O}$ ataque direto sobre a propriedade escrava seria abortado, mas o contrabando continuaria na alça de mira dos cruzeiros ingleses. Valdés viu-se impelido a arregaçar as mangas e fechar as forneiras do comércio negreiro. Logo em 1842 houve uma redução expressiva no ingresso de cativos na ilha, observando-se uma queda de aproximadamente $66 \%$ em relação ao ano anterior ${ }^{585}$. Ao mesmo tempo, o capitão general tratou de elaborar um novo regulamento a fim de assegurar os meios para a conservação da escravidão, já que ela não devia ser perpetuada pelo tráfico ${ }^{586}$. Ele, então, enviou uma carta

\footnotetext{
583 Guerra y Sánchez. Manual de Historia de Cuba..., p.423.

${ }^{584}$ Guerra y Sánchez. Manual de Historia de Cuba..., pp.427-434.

${ }^{585}$ Disponível em: <www.slavevoyages.com>. Acessado em 10 de jun. 2014.

${ }^{586}$ Antonio Bachiller y Morales. Los negros. Barcelona: Gorgas y Compañía, 1887, p.71.
} 
circular aos hacendados locais para colher opiniões a respeito da melhor maneira de propiciar condições de vida compatíveis com a reprodução interna dos escravos. Entre os proprietários consultados estavam o marquês de Arcos, o conde de Fernadina, D. Domingo Aldama, D. Wenceslao de Villa Urrutia e D. Rafael O’Farril, já mencionado aqui. As perguntas abordaram a conveniência de se dar uma ração crua, como de costume, ou algo cozido em horas determinadas; a quantidade e o tipo de alimentos a serem administrados, e de roupas a serem fornecidas; a amplitude da jornada de trabalho; o modo mais conveniente para a regularização dos costumes da moralidade dos casados; se fizer as famílias viverem em bohíos separados trazia alguma inconveniência aos donos; o sistema de enfermaria mais adequado e os procedimentos a serem tomados com relação às grávidas e lactantes; se era adequado o sistema geralmente seguido de proporcionar aos escravos um pedaço de terreno chamado conuco para que produzissem suas pequenas roças e criações $^{587}$. Como destacou Lucena Salmoral, a principal referência utilizada por Valdés e seus assessores para a formulação do novo texto normativo seria o Reglamento sobre la educación, trato y ocupaciones que deben dar a sus esclavos los dueños mayordomos de esta Isla de Puerto Rico, de 12 de agosto de 1826, que, por sua vez, teve como referência a Instrucción de $1789^{588}$.

Há realmente uma coincidência entre o regulamento porto-riquenho e a normativa Setecentista, especialmente quanto a regras sobre alimentação e vestuário, instrução, diversões, matrimônio, as obrigações dos escravos e penas corretivas e as normas contrárias a maus-tratos, o que, aliás, remontava o teor das ordenanzas de negros, comumente editadas no universo hispano-americano desde o século $\mathrm{XVI}^{589}$. Porém, é possível observar no documento preparado pelo jurista Marcos Santaella, por ordem do capitão general Miguel de La Torre, um salto considerável em relação à disposição metropolitana e a outras ordenenzas de cunho semelhante editadas no império espanhol, especialmente com relação à regulação de aspectos em torno da coartação e da alforria plena dos escravos. Esses avanços seriam incorporados, com acréscimos, vale destacar, no texto editado em solo cubano.

Com alguns protestos por parte dos proprietários, em 14 de novembro de 1842 foi publicado o Reglamento de esclavos, como anexo do Bando de Gobernación y Polícia de la isla de Cuba. Composta por 48 artigos, esta extensa normativa impôs a obrigatoriedade da instrução católica dos escravos (artigos $1^{\circ}-5^{\circ}$ ); estabeleceu que os amos dessem a seus escravos dois ou três refeições ao dia, como melhor lhes aprouvesse, contanto que fossem suficientes

\footnotetext{
587 Tardieu. “Morir o dominar” ..., pp.206-208.

${ }^{588}$ Lucena Salmoral. "Leyes para esclavos: el ordenamiento jurídico sobre la condición,...”, p.295.

${ }^{589}$ Silva Júnior. História, direito e escravidão.
} 
para o seu sustento (art. $6^{\circ}$ ) e que forneceriam peças roupas básicas duas vezes ao ano, uma em dezembro, outra em maio $\left(\operatorname{art.} 7^{\circ}\right.$ ); ditou cuidados especiais os recém nascidos e as crianças pequenas. Aqueles cujas mães fossem aos trabalhos das fincas, seriam alimentados com sopas, mingaus, leite ou coisas semelhantes, até que saíssem da amamentação, permanecendo, todos, em uma casa ou quarto específico para este fim, que todos os ingenios e cafetales deveriam dispor (arts. $8^{\circ}-11^{\circ}$ ); regulou a jornada de trabalho, prescrevendo que, em tempos ordinários, os escravos trabalhariam não mais que 9 ou 10 horas diárias. Nos ingenios, na época de safra, a carga poderia chegar a 16 horas de trabalho, repartidas de modo que fossem proporcionados dois momentos de descanso durante o dia e outro pela noite, para o sono (art.12 ${ }^{\circ}$; nos domingos e dias de festa, em suas horas de descanso, deveria ser permitido que os escravos se empenhassem dentro da finca em manufaturas e ocupações voltadas ao seu benefício pessoal para que adquirissem pecúlio que lhes proporcionasse meios para a compra de sua liberdade $\left(\operatorname{art.13^{\circ }}\right.$ ); os escravos homens menores de 17 e maiores de 60 anos não poderiam ser colocados para a realização de trabalho pesado, tampouco seria permitido empregar as mulheres em trabalhos não conformes a seu gênero, idade, forças e robustez (art.14).

Medidas de segurança foram prescritas. Os instrumentos de trabalho deveriam ser bem guardados e controlados para que não fossem utilizados como armas. Os escravos de uma finca não poderiam visitar os de outra sem o consentimento expresso dos amos ou mayordomos de ambas; quando tivessem que sair da sua finca, que levassem licença escrita contendo dados do escravo, data, destino e motivação. Todo indivíduo de qualquer classe, cor ou condição estaria autorizado a apreender um escravo que se encontrasse fora dos domínios de seu amo sem licença. Com exceção dos hacendados, que o fariam por força de serviço recíproco, os apreensores seriam remunerados pelas capturas (arts. $16^{\circ}-22^{\circ}$ ). A diversão também foi regulada. O divertimento moderado em dias festivos seria permitido, mas somente após haverem cumprido com as práticas religiosas. As festividades deveriam acontecer entre escravos de uma mesma finca, sem saídas ou acolhida de homens livres de cor de outros lugares e sem excesso de bebida alcoólica (arts. $23^{\circ}$ e $24^{\circ}$ ); os moldes da moradia escrava foram discriminados, definindo-se um padrão para o sistema de barracones, que deveriam ter separação entre os sexos, boa ventilação e uma ala exclusiva para doentes. Tudo muito bem trancado à chave, claro (arts. 25-28); para evitar "tratos ilícitos", os donos deveriam fomentar matrimônios, mesmo entre escravos de donos diferentes, propiciando-se aos casais reunião sob um mesmo teto. Quando o casal pertencesse a senhores distintos, a mulher deveria, preferencialmente, seguir o marido, tratando seu senhor da compra por um preço acomodado ou, em caso de divergência, mediante avaliação judicial (arts. $29^{\circ}-31^{\circ}$ ). 
Obrigações e penalidades também foram discriminadas. Por sua condição, os escravos estavam forçados a obedecer e respeitar seus donos, mayordomos e mayorales e demais superiores "como a padres", e a desempenhar integramente suas tarefas e obrigações. Caso contrário, não só poderiam como deveriam ser castigados correcionalmente, segundo a gravidade da infração, com "prisión, grillete, cadena, maza o cepo, donde se le pondrá por los piés, y nunca de cabeza" ou com até 25 chibatadas. Apenas os senhores ou pessoas por eles autorizadas poderiam castigar correcionalmente os escravos. Para os delitos de maior gravidade, caberia ao judiciário estabelecer punições mais severas, com acompanhamento do Síndico Procurador, na qualidade de protetor dos escravos. Aqueles que se excedessem na aplicação dos castigos, causando contusões graves, feridas ou mutilação de membros, além do pagamento de multas, seriam implicados criminalmente (arts. $41^{\circ}-45^{\circ}$ ). Refinando punição prevista no Direito romano e encampada pelas Siete Partidas, previu-se a obrigação da venda dos escravos que sofressem vexações, maus-tratos ou outros excessos "contrarios a humanidad" e aos modos mais racionais de mantê-los. A venda seria feita por preço definido por peritos indicados por ambas as partes, com a interferência de um terceiro em caso de discórdia, salvo se houvesse um comprador disposto a entregar o preço exigido pelo amo $\left(\operatorname{art} .32^{\circ}\right)$. Em caso de invalidez, o senhor deveria outorgar a liberdade e contribuir com uma quota diária estipulada pela justiça para a sua manutenção e vestuário enquanto o escravo vivesse $\left(\operatorname{art} .46^{\circ}\right)^{590}$.

Diversos artigos tocaram na questão da manumissão e da coartação dos escravos. Por isso, merecem consideração especial aqui. $\mathrm{O}$ artigo $15^{\circ}$, que previu o sustento dos escravos idosos ou incapacitados para o trabalho por motivo de doença, estipulou que os senhores não poderiam manumiti-los para se isentarem de sua responsabilidade. A alforria só poderia ocorrer caso eles tivessem recursos para se manterem, o que seria avaliado pela justiça, com acompanhamento do Procurador Síndico.

$\mathrm{O}$ artigo $34^{\circ}$ determinou que nenhum amo poderia resistir a coartar seus escravos que entregassem ao menos 50 pesos para o rebaixamento do seu preço. Aqui a coartação ganhou, pela primeira vez no universo espanhol, uma forma legal, e com um desenho bastante favorável. Não se tratava de uma quantia percentual, mas de um valor fixo, sem correção inflacionária prevista, que equivalia já naquela época à oitava parte do preço de um escravo adulto. $\mathrm{O}$ artigo $35^{\circ}$ determinou que os escravos coartados não poderiam ser vendidos em maior preço do que o

\footnotetext{
${ }^{590}$ Lucena Salmoral. "Leyes para esclavos: el ordenamiento jurídico sobre la condición,...”, p.434; Marquese. Feitores do corpo, missionários da mente..., pp.317-320; Tardieu. Morir o dominar..., pp.178-277.
} 
afixado em sua última coartação, isto é, no ato de sua última contribuição para o rebaixamento do seu preço, “y com esta condición pasarán de comprador a comprador". Porém,

\footnotetext{
"Si el esclavo quisiera ser vendido contra la voluntad de su amo, sin justo motivo para ello, o diere margen con su mal proceder a la enajenación, podrá el amo aumentar al precio de la coartación el importe de la alcabala y los derechos de la escritura que causare su venta"591.
}

Tal como na cédula de 21 de junho de 1768, o texto levava ao entendimento de que o coartado poderia, valendo-se de artifícios diversos, forçar a sua venda, o que inegavelmente atesta a recorrência fática dessa situação. Ademais, o ônus da alcabala não era um obstáculo intransponível, equivalendo a $6 \%$ do valor da venda.

A única limitação à coartação era conferida pelo artigo $36^{\circ}$. Acompanhando a real cédula de 10 de fevereiro de 1789, ele caracterizava o instituto como um benefício "personalíssimo", não gozando dele os filhos das mães coartadas, os quais poderiam ser vendidos como escravos inteiros. Desta forma, não se deixava margem para interpretações dissonantes sobre a transmissão da condição de coartação pelo ventre, como houve no Brasil a respeito do statuliber.

$\mathrm{O}$ artigo $37^{\circ}$ confirmava o direito consolidado, definindo que os donos dariam a liberdade a seus escravos no momento em que eles aprontassem o preço de sua estimação legitimamente adquirido. O preço, no caso de não haver acordo entre os envolvidos, seria fixado por um perito indicado pelo amo (ou pela justiça, caso ele não o fizesse), e outro eleito pelo síndico procurador general em representação do escravo. No caso de divergência, um terceiro seria nomeado pela justiça. Diante do que já foi exposto aqui, fica claro que, também neste ponto, não se fazia mais do que regulamentar um procedimento já em pleno uso.

$\mathrm{O}$ artigo $38^{\circ}$, recobrando o disposto no Reglamento de Porto Rico, que havia sido editado em um momento bastante conturbado, estabeleceu que ganhasse a liberdade, além da expressiva quantia de 500 pesos de prêmio, o escravo que descobrisse qualquer conspiração "tramada por otro de su clase, o por personas libres, para transtornar el orden público". Na sequência, recomendava, sem obrigar, que os senhores usassem de generosidade para com os escravos que denunciassem "una confabulación, o el proyecto de algún atentado de esclavo u hombre libre contra el dueño, su mujer, hijo, padres, administrador o mayoral de finca", por ser muito conveniente oferecer estímulos à lealdade ${ }^{592}$. O preço da liberdade e do prêmio

\footnotetext{
${ }^{591}$ Lucena Salmoral. "Leyes para esclavos: el ordenamiento jurídico sobre la condición,...”, p.1262.

592 Idem, ibidem.
} 
estipulado seria subvencionado pelo fundo formado pela aplicação das multas exigidas pelas infrações do Reglamento $\left(\operatorname{art} .39^{\circ}\right)^{593}$.

De acordo com o artigo $48^{\circ}$, o cumprimento do Reglamento caberia aos "tenientes de gobernador, justicias y pedáneos". O problema é que o mesmo bando no qual foi publicado o Reglamento trazia em anexo Instrucciones de Pedáneos, que tiravam daquelas autoridades qualquer possibilidade de intervirem diretamente nas fazendas a fim de fiscalizarem as condições de tratamento dos escravos:

\footnotetext{
"Debo advertir en cuanto al Reglamento de esclavos que su artículo 48 no faculta a las autoridades, justicias y pedáneos para introducirse en las fincas del campo, ni en el manejo doméstico de la esclavitud, ni en género alguno de pesquisa directa o indirecta, sino únicamente para dar cuenta a este gobierno superior político de cualquiera infracción que llegue a noticia de dichas autoridades" ${ }^{" 594}$.
}

A mudança se deve aos protestos realizados pelos proprietários cubanos frente à violação de sua soberania doméstica, o que representa um claro retrocesso em relação ao Reglamento de Porto Rico, que ordenou visitações anuais às fazendas e a acolhida de denúncias populares às eventuais infrações. Na prática, o Reglamento de 1842 ampliava o amparo legal apenas para os cativos que de algum modo conseguissem extrapolar as barreiras de seu domínio e chegar até as autoridades, o que se tornava cada vez mais difícil com a intensificação da produção agrícola: eis o ponto de chegada do intervencionismo hispano-cubano. Consequentemente, um instrumento que nasceu para ajustar a gestão da exploração do cativeiro em larga escala, incidiria especialmente, ainda que não exclusivamente, sobre os cativos situados nas zonas urbanas, pela margem maior de autonomia de que dispunham ${ }^{595}$. Dessa forma, o núcleo duro do sistema de exploração do trabalho escravo que estava na base da produção açucareira cubana era preservado. Ademais, uma nova mudança política na Espanha, em 1843 - que provocou a queda de Espartero e a redução da influência britânica em Madri, envolvendo a sua versão do Golpe da Maioridade, conduzindo Isabel II ao trono, com apenas treze anos de idade -, implicou uma troca no comando da ilha. Em setembro daquele ano, a elite local conseguiu arrancar do novo governo moderado a substituição de Valdés por Leopoldo O’Donnell, que romperia com a política de seu antecessor, alinhando-se

\footnotetext{
593 Idem, ibidem.

${ }^{594}$ Apud Tardieu. "Morir o dominar” ..., p.183.

595 Ynaê Lopes dos Santos. Irmãs do Atlântico. Escravidão e espaço urbano no Rio de Janeiro e Havana (17631844). Tese de Doutorado em História Social defendida na Universidade de São Paulo, 2012.
} 
perfeitamente ao establishment colonial. Com Valdés e Turnbull fora da jogada, o tráfico seria reaberto, o teor Reglamento abrandado ${ }^{596}$.

É importante acrescentar que a conjuntura interna da ilha era bastante incendiária àquela altura. Movimentos insurrecionais sucederam-se, principalmente em regiões com maior concentração de escravos no Ocidente da ilha. Em 1840, explodiram levantes em várias plantações de Trinidad e Cienfuegos. No ano seguinte, foi a vez de Lagunillas, Macuriges, Matanzas e da própria capital, Havana, que enfrentou a sublevação de 50 escravos lucumies. No primeiro trimestre de 1843 , a região matancera foi palco de acontecimentos ainda mais ruidosos, envolvendo centenas de escravos. A revolta começou na noite de 27 de março no ingenio Alcancía, em Cárdenas, mas logo se espalhou por vários outros ingenios, La Luisa, La Trinidad, Las Nieves e La Aurora, assim como pelo cafetal Moscú e o potrero Ranchuelo; cativos que trabalhavam na obra do ferrocarril de Cárdenas y Júcaro também se somaram à rebelião. Para contê-los, o capitão general enviou um vultoso contingente de cerca de cinco mil soldados. Foi uma verdadeira carnificina. Mesmo assim, em novembro, novos levantes vieram à tona. Partindo do ingenio Triunvirato, em Matanzas, os revoltosos engrossaram suas fileiras com negros da dotação de Acana e, imbuídos do lema "muerte, fuego y libertad", invadiram as plantações de La Concepción, San Miguel, San Lorenzo, e San Rafael. Mas, quando se dirigiam ao povoado de Santa Ana, foram detidos por um regimento de cavalaria composto por cerca de 300 jineteros. Resultado: 50 mortos e 200 prisioneiros. A ordem foi restabelecida, mas o ambiente ainda era bastante instável. No início do mês seguinte, o hacendado Esteban Santa Cruz de Oviedo, da região de Sabanilla, revelou às autoridades que uma escrava gangá, de sua propriedade, chamada Polonia, afirmava saber do plano de uma nova rebelião de grandes proporções, marcada para ocorrer no natal de $1843^{597}$.

A denúncia serviu de pretexto para uma verdadeira caça às bruxas. Com o exemplo do Haiti na cabeça e receosos quanto à existência de um projeto de independência e de abolição da escravidão, a plantocracia local deu todo apoio para que O’Donnell comandasse uma varredura febril em busca de rebeldes entre escravos e negros livres por meio de um inquérito totalmente arbitrário e desumano. Como o método bárbaro empregado pelas autoridades era amarrar os suspeitos em uma escada e açoitá-los até que confessassem ou sucumbissem, o suposto plano insurrecional, passou para a história como Conspiración de la Escalera. A delação das cabeças

\footnotetext{
596 Tardieu. "Morir o dominar” ..., pp.183-197; Gloria García Rodríguez. Voices of the Enslaved in NineteenththCentury Cuba: a documentar history. Chapel Hill: The University of North Carolina Press, 2011, pp.74-84.

${ }^{597}$ Gabino La Rosa Corzo. “Matanzas, 1844: ¿Conspiración esclava o manipulación esclavista?”. Disponível em: <http://www.angelfire.com/planet/islas/Spanish/v1n3-pdf/38-45.pdf>. Acesso em: 28 de março de 2015.
} 
do movimento foi arrancada do mulato Seguí. Mediante tortura, ele envolveu Turnbull, como principal articulador, e o mulato Gabriel de La Concepción Valdés, poeta e artesão conhecido como Plácido - que já estava na mira das autoridades havia algum tempo - como "presidente de nosotros". Depois, o mesmo seria reiterado, com o uso dos mesmos artifícios, por vários outros interrogados. No dia 25 de julho de 1844, Polonia recebeu a sua carta de liberdade e o prêmio de 500 pesos, bem nos termos do artigo 38 do Reglamento de 1842. No dia 28, Plácido seria conduzido ao pelotão de fuzilamento, juntamente com outros envolvidos, e executado pelas costas. Dados coletados pela Comissão Militar montada para a apuração dos envolvidos apontam para 78 execuções, sendo 39 escravos, 38 negros livres e 1 branco, mas o total de pessoas punidas com penas de prisão, açoite, banimento e trabalhos forçados passou de três mil, dos quais, 2187, foram apontados como de "color libres", o que equivale a 71,09\% dos $\operatorname{condenados}^{598}$. Problematizando a questão, Gabino La Rosa Corzo observa que as investigações demonstraram certos "vínculos conspirativos entre escravos e "morenos y pardos libres", mas não provaram a existência de um plano geral orquestrado por estes últimos. E convincentemente arremata:

\footnotetext{
"Si el plan de las autoridades coloniales y hacendados esclavistas fue sólo el de frenar los alzamientos continuos de las dotaciones esclavas en la región de Matanzas, la represión desatada y sus formas brutales fueron más que suficientes para frenar de cuajo las rebeliones, las que desde entonces no volvieron a alcanzar los niveles del 44" 599 .
}

Havendo ou não o complô alegado, o fato é que aquela brutal devassa serviu para debelar a rebeldia no interior das escravarias daquela região e extirpar os inimigos políticos identificados entre negros e mulatos livres e libertos. A população branca também não passou incólume. Entre os 96 investigados ou julgados, incluíam-se nomes de peso como Domingo Del Monte e José de la Luz Caballero ${ }^{600}$.

Os acontecimentos de Matanzas colocaram em xeque a vigência do Reglamento de Valdés. Em 29 de fevereiro de 1844, O’Donnell solicitou ao presidente da Junta de Fomento, órgão destinado a fomentar o avanço do comércio e da agricultura da ilha, um parecer sobre aquela "codificação". O documento produzido em resposta pela comissão formada para este fim pelo conde de Romero, o conde de Cañongo e Antonio María de Escovedo, foi entregue em 17 de abril. O seu teor era bastante conservador, atribuindo os levantes ocorridos recentemente à agitação política suscitada a partir do exterior, nada tendo a ver com o

\footnotetext{
${ }^{598}$ Paquette. Sugar is made with blood..., p.229.

${ }^{599}$ La Rosa Corzo. “Matanzas, 1844: ¿Conspiración esclava o manipulación esclavista?”..., p.43.

${ }^{600}$ Idem, ibidem.
} 
tratamento propiciado internamente aos cativos. A promulgação daquele regulamento teria sido um ato de irresponsabilidade sem tamanho, visto que claramente moderavam a autoridade domínica, “desnudándola a los ojos Del esclavo de aquel prestigio que le hacía mirar a su amo a um poder único absoluto y legítimo" 601 . Para a comissão, nada de "medidas contemplativas", a força era a única forma de sustentar a escravidão dali para diante. Nesse sentido, a manumissão servia apenas para suscitar um irresistível apego à liberdade, habilmente utilizado pelos abolicionistas para erodir o sistema produtivo da ilha. Interessante que entre as proposições, que se dividiram entre as medidas que tocavam o governo e aqueles que tocavam aos donos de fincas rurais e seus administradores "bajo la más estricta responsabilidade", constava apenas a deportação ou expulsão imediata dos emancipados, de negros livres sem ofício, propriedade ou meio de vida, e de todos os negros estrangeiros de passagem pela ilha, aos quais deveria ser impedida a entrada dali para frente. No entanto, não foi sugerida nenhuma restrição à alforria ou à coartação, o que não é nada desprezível. Se existiu um momento oportuno para a proposição de uma espécie de estrangulamento da alforria em Cuba foi esse. Mas, ao que parece, no cálculo político realizado por aqueles representantes da ala mais reacionária da elite escravagista cubana, era mais simples e de efeitos mais imediatos, excluir indivíduos beneficiados pelas diversas formas de liberação já existentes na sociedade do que pôr freio no benefício em si ${ }^{602}$.

Após algumas reuniões para debater o assunto, O’Donnell emitiu duas circulares de polícia em 31 de maio, uma para os donos de escravos possuidores de fincas e outra as autoridades locais. Conforme o governador, a experiência havia demonstrado a necessidade de se adotarem medidas que, ao mesmo tempo, mantivessem a escravidão em obediência e respeito, e definissem como devia ser regido o seu "gobierno interior". Depois de haver ouvido o assessor segundo do Governo Superior Civil da ilha e conformidade com o proposto pela Junta de Fomento, chegou ao entendimento de que deviam ser observadas as seguintes regras. Primeiro, que o administrador, mayoral ou mayordomo, de cada finca cuidasse da instrução básica da religião católica. Segundo, que usando em toda a plenitude da autoridade domínica que lhes concediam as leis sobre os escravos, "como el único medio de mantenerlos en subordinación", resolveriam, como achassem mais conveniente, a forma e a quantidade de alimentos, vestuário e assistência em caso de enfermidade a serem administrados. Do mesmo modo, ficaria sob seu "prudente arbítrio" o castigo a ser imposto aos escravos delinquentes quanto ao número de açoites, tempo de prisão e designação do empregado a aplicar a punição,

\footnotetext{
${ }^{601}$ Apud Tardieu. “Morir o dominar” ..., p.262.

${ }^{602}$ Idem, pp.268-271.
} 
com a única instrução de que se inclinassem mais à moderação do que ao excesso. Terceiro, que após a tranca das portas e até o amanhecer houvesse uma ronda capitaneada por um homem branco; que o administrador, mayoral ou mayordomo só saísse da finca com permissão expressa do dono; que todo negro, livre ou escravo, ou branco em atitude suspeita, que entrasse na finca sem permissão, fosse preso e enviado ao juez de partido, que os empregados mantivessem sob vigilância a conduta das personas libres de color que estivessem trabalhando na finca. Ademais, como a comunicação entre escravos de diferentes fincas havia facilitado como nenhum outro fator a conspiração de escravos recentemente descoberta, administradores e afins seriam diretamente responsabilizados caso não tomassem as medidas necessárias para preveni-la. Quarto, qualquer caso de morte, ferimento ou sintoma de insurreição deveria ser informado com máxima urgência ao capitão do partido. Quinto todos os empregados que desempenhassem funções que demandassem a saída das fincas fossem brancos. Sexto, que cada finca, por maior que fosse, dispusesse de um número de empregados correspondente a $5 \%$ de sua dotación de color $^{603}$.

$\mathrm{Na}$ circular enviada às autoridades, foi estabelecido, primeiro, o recolhimento dos negros emancipados existentes na ilha para as tratativas de sua deportação tão logo ocorresse o término de sua instrução civil e religiosa; segundo, a averiguação geral dos hombres de color libres sem ofício, propriedade ou modo de vida conhecido, a fim de que fossem julgados como prejudiciais à sociedade; terceiro, a expulsão em tempo breve dos hombres de color libres procedentes de quaisquer outros países; quarto, a interdição efetiva do desembarque de hombre de color libre ou de escravos na ilha; quinto, as autoridades locais vigiariam a conduta dos arrendatários negros que viviam nos campos; sexto, seria observada com exatidão a proibição de reuniões da "gente de color" sem permissão da respectiva autoridade local, corrigindo-se com severidade qualquer falta contra os brancos; sétimo, por nenhum motivo hombres de color libres seriam empregados em boticas; oitavo, nos campos, seriam suprimidas as tabernas de má situação ou que demonstrassem não oferecer utilidade ao público; nono, ficava totalmente proibida a venda de aguardente pelos campos; décimo, os donos das fincas seriam incitados a custear eclesiásticos de virtude conhecida para que instruíssem suas respectivas "negradas" nos preceitos da religião católica e nos deveres da moralidade, obediência e submissão ${ }^{604}$.

Por estes dois instrumentos fica claro que o governador abrandou as medidas do Reglamento de Valdés, sem revogá-lo ou editar um novo. Por que? Para não atrair a atenção negativa dos ingleses, como sugeriram Berbel, Marquese \& Parron? De fato, esta é uma

\footnotetext{
${ }^{603}$ Lucena Salmoral. "Leyes para esclavos: el ordenamiento jurídico sobre la condición,...”, pp.1266-1267.

${ }^{604}$ Lucena Salmoral. "Leyes para esclavos: el ordenamiento jurídico sobre la condición,...., p.268.
} 
explicação possível. Segundo os autores, "no lugar da reforma ou da revogação do Reglamento, porém, a melhor saída era pôr uma pá de cal sobre ele, para que não se agravassem as relações diplomáticas com a Grã-Bretanha, não se irritassem os escravos nem se ventilasse mais a matéria." ${ }^{\circ 05}$ Mas é necessário lembrar que, primeiro, esta tal "pá de cal", no que se refere ao primum mobile do dispositivo, isto é, a gestão das grandes escravarias, já nasceu embutida na publicação do Reglamento, quando se vedou a possibilidade de visitações fiscalizadoras às fazendas pelas autoridades constituídas e que, segundo, as circulares de 1844 representaram, sim, uma reforma parcial do seu conteúdo. Quanto à vigência daquele dispositivo, a expressão "pá de cal” é inapropriada, pois dá a entender que o Reglamento foi condenado à letra morta, o que é um equívoco, como os próprios autores observam em sua narrativa. O seu teor (abrandado pelas circulares) informou, sim, a prática jurídica local, como já demonstrou Alejandro de La Fuente, em causas envolvendo a alforria e a coartação ${ }^{606}$. É possível depreender que a concepção socialmente vigente a respeito da estrutura funcional do poder senhorial passava pelo gerenciamento autônomo da disciplina, do sustento e do cuidado, não pela contenção do direito à liberdade onerosa ou da prerrogativa dos senhores quanto à administração de seus modos graciosos. Em um ambiente bastante racializado, no qual os brancos constituíam a maioria entre a população livre, mas a minoria, no cômputo total da sociedade, as medidas destinadas à exclusão de emancipados e negros livres sem ocupação, propriedade ou meio de vida complementou a política criminal adotada na repressão das revoltas e na apuração da suposta conspiração de La Escalera. Madri chancelou a deportação de emancipados. Os que desejassem e tivessem meios para embarcar, poderiam seguir para Fernando Pó, aquela mesma possessão que os espanhóis obtiveram dos portugueses. Outros seriam entregues às autoridades britânicas: entre 1845 e 1851, o cônsul inglês receberia 657 emancipados de Cuba. Além disso, negros e mulatos livres não escaparam da aplicação da determinação de O’Donnell. Segundo Pedro Deschamps Chapeaux, houve ao menos 739 expulsões, 416 para o México, 92 para a África, 40 para os Estados Unidos e o restante para Jamaica, Brasil e Europa ${ }^{607}$. Evidentemente, isto não representou uma varrição étnica entre a população livre. O número de pessoas "libres de color" até cresceu entre as contagens de 1841 e 1846, passando de 147.787 para $149.226^{608}$. O que se fez foi uma exclusão de pessoas tidas como perigosas pelas autoridades. Punição

\footnotetext{
${ }^{605}$ Berbel, Marquese \& Parron. Escravidão e Política..., p. 295.

606 Alejandro de la Fuente. "Slaves and the Creation of Legal Rights in Cuba"..., pp.662-692.

${ }^{607}$ Paquette. Sugar is made with blood..., p.228.

${ }^{608}$ Vale notar que a população branca cresceu mais ainda, passando de 408.966 para 425.769; Kiple. Blacks in Colonial Cuba, pp.5-6.
} 
exemplar, expulsão pontual e endurecimento do sistema privado e público de controle e repressão: esta foi a receita adotada.

Enquanto todas essas medidas sobre a restauração da ordem eram tomadas, o tráfico de escravos também estava na pauta das deliberações. Em 2 junho de 1843, a Coroa fez uma consulta sobre o possível teor da lei penal prevista no convênio de 1835 e que ainda não havia sido editada até aquela data. A diplomacia britânica havia mudado de estratégia, trocando a abordagem agressiva simbolizava pelas investidas de Turnbull por uma via mais legalista, passando agora a cobrar a promulgação da normativa prometida, que vinha sendo protelada com a justificativa das Guerras Carlistas. Como ressaltaram Berbel, Marquese \& Parron como compensação à exclusão formal dos cubanos do sistema político representativo constitucional, que passava por uma nova reformulação naquele momento, o governo metropolitano incluiu a elite local, pela consulta direta aos nomes mais proeminentes, em comissões especialmente criadas ou por meio dos principais órgãos estabelecidos na ilha, principalmente na capital, para a deliberação dos assuntos centrais, fundamentalmente, o tráfico ${ }^{609}$.

Em 17 de agosto de 1844, O’Donnell - que já havia solicitado no inicio do ano informes a alguns hacendados de destaque (Domingo de Aldama, Ignacio de Herrera, José Pizarro y Gardín, Wenceslao de Villa Urrutia), corporações (Tribunal de Comercio, Ayuntamiento, Real Sociedad Patriótica e Junta de Fomento) e órgãos públicos (Superintendencia General Delegada de la Hacienda, Audiencia y Cancellería de Puerto Príncipe e Audiencia de Puerto Príncipe), os quais, apesar de pontos de divergência, estavam convencidos de que prosseguir com a importação de escravos havia se tornado objetivamente impossível - se reuniu com uma Junta nomeada para "informar acerca de la ley penal que debe formularse en conformidad al art. 2 del tratado de 1835 que prohíbe el tráfico clandestino de negros en África". Os participantes da reunião foram o conde de Fernandina, o marquês de Esteva de las Delicias, D. Rafael de Quesada e D. Joaquín Goméz, este último notório traficante de escravos ${ }^{610}$. Após a exposição dos membros da junta e levando em consideração os informes enviados pelas corporações, autoridades e particulares consultados, chegou-se a uma proposta unificada: todo barco apreendido com carregamento de negros bozales ou cuja destinação àquele comércio fosse comprovada deveria ser confiscado juntamente com sua carga e o seu produto aplicado em benefício do Estado; o capitão, os pilotos e o mestre de todo navio que fosse declarado "buena presa" deveriam cumprir, na primeira condenação, 6 anos de presídio na África, na

\footnotetext{
${ }^{609}$ Berbel, Marquese \& Parron. Escravidão e Política: Brasil e Cuba, c. 1790-1850, p. 296.

${ }^{610}$ Francisco de Solano e Augustín Guimerá (org). Esclavitud y Derechos Humanos: La Lucha por la libertad del negro en el siglo XIX. Madrid: Consejo Superior de Investigaciones Científicas, 1990, p.85.
} 
segunda, 8 anos, na terceira, 10 anos; a mesma punição caberia ao dono da embarcação caso não justificasse plenamente que não tinha conhecimento do destino; aos contramestres caberia uma pena de 4 anos de serviços forçados nos navios de guerra, 6 anos do mesmo em caso de reincidência, e oito anos de prisão da terceira vez; os negros apreendidos seriam declarados livres e, conforme as regras já previstas no Tratado de 1835 , receberiam suas cartas de emancipação do governo onde residissem depois de ter cumprido o tempo de aprendizagem "para hallarse em estado de que no hagan mal uso de la libertad"; que o conhecimento destas causas e a aplicação das penas correspondentes fossem privativos dos capitães generais de Cuba ou dos governados de Fernando Poo e Annobón, "sin intervención de ningún tribunal espacial por no considerarse conveniente ni necessário"; que a responsabilidade e a penalização dos cruzeiros ingleses apresadores e dos juízes que prejudicassem o comércio espanhol deveria ser efetiva quanto ao ressarcimento das perdas indevidamente causadas ${ }^{611}$.

Como se nota, a proposta apresentada trazia punições severas para os operadores do tráfico, entre tripulantes e donos das embarcações, mas isentava totalmente os proprietários locais que houvessem adquirido africanos ilegais. Além do mais, buscou-se preservar a autonomia local quanto à averiguação das infrações, algo que, caso fosse aceito, abriria uma avenida larga para o descumprimento da lei. No final da ata da reunião, registrou-se a opinião do capitão general, segundo a qual fosse evitada qualquer discussão pública nas Cortes do Reino a respeito desta matéria, no que convergia com os membros da Junta. Além disso, declarava que, como empregado e representante máximo de Sua Majestade em Cuba, estaria firmemente empenhado em fazer cumprir todas as ordens e tratados vigentes, mas deixava consignado que em sua opinião "la prohibición absoluta de la introducción de esclavos en esta isla, era contraria a su prosperidad y produciría en un número de años la decadencia y el menoscabo de su comercio con directo daño del país y de los intereses positivos de la metrópoli”. Em seguida, pontuou os impeditivos para que houvesse uma reposição satisfatória da mão de obra sem o tráfico:

" $1^{\circ}$ por que la producción de la casta negra criolla no podía equilibrar el déficit que producía la muerte y
las enfermedades que imposibilitan para el trabajo pues aquella estaba reputada solo a uno por ciento y
esta no bajaba cuando menos del cinco: $2^{\circ}$ porque los matrimonios no podían protegerse ni fomentarse al
punto que convenía cuando estaba demostrado y era una verdad de hecho que el número de hembras era
infinitamente menor que el de varones: $3^{\circ}$ por los trabajos de la agricultura en este clima, especialmente
los que exige la elaboración del azúcar, no podían deportarse por hombres blancos sin producir gastos
enormes que el producto del fruto no recompensaría en su concurrencia en los mercados de Europa: $4^{\circ}$
porque la colonización de hombres blancos, además de considerar que su aglomeración en este país podía

${ }^{611}$ Biblioteca Nacional de Cuba. Colección de Manuscritos, Act. N. 1. Acta de la reunión celebrada por los sres. Que constituyen la junta creada para informar acerca de la ley penal que debe formularse en conformidad al art. 2 del tratado de 1835 que prohíbe el tráfico clandestino de negros en África. 
producir más bien males que ventajas, porque tanto los varones como las hembras que llegasen a venir a consecuencia de contratas serian de mala moralidad y costumbres se presentaba tan difícil y costosa, que la Junta de Fomento animada de los mejores deseos y con medios bastantes eficaces para realizarlos, no había podido dar a un principio a un sistema de colonización practicable y conveniente; y $5^{\circ}$ porque la sustitución de máquinas para disminuir el empleo de brazos además de ser inmensamente costosas, no habían tenido aceptación en el país ni pasaban de tres las que se habían introducido"612.

Tais argumentos podem até integrar certo entendimento vigente na época sobre uma vinculação necessária entre plantação tropical, trabalho compulsório e importação de africanos, mas é certo esta sua lógica se ajusta bem a seus interesses pessoais. Como destacou David Murray, O’Donnell, assim como Tacón, havia deixado sua ideologia na Espanha, rumando para Cuba para fazer sua fortuna ${ }^{613}$. A corrupção montada em torno do tráfico era o canal certo para isso. Todo este arrazoado tecido pelo capitão general soa como uma justificativa para o emprego da antiga fórmula utilizada a rodo pela administração espanhola nas Índias desde os primeiros tempos da colonização: obedezco pero no cumplo.

Apesar da solicitação que partiu de Cuba, o debate que precedeu a aprovação da lei não foi secreto. José Antonio Saco, exilado na Europa, congratulou o governo espanhol por abrir espaço para a coação efetiva do infame comércio. Houve certa movimentação política na ocasião, com a publicação de panfletos antiescravistas, dois dos quais chegariam a circular no interior de $\mathrm{Cuba}^{614}$. No dia 23 de dezembro, a lei entrou para a pauta de deliberações do Senado espanhol, mas o ministro de Estado, Martínez de La Rosa, tratou logo de podar as asas dos mais exaltados, deixando claro que ninguém tocaria na questão da escravidão. Pelo contrário, o que estava em jogo era favorecer a supressão do tráfico como meio mais seguro e eficaz de proteger a propriedade dos cativos existentes, cumprindo-se um ponto ainda pendente do Tratado de 1835, contentando-se o governo inglês. O mérito do projeto foi deixado de lado, e os parlamentares passaram imediatamente ao exame dos artigos, abafando-se qualquer tipo de polêmica no círculo parlamentar. No dia 2 de março de 1845, a Lei penal espanhola contra o tráfico de escravos finalmente foi sancionada. O que chama atenção de imediato é teor de seu artigo 9, segundo o qual “en ningún caso, ni tiempo, podrá procederse, ni inquietar en su posesión, a los propietarios de esclavos, con pretexto de su procedência" ${ }^{\prime 615}$, ponto digno de causar inveja aos políticos Saquaremas do Império brasileiro. Como está claro, a Lei isentavam de forma taxativa os proprietários de cativos ilegalmente traficados de qualquer

\footnotetext{
612 Idem, ibidem.

${ }^{613}$ Murray. Odious Commerce..., p.191.

${ }^{614}$ Idem, p.

${ }^{615}$ Lucena Salmoral. "Leyes para esclavos: el ordenamiento jurídico sobre la condición,...”, p.1271.
} 
responsabilidade, o que desde logo inibia inquirições do tipo proposto por Palmerston para averiguação da procedência e consecutiva liberação ${ }^{616}$.

De maneira convergente em relação ao que haviam sido sugeridas pela Junta havanesa, as penalidades recaíram sobre a tripulação, proprietários das embarcações e financiadores. $\mathrm{O}$ título $1^{\circ}$, de las penas em que incurren los que se emplean o toman parte em el ilícito comercio de esclavos, encampou as penas indicadas desde Cuba quanto à intensidade, mas com ajustes. A gradação das punições se daria, não pela reincidência, mas pelo critério da resistência. Para capitães e demais superiores dos navios, caberia a pena de 6 anos de presídio caso não apresentassem resistência; caso resistissem sem deixar mortos ou provocar ferimentos graves pegariam 8 anos de cadeia; aqueles cuja resistência acarretasse morte ou ferida grave deveriam ser punidos conforme a legislação penal corrente. Marinheiros e demais tripulantes seriam punidos de modo semelhante, com pena a partir de 4 anos de prisão. Os proprietários dos barcos e dos carregamentos, armadores e financiadores das expedições seriam condenados aos mesmos anos de desterro a mais de 50 léguas de seu domicílio pelos quais o respectivo capitão fosse condenando à pressão. Além do que, satisfariam multas entre mil e 10 mil pesos fortes, segundo a gravidade (não foi prevista a perda da embarcação indicada pelos cubanos). No título $2^{\circ}$, que regulou o modo de proceder en los delitos que son objeto de esta ley, foi estabelecido que às autoridades superiores, tribunais, juízes ordinários e fiscais de S. M. caberia a competência de tomar conhecimento e julgar estes casos. Novamente indo ao encontro da reivindicação cubana, foi estipulado, pelo artigo 12, que os Tribunais Mistos instituídos pelo Tratado de 1835 passariam para a autoridade dos governadores das Antilhas, os capitães generais de Cuba e Porto Rico. O mesmo valeria para os estabelecidos em Serra Leoa, que passaria ao Regente das Audiências das ilhas Canárias ${ }^{617}$.

O contrabando não foi suprimido, mas os ingressos foram substancialmente rebaixados por algum tempo. O ano de 1846 anotou um recorde negativo, com 480 entradas. Nos anos seguintes, embora os números atingissem novamente a casa do milhar, os índices seguiram relativamente baixos até 1848 . Aí reside, sem sombra de dúvida, um dos motivos pelos quais a Grã-Bretanha não direcionou para Cuba a mesma carga de força descarregada contra o contrabando do Brasil, que naquela época bateria os 60 mil ingressos. Berbel, Marquese \& Parron anotaram, ainda, os termos do Tratado de 1835, que abreviava a possibilidade de

\footnotetext{
${ }^{616}$ Ramiro Guerra, p.444

${ }^{617}$ Ainda que esvaziado em suas atribuições, o Tribunal Misto de Havana continuou existindo formalmente pelo menos até 1871. Cf. Leslie Bethell. "The Mixed Commissions for the Suppression of the Transatlantic Slave Trade in the Nineteenth Century". The Journal of African History, v. 7, n. 1 (1966), pp. 79-93.
} 
intervenções por meio de bills, como os editados contra Portugal (1839) e o Brasil (1845), e o receio de que a ilha, em caso de intervenção, passasse para as mãos dos Estados Unidos, que em caso de guerra assumiriam facilmente o controle do Caribe, ameaçando os interesses britânicos ${ }^{618}$. Como destacou Ramiro Guerra, desde o princípio da década, quando Espartero ordenou a investigação sobre os cativos ilegais instigada pelos ingleses, ganhou ânimo entre os expoentes da oligarquia cubana a tendência anexionista. Esta inclinação seria reforçada pelo ressentimento de alguns setores quanto à segregação política no círculo representativo nas Cortes estabelecido em 1837; pelo aumento na carga tributária, que abocanhava $30 \%$ da renda bruta da ilha. A união aos Estados Unidos parecia para muitos uma saída possível para, sob o amparo de uma grande confederação liberal, proteger a escravidão e as riquezas produzidas localmente. A dantesca repressão às insurreições de 1843 e de La Escalera, bem como a garantia dos direitos sobre a propriedade escrava propiciada pela Lei de 1845 abrandaram a vertente da anexação, mas uma investida mais forte por parte do governo londrino poderia pôr tudo a perder ${ }^{619}$. Tal investida não ocorreu, o governo espanhol reatou suas boas relações com os hacendados, a soberania doméstica foi no essencial resguardada e os sucessores de O’Donnell retomaram a velha política de proteção ao tráfico de escravos ${ }^{620}$. Como mapeou recentemente a investigação do historiador Leonardo Marques, após a abolição do infame comércio pelo Império do Brasil, traficantes brasileiros e portugueses se engajaram no abastecimento da ilha de Cuba, da mesma forma que os portos estadunidenses se tornaram muito mais integrados ao circuito negreiro. Os desembarques subiram de 68.950 na década de 1840 para 111.661 nos anos 1850, sustentando a indústria açucareira cubana e amainando possíveis efeitos corrosivos da prática da manumissão ${ }^{621}$.

Cumpre destacar que, na década de 1840, ao pé da reconfiguração parcial do ordenamento jurídico referente à regulação do cativeiro efetuada entre a edição do Reglamento de Valdés e a promulgação da Lei penal de 1845, haviam sido consolidadas as atribuições dos síndicos procuradores e os meios de acesso dos cativos ao poder judiciário. O Auto acordado de la Audiencia Pretorial de La Habana sobre trámites y derechos em las cuestiones y querellas de esclavos, expedido em 24 de outubro de 1840, regulamentou diversos procedimentos relativos ao direito de assistência dos escravos: os escravos poderiam recorrer indistintamente aos juízes ou aos síndicos para realizar suas queixas em relação aos seus amos; quando os

\footnotetext{
${ }^{618}$ Berbel, Marquese \& Parron. Escravidão e Política: Brasil e Cuba, c. 1790-1850, pp.339-343.

${ }^{619}$ Guerra y Sánchez. Manual de Historia de Cuba..., pp.452-453.

${ }^{620}$ José Antonio Piqueras Arenas. "La vida política entre 1780 y 1878", in: Consuelo Naranjo Orovio.(coord.) Historia de la Antillas, vol. I: Historia de Cuba. Madri: CSIC/Ediciones Doce Calles, 2009, p.289.

${ }^{621}$ Marques. The United States and the Transatlantic Slave Trade to the Americas, 1776-1867, pp.156-201.
} 
escravos apresentassem suas queixas diretamente aos juízes, estes deveriam examinar preliminarmente a causa e, se a julgassem justa, poderiam citar o amo e o síndico para determinar, com sua audiência, o andamento da causa ou, então, deveriam mandar por ordem escrita que o amo passasse na casa do síndico para que este esclarecesse os motivos do escravo queixoso, procurando terminar extrajudicialmente com a demanda, encaminhando-se a defesa em casos de "absoluta ou indispensável necessidade"; afora casos de liberdade ou de queixas contra os amos, os síndicos não deveriam tomar a defesa dos escravos sem a autorização dos donos ou dos juízes ${ }^{622}$.

Em conformidade com essas regras, em primeiro de agosto de 1841, D. Ramón de Armas, personalidade de destaque da ilha, na qualidade de síndico procurador general, reportou-se ao teniente de gobierno, que tinha jurisdição sobre reclamações de liberdade, alegando que o negro Juan Bautista Irene, a quem estava representando, havia adquirido o direito de liberdade por ocasião de seu nascimento pela entrega do preço de sua liberdade antes de que fosse ministrado o sacramento do batismo por María del Pilar, sua mãe, a seu antigo senhor, D. José de Castro Palomino, como atestava documento apenso datado de primeiro de setembro de 1811. Mesmo assim, Juan permaneceu escravizado, figurando como objeto de compra e venda entre Andrés López (comprador e réu da ação) e Gertrudis López de Toledo (vendedora). Conforme o síndico, nenhum argumento produzido pelas partes contratantes podia conferir-lhes o direito de transmissão da propriedade de um homem livre, que havia mais de 30 anos estava submetido de forma ilegal ao duro jugo da escravidão, conforme Ley 24, tit. 29 , Partida III, que seguia em pleno vigor ${ }^{623}$. E prossegue:

\footnotetext{
"El hombre libre non muda de condición ni su estado ni le puede apremiar ni demandar por siervo en ninguna manera por razón del tempo que un home tuvo por siervo [...] pues cualquiera que sea el pretexto o el motivo de haber tenido Andrés López a Juan Bautista Irene por esclavo, y de haberle vendido como tal: cualquiera que sean las confecciones e implicancias a que puede haber obligado a Juan Bautista Irene la desgracia de su situación... Interpongo formal demanda contra D. Andrés López para que se declare la libertad de Juan Bautista Irene, si no para que se le paguen los jornales que ha debido devengar en todo el tempo en que ha prestado a los que se dicen sus dueños unos servicios a que no estaba obligado [...] Suplico se sirva, habiendo por interpuesta la demanda, y por presentados los documentos, declarados en definitiva la libertad de Juan Bautista Irene, condenando a D. Andrés López en el pago de los jornales que ha debido devengar y en el de las costas [...]"624.
}

\footnotetext{
${ }^{622}$ El libro de los síndicos de Ayuntamiento..., pp.17-19.

${ }^{623}$ Trata-se da lei intitulada "como puede home pedir en juicio la posesión et la tenencia de la cosa á aquel que fallare que es tenedor della". Las Siete Partidas del Rey don Alfonso el Sabio, cotejada con varios códices antiguos por la Real Academia de la Historia. Tomo II, Partida II e III. Madri: Imprenta Real, 1807, p.371.

${ }^{624}$ Autos que ha promovido el Caballero Síndico Pdor. Gral contra d. Andrés López sobre la libertad del negro Juan Bautista Irene y sus jornales, 1841-1845, ANC, Escribanías (Vergel), leg. 55, exp. 4.
} 
Para segurança de Juan, D. Ramón de Armas solicitou ademais o seu depósito na Casa de Beneficência, no que foi atendido.

D. Andrés apresentou-se em juízo buscando manifestar a sua boa fé em toda aquela história; afirmou haver comprado Juan pela quantia de 250 pesos, apresentou a escritura e sustentou que a vendedora era quem deveria ser interpelada. D. Gertrudis foi, então, citada. Em sua manifestação, ela negou a acusação, afirmando que o Juan Bautista havia sido seu escravo de maneira legítima, e que não era o mesmo citado no documento que atestava a liberdade. Mas, testemunhas arroladas, entre as quais constavam inclusive os herdeiros do antigo senhor, felizmente corroboraram a história de Juan Bautista. Em 18 de julho de 1845, foi proferida a seguinte sentença:

\footnotetext{
"Vistas desde luego las probanzas ministradas por el caballero síndico y pesadas las razones convenientes para administrar complicada justicia: en su virtud se condena a D. Andrés López a que dentro de 24 horas otorgue la escritura de libertad de aquel, muestreándose en ella esta resolución [...] luego que esté ejecutoriada, se le reserva a dicho d. Andrés López el derecho para reclamar de da. Gertrudis López de Toledo los 250 pesos que la expresa la antedicha escritura y los menoscabos: y a Juan Bautista Irene también el suyo para el cobro de los jornales u para lo demás que halla lugar, y por último se condena a la repetida López de Toledo en todas las costas de esta actuación [...]”,625.
}

A existência de provas documentais e testemunhais deu suporte à decisão judicial em favor de Juan Bautista, que ainda deveria abrir um processo contra D. Gertrudis caso quisesse receber os jornais de todo seu período de cativeiro ilegal. Alguns pontos podem ser indagados. Por que Juan demorou tanto tempo para procurar a justiça? O que aconteceu com a sua mãe? Por que ela não intercedeu por ele? Quando o documento que atestava a compra da alforria chegou às suas mãos? Quando ele tomou conhecimento de que poderia reclamar a sua liberdade? Quem o ajudou? Alguém o ajudou? Ele era realmente o mesmo Juan que constava do documento? Por que um processo que poderia ser resolvido de maneira sumária demorou quase quatro anos para ser resolvido? Tudo isto subjaz ao documento, mas não pode ser desvendado a partir dele. Juan pode ter acessado o documento de outro escravo, por casualidade, e resolvido utilizá-lo a seu favor, com a cumplicidade maior ou menor dos herdeiros de José Palomino. Ou a injustiça aconteceu exatamente como descrito e Juan descobriu a existência do documento tardiamente, de alguma forma. Enfim, o leque de possibilidades é bastante amplo e demonstra a complexidade daquela sociedade. Quanto à morosidade, não é descabido supor que o contexto conturbado possa ter atravancado o andamento do processo, quanto mais se considera a competência do teniente de gobierno, que 
acumula funções de natureza administrativa, além das judiciais. Como é possível notar, esta causa teve como pano de fundo todo aquele tumultuado momento de revoltas, repressão, mudanças no quadro normativo, descrito no tópico anterior. Não obstante, ao final, o sistema judiciário funcionou: reconheceu-se o direito adquirido e comprovado, e Juan teve melhor sorte do que muitos de seus pares, apesar de ter perdido os seus anos de maior vigor sob o jugo do cativeiro.

Apesar do resultado desta causa, não é possível observar uma variação quanto a uma inclinação ou predisposição do judiciário cubano em favor à liberdade dos escravos. Se o postulante à manumissão não apresentasse a quantia necessária para se alforriar ou coartar, em atenção aos seus direitos legalmente reconhecidos, deveria apresentar evidências consistentes de suas alegações, preferencialmente por escrito e registradas, vale a pena insistir. A este respeito, cumpre acompanhar o que aconteceu naquela época com a mulher negra Juliana Camacho, que moveu uma ação judicial em 4 de fevereiro de 1846, representada pelo síndico Fernando de Peralta. Juliana havia engravidado e passado por uma gestação bastante complicada. Quando estava em "avanzada preñez", sem saber se sobreviveria ao parto, entregou por sua liberdade à María Ochoa, sua senhora, 25 onzas de ouro, o equivalente a 425 pesos, que havia economizado a custa de seu trabalho e economia. Em função de seu estado delicado, não teve condições de exigir documento que comprovasse a contratação da alforria. Porém, contava com testemunhas dispostas a confirmar em juízo que ela havia entregado aquela soma. Por isso, solicitava a imediata outorga de sua carta de liberdade. No dia 9 de fevereiro, foi realizada uma audiência de conciliação, mas "la demandada dijo que es falio que haya recibido cantidad alguna de La negra Julia y que por ló tanto no puede prestarse a la solicitud del Caballero Síndico". Não obstante os testemunhos, no dia 6 de setembro, o alcalde considerou não provado as alegações de Julia e a condenou nas custas processuais. O síndico ainda recorreu à Audiencia de Havana, mas, em 14 de julho de 1847, o tribunal superior apresentou veredito confirmando a sentença proferida em primeira instância ${ }^{626}$.

O mesmo síndico Fernando de Peralta, ao mesmo tempo em que tocava o processo de Juliana, representou o párvulo Ricardo Valdez em ação iniciada em 20 de abril de 1846. A parda Dolores Valdez, sua ama, teria prometido alforriá-lo caso a mãe dele, também uma escrava de sua propriedade, chamada Catalina, entregasse a soma correspondente à liberdade dela, como uma espécie de bonificação pelo empenho. Catalina conseguiu comprar a sua alforria, mas a liberdade de Ricardo não foi concedida. Como é possível notar, trata-se de um

\footnotetext{
${ }^{626}$ Autos seguidos por el Caballero Síndico Pdor Gral contra la libertad de la negra Julia Camacho. 1846-1847,
} ANC, Escribaínas (Pontón), leg. 231, exp. 20. 
caso bastante semelhante aos verificados no Brasil, dependente da comprovação da vontade serial uma vez manifestada. O síndico tentou um acerto extrajudicial, mas D. Dolores não aceitou. Em 18 de maio, ela compareceu em juízo declarando serem falsas aquelas alegações; disse ter ficado muito espantada com o fato de o senhor síndico ter dado crédito aos acessos gratuitos da mãe de Ricardo. Ademais, afirmou que nunca teve sierva chamada Catalina, que era Rita o nome da mãe de Ricardo, acrescentando que:

\begin{abstract}
"Todo el fundamento de la demanda es una supuesta promesa que dice Rita haberle yo hecho sobre manumisión de su hijo siempre que consiguiese su enajenación por cierto precio: promesa, permítase decirlo, falsa e incierta y que solo ha podido existir en la imaginación de la mal aconsejada madre. No es posible que en mis críticas y apuradas circunstancias hiciera tal ofrecimiento" ${ }^{1627}$.
\end{abstract}

Dessa forma, a senhora, assinalando a sua condição humilde, nega peremptoriamente haver feito tal promessa, já que não tinha meios para dispor dessa forma de seus bens. Sobre a situação de Rita, assinala tê-la comprado em agosto de 1844 coartada na quantia inalterável de 250 pesos. Por isso, não faria sentido, sob sua perspectiva, efetuar tal promessa, já que não poderia ganhar um maravedí a mais pela liberação, e arremata: “Sería yo tan necia o loca, que había de regalar ciento dos pesos que era entonces el valor de Ricardo?" 628 . O processo parou por aí. O caso não foi adiante e não é possível saber se houve algum acerto entre Catalina/Rita e a parda Dolores, mas a situação é exemplar, pois atesta como o padrão de propriedade escrava e o dispositivo da alforria encobria a racialização da sociedade cubana, dificultado a aliança entre a população negra livre e cativa. O sistema escravista cubano e seu correspondente aparato jurídico traziam para o epicentro do conflito social a oposição entre proprietários de escravos e escravos, não entre brancos e negros, não obstante toda a tensão e a exclusão racial existentes. A década de 1850 despontou com um sistema jurídico consolidado e uma economia ainda em expansão $^{629}$. A introdução das estradas de ferro nos anos 1830 havia permitido a ampliação da fronteira agrícola e tecnológica para o interior rumo ao centro-leste da ilha, compensando a degradação ambiental e o esgotamento das terras na região mais próxima a Havana. A pressão britânica sofreu uma retração, o que permitiu uma nova injeção de braços cativos na economia

\footnotetext{
${ }^{627}$ Grifo meu. Diligencias formadas a instancia del Síndico Pdor Gral reclamando la libertad del negrito Ricardo a la parda Dolores, 1846, ANC, Escribanías (Pontón), leg. 239, exp. 6.

${ }^{628}$ Idem.

${ }^{629}$ Sobre o desenvolvimento da economia de plantação em Cuba na passagem para a década de 1850, ver: Fraginals. El ingenio: complejo económico social cubano del azúcar, t.1., pp.174-216; Gloria García \& Orestes Gárciga "El inicio de la crisis de la economia esclavista", in: Historia de Cuba: la Colonia, evolución socioeconómica y formación nacional, de los origenes hasta 1867. Havana: Editora Politica, 1994, pp.360-394; Reinaldo Funes Monzote. From rainforest to cane field in Cuba: an environmental history since 1492. Chapel Hill: University of North Carolina Press, 2008, pp.127-178.
} 
local. O Reglamento de 1842 havia alargado a ordem legal, instituindo o direito à coartação, sem pôr reparo nos modos já consolidados de aquisição da liberdade, que continuaram vindicados ${ }^{630}$.

A criolla Genoveva foi libertada pelo testamento de seu senhor, D. José Hernandez, em 14 de novembro de 1836. No entanto, por alguma razão obscura, ela se encontrava depositada havia anos na Casa de Beneficência. O advogado Eusébio Ximenez foi quem se deu conta da situação e enviou uma petição ao juiz, pretendendo ele mesmo se encarregar da defesa de Genoveva, alegando que "La ley de Indias, como las de Partida, autorizan a cualquier abogado para defender derechos tan sagrados como estos, sin necesidad de poder". A causa foi aceita, mas o pedido de representação foi negado. O tribunal passou o caso ao síndico. Uma cópia do testamento foi anexada e não restou dúvida. Em sua cláusula 16, constava o seguinte: “declaro que es mi voluntad que la negrita Genoveva después de mis días quede libre, pero por la menor edad quedará sujeta a servidumbre hasta su mayoridad y al cargo y cuidado de mi hermana d. Juanita". A menoridade já havia sido superada, a autoria havia nascido em 12 de dezembro de 1830, portanto, não cabia outra ação do judiciário, que não a decretação da outorga da carta de liberdade. Assim foi feito. Em 21 de fevereiro de 1853, o magistrado, considerando o mérito da questão, considerou Genoveva isenta de toda a servidumbre e determinou que fosse enviado ofício ao administrador do depósito da Real Casa de Beneficência para que permitisse a sua saída ${ }^{631}$.

Por essa época, continuava em pleno vigor o antigo princípio romano do partus sequitur ventrem, afirmado nas Siete Partidas: "los hijos que naciesen de madre libre e padre siervo serían libres, porque siempre siguen la condición de la madre" (ley II tít. 21, Partida IV) ${ }^{632}$. Com base neste preceito, era comum o empenho das mães no sentido de concretizarem a alforria antes do parto quando tinham oportunidade. Em 18 de janeiro de 1854, o síndico procurador entrou com uma ação em nome da morena Juana Nepomuceno Duraño, uma menina que havia nascido da união de María del Carmen - ex-escrava de D. Cecilia Hernandez - e do moreno Santigo - escravo de D. Francisco Duraño. A reclamação baseava-se na alegação feita por María de que, antes de seu próprio livramento, teria cuidado da libertação também de sua "criatura" que havia de nascer, oferecendo o "preço de costume" para sua ama, que se recusou indevidamente a recebê-lo durante a gravidez. No entanto, a alforria teria se consumado, pois

\footnotetext{
${ }^{630}$ Berbel, Marquese \& Parron. Escravidão e Política..., pp.276-290.

${ }^{631}$ El síndico del Exmo. Ayuntamiento sobre la libertad de la morena Genoveve criolla, 1853, ANC, Escribanías (de Gobierno), leg.732, exp.9.

${ }^{632}$ Lucena Salmoral. “Leyes para esclavos: el ordenamiento jurídico sobre la condición,...”, p.536.
} 
Juana fora batizada como livre, acompanhando a condição da mãe no ato do sacramento, ocorrido quando já era liberta. Desde então, Juana vivia com a mãe em uma pensão em frente ao Arsenal. Pensionistas confirmaram em juízo terem conhecimento de que a menina havia sido batizada como livre e vivia como tal em companhia de sua mãe e com a assistência do pai. Ademais, o síndico obteve uma declaração da cura reconhecendo haver batizado a menina como pessoa livre, registrando-a no livro correspondente.

Em 11 de março de 1854, o juiz declarou Juana livre de toda a servidão, determinado que D. Cecilia declarasse a dita liberdade em escritura pública. Porém, Felipe Perera, advogado de dona Cecilia levou o caso à Audiência de Havana, pedindo a reforma da sentença, alegando que os pais haviam procedido de má fé ao tentar transferir o atual estado da mãe para a filha no momento do batismo, o que configurava um claro ataque à propriedade privada. De acordo com o licenciado, Juana deveria seguir a condição do ventre à época de seu nascimento, o que fazia dela escrava de D. Cecilia. Além do que, deveria pesar o fato de que os pais haviam enganado o pároco, apresentando-se a ele como pessoas livres, o que o teria feito registrar a menina, erroneamente, no livro dedicado às pessoas dessa condição. No dia 20 de abril, veio a lume uma notícia terrível para Juana e sua família. O Tribunal superior revogou a decisão anterior e sentenciou Juana Nepomuceno Duraño pertencente à propriedade de D. Cecilia Hernandez ${ }^{633}$. A regra jurídica prevaleceu sobre qualquer possível favorecimento à liberdade.

Os casos que vêm sendo abordados até aqui reforçam a percepção geral de que a alforria onerosa e a coartação eram práticas eminentemente urbanas. Os casos de escravos trabalhadores de ingenios citados até aqui tinham laços muito fortes de amizade e parentesco consolidados na cidade. Como destaca a historiadora Claudia Varella, as oportunidades de ahorros em grandes plantações surgiam quando havia algum tipo de contrariedade em torno da propriedade, como no caso do ingenio Barracoa, situado em Bauta, na jurisdição havanesa. Integramente nas mãos do bispado de Havana até 1838, a finca foi parcialmente incorporada pelo governo espanhol, passando a ser coadministrada por um órgão estatal denominado Administración de bienes regulares $^{634}$. Consta do difuso fundo Miscelánea de Expedientes do Arquivo Nacional de Cuba um expediente aberto pela negra Asunción Carambot, pertencente à dotação daquele ingenio, para a amortização do preço de sua liberdade. Em 26 de junho de 1859, o Administrador general de bienes regulares escreveu ao bispo dando conta de que havia recebido de Asunción a quantia de 50 pesos a conta dos 300 pelos quais estava coartada; solicitou a aprovação do recibo

\footnotetext{
633 Cab. Síndico Prol. Gral. Primero contra d. Cecilia Hernandez sobre la libertad de la morena Juana Nepomuceno Duraño, 1854, ANC, Escribanías (Vergel), leg. 38, exp. 15.

${ }^{634}$ Claudia Varella.Esclavos a sueldo: la coartación cubana en el XIX..., pp.225-234.
} 
emitido, o abatimento daquela quantia na coartação e a anexação desse expediente a outros análogos que estavam em seu poder. No dia 29, o Bispo respondeu com um extenso informe, extrapolando a situação específica da escrava e oferecendo um interessante registro de sua percepção sobre o contexto.

\begin{abstract}
“Tan solo por el impulso de mi corazón a favor de los esclavos de la Isla todos serian libres, pues quisiera que la palabra esclavitud no resonara entre cristianos; mas como esta clase de individuos constituye una parte considerable de la riqueza material de la misma, veo que no es posible un total desprendimiento de tamaños intereses. Hoy para la adquisición de cualquier siervo por inútil que parezca, necesario es sacrificar un gran cantidad; de modo que si continua en el Ingenio Baracoa se procede con la facilidad que hasta ahora a recibir el precio de personal esclavo, que constituye parte esencial de su valor, ha de resultar precisamente suma imposible para su reposición; puesto que dándolos libres por un precio demasiado equitativo resultará al fin, que para reponer uno habrá de desembolsarse el valor de tres de los libertados, y en esto caso a no ser un muy notable sacrificio, quedaría por consumación demolida la finca. [...] creo que en lo adelante debe hacerse una nueva tasación del esclavo que pretenda su manumisión o coartación... a fin de que se verifique su justo precio y conforme a las circunstancias. Sin embargo, como la sierva Asunción, a que es referente el oficio de V.E. de 26 del actual, a que tengo la honra de informar, tenia ya iniciada su libertad con el hecho de haber entregado anticipadamente casi la mitad de su precio, no tengo inconveniente en que se la admitan los 250 pesos que hoy promete como completo de los 450 de su tasación, sin que este equitativo manejo preste derecho a los demás, para que quieran ser comprendidos en el mismo precio que se avaluaron en $1858^{\prime 635}$.
\end{abstract}

Asunción, portanto, conseguiu, sem problemas realizar o rebaixamento do valor entregue. Antes de comentar o teor restante do informe do religioso, vale reproduzir os dados referentes os valores entregues pelos escravos para alforriamentos e coartações, entre 1857 e 1859 , fornecidos por ele.
Relación de las cantidades recibidas por cuenta de liberdades, coartaciones y ventas de esclavos de la dotación del Ingenio San Cristobal de Barracoa desde $1^{\circ}$ de enero de 1857 à fin de abril de 1859

\begin{tabular}{|c|c|c|}
\hline Data & Nome & $\begin{array}{c}\text { Valor } \\
\text { (en Pesos) }\end{array}$ \\
\cline { 2 - 3 } $16 / 03 / 1857$ & Blas Gagigal (por resto de su libertad) & 90,000 \\
$14 / 04 / 1857$ & María Fragon (por cuenta de su libertad) & 204,000 \\
\hline $30 / 06 / 1857$ & María Fragon (por resto de su libertad) & 296,000 \\
\cline { 2 - 3 } $30 / 06 / 1857$ & Melitona Rubio (por cuenta de su libertad) & 250,000 \\
\hline $11 / 07 / 1857$ & Agostina Reinoso (por cuenta de su libertad) & 387,375 \\
\hline $28 / 07 / 1857$ & Agostina Reinoso (por resto de su libertad) & 62,625 \\
$19 / 02 / 1858$ & Valentina Martinez (por libertad del feto) & 25,000 \\
\cline { 2 - 3 } $31 / 08 / 1858$ & María Aragon (por libertad del feto, de su hijo) & 100,000 \\
$30 / 10 / 1858$ & Blas Gagigal (por cuenta de la de su mujer Teresa & 216,000 \\
$30 / 10 / 1858$ & Trevejos) & 360,000 \\
\hline
\end{tabular}

${ }^{635}$ Expediente promovido por la negra Asunción Carambot, esclava del ingenio Baracoa, sobre su libertad. 1859, ANC, Miscelánea de Expedientes, leg. 3591 Letra Av. 


\begin{tabular}{|c|c|c|}
\cline { 2 - 3 } $08 / 11 / 1858$ & María Taboada (por la de su hijo Saturnino & 400,000 \\
\hline $08 / 11 / 1858$ & Matemayor) & 350,000 \\
\cline { 2 - 3 } $08 / 11 / 1858$ & Joaquin Lozano (por su libertad) & 306,000 \\
$30 / 11 / 1858$ & Angel Belén (por cuenta de su libertad) & 194,000 \\
\hline $30 / 11 / 1858$ & Valentina Martinez (por su coartación) & 100,000 \\
\cline { 2 - 3 } $30 / 11 / 1858$ & Valentina Martinez (por su venta a Da María de Regla & 200,000 \\
\hline $22 / 12 / 1858$ & Polanco) & 150,000 \\
\hline $08 / 04 / 1859$ & Asunción Caramabot (por cuenta de su libertad) & 50,000 \\
\hline $12 / 04 / 1859$ & $\begin{array}{c}\text { Blas Gagigal (por libertad de Lazaro José, hijo de } \\
\text { Tereza Trevejos, esclava del mismo ingenio) }\end{array}$ & 50,000 \\
\hline & Asunción Caramabot (por cuenta de su libertad) & $3.791,000$ \\
\hline
\end{tabular}

Fonte ${ }^{636}$ : Miscelánea de Expedientes. Legajo 3591 Letra Av

Como é possível observar, apesar de toda a reclamação do Bispo, apenas 13 escravos (9 mulheres e 4 homens), de uma dotação de mais de 180, conseguiram efetuar pagamentos em prol de sua liberdade. Ainda assim, é possível sustentar que a situação desta finca era excepcional. Caso este fosse o padrão seguido pelas grandes haciendas cubanas, o sentido da prática da alforria e da coartação na dinâmica das relações produtivas teria sido substancialmente distinto do que foi impactando diretamente a estabilidade das forças produtivas. O fato é que a administração dos escravos nas grandes plantações cubanas, na era da segunda escravidão, vedou taxas de liberações graduais ou imediatas compatíveis com esta ilustrada pelo ingenio Barracoa.

De volta ao contexto urbano, cabe abordar outro aspecto que fazia parte daquela realidade, a exploração sexual. Em 18 de dezembro de 1863, um informe da Comisaria de Policia do primeiro distrito de Havana relata que durante uma averiguação no Hospital de Paula foi encontrada a escrava parda Leonor Dufan, de 19 anos de idade, natural da Guiana, que havia tentado suicídio anos atrás. Ao ser interrogado por particulares, disse ter sido vendida por D. José Briones, cura de Guanajay, a uma "mulher pública” chamada Magdalena Garambau. Então, quando tinha apenas 14 anos de idade, foi instalada na "vida pública",

\footnotetext{
"aburrida de su existencia por ejercitarse en una vida que no le convenía, a principio de nov. de 1859, salió de la casa de su ama y dirigiéndose a la Alameda de Paula se arrojo al agua con intención de suicidarse, lo que no pudo verificar porque la ropa que vestía la sostuvo sobre el agua y al pasar unos negros en una lancha, la recogieron y la presentaron al Celador de Casa Blanca" ${ }^{637}$.
}

\footnotetext{
${ }^{636}$ Agradeço ao historiador Breno Aparecido Servidone Moreno pela formatação deste quadro.

${ }^{637}$ El sr. Regidor Síndico segundo del Excmo Ayuntamiento de esta ciudad en representación de la esclava Leonor Dalfan, contra da. Rosa Constans para que por esta se otorgue carta de libertad a la espresada sierva, 1864, ANC, Escribanías (Vergel), leg. 124, exp 7.
} 
Daí, então, foi levada para aquele mesmo hospital, onde estava havia permanecido cerca de um ano e meio. Com aporte judicial, ela tinha conseguido transferir-se de amo, passando para o poder de Guilhermo García, morador da Plaza Vieja, onde tinha uma loja de roupas. García, por sua vez, a transferiu para D. José Vargas, que havia se mudado para Matanzas. O problema todo foi que aqueles dois indivíduos nunca teriam se servido de Leonor, havendo entrado em acordo com Magdalena, que continuou durante todo o tempo a tendo como meretriz. Por fim, em 20 de fevereiro de 1861, Leonor fora vendida a uma outra senhora chamada Rosa Constant, que declarou na escritura de compra que lhe daria a liberdade após três anos de serviços prestados (consta do processo cópia do recibo com os termos da alforria após o período mencionado). A pobre Leonor imaginava que seria encaminhada ao serviço doméstico, mas também D. Rosa tinha uma casa de meretrizes na Rua Villegas, perto da Obispo, explorando-a da mesma maneira, se apoderando de todo o seu dinheiro. Diante de toda a história, o subcomissário encaminhou a escrava ao síndico, que, por sua vez, encaminhou uma representação ao Alcalde Mayor ressaltando, além do cumprimento da condição estipulada, a questão da exploração sexual de Leonor, que, conforme a Lei 4, tit, 22, Partida IV, já configurava causa de alforria, suplicando a condenação de Rosa Constant à perda do domínio de Leonor, com a correspondente outorga da carta de liberdade, e ao pagamento das custas. Em 31 de maio de 1864, o magistrado deu sentença favorável à liberdade ${ }^{638}$.

Ao longo do trabalho, foi enfatizada a importância da apresentação de documentos escritos e de preferência registrados para a comprovação das intenções em torno da liberdade. Mas é possível encontrar situações nas quais provas testemunhais bem circunstanciadas compreendidas como satisfatórias pelo judiciário. Em 21 de outubro de 1864, Dolorez Sanchez, moradora da rua do Consulado, n. 4, havia vendido para Leonor Font, moradora do terceiro distrito de Havana, uma negra criolla chamada Encarnación, de 29 anos de idade, lavadeira e cozinheira pela quantia de mil pesos. Tempos mais tarde, na frente de dez testemunhas reconhecidas, D. Leonor havia concedido a liberdade a Encarnación, encarregando seu marido, D. Rosendo Rodriguez, da outorga da escritura de ahorro. Com base nisto, o síndico Antonio Gonzalez de Mendonza ajuizou uma ação para o reconhecimento de sua liberdade, que estava sendo obstado por D. Narciso Font, pai de Leonor, que havia falecido. Base legal de suas alegações foi extraída da Lei $1^{\mathrm{a}}$, tit, 22, Partida IV, que previa ser possível conceder a manumissão "en iglesia o fuera della, o delante Del juez, o en otra parte, o en testamento, o 
sin testamento, o por carta", diante de ao menos 5 testemunhas ${ }^{639}$. Ao final, ouvidas as partes, realizados os interrogatórios, em 19 de setembro de 1868, o ex-síndico, Ramon de Armas, que havia se tornado Alcalde Mayor, emitiu a seguinte sentença:

\begin{abstract}
"Considerando que si en el ánimo judicial abrase alguna duda sobre la eficacia de la manumisión, esa duda habría de resorberse en sentido afirmativo por que según la regla primera y segunda del título 34, Partida VII el jugador debe ayudar a la libertad que es amiga de la natura y la servidumbre es cosa que aborrecen amesna naturalmente: estando además declarada en la ley primera título 21 Partida IV que la servidumbre es postura contra razón de natura. Vistas las leyes citadas definitivamente juzgado declaro con lugar la demanda y condeno a d. Narcizo Font a que reconozca el estado de libertad de la morena Encarnación criolla y otorgue a esta su carta de ahorro como heredero de su legítima hija da. Leonor imponiéndole el integro pago de las costas al mencionado d. Narciso. Así mandó y firmo el Sr. Alcalde Mayor del distrito de Guadalupe de que doy fe" ${ }^{\prime 640}$.
\end{abstract}

Além da vitória de Encarnación, é relevante destacar o caráter prolixo da sentença. Sentenças com esse tipo de elaboração mais extensa são raras até fins da década de 1850 . Foi com a crescente especialização das magistraturas que este tipo de arrazoado passou a emanar da pena dos juízes. Também, é possível notar certa inclinação do juiz à causa da liberdade, à qual ficará ainda mais evidente na parte final do capítulo. No entanto, impossível situar a postura de Ramon de Armas a uma inclinação geral das sentenças cubanas em favor da liberdade dos escravos litigantes, ao contrário do que se viu no Brasil. Os dados disponíveis, levantados, em especial, pelos estudos de Perera \& Meriño dão conta de que o quadro estatístico das sentenças permaneceu estático ao longo do tempo, o que se conjugou a uma diminuição volumétrica na abertura de ações judicias nos anos 1860, justamente quando houve acréscimos no Império brasileiro. Talvez seja possível explicar este contraste atribuir a inexistência em Cuba de um movimento crescente de contestação da ordem escravocrata que se espraiou pelas malhas dos tribunais, como o que houve no Brasil. Inexistência esta bastante associada ao contexto de guerra pela independência, que polarizou o ocidente, escravista, ao oriente abolicionista, como será retomado no epílogo da tese ${ }^{641}$.

\footnotetext{
${ }^{639}$ Lucena Salmoral. "Leyes para esclavos: el ordenamiento jurídico sobre la condición,...”, p.22.

${ }^{640}$ El síndico primero de Exmo Ayuntamiento contra d. Narciso Font para que reconozca y declare la libertad de la morena Encarnación,1869, (ANC), Archivo de Manuel Barreto, leg. 265, exp.69.

${ }^{641}$ Aisnara Perera \& María de los Angeles Meriño. Estrategias de libertad: un acercamiento a las acciones legales de los esclavos en Cuba (1762-1872). No prelo, versão cedida pelas autoras.
} 


\section{Coartação e os direitos dos escravos no debate jurídico cubano}

A percepção a respeito dos preceitos legais que balizavam as reclamações judiciais não foi tão uniforme quando se pode supor. De fato, o direito positivo vigente em Cuba, menos dependente do direito subsidiário do que o brasileiro abria uma margem comparativamente mais estreita para interpretações dissonantes ou adaptações. Por conta da relativa simetria entre lei e costume, a citação de textos legais e jurídicos nos arrazoados constantes das ações era bastante esporádica e, muitas vezes, inexistente. Como já apontado, a campeã de citações continuou sendo, talvez por desconhecimento dos outros textos normativos, as Siete Partidas, inclusive após a edição do Reglamento de 1842, que converteu também a coartación em um direito legal dos escravos cubanos. A apresentação dos 50 pesos, com o movimento inflacionário da década de 1850 , se tornaria cada vez menos complicado, representando, muitas vezes, um desafio, se não à autoridade senhorial, em termos sistêmicos, ao controle de muitos senhores sobre seus cativos, gerando uma condição social diferenciada, intermediária entre escravos inteiros e livres, apesar da previsão legal a respeito da equiparação de inteiros e coartados na condição de escravidão. Como destaca o historiador Alejandro de la Fuente, em 1853 chegou a ser montada uma Comissão Revisora na Audiência de Havana para modificar, em especial os artigos 34 (“ningún amo podrá resistirse a coartar sus esclavos, siempre que se le exhiban al menos cincuenta pesos a cuenta de su precio") e 35 (“los esclavos coartados no podrán ser vendidos en más precio que el que se les hubiere fijado en su última coartación, y con esta condición pasarán de comprador a comprador") ${ }^{642}$. Recomendações de reforma foram enviadas ao Governador, que acusou o seu recebimento, mas a deliberação sobre o assunto foi transferida para um momento posterior, que nunca chegaria ${ }^{643}$. Pouco mais tarde, haveria uma intensa discussão jurídica a respeito das prerrogativas atinentes à condição dos coartados.

No dia 2 de novembro de 1856, o influente jornal cubano Diario de la Marina, sediado em Havana, publicou uma comunicação enviada por Juan Antonio Olavarría, de Santiago de Cuba, com algumas ponderações sobre a coartação e a venda de escravos. Com a epígrafe Cuestión local, o autor começava por advertir os leitores de que, como seria de se supor, o artigo não ía tratar de temas candentes à época como a expansão de ferrocarriles ou barcos a vapor. O título devia-se, antes, à frequência incomparável em sua cidade da coartación e da venta obrigatoria “cada vez que estos quieren y sin mas motivo que su voluntad". O primeiro ponto realçado foi o da subestimação dos preços avaliados pelos peritos indicados pelos

\footnotetext{
${ }^{642}$ Lucena Salmoral. "Leyes para esclavos: el ordenamiento jurídico sobre la condición,...”, p.1262.

${ }^{643}$ De la Fuente. "Slaves and the Creation of Legal Rights in Cuba: Coartación and Papel"..., pp.35-36.
} 
síndicos. Segundo ele, conforme o $2 \S$ art. 32 do Reglamento de 1842 havia determinado, as avaliações deveriam ser efetuadas por peritos de notória honradez, preferencialmente, indivíduos que reunissem a circunstância de serem, em escala maior, donos de escravos, compradores e vendedores frequentes ${ }^{644}$, por serem capazes de julgar com maior precisão o preço atualizado daquela "clase de propriedad". Mas, "por desgracia", esta orientação estaria sendo frustrada em sua cidade, pois, enquanto que os senhores procuravam indicar pessoas idôneas, os síndicos nem sempre atuavam dessa forma, ocasionando a nomeação de um terceiro perito, o qual, via de regra, "por sanos o pecaminosos motivos", parecia interessado em dar o melhor possível aos escravos, "de lo cual con lastimosa repeticón resulta que un criado comprado muy poco antes por cierta suma es tasado para su coartación en un importe considerablemente inferior cuando ese esclavo si se pusiera em venta pública en el mismo dia en que es coartado alcanzaría e un precio muy superior al que ha recibido para su coartación". Para entender o teor desta argumentação é preciso observar que vender um coartado era mais proveitoso ao dono do que libertá-lo pelo preço estipulado. Embora o artigo 35 do Reglamento de Valdés previsse a inalterbilidade do contrato original, o estudo de Bergard, Fe Iglesias \& María Del Carmen Barcia revela que a demanda de trabalho, especialmente o feminino em áreas urbanas, foi tão grandes que muitos compradores se mostraram dispostos a pagar preços pelos coartados maiores do que o restante para a libertação, o que denota a perspectiva de uma manutenção no cativeiro suficientemente longa a ponto de justificar o investimento maior do que o recebido na eventual compra da alforria. Como o preço do coartado era sempre menor, em termos nominais, do que um inteiro em condições semelhantes, a aquisição tendia a ser um ótimo negócio ${ }^{645}$. O que estava por trás da reclamação de Olavarría, conectada à suposta falta de alinhamento ético dos peritos com os interesses da classe senhorial, era a incorporação do preço de mercado dos coartados à avaliação judicial.

Olavarría seguiu sustentando que o prejuízo sofrido pelos donos de escravos era agravado por uma interpretação equivocada realizada por parte dos síndicos do Ayuntamiento de Santiago sobre o artigo 35 do Reglamento, que consistia "en que los síndicos opinan que según su contexto todo siervo coartado tiene derecho a ser vendido obligatoriamente por su sola voluntad, y sin que existan los motivos que el artigo 32 explica". Esta forma de ver a referida disposição teria dado vazão ao "deploravel abuso que diariamente palpamos y que justamente indigna a las gentes de ánimo recto, de que cualquier individuo poco delicado que

\footnotetext{
${ }^{644}$ Isto o autor acrescenta livremente: não consta da normativa. Ver: Lucena Salmoral. "Leyes para esclavos: el ordenamiento jurídico sobre la condición,...”, p.1261.

${ }^{645}$ Bergard, Iglesias \& Barcia. The Cuban Slave Market, 1790-1880, pp.125-128.
} 
desea hacerse de un criado que le conviene, y que de otra manera no podría adquirir, lo seduce dándole cincuenta pesos para su coartación”. Daí, então, o escravo pedia para ser vendido, intervindo o síndico a seu favor caso o amo se recusasse, consequentemente, a alienação acabava acontecendo e, por vezes, a um preço muito inferior ao que havia pagado pouco tempo antes. Assentado este princípio de ser justo obrigar o amo à venda de um escravo coartado, e admitindo-se a sua legalidade, prosseguia o autor, “Habrá quien desconozca que ese mismo principio pode hacerse extensivo a la dotación entera de un ingenio?". O terrorismo embutido na fala era claro: era preciso cortar o mal pela raiz antes que aquela prática passasse da cidade ao campo, afetando a estabilidade da produção açucareira, com possíveis atos predatórios entre vecinos desejosos de usurpar os escravos dos outros. A consumação desse preceito seria um evidente atentado contra a propriedade, "y de más latitude de lo que a primera vista parece, porque no solo implicaria una injustificable enagenación forzosa de los si de los siervos sino que acarretaria al hacendado la pérdida casi total del fundo, con sus establecimentos y máquinas por la introvertible razón de que una hacienda sin brzos nada puede producir. Un ingenio sin negros es un cuerpo sin alma". A nos fiarmos em tais assertivas alarmistas poderíamos assumir um efeito destrutivo da coartação que ela, de fato, nunca teve. A jurisdição de Santiago de Cuba não é contemplada pela presente investigação, mas os dados disponíveis dão conta de que $3 / 4$ de todas as transações envolvendo coartados ocorreram em Havana. Portanto, há diversos exageros nessa fala. Mesmo assim, interessa acompanhar o desfecho do argumento. $\mathrm{O}$ autor chegou mesmo a especular se não tocava aos síndicos o pensamento de menoscabar ou mesmo destruir a propriedade escrava. Se não fosse o caso, deveriam imediatamente retificar sua conduta, atentando para a real intenção do legislador, que de modo algum passava pela venda forçosa dos escravos sem motivo grave. A missão dos síndicos seria tão somente a de proteger os escravos contra a sevícia e fazer com que lhes fosse admitido o preço de sua liberdade quando tivessem o suficiente para adquiri-la, ou a soma de que dispusessem, não baixando o patamar mínimo de 50 pesos para a sua coartação. Afora isto, os coartados deveriam ser tratados como os escravos inteiros, não cabendo a eles nenhum direito a mais, como o de serem vendidos somente por sua vontade. Por fim, acrescenta que, ao contrário do que colocavam alguns indivíduos, o ofício conhecido pelos escravos deveria ser considerado no ato da avaliação, inclusive quando o objetivo era a promoção da liberdade: "opinamos que en los casos de libertad debería conciliarse la consideración de humanidad que de debe con el respecto a que es atendible el interés del dueño"646.

${ }^{646}$ Diario de la Marina: periódico oficial del apostero de la Habana, domingo, 2 de noviembre de 1856. 
Apenas pela natureza das assertivas feitas nesta colocação, a comunicação de Olavarría já valeria a menção. Ela deixa transparecer a existência de vertente reacionária instalada na sociedade cubana a respeito dos avanços da legislação sobre a escravidão. Seria necessária uma pesquisa à parte para comprovar as suas acusações sobre a inclinação antiescravista de síndicos e peritos de Santiago de Cuba. Mas, montados como estamos nos ombros do gigante do tempo, podemos dizer com segurança que seus temores mais drásticos não se verificaram. Afora esta reflexão, o interesse desse texto vem do fato dele ter suscitado uma polêmica entre pesospesados do direito havanês. O artigo chamou a atenção do notável intelectual, historiador, jurista, professor universitário, advogado formado pela Universidade de Havana em 1832, Antonio Bachiller y Morales, que desempenhava a função de síndico procurador àquela altura $^{647}$.

No dia 6 de novembro, veio a lume no mesmo Diario de la Marina o comentário de Bachiller y Morales sobre o texto publicado no dia 2:

\footnotetext{
"Acerca del interesante asunto tratado en la comunicación que remitida desde Santiago de Cuba publicamos ultimamente se nos ha favorecido por el distinguido escritor sr. Bachiller y Marales con el artículo que publicamos a continuación y que en nuestro humilde entender no deja lugar a duda alguna a lo prescrito en nuestre legislación”648.
}

Com o título Esclavos coartados - venta - Libertad, o advogado começou por assinalar que as disposições vigentes sobre negros coartados, inalteradas pelo Reglamento de escravos que fez parte do Bando de Polícia y Gobernación de 1842, resolviam todas as indagações colocadas por Juan Antonio Olavarría. Todavia, acusava haver, sim, uma prática incongruente com o quadro legal, "y que el negro coartado se cree hábil para pedir licencia y obtenerla obligatoria para ganar jornal". Era preciso, portanto, que a autoridade constituída tornasse a lei eficaz. Para não deixa dúvidas, se por a responder tópico a tópico.

Primeiro, podia o negro coartado pedir novo amo sem motivo?

A Real Cédula de 27 de setembro de 1769 havia declarado de forma peremptória que o escravo coartado não podia variar de amo sem a vontade deste e a Real cédula de 8 de abril de

\footnotetext{
${ }^{647}$ Para algunas obras de Bachiller Y Morales, ver: Prontuario de agricultura para el uso de los labradores y hacendados de la Isla de Cuba. La Habana: Imprenta de Baruni, 1856; Elementos de filosofía del Derecho o curso de Derecho natural. La Habana: Imprenta del Tiempo, 1857; 1859-1861: Apuntes para la Historia de las Letras y de la Instrucción Pública en la isla de Cuba. La Habana: Imprenta de P. Massana, 1861; 1883: Cuba primitiva. Origen, lenguas, tradiciones e historia de los Indios de las Antillas Mayores y las Lucayas. La Habana: Librería de M. de Villa, 1883; Cuba: Monografía histórica sobre la pérdida de La Habana hasta la Restauración Española. La Habana: Librería de M. de Villa, 1883; Los negros. Barcelona: Gorgas y Compañía, 1887.

${ }^{648}$ Diario de la Marina: periódico oficial del apostero de la Habana, jueves, 6 de noviembre de 1856.
} 
1788, dirigida à Real Audiência de Santo Domingo, continha em seu preâmbulo a repetição de todas as práticas abusivas que hodiernamente se lamentavam e a sua reprovação.

"He aquí sus disposiciones que presento en la forma de artículos para más claridad:

- Los dueños pueden vender sus esclavos no coartados en lo que quisieren y los estimaren.

- Cuando se les obligue a venderlos por justicia se tasarán judicialmente por lo que valgan en la actualidad.

- Aun en ese caso, en que es obligatoria la venta, si encuentran comprador por un precio estimativo podrán venderlo sin tasación, sin que sea licito a la justicia impedirlo, sino en el caso de perjudicarse el derecho de la alcabala con lo ecsiguo del precio.

- En todos estos casos paga el vendedor la alcabala del esclavo.

- En el caso de que el esclavo coartado se enagene por causa suya puede el amo agregar el precio de la alcabala a su coartación y pasa al comprador con ese aumento.

- El dueño está obligado a dar la libertad al esclavo tan pronto como le entregue su precio, adquirido por medios lícitos, sin pagar alcabala.

- El coartado que se enajena solo paga alcabala de la diferencia de precio por que permanezca esclavo"649.

Bachiller y Morales claramente reproduzia este sumário da cédula de 1778 a fim de ajudar na orientação da aplicação do direito concernente àqueles pontos, indicando como falha de José María Zamora não haver incluído estas disposições em sua Biblioteca de Legislación Ultramarina (1844-46), colocando apenas uma rápida menção à última cédula sobre a cobrança da alcabala. A lacuna na principal obra de referência, aliada à inexistência de coleções completas sobre as numerosas disposições locais, estaria contribuindo para que os tribunais inferiores não estivessem sempre afinados à legislação, a qual, segundo o autor, soubera conciliares preceitos humanitários aos direitos de propriedade. Por fim, acresceu que ao esquecimento dos princípios consagrados pela sanção das leis contribuiu o que ele chamou de escuela sentimentalista que teria se apoderado da legislação no século anterior. Os escravos das colônias espanholas teriam sido os mais felizes entre seus pares, sendo inúteis as declarações que os escritores europeus lançavam contra o sistema haitiano. Para ilustrar o seu ponto, reproduziu uma frase de Thomas Madiou: "en la colonia española la esclavitud era dulce y el negro un criado que hacia parte de la familia" ${ }^{650}$. Por essa explicação, a lassidão na

\footnotetext{
${ }^{649}$ Diario de la Marina: periódico oficial del apostero de la Habana, jueves, 6 de noviembre de 1856. ${ }^{650}$ A obra em questão é: Thomas Madiou. Histoire d'Haiti. Porto Príncipe: J. Courtois, 1848.
} 
administração da justiça oitocentista era filha de uma época idílica da escravidão hispanoamericana, que teria contaminado todo o ordenamento jurídico e a prática dos tribunais ${ }^{651}$.

O que deveria ser uma palavra de autoridade para encerrar a discussão ascendeu o debate entre os juristas mais notáveis de Havana. Do Diario de la Marina, a discussão ocupou várias páginas da edição de 1856 da Revista de Jurisprudencia, periódico cubano especializado no qual eram reproduzidos textos legais comentados, trechos de processos judiciais de diferentes ramos, posicionamentos jurisprudenciais e discussões doutrinárias diversas. Em resposta a Juan A. Olavarría e a Bachiller y Morales, o jurista José Ignacio Rodriguez, um dos redatores da revista, escreveu um artigo, o primeiro inserido em uma série aberta no interior do volume, La coartación y SUS efectos, apresentando uma visão oposta. Segundo ele, era ponto pacífico a avaliação de que a legislação espanhola tinha supremacia em relação à de outros países com relação ao tema da escravidão,

\begin{abstract}
"porque, en efecto, ninguna tan adelantada como ella, ha sabido aplicar tanto los dogmas salvadores del cristianismo, ni ninguna tampoco ha sabido hermanar mejor que ella los principios humanitarios y de justicia, con las exigencias nunca satisfechas por desgracias del interés individual. En armonía con el sistema legal, nuestras costumbres, (y tenemos un justo y santo orgullo en consignarlo así) son sin duda las que, en materias de esclavitud, han llevado la humanidad y beneficencia hasta el punto que era posible se llevasen"652.
\end{abstract}

Como é possível facilmente depreender, enquanto os antagonistas, mormente Bachiller y Morales, viam defeito na compleição do quadro jurídico espanhol, Rodriguez assumia a linha tradicional daqueles que identificavam na confluência entre legislação e costume com vistas ao equilíbrio entre "princípios humanitários" (direito dos escravos) e interesses privados (exigências dos amos) um ponto fundamental para a administração da justiça e a manutenção ordem social em terras espanholas. Entre os direitos dos escravos, um dos mais importantes seria, sem dúvida, o conhecido pelo nome de coartación:

\footnotetext{
"Mediante una suma, de cincuenta pesos, por lo menos, el esclavo coarta el dominio de su amo sobre él: le coarta la libertad de ponerle precio, antes tan ilimitada y a su arbitrio, como la de exigir por cualquiera propiedad suya la paga o estimación que mejor le agradare. La coartación fija un limite al valor del esclavo, limite que es un barrera insuperable, y a la vez, un comienzo de libertad o una esperanza positiva de que su suerte no es enteramente irrevocable y sin remedio" 653 .
}

Por esta interpretação, a coartação cubana representava bem mais do que a amortização gradual do preço correspondente à liberdade: tratava-se de uma restrição direta ao domínio

${ }^{651}$ Diario de la Marina: periódico oficial del apostero de la Habana, jueves, 6 de noviembre de 1856.

652 José Ignacio Rodriguez. "La coartación y sus efectos", in: Revista de Jurisprudencia: ciencia, literatura y variedades, t.I. Havana: Imprenta de Spencer y Cia, 1856, pp.353-364.

${ }^{653}$ Grifo meu. Idem, ibidem. 
senhorial, que era embarreirado pelos limites impostos pela nova condição, em especial no tocante à estipulação do preço; pela ótica dos escravos, seria um dado positivo, um estímulo diante da expectativa de remissão do cativeiro. Segundo Rodriguez, enganavam-se quem via no Reglamento de 1842 a origem daquela instituição "caritativa y dignísima". A coartação e todos seus efeitos seriam conhecidos na América desde os primeiros tempos da colonização e comuns a todas as províncias espanholas onde houve escravidão, sempre com a aprovação dos governos locais, como o de Valdés. O seu regulamento, portanto, não teria constituído nenhuma novidade $^{654}$.

Dito isso, buscou dialogar mais diretamente com o artigo de Bachiller y Morales, observando que, ao contrário do que afirmou o síndico, o coartado não continuava na mesma condição que o escravo inteiro. Dizer isso seria um engano tremendo, que estava na base de todos os erros cometidos em torno da matéria. Rodriguez insistia que o escravo coartado não era tão escravo quanto o inteiro porque o domínio do senhor perdia sua plenitude, passando a enumerar três diferenças básicas. $1^{\mathrm{a}}$ ) $\mathrm{O}$ escravo coartado não representava um valor sujeito ao capricho de seu amo e às varrições do mercado; ele assumia um preço fixo, imutável diante de variações de abundância e escassez. $2^{\mathrm{a}}$ ) $\mathrm{O}$ amo do escravo inteiro podia receber todos os proventos do seu trabalho, já o senhor de um coartado tinha esse direito limitado a uma fração dos jornais, costumeiramente estimada em 39\% anuais ou 1 real forte a cada 100 pesos arrecadados por dia. $3^{\mathrm{a}}$ ) O domínio sobre o inteiro era pleníssimo, regido pelas leis gerais sobre a propriedade perfeita e exclusiva, enquanto que o domínio sobre o coartado era limitado, regendo-se por um enquadramento específico, correspondente a uma propriedade pertencente a dois senhores. Ninguém duvidava nem por um instante, segundo Rodriguez, de que o senhor podia dispor e usufruir apenas da parcela pela qual o escravo estava coartado. O restante, já compensado, pertencia ao próprio escravo. Em síntese, na coartação, o amo seria coproprietário junto com o escravo. Portanto, esta seria uma condição média, “que supo hallar y estabelecer la mano poderosa de la civilización Cristiana entre la servidumbre y la libertad"655.

Diante da tese da copropriedade e das demais diferenças pontuadas, o autor recolocou a questão sobre se seria legal a alienação forçosa do escravo. Como é possível depreender, diferentemente de Bachiller y Morales, Rodriguez cria que sim. Para este, tratava-se de um sofisma dizer que a imposição da venda pela vontade do coartado derivava de uma má interpretação do artigo 35 do Reglamento de esclavos cunhado com o objetivo de reformar a

\footnotetext{
${ }^{654}$ Em verdade, o Reglamento de Valdés foi a primeira norma a instituir o direito à coartación. Lucena Salmoral. "Leyes para esclavos: el ordenamiento jurídico sobre la condición,...”, pp.275-287.

${ }^{655}$ Rodriguez. "La coartación y sus efectos”, p.356.
} 
legislação em proveito dos proprietários: "la ley no está mal interpretada, ni los síndicos se equivocan al entenderla como la entienden. La ley es clara". O caso de venda sem justo motivo (maus tratos) estava expressamente previsto no artigo, não havia o que mal interpretar. Quando o senhor não cumpria com seus deveres, era castigado pelos termos do capítulo 32, com a obrigação da venda. Mas, o artigo 35 previa que, mesmo quando o amo cumpria com seus deveres, o escravo tinha o direito de se alienar a contrapelo, sem alegar justo motivo, algo que, pelo observado, estava conforme, inclusive, com a propriedade senhorial, já que havia uma indenização de $6 \%$ correspondente o valor da alcabala. Ademais, acrescentava que isto era socialmente salutar, posto que não havia um só senhor de escravos, dotado de mediana sensatez, que não considerasse uma calamidade servir-se de um escravo, "que no está a gusto", como se disse em "nuestra lenguage familiar" 656 .

As relações domésticas, seguia, estavam baseadas em certa espécie de harmonia entre o senhor e seus escravos, sem a qual a disciplina era relaxada e se abria espaço para o conflito, o mal serviço, as fugas e as conspirações. As reprimendas e os castigos não serviam para nada além de atacar os sintomas, sem curar as causas. A Lei estava para prevenir esta situação, e por isso havia consentido no direito de que o escravo pudesse mudar de amo ao seu gosto, o que acabava sendo benéfico também para o senhor malquisto, que teria em seu poder um escravo laborioso, empenhando em reunir, por meios lícitos e honestos, ao menos os 50 pesos necessários para se coartar e buscar novo domínio. A própria prática se encarregava, conforme o autor, de pôr freio a abusos nas trocas de amo, visto que sucedia de um coartado acumular sobre si 4 ou 5 alcabalas e outros tantos encargos com escrituras que distanciavam o sonho da liberdade. Sobre os abusos descritos quanto à tasación dos escravos, indicou que o texto do Reglamento quanto a este tópico nada tinha de abusivo ou atentatório: a avaliação seria feita por um perito nomeado pela parte do escravo e outro pela parte do senhor, cabendo a um terceiro decidir em caso de divergência. Os abusos cometidos pelos avaliadores designados podiam porventura ser corrigidos com novas regras para o procedimento, mas a existência de três peritos já existia para amainar os desvios. Não haveria motivo forte o suficiente para se alterar a legislação vigente.

O articulista de Santiago supunha, observou Rodriguez, que a tasación devia ser feita por proprietários em grande escala, o que era outro equívoco, já que os grandes proprietários adquiriam escravos com menor frequência e dificilmente vendiam os que possuíam. Os únicos peritos realmente especializados seriam os traficantes, "clase que teme mucho ver la luz

\footnotetext{
${ }^{656}$ Pelo jeito, o senhor de Bernardo Lucumí, referido páginas atrás, não estava entre os medianamente sensatos. Rodriguez. "La coartación y sus efectos", p.357.
} 
pública, porque la civilización la repugna y rechaza" 657 . Por outro lado, os escravos não oscilavam tanto de preço como as demais mercadorias, sendo de conhecimento corrente o seu preço médio. Sobre o argumento de que somente se atendia ao físico dos escravos nas avaliações, sem tomar em conta os seus ofícios, Rodriguez apontou que o fundamento da queixa era também inexato quanto a este particular, visto que a sua eventual desconsideração das habilidades dos escravos não era culpa dos síndicos nem da Lei. Além do que, não eram raros também os casos de haverem avalições elevadíssimas, acima do preço de mercado. Por isso, a suposição de que em vendas públicas os escravos alcançavam preço maior seria outro sofisma. As avaliações envolvendo escravos estavam tão sujeitas a variações assim como toda espécie de propriedade. A respeito da sedução promovida por vecinos que, desejosos de escravos alheios, entregavam a eles os 50 pesos para sua coartação, esperando uma avaliação subestimada para então adquiri-los, respondeu que a condição para a aceitação do dinheiro era a sua origem lícita. Portanto, que os amos não se descuidassem da averiguação da procedência do valor apresentado. Sobre o perigo da coartación para as dotações do ingenios, o autor rebateu argumentando que

\begin{abstract}
"La coartación es casi inútil en las fincas. De hecho, casi nunca se practica. Muy pocas son las fincas que tengan coartado algún esclavo entre los que componen su dotación. Y eso sucede, porque en primer lugar la suerte de los esclavos del campo, es casi la misma en todas fincas, pues en todas rige poco más o menos una misma disciplina y eso hace que poco les importe el derecho de cambiar de dueño. Además todos sabemos, que estando completamente incomunicados los esclavos de una finca con los de otra, por virtud del régimen establecido, pocas ocasiones se presentaran al esclavo para restablecer comparaciones, y esperar un mejora con el cambio. En segundo lugar, el derecho de disponer para si de una parte de su trabajo, es ilusorio en un esclavo de campo coartado, porque en las tareas agrícolas no hay salario, ni jornal, y el trabajo es común y siempre el mismo. Una tercera consideración, y la más importante, para hacer la coartación un fenómeno rarísimo en los campos, hay que buscarla en el sin número de relaciones de afecto, que se engendran entre el esclavo desgraciado y la tierra testigo de sus padecimientos. [...]: así el esclavo siente profundo cariño por aquella naturaleza en que vive, se apega a la tierra con quien está en íntima relación y quiere con afecto entrañable la choza en que se abriga y el conuco, que es su parque y su dominio $[\ldots]^{3658}$.
\end{abstract}

Portanto, a coartación era um fenômeno urbano por excelência e, nos raros casos em que ocorria no campo, era altamente positiva para o contexto, já que resultava de um empenho extraordinário e afetivo dos escravos no cultivo de seus conucos. Mas, supondo o contrário, não haveria vantagem alguma para um grande hacendado coartar uma dotação inteira para adquirir trabalhadores com preço fixo e com domínio limitado.

Em resumo, Rodriguez reafirmava taxativamente que a coartação dos escravos, conforme estabelecido pelas leis vigentes, era um fato consagrado pelo tempo, eminentemente

\footnotetext{
${ }^{657}$ Idem, p.359.

${ }^{658}$ Rodriguez. "La coartación y sus efectos”, p.361.
} 
sábio e filosófico. Esta prática, assim como a alienação forçosa, produzia os males repetidos e exagerados pelos interlocutores. A legislação havia posto remédio para tudo, em um perfeito equilíbrio entre a justiça e as devidas considerações à propriedade ${ }^{659}$.

$\mathrm{Na}$ sequência, outro redator da revista, D. Nicolas Azcárate também tomou parte no debate, sustentando que a voz de autoridade de Bachiller y Morales, "nuestro amigo y maestro, no nos convence ahora, como nos ha convencido casi siempre", ao dizer que havia legislação proibindo o costume da variação de dono por parte dos coartados. Após reproduzir a parte principal do artigo publicado no dia 6 de novembro no Diario de la Marina, Azcárate afirmou haver lhe causado espécie a menção do Reglamento apenas para dizer que não derrogava as disposições anteriores. No entanto, destoando de Rodriguez, afirmava que o artigo 35 daquele regulamento era o único que discernia com clareza e precisão o ponto questionado, o que seria entendimento corrente entre os síndicos e entre os tribunais da ilha. Para ele, não cabia reformar o quadro normativo estabelecido em 1842, que nada tinha feito além de confirmar o costume cubano, costume que, segundo sua visão, precedia a lei como fonte do direito dos coartados, sendo, ademais, reconhecido pelos proprietários de escravos em geral, grandes, médios e pequenos. Por isso, não deveria ser levada em consideração a voz histérica de meia dúzia de indivíduos, que, ávidos por defenderem os interesses escravocratas, deixando-se levar perigosamente por casos excepcionais, tornavam-se, em verdade, os piores inimigos de sua classe $^{660}$. Em seguida, Azcárate ponderou que o sentimentalismo ridicularizado por Bachiller inebriador das ideias nacionais sobre as questões de escravidão; argumento principal na voz daqueles que pediam reformas na legislação vigente, a fim de que fosse obstruído o direito dos coartados saírem do domínio indesejado - havia sido a salvação da escravidão cubana, garantindo aos espanhóis a possibilidade de obstruir os tratados que vedavam a continuidade do tráfico negreiro, permitindo o prolongamento do comércio com a África, mesmo depois de ele ter sido declarado desonroso.

\footnotetext{
"El sentimentalismo era en efecto el que hacia vencer la distancia y los peligros de la travesía, para ir a buscar salvajes que se mataban unos a otros y civilizarlos y educarlos: por un sentimentalismo exagerado se teme que esa facultad del esclavo coartado haga subir su valor a un precio fabuloso, en virtud del aumento de las alcabalas, e imposibilite su manumisión: por sentimentalismo seguramente se quiere que cediendo el infeliz a una seducción maligna, se exponga a mas recios trabajos y peores tratamientos. ¡Cuidado, sin embargo con la sensibilidad que puede engañarnos fácilmente! En esta parte estamos enteramente de acuerdo con Bachiller: somos utilitarios y egoístas: poco nos importa que unos a otros se devoren en su tierra: si por torpeza se cierran ellos mismos la puerta de su redención, paguen la culpa de su torpeza: sufran las consecuencias de la seducción los que se dejan engañar: nosotros solo pediremos
}

\footnotetext{
${ }^{659}$ Idem, p.362.

${ }^{660}$ Nicolas Azcárate. "La coartación y sus efectos", in: Revista de Jurisprudencia: ciencia, literatura y variedades, t.I. Havana: Imprenta de Spencer y Cia, 1856, p.363.
} 
siempre que se asegure la propiedad, en bases sólidas, prudentes y del mayor provecho posible para el amo, sin necesidad - que no la hay - de que sean inhumanas. Creemos que ningún tipo más acertado que la opinión sensata y general de los mismos amos, de los propietarios de esclavos, y esa opinión se ha expresado clara y terminantemente en la costumbre a que hemos hecho referencia, y cuya antigüedad es innegable" $" 661$.

Azcárate retoma nesta argumentação tecida com tom irônico o ideário que vinha justificando a continuidade da escravidão e do tráfico em território castelhano desde o final do século XVIII. O sentimentalismo, atacado por Bachiller y Morales, e enaltecido por ele, diria respeito à fórmula encontrada no interior do império espanhol para propiciar a civilização dos povos africanos na América em um regime seguro de propriedade e emprego da mão de obra escrava. Sobre a lacuna presente na obra de Zamora quanto à real cédula de 27 de setembro de 1769, argumentava que tampouco ela havia sido mencionada no livro de José Serapio Mojarrieta, Exposición sobre el origen, utilidad, prerrogativas, derechos y deberes de los síndicos procuradores generales de los pueblos $(1830)^{662}$, no qual o autor havia feito questão de criticar os abusos da coartação. Por isso, parecia muito estranho que um magistrado tão erudido não fizesse menção a uma norma que se encaixaria perfeitamente em seu argumento. Por fim, pontuava que o Real Acuerdo remetido em $1^{\circ}$ de setembro ao Governador Civil, tratando daquele assunto, também não fizera menção à dita cédula, que também era desconhecida dos síndicos ou os juízes em geral. Ele próprio, apesar dos seus esforços, não teria sido capaz de encontrá-la, duvidando que tenha passado em algum momento pela mente soberana a derrogação de tão geral e conveniente costume.

O que se sabia, pelo contrário, era que tinham sido reconhecidas um ano antes da suposta disposição, pela Real Cédula de 21 de junho de 1768, “disputas suscitadas en orden a la satisfacción de los derechos de alcabala nuevamente establecidos, que causa la venta voluntaria o involuntaria de esclavos coartados" ${ }^{\prime 63}$. Além do que, a segunda Real Cédula, a de 8 de abril de 1778, nada versava em sua parte expositiva contra ou a favor de um costume tão constante e universal quanto aquele. Por último, lembra que Gerónimo Valdés, apoiado por notáveis consultores, tinha pleno conhecimento de todas as circunstâncias que envolviam a prática da coartación. Portanto, o artigo 35 foi elaborado com pleno conhecimento de causa. Além do que, "nadie dudará que sus disposiciones, en buenos términos de derecho, son derogatorias de todas las anteriores que fuesen contrarias", ou seja, o teor da cédula de 1769 ,

\footnotetext{
${ }^{661}$ Grifo meu. Idem, p.363.

662 José Serapio Mojarrieta, Exposición sobre el origen, utilidad, prerrogativas, derechos y deberes de los síndicos..., op.cit.

${ }^{663}$ Conforme Azcárate, a cédula de 1768, sim, seria de conhecimento geral, já que inserida no verbete Alcabalas do Diccionario de Zamora. Cf. Zamora y Coronado. Biblioteca de Legislación Ultramarina. Madri: Imprenta de Alegría y Charlaín, 1844, T. I, pp.162-165.
} 
supondo a sua existência, teria, de qualquer forma, perdido a validade. Não haveria, portanto, "tal derecho desconocido: nuestros Síndicos y nuestros Tribunales saben bien lo que han hecho y la generalidad y antigüedad de la costumbre es la mejor garantía de su conveniencia" 664 . Em sua conclusão, fez uma espécie de homenagem crítica ao jurisconsulto antagonista, afirmando ser grande apreciador das conferências de sua cátedra e das explicações privadas das quais havia usufruído, chamando-lhe especial atenção a impugnação do princípio Benthamista ${ }^{665}$ da utilidade e a sustentação, "con la filosófica rectitud de ideias que le es característica", que a Justiça era e deveria ser o único fundamento da Lei. Portanto, "si el sr. Bachiller y Moralles y nosotros hubiésemos buscado la Justicia, habríamos seguramente seguido el mismo caminho; y defendido a uma voz y com el mismo entusiasmo el artículo 35 del Reglamento". 666

Evidentemente, Bachiller y Morales não deixou barato e apresentou a sua réplica, agradecendo com ar de superioridade amigos e discípulos pelo espaço cedido. Gastando algo de sua erudição, afirmou que não era seu ânimo tratar a questão como de direito constituinte e tampouco entrar em considerações econômicas e sociais. Como jurisconsulto,

\begin{abstract}
"Puesta la mano en el pecho he dicho: esta institución, tales deben de ser las consecuencias: no es cuestión ni de utilidad, ni de justicia; es la ley durísima de la necesidad, esa ley que tuvo Kant que aceptar en la confusión de los actos del derecho, para ser equitativos, ya que no justificados; y que tenemos que reconocer como un hecho consumado los que vemos en el orden y el respecto a la propiedad el fundamento de la prosperidad de los Estados" $" 667$.
\end{abstract}

Com esse seu pragmatismo liberal, Bachiller y Morales prosseguiu recordando, com certo escárnio, que a escravidão era uma criação do direito positivo que existia em Cuba. Ante esta constatação, o homem da lei devia buscar saber se havia alguma coisa que podia ser e não ser ao mesmo tempo. O escravo em venta real (os inteiros) e os coartados eram ambos escravos.

\begin{abstract}
"Lógica y legalmente es esclavo el que no tiene libertad civil: in servorum conditione nulla est differentia. Desde que se escribió la instituta del Emperador Justiniano fue proclamada esa verdad lógica, que tiene que ser fatal como toda ley intelectual o física, dos y dos tienen que ser cuatro; precisamente la esclavitud es la negación de la ley moral única en que cabe la infracción de la voluntad. El esclavo aun que varié de ocupación y sea más o menos llevadera su suerte, nemo tamen satatum, sen conditionem servilem exercitio commutat: así lo expresa uno de sus comentadores. Pudiera decir que esa es la ley romana y no la española; pero esa es la ley de las cosas, que no puede revocarse, que es de todas partes: no es esclavo el que es
\end{abstract}

\footnotetext{
${ }^{664}$ Azcárate. "La coartación y sus efectos", in: Revista de Jurisprudencia: ciencia, literatura y variedades, t.I. Havana: Imprenta de Spencer y Cia, 1856, p.364.

665 Sobre isto, ver: Rubén Sierra Mejía. Antonio Miguel Caro y la cultura de su época. Bogotá: Editorial El Malpensante, 2002, pp.66-90.

666 Azcárate. "La coartación y sus efectos”..., p.364.

${ }^{667}$ Antonio Bachiller y Morales. "La coartación y sus efectos”, in: Revista de Jurisprudencia: ciencia, literatura y variedades, t.I. Havana: Imprenta de Spencer y Cia, 1856, p.426.
} 
libre; y no hay esclavitud a medias; o el hombre es escavo o libre en el concepto lógico y en el concepto legal. La Ley de Partida aceptó casi todas las disposiciones romanas sobre el hombre-cosa [...]"668.

Conforme o jurista, muito embora os costumes cristãos tivessem de certa forma dulcificada a escravidão espanhola, a legislação romano-hispana sobre escravos havia sido introduzida integralmente na América pelos colonizadores, permanecendo sem alterações essenciais. As leis referentes ao cativeiro criadas após início da colonização podiam ser divididas em dois períodos: as que foram ditadas com vistas à introdução dos negros e as que foram expedidas para o seu melhor governo nas Índias. Em seus estudos sobre a matéria, não havia visto nenhuma disposição que alterasse o conceito lógico e legal da escravidão cubana, derivado do Direito romano, que interditava qualquer possibilidade de rebaixamento da Dominica potestas pela coartação. O estranhamento do Sr. Azcárate sobre sua suposição de que o Reglamento de escravos não derrogava a legislação vigente era totalmente descabida. Bachiller afirmava não compreender da mesma forma como seu interlocutor o artigo 35.

"No es para mí una ley el reglamento: el honrado General d. Gerónimo Valdés quiso hacer e hizo un
reglamento; el gobierno supremo aprobó el reglamento y es evidente que ni aquel respetabilísimo, y para
mi inolvidable jefe, pretendió legislar, ni el supremo Gobierno le dio otro carácter que el de reglamento
por lo que no derogó las leyes que regulaba. La disposición reglamentaria no puede entenderse como lo
suponen mis adversos y para conseguirlo tienen que truncar las disposiciones, alterar la esencia de la
institución de la esclavitud sin gran provecho, a mi humilde juicio, de los mismos a quienes se cree
favorecer" 669 .

Na sequência, o jurisconsulto tratou de esclarecer o significado legal de uma coartación. Segundo ele, a definição podia ser extraída da Real Cédula de 8 de abril de 1778 em cujo preâmbulo se lia que era quando "el esclavo entregara a su amo parte del precio que le costó con el fin de que rebajado de su valor integral quedase este mas moderado y él en mayor aptitud de conseguir su libertad, se anotase". O objetivo desta disposição era propiciar um benefício aos escravos, que, aliás, contrariava o direito existente, pois se sabia que nenhum credor podia ser obrigado a receber sua dívida em parcelas. O Reglamento, ao falar dos casos de alienação, havia determinado em seu artigo 32 as situações nas quais o judiciário deveria intervir. No que tangia os escravos coartados, ficou estabelecido que o dono pudesse acrescer a alcabala ao preço da coartação e os direitos de escritura, simplesmente isso. Se o escravo pedisse papel de venda e o amo se recusasse, mas acabasse cedendo "por razões muito óbvias", então era o caso de se aplicar o disposto no artigo 35, que de modo algum havia falado de enajenación forzosa. O senhor tinha o poder de ceder ou não ao pedido de seus possuídos em vendas extrajudiciais.

\footnotetext{
${ }^{668}$ Idem, ibidem.

${ }^{669}$ Bachiller y Morales. "La coartación y sus efectos”..., p.428.
} 
Em decorrência de maus feitos dos seus escravos, o dono podia se convencer a vendê-lo, daí cabendo o acréscimo da alcabala como castigo. Mesmo assim, imperativa a decisão do senhor, não a vontade do coartado, que permanecia tão escravo quanto qualquer outro. A venda involuntária, provocada por circunstâncias adversas ou por necessidade, era do que tratava o artigo 35, diferirindo substancialmente do que seriam alienações forçosas.

A dúvida de Azcárate sobre a existência da cédula de 1769, apoiada por sua falta no trabalho de Mojarrieta e em outros documentos, podia ser dirimida pela constatação de que no século passado a haviam citado o capitão general Marquês de la Torre, o Cabildo Secular de Havana e o próprio monarca espanhol que promulgou a Real cédula de 8 de abril de 1778 , anunciada em Bando público na capital, com comunicação ao seu Ayuntamiento e à Real Audiencia de Santo Domingo.

\footnotetext{
"Las palabras en que he fundado mi aserción se encuentran textuales en las siguientes de la Real cédula de 8 de abril de 1778: cita la de 1768 y agrega: - 'Confirmada por otra Real Cédula (habla de alcabala) de 27 de setiembre de 1769 con solo la diferencia de que por lo que tocaba a los esclavos coartados, que estos no pudieron mudar de dueño, sin la voluntad de este a excepción de los casos exceptuados y prevenidos por derecho" $" 670$.
}

Além do mais, Bachiller e Morales anotavam que o Sr. Mojarrieta, citado por seu interlocutor, entendia os efeitos da coartação exatamente como ele, isto é, como um procedimento que não implicava redução do domínio senhorial, não implicando a aquisição de prerrogativas das pessoas livres. Não podiam, portanto, de modo algum, trocar de amo por sua vontade "y por eso hemos visto que la Real Audiencia siempre ha repelido semejantes demandas en cuantos procesos se han elevado sobre este punto a su superior comprensión"671. A coartação incidia, portanto, sobre o preço do escravo, não sobre o poder senhorial.

Para terminar, Bachiller disse aceitar com muito a apreciação feita pelo Sr. Azcárate sobre os seus princípios filosóficos, os quais, porém, não acreditava haver subvertido; aceitava a lei como expressão do direito e mesmo do direito consuetudinário, quando o costume não contrariava a lei escrita; compreendia, de fato, que a justiça era e deveria ser a única base da lei e que a sua utilidade repousava numa relação de efeito para com a causa. Por isso havia citado o texto do haitiano Madiou em seu artigo do dia 6; para provar que a utilidade estava em relação de causa e efeito com a justiça e que eram inúteis, pelo menos em Cuba, os lamentos do sentimentalismo. Com é possível depreender, a utilidade de que falava o jurista era a do chamado "bem público", que na ilha passava pela garantia da propriedade, da ordem social e

\footnotetext{
${ }^{670}$ Bachiller y Morales. "La coartación y sus efectos"..., p.428.

${ }^{671}$ Apud Bachiller y Morales. "La coartación y sus efectos"..., p.429.
} 
do respeito estrito ao estabelecido pelo Direito positivo. Para concluir, enalteceu o entusiasmo, desacreditando, porém, a posição tomada por seu impugnador:

\begin{abstract}
"El entusiasmo que hoy anima al jóven distinguido que me há impugnado, lo tuve vivíssimo no há muchos años: ahora mismo hago um esfuerzo para contestar, por que es noble esse deseo, es santo esse propósito de dulcificar um mal irremediable de momento, pero ante la severa realidade, ante los reconocidos fueros de uma propiedad; ante las consecuencias im previstas de uma interpretación imprudente, no me falta el ánimo para consagrar al bien de mi país el testimonio de uma verdade desagradable: lo que se defende ni es legal ni es conveniente para la conservación del orden actual. No agregaré ni uma palavra más a la discusión" $"$.72.
\end{abstract}

De fato, esta foi a palavra final de Bachiller y Morales, mas houve novas intervenções. O distinguido jurista, síndico e magistrado, Ramon de Armas, já citado ao longo destas páginas, também se posicionou por meio de carta enviada em resposta aos diretores da Revista de Jurisprudencia, que solicitaram o seu parecer sobre o assunto, levando em conta o seu íntimo conhecimento a respeito do espírito que havia presidido a redação dos artigos daquela normativa, em especial o $35^{\circ}$, já que desempenhava a função de síndico procurador em Havana no exato momento de elaboração do Reglamento de 1842, podendo, inclusive, ter participado diretamente dos trabalhos de elaboração.

De Armas esclareceu que, apesar do convite, tinha sido obrigado a recusar a honra de participar da comissão encarregada da redação do Bando de Gobernación y Polícia por "motivos especiales", os quais não exigiam publicidade. No entanto, anotou ter gozado da amizade e da confiança de Valdés, havendo compartilhado suas opiniões sobre os pontos mais importantes do dito bando e, por conseguinte, do Reglamento de escravos. O ex-síndico assegurava que o sentido e a letra do artigo 35 estavam plenamente de acordo com o pensamento daquele ilustre general sobre a faculdade que os escravos coartados tinham de pedir e obter, quantas vezes quisessem, a variação de dono; faculdade esta sobre a qual repousava, no entender de De Armas, a principal diferença entre coartados e inteiros.

\footnotetext{
"El general Valdés con otras apreciables cualidades tenia un recto juicio o sana razón para encontrar siempre el punto de dificultad en cualquiera cuestión que se ventilara y para resolverla las mas veces con acierto. Él había leído el tratado del sr. Mojarrieta (con cuya amistad también me honro) y cuando le manifesté que mi opinión no estaba acorde con la de ese apreciable Magistrado en cuanto al derecho que supone en el dueño del esclavo coartado para no ser compelido a su venta sin justo motivo, tuve el gusto de oír a $S$. E. las razones que había en pro y en contra de ese punto, presentándolas con tanta y tal lucidez que me seria imposible referirlas ahora de una manera mas clara y apreciarlas de un modo más satisfactoria. Procuraré sin embargo recordar esas razones para llenar, si puedo, las miras de Valdés"673.
}

\footnotetext{
672 Bachiller y Morales. "La coartación y sus efectos”..., p.430.

${ }^{673}$ Grifo meu. Ramon de Armas.Revista de Jurisprudencia: ciencia, literatura y variedades, t.I. Havana: Imprenta de Spencer y Cia, 1856, pp.430-434.
} 
Pela pena de Ramon de Armas, que adiantou sua posição favorável ao direito dos coartados mudarem de amo a seu gosto, os leitores passam a acessar uma reconstituição do pensamento do antigo capitão general, claramente embaralhada com a visão do próprio narrador. O ponto de partida é uma retomada das origens do instituto, com uma narrativa que buscava valorizar a tradição espanhola; recordava que outras nações, nos tempos recentes alçadas à condição de filantropas, antes adotavam uma legislação bárbara enquanto a Espanha concedia aos escravos direitos e benefícios importantes; que os filhos dos espanhóis estiveram sempre integrados aos escravos desde a infância, alimentando-se do mesmo leite; que eram raras as disposições testamentárias outorgadas sem a inclusão de alguma graça aos escravos; que os costumes hispânicos haviam sido probos na conciliação de ideias conservadoras e humanitárias com as do progresso lento, embora constante e benéfico. Conforme o autor, seria sempre inquestionável que a coartación teve um princípio correlato, no mínimo, à importação de escravos da África pelos espanhóis. Mas, muito provavelmente, remontava tempos ainda mais antigos. Na Península, escravos que resgatavam ou compravam a sua liberdade eram chamados cortados e não lhe parecia descabido supor que daí viesse a palavra coartado. No início do século XVIII, ainda existiriam na Espanha mouros cortados ou livres, cuja expulsão foi decretada por Felipe V. Na Ley 5, tít. 2, Livro XII da Novísima Recompilación (1805) constava essa denominação cortados para os que resgatassem a sua liberdade entregando o justo preço. Com efeito, adquirir a liberdade era cortar a escravidão, logo, diminuí-la em uma alguma parte significaria também cortá-la, ainda que não totalmente. A mesma Lei citada assinalaria outra classe de escravos, os cortados a tiempos, isto é, aqueles que tinham efetuado ajustes para servir durante certo período antes da obtenção da liberdade, entregando, antes, uma quantia determinada quantia. Diante de tais coincidências, concluiu que a coartación praticada em Cuba era uma variação de tais modalidades registradas na metrópole e introduzidas pelos primeiros colonizadores. Desconhecida que era entre as outras nações, a coartación seriam uma das eloquentes demonstrações de excelência da legislação produzida pela Espanha.

Contudo, o mero congelamento do preço seria um benefício demasiadamente brando para tamanho esforço. " ¿Y que menos puede pedir um esclavo que la facultad, ya que ha dado parte de su precio, de buscar otro dueño si no acomoda el que tiene?". Em vão seriam as alegações de que isto significa um ataque ao direito sagrado de propriedade. Na mesma linha traçada por Rodriguez, argumentou que na pessoa do coartado havia uma espécie de condomínio ou sociedade, que lhe conferia a prerrogativa de dispor de si. Ademais, se o amo estava compelido a receber o preço para o resgate total fixado, por que não havia de estar a passar o escravo para o domínio de outro? Isto referendava o costume. 


\begin{abstract}
"La costumbre que muchas veces es contra ley y prevalece y se hace mas fuerte que ella, había sancionado esa facultad del esclavo antes de que se intentase redactar el Reglamento. La opinión particular del sr. Mojarieta, que es por cierto respetable, prueba por su misma singularidad la existencia de esa costumbre, y en el Reglamento no podía abolirse ni revocarse. ¿Convenía sin embargo, definir la facultad del esclavo en ese Reglamento? ¿Se debía solamente consignarla, como verdad inconcusa, como punto no sujeto a dudas? Entre estos dos extremos el Excmo. Sr. Valdés escogió con sobrada razón el último" ${ }^{674}$.
\end{abstract}

Por este argumento de Ramon de Armas, entre a clareza e a imprecisão, o capitão general teria escolhido a segunda opção para preservar o costume estabelecido. De fato, apesar da abrangência do quadro legal pertinente à escravidão, o costume permanecia como fonte nodal do direito em Cuba, especialmente por conta do seu enquadramento como colônia na ordem jurídica do segundo império espanhol, que a alijava do movimento geral de sistematização do direito pertinente à ordem constitucional metropolitana. Mas havia uma questão mais pontual por trás disso, que envolvia a esfera das competências legislativas.

É mais do que evidente que o texto de 1842 reproduziu a ambiguidade da Real Cédula de 1768. Isto abriu um espaço para uma incerteza que já havia sido sanada em 1769. Descartando a possibilidade de um simples descuido, parece razoável aventar a hipótese de que Valdés e seus conselheiros tinham clareza a respeito das limitações do Reglamento enquanto texto normativo tal como observou Bachiller y Moralles, ou seja, sabiam que os artigos do regulamento que estavam elaborando não poderiam derrogar a legislação metropolitana que havia vedado totalmente a possibilidade do escravo coartado trocar de amo arbitrariamente. Para não mexer no vespeiro que representaria vetar ou chancelar expressamente aquela prática, a solução encontrada foi redigir um artigo 35 volátil o suficiente para não embarreirar o costume e, ao mesmo tempo, driblar um possível impedimento para a aprovação do texto em Madri e futuras alegações ilegalidade por ter pretendido derrogar uma disposição régia. Se foi isso, funcionou por algum tempo, mas abriu caminho para toda essa polêmica e, mais importante, para apreciações dissonantes no interior do sistema judiciário ilhéu.

José Cintra, também síndico procurador, também expôs o seu ponto de vista sobre a matéria. Primeiramente, propôs-se a discutir a vigência da Real cédula de 21 de junho de 1768 . Manifestando ignorância sobre se na prática comum de Santiago de Cuba (ou em algum caso particular) os síndicos (ou algum único síndico) haviam considerado vigentes as disposições da enunciada cédula, mas podia assegurar que em Havana não tinha notícias de que os síndicos, no exercício de suas atribuições de defesa dos escravos, tenham procurado fazer valê-las ante os juízos e tribunais. Puxando pela memória, recordava ter ouvido de um síndico em 1824 que

${ }^{674}$ Ramon de Armas.Revista de Jurisprudencia..., p.433. 
a mencionada cédula havia sido suplicada, o que significava que estavam suspensas as suas disposições e podia dizer assertivamente que os síndicos dos últimos tempos, os senhores Armas, Galarraga, Peralta, Larrinaga, Morales, Cárdenas, Goiry, Storch, Cruz, os atuais e o ele próprio, sempre compreenderam que esta cédula não estava vigente e, portanto, não se baseavam nela no desempenho de suas funções. Antes, sempre haviam se guiado pelos preceitos do Direito comum, por disposições das Siete Partidas, pelo Reglamento de esclavos e por costumes antigos, os quais, observados e sustentados pelas autoridades, tinham adquirido força de Lei, não podendo ser alterados. Segundo tais disposições e costumes, não era proibido que o senhor pedisse do servo em troca de sua liberdade maior preço do que ele havia custado, mas se o valor cobrado fosse exagerado, deveria ser procedida avaliação judicial, conforme o artigo 37 do Reglamento, que, por sua vez, tinha o seu fundamento jurídico na lei $2^{\mathrm{a}}$, tít. 21, Partida IV e na lei $3^{\text {a }}$, tít. 5, Partida V. Sobre a variação de amo por vontade do escravo coartado, Cintra confirmava que tal prática estava fundada primeiramente no costume, o que seria possível abstrair do próprio Reglamento, que reconhecia, pelo artigo 35, a existência de vendas efetuadas por vontade dos coartados, dado que configurava uma qualidade inerente à sua condição. Do se podia inferir com segurança que não havia sido ilegal a prática dos tribunais e dos síndicos no sentido de reconhecer aos coartados a prerrogativa de mudar de amo sem a necessidade de apontar motivos legais para tanto ${ }^{675}$.

A discussão foi fechada com uma entusiasmada réplica a Antonio Bachiller y Morales por de Nicolas Azcárate, que se propôs a destruir as razões de seu antagonista, provando que o direito vigente concedia, sim, ao escravo coartado a faculdade de mudar de amo sempre que pretendesse, sem maior gravame do que o acréscimo da alcabala. De partida, manifestava o entendimento de que o jurisconsulto havia malgastado a sua erudição de direito, visto que pouco ou nada as instituições atuais tinham que ver com a escravidão do tempo do imperador Justiniano. Claramente se observa aqui uma divergência relevante em relação à perspectiva do preopinante, José Cintra, que assinalou o relevo hodierno das fontes do Direito comum, baseadas, como sabemos na tradição do Corpus Iuris Civilis. Para desconstruir o argumento de Bachiller y Morales, Azcáreate sustentou que: “La frase del Emperador Justiniano será siempre muy respetable, y sobre todo curiosa, como documento histórico.” O jovem jurista de 28 anos, cuja geração despregava-se um pouco mais da escola romanista, entendia que os textos justinianeus pouco tinham a dizer sobre as práticas coevas envolvendo a entrega de uma parcela do valor para a obtenção da coartação e a avaliação judicial dos escravos, "porque eso es

${ }^{675}$ José Cintra. Revista de Jurisprudencia: ciencia, literatura y variedades, t.I. Havana: Imprenta de Spencer y Cia, 1856, pp.474-476. 
reconocer derechos, el de la coartación y el de intervenir en su precio a quien era cosa y solo cosa por el derecho romano" "676.

Descolando seu foco para o direito vigente, Azcárate insistiu em deixar sob suspeição a existência de algum desígnio por parte da Coroa no sentido vedar a prerrogativa dos coartados mudarem de amo a seu gosto; argumentou que o foco das cédulas de 1768 e 1769 havia sido única e tão somente fixar o pagamento da alcabala; admitiu a afirmação de Bachiller no sentido de que o Reglamento de 1842 não derrogou as leis existentes sobre coartação, mas que isto em nada importava, "porque no conocemos ninguna que la haya negado el efecto que la costumbre inmemorial le venía atribuyendo, de dar al esclavo la facultad de cambiar de amo sin voluntad de este." Mesmo assim, buscou reafirmar a força legislativa do regulamento baixado por Valdés. De fato, reconhecia o autor, a literatura jurídica contemporânea indicava que os regulamentos do poder Executivo não podiam derrogar as leis ditadas pelo poder Legislativo, mas acenava para a situação específica de Cuba:

“¿Es o no cierto que los Monarcas de España son el poder legislativo de la Isla? ¿Es o no cierto que los Gobernadores Capitanes Generales han tenido siempre la facultad de legislar interinamente y a reserva de la aprobación de S. M.? Eso se hace hoy todos los días, como se ha hecho siempre: y tales disposiciones, sancionadas por S. M. tienen fuerza de ley entre nosotros y derogan las leyes anteriores cuando son contrarias. [...] No hay pues razón ninguna para dudar que el Reglamento ha emanado de quien tenía facultad para legislar, y de consiguiente es ley, aunque se llame Reglamento"677.

Daí em diante, a investida de Azcárate incidiu sobre a diferenciação feita por Bachiller y Morales entre venda forzasa e involuntaria. No seu entender, esta oposição era totalmente esdrúxula: se o amo não pensava ou não queria vender, mas acabou vendendo por razões externas, que não convinham ser explicitada, isto significava que estava agindo contra a sua vontade e ponto. Considerando que toda venda implicava a livre vontade entre as partes, devia estar claro que, nas circunstâncias envolvendo os coartados, cabia a estes o arbítrio sobre a alienação, a não ser pelos termos previstos no artigo 32. Assim havia pensado Valdés, conforme assegurou Ramon de Armas, tal como outras autoridades administrativas e judiciárias da ilha. A sua conclusão era uma só: todo escravo coartado tinha o direito a ser vendido por seu amo quando solicitasse. $\mathrm{O}$ artigo 35 do Reglamento de esclavos, que valia como lei, assim o estabelecia $^{678}$.

\footnotetext{
${ }^{676}$ Nicolas Azcárate. "Replica al Señor don Antonio Bachiller y Morales". Revista de Jurisprudencia: ciencia, literatura y variedades, t.I. Havana: Imprenta de Spencer y Cia, 1856, pp.478.

${ }^{677}$ Azcárate. "Replica al Señor don Antonio Bachiller y Morales"..., p.480.

${ }^{678}$ Idem, p.481.
} 
Toda essa discussão permite perceber, em primeiro lugar, que houve uma confluência significativa entre o costume e o direito escrito em Cuba desde fins do século XVIII. Em 1842, o direito à coartação, costume social fundamental da escravidão cubana, foi legalmente reconhecido. A polêmica em torno do estatuto jurídico dos coartados, isto é, se eram tão escravos quanto os não-coartados, é um ponto de exceção em um ordenamento jurídico reconheceu durante todo o século XIX o direito dos escravos à alforria por indenização, à coartação e à avaliação judicial. Em segundo lugar, ficam evidentes que a mudança de amo ou o pedido de papéis de venda eram práticas absolutamente consolidadas em torno da coartação, com traços de compulsoriedade semelhantes aos que circundavam a alforria onerosa no Brasil. Em terceiro lugar, é possível perceber claramente as implicações jurídicas da conservação do estatuto colonial cubano. Aqui, a concepção de continuidade descontínua utilizada para pensar o caso do Brasil também se encaixa muito bem. A ilha havia passado por uma revolução econômica e estava transitando na corda bamba de um casamento político cujos votos tinham que ser sucessivamente renovados mediante a garantia de uma estreita reciprocidade de interesses. Apesar das adequações feitas pela metrópole no governo da ilha e o judiciário local, a forma como Cuba se inseria nos quadros do império espanhol (com a manutenção do regime de faculdades onímodas) e na própria dinâmica temporal do sistema econômico mundial deixava espaço para a coexistência de concepções bastante plurais a respeito do quadro jurídico e social do mundo da escravidão. Era possível defender o direito à mudança de amo aos coartados tanto com base na tradição do direito comum, que admitia largamente o costume na conformação das práticas jurídicas, quanto por concepções mais modernas, que defendesse antes de qualquer coisa o imperativo da Lei. Como se pode notar, Bachiller y Morales aproxima-se bastante da perspectiva adotada por Teixeira de Freitas no Brasil, não só pelo viés romanista, mas pelo entendimento objetivo a respeito do caráter inequívoco da condição de escravidão. Assim, como o statuliber, para o primeiro, o coartado, para o segundo, deveria estar sujeito a todas as privações que aos escravos cabiam. Não obstante os contorcionismos de Azcárate para negar o inegável, isto é, que a cédula de 1769 havia expressamente recusado aos coartados a prerrogativa de buscarem novo amo quando desejassem, a sua exposição a respeito das competências executivas e legislativas dos capitães generais havia mudado pouquíssimo desde o período que antecedeu a explosão da plantação escravista na ilha. O que havia mudado 
eram as relações sociais de produção e tudo que veio agregado a isso, incluindo a ampliação da ordem legislativa no nível local, abalizada pelo regime de faculdades ominadas.

Como já sugerido, estas divergências que vieram o público em 1856 estavam imiscuídas na administração do direito. Depois de tudo isso, alguém pode duvidar qual seria o destino do escravo ou escrava em Havana que porventura procurasse o síndico procurador general Antonio Bachiller y Morales para trocar de amo sem justo motivo? Muitos dos papéis produzidos por este advogado, quando de sua atuação como síndico na década de 1850, estão guardados na Biblioteca Nacional de Cuba em sua seção de manuscritos. Muito organizado que era, o advogado deixou registros completos dos cativos que foram procurá-lo solicitando serem cortados ou reivindicando benefícios relacionados à sua condição. Mês a mês, ele ia registrando, por exemplo: "Felix congo de D. Pedro Real, vive en la calle de las Nesturas entre Pervenanzo y Lealdad, n.92, Tabaqueria". Ao em torno de 30\% dos registros traziam a seguinte inscrição: "se le entrego a su dueño por no tener razón"679. Ou estes indivíduos alegavam sem provas haverem entregado alguma soma de dinheiro para iniciar a sua coartación ou vinham reivindicar a obtenção de papel para buscarem novo amo, fora dos termos do artigo 32 do Reglamento. Evidentemente, na prática social os escravos conseguiam como já se demonstrou aqui, variarem de amo por iniciativa própria, ou obtinham o auxílio de síndicos que pensavam como Ramon de Armas, por exemplo. Este dado só demonstra a complexidade daquela realidade e as dificuldades que os escravos cubanos tinham que enfrentar, não obstante todo o amparo legal existente.

Em 1861, foi aprovada a criação de um Consejo de Administración para a ilha de Cuba, o qual assumiria, sob a presidência do capitão general, competências de assessoria e jurisdição sobre contenciosos de ordem administrativa, até então pertencentes à alçada da Audiencia de Havana $^{680}$. Diante de diversas representações enviadas proprietários requisitando, por exemplo, a atualização do preço mínimo da coartação para 200 pesos, tendo-se em conta que o médio que atingia os 800 pesos, o novo órgão emitiu, em 1862, um parecer sobre a questão da coartação sopesando uma possível reforma legislativa, especialmente por conta da enorme defasagem que àquela altura representava o depósito de 50 pesos para o início da coartação ${ }^{681}$. Considerando o conflito de interesses em jogo, envolvendo, por um lado, o imperativo da propriedade privada e os fundamentos da disciplina e do domínio senhorial, e, por outro,

\footnotetext{
${ }^{679}$ Biblioteca Nacional de Cuba, C.M. Bachiller, n.695, 1858, "Relación de negros presentados solicitando ser coartados."

${ }^{680}$ Piqueras. Sociedad civil y poder en Cuba, p.90.

${ }^{681}$ Bergard, Iglesias \& Barcia. The Cuban Slave Market, 1790-1880, p.77.
} 
direitos consolidados e legalmente reconhecidos, o órgão posicionou-se contra a realização de qualquer modificação no Reglamento de Valdés pelos inconvenientes sociais que poderiam causar, mas apresentou algumas sugestões que seriam incorporadas a um novo instrumento ${ }^{682}$.

Em 28 de janeiro de 1863, o governador Domingo Dulce promulgou um Reglamento para las sindicaturas en La presentación de quejjas de los esclavos contra sus amos, discernindo mais alguns pontos em seus 19 artigos. A respeito do preço da liberdade dos fetos, por exemplo, que ainda não havia sido regulado, ficou estabelecido, pelo artigo $9^{\circ}$, que se continuaria seguindo o costume, ou seja, não mudou nada. Segundo Alejandro de La Fuente, isto significou a chancela ao pagamento de 25 pesos pela liberdade dos nascituros ${ }^{683}$. O artigo 11 estipulou que os amos dos escravos coartados que os mantivessem sobre o seu serviço direto deveriam pagar a eles apenas diferença entre o jornal que lhes coubesse satisfazer e o que os coartados pudessem obter trabalhando por conta, "lo cual no excluye el acuerdo entre dueño y esclavo sobre el particular". Como tal diferença não era baseada absolutamente em nenhuma referência concreta, claramente se referendava o ajuste privado. Contrariando uma queixa comum, presente artigo de Juan Olavarría, por exemplo, o artigo 12 estabeleceu que,

"No siendo justo que al siervo de buena conducta y capacidad, que sepa además algún oficio, le sea más
difícil aspirar a su libertad con los ahorros u otros medios lícitos, que al vicioso y torpe, porque el precio
de aquél sea mayor que el de éste, los tasadores, tratándose de liberto o coartación, sólo tendrán en cuenta
la edad, salud y aspecto físico del esclavo, y lo que hubiese gastado el amo en enseñarle oficio o lo que
importase prudentemente esta enseñanza, si ya con sus servicios no estuviere indemnizado."

É mais do que evidente que o argumento usual dos proprietários de que o valor agregado ao cativo em virtude das habilidades e ofícios aprendidos era fruto de seu investimento era descartado com a convincente justificativa de que os serviços prestados já serviam de indenização. Os avaliadores que assim vinham procedendo ganhavam, agora, a chancela do executivo local. O tópico da venda é encarado neste novo Reglamento, em seu artigo 13, segundo o qual:

\footnotetext{
"No dando motivo el esclavo para ser vendido y siendo la venta por pura voluntad del dueño, tiene derecho a que se le autorice por esta con un plazo de tres días, a fin de proporcionarse nueve amo, dándole para el efecto; transcurrido este término queda el propietario en aptitud de venderlo a quien le plazca" ${ }^{685}$.
}

\footnotetext{
${ }^{682}$ De la Fuente. "Slaves and the Creation of Legal Rights in Cuba: Coartación and Papel", pp.35-39.

${ }^{683}$ Esta informação não pôde ser confirmada no âmbito desta pesquisa, cf. Idem, p.35.

${ }^{684}$ Grifo meu. Lucena Salmoral. "Leyes para esclavos: el ordenamiento jurídico sobre la condición,...”, p.1297.

${ }^{685}$ Idem, ibidem.
} 
Como é possível depreender, a base desta permissão para a busca de um novo amo dependia da condição de que o escravo, inteiro ou coartado, não houvesse dado motivo para a alienação. Ao que parece, neste ponto o legislador buscou um meio termo tendo como base para a equidade na atribuição de direitos o bom comportamento, tanto daquele que se esmerava para poupar o necessário para a compra da liberdade, que não teria o seu ofício pesando na fixação do seu preço, quanto daquele que poderia sair a buscar um novo senhor. Mesmo assim, não foi posto um embaraço direto à troca de amo contra a vontade senhorial. Os termos do artigo 35 do Reglamento de Valdés foram mantidos intocados. O quadro normativo pertinente à liberdade dos escravos sofreria alterações substanciais apenas com a Lei de 4 de julho de 1870, que decretou a liberação do ventre, já com o tráfico negreiro efetivamente interditado.

Ao longo das páginas deste capítulo, vários elementos foram levantados a respeito da dinâmica jurídica que envolvia a busca dos escravos pela liberdade. Neste ponto, não deve restar dúvidas que a inclusão da expressão o direito dos escravos no título deste capítulo expressa o reconhecimento de um traço específico do regime escravocrata hispano-cubano, que, à diferença do brasileiro, contemplou o reconhecimento legal do direito à alforria onerosa paga no ato e à coartação aos seus cativos. Dizer isto não significa encampar visões coevas que propagavam as virtudes da legislação e da escravidão espanhola, que sempre foi tão violenta quanto qualquer outra. Trata-se, antes, de buscar compreender a cultura da escravidão criada naquele lugar, a qual teve como eixo fundamental um modo de normatização das relações de escravidão que, a partir dos precedentes básicos das Siete Partidas e de uma prática legislativa tradicionalmente mais abrangente do que a brasileira, respondeu às transformações ocorridas no mundo atlântico após da Guerra dos Sete Anos reconhecendo direitos aos escravos, sem solapar as condições fundamentais para o exercício do poder senhorial, especialmente no coração das zonas produtivas ligadas ao movimento da chamada segunda escravidão. Não sem o enfrentamento de incertezas e momentos de crises insurrecionais, é possível creditar ao quadro jurídico um papel importante na amortização das tensões sociais da ilha e na reprodução da ordem escravocrata, sem desconsiderar, evidentemente, o protagonismo da população negra que buscou explorar as brechas existentes para transformar as suas vidas. 


\section{Epílogo}

O enraizamento da prática escravista no Brasil e em Cuba no momento fundador do escravismo oitocentista - associado aos traços específicos das respectivas culturas jurídicas e ao seu estatuto político - deu o tom da articulação entre Direito, escravidão e liberdade. Durante largo período, faltaram razões suficientemente fortes para pressionar o Legislativo brasileiro a reconhecer o direito legal dos escravos à alforria onerosa. Havia um modo de normatização das relações de escravidão que articulava de forma dinâmica legislação, costume, doutrina e jurisprudência, preservando a tradição em torno da integridade do domínio senhorial. O quadro hispano-cubano passou por um processo distinto. Até o século XVIII, não existia uma sociedade propriamente escravista na ilha. Isto tornou possível o encurtamento pontual de uma das prerrogativas senhoriais, a concessão da liberdade mediante indenização, sem grandes percauços ou reações contrárias. Mais do que isso, diante da insuficiência para promover abalos significativos à reserva de mão de obra, o direito dos escravos, ampliado em 1842 pelo reconhecimento da coartação, ajustou-se à lógica sistêmica da escravidão em Cuba. Mas, nos anos 1860, foram lançadas as bases para a desarticulação de ambos os ordenamentos escravistas. O destino da Guerra Cilvil dos Estados Unidos (1861-1865) foi crucial para este efeito. ${ }^{686}$

Em primeiro de janeiro de 1863, entrou em vigor o Emancipation Proclamation do presidente Abraham Lincoln. Aprovado em 22 de setembro do ano anterior, o famoso documento estabeleceu que "all persons held as slaves within any State, or designated part of a State, the people whereof shall then be in rebellion against the United States shall be then, thenceforward, and forever free." ${ }^{687}$ A emancipação não era completa, já que ela não se estendia aos territórios da União, mas atingia em cheio o coração do escravismo estadunidense localizado nos estados confederados ${ }^{688}$. A repercussão externa foi imediata. No dia 13, o Diario de la Marina publicou um editorial repelindo de forma contundente aquele ato:

"Había producido la tal proclama del 22 de septiembre la reprobación universal de América y Europa:
había escandalizado y alarmado a todos los hombres del norte que desean la terminación de la guerra, que
veían en ella un acto irreflexivo del despecho de un partido extremo, inútil si no se llevaba á cabo, capaz
de alargar indefinidamente la guerra y de prestarle un carácter espantoso de sanguinaria crueldad; había

\footnotetext{
${ }^{686}$ Rafael de Bivar Marquese \& Tâmis Peixoto Parron. "Internacional escravista: a política da segunda escravidão". Topoi, v. 12, n. 23, jul.-dez. 2011 p. 97-117.

${ }^{687}$ Disponível em:

<http://www.archives.gov/exhibits/featured_documents/emancipation_proclamation/transcript.html>. Acesso em: 18 de março 2015.

${ }^{688}$ Edward E. Baptist. The half has never been told: slavery and the making of American capitalism. Nova York: Basic Books, 2014, p.429.
} 
sido mal recibida en el ejército; los banqueros y todas las clases conservadoras la repugnaron; hizo aumentar el interés del dinero; afecto todos los valores; la reprobó la generalidad de la imprenta del Norte; fue rechazada, por último, en las urnas electorales que al dar la mayoría á los candidatos demócratas protestaron solemnemente contra un acto que se consideró justamente producto de una rencorosa impotencia. [...] Pero la Providencia, como dice un muy estimado periódico de Nueva York, no ha querido disipar la funesta ceguera que impele á los hombres políticos de Washington á perder irremisiblemente la Unión bajo el pretexto de salvarla. Medida ineficaz para atraer á la concordia á los llamados rebeldes, no hará más que ahondar la sina que los divide, é infundirles el supremo valor de la desesperación: contraria al mismo principio que le sirve de fundamento, ni tan siquiera puede reclamarse en favor de su adopción las teorías absolutas del radicalismo: lanzada ab trato y contra las prescripciones generales de la ley fundamental de la Unión y las de los estados particulares, es inconstitucional á todas luces y violadora del pacto federal. Es por último la más grave, la más suprema falta de la administración republicana, la que va á determinar, á no dudarlo, el principio de una revolución política en los Estados federales, cuyas consecuencias no es dado por lo pronto adivinar" ${ }^{\prime \prime}$.

De fato, houve resistência por parte de diversos setores, incluindo políticos próximos à presidência dos Estados Unidos. Mas o devir histórico nos mostra que este prognóstico pessimista, fortemente alinhado aos interesses do sistema de escravidão, estava equivocado quanto aos seus desdobramentos, que culminariam na abolição total aprovada em 6 de dezembro de 1865 . No plano externo, a medida anulou a possibilidade de intervenção de países como Inglaterra e França, cujos governos chegaram a cogitar uma intervenção em favor do Sul para ampliar a sua influência no continente americano. Ao trazer o término do cativeiro para o primeiro plano da Guerra, o Emancipation Proclamation conferiu legitimidade aos esforços unionistas em meio à opinião pública europeia afeita aos ideais abolicionistas, vetando quaisquer pretensões intervencionistas dos seus países contra as diretrizes de Washington. Internamente, apesar de não desestruturar de imediato a ordem escravocrata no Deepest South, a disposição enfraqueceu progressivamente os efetivos confederados que se valiam dos negros cativos para as operações militares em função das crescentes deserções, e fortaleceu de maneira importante as fileiras Yankees como consequência da cláusula que previa o alistamento dos escravos emancipados. As United States Colored Troops integrariam até o final da Guerra cerca de 200 mil afro-americanos, entre Exército e Marinha ${ }^{690}$.

A evolução do conflito em favor das tropas unionistas levou D. Pedro II a escrever a Zacarias de Góes, chefe do Conselho de Ministros, no dia 14 de janeiro de 1864, manifestando que:

"Os sucessos da União americana exigem que pensemos no futuro da escravidão no Brasil, para que não
nos suceda o mesmo que a respeito do tráfico dos Africanos. A medida que me tem parecido profícua é a
liberdade dos filhos das escravas, que nascerem daqui a certo número de anos. Tenho refletido sobre o

${ }^{689}$ Diario de la Marina: periódico oficial del apostero de la Habana, 13 de janeiro de 1863, p.2.

${ }^{690}$ Robin Blackburn. Marx and Lincoln: An Unfinished Revolution. Londres/Nova York: Verso, 2011, p.39. 
modo de executar a medida; porém é de ordem das que cumpre realizar com firmeza, remediando os males que ela necessariamente originará, conforme as circunstâncias o permitirem"691.

Mais claro impossível: o Imperador, antevendo o desenlace antiescravista do conflito norte-americano e a consequente desarticulação da retaguarda sulista para a continuidade da escravidão no país, solicitava o início de um debate para a liberação do ventre escravo, antes que a soberania nacional fosse vilipendiada, como havia ocorrido em 1850, quando da aprovação da segunda lei de abolição do tráfico negreiro. O governo espanhol também teria que se mexer. O contrabando de africanos que ainda persistia em seus domínios ficaria insustentável. O último fôlego da escravidão cubana dependia diretamente do fim das importações. Em 1865, finalmente a Espanha destinou forças navais efetivas para o combate ao infame comércio, de forma coordenada às ações do então governador da ilha, Domingo Dulce y Garay. Um novo projeto de lei antitráfico de 19 de fevereiro de 1866 foi discutido nas Cortes espanholas, mas, por falta de quórum, não chegou a ser votado no Congresso, apenas no Senado $^{692}$. Ainda assim, a rainha, de forma extraordinária, validou as disposições do projeto em 29 de setembro daquele ano, quando a repressão já havia se tornado eficaz. Naquele ano, apenas um navio, contendo cerca de 700 escravos, conseguiu efetuar o desembarque na ilha. Foi o último carregamento de escravos a entrar nos portos cubanos ${ }^{693}$.

No Brasil, a discussão sobre a escravidão havia sido efetivamente reaberta na arena política. Em junho de 1865, Montezuma, agora visconde de Jequitinhonha, depois de apresentar dois projetos sobre alforria, um para os escravos "achados de vento" (de senhores desconhecidos) e outro para os que sentassem praça nos efetivos militares como voluntários encaminharam ao Senado uma primeira proposta bastante acanhada de liberação do ventre para a "escrava que tivesse sido legada ou doada para serviço, por determinado tempo, sem a transmissão de domínio e sem a cláusula expressa de voltar ao antigo cativeiro": não foi adiante ${ }^{694}$. Atendendo a solicitação realizada no final do ano anterior, José Antônio Pimenta

691 Apud Heitor Lyra. História de d. Pedro II. (1825-1891). Volume II: Fastígio. São Paulo Companhia Editora Nacional, 1939, p.236. Sobre a relação direta entre a Guerra Civil e o processo que culminou na promulgação da Lei do Ventre Livre, ver: Luiz A. Moniz Bandeira. Presença dos Estados Unidos no Brasil (1 ${ }^{\mathrm{a}}$ ed., 1972). Rio de Janeiro: Civilização Brasileira, 2007, pp.155-161; Robert Conrad, Os últimos anos da escravatura no Brasil, 18501888 (trad.port.). Rio de Janeiro: Civilização Brasileira, 1975, pp.88-100; Eduardo Spiller Pena. Pajens da casa imperial: jurisconsultos, escravidão e a lei de 1871. Campinas: Ed. Unicamp, 2001; Sidney Chalhoub. Machado de Assis, Historiador. São Paulo: Companhia das Letras, 2003, pp.139-142; Ricardo Salles. E o Vale era o escravo: Vassouras, século XIX. Senhores e escravos no coração do Império. Rio de Janeiro: Civilização Brasileira, 2008, pp. 79-110.

${ }^{692}$ Manuel Lucena Salmoral. “Leyes para esclavos: el ordenamiento jurídico sobre la condición,...”, pp.408-409.

${ }^{693}$ Leonardo Marques. The United States and the Transatlantic Slave Trade to the Americas, 1776-1867. Tese de Doutorado, Emory University, 2013, p.362.

${ }^{694}$ A Abolição no Parlamento. Brasília: Senado Federal, 1988, pp.234-237. 
Bueno, o marquês de São Vicente, encaminhou a D. Pedro II, Em 23 de janeiro de 1866, cinco projetos complementares sobre a emancipação dos escravos: $n^{\circ} 1$ - liberdade para os filhos de mulher escrava, $n^{\circ} 2$ - criação de junta central protetora da emancipação em cada província, $n^{\circ}$ 3 - matrícula de escravos (isentos de taxa) na coletoria das respectivas paróquias ou municípios, $\mathrm{n}^{\mathrm{o}} 4$ - liberdade para todos os escravos no prazo de cinco anos (mediante indenização), $\mathrm{n}^{\mathrm{o}} 5$ emancipação dos escravos de ordens religiosas ${ }^{695}$. Segundo sua projeção, a escravidão seria totalmente extinta do país até a distante data de 31 de dezembro de 1899. Ampliando o ambiente favorável àquele debate, em meados daquele ano, Sua Majestade recebeu uma correspondência do Comité pour l'Abolition de l'Esclavage, importante sociedade abolicionista francesa, que lhe pediu para usar de sua influência e poder para promover a abolição da escravatura ${ }^{696}$. Mas havia medidas emergenciais a serem tomadas antes do encaminhamento decisivo da discussão. O país estava envolvido na Guerra contra o Paraguai havia quase dois anos, e o término do conflito não parecia estar nada próximo. Em meio à crise de recrutamento para os combates contra as tropas de Solano López, o Executivo decretaria, a 6 de novembro, a liberdade para os escravos que se alistassem no Exército e às suas esposas. Esta foi a primeira disposição de liberação coletiva promovida pelo Estado imperial ${ }^{697}$.

Finalmente, em primeiro de fevereiro de 1867, o presidente do Conselho de Ministros enviou aos Conselheiros de Estado uma consulta confidencial com o seguinte teor:

\footnotetext{
"Ilm ${ }^{\circ}$ e Exm ${ }^{\circ}$ Sr. - O problema da extinção da escravatura no Brasil, visto o estado atual da opinião do mundo civilizado, requer da sabedoria e previdência dos altos poderes do Império o mais sério cuidado para que os acontecimentos, que vão acelerando por toda a parte o termo desse trato, hoje condenado sem reserva, não venham colher desprevenido o Governo em assunto tão grave e onde melhor que a ninguém lhe cabe a iniciativa a fim de obviar grandes perturbações e desgraças. Posto isso, deseja o Governo que o Conselho de Estado, examinando acuradamente a matéria do indicado problema, se prepare para no dia de março ou abril, que for oportunamente marcado, emitir o seu esclarecido parecer sobre os seguintes pontos: $1^{\circ}$ Convém abolir diretamente a escravidão? No caso de afirmativa: $2^{\circ}$ Quando deve ter lugar a abolição? $3^{\circ} \mathrm{Como}$, com que cautelas e providências cumpre realizar essa medida?" 698 .
}

Como bases para o estudo da matéria foram anexadas os projetos enviados pelo marquês de São Vicente, que também fazia parte do Conselho. Os conselheiros se pronunciaram na

\footnotetext{
${ }^{695}$ Idem, pp.241-257.

${ }^{696}$ Chalhoub. Machado de Assis, Historiador, p.140.

${ }^{697}$ Não é ocioso lembrar que a presença dos negros nas Forças Militares acirraria os clamores internos pelo fim da escravidão nos anos vindouros. Cf. Joaquim Nabuco. O Abolicionismo. Rio de Janeiro: Nova Fronteira/São Paulo: Publifolha, 2000, pp,42-43. Sobre a participação dos escravos na Guerra, ver: Ricardo. Guerra do Paraguai: escravidão e cidadania na formação do exército. Rio de Janeiro, Paz e Terra, 1990.André Amaral de Toral. "A participação dos negros escravos na guerra do Paraguai”. Estudos Avançados, v.9, n.24, (agosto, 1995) pp.287296, Disponível em: <http://www.scielo.br/scielo.php?script=sci_arttext\&pid=S010340141995000200015\&lng=en\&nrm=iso>. Acesso em 20 de abril de 2015.

${ }^{698}$ Atas do Conselho de Estado Pleno. Terceiro Conselho de Estado, 1865-1867, p.93.
} 
sessão do dia 2 de abril de 1867. Entre os presentes, além do próprio imperador, estavam os viscondes de Abaeté, de Jequitinhonha, de Itaboraí e de São Vicente, Eusébio de Queiroz, José Maria da Silva Paranhos, Bernardo de Sousa Franco, José Thomas Nabuco de Araújo, Francisco de Salles Torres Homem e o Barão de Muritiba, dos Ministros e Secretários de Estado, Zacarias de Góes e Vasconcelos (Fazenda e Presidente do Conselho de Ministros), José Joaquim Fernandes Torres (Império), Martim Francisco Ribeiro de Andrada (Justiça), Antônio Coelho de Sá e Albuquerque (dos Estrangeiros), entre outros. Apesar das repostas afirmativas às questões colocadas quanto à necessidade de se encaminhar o término da escravidão, salvo Jequitinhonha, todos se mostraram contrárias a uma discussão pública no Parlamento. Após o debate, foi nomeada uma comissão presidida por Nabuco de Araújo para revisar os projetos de São Vicente, unificando-os em um texto mais conciso, em conformidade com a maioria das opiniões proferidas.

Em função do ar reticente dos estadistas do Império, D. Pedro II se posicionou abertamente sobre a questão do "elemento servil" na célebre Fala do Trono proferida na Sessão de Abertura da $13^{\mathrm{a}}$ Legislatura da Assembleia Geral, aos 22 de maio de 1867. Em verdade, vale dizer que a questão da escravidão foi uma pequena parte de uma exposição que abordou diferentes assuntos de Estado, com grande destaque para os esforços diplomáticos e militares para pôr fim à Guerra do Paraguai. Sobre o cativeiro, o imperador o seguinte:

\footnotetext{
"O elemento servil no Império não pode deixar de merecer oportunamente a vossa consideração, provendo-se de modo que, respeitada a propriedade atual, e sem abalo profundo em nossa primeira indústria - a agricultura -, sejam atendidos os altos interesses que se ligam a emancipação"699.
}

Os parlamentares recebiam, assim, a incumbência de conduzir uma dissolução segura do regime de escravidão, respeitando a propriedade e a agricultura do país. Nabuco de Araújo, então, pôs-se a redigir o projeto único para a emancipação dos escravos, que foi apresentando em 20 de agosto de $1867^{700}$. Com algumas emendas feitas por Torres Homem e pelo visconde de Sapucaí, o texto final chegou ao escrutínio do Conselho de Estado em 11 de abril de 1868 e o seu exame se estendeu por várias sessões. Dava-se o pretexto da Guerra para adiar a remissão do texto ao Legislativo. Na Fala do trono proferida em sessão de 9 de maio de 1868, D. Pedro II informou os parlamentares de que "o elemento servil tem sido objeto de assíduo estudo e oportunamente submeterá o Governo a vossa sabedoria a conveniente proposta"701. A

\footnotetext{
${ }^{699}$ A Abolição no Parlamento. Brasília: Senado Federal, 1988, p.269.

${ }^{700}$ Idem, pp.322-326.

${ }^{701}$ Idem, p.358.
} 
conjuntura política, porém, estava longe da estabilidade. O Gabinete Liberal chefiado por Zacarias de Góes não resistiu aos êxitos militares do comandante das Forças Armadas, o conservador duque de Caxias. Em julho, o Gabinete foi entregue pela segunda vez a Joaquim José Rodrigues Torres, o visconde de Itaboraí, antigo líder saquarema. De maioria liberal, a Câmara foi dissolvida, novas eleições foram realizadas e os conservadores dominaram uma vez mais o Parlamento: compunha-se um cenário político hostil à abolição da escravatura ${ }^{702}$.

A política no mundo espanhol fervilhava ainda mais intensamente. O panorama de retração econômica e o autoritarismo de lideranças como Luis González Bravo e Ramón María Narváez havia ampliado o descontentamento com o governo moderado que ocupava o poder havia duas décadas, com o suporte da rainha Isabel II. Em setembro de 1868, irrompeu uma nova rebelião armada que passou para a história como Revolución Gloriosa. A monarquia foi derrubada e outro processo constitucional foi aberto: o mais democrático de todos. A Sociedade Abolicionista Espanhola, fundada em dezembro de 1864, que havia sido silenciada nos últimos anos, ressurgiu com toda força sob a batuta de Rafael María de Labra, redator da proposta de liberação do ventre para as colônias espanholas que seríamos encampadas pela Junta Revolucionária de Madri, comandada por Joaquín Aguirre. Em 15 de outubro, o texto foi encaminhado para aprovação em caráter emergencial pelo Governo Provisório, que era chefiado pelo general Serrano, até que se formassem a Cortes Constituintes e se promulgasse uma lei definitiva. Com efeito, foi emitido um decreto bastante sumário declarando livres todos os nascidos de mulher escrava a partir de 17 de setembro de 1868, que, no entanto, não chegou a ter efeitos concretos imediatamente ${ }^{703}$.

Em Cuba, a situação entraria em convulsão no dia 10 de outubro, quando o hacendado Carlos Manuel Céspedes, no partido de Yara, em Manzanillo, jurisdição situada na parte oriental da ilha, liderou um movimento que proclamou a independência em relação a Espanha; dava-se o famoso Grito de Yara que provocou a Guerra de los Diez Años pela emancipação política cubana. Aos ideais independentistas e liberais incorporados pelos rebeldes somava-se a antiga insatisfação com relação à hegemonia política e econômica do eixo açucareiro sediado em Havana. Mas vale notar que não existia um posicionamento unitário entre os insurgentes. Enquanto alguns apoiavam a independência completa, outros eram favoráveis à anexação aos Estados Unidos. O tema da escravidão também não encontrava unanimidade. Céspede ficou

\footnotetext{
702 Jeffrey Needell. The Party of Order: The Conservatives, the State and Slavery in the Brazilian Monarchy, 1831 1871. Stanford, California: Stanford University Press, 2006, pp.240-266; Chalhoub. Machado de Assis historiador, p.155.

${ }^{703}$ Manuel Lucena Salmoral. "Leyes para esclavos: el ordenamiento jurídico sobre la condición,...”, p.462.
} 
famoso por libertar seus escravos e incorporá-los à luta, defendendo a emancipação gradual com indenização. Mas muitos de seus correligionários respeitavam a propriedade escrava e eram avessos a medidas mais radicais, que pudessem comprometer um eventual suporte dos hacendados ao movimento. Céspede acabou cedendo. Em novembro, decretou a pena de morte para todo aquele que incitasse os escravos à rebelião e no mês seguinte deixou claro que a abolição era matéria a ser tratada depois que a independência fosse consumada. Contudo, conforme o movimento insurgente avançou pelo território cresceram os clamores em prol da abolição, em especial pelas regiões pecuaristas do centro da ilha na jurisdição de Camaguey, menos dependentes da escravidão e cujo grupo político assumiria o comando do movimento. Cortejar o apoio estadunidense, após a aprovação da décima terceira emenda, também dependia de posições mais claras em prol da abolição da escravidão. A constituição aprovada em Guáimaro em abril de 1869 declarou com todas as letras que todos os habitantes da nova república eram inteiramente livres. Inicialmente a liberação não foi incondicional. Em 5 de julho foi publicado um Reglamento de Libertos instituiu um regime de patronato, que manteve os ex-escravos sob a tutela dos antigos senhores, com obrigações laboriosas e restrições à circulação. Mas o documento vigorou só até 25 de dezembro de 1870, quando passou a vigorar a liberdade completa em território mambise. Enquanto isso, em Havana, explodia um clima de exaltação patriótica canalizada no Cuerpo de Voluntarios que engrossaria a infantaria espanhola contra os rebeldes. O capitão general Francisco de Lersundi assegurava o governo de Madri que contava com efetivos suficientes para dar conta dos rebeldes do Departamento Oriental em pouco tempo. O otimismo do capitão era demasiado, bem o sabemos ${ }^{704}$.

$\mathrm{Na}$ Espanha, as opiniões eram diversas. Se por um lado, o movimento abolicionista ganhava força com apoio das mobilizações em Porto Rico, por outro, existiam os grupos que apoiavam a preservação da escravidão, ciosos de seus interesses mercantis. Mas o cenário simplesmente impedia uma nova guinada totalmente pró-escravista. O compromisso dos independentistas com a abolição, ainda que ambivalente no começo retraísse os impulsos antiescravistas do novo governo, sobretudo em função de seus abalos para as atividades econômicas. Mas a declaração da liberdade realizada pela República de Cuba em Armas representava uma vantagem para as tropas insurrecionais, que teria a seu favor o engajamento de escravos em busca de sua emancipação, de pelo menos parte da população negra livre e de

\footnotetext{
${ }^{704}$ Como realçou Ada Ferrer, quase dez anos e trezes governadores depois, as autoridades espanholas continuariam incapazes de promover a pacificação da ilha, cf. da autora: "Esclavitud, ciudadanía y los límites de la nacionalidad cubana: la guerra de los diez años, 1868-1878”. Historia Social, n. 22 (1995), pp.101-102. Sobre o período, ver: Rebecca J. Scott. Emancipação escrava em Cuba: a transição para o trabalho livre, 1860-1899. São Paulo: Paz e Terra/Campinas: Editora da Unicamp, 1991, pp.63-65.
} 
brancos abolicionistas. A sombra persistente da diplomacia inglesa e, agora, de um governo estadunidense francamente contrário a pratica da escravidão também encurralavam Madri. As Cortes chegaram a rejeitar o primeiro projeto para a liberação do ventre. No início do reinado de Amadeo de Saboya, os liberais espanhóis apresentaram outra proposição para a abolição do cativeiro, desta vez, apenas em Porto Rico. Também não passou no Parlamento. Mas, como observou Rebecca Scott, “considerações estratégicas e internacionais exigiam que o novo governo tomasse certas medidas, mesmo que parciais, repudiando a escravidão" ${ }^{\text {,05 }}$. No dia 28 de maio de 1870, o ministro do Ultramar e abolicionista moderado, Segismundo Moret y Prendergast encaminhou o projeto de abolição gradual que efetivamente emplacaria no Congresso espanhol. As discussões se estenderam pelo mês seguinte. Um dos embates mais intensos ocorreu no dia 20 de junho entre Emilio Castelar, futuro presidente da República espanhola, e o autor do projeto. Em uma fala bastante erudita, prolixa e eloquente, que chegou a arrancar aplausos de seus pares, Castelar clamava para que a Espanha se levantasse em favor dos princípios sociais mais progressistas e retomasse a sua grandeza perante o mundo civilizado e pusesse um fim imediato à escravidão, extirpando a um só golpe a mancha que maculava a história espanhola. Moret respondeu apelando para a necessidade de se respeitar "por espíritu de justicia y deber político" os interesses dos proprietários de escravos, que de forma inconsequente haviam sido castigados pelas leis abolicionistas de outras nações; defendeu seu projeto, afirmando que a lei consistia em um sistema benéfico que permitia a conexão adequada entre elementos conservadores e revolucionários ${ }^{706}$.

Com algumas emendas ao texto original, a Lei de Ventres Livres, também conhecida como Ley Moret, foi aprovada pelas Cortes espanholas no dia 23 de junho, sendo publicada por decreto do dia 4 de julho. Composta por 21 artigos, a Lei estabeleceu que "todos los hijos de madres esclavas que nazcan después de la publicación de esta Ley son declarados libres" $\left(\operatorname{art} .1^{\circ}\right)$. Regredindo as emancipações para o início da Gloriosa, dando cumprimento ao decreto original, o texto previu que todos os escravos nascidos após 17 de setembro de 1868 até a publicação desta Lei, seriam adquiridos pelo Estado mediante a indenização $\left(\operatorname{art} .2^{\circ}\right.$ ). Os escravos que estivessem servindo o pavilhão espanhol nos combates à insurreição cubana seriam declarados livres mediante indenização aos proprietários fieis à causa espanhola. $\left(\operatorname{art.} 3^{\circ}\right)$; os que atingissem a idade de sessenta anos seriam declarados livres sem indenização (arts. $4^{\circ}$ e $14^{\circ}$ ); os pertencentes ao Estado seriam também libertados, assim também os

\footnotetext{
705 Scott. Emancipação escrava em Cuba..., p.80.

${ }^{706}$ Diario de sesiones de las Cortes Constituyentes, dieron principio el día 11 de febrero de 1869. Madri: Imprenta de J.A. García, 1870, v 14, pp.8981-8999.
} 
emancipados que ainda estivessem sob a guarida do Estado, entrariam em pleno exercício dos direitos dos ingênuos (art. $5^{\circ}$ ); os libertos, por ministério da Lei, conforme os dois primeiros artigos ficariam sob patronato dos donos de suas mães (art. $\left.6^{\circ}\right)$.

O patrono ficava com a obrigação de manter seus "clientes", vesti-los, assisti-los em suas enfermidades e dar-lhes as instruções primárias e a educação necessária para o exercício de arte ou ofício $\left(\operatorname{art} .7^{\circ}\right)$. A contrapartida vinha na forma de trabalho, sem transtornos $\left(\operatorname{art} .14^{\circ}\right)$. O liberto, ao atingir a 18 anos de idade, passaria a ganhar a metade do jornal de um homem livre, segundo sua classe e ofício. Deste jornal, lhe seria entregue a metade, reservando-se a outra para a formação de um pecúlio $\left(\operatorname{art} .8^{\circ}\right.$ ). Ao atingir 22 anos, o liberto adquiriria o pleno gozo de seus direitos, cessando-se o patronato e sendo-lhe entregue o seu pecúlio $\left(\operatorname{art.} .9^{\circ}\right) . \mathrm{O}$ patronato terminaria, também, por matrimônio do liberto (a partir dos 14 anos as mulheres e dos 18 anos os homens), por castigos abusivos ou falta do cumprimento dos deveres especificados no $\operatorname{artigo} 7^{\circ}$, e por exploração da prostituição (arts. $10^{\circ}$ e $17^{\circ}$ ); era transmissível e renunciável por justa causa; os pais legítimos ou naturais, que fossem livres, poderiam reivindicá-lo, desde que indenizassem os patronos (art.11 $\left.{ }^{\circ}\right)$.

Os escravos contemplados pelos artigos $3^{\circ}$ e $5^{\circ}$ deveriam ser listados no prazo de um mês pelo Governo Superior Civil e ficariam sob a proteção estatal; aqueles que preferissem seguir para a África, sendo conduzidos para lá à custa do Estado (arts. $12^{\circ}$ e $13^{\circ}$ ). Também seriam consideradas livres todas as pessoas que não constassem dos recenseamentos de 31 de dezembro de 1869, realizado em Porto Rico, e de 31 de dezembro de 1870, ainda por ser verificado em Cuba $\left(\operatorname{art.19^{\circ }}\right)^{707}$. Por fim, previu-se que o governo apresentaria às Cortes, quando nelas fossem admitidos deputados de Cuba, um projeto de lei para a emancipação indenizada dos escravos que persistissem em cativeiro conforme os termos desta Lei; também, proibiram-se os castigos de açoites e a venda em separado de cônjuges e de mães e filhos menores de quatorze anos ${ }^{708}$.

Não obstante o seu tom moderado, a Ley Moret efetivamente encaminhou a abolição gradual da escravidão em Cuba e Porto Rico, além de anunciar para um futuro próximo a adoção

\footnotetext{
${ }^{707}$ Uma contagem chegou a ser realizada em 1871, mas, por causa da Guerra, os dados são bastante lacunares. Cf. Kenneth F. Kiple. Blacks in Colonial Cuba (1774-1899). Flórida: University of Florida Press, 1976, pp.65-68.

${ }^{708}$ Manuel Lucena Salmoral. “Leyes para esclavos: el ordenamiento jurídico sobre la condición,...”, pp.1321-1323. Em 18 de agosto de 1872, foi editado em Madri um Reglamento refinando alguns pontos da Lei Moret. O documento instituía e discernia o funcionamento de Juntas Protectoras de Libertos, que seriam responsáveis por fiscalizar o cumprimento das obrigações dos patronos e do trabalho a ser realizado pelos patrocinados para que fosse mais adequado "al desarrollo de la agricultura y a las necesidades de orden público"; também deveriam estipular o preço dos jornais a serem pagos e promover a mudança de patronos em casos de maus-tratos e outros abusos. Outrossim, foi especificada a limitação à capacidade jurídica dos patrocinados: "Los libertos deben obediencia y respeto a sus patronos como a sus padres, y no pueden sin su anuencia comprar, vender, ceder, ni enajenar, bajo la pena de nulidade". Idem, pp.1327-1333.
} 
de uma solução para os cativos não contemplados. Depois disso, o Brasil ficou mesmo isolado no cenário internacional. Em verdade, o panorama político no país já havia começado a mudar quando as Cortes espanholas ainda discutiam a sua legislação. O retorno dos combatentes vitoriosos diante do Paraguai entre o final de 1869 e o início de 1870 acendeu os ânimos populares pelo fim da escravidão. O pretexto da Guerra para o adiamento dos debates sobre o “elemento servil" se desfez em março, quando o conflito chegou ao fim. O Gabinete de Itaboraí não conseguiu atravancar o processo por muito mais tempo.

Em 23 de maio, a Câmara dos Deputados nomeou uma comissão para discutir o tema, resgatando as propostas elaboradas no âmbito do Conselho de Estado. D. Pedro II agiu novamente e desfez o Gabinete conservador, nomeando São Vicente para chefiar o Conselho de Ministros e conduzir dos trabalhos para a aprovação de uma lei emancipacionista no país. No dia 16 de agosto, a comissão apresentou o seu Projeto de Lei sobre Elemento Servil e um parecer sobre a questão, contendo referências à legislação adotada em outros países, inclusive a que acabara de ser aprovada pela Espanha. Segundo seu texto, "a dificuldade, pois, consiste na escolha e aplicação das medidas já executadas desde longa data, e largamente discutidas. A nossa tarefa é resolver da oportunidade e do modo de ação"709. Esta devia ser realizada sem ônus exagerado para o Estado e para os proprietários, cuidando-se também para a preservação da indústria do país. Ainda naquele ano outros projetos individuais seriam apresentados por Teodoro da Silva, Araújo Lima, Perdigão Malheiro e José de Alencar.

São Vicente não ficaria para comandar os trabalhos. Possivelmente por ter maior capacidade de reunir a maioria necessária para a aprovação da mudança na legislação do país, em 7 de março de 1871, o conservador José Maria da Silva Paranhos, o visconde do Rio Branco, assumiu a chefia do Gabinete imperial. Na Fala do Trono do dia 3 de maio, o imperador deu um ultimato aos parlamentares:

\footnotetext{
“Considerações da maior importância aconselham que a reforma da legislação sobre o estado servil não continue a ser uma aspiração nacional indefinida e incerta. E tempo de resolver esta questão, e vossa esclarecida prudência saberá conciliar o respeito à propriedade existente com esse melhoramento social, que requerem nossa civilização e até os interesses dos proprietários. O Governo manifestar-vos-á oportunamente todo o seu pensamento sobre as reformas para que tenho chamado a vossa atenção. Augustos e digníssimos senhores representantes da nação: as estabilidades de nossas instituições e as prosperidades do Brasil muito vos devem. Confio que, examinando com o mais decidido empenho os projetos que vos serão apresentados, habilita reis o Governo para realizar, quanto esteja ao seu alcance, o bem de nossa pátria" 710 .
}

\footnotetext{
${ }^{709}$ A Abolição no Parlamento. Brasília: Senado Federal, 1988, p.357.

${ }^{710}$ Idem, p.464.
} 
O projeto aprovado sairia do próprio Executivo, sendo remetido à apreciação parlamentar no dia 27 de maio. A nova Comissão Especial encarregada de analisá-lo emitiu seu parecer no dia 30 de junho, classificando a escravidão como uma "doença social”, um "cancro político" que havia de ser extirpado, "porque assim o demandam a opinião universal do século em que vivemos os princípios da religião, da moral e da politica, a necessidade de nos sentarmos em pé de igualdade no convívio das nações, e especialmente a unanimidade do sentimento brasileiro" "711. A última afirmação era por demasiado otimista, como se pode notar. Se o tal "sentimento brasileiro" sobre o problema da escravidão puder ser medido pelas vozes que ecoaram no Parlamento imperial, nem com muita boa vontade poderemos encontrar tal unanimidade, inclusive no interior das bancadas liberal e conservadora ${ }^{712}$.

O autor de Iracema, José de Alencar, seria um dos deputados mais críticos ao projeto, pelo risco que representava à propriedade, às lavouras do país, à ordem social e à integridade Estada. Disse ele: "É uma triste verdade, senhores, o Brasil tem representado nesta magna questão o papel de uma criança, de cujo destino decide sem consultar-lhe a vontade". Tudo obra da "pressão propagandista" promovida por "emissários da revolução" e "apóstolos da

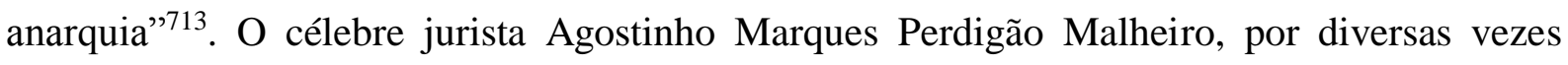
crítico das mazelas da escravidão, foi outro deputado a erguer sua voz para repudiar o projeto em discussão, em especial, por reduzir a amplitude do arbítrio senhorial. Buscou afirmar sua coerência com as posições passadas, repelindo a pecha de escravagista; recordou que havia libertado todas as mulheres e crianças cativas de sua propriedade, e que estava cuidando de sua educação. Os homens que ainda possuía, estariam sendo instruídos para que, depois de libertos, fossem úteis à sociedade. Segundo ele, o desacordo não estava no fim, visto que ele mesmo havia apresentado um projeto de emancipação gradual, mas no meio eleito para promovê-lo ${ }^{714}$. No dia 28 de agosto, por 61 votos a 35, o projeto do Gabinete Rio Branco foi aprovado na Câmara $^{715}$.

No Senado, entre os pontos a gerar polêmica esteve, claro, os que reconheciam o direito ao pecúlio e à alforria mediante indenização. Na sessão do dia 20 de setembro, José Ildefonso de Sousa Ramos, barão das Três Barras, argumentou que tais tópicos, com razão, haviam excitado as reclamações dos senhores de escravos, principalmente dos fazendeiros. No entender

\footnotetext{
711 Idem, pp.466-467.

712 Jeffrey Needell. The Party of Order: The Conservatives, the State and Slavery in the Brazilian Monarchy, 1831 1871. Stanford, California: Stanford University Press, 2006, pp.272-302.

713 Anais da Câmara dos Deputados (ACD), 13 de julho de 1871, p.134.

${ }^{714}$ Anais da Câmara dos Deputados (ACD), 12 de julho de 1871, pp.116-117. Cf. Eduardo Spiller Pena. Pajens da Casa Imperial: jurisconsultos, escravidão e a Lei de 1871. Campinas: Editora da Unicamp, 2001, pp.272-338. 715 Needell. The Party of Order..., p.300.
} 
do senador, as disposições nesse sentido colocariam "os senhores de escravos em uma posição dificultosa, e não seria exagerado dizendo insuportável”. Prosseguia argumentando que ninguém acusava os senhores de se apoderarem daquilo que os escravos adquiriam pelo seu trabalho ou lhes era provido de forma lítica. Portanto, a providência sobre o pecúlio não tinha razão de ser e só traria prejuízos e inconvenientes combinada à alforria forçada, que - podendo ser promovida com a interferência irrestrita de terceiros - faria com que os estabelecimentos rurais ficassem "expostos à malignidade, à especulação de qualquer". Para o senador, era fundamental que fosse inserida a anuência senhorial, por isso, a seguinte emenda: "É permitido ao escravo a formação de um pecúlio com o que lhe provier de doações, legados e heranças, e com o que, com consentimento do senhor, obtiver do seu trabalho e economias. O governo providenciará nos regulamentos sobre a colocação e segurança do mesmo pecúlio", o que foi inserido ao texto final, excluindo-se a inscrição anterior que previa a aquisição da soma necessária à alforria por "liberalidade de outrem""716.

Aprovada no dia 27, a Lei $\mathrm{n}^{\circ} 2.040$ foi sancionada no dia 28 de setembro de 1871 pela Princesa Isabel, que estava na regência. $\mathrm{O}$ exemplo do que havia sido estabelecido pelos espanhóis, o artigo primeiro da normativa brasileira determinou que "os filhos da mulher escrava, que nascerem no Império desde a data desta lei, serão considerados de condição livre". O seu $\S 1^{\circ}$ instituiu um regime de tutela laboral semelhante ao da Ley Moret, prevendo que os filhos menores ficariam "em poder e sob a autoridade dos senhores de suas mães", os quais teriam a obrigação de "criá-los e tratá-los" até os oito anos de idade, quando poderiam optar entre receber do Estado uma indenização de $600 \$ 000$ ou utilizar os seus serviços até os 21 anos completos. Há aqui já uma diferença. Lembremos que a lei espanhola não previu tal possibilidade, estendendo o patronato até os 22 anos, com remuneração parcial a partir dos 18 .

Outro ponto a destacar é que a Lei Rio Branco não criou um estatuto jurídico específico para a tutela, como feito pela Lei Moret. Simplesmente, atribuiu-se o direito à exploração temporária de serviços aos senhores das mães escravas, sem criar uma figura diferenciada como a do patrono. Se, por um lado, isto de certo modo mantinha a integridade do domínio senhorial, por outro, impedia que se verificassem vendas e cessões de patronato como aconteceu em Cuba, o que não atendia apenas interesses escravocratas. Aisnara Perera \& María Meriño, ao analisar as escrituras produzidas para aquela finalidade, verificaram que muitas famílias escravas

\footnotetext{
${ }^{716}$ Anais do Senado (AS), 20 de setembro de 1871, p.200. Cf. Sidney Chaloub. Visões da liberdade: Uma história das últimas décadas da escravidão na corte. São Paulo: Companhia das Letras, 1990, p.157.
} 
conseguiam explorar as brechas da Lei para trazer as crianças libertas para perto de $\mathrm{si}^{717}$. No Brasil era um pouco diferente: seria possível transferir o direito de exploração dos serviços, mas com a alienação da mãe. A tutela em si era transferível apenas em caso de sucessão necessária. Havia outras diferenças: o ônus de servir poderia ser extinto mediante indenização pecuniária; caberia aos senhores o sustento dos filhos das escravas que estivessem prestando serviços, findando-se a obrigação ao término da condição; se a mulher obtivesse a liberdade, os filhos lhe seriam entregues, exceto por opção de deixá-los. Entretanto, casos de maus-tratos e castigos excessivos também geravam a cessação do direito à exploração da prestação de serviços ordem do juízo criminal.

De forma semelhante ao efetuado na Lei espanhola, declarou-se a liberdade dos escravos pertencentes ao Estado ou dados em usufruto à Coroa, acrescentando-se os de heranças vagas e os abandonados. Todavia, como sabido, os sexagenários não foram emancipados. Por aqui, eles teriam que esperar até 1885 . Por outro lado, uma importante especificidade da Lei brasileira foi à instituição do fundo de emancipação, o que conferia à legislação brasileira um alcance maior. Sabe-se que entre 1876, ano em que o sistema começou a funcionar, e 1887, quando foi distribuída a última cota, foram libertados cerca de 32 mil escravos em todo o Império, mobilizando aproximadamente 27 mil contos de réis ${ }^{718}$.

Como já adiantado desde o início, a alforria onerosa finalmente foi sancionada. $\mathrm{O}$ artigo $4^{\circ}$, incorporando a emenda de Três Barras, reconheceu aos escravos o direito à formação de pecúlio com doações, legados e heranças, bem como "que por consentimento do senhor" obtivesse de seu trabalho. Por morte, metade do pecúlio pertenceria ao cônjuge, se houvesse, e a outra metade aos herdeiros. Na falta destes, seria destinado ao fundo de emancipação.

Conforme o $\S 2^{\circ}$ daquele mesmo artigo $4^{\circ}$, "o escravo que, por meio de seu pecúlio, obtiver meios para indenização de seu valor, tem direito à alforria". Se a indenização não fosse fixada por acordo, o seria por arbitramento; nas vendas judiciais ou nos inventários, o preço da alforria seria determinado por avaliação. A alforria condicional também foi regulamentada: o $\S$ $3^{\circ}$ estabeleceu que fosse permitido ao escravo, com consentimento do senhor, entrar em acordo com um terceiro para que fosse adquirido para a liberação futura, em troca da prestação de serviços por tempo não superior a sete anos, e o $\S 5^{\circ}$ determinou que a alforria com cláusula de serviços durante certo tempo não seria anulada, mas o liberto seria compelido a prestá-los em

\footnotetext{
${ }^{717}$ Aisnara Perera Díaz \& Maria de los Angeles Meriño Fuentes. "La cesión de patronato: una Estrategia Familiar em la emancipación de esclavos en Cuba, 1870-1880”. Revista de História, n.152 (1 - 2005), pp.29-55.

718 Fabiano Dauwe. A libertação gradual e a saída viável: os múltiplos sentidos da liberdade pelo fundo de emancipação de escravos. Dissertação de mestrado, Universidade Federal Fluminense, 2004, p.7.
} 
estabelecimentos públicos ou por contratos de serviços particulares. Além do que, o $\S 9^{\circ}$ derrogou a Ord. Liv. $4^{\circ}$, tit. 63 , na parte que previa a revogação das alforrias por ingratidão.

Portanto, a Lei de 1871 ía muito além da liberação dos recém-nascidos. Ela preenchia os vazios legislativos fundamentais do ordenamento jurídico atinente à escravidão no Brasil. O contexto, porém, era muito distinto daquele que havia levado a Coroa espanhola a editar a cédula de 1768. A eliminação do tráfico negreiro, a persistência de altos índices de mortalidade, o aumento progressivo da movimentação antiescravista no espaço público e nas senzalas inseriram o direito ao pecúlio e à alforria onerosa, conjugada às demais medidas contidas na Lei Rio Branco, em uma dinâmica de desconstrução gradual do domínio senhorial e do cativeiro, com uma redução de $52 \%$ da população escrava entre $1872(1,509,827)$ e 1887 $(723,175)^{719}$.

Se no Brasil, ocorreu uma ampliação do reconhecimento dos direitos dos escravos, na Perla de las Antillas, verificou-se certa retração nesse campo, especialmente em relação aos coartados. Em primeiro de maio de 1871, o governo local vedou-lhes a possibilidade de trocarem de amo e, em abril de 1875, foi-lhes interditado o direito de receberem jornais pertinentes a trabalhos realizados aos domingos e dias festivos. O governo havanês em aliança com a plantocracia ocidental buscaria resguardar as bases do controle senhorial sobre os cativos existentes $^{720}$. Mesmo assim, o sistema de escravidão entraria em franco declínio. Segundo apurou Rebecca Scott, os termos da Lei Moret foram diretamente responsáveis pela liberação de 32.347 escravos entre 1871 e 1877. Apesar das restrições observadas, a prática ordinária da manumissão continuaria em observância, superando as 5 mil liberações naquele mesmo período. Apesar de sua legalização secular, a observância do direito legal à alforria e à coartação assumiria novo significado social e político no contexto de crise, intensificando-a em termos quantitativos. Os dados existentes apontam para uma queda na população escrava também no nível dos 52\%, passando de 379,523, em 1872, para 199,885, em $1880^{721}$.

Portanto, a execução de ambas as Leis em tela desempenhou papel importante no processo de ruptura da dinâmica de reprodução sistêmica da escravidão, que havia começado a ruir com o fechamento do tráfico negreiro. Mas, se a configuração das respectivas ordens escravocratas carregou traços específicos, especialmente no campo jurídico, o mesmo se deu quanto à sua desconstrução. Na década de 1870, com a formação de uma "classe dos homens

\footnotetext{
${ }^{719}$ Francisco Vidal Luna \& Herbert S. Klein. Slavery in Brazil. Cambridge: Cambridge University Press, 2010, p.296.

${ }^{720}$ Scott. Emancipação escrava em Cuba..., p.94-95.

${ }^{721}$ Kiple. Blacks in Colonial Cuba (1774-1899), p.8.
} 
de cor" cada vez mais perceptível, o desligamento de parte dos setores intelectuais da classe senhorial, o surgimento de novas forças político-partidárias, seria sedimentado as bases para a futura ascensão de um movimento abolicionista que daria novo significado às lutas emanadas das senzalas ${ }^{722}$. Já Cuba, nos tempos de crise da escravidão, seria dividida por uma guerra intestina que polarizou uma região escravista e interessadamente fiel à metrópole a outra independentista e abolicionista. $\mathrm{O}$ repertório coercitivo constituído no ocidente da ilha, em um ambiente com maiores restrições à imprensa e à participação política, somar-se-ia ao efeito cumulativo de uma política estatal tradicionalmente intervencionista, contendo a ascensão de um movimento abolicionista nas regiões urbanas vinculadas materialmente à plantação açucareira.

${ }^{722}$ Ricardo Salles. "Abolição no Brasil: resistência escrava, intelectuais, e política (1870-1888)". Revista de Indias, 2011, vol. LXXI, núm. 251 p.271. 


\section{Fontes Consultadas}

\section{Brasil}

\section{Legislação}

Compêndios/Bases de dados consultadas:

Silvia Hunold Lara. "Legislação sobre escravos africanos na América portuguesa", in: José Andrés-Gallego (coord). Nuevas Aportaciones a la Historia Jurídica de Iberoamérica. Madrid: Fundación Histórica Tavera/Digibis/Fundación Hernando de Larramendi, 2000 (Cd-Rom).

Isabele Mello. Legislação, escravidão, século XIX. Tribunal de Justiça do Estado do Rio de Janeiro. Serviço de Gestão de Acervos Arquivísticos Permanentes (DGCON/ SEGAP) (mimeo), 2010.

Base de dados Legislação: trabalhadores e trabalho em Portugal, Brasil e África colonial portuguesa, do Centro de Pesquisa em História Social da Cultura - CECULT, daUniversidade Estadual de Campinas [online]. Disponível em: <http://www.ifch.unicamp.br/cecult/lex/web/>.

Ius Lusitaniae - Fontes Históricas do Direito Português

Disponível em: <http://www.iuslusitaniae.fcsh.unl.pt/>

Câmara dos Deputados.

Disponível em: 〈http://www2.camara.leg.br/atividade-legislativa/legislacao >

\section{Documentação parlamentar}

Annaes do Parlamento Brazileiro: Assembleia Constituinte. Disponível em www.camara.gov.br/publicações

Anais da Câmara dos Deputados do Império do Brasil, 1826-1850. Disponível em www.camara.gov.br/publicações

Anais do Senado do Império do Brasil, 1826-1850. Disponível em www.senado.gov.br

\section{Documentação judicial}

\section{a) Arquivo Histórico Ultramarino (Portugal)- Projeto Resgate}

Colônia: Rio de Janeiro

Localidade: desconhecida

Data: 1760

Verbete: REQUERIMENTO do pardo José Ramos ao [desembargador] José Mascarenhas Pacheco Pereira Coelho de Melo, solicitando que o prior do Monte do Carmo frei Serafim lhe passe carta de liberdade, visto ter sido escravo do falecido padre Inácio da Madre de Deus. AHU-Rio de Janeiro, cx. 295, doc. 22

AHU_Rio de Janeiro_ACL_CU_17, Cx. 60, D. 5779

Colônia: Rio de Janeiro 
Localidade: Lisboa

Data: 1779, julho, 24

Verbete: OFÍCIO (minuta) do [secretário de estado da Marinha e Ultramar, Martinho de Melo e Castro], ao [vice-rei do Estado do Brasil], Luís de Vasconcelos e Sousa, determinando a libertação do escravo Diogo Dias e mais descendentes, cuja alforria havia sido concedida pelo falecido Ambrósio Dias.

AHU-Rio de Janeiro, cx. 120, doc. 18

AHU_ACL_CU_017, Cx. 110, D. 9166

Colônia: Rio de Janeiro

Localidade: Lisboa

Data: 1779, agosto, 7 (buscar resposta)

Verbete: REQUERIMENTO do comerciante da praça do Rio de Janeiro, Manoel Gomes Cardoso, à rainha [D. Maria I], solicitando ordens para que o provedor da Alfândega [do Rio de Janeiro] averigue junto dos negociantes de Lisboa a conduta do suplicante e do tratamento aplicado a 5 escravos seus, de modo a apelar da acusação de maus tratos contra si proferida pelos ditos escravos, uma vez que os mesmos apenas pretendiam alcançar a sua liberdade e regressar a Benguela, sua pátria.

AHU-Rio de Janeiro, cx. 120, doc. 27.

AHU_ACL_CU_017, Cx. 110, D. 9172.

Colônia: Rio de Janeiro

Localidade: desconhecida

Data: 1785 , julho, 12

Verbete: REQUERIMENTO de Emerenciana, Ângela e Teresa, irmãs pardas, à rainha [D. Maria I], solicitando provisão para poderem contestar fora do prazo a decisão da $1^{\mathrm{a}}$ instância no Rio de Janeiro, numa contenda que têm com Antônio Gonçalves Montejo para obterem a sua liberdade.

AHU-Rio de Janeiro, cx. 136, doc. 31.

AHU_ACL_CU_017, Cx. 126, D. 10084

Colônia: Rio de Janeiro

Localidade: desconhecida

Data: 1787 , julho, 5

Verbete: REQUERIMENTO de Felipe, escravo de Custódio Martins Pinheiro, da cidade do

Rio de Janeiro, à rainha [D. Maria I], solicitando que o seu senhor seja compelido, em juízo, a dar-lhe a liberdade pelos 256 mil réis acordado entre ambos.

AHU-Rio de Janeiro, cx. 140, doc. 9.

AHU_ACL_CU_017, Cx. 130, D. 10315

Colônia: Rio de Janeiro

Localidade: Rio de Janeiro

Data: 1790, Agosto, 19

Verbete: REQUERIMENTO (cópia) da escrava Luzia ao [vice-rei do Estado do Brasil, conde Resende, D. José Luís de Castro], pedindo a sua carta de liberdade por ter falecido o seu proprietário Francisco Xavier de Mendonça, que morreu queimado sem deixar herdeiros AHU-Rio de Janeiro, cx. 145, doc. 105.

AHU_ACL_CU_017, Cx. 137, D. 10849

Colônia: Rio de Janeiro 
Localidade: Rio de Janeiro

Data: 1794, dezembro, 29

Verbete: OFÍCIO (cópia) do [vice-rei do Estado do Brasil], conde de Resende, [D. José Luís de Castro] ao [secretário de estado da Marinha e Ultramar], Martinho de Melo e Castro, informando as averiguações feitas sobre as idéias da Revolução Francesa em relação à liberdade de religião dentro do Rio de Janeiro, bem como a dissolução de uma sociedade literária e a prisão de seus membros.

AHU-Rio de Janeiro, cx. 157, doc. 53.

AHU_ACL_CU_017, Cx. 153, D. 11599

Colônia: Rio de Janeiro

Localidade: Rio de Janeiro

Data: 1799 , abril, 7

Verbete: OFÍCIO do [vice-rei do Estado do Brasil], conde de Resende, [D. José Luís de Castro], ao [secretário de estado da Marinha e Ultramar], D. Rodrigo de Sousa Coutinho, sobre ter cumprido a ordem para libertar ao homem pardo Antônio Francisco Granjeiro, escravo de Joaquim Vicente dos Reis, contra o depósito do montante da sua avaliação. AHU-Rio de Janeiro, cx. 173, doc. 38.

AHU_ACL_CU_017, Cx. 170, D. 12630

Colônia: Rio de Janeiro

Localidade: desconhecida

Data: 1800, agosto, 25

Verbete: REQUERIMENTO de Lauriana Rosa, por seu procurador Constantino José de Abreu, ao príncipe regente [D. João], solicitando provisão para agravar ordinariamente para a Relação do Rio de Janeiro, o processo que lhe moveu a escrava Matilde Bernardina, acusando a suplicante de maus tratos, com o objetivo de ter liberdade.

AHU-Rio de Janeiro, cx. 185, doc. 89; cx. 190, doc.58.

AHU_ACL_CU_017, Cx. 184, D. 13385

Colônia: Rio de Janeiro

Localidade: Rio de Janeiro

Data: 1800 , agosto, 27

Verbete: REQUERIMENTO do escravo e mestre alfaiate, Francisco Correia das Chagas ao príncipe regente [D. João], solicitando aviso para que o vice-rei [do Estado do Brasil conde de Resende, D. José de Castro] passe sua carta de alforria.

AHU-Rio de Janeiro, cx. 186, doc. 1.

AHU_ACL_CU_017, Cx. 184, D. 13388

Colônia: Rio de Janeiro

Localidade: desconhecida

Data: 1805, abril, 29

Verbete: REQUERIMENTO do escravo Antônio Francisco Granjeiro, ao príncipe regente [D. João], solicitando que seja reexaminado seu processo, ficando em vigor a sentença de liberdade que obteve, e a Mesa da Santa Casa de Angola o deixe ir ficando com o valor que por si deu, sendo reparado judicialmente pelos danos que lhe tem causado o seu exproprietário Joaquim Vicente dos Reis.

AHU-Rio de Janeiro, cx. 221, doc. 6.

AHU_ACL_CU_017, Cx. 226, D. 15492 
Colônia: Rio de Janeiro

Localidade: desconhecida

Data: 1807

Verbete: REQUERIMENTO do escravo Silvestre, por seu procurador Manoel José Correia Cané, ao príncipe regente [D. João], solicitando que por aviso ao vice-rei do Estado do Brasil, [conde dos Arcos, D. Marcos de Noronha e Brito] ou ao chanceler da cidade do Rio de Janeiro se ordene a avaliação do suplicante a fim de depositar o respectivo valor e obter a alforria do seu senhor Antônio de Sá Brandão.

AHU-Rio de Janeiro, cx. 300, doc. 48.

AHU_ACL_CU_017, Cx. 251, D. 17065

Colônia: Rio de Janeiro

Localidade: Rio de Janeiro

Data: 1818, maio, 18

Verbete: INSTRUMENTO DE JUSTIFICAÇÃO acerca da pretensão do preto forro José Ferreira de Araújo de reaver dois escravos que se encontram no morro de Gaspar Soares, em Vila Rica, sob a guarda do sapateiro e pardo forro, Faustino Fernandes Dias.

AHU-Rio de Janeiro, cx. 272, doc. 43.

AHU_ACL_CU_017, Cx. 280, D. 19535

\section{b) Arquivo Edgard Leuenroth $(A E L)^{723}$}

Ref. Proc. n. 9/Caixa: 3690 (AEL 1812-1817 mr 001)

Fundo/Coleção: Corte de Apelação

Autor: André Luiz Quaresma

Réus: Felisberto e João

Data inicial: 1812

Data Final: 1817

Ref. EJ.0.ACI.3 (antiga - C3686, N7)- (NA_002_2006)

Fundo: Casa da Suplicação

Série: Apelação Cível

Apelante: Joaquina Maria (escrava de Antônio de Oliveira)

Apelado: Teresa Maria de Jesus

Data inicial: 07/11/1815

Data Final: 20/07/1822

Ref. EJ.0.ACI.16 (Antiga C3687N1) (arquivo NA_007_2006)

Fundo: Casa da Suplicação

Série: Apelação Cível

Apelante: Francisco Pedro (escravo de Miguel Pedro)

Apelado: Matilde Isidora

Data inicial: $14 / 04 / 1828$

Data Final: 22/08/1828

Ref. 84.0.ACI.207 (1833-1836 RRJ mr 063) (Antiga C3683N544)

Fundo/Coleção: Relação do Rio de Janeiro

Série/subsérie: Apelação Cível

${ }^{723}$ As ações cíveis envolvendo a liberdade de escravos retiradas do AEL são reprodução em microfilme do acervo do Arquivo Nacional (Rio de Janeiro). 
Apelante: Maria Teresa

Apelado: Ana do Rocher

Data inicial: 09/02/1833 (29/05/1829 - libelo)

Data Final: 18/02/1836

Ref. BU.0.RCI.5 (C3683N544) (1833-1836 STJ mr 003)

Fundo: SUPREMO TRIBUNAL DE JUSTIÇA

Série: REVISTA CÍVEL

Recorrente: Vicente Ferreira (escravo de Antônio José Francisco Guimarães)

Recorrido: Antônio José Francisco Guimarães

Data inicial: $22 / 07 / 1833$

Data Final: 04/04/1936

Ref. 84.0.ACI.13 (C3682N648) (1836-1838 RRJ mr 004)

Fundo: RELAÇÃO DO RIO DE JANEIRO

Série: APELAÇÃO CÍVEL

Apelante: Catarina Maria da Nação Congo (escrava de Marcelino Guedes Pereira Amorim)

Apelado: Marcelino Guedes Pereira de Amorim

Data inicial: $11 / 06 / 1836$

Data Final: 26/03/1838

Ref. 84.0.ACI.14 (C3685N866) (1836-1839 RRJ mr 004)

Fundo: RELAÇÃO DO RIO DE JANEIRO

Série: APELAÇÃO CÍVEL

Apelante: Felisminda (escrava de Antônio Marua de Jesus)

Apelado: Francisco Machado

Data inicial: $18 / 05 / 1836$

Data Final: 07/02/1839

Ref. 84.0.ACI.19 (C3694N33) (1838-1850 mr 005)

Fundo: RELAÇÃO DO RIO DE JANEIRO

Série: APELAÇÃO CÍVEL

Apelante: José (escravo de Francisca Maria Teles)

Apelado: Manuel Gomes de Abreu

Data inicial: $30 / 06 / 1938$

Data Final: 02/05/1850

Ref. 84.0.ACI.24.2 (C3689N104) (1840-1846 RRJ mr 007)

Fundo: Relação do Rio de Janeiro

Série: Apelação Cível

Apelante: Joaquina (escrava de Domingos dos Santos Carvalho)

Apelado: Florêncio Paz

Data inicial: 30/06/1840

Data Final: 17/04/1846

Ref. BU.0.RCI.14 (C3694N20) (1844-1847 STJ mr 007)

Fundo: Supremo Tribunal de Justiça

Série: Revista Cível

Recorrente: Caetano Congo (escravo de Manuel de Alcântara Ferreira e Costa)

Recorrido: Manuel Pedro de Alcântara Ferreira e Costa 
Data inicial: $12 / 01 / 1844$

Data Final: 13/02/1847

Ref.84.0.ACI.42 (C3686N3370) (1847-1849 RRJ mr 014)

Fundo: Relação do Rio de Janeiro

Série: Apelação Cível

Apelantes: Antônio José Vitorino de Barros; Maria Joaquina de Melo Menezes Palhares

Apelados: Benedita (escrava de Pedro José Taveira da Veiga); Joana (escrava de Pedro José Taveira da Veiga) \{a forra Benedita, demanda a propriedade sobre Joana\}

Data inicial: $14 / 10 / 1847$

Data Final: 13/11/1849

Ref. 84.0.DIV.2 (C3688N1189) (1850-1850 RRJ mr 119)

Fundo: Relação do Rio de Janeiro

Série: Diversos

Apelante: Florinda

Apelado: Antonio Joaquim de Sampaio Porto

Data inicial: $27 / 06 / 1850$

Data Final: 24/07/1850

Ref. 84.0.ACI.45 (C3683N4975) (1850-1852 RRJ mr 015)

Fundo: Relação do Rio de Janeiro

Série: Apelação Cível

Apelante: Isabel (escrava de Antônio Dias de Sousa Castro)

Apelado: Antônio Dias de Sousa Castro

Data inicial: $31 / 08 / 1850$

Data Final: 07/12/1852

Ref. 84.0.ACI.54 (C3682N183) (1852-1854 RRJ mr 019)

Fundo: Relação do Rio de Janeiro

Série: Apelação Cível

Apelantes: Manuel, João, Francisco, Maria, Emerenciana (escravos de José Manuel de Sá)

Apelado: Joaquim de Sousa Monteiro

Data inicial: 26/04/1852

Data Final: 17/06/1854

Ref. 84.0.RCI.1 (N5958C3686) (1858-1858 RRJ mr 119)

Fundo: Relação do Rio de Janeiro

Série: Revista Cível

Recorrente: Manoela Maria de Moraes

Recorrido: José, Paulina e Vicência (escravos de Ana campos)

Data inicial: $29 / 04 / 1858$

Data Final: 11/08/1858

Ref. 84.0.ACI.78 (N8367C3690) (1858-1861 RRJ mr 026)

Fundo: RELAÇÃO DO RIO DE JANEIRO

Série: APELAÇÃO

Apelante: Casimiro (escravo de Joana Nepomuceno da Silva Bitencur)

Apelado: Higino de Assunção Gomes

Data inicial: 20/12/1858 
Data Final: 21/03/1861

Ref. 84.0.ACI.99 (C3680N10002) (1862-1864 RRJ mr 033)

Fundo: RELAÇÃO DO RIO DE JANEIRO

Série: APELAÇÃO

Apelante: Odorico (escravo de Felismina Cândida Teixeira)

Apelado: Felismina Cândida Teixeira

Data inicial: $19 / 11 / 1862$

Data Final: 118/04/1864

Ref. (C3689N6907) (1864-1866 STJ mr 014)

Fundo: SUPREMO TRIBUNAL DE JUSTIÇA

Série: REVISTA CÍVEL

Recorrente: João Inácio Teixeira de Magalhães

Recorrido: Brenda e Julieta Andrade (escravas de João Inácio Teixeira de Magalhães)

Data inicial: 15/06/1864

Data Final: 02/06/1866

Ref. (C3694N11037) (1866-1867 RRJ mr 037)

Fundo: RELAÇÃO DO RIO DE JANEIRO

Série: APELAÇÃO CÍVEL

Apelante: Paulo (escravo de José Alves de Castilho)

Apelado: Manuel José da Silva Cruz

Data inicial: 13/07/1866

Data Final: 02/07/1867

Ref. 84.0.ACI.137 (C3694N12098) (1867-1869 RRJ mr 042)

Fundo: RELAÇÃO DO RIO DE JANEIRO

Série: APELAÇÃO CÍVEL

Apelante: Bento (escravo de Joaquim Moreira da Silva Azevedo)

Apelado: Joaquina Maria Rosa

Data inicial: $11 / 07 / 1867$

Data Final: 07/05/1869

c) Arquivo Nacional (AN)

\section{Rio de Janeiro}

Apelação cível - ACI

Casa da Suplicação do Brasil

1809-1815

Apelante: Catarina Maria; Apelado: Salvador da Silva Campelo. A apelante requer sua liberdade ao apelado que anteriormente foi concedida por sua dona já falecida.

Local: Rio de Janeiro

Referência: EJ.0.ACI.0584

Ficha: 182311

Microfilme: AN 018-2011

Apelação cível - ACI 
Casa da Suplicação do Brasil

07.11.1815 a 20.07.1822

Apelante: Joaquina Maria; Apelado: Teresa Maria de Jesus. Requerimento de liberdade no qual apelante é escrava de Antônio Novais de Oliveira.

Local: Rio de Janeiro

Referência: EJ.0.ACI.0003

Ficha: 113018

Microfilme: AN 002-2006

Apelação cível - ACI

Casa da Suplicação do Brasil

1828

Apelante: Francisco Pedro; Apelado: Maria Isidora. Requerimento de liberdade no qual apelante é escravo de Miguel Pedro.

Local: Rio de Janeiro

Referência: EJ.0.ACI.0016

Ficha: 113421

Microfilme: AN 007-2006 Aditamento AN 072-2006

\section{Espanha/Cuba}

\section{Legislação}

Compêndios/Bases de dados consultadas:

Las Siete Partidas del rey Don Alfonso el Sabio, cotejadas con varios códices antiguos por la Real Academia de la Historia. 3 tomos. Madrid: Imprenta Real, 1807.

Manuel Lucena Salmoral, "Leyes para esclavos: el ordenamiento jurídico sobre la condición, tratamiento, defensa y represión de los esclavos en las colonias de la América española", in José Andrés-Gallego (coord), Nuevas Aportaciones a la Historia Jurídica de Iberoamérica. Madrid: Fundación Histórica Tavera/Digibis/Fundación Hernando de Larramendi, 2000 (Cd-Rom).

\section{Documentação parlamentar}

Diario de las sesiones de Cortes: legislatura extraordinaria (Esta legislatura dio principio en 22 de setiembre de 1821 y terminó el 14 de febrero de 1822). Disponível em: $<$ http://www.constitucion1812.org >

Diario de sesiones de las Cortes Constituyentes, dieron principio el día 11 de febrero de 1869. Disponível em: 〈http://www.constitucion1812.org>

\section{Documentação judicial}




\section{Archivo Nacional de Cuba}

ANC, Escribanía de Salinas, legajo 825, expediente 9788 (1799)

ANC, Escribanía de Varios, legajo 756, expediente 12800 (1784-1800)

ANC, Escribanía de Varios, legajo 627, expediente 10162 (1781)

ANC, Escribanía de Gobierno, legajo 18, expediente 11 (1786)

ANC, Escribanía de Varios, legajo 636, expediente 10312 (1789)

ANC, Escribanía de Daumy, legajo 693, expediente 22 (1802)

ANC, Escribanía de Galleti, legajo 917, expediente 3 (1811)

ANC, Escribanía de Daumy, legajo 778, expediente 3 (1820)

ANC, Escribanía de Pontón, legajo 50, expediente 10 (1825)

ANC, Escribanía de Luis Blanco, legajo 332, expediente 4 (1826)

ANC, Escribanía de Salinas, legajo 722, expediente 8360 (1826)

ANC, Archivo (escribanía) de Galleti, legajo 780, expediente n.4. (1828)

ANC, Escribanía de Vergel, legajo 13, expediente 15 (1836)

ANC, Escribanía de Daumy, legajo 661, expediente 9 (1837)

ANC, Escribanía de Barreto, legajo 145, expediente 15 (1839)

ANC, Escribanía de Barreto, legajo 147, expediente 6 (1842)

ANC, Escribanía de Pontón, legajo 230, expediente 4 (1845)

ANC, Escribanía de Vergel, legajo 55, expediente 4 (1841-45)

ANC, Escribanía de Pontón, legajo 231, expediente 20 (1846-47)

ANC, Escribanía de Pontón legajo 239, expediente 6 (1846)

ANC, Escribanía de Cabello-Ozeguera, legajo 197, expediente 22 (1850)

ANC, Escribanía de Gobierno, legajo leg.732, expediente 9 (1853).

ANC, Escribanía de Vergel, legajo 38, expediente 15 (1854)

ANC, Escribanía de Luis Blanco, legajo 332, expediente 6 (1857)

ANC, Escribanía de Vergel, legajo 124, expediente 7 (1864)

ANC, Archivo (escribanía) de Manuel Barreto, legajo 265, expediente 69 (1864)

ANC, Escribanía de Vergel, legajo 124 - exp 7 (1864)

ANC, Archivo (escribanía) de Valerio Ramírez 223, n.3178 (1865)

ANC, Escribanía de Portocarrero, legajo 17, expediente 7 (1868)

ANC, Escribanía de Brezmes, legajo 119, expediente 8 (1870-72)

ANC, Archivo (escribanía) de Salinas, legajo 583, expediente 6741 (1777)

ANC, Archivo (escribanía) de Daumy, legajo 382, expediente 1 (1782)

ANC, Archivo (escribanía) de Ortega, legajo 157, expediente 4 (1784)

ANC, Archivo (escribanía) de Valerio Ramírez, legajo 737, expediente 10799 (1817)

ANC, Archivo (escribanía) de Galleti, legajo 537, expediente 5 (1883-85)

ANC, Gobierno Superior Civil, legajo 937, expediente 33057 (1835)

ANC, Gobierno Superior Civil, 938, expediente 33083 (1836)

ANC, Gobierno Superior Civil, 938, expediente 33106 (1838)

ANC, Gobierno Superior Civil, legajo 939, expediente 33118 (1838)

ANC, Gobierno Superior Civil, legajo 941, expediente 33216 (1843)

ANC, Gobierno Superior Civil, legajo 943, expediente 33271 (1845)

ANC, Gobierno Superior Civil, legajo 944, expediente 33306 (1846)

ANC, Gobierno Superior Civil, legajo 350, expediente 12755 (1848)

ANC, Gobierno Superior Civil, legajo 947, expediente 33429 (1852)

ANC, Gobierno Superior Civil, legajo 948, expediente 33497 (1853)

ANC, Gobierno Superior Civil, legajo 948, expediente 33508 (1853)

ANC, Gobierno Superior Civil, legajo 950, expediente 33616 (1854-58)

ANC, Gobierno Superior Civil, legajo 951, expediente 33621 (1856) 
ANC, Gobierno Superior Civil, legajo 954, expediente 33671 (1861)

ANC, Gobierno Superior Civil, legajo 954, expediente 33679 (1861)

ANC, Gobierno Superior Civil legajo 954, expediente 33747 (1862)

ANC, Miscelánea de Expedientes, legajo 4134 L (1816)

ANC, Miscelánea de Expedientes, legajo 4134 K (1818)

ANC, Miscelánea de Expedientes, legajo 610 Ag (1839)

ANC, Miscelánea de Expedientes, legajo 3588 A (1843)

ANC, Miscelánea de Expedientes, legajo 18, expediente F (1844)

ANC, Miscelánea de Expedientes, legajo 610 Ad (1856)

ANC, Miscelánea de Expedientes, legajo 612 I (1856)

ANC, Miscelánea de Expedientes, legajo 3591 Letra Av (1859)

ANC, Miscelánea de Expedientes, legajo 3582 Cn (1868)

ANC, Miscelánea de Expedientes, legajo 3585 Bj (1874)

\section{Periódicos}

Aurora de Matanzas, 1839-1869.

Diario de la Habana, 1811.

Gaceta de la Habana, 1863.

Diario de la Marina, 1863.

Memorias de la Real Sociedad Económica dirección beso , 1836-1863.

Revista de Jurisprudencia, vols. I (1856) e VIII (1863).

\section{Documentação diversa}

\section{Biblioteca Nacional José Martí, Colección de Manuscritos}

C. M. Bachiller, n. 187, "Documentos diversos sobre la esclavitud. Habana, Trinidad, 1773$1858 "$.

C. M. Bachiller, n. 375, "Número de esclavos en la isla de Cuba, prudencial y no oficialmente considerados".

C. M. Bachiller, n. 695, "Relación de negros presentados solicitando ser coartados. Habana, enero 19, 1858". 


\section{Referências Bibliográficas}

Alencastro, Luiz Felipe de. Le commerce des vivants: traite d'esclaves et "pax lusitana" dans l'Atlantique sud. 3v. Tese de doutorado. Paris: Universidadede Paris X, 1986.

Alencastro, Luiz Felipe. "La traite négrière et l'unité nationale brésilienne. Revue française d'histoire d'outre-mer". Histoire et politologie en Amérique Latine, tome 66, n.244-245 (3e et 4e trimestres 1979). pp. 395-419.

Alencastro, Luis Felipe de. O trato dos Viventes. Formação do Brasil no Atlântico Sul. São Paulo: Cia das Letras, 2000.

Alencastro, Luis Felipe de. "Le versant brésilien de l'Atlantique-Sud: 1550-1850". Annales. Histoire, Sciences Sociales 2/2006 (61e année), pp.359-361.

Alexandre, Valentim. Os Sentidos do Império. Questão Nacional e Questão Colonial na Crise do Antigo Regime Português, Porto: Afrontamento, 1993.

Alexandre, Valentim. "O império luso-brasileiro em face do abolicionismo inglês (18071820)”. In: Maria Beatriz Nizza da Silva (org.). Brasil. Colonização e escravidão. Rio de Janeiro: Nova Fronteira, 2000.

Almeida, João Mendes de. Direito Judiciário Brasileiro. Rio de Janeiro: Freitas Bastos, 1960.

Alonso Romero, Maria Paz. Cuba en la España liberal (1837-1898). Madrid: Centro de Estudios Políticos y Constitucionales, 2002.

Álvarez Cuartero, Izaskun. Memorias de la Ilustración: las Sociedades Económicas de Amigos del País en Cuba (1783-1832). Madrid: RSBAP, 2000.

Alves filho, Ivan. Memorial dos Palmares. Rio de Janeiro: Xenon, 1988.

Andrés-Gallego, José. La esclavitud en la América española. Madrid: Ediciones Encuentro Fundación Ignacio Larramendi, 2005.

Appleby, John C. “War, Politics, and Colonization, 1558-1625”. In: N.Canny (ed.), The Oxford History of British Empire. Vol. 1 - The Origins of the Empire. British Overseas Enterprise to the Close of the Seventeenth Century. New York: Oxford University Press, 1998.

Armitage, David. "Three Concepts of Atlantic History". In: D.Armitage \& M.J.Braddick (ed), The British Atlantic World, 1500-1800. New York: Palgrave-MacMillan, 2002.

Arrighi, Giovanni. O longo século XX: dinheiro, poder e as origens de nosso tempo. (trad.port.)

Rio de Janeiro: Contraponto/Ed.Unesp, 1996.

Artola, Miguel et.alli. Cortes de Cádiz (LAS). Marcial Pons Librero, Madri, 1991.

Artola, Miguel. Espanha de Fernando VII, Madrid: Espasa, 1999. 
Asiegbu, Johnson U. J. Slavery and the Politics of Liberation, 1787-1861: A Study of Liberated African Emigration and British Antislavery Policy. New York: African Corp., 1969.

Aubert, Vilhelm. Sociologia del derecho. Caracas: Editorial Tiempo Nuevo, 1971.

Azevedo, Celia Maria Marinho de. Abolocionismo: Estados Unidos e Brasil, uma história comparada (século XIX). São Paulo: Annablume, 2003.

Azevedo, Elciene. Orfeu de carapinha: a trajetória de Luiz da Gama na imperial cidade de São Paulo. Campinas: Editora Unicamp, 1999.

Azevedo, Luiz Carlos de. Introdução à História do Direito. São Paulo: Editora Revista dos Tribunais, 2007.

Bahamonde, Angel; Cayuela, José. Hacer las Américas: las elites coloniais españolas en el siglo XIX. Madrid: Alianza Editorial, 1992.

Bailyn, Bernard. As origens ideológicas da Revolução Americana (1ª ed: 1967, trad.port.). Bauru: Edusc, 2003.

Bailyn, Bernard. Atlantic History. Concept and Contours. Cambridge, Ma.: Harvard University Press, 2005.

Baptist, Edward E.. The half has never been told: slavery and the making of American capitalism. Nova York: Basic Books, 2014

Barcia, Manuel. Seeds of Insurrection: Domination and Resistence in Western Cuban Plantations, 1808-1848. Baton Rouge: Louisiana State University Press, 2008.

Barceló, Javier Malagón. Código Negro Carolino (1784). São Domingos: Editora Taller, 1974.

Bender, Thomas (ed.). The Antislavery Debate. Capitalism and abolitionism as a problem in historical interpretation. Berkeley: University of California Press, 1992.

Berbel, Márcia Regina. A Nação como Artefato. Deputados do Brasil nas Cortes Portuguesas (1821-1822). São Paulo: Hucitec, 1999.

Berbel, Márcia, Marquese, Rafael e Parron, Tâmis. Escravidão e Política: Brasil e Cuba, c. 1790-1850. São Paulo: Hucitec, 2010.

Bergad, Laird W. The Comparative Histories of Slavery in Brazil, Cuba, and the United States. Cambridge: Cambridge University Press, 2007.

Berman, Harold Joseph. La formación de la tradición jurídica de Occidente. México: FCE, 1996.

Bernand, Carmen; Gruzinski, Serge. História do Novo Mundo. Da descoberta à conquista, uma experiência européia (1492-1550). (trad.port.) São Paulo: Edusp, 2001. 
Bethell, Leslie. A abolição do comércio brasileiro de escravos. A Grã-Bretanha, o Brasil e a questão do comércio de escravos, 1807-1869. (1ªed: 1969; trad.port.) Brasília: Senado Federal, 2002.

Bicalho, Maria Fernanda. A cidade e o império. O Rio de Janeiro no século XVIII. Rio de Janeiro: Civilização Brasileira, 2003.

Bicalho, Maria Fernanda Bicalho, "O que significava ser cidadão nos tempos coloniais". In: Marta Abreu e Rachel Soihet (org.). Ensino de história. Conceitos, temáticas e metodologia. Rio De Janeiro: Casa da Palavra, 2003, pp.139-151.

Blackburn, Robin. The Overthrow of Colonial Slavery. London: Verso, 1988.

Blackburn, Robin. The Making of New World Slavery. From the Baroque to the Modern, 14921800. London: Verso, 1997.

Blackburn, Robin, “The Force of Example”. In: David P. Geggus (ed.). The Impact of the Haitian Revolution in the Atlantic World. Columbia: University of South Carolina Press, 2001.

Blanchard, Peter. Under the Flags of Freedom. Slave Soldiers \& the Wars of Independence in Spanish South America. Pittsburgh: University of Pittsburgh Press, 2008.

Bowser, Frederick P. El esclavo africano en el Perú colonial, 1524-1650 (trad.esp.) México: Siglo XXI, 1977.

Boxer, C.R. A Idade de Ouro do Brasil. Dores de crescimento de uma sociedade colonial. (1 ${ }^{\text {a }}$ ed: 1962; trad.port.) Rio de Janeiro: Nova Fronteira, 2000.

Boxer, C.R. O Império Marítimo Português (1415-1825) (trad.port.). Lisboa: Edições 70, 2001.

Brading, D.A. “A Espanha dos Bourbons e seu Império Americano”. In: L. Bethell (org.) História da América Latina. Vol. I. América Latina Colonial. (Trad.port.) São Paulo/ Brasília: EDUSP/FUNAG, 1997.

Brandão, Júlio de Freitas. "O escravo e o direito". Anais do VI Simpósio Nacional dos Professores Universitários de História: Trabalho Livre e Trabalho Escravo, 1, 1973, pp. 255-284.

Braudel, Fernand. Civilização Material, Economia e Capitalismo - séculos XV-XVIII. Vol. 3 O tempo do mundo (trad.port.). São Paulo: Martins Fontes, 1996.

Brown, Christopher Leslie. Moral Capital. Foundations of British Abolitionism. Chapel Hill: The University of North Carolina Press, 2005.

Cabrera, Raimundo. Cuba y sus jueces. (Rectificaciones oportunas), Filadélfia: Levytype, 1891.

Caetano, Marcelo. História do Direito Português (1140-1495). Lisboa: Verbo, 1981. 
Câmara, Leandro Calbente. Administração colonial e poder: a governança da cidade de São Paulo (1765-1802). Dissertação de Mestrado. São Paulo: FFLCH/USP, 2008.

Campos, Adriana Pereira. Nas barras dos tribunais: direito e escravidão no Espírito Santo do século XIX. Tese de Doutorado. Rio de Janeiro: IFCS, 2003.

Capela, José. As burguesias portuguesas e a abolição do tráfico da escravatura. Porto: Afrontamento, 1979.

Carmen Barcia, Maria del; Torres-Cuevas, Eduardo Torres-Cuevas. "El debilitamiento de las relaciones sociales esclavistas. Del reformismo liberal a la revolución independentista". In: Instituto de Historia de Cuba. Historia de Cuba: la colonia, evolución socioeconómica y formación nacional, de los orígenes hasta 1867. La Habana: Editora Política, 1994.

Carreira, Liberato de Castro. História Financeira e Orçamentária do Império do Brasil. Brasília-RJ: Senado Federal/Fundação Casa Rui Barbosa/Mec, 1980.

Carvalho, José Murilo de. A construção da ordem. Teatro de sombras. Rio de Janeiro: Civilização Brasileira, 2003.

Carvalho, Marcus J.M. “Os negros armados pelos brancos e suas independências no Nordeste (1817-1848)”. In: István Jancsó (org.). Independência: História e Historiografia. São Paulo: Hucitec-Fapesp, 2005.

Castro, Jeanne Berrance de. A milícia cidadã: a Guarda Nacional de 1831 a 1850. São Paulo: Companhia Editora Nacional, 1977.

Castro, Paulo Pereira de. “A experiência 'republicana', 1831-1840”. In: Buarque, Sérgio Buarque de (org.). História geral da civilização brasileira. Tomo II, volume 2. O Brasil monárquico: dispersão e unidade, São Paulo: Difel, 1985.

Cauna, Jacques. Au Temps des Isles à Sucre. Histoire d'une plantation de Saint-Domingue au XVIIIe siècle. Paris: Karthala, 1987.

Cayuela Fernández, José G. "Los capitanes generales ante la cuestión de la abolición (18541862)". In: Francisco de Solano Agustín Guimerá (ed.). Esclavitud y derechos humanos - la lucha por la libertad del negro en el siglo XIX. Madrid: Consejo Superior de Investigaciones Científicas, 1990.

Chalhoub, Sidney. Visões da Liberdade. Uma história das últimas décadas da escravidão na Corte. São Paulo: Companhia das Letras, 1990.

Chalhoub, Sidney. A força da escravidão: ilegalidade e costume no Brasil oitocentista. São Paulo: Companhia das letras, 2012. 
Chalhoub, Sidney. Machado de Assis, Historiador. São Paulo: Companhia das Letras, 2003

Childs, Matt D. The 1812 Aponte Rebellion in Cuba and the struggle against Atlantic Slavery. Chapel Hill: The University of North Carolina Press, 2006.

Chust, Manuel. La question nacional americana en las Cortes de Cádiz. Valência: Centro Francisco Tomás y Valiente - Fundación Instituto Historia Social - Instituto de Investigaciones Históricas/UNAM, 1999.

Chust, Manuel. "Nación y federación: cuestiones del doceañismo hispano". In: M. Chust (ed.) Federalismo y cuestion federal en España. Valência: Universitat Jaume I, 2004.

Clarence-Smith, W.G.; Topik, Steven. The Global Coffee Economy in Africa, Asia, and Latin America, 1500-1989. Cambridge: Cambridge University Press, 2003.

Corbitt, Duvon C. "Immigration in Cuba". In: The Hispanic American Historical Review. 22 (2): 280-308, May 1942.

Conrad, Robert. Os últimos anos da escravatura no Brasil, 1850-1888 (trad.port.). Rio de Janeiro: Civilização Brasileira, 1978

Conrad, Robert. Tumbeiros. O tráfico de escravos para o Brasil. (trad.port.) São Paulo: Brasiliense, 1985.

Cottrol, Robert J. “Comparative Slave Studies: Urban Slavery as a Model, Travelers' Accounts as a Sourse - Bibliographical Essay”. Journal of Black Studies, 8, n.1 (1977), pp.3-12.

Cottrol, Robert J. "The long lingering shadow: law, liberalism, and cultures of racial hierarchy and identity in the Americas”. Tulane Law Review, New Orleans, 76/1, 2001.

Corwin, Arthur F. Spain and the Abolition of Slavery in Cuba, 1817-1886. Austin: The University of Texas Press, 1967.

Costa, Emília Viotti da. Da Senzala à Colônia (1ª ed: 1966). São Paulo: Ed.Unesp, 1998.

Costa, Emília Viotti da. Da Monarquia à república - momentos decisivos. São Paulo: Ed.Unesp, 1999.

Costa, Emília Viotti da. Coroas de Glória, Lágrimas de Sangue. A rebelião dos escravos de Demerara em 1823. (trad.port) São Paulo: Companhia das Letras, 1998.

Craton, Michael. Testing the Chains. Resistance to Slavery in the British West Indies. Ithaca: Cornell University Press, 1982.

Cruz-Taura, Graciella. “Annexation and National Identity: Cuba's Mid-Nineteenth-Century Debate”. In: Cuban Studies. 27: 90-109, 1997.

Curto, Diogo Ramada et alli. A Casa Literária do Arco do Cego (1799-1801). Bicentenário. Lisboa: Biblioteca Nacional-Imprensa Nacional-Casa da Moeda, 1999. 
Cunha, Manuela Carneiro da. "Sobre os silêncios da Lei: lei costumeira e positiva nas alforrias de escravos no Brasil do século XIX”. in: Antropologia do Brasil: mito, história, etnicidade. São Paulo: Editora Brasiliense, 1987, pp.123-144.

Davis, David Brion. The Problem of Slavery in Western Culture (1 ${ }^{\mathrm{a}} \mathrm{ed}$ : 1966). New York: Oxford University Press, 1988.

Davis, David Brion. The Problem of Slavery in the Age of Revolution, 1770-1823 (1 ${ }^{\mathrm{a}} \mathrm{ed}$ : 1975). Oxford: Oxford University Press, 1999.

Debbash, Yvan. “Au coeur du 'gouvernement des esclaves': la souveraineté domestique aux Antilles françaises (XVIIe-XVIIIe siècles).” In: Revue française d'Histoire d'OutreMer. LXXII, no 266: 31-54, 1985.

De La Fuente, Alejandro. "Los ingenios de azucar en la Habana del siglo XVII (1640-1700) Estructura y mano de obra". Revista de Historia Económica, vol. IX, n.1 (1991), pp. 3567.

De La Fuente, Alejandro. "Slavery and claims-making in Cuba: The Tannenbaum debate revisited". Law and History Review, vol. 22, 2004, pp. 339-69.

De La Fuente, Alejandro. "La esclavitud la ley, y la reclamación de derechos en Cuba: repensando el debate de Tannenbaum". Debate y Perspectivas. Cuadernos de Historia y Ciencias Sociales - Su único derecho: los esclavos y la ley. Madri: Fundación Mapfre Tavera, n. ${ }^{\circ}$ 4, 2004, pp.37-68.

De La Fuente, Alejandro. "Slaves and the Creation of Legal Rights in Cuba: Coartación and Papel”. Hispanic American Historical Review, vol.87, n.4 (Nov. 2007), 659-92.

De La Fuente, Alejandro. Havana and the Atlantic in the Sixteenth Century. University of North Carolina Press, 2008.

De la Fuente, Alejandro \& Gross, Ariela. "Comparative Studies of Law, Slavery and Race in the Americas". University of Southern California Legal Studies Working Paper Series (February, 2010).

Dias, Maria Odila Leite da Silva. A interiorização da metrópole e outros estudos. São Paulo: Alameda, 2005.

Dohlnikoff, Miriam. O pacto imperial. Origens do federalismo no Brasil. São Paulo: Globo, 2005.

Dorigny, Marcel; Gainot, Bernard. La Société des Amis des Noirs, 1788-1799-Contribution à l'Histoire de l'Abolition de l'Esclavage. Paris: Unesco-Unicef, 1998. 
Drescher, Seymor. Capitalism and Antislavery. British Mobilization in Comparative Perspective. New York: Oxford University Press, 1987.

Drescher, Seymour. "The Limits of Example”. In: David P. Geggus (ed.). The Impact of the Haitian Revolution in the Atlantic World. Columbia: University of South Carolina Press, 2001.

Dubois, Laurent. A Colony of Citizens. Revolution \& Slave Emancipation in the French Caribbean, 1787-1804. Chapel Hill: University of North Carolina Press, 2004.

El Youssef, Alain. O problema da escravidão em periódicos brasileiros da década de 1830: Jornal do Comércio, Diário da Bahia, O Justiceiro, O Sete d'Abril e O Catão. FAPESP. Relatório de Iniciação Científica. São Paulo, 2006.

Elkins, Stanley. Slavery. A Problem in American Institutional and Intelectual Life. Chicago: The University of Chicago Press, 1959.

Elliott, J.H. Spain and its World, 1500-1700. New Haven: Yale University Press, 1989.

Elliott, J.H. Empires of the Atlantic World. Britain and Spain in America, 1492-1830. New Haven: Yale University Press, 2006.

Eltis, David. Economic Growth and the Ending of the Transatlantic Slave Trade. New York/Oxford: Oxford University Press, 1987.

Emmer, P.C. "The Dutch and the making of the second Atlantic system". In: Barbara L. Solow (ed.). Slavery and the Rise of the Atlantic System. Cambridge: Cambridge University Press, 1991.

Faria, Sheila de Castro. "A riqueza dos libertos: os alforriados no Brasil escravista". In: Cláudia Maria das Graças Chaves \& Marco Antonio Silveira (org.). Território, conflito e identidade. Belo Horizonte: Argvmentvm, 2007.

Farr, James. "'So Vile and Miserable an Estate': The Problem of Slavery in Locke's Political Thought". In: Political Theory, 14 (2): 263-89, May 1986.

Ferreira, Roquinaldo Amaral. Dos sertões ao Atlântico: tráfico ilegal de escravos e comércio lícito em Angola, 1830-1860. Dissertação de mestrado. Rio de Janeiro: Instituto de Filosofia e Ciências Sociais, UFRJ, 1996.

Ferreira, Roquinaldo Amaral. “Brasil e Angola no tráfico ilegal de escravos, 1830-1860”. In: Selma Pantoja \& José Flávio Sombra Saraiva (org.). Angola e Brasil: nas rotas do Atlântico Sul. Rio de Janeiro: Bertrand Brasil, 1999.

Ferrer, Ada. "Cuba en la sombra de Haití: noticias, sociedad y esclavitud”. In: M.Dolores González-Ripoll; C.Naranjo; A.Ferrer; G.García; J. Opatrný. El Rumor de Haití en Cuba: Temor, Raza y Rebeldía, 1789-1844. Madri: CSIC, 2004. 
Ferrer, Ada. "Speaking of Haiti: Slavery, Revolution, and Freedom in Cuba Slave Testimony". In: David P. Geggus; N. Fiering (eds.). The World of the Haitian Revolution. Bloominton: Indiana University Press, 2009.

Ferrer, Ada. Freedom's Mirror: Cuba and Haiti in the Age of Revolution. Cambridge: Cambridge University Press, 2014.

Fick, Carolyn E. The Making of Haiti. The Saint-Domingue Revolution from Below. Knoxville: The University of Tessessee Press, 1990.

Fioravanti, Maurizio. Los derechos fundamentales: apuntes de la Historia de las constituciones. Madri: Trotta, 1998;

Fioravanti, Maurizio. Constitución: de la Antigüedad a nuestros días. Madri: Trotta, 2001.

Florentino, Manolo Garcia. Em Costas Negras. Uma História do Tráfico Atlântico de Escravos entre a África e o Rio de Janeiro (séculos XVIII e XIX). Rio de Janeiro: Arquivo Nacional, 1995.

Flory, Thomas. Judge and Jury in Imperial Brazil, 1808-1850. Social Control and Political Stability in the New State. Texas: University of Texas Press, 1981.

Flory, Thomas. "Race and Social Control in Independent Brazil". In: Journal of Latin American Studies. 9 (2): 199-224, nov, 1977.

Flouret, Michèle. "Ilustración y esclavitud en Cuba. El testimonio de la condesa de Merlín sobre la esclavitud en Cuba a mediados del siglo XIX”. In: Homenaje a Noël Salomon: ilustración española e independencia de América. Barcelona: Universidad Autónoma de Barcelona, 1979.

Foner, Philip S. A History of Cuba and its Relations with The United States: 1845-1895. New York: International Publishers Company, 1963.

Forner, Laura e Genovese, Eugene. (orgs.). Slavery in the New World. A Reader, in Comparative History. New Jersey: Englewood Cliffs, 1969.

Foucault, Michel. Vigiar e punir. Petrópolis: Vozes, 1977.

Foucault, Michel. “A governabilidade”, in: Microfísica do poder. Rio de Janeiro: Graal, 1979.

Fournier, Fernando. Historia del derecho. San José: Publicaciones de la Universidad de Costa Rica. Serie Ciencias jurídicas y sociales, 1967.

Fradera, Josep M. Gobernar colonias. Barcelona: Ed.Península, 1999.

Fradera, Josep M. Colonias para después de un imperio. Barcelona: Edicions BellaTerra, 2005.

Fradera, Josep M. “L'esclavage et la logique constitutionnelle des empires". In: Annales. Histoire, Sciences Sociales. 63 (3): 533-60, mai-juin 2008. 
Frasquet, Ivana. Las caras del águila. Del liberalismo gaditano a la república federal mexicana (1820-1824). Castellón: Publicacions de laUniversitat Jaume I, 2008.

Freehling, William W. The Road to Disunion. New York: Oxford University Press, 1990.

Freire, Pascoal José de Mello Freire. Instituições de Direito Civil português: tanto público como particular. Livro I, Título I. (1 $1^{\text {a }}$ edição, 1789 - tradução de Miguel Pinto de Meneses). Lisboa: Procuradoria Geral da República, 1967.

Freitas, Augusto Teixeira. Consolidação das Leis Civis. (terceira edição) Rio de Janeiro: Garnier, 1876,

Funes Monzote, Reinaldo. De bosque a sabana. Azúcar, deforestación y médio ambiente en Cuba: 1492-1926. México: Siglo XXI, 2004.

Furstenberg, François. "Beyond Freedom and Slavery: Autonomy, Virtue, and Resistance in Early American Political Discourse”. In: Journal of American History, 89 (4): 1295 1330, March 2003.

Gainot, Bernard. "Métropole/Colonies. Projets constitutionnels et rapports de forces, 17981802”. In: Y.Benot \& M.Dorigny (ed). Rétablissement de l'esclavage dans les colonies françaises, 1802. Paris: Maisonneuve \& Larose, 2003.

Galloway, J.H. "Agricultural reform and the Enlightenment in Late Colonial Brazil". In: Agricultural History. 53 (4): 763-79, October 1979.

García-Gallo, Alfonso. Estudios de historia Del derecho indiano. Madri: Instituto Nacional de Estudios Juridicos, 1972.

García, Gloria. La esclavitud desde la esclavitud. Havana: Editoral de Ciencias Sociales, 2003.

García, Gloria. "Vertebrando la resistencia: la lucha de los negros contra el sistema esclavista, 1790-1845”. In: M. D. Gonzáles-Ripoll, Consuelo Naranjo, Ada Ferrer, Gloria García \& Josef Opatrný. El rumor de Haití en Cuba: temor, raza y rebeldía, 1789-1844. Consejo Superior de Investigaciones Científicas, 2004.

García Rodríguez, Mercedes. La aventura de fundar ingenios. La refacción azucarera en La Habana del siglo XVIII. Havana: Editorial de Ciencias Sociales, 2004.

Garrigus, John D. Before Haiti: Race and Citizenship in French Saint-Domingue. New York: Palgrave-Macmillan, 2006.

Geggus, David. "Racial Equality, Slavery, and Colonial Secession during the Constituent Assembly”. In: The American Historical Review, 94 (5): 1290-1308, December 1989. 
Geggus, David P. "The effects of the American Revolution on France and its empire”. In: Jack P. Greene \& J.R.Pole (ed.), A Companion to the American Revolution. Malden, Mass.: Blackwell Publ., 2004.

Geggus, David P. (ed.). The Impact of the Haitian Revolution in the Atlantic World. Columbia: University of South Carolina Press, 2001.

Genovese, Eugene. A economia política da escravidão (1 ${ }^{\mathrm{a}}$ ed: 1965; trad.port.) Rio de Janeiro: Pallas, 1976.

Godoy, Garcia. Las Cortes de Cádiz y América. El primero vocabulario liberal y mejicano (1810-1814). Sevilla: Diputacion de Sevilla, 1998.

Gerson, Brasil. A escravidão no Império. Rio de Janeiro: Pallas, 1975.

Gomariz, José. "Francisco de Arango y Parreño: El discurso esclavista de la ilustración cubana”. In: Cuban Studies. 35: 45-61, 2004.

Gomes, Flávio dos Santos. Histórias de quilombolas: mocambos e comunidades de senzalas no Rio de Janeiro, século XIX. Rio de Janeiro: Arquivo Nacional, 1995.

Gomes, Flávio dos Santos. "Experiências transatlânticas e significados locais: idéias, temores e narrativas em torno do Haiti no Brasil Escravista.”. Tempo, 13 (2002), pp.209-246.

Gómez Urdáñez, Gracia. "Progresismo y poder político en la España isabelina: el gobierno de Olózaga a finales de 1843”. In: Hispania: Revista Española de Historia. LX (2): 62371, mayo-agosto 2000.

González-Ripoll Navarro, Maria Dolores. Cuba, La Isla de los Ensayos. Cultura y Sociedad (1790-1815). Madrid: CSIC, 1999.

Goveia, Elsa. "The West Indian Slave Laws of the Eighteenth Century". In: H.Beckles \& V.Shepherd (ed.). Caribbean Slave Society and Economy. Kingston-Jamaica/London: Ian Randle-James Currey Publishers, 1991.

Graden, Dale T. “An Act 'Even of Public Security': Slave Resistance, Social Tensions, and the End of the International Slave Trade to Brazil, 1835-1856”. In: Hispanic American Historical Review. 76 (2): 249-82, May 1996.

Greene, Jack P. "Empire and Identity from the Glorious Revolution to the American Revolution”. In: P.J.Marshall (ed.). The Oxford History of British Empire. Vol. II - The Eighteenth Century. New York: Oxford University Press, 1998.

Greene, Jack P. "Liberty, slavery, and the transformation of British identity in the eighteenthcentury West Indies”. In: Slavery \& Abolition, 21 (1): 1-31, April 2000.

Grinberg, Keila. Liberata: a lei da ambigüidade - As ações de liberdade da Corte de Apelação do Rio de Janeiro no século XIX. Rio de Janeiro: Relume Dumara, 1994. 
Grinberg, Keila. “Alforria, direito e direitos no Brasil e nos Estados Unidos”. Revista Estudos Históricos. Rio de Janeiro, n.28, 2001.

Grinberg, Keila. O fiador dos brasileiros. Cidadania, escravidão e direito civil no tempo de Antonio Pereira Rebouças. Rio de Janeiro: Civilização Brasileira, 2002.

Grinberg, Keila. "Reescravização, direitos e justiças no Brasil”, in: Silvia Hunold Lara \& Joseli Mendonça (org). Direitos e Justiças no Brasil. Campinas: UNICAMP, 2006, pp. 101128.

Grinberg, Keila \& Silva, Cristina Nogueira da. "Soil Free from Slaves: Slave Law in Late Eighteenth- and Early Nineteenth-Century Portugal”. Slavery \& Abolition, v. 32 (2011), pp.431-446.

Guedes, Roberto. Egressos do Cativeiro. Trabalho, família, aliança e mobilidade social (Porto Feliz, São Paulo, c.1798-1850). Rio de Janeiro: Mauad X-Faperj, 2008.

Guerra, François-Xavier. Modernidad e independencias. México: Fondo de Cultura Econômica, 1997.

Guerra y Sanchéz, Ramiro. Manual de Historia de Cuba (1 ${ }^{\mathrm{a}}$ Ed: 1938). Havana: Editorial de Ciencias Sociales, 1971.

Halperin Donghi, Tulio. Reforma y Disolución de los Impérios Ibéricos. Madrid: Alianza Editorial, 1985.

Hanke, Lewis. Aristotle and the American Indians. London: Hollis \& Carter, 1959.

Harris, Marvin. Patterns of Race in the Americas. New York: Greenwood Publ., 1964.

Heckscher, Eli. La Época Mercantilista (trad.esp.). México: Fondo de Cultura Económica, 1943.

Helg, Aline. "Race and Black Mobilization in Colonial and Early Independent Cuba: a Comparative Perspective”. In: Ethnohistory. 44 (1): 53-74, Winter 1997.

Henderson, Gavin B. "Southern Designs on Cuba, 1854-1857 and Some European Opinions". In: The Journal of Southern History. 5 (3): 371-85, August 1939.

Hernández González, Manuel. "El liberalismo criollo cubano en el Trienio liberal: El Americano Libre”. In: Imilcy Balboa \& José A. Piqueras (ed). La excepción americana. Cuba en el ocaso del imperio americano. Valencia: Centro Francisco Tomás y Valiente - Fundación Instituto Historia Social, 2006. Hernández González, Manuel. "El liberalismo exaltado en el Triênio Liberal cubano". In Josef Opatrný (ed.). Cuba, algunos problemas de su historia. Praga: Universidad Carolina de Praga, 1995.

Herzog, Tamar. "Communities Becoming a Nation: Spain and Spanish America in the Wake of Modernity (and Thereafter)”. In: Citizenship Studies, 11 (2): 151-72, may 2007 
Holanda, Sérgio Buarque de (org.). História Geral da Civilização Brasileira, t.I, A Época Colonial, v.1. Do Descobrimento à Expansão Territorial. (1ª.ed: 1960). São Paulo: Bertrand, 2001.

Hurwitz, Samuel J.; Hurwitz, Edith F. “A Token of Freedom: Private Bill Legislation for Free Negroes in Eighteenth-Century Jamaica". In: The William and Mary Quarterly. Third Series, 24 (3): 423-31, July 1967.

Iglésias, Francisco. "Vida política, 1848-1868". In: Sérgio Buarque de Holanda (org.). História geral da civilização brasileira, t. II, O Brasil monárquico, v.3, Reações e transações (1 ${ }^{\mathrm{a}}$ ed: 1967). Rio de Janeiro: Bertrand Brasil, 2004.

Isaac, Rhys. Landon Carter's Uneasy Kingdom. Revolution and Rebellion on a Virginia Plantation. Oxford: Oxford University Press, 2004.

Jancsó, István. Na Bahia, contra o império. História do ensaio de sedição de 1798. São Paulo: Hucitec-EDUFBA, 1996.

Jancsó, István. “Bahia 1798. A hipótese de auxílio francês ou a cor dos gatos”. In: Júnia Ferreira Furtado (org.). Diálogos Oceânicos. Minas Gerais e as novas abordagens para uma história do Império Ultramarino Português. Belo Horizonte: Ed.UFMG, 2001.

Jancsó, István; Pimenta, João Paulo. "Peças de um mosaico (ou apontamentos para o estudo da emergência da identidade nacional brasileira". In: Carlos G. Motta (org.). Viagem incompleta. A experiência brasileira 1500-2000. São Paulo: SENAC, 2000.

Jenergan, Marcus W. "Slavery and Conversion in the American Colonies". In: The American Historical Review. 21 (3): 504-27, April 1916.

Jordan, Winthrop. White over black: American attitudes toward the Negro, 1550-1812. Chapel Hill: University of North Carolina Press, 1968.

Kagan, Robert L. "Prescott's Paradigm: American Historical Scholarship and the Decline of Spain”. In: The American Historical Review, 101 (2): 423-446, April 1996.

Kaplanoff, Mark D. “The Federal Convention and the Constitution”. In: Jack P. Greene \& J.R.Pole (ed.), A Companion to the American Revolution. Malden, Mass.: Blackwell Publ., 2004.

Karasch, Mary C. A vida dos escravos no Rio de Janeiro, 1808-1850 (trad.port.). São Paulo: Cia. das Letras, 2000.

Keen, Benjanim. “The Black Legend Revisited: Assumptions and Realities”. In: The Hispanic American Historical Review. 49 (4): 703-719, November 1969.

King, James F. "The Colored Castes and American Representation in the Cortes of Cadiz". In: The Hispanic American Historical Review. 33 (1): 33-64, feb.1953. 
Klein, Herbert S. "Anglicanism, Catholicism and the Negro Slave". In: Comparative Studies in Society and History. 8 (3): 295-327, April 1966.

Klein, Herbert S. Slavery in the Americas: a comparative study of Cuba and Virginia, Chicago: Chicago University Press, 1967.

Klein, Herbert S. O tráfico de escravos no Atlântico. (trad.port.) Ribeirão Preto/SP: FUNPEC Editora, 2004.

Klein, Herbert S.; Vinson III, Ben. La Esclavitud Africana en América Latina y el Caribe (2a ed; trad.esp.) Lima: IEP, 2008.

Knight, Franklin W. Slave Society in Cuba during the Nineteenth Century. Madison: The University of Wiscousin Press, 1970.

Koselleck, Reinhart. Futuro Passado. Contribuição à semântica dos tempos históricos. ( $1^{\mathrm{a}} \mathrm{Ed}$ : 1979; trad.port.) Rio de Janeiro: Contraponto-Ed.PUC-RJ, 2006.

Koselleck, Reinhart. Los estratos del tiempo: estudios sobre la historia (trad. esp). Barcelona: Paidós, 2001.

Kuethe, Alan J. Cuba, 1753-1815. Crown, Military, and Society. Knoxville: The University of Tennessee Press, 1986.

Kury, Lorelai (org.). Iluminismo e Império no Brasil. O Patriota (1813-1814). Rio de Janeiro: Editora Fiocruz-Fundação Biblioteca Nacional, 2007.

Lara, Silvia Hunold. Campos da Violência. Escravos e Senhores na Capitania do Rio de Janeiro, 1750-1808. Rio de Janeiro: Paz \& Terra, 1988.

Lara, Silvia Hunold. "Legislação sobre Escravos Africanos na América Portuguesa”, in: José Andrés-Gallego (coord), Nuevas Aportaciones a la Historia Jurídica de Iberoamérica. Madrid: Fundación Histórica Tavera/Digibis/Fundación Hernando de Larramendi, 2000 (Cd-Rom).

Lara, Silvia Hunold. Fragmentos Setecentistas. Escravidão, cultura e poder na América portuguesa. São Paulo: Companhia das Letras, 2007.

Lara, Silvia Hunold. Palmares \& Cucaú: o aprendizado da dominação. Tese apresentada para o concurso de Professor Titular Área de História do Brasil IFCH/Unicamp, 2008.

Levaggi, Abelardo. "Condición jurídica del esclavo en la época Hispana". Revista de Historia del Derecho, Instituto de Investigaciones de Historia del Derecho, Buenos Aires, 1, (1973), pp.83-175.

Giovanni Levi. "Sobre a micro-história". In: Peter Burke (org.). A escrita da História. (trad.port.). São Paulo: UNESP, 1992. 
Lima, Adriano Bernardo Moraes Lima. “'O homem só consegue enxergar o meio-dia da porta de sua casa': olhares sobre a prática da alforria no Brasil setecentista". Texto apresentado no III Encontro Escravidão e Liberdade no Brasil Meridional, realizado em maio de 2007.

Lockhart, James; Schwartz, Stuart B. A América Latina na época colonial (trad.port). Rio de Janeiro: Civilização Brasileira, 2002.

Lombardi, John. The Decline and Abolition of Negro Slavery in Venezuela, 1820-1854. Westport: Greenwood Publishing Corporation, 1971.

Lombardi, John V. "Comparative Slave Systems in the Americas: A Critical Review". In: GRAHAM, R. E SMITH, P. (orgs.). New Approachs to Latin American History. Austin: University os Texas Press, 1974.

Lucena Salmoral, Manuel. Los códigos negros de la América española. Alcalá de Henares: Ediciones UNESCO/Universidad de Alcalá, 1996.

Lucena Salmoral, Manuel. "Leyes para esclavos: el ordenamiento jurídico sobre la condición, tratamiento, defensa y represión de los esclavos en las colonias de la América española”, in: José Andrés-Gallego (coord), Nuevas Aportaciones a la Historia Jurídica de Iberoamérica. Madrid: Fundación Histórica Tavera/Digibis/Fundación Hernando de Larramendi, 2000 (Cd-Rom).

Lyra, Maria de Lourdes Viana. A utopia do poderoso império. Portugal e Brasil: Bastidores da Política, 1798-1822. Rio de Janeiro: Sette Letras, 1994.

Lopes, José Reinaldo Lima. O direito na história: lições introdutórias. São Paulo: Max Limonad, 2002.

Lopes, José Reinaldo Lima. As palavras e a lei: Direito, ordem e justiça na história do pensamento jurídico moderno. São Paulo: Editora 34, 2004.

Machado, Maria Helena P. T. O plano e o pânico: os movimentos sociais na década da abolição. São Paulo: EDUSP, 1994;

Malheiro, Agostinho Marques Perdigão. A escravidão no Brasil: ensaio histórico, jurídico, social. (1866), 2.v. Fonte Digital: eBooksBrasil, 2008.

Mamigonian, Beatriz Galloti. To be a liberated African in Brazil-labour and citizenship in the nineteenth century. Tese de Doutorado. Ontário, Canadá: University of Waterloo, 2002. 
Mamigonian. "O direito de ser africano livre”, in: Silvia Hunold Lara \& Joseli Maria Nunes Mendonça. Direitos e justiças no Brasil: ensaios de história social. Campinas: Editora Unicamp, 2006.

Mansuy-Diniz Silva, Andrée. “Portugal e Brasil: a reorganização do Império, 1750-1808.” In: L. Bethell (org.). História da América Latina. Vol. I. América Latina Colonial. (Trad.port.) São Paulo/ Brasília: EDUSP/FUNAG, 1997.

Marques, Marques. The United States and the Transatlantic Slave Trade to the Americas, 17761867. Tese de Doutorado, Emory University, 2013.

Marques, João Pedro. Os Sons do Silêncio: o Portugal de Oitocentos e a Abolição do Tráfico de Escravos. Lisboa: Imprensa de Ciências Sociais, 1999.

Marquese, Rafael de Bivar. Feitores do corpo, missionários da mente. Senhores, letrados e o controle dos escravos nas Américas, 1660-1860. São Paulo: Companhia das Letras, 2004.

Marquese, Rafael de Bivar. "Escravismo e Independência: a ideologia da escravidão no Brasil, em Cuba e nos Estados Unidos nas décadas de 1810 e 1820”. In: István Jancsó (org.). Independência: História e Historiografia. São Paulo: Hucitec, 2005.

Marquese, Rafael de Bivar; Parron, Tâmis Peixoto. “Azeredo Coutinho, Visconde de Araruama e a Memória sobre o comércio de escravos de 1838”. In: Revista de História. 152: 99$126,1^{\circ}$ semestre de 2005.

Marquese, Rafael de Bivar. "A dinâmica da escravidão no Brasil. Resistência, tráfico negreiro e alforrias, séculos XVII a XIX”. In: Novos Estudos Cebrap, 74: 107-123, março 2006.

Marquese, Rafael de Bivar. "Estrutura e agência na historiografia da escravidão: a obra de Emília Viotti da Costa". In: A.C.Ferreira, H.G.Bezerra, T.R.de Luca (org.), $O$ historiador e seu tempo. São Paulo: Ed.Unesp, 2008.

Marquese, Rafael; Tomich, Dale. "O Vale do Paraíba escravista e a formação do mercado mundial do café no século XIX”. In: Keila Grinberg \& Ricardo Salles (orgs.). O Brasil Império (1808-1889). Rio de Janeiro: Civilização Brasileira (no prelo).

Martinez, Pascual. La unión con España, exigência de los diputados americanos en las Cortes de Cádiz. Madrid: Editorial Castalia, 2001.

Martínez-Fernández, Luis. Torn Between Empires: Economy, Society, and Patterns of Political Thought in the Hispanic Caribbean, 1848-1878. Athens: University of Georgia Press, 1994.

Martins, José de Souza. O cativeiro da terra (1ª ed. 1986). São Paulo: Hucitec, 1996. 
Matthew, Gelien. Caribbean Slave Revolts and the British Abolitionist Movement. Baton Rouge: Louisiana State University Press, 2006.

Mattos, Hebe Maria. Das cores do silêncio: os significados da liberdade no sudeste escravista. Rio de Janeiro: Nova Fronteira, 1998.

Mattos, Hebe Maria. Escravidão e cidadania no Brasil monárquico. Rio de Janeiro: Jorge Zahar, 2000.

Mattos, Hebe Maria. “A escravidão moderna nos quadros do Império português: o Antigo Regime em perspectiva atlântica”. In: M.F. Bicalho; M.de F. Gouvêa; João Fragoso (org.) Antigo Regime nos Trópicos. A dinâmica imperial portuguesa (séc.XVI-XVIII). Rio de Janeiro: Civilização Brasileira, 2001.

Mattos, Ilmar Rohloff. O tempo saquarema. A formação do Estado Imperial (1 $1^{\text {a }}$ ed: 1986). São Paulo: Hucitec, 2004.

Mattoso, José (dir.). História de Portugal. Segundo Volume - A Monarquia Feudal (10961480). Lisboa: Estampa, 1993.

Maxwell, Kenneth. A Devassa da Devassa. A Inconfidência Mineira: Brasil e Portugal, 17501808 (trad.port). Rio de Janeiro: Paz \& Terra, 1978.

Maxwell, Kenneth. Marquês de Pombal. Paradoxo do Iluminismo (trad.port.) Rio de Janeiro: Paz \& Terra, 1996.

Maxwell, Kenneth. "The impact of the American Revolution on Spain and Portugal and their empires". In: Jack P. Greene \& J.R.Pole (ed.). A Companion to the American Revolution. Malden, Mass.: Blackwell Publ., 2004.

McMichael, Philip. "Incorporating Comparison within a World-Historical Perspective: An Alternative Comparative Method”. In: American Sociological Review. 55 (3): 385-97, jun 1990.

Medina Plana, Raquel. Soberania, Monarquia y Representación en las Cortes del Trienio. Madri: Fundación Universitária Española, 2005.

Meinig, D.W. The Shaping of America. A Geographical Perspective on 500 years of History. Volume I: Atlantic America, 1492-1800. Yale: Yale University Press, 1986.

Mendonça, Joseli. Entre a mão e os anéis: a lei dos sexagenários e os caminhos da abolição no Brasil. Campinas: Editora Unicamp, 1999.

Meriño Fuentes, María de los Ángeles \& Perera Díaz, Aisnara. Para librarse de lazos, antes buena familia que buenos brazos: apuntes sobre la manumisión en Cuba (1800-1881). Santiago de Cuba: Editorial Oriente, ano. 
Miller, Joseph C. Way of Death: Merchant Capitalism and the Angolan Slave Trade, 17301830. University of Wisconsin Press, 1988.

Miller, Joseph C. “O Atlântico escravista: açúcar, escravos e engenhos”. Afro-Ásia, n.19/20 1997, pp.9-36.

Miller, Joseph C. “A economia política do tráfico angolano de escravos no século XVIII”. In: Selma Pantoja \& José Flávio Sombra Saraiva (org.). Angola e Brasil nas rotas do Atlântico Sul. Rio de Janeiro: Bertrand Brasil, 1999.

Miller, Joseph C. "Stratégies de marginalité. Une approche historique de l'utilisation des êtres humains et des ideologies de l'esclavage: progéniture, piété, protection personele et prestige - produit et profits des propriétaires". In: Isabel Castro Henriques \& Louis SalaMoulins (dir.), Déraison, esclavage et droit: lês fondements idéologiques et juridiques de la traite négrière et de l'esclavage. Paris: Ed.Unesco, 2002.

Miller, Joseph C. "A Theme in Variations: A Historical Schema of Slaving in the Atlantic and Indian Ocean Regions”. In: Slavery \& Aboliton. 25 (2): 169-94, August 2004.

Mintz, Sidney W. O Poder Amargo do Açúcar. Produtores escravizados, consumidores proletarizados (trad.port.). Recife: Ed.UFPE, 2003.

Morgan, Kenneth. "Slavery and the Debate over Ratification of the United States Constitution". In: Slavery and Abolition. 22 (3): 40-65, December 2001.

Moreno García, Julia. “Actitudes de los nacionalistas cubanos ante la ley penal de abolición y represión del tráfico de esclavos (1845)”. In: Francisco de Solano e Augustín Guimerá (org). Esclavitud y Derechos Humanos: La Lucha por la libertad del negro en el siglo XIX. Madrid: Consejo Superior de Investigaciones Científicas, 1990.

Moreno Fraginals, Manuel. "Nación o Plantación (El Dilema Político Cubano Visto a través de José Antonio Saco)”. In: Estudios Historicos Americanos - Homenaje a Silvio Zavala. México: El Colégio de México, 1953.

Moreno Fraginals, Manuel. El ingenio: complejo econômico social cubano del azúcar. Habana: Editorial de Ciencias Sociales, 1978, 3v.

Moreno Fraginals, Manuel. Cuba/España, España/Cuba: Historia Común. Barcelona: Crítica, 1995.

Motta, Márcia Maria Menendes. Nas fronteiras do poder: conflitos de terra e direito agrário no Brasil de meados do século XIX. Rio de Janeiro: Vício de Leitura/Arquivo Público do Estado do Rio de Janeiro, 1998.

Moura, Clóvis. Rebeliões da Senzala. Quilombos Insurreições Guerrilhas. 3. ed. São Paulo: Livraria Editora Ciências Humanas, 1981. 
Moura, Clóvis. Dicionário da escravidão negra no Brasil. São Paulo: Edusp, 2004.

Moya Pons, Frank. Historia del Caribe. Azúcar y plantaciones en el mundo atlântico. Santo Domingo: Editora Búho, 2008.

Murray, David. Odious Commerce. Britain, Spain and the Abolition of the Cuban Slave Trade. Cambridge: Cambridge University Press, 1980.

Murray, David. "The Slave Trade, Slavery and Cuban Independence". Slavery and Abolition, 20 (3) (December 1999), pp. 106-26.

Naranjo Orovio, Consuelo (coord.). Historia de Cuba, vol. 1 de Historia de las Antillas. Madrid: Doce Calles-CSIC, 2009.

Needell, Jeffrey. The Party of Order: The Conservatives, the State and Slavery in the Brazilian Monarchy, 1831-1871. Stanford, California: Stanford University Press, 2006.

Novais, Fernando A. Portugal e Brasil na crise do Antigo Sistema Colonial (1777-1808). São Paulo: Hucitec, 1979.

Novais, Fernando A. Aproximações. Estudos de História e Historiografia. São Paulo: Cosac Naify, 2005.

Opatrný, Josef. “El Estado-nación o la 'cubanidad': los dilemas de los portavoces de los criollos cubanos de la época antes de La Escalera.” In: M.Dolores González-Ripoll; C.Naranjo; A.Ferrer; G.García; J. Opatrný. El Rumor de Haití en Cuba: Temor, Raza y Rebeldía, 1789-1844. Madri: CSIC, 2004.

Ortiz, Fernando. Los esclavos negros (1 ${ }^{\mathrm{a}}$ ed. 1916). Havana: Editorial de Ciencias Sociales, 1996.

Ortiz, Fernando. Contrapunteo cubano del tabaco y el azúcar (1ª ed: 1940). Caracas: Biblioteca Ayacucho, 1987.

Ots Capdequí, José Maria. Manual de Historia del Derecho Español en las Indias y del Derecho Propiamente indiano. Buenos Aires: Editorial Losada, 1945.

Ots Capdequí, José Maria. El Estado Español em las Indias. Mexico: Fondo de Cultura Economica, 1946.

Paes, Mariana Armond Dias. Sujeitos da História, Sujeitos de Direitos: personalidade jurídica no Brasil escravista (1860-1888). Dissertação de mestrado, Faculdade de Direito/Universidade de São Paulo, 2014.

Palacios, Guillermo. Cultivadores libres, Estado y crisis de la eclavitud en Brasil en la época de la Revolución industrial. México: Fondo de Cultura Económica, 1998. 
Palmer, Colin. Human Cargoes. The British Slave Trade to Spanish America, 1700-1739. Urbana: University of Illinois Press, 1981.

Pamplona, Marco. Revoltas, república e cidadania. Nova York e Rio de Janeiro na consolidação da ordem republicana. Rio de Janeiro: Record, 2003.

Paquette, Gabriel B. Enlightenment, Governance, and Reform in Spain and its Empire, 17591808. New York: Palgrave MacMillan, 2008.

Paquette, Robert. Sugar is made with Blood: The Conspiracy of La Escalera and the Conflict between Empires over Slavery in Cuba. Middletown, Connecticut: Wesleyan University Press, 1988.

Paquette, Robert L. "Revolutionary Saint-Domingue in the Making of Territorial Louisiana". In: D.P.Geggus; D.B.Gaspar (org.). A Turbulent Time. The French Revolution and the Greater Caribbean. Indianápolis: Indiana University Press, 1997.

Parron, Tâmis. “A Nova e Curiosa Relação (1764): escravidão e Ilustração em Portugal durante as reformas pombalinas”. In: Almanack Brazilienze. 8: 92-107, novembro de 2008.

Parron, Tâmis. A política da escravidão no Império do Brasil, 1826-1865. Rio de Janeiro: Civilização Brasileira, 2011.

Parron, Tamis. "Escravidão e direito natural: da guerra justa às guerras bárbaras". Artigo ainda não publicado - versão cedida pelo autor.

Patterson, Orlando. "Slavery”. In: Annual Review of Sociology. 3: 407-449, 1977.

Patterson, Orlando. Escravidão e morte social - Um estudo comparativo (trad.port.). São Paulo: Edusp, 2008.

Paz Sánchez, Manuel de. “'El Lugareño’ contra la esclavocracia: las cartas de Gaspar Betancourt y Cisneros (1803-1866)”. Revista de Indias. LVIII (214): 617-39, 1998.

Pena, Eduardo Spiller. Pajens da casa imperial: jurisconsultos, escravidão e a Lei de 1871. Campinas: Editora Unicamp, 2001.

Pereira da Silva, João Manoel. História do Brasil durante a menoridade de D. Pedro II (18311840). Rio de Janeiro: Garnier, 1878.

Pérez-Cisneros, Enrique. La abolición de la esclavitud en Cuba. San José de Costa Rica: Litografía e Imprenta Lil, 1987.

Pérez de la Riva, Juan. El Barracón. Esclavitud y capitalismo en Cuba. Barcelona: Editorial Crítica, 1978.

Pérez de la Riva, Juan. "Una isla con dos historias" (1 ${ }^{\text {a }}$ ed: 1968). In: La conquista del espacio cubano. Havana: Fundación Fernando Ortiz, 2004. 
Perez Jr., Louis A. "In the Service of the Revolution: Two Decades of Cuban Historiography, 1959-1979”. In: The Hispanic American Historical Review, 60 (1): 79-89, feb.1980.

Pérez Jr., Louis A. "Cuba and the United States: Origins and Antecedents of Relations, 1760s1860s". Cuban Studies. 21: 57-82, 1997.

Pérez Murillo, María Dolores. "El Pensamiento Esclavista del Tribunal de Comercio de La Habana (Año de 1841)”. In: Francisco de Solano e Augustín Guimerá (org.). Esclavitud y Derechos Humanos: La Lucha por la libertad del negro en el siglo XIX. Madrid: Consejo Superior de Investigaciones Científicas, 1990.

Pezuela, Jacobo de la. Historia de la isla de Cuba. Madrid: Bailly-Bailliere, 1878.

Pierson, William Whatley. "Francisco de Arango y Parreño". In: Hispanic American Historical Review. 16 (4): 451-78, November 1936.

Pietschmann, Horst (ed.). Atlantic History. History of the Atlantic System, 1580-1830. Göttingen: Vandenhoeck \& Ruprecht, 2002.

Pimenta, João Paulo Garrido. O Brasil e a América espanhola (1808-1822). Tese de Doutorado. São Paulo: FFLCH/USP, 2004.

Pimenta, João Paulo Garrido. Brasil y las independencias de Hispanoamérica. Castelló de la Plana: Publicaciones de la Universitat Jaume I, 2007.

Pinto, Virgílio Noya. O ouro brasileiro e o comércio anglo-português. São Paulo: Companhia Editoral Nacional, 1979.

Pinheiro, Fernanda Aparecida Domingos. "Transformações de uma prática contenciosa: as ‘Ações de Liberdade' produzidas em Mariana - 1750/69 e 1850/69”. Locus: revista de história, v.17, n.1 (Juiz de Fora, 2011), pp. 253-271.

Piqueras, José Antonio. “La política de los intereses en Cuba y la revolución (1810-1814)”. In: J.A.Serrano \& M.Terán (eds.). Las guerras de independencia en la América española. Zamora: Instituto Nacional de Antropologia e Historia/El Colégio de Michoacán/Universidad Michoacan, 2002.

Piqueras, José Antonio. "Leales en época de insurrección. La élite criolla cubana entre 1810 y 1814.” In: Izaskun Álvarez Cuartero \& Julio Sánchez Gómez (org.). Visiones y revisiones de la independencia americana. Salamanca: Ediciones Universidad de Salamanca, 2003.

Piqueras, José Antonio. Sociedad civil y poder en Cuba: colonia y poscolonia. Madrid: Siglo XXI, 2005. 
Piqueras, José Antonio. "El mundo reducido a una isla. La unión cubana a la metrópoli en tiempos de tribulaciones”. In: J.A.Piqueras (ed.). Las Antillas en la era de las Luces y la Revolución. Madri: Siglo XXI, 2005.

Piqueras, José Antonio. "De español americano a patriota cubano: el itinerario político e ideológico de Félix Varela". In: Félix Varela y la prosperidad de la pátria criolla. Madrid: Fundación Mapfre/Doce Calles, 2007.

Piqueras, José Antonio. "Los Amigos de Arango en la Corte de Carlos IV". Trabalho apresentado ao Congresso Internacional Francisco Arango y la invención de la Cuba azucarera, Madrid, CSIC, junho de 2008.

Portuondo Zúñiga, Olga. “La consolidación de la sociedad criolla (1700-1765)”. In: Instituto de História de Cuba. Historia de Cuba. La Colonia. Evolución socioeconómico y formación nacional. Havana: Editora Política, 1994.

Prado Jr., Caio. História econômica do Brasil. São Paulo: Brasiliense, 1945.

Prieto, Alfredo (ed.). Órbita de Manuel Moreno Fraginals. Havana: Ediciones UNIÒN, 2009.

Poveda Velasco, Ignácio. "Direito, jurisprudência e justiça no pensamento clássico (GrecoRomano)". Revista da Faculdade de Direito da USP, v.101 (jun./dez.2006), pp.21-32.

Reis, João José; Silva, Eduardo. Negociação e conflito. A resistência negra no Brasil escravista. São Paulo: Companhia das Letras, 1989.

Reis, João José. Rebelião escrava no Brasil. A história do levante dos Malês em 1835 (Edição revista e ampliada). São Paulo: Cia. das Letras, 2003.

Reis, João José; Gomes, Flávio dos Santos. "Repercussions of the Haitian Revolution in Brazil, 1791-1850”. In: David P. Geggus; N. Fiering (eds.). The World of the Haitian Revolution. Bloominton,: Indiana University Press, 2009.

Revel, Jacques (org.). Jogos de escalas: a experiência da microanálise. (trad.port.). Rio de Janeiro: FGV, 1998.

Ribeiro, Gladys Sabina. A Liberdade em Construção. Identidade nacional e conflitos antilusitanos no Primeiro Reinado. Rio de Janeiro: Relume Dumará, 2002.

Ribeiro Jr., José. Colonização e Monopólio no Nordeste Brasileiro. A Companhia Geral de Pernambuco e Paraíba (1759-1780). São Paulo: Hucitec, 1976.

Rieu-Millan, Marie Laure. Los diputados americanos em las Cortes de Cadiz. Madrid: Consejo Superior de Investigaciones Cientificas, 1990.

Rocha, Antonio Penalves. A Economia Política na Sociedade Escravista (Um estudo dos textos econômicos de Cairu). São Paulo: Hucitec/PPG-HE-USP, 1996. 
Rocha, Antonio Penalves. "Idéias antiescravistas da Ilustração européia na sociedade escravista brasileira.” In: Revista Brasileira de História. Vol.20, n³9: 37-68, 2000.

Rodrigues, Jaime. "Liberdade, humanidade e propriedade: os escravos e a Assembléia Constituinte de 1823.” In: Revista IEB. 39: 159-167, 1995.

Rodrigues, Jaime. O infame comércio. Propostas e experiências no final do tráfico de africanos para o Brasil (1800-1850). Campinas: Ed.Unicamp, 2000.

Rodrigues, Jaime. De Costa a Costa. Escravos, marinheiros e intermediários do tráfico negreiro de Angola ao Rio de Janeiro (1780-1860). São Paulo: Companhia das Letras, 2005.

Röhrig Assunção, Matthias; Zeuske, Michael. “'Race', Ethnicity and Social Structure in $19^{\text {th }}$ Century Brazil and Cuba”. In: Ibero-Amerikanisches Archiv, 24, 3/4, pp.375-443, 1998.

Russell-Wood, A.J.R. Escravos e libertos no Brasil Colonial (trad.port.). Rio de Janeiro: Civilização Brasileira, 2005.

Saco, José Antonio. Historia de la Esclavitud desde los tiempos mas remotos hasta nuestros dias. (2 ed). Havana: Editoral “Alfa”, 1944, 6v.

Saiz Pastor, Candelaria. "El colonialismo español en el Caribe durante el siglo XIX: el caso cubano, 1833-1868”. In: Consuelo O. Naranjo \& Tomás Mallo Gutiérrez (eds.). Cuba: la perla de las Antillas. Actas de las I Jornadas sobre "Cuba y su Historia”. Madrid: Doce Calles/CSIC, 1994.

Saiz Pastor, Candelaria. "Império de ultramar y fiscalidad colonial”. In C. Saiz Pastor. \& Salvador Palazón Ferrando (eds.). La ilusión de un império. Las relaciones económicas hispano-cubanas en el ultimo siglo de dominación colonial. Alicante: Universidad de Alicante, 1998.

Sala-Molins, Louis. Le Code Noir, ou le Calvaire de Canaan. Paris: PUF, 1987.

Salles, Ricardo. E o Vale era o Escravo. Vassouras, século XIX. Senhores e escravos no coração do Império. Rio de Janeiro: Civilização Brasileira, 2008.

Sanchez-Albornoz, Nicolás. “A população da América espanhola colonial”. In: L. Bethell. (org.), História da América Latina. Vol.II. América Latina Colonial. (trad.port.) São Paulo: EDUSP-Brasília: Fundação Alexandre de Gusmão,1999.

Santos, Guilherme de Paula Costa. A Convenção de 1817: debate político e diplomático sobre o tráfico de escravos durante o governo de D. João no Rio de Janeiro. Dissertação de Mestrado em História Social. São Paulo: FFLCH/USP, 2007.

Santos, Ynaê Lopes dos. Irmãs do Atlântico. Escravidão e espaço urbano no Rio de Janeiro e Havana (1763-1844). Tese de Doutorado - FFLCH/USP, 2013. 
Saunders, A.C. de C.M. História social dos escravos e libertos negros em Portugal, 1441-1555 (trad.port.) Lisboa: Imprensa Nacional - Casa da Moeda, 1994.

Schmidt-Nowara, Christopher. Empire and Antislavery: Spain, Cuba, and Puerto Rico, 18331874. Pittsburgh: University of Pittsburgh Press, 1999.

Schmidt-Nowara, Christopher. The Conquest of History. Spanish Colonialism and National Histories in the Nineteenth Century. Pittsburgh: University of Pittsburgh Press, 2006.

Schultz, Kirsten. "La independencia de Brasil, la ciudadanía y el problema de la esclavitud: A Assembléia Constituinte de 1823.” In: Jaime E. Rodríguez O. (coord.). Revolución, independencia y las nuevas naciones de América. Madrid: Fundación Mapfre Tavera, 2005.

Schultz, Kirsten. Versalhes Tropical. Império, monarquia e a corte real portuguesa no Rio de Janeiro, 1808-1821 (trad.port.). Rio de Janeiro: Civilização Brasileira, 2008.

Schwartz, Stuart B. Segredos Internos. Engenhos e escravos na sociedade colonial, 1550-1835 (trad.port.). São Paulo: Companhia das Letras, 1988.

Scott, Rebecca. Emancipação escrava em Cuba: a transição para o trabalho livre, 1860-1899 (trad.port.). São Paulo: Paz e Terra, 1991.

Serrão, Joel (ed.). Liberalismo, Socialismo, Republicanismo. Antologia de Pensamento Político Português, 2a . ed., Lisboa, Livros Horizonte, 1979.

Serrão, José Vicente. “O quadro econômico”. In: José Mattoso (dir.), História de Portugal vol. IV: António Manuel Hespanha (coord), O Antigo Regime. Lisboa: Estampa, 1993.

Sheridan, Richard B. Sugar and Slavery. An Economic History of the British West Indies, 16231775 (1 ${ }^{\mathrm{e}} \mathrm{ed}$ : 1974). Kingston-Jamaica: Canoe Press, 1994.

Sheridan, Richard B. "Eric Williams and Capitalism and Slavery: a Biographical and Historiographical Essay". In: B.Solow \& S.Engerman (ed.), British Capitalism and Caribbean Slavery. The Legacy of Eric Williams. Cambridge: Cambridge University Press, 1987.

Sheridan, Richard B. "The Formation of Caribbean Plantation Society, 1689-1748". In: P.J.Marshall (ed.). The Oxford History of British Empire. Vol. II - The Eighteenth Century. New York: Oxford University Press, 1998.

Shy, John. “The American Colonies in War and Revolution, 1748-1783”. In: P.J.Marshall (ed.). The Oxford History of British Empire. Vol. II - The Eighteenth Century. New York: Oxford University Press, 1998.

Silva, Alberto da Costa e. Francisco Félix de Souza: mercador de escravos. Rio de Janeiro: Nova Fronteira-Eduerj, 2004. 
Silva, Ana Cristina Nogueira da. A cidadania nos trópicos. O ultramar no constitucionalismo monárquico português (1820-1880). Tese de Doutoramento. Lisboa: Universidade Nova de Lisboa, 2004.

Silva, Ana Rosa Cloclet da. Construção da nação e escravidão no pensamento de José Bonifácio, 1783-1823. Campinas: Ed.Unicamp/CMU, 1999.

Silva, Ana Rosa Cloclet da. "Identidades políticas e a emergência do novo Estado nacional: o caso mineiro”. In: István Jancsó (org.). Independência: História e Historiografia. São Paulo: Hucitec-Fapesp, 2005.

Silva, Ana Rosa Cloclet da. Inventando a Nação. Intelectuais Ilustrados e Estadistas LusoBrasileiros na Crise do Antigo Regime Português (1750-1822). São Paulo: Hucitec, 2006.

Silva, Luiz Geraldo. "Esperança de liberdade. Interpretações populares da abolição ilustrada (1773-1774)". Revista de História, n.144 (1º semestre de 2001), pp.107-49.

Silva, Luiz Geraldo. "Negros patriotas. Raça e identidade social na formação do Estado nação (Pernambuco, 1770-1830)”. In: István Jancsó (org.), Brasil: Formação do Estado e da Nação. São Paulo: Hucitec-Fapesp-E.Unijuí, 2003.

Silva, Luiz Geraldo. "Negros y pardos en la era de las independencias latinoamericanas: militarización, ciudadanía y política (1780-1830)". Texto apresentado ao Seminário Bicentenarios de Indepependencias: nuevas miradas, Cartagena, Colombia, outubro de 2008.

Silva Júnior, Waldomiro Lourenço da. História, direito e escravidão: A legislação escravista no Antigo Regime ibero-americano. São Paulo: Annablume, 2013 (no prelo)

Silva, Nuno J. Espinosa Gomes da. História do Direito Português. Fontes de direito. Lisboa: Fundação Calouste Gulbenkian, 1992.

Silva, Luiz Geraldo. "Esperança de liberdade. Interpretações populares da abolição ilustrada (1773-1774)". In: Revista de História. 144: 107-49, $1^{\text {o }}$ semestre de 2001.

Silva, Luiz Geraldo. "Negros patriotas. Raça e identidade social na formação do Estado nação (Pernambuco, 1770-1830)"'. In: István Jancsó (org.), Brasil: Formação do Estado e da Nação. São Paulo: Hucitec-Fapesp-E.Unijuí, 2003.

Silva, Luiz Geraldo. "Negros y pardos en la era de las independencias latinoamericanas: militarización, ciudadanía y política (1780-1830)”. Texto apresentado ao Seminário Bicentenarios de Indepependencias: nuevas miradas, Cartagena, Colombia, outubro de 2008. 
Silveira, Marco Antonio. "Soberania e luta social: negros e mestiços libertos na Capitania de Minas Gerais (1709-1763)”. In: Cláudia Maria das Graças Chaves \& Marco Antonio Silveira (org.). Território, conflito e identidade. Belo Horizonte: Argvmentvm, 2007.

Silveira, Marco Antonio. “Acumulando forças: luta pela alforria e demandas políticas na capitania de Minas Gerais (1750-1808)". In: Revista de História. 158: 131-56, $1^{\circ}$ semestre de 2008.

Sio, Arnold A. "Interpretations of Slavery: the Slave Status in the Americas". In: Comparative Studies in Society and History, 7 (3): 289-308, April 1965.

Slemian, Andréa. "Seriam todos Cidadãos? Os impasses na construção da cidadania nos primórdios do constitucionalismo no Brasil (1823-1824).” In: I. Jancsó (org.). Independência: História e Historiografia. São Paulo: Hucitec, 2005.

Slemian, Andréa. Sob o império da lei: Constituição e unidade nacional na formação do Brasil (1822-1834). São Paulo: Hucitec/Fapesp, 2009.

Slenes, Robert. Na senzala, uma flor: esperanças e recordações na formação da família escrava - Brasil Sudeste, séc. XIX. Rio de Janeiro Nova Fronteira, 1999.

Smith, Robert Freeman. "Twentieth-Century Cuban Historiography". The Hispanic American Historical Review, 44 (1): 44-73, feb.1964.

Soares, Luiz Carlos. O "povo de Cam” na capital do Brasil: a escravidão no Rio de Janeiro do século XIX. Rio de Janeiro Faperj/7 Letras, 2007, p.449.

Soares, Márcio de Sousa. A Remissão do Cativeiro. A dádiva da alforria e o governo dos escravos nos Campos dos Goitacases, c.1750-c.1830. Rio de Janeiro: Apicuri, 2009.

Stanley J. Stein, Vassouras. Um município brasileiro do café, 1850-1900. (1 ${ }^{\text {a }}$ ed: 1957; trad.port.) Rio de Janeiro: Nova Fronteira, 1990.

Sztompka, Piotr. A sociologia da mudança social. Rio de Janeiro: Civilização Brasileira, 2005.

Tannenbaum, Frank. Slave and Citizen. New York: Alfred A. Knopf, 1946.

Tardieu, Jean-Pierre. "Morir o dominar": en torno al reglamento de esclavos de Cuba (18411866). Frankfurt: Vervurt; Madrid: Iberoamericana, 2003.

Tau Anzoátegui, Victor. Casuísmo y sistema: indagación histórica sobre el espíritu de Derecho Indiano. Buenos Aires: Instituto de Investigaciones e Historia Del Derecho, 1992.

Tau Anzoátegui, Victor. "El poder de la costumbre: Estudios sobre el derecho consuetudinario en América hispana hasta la Emancipación", in: José Andrés-Gallego (coord), Nuevas Aportaciones a la Historia Jurídica de Iberoamérica. Madrid: Fundación Histórica Tavera/Digibis/Fundación Hernando de Larramendi, 2000 (Cd-Rom). 
Telles, José Homem Correia. Commentario crítico á Lei da Boa Razão, em data de 18 de agosto de 1769. (1 ${ }^{\mathrm{a}}$ edição 1824). Lisboa: Typografia de Maria da Madre de Deus, 1865.

Tomás y Valiente, Francisco. Manual de Historia del Derecho Español. Madri: Editorial Tecnos, 1979.

Tomich, Dale. "The Wealth of Empire: Francisco Arango y Parreño, Political Economy, and the Second Slavery in Cuba”. In: Comparative Studies in Society and History, 45 (1): 428, 2003.

Tomich, Dale. Through the Prism of Slavery. Labor, Capital, and World Economy. Boulder, Co.: Rowman \& Littlefield Publ., 2004.

Tomich, Dale. "O Atlântico como espaço histórico". Estudos Afro-Asiáticos. 26 (2) (mar-ago 2004), pp.221-240.

Dale Tomich. "The Order of Historical Time: The Longue Durée and Micro-History". Texto inédito cedido pelo autor

Thompson, Edward Palmer. Senhores e caçadores: a origem da lei negra. (trad.port.) Rio de Janeiro: Paz e Terra, 1987.

Thompson, Edward Palmer. Costumes em comum: estudos sobre a cultura popular tradicional. (trad.port.) São Paulo: Cia das Letras, 1998.

Tornero Tinajero, Pablo. Crecimiento económico y Transformaciones sociales. Esclavos, Hacendados y Comerciantes en la Cuba Colonial (1760-1840). Madrid: Ministerio de Trabajo y Seguridad Social, 1996.

Torres-Cuevas, Eduardo. “De la Ilustración reformista al reformismo liberal.” In: Instituto de Historia de Cuba. Historia de Cuba. La Colonia. Evolución socioeconómico y formación nacional. La Habana: Editora Política, 1994.

Trípoli, Cesar. História do Direito Brasileiro. São Paulo: RT, 1936-1974, 2.v.

Trouillot, Michel-Rolph. Silencing the Past. Power and the Production of History. Boston: Beacon Press, 1995.

Varella, Claudia. Esclavos a sueldo: la coartación cubana en el XIX. Tese de Doutorado. Castellión: Universitat Jaime I, 2010.

Van der Linden, Marcel. Trabalhadores do mundo: ensaios para uma história global do trabalho. (trad.port.) Campinas: Editora Unicamp, ano.

Venegas Delgado, Hernán. "El fantasma de la Revolución Haitiana y la independencia de Cuba”. In: Projeto História, 31: 25-54, dez.2005.

Watson, Alan. Slave Law in the Americas. Athens: University of Georgia Press, 1989. 
Wallerstein, Immanuel. The Modern World-System II. Mercantilism and the Consolidation of the European World-Economy, 1600-1750. New York: Academic Press, 1980.

Wallerstein, Immanuel. The Modern World-System III. The Second Era of Great Expansion of the Capitalist World-Economy, 1730-1840s. New York: Academic Press, 1989.

Wallerstein, Immanuel. The Modern World-System IV. Centreist Liberalism Triumphant, 17891914. Berkley, Los Angeles, Londres: University of California Press, 2011.

Watts, David. Las Indias Occidentales. Modalidades de desarrollo, cultura y cambio medioambiental desde 1492 (trad.esp.). Madrid: Alianza Editorial, 1992.

Williams, Eric. Capitalismo e Escravidão. ( $1^{\text {a }}$ ed: 1944; trad.port.) Rio de Janeiro: Ed.Americana, 1975.

Wissembach, Maria C. Cortez. Sonhos africanos, vivências ladinas: escravos e forros em São Paulo, 1850-1880. São Paulo: Hucitec, 1998.

Zanetti Lecuona, Oscar. "Las relaciones comerciales hispano-cubanas en el siglo XIX”.In: C. Saiz Pastor. \& Salvador Palazón Ferrando (eds.). La ilusión de un império. Las relaciones económicas hispano-cubanas en el ultimo siglo de dominación colonial. Alicante: Universidad de Alicante, 1998.

Zeuske, Michael. "Comparing or interlinking? Economic comparisons of early nineteenthcentury slave systems in the Americas in historical perspective”. In: Enrico dal Lago \& Constantina Katsari (ed), Slave Systems. Ancient and Modern. Cambridge: Cambridge University Press, 2008. 